\author{
Universidade de São Paulo \\ Faculdade de Filosofia, Letras e Ciências Humanas \\ Programa de Pós-Graduação em Filologia e Língua Portuguesa
}

Feitiçaria paulista: transcrição de processo-crime da Justiça Eclesiástica na América portuguesa do século XVIII

São Paulo 


\author{
Universidade de São Paulo \\ Faculdade de Filosofia, Letras e Ciências Humanas \\ Programa de Pós-Graduação em Filologia e Língua Portuguesa
}

\title{
Feitiçaria paulista: transcrição de processo-crime da Justiça Eclesiástica na América portuguesa do século XVIII
}

Dissertação apresentada ao Programa de PósGraduação da Faculdade de Filosofia, Letras e Ciências Humanas da Universidade de São Paulo, como parte dos requisitos para obtenção do título de Mestre em Filologia e Língua Portuguesa.

Orientador: Prof. Dr. Marcelo Módolo

VERSÃO CORRIGIDA

São Paulo 


\section{ENTREGA DO EXEMPLAR CORRIGIDO DA DISSERTAÇÃO/TESE \\ Termo de Ciência e Concordância do (a) orientador (a)}

Nome da aluna: Narayan Pereira Porto

Data da defesa: $27 / 11 / 2018$

Nome do Prof. orientador: Marcelo Módolo

Nos termos da legislação vigente, declaro ESTAR CIENTE do conteúdo deste EXEMPLAR CORRIGIDO elaborado em atenção às sugestões dos membros da comissão Julgadora na sessão de defesa do trabalho, manifestando-me plenamente favorável ao seu encaminhamento e publicação no Portal Digital de Teses da USP.

São Paulo, 19/2/2019.

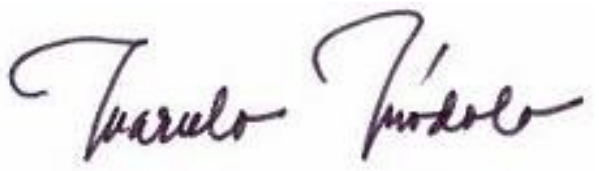

Assinatura do orientador. 
Autorizo a reprodução e divulgação total ou parcial deste trabalho, por qualquer meio convencional ou eletrônico, para fins de estudo e pesquisa, desde que citada a fonte.

Catalogação na Publicação

Serviço de Biblioteca e Documentação

Faculdade de Filosofia, Letras e Ciências Humanas da Universidade de São Paulo

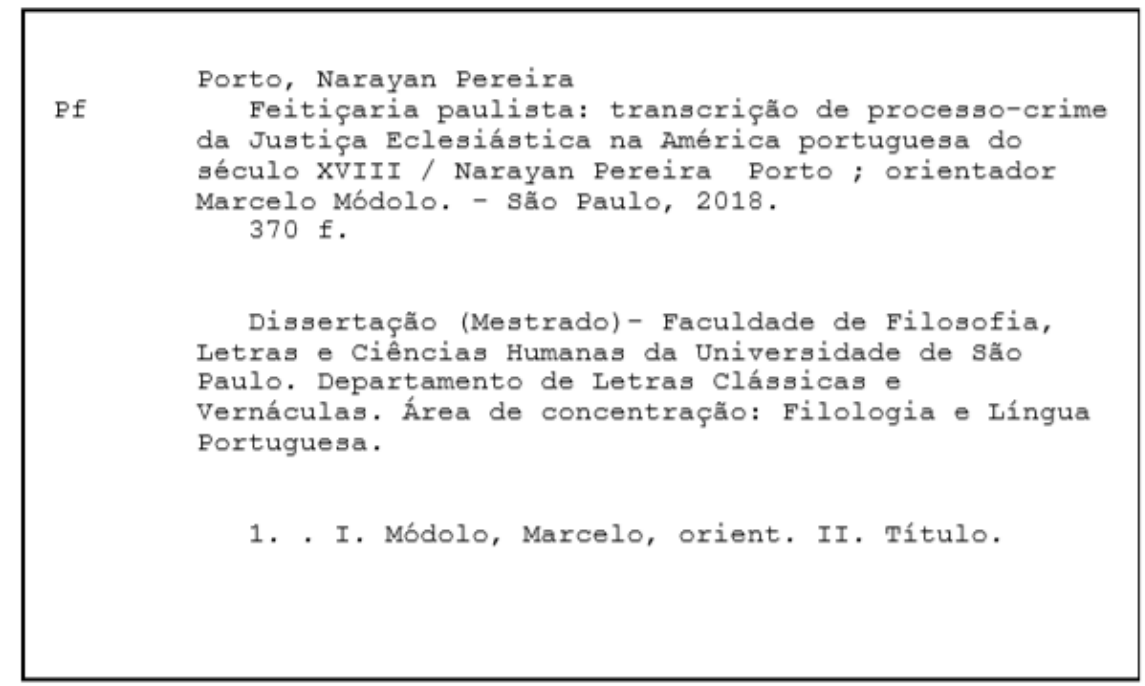


PORTO, N. P. Feitiçaria Paulista: transcrição de processo-crime da Justiça Eclesiástica na América portuguesa do século XVIII. Dissertação apresentada à Faculdade de Filosofia, Letras e Ciências Humanas da Universidade de São Paulo para obtenção do título de Mestre em Filologia e Língua Portuguesa.

Aprovado em:

Banca examinadora

Prof. Dr. Instituição:

Julgamento: Assinatura:

Prof. Dr. Instituição:

Julgamento: Assinatura:

Prof. Dr. Instituição:

Julgamento: Assinatura: 


\section{Agradecimentos}

Em primeiro lugar, gostaria de agradecer a minha mãe, Zulene Pereira Machado, por sempre estar ao meu lado e me apoiar incondicionalmente, por toda a paciência e todo o suporte. Gostaria de agradecer também ao meu pai, Uilton Alves Porto, por sempre me apoiar e acreditar no meu potencial. Ao meu irmão, Rafael, por me emprestar seu quarto, sempre que precisei, para poder me concentrar, estudar e escrever a dissertação.

Os meus mais sinceros agradecimentos vão também para a minha "segunda mãe", Sirlei Rufatto, por todos os incentivos, apoio, amor, encorajamento e rigorosidade. Às minhas queridas amigas, amores da minha vida, Marina Gialluca, Gabriela Chiarelli Milito, Vanessa Serra, Thaís Trindade, Keyse Braga, Gabriela Pimenta, Fernanda Caetano, Mariana Pereira, Caroline Calixto e Nathalia Ribeiro Bignotto, agradeço profundamente todo o amor, carinho e apoio que recebi. Sem vocês, minha existência não teria sentido. Muito obrigada por serem o arco-íris em minha vida. Agradeço também à Christina Gialluca pelo apoio, cuidado e por me receber em sua casa de braços abertos, para que eu pudesse redigir a dissertação.

Um agradecimento mais do que especial à minha amiga, Kathlin de Morais: muito obrigada por dividir essa jornada de mestrado comigo (que foi, aliás, quando nos tornamos amigas), por cursarmos as disciplinas juntas, pelo apoio mútuo, por me ajudar com minhas dúvidas e por dividir comigo o sufoco e desespero para fazer os trabalhos. Agradeço, principalmente, por permitir que eu aprendesse um novo idioma, dando-me aulas de francês. Merci beaucoup!

À minha querida prima, Letícia Martins, agradeço por dividir esse sonho de USP comigo e por dividir também as idas e vindas de ônibus durante esses anos todos. Agradeço também à minha tia, Rosa Pereira Machado, pelo apoio, por acreditar e sentir orgulho de mim.

Gostaria de dirigir os meus mais sinceros agradecimentos ao senhor Jair Mongelli Júnior, diretor do Arquivo da Cúria Metropolitana de São Paulo, por ceder a documentação utilizada para a realização da pesquisa.

Agradeço imensamente a meu orientador, professor Doutor Marcelo Módolo, não apenas por me auxiliar nessa longa jornada de pesquisa acadêmica, que se iniciou em 2013, mas também pela paciência, dedicação e palavras de apoio e incentivo. Muito obrigada por tudo, por acompanhar o início da pesquisa, desde a iniciação científica, até seu pleno desenvolvimento, no mestrado. Ofereço não apenas meus sinceros, mas especiais agradecimentos ao senhor.

Gostaria de agradecer à Helena de Oliveira e Nathalia Fernandes, não apenas por participarem das bancas de qualificação (Helena), defesa e por me auxiliarem quando necessário, mas principalmente pelo achado da documentação no Arquivo da Cúria. Sem vocês, essa pesquisa não existiria. Muito obrigada. 
Finalmente, meu "muito obrigada" à Professora Helena de Oliveira e ao Professor Joaci Pereira Furtado pelas considerações feitas no meu exame de qualificação, as quais muito nos ajudaram a amadurecer este trabalho. 


\section{Resumo}

PORTO, N. P. Feitiçaria paulista: transcrição de processo-crime da Justiça Eclesiástica na América portuguesa do século XVIII. Dissertação apresentada à Faculdade de Filosofia, Letras e Ciências Humanas da Universidade de São Paulo para obtenção do título de Mestre em Filologia e Língua Portuguesa.

O objetivo da presente dissertação é a transcrição semidiplomática e análise filológica de um processo inquisitorial aberto pela Justiça Eclesiástica paulista, no ano de 1754, em Jundiaí, no qual as rés, Thereza Leyte e Escholastica Pinta da Silva (mãe e filha) são acusadas de matar o primeiro marido de Escholastica utilizando-se de feitiços, de matarem outros homens e de terem pacto com o demônio. A pesquisa procura também contribuir para elucidar o modo pelo qual o Tribunal do Santo Ofício agiu na Europa e na América portuguesa, buscando esclarecer sua atuação no Brasil colonial. Além disso, é apresentado um estudo codicológico e paleográfico da documentação, abordando aspectos relacionados ao papel utilizado, às tintas, às abreviaturas e a outros aspectos relacionados à escrita da língua portuguesa no século XVIII. Ao final do trabalho, é apresentada a transcrição semidiplomática da documentação, juntamente com os fac-símiles dos manuscritos originais.

Palavras-chave: Filologia, Inquisição, São Paulo colonial, Jundiaí, transcrição semidiplomática, codicologia, paleografia. 


\begin{abstract}
PORTO, N. P. Witchcraft from São Paulo: transcription of a lawsuit by the Ecclesiastical Court in Portuguese America of the 18th century. Dissertação apresentada à Faculdade de Filosofia, Letras e Ciências Humanas da Universidade de São Paulo para obtenção do título de Mestre em Filologia e Língua Portuguesa.
\end{abstract}

The present thesis aims to offer the semidiplomatic transcription and philological analysis of an inquisitorial lawsuit started by the Ecclesiastical Court from São Paulo, in 1754, in Jundiaí, in which the defendants, Thereza Leyte and Escholastica Pinta da Sylva (mother and daughter), are accused of killing Escholastica's first husband by means of witchcraft. They are also accused of killing other men and of having a pact with the devil. The research also seeks to contribute to elucidate the means through which the Holy Office acted in Europe and in Portuguese America, with the objective of enlightening its actuation in colonial Brazil. Furthermore, a codicological and paleographic study of the documentation is presented, approaching aspects related to the paper used, the inks, the abbreviation system and other aspects related to the Portuguese language writing in the $18^{\text {th }}$ century. At the end of the paper, the semidiplomatic transcription is presented along with the facsimiles of the original manuscripts.

Key-words: Philology, Inquisition, colonial São Paulo, Jundiaí, semidiplomatic transcription, codicology, paleography. 


\section{SUMÁRIO}

Feitiçaria Paulista: transcrição de processo-crime da Justiça Eclesiástica na América portuguesa do

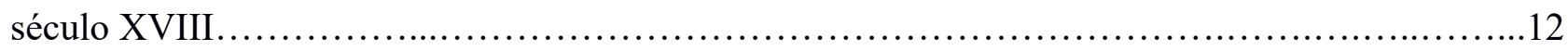

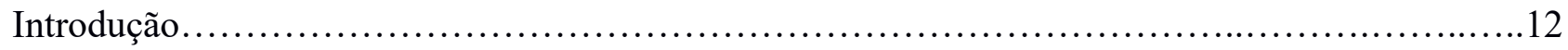

1. O Arquivo da Cúria Metropolitana de São Paulo..........................................14

2. Contextualização histórica......................................................... 15

2.1. O Tribunal do Santo Ofício......................................................... 16

2.2. O Tribunal do Santo Ofício na América portuguesa......................................41

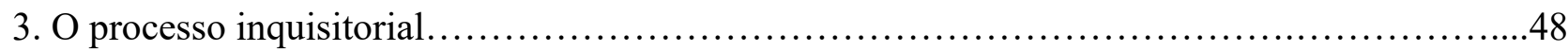

3.1. A legislação da época: As Ordenações Filipinas..........................................57

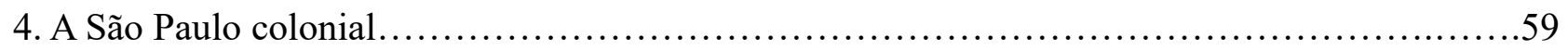

4.1. Vila da Nossa Senhora do Desterro: Jundiaí.............................................65

5. O processo: as rés, o falecido, a acusação e demais envolvidos............................. 70

6. Etimologia das palavras "bruxaria" e "feitiçaria"

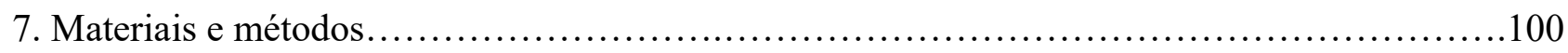

7.1. Estudo filológico da documentação............................................103

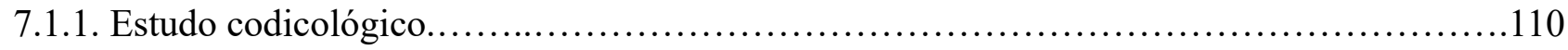

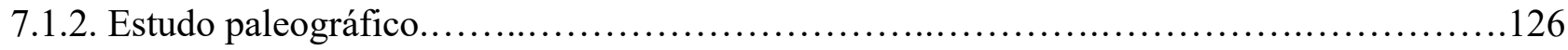

8. O processo-crime de Manoel Garcia contra Escholastica Pinta da Sylva e Thereza Leyte: facsímiles e transcrições............................................................ 171

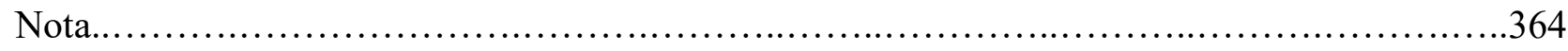

Considerações finais................................................................. 365

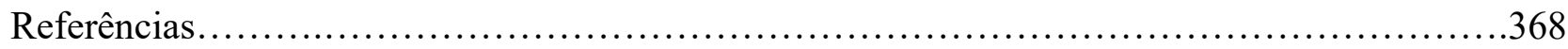





\section{Feitiçaria paulista: transcrição de processo-crime da Justiça Eclesiástica na América portuguesa do século XVIII}

\section{INTRODUÇÃO}

O contato com o processo de Thereza Leyte e Escholastica Pinta da Sylva se deu, pela primeira vez, nas aulas de Filologia Portuguesa, ministradas pelo Professor Dr. Marcelo Módolo, no ano de 2013. O Professor Marcelo havia mencionado a documentação durante uma das aulas, na qual eu estava presente. Assim, surgiu em mim o interesse de fazer parte do projeto "Bruxas Paulistas" e trabalhar para revelar os mistérios que cercavam as figuras dessas mulheres e para melhor compreender questões relacionadas à feitiçaria e ao Tribunal do Santo Ofício (Inquisição). Passei a integrar definitivamente o projeto em 2014, quando comecei a iniciação científica com a proposta de transcrever apenas alguns dos manuscritos deste mesmo processo-crime. A iniciação científica foi concluída em 2015, mas havia o desejo de continuar no projeto e transcrever a documentação na íntegra, desejo este materializado em projeto de mestrado e, consequentemente, nesta dissertação.

Logo, esta dissertação objetiva a transcrição semidiplomática e estudo de um processo sobre feitiçaria do século XVIII, manuscrito, depositado nos arquivos da Cúria Metropolitana de São Paulo.

O corpus para a presente pesquisa constitui-se, portanto, de um dos processos recémdescobertos pelas colegas, Professoras Doutoras Nathalia Reis Fernandes e Helena de Oliveira Belleza Negro, processo nunca antes transcrito ou publicado, composto de acusação de prática de feitiçaria no Brasil, durante o século XVIII. Sendo assim, a transcrição e posterior publicação dos referidos manuscritos contribuirá para o conhecimento não só de como a Inquisição interferiu, participou e influenciou a cultura paulista, mas também para o estudo de aspectos da língua portuguesa escrita no período mencionado, sendo de grande valia para historiadores e linguistas.

A Cúria Metropolitana de São Paulo foi criada em 1/4/1918 por Dom Duarte Leopoldo e Silva - primeiro arcebispo da Arquidiocese e Província Eclesiástica de São Paulo -, com o propósito de recolher e preservar os documentos eclesiásticos paulistas, como afirma Jair Mongelli, diretor do Arquivo: “Além do cumprimento da legislação eclesiástica, Dom Duarte 
objetivava com sua decisão preservar e organizar esse importante acervo da história eclesiástica de São Paulo."

O Arquivo possui uma vasta gama de documentos, dentre os quais os registros de crimes de foro eclesiástico, o corpus da pesquisa proposta.

Em artigo publicado por BOCCIA (1999), constam alguns exemplos de pessoas processadas e acusadas de praticar feitiçaria em São Paulo. Dentre elas, pode-se citar o caso da escrava paulistana de nome Páscoa, acusada de enfeitiçar e assassinar pessoas utilizando fragmentos de unhas e fios de cabelo. Esse caso foi encaminhado ao Tribunal do Santo Ofício, em Lisboa, no ano de 1750. Outro caso a ser mencionado é o de Isabel Pedrosa de Alvarenga, denunciada e processada em 1767 sob a acusação de bruxaria por guardar consigo umbigos de crianças, fios de cabelo e tecidos ensanguentados. E, por fim, pode-se mencionar o processo de Patrício Bicudo da Silva, colono de Santana de Parnaíba, acusado de carregar cobras vivas e não ser picado por nenhuma delas, o que foi considerado prática de magia.

Por meio dos casos acima citados, pode-se assentir nas palavras de BOCCIA (1999: 63): "A definição de magia era vaga e podia incluir qualquer acontecimento incomum."

Sabe-se que as punições direcionadas a hereges incluíam multas, excomunhão, exílio na África e, finalmente, a morte na fogueira.

O objetivo principal da pesquisa é a elaboração de uma edição fac-similar e semidiplomática de um processo-crime aberto no interior de São Paulo - à época "Villa da Nossa Senhora do Desterro de Iundiahy" - no ano de 1754. Além disso, a presente dissertação apresentará também um estudo codicológico e paleográfico, referente aos manuscritos em questão. Neste processo, Thereza Leyte e Escholastica Pinta da Sylva são acusadas de matar Manoel Garcia de Oliveira - genro e marido das rés, respectivamente - utilizando de feitiçaria. Ademais, mãe e filha também são acusadas de outras mortes e de terem pacto com o demônio.

Os resultados da pesquisa realizada configurarão nas transcrições dessa documentação e dos respectivos estudos. CAMBRAIA (2005: 111), afirma que "transcrever significa aqui reproduzir um dado texto em um novo suporte material." Assim, as transcrições são, a grosso modo, uma nova cópia dos documentos, feita em outro suporte material, pois o original pode estar gasto ou corroído, tornando a leitura difícil de ser realizada. Além disso, a transcrição é feita de modo a reproduzir o sistema de escrita da época à qual o documento pertence, e para a

1 "O Arquivo da Cúria Metropolitana de São Paulo: acervo, atividades e projetos". Disponível em: http://www.mundoarchivistico.com/?menu=articulos\&id=200. Consultada em 25/8/2018. 
realização de tal tarefa o manuscrito original passa a ser digitoscrito $^{2}$, pois a letra do documento original pode ser de difícil compreensão para o leitor. As transcrições, portanto, serão apresentadas com a edição fac-similar dos manuscritos originais, ao final do trabalho.

\title{
1. O ARQUIVO DA CÚRIA METROPOLITANA DE SÃO PAULO
}

Os manuscritos que serão utilizados para a transcrição encontram-se no Arquivo da Cúria Metropolitana de São Paulo, instituição, como já salientado, criada no dia primeiro de abril de 1918 por Dom Duarte Leopoldo e Silva - primeiro arcebispo da Arquidiocese e Província Eclesiástica de São Paulo -, com o propósito de recolher e preservar os documentos eclesiásticos paulistas.

Inicialmente, Dom Duarte Leopoldo e Silva encarregou-se de solicitar aos párocos da Arquidiocese todos os livros e processos manuscritos que já estavam fora de uso com o objetivo de armazená-los no Arquivo, localizado inicialmente em um pequeno imóvel no centro da cidade de São Paulo. Nas palavras de MONGELLI (2010):

\begin{abstract}
Além do cumprimento da legislação eclesiástica, Dom Duarte objetivava com sua decisão preservar e organizar esse importante acervo da história eclesiástica de São Paulo. Em seus diários de visita pastoral, ele já vinha registrando a grande dificuldade de manutenção de documentos mais antigos pelas paróquias.
\end{abstract}

No ano de 1921, o Arquivo foi transferido para o novo prédio da Cúria Metropolitana, cujas instalações eram mais adequadas para o armazenamento do acervo, além de contar com uma oficina de restauração. Já em 1974, o Arquivo foi mais uma vez transferido, desta vez para um prédio ao lado da antiga Cúria, ainda no centro da capital, por conta não somente da implantação do transporte metroviário e da remodelação da Praça da Sé, mas também pelo crescimento do acervo. Na época, o então Cardeal Arcebispo Dom Paulo Evaristo Arns decidiu transferir novamente o Arquivo, a fim de encontrar instalações mais amplas que atendessem às necessidades de armazenamento do acervo, que se encontrava em constante expansão. A instituição foi transferida para o bairro do Ipiranga, localizado na zona sul de São Paulo.

Assim, no ano de 1984 foi inaugurado o Arquivo Metropolitano "Dom Duarte Leopoldo e Silva" no campus da Pontifícia Faculdade de Teologia Nossa Senhora da

2 CAMBRAIA (2005: 64) afirma que os documentos digitoscritos são aqueles "registrados por meio de computador". 
Assunção. Um prédio já existente foi reformado e um novo prédio foi construído, para abrigar todo o acervo documental e a biblioteca da Faculdade de Teologia. Segundo o diretor do Arquivo da Cúria, Jair Mongelli: “o Arquivo foi e é a instituição responsável pelo recebimento e pela organização de um dos mais importantes acervos da História Eclesiástica do Brasil."

O Arquivo da Cúria Metropolitana de São Paulo conta atualmente com documentação datada desde o ano de 1632 até 2010, e continua recebendo documentos provenientes também de doações. O acervo dispõe de uma vasta gama de documentos, entre eles livros manuscritos de batizados, matrimônios, óbitos, divórcios, inventários, testamentos, registros de crimes de foro eclesiástico - que é o caso dos manuscritos utilizados como corpus desta pesquisa -, biografias de sacerdotes diocesanos, partituras de música sacra, fotografias e plantas de projetos arquitetônicos, inclusive documentação relacionada aos escravos, como registros de casamento e óbito e o livro de batismo de filhos de escravos.

Além disso, deve ser observado o fato de que o acervo do Arquivo da Cúria é composto por documentos referentes ao município de São Paulo e a algumas cidades da Região Metropolitana de São Paulo. Contudo, a partir do ano de 1989, a documentação referese somente às atuais 287 paróquias da Arquidiocese de São Paulo.

Como dito acima, a documentação estudada está relacionada aos registros de crimes de foro eclesiástico armazenados na Cúria, documentos esses diretamente relacionados ao Tribunal do Santo Ofício.

\section{CONTEXTUALIZAÇÃO HISTÓRICA}

Como já salientado, o processo-crime utilizado como corpus foi aberto no interior de São Paulo, à época "Villa de Iundiahy” (Jundiaí), no ano de 1754. Neste processo, "Thereza Leyte" e "Escholastica Pinta ${ }^{4}$ da Sylva" são acusadas de matar Manoel Garcia, marido de Escholastica e genro de Thereza, utilizando-se de feitiçaria, além de serem culpadas por outras mortes e de possuírem o já mencionado pacto com o demônio.

3 Cf. "O Arquivo da Cúria Metropolitana de São Paulo: acervo, atividades e projetos". In: Mundo Archivistico. Disponível em: http://www.mundoarchivistico.com/?menu=articulos\&id=200.

4 O sobrenome da acusada seria "Pinto da Silva", porém, àquela época, os sobrenomes faziam concordância com o gênero. Logo, como trata-se de uma mulher, seu sobrenome passa a ser "Pinta da Silva". 


\subsection{O TRIBUNAL DO SANTO OFÍCIO}

O Tribunal do Santo Ofício possuía como objetivo julgar e condenar pessoas que eram acusadas de praticarem ações contrárias ao que era aceitável pela Igreja Católica, em outras palavras, condenar os acusados de heresia.

A Santa Inquisição, ou Tribunal do Santo Ofício, não iniciou suas atividades de perseguição aos hereges como uma instituição estável, instaurada nos moldes conhecidos atualmente e que foram popularizados e estereotipados ao longo do tempo, implantando torturas e acendendo fogueiras, com a finalidade de punir fisicamente todo e qualquer ato contrário à fé católica. Segundo afirma HERCULANO (1960: 25): “Como é facil de crer, essa instituição fatal nasceu debil e desenvolveu-se gradual e lentamente. [...]"

Geralmente, se faz referência à Inquisição no singular, pois todos os tribunais da fé possuíam uma característica em comum: a delegação de poderes era feita pelo papa. Entretanto, os tribunais não eram exatamente iguais, não seguiam exatamente as mesmas regras, possuindo suas particularidades e também adaptando-se a diferentes contextos sociais. De acordo com BETHENCOURT (2000: 10):

As Inquisições são referidas, geralmente, no singular. Essa tradição exprime uma realidade: os diferentes tribunais da fé têm como fonte comum de legitimidade a delegação de poderes, feita pelo papa, em matéria de perseguição das heresias. A designação única pode ser cômoda, mas esconde realidades muito diversas: a Inquisição pontifícia estabelecida no século XIII desenvolve um modelo de ação estranho aos modelos (no plural) seguidos, por exemplo, pelos tribunais de Veneza, Modena ou Nápoles do século XVI ao século XVIII; a Inquisição espanhola (criada em 1478), tal como a Inquisição portuguesa (estabelecida em 1536), tem um estatuto particular que se traduz por uma quase completa independência de ação em relação à cúria romana; os tribunais hispânicos que operam na América ou na Ásia transportam com eles estruturas, maneiras de fazer e representações comuns, mas adaptam-se a diferentes contextos.

Segundo HERCULANO (1960: 25-26), inicialmente o Tribunal do Santo Ofício realizava sua atuação como pequenos conselhos, cuja função era identificar e registrar os casos de heresia, utilizando-se das penas espirituais para corrigir os hereges. Tais conselhos, dependentes do bispo, eram chamados de "sínodos".

É importante enfatizar que, inicialmente, as penas não consistiam em castigos corporais, chegando, no máximo, a confisco de bens. ${ }^{5}$ Além disso, não havia juízes específicos (inquisidores) para julgar os casos de heresia, sendo estes casos delegados aos

5 HERCULANO, 1960, p. 25. 
tribunais ordinários e, diferentemente do que ocorreu do século XIII em diante, nenhuma etapa do processo era ocultada ao réu, cuja defesa também era assegurada:

[...] todavia, no meio do fanatismo que inspirava semelhantes crueldades, o systema de processo contra os delinquentes desta especie não tinha analogia alguma com o que depois a Inquisição adoptou. Não havia juizes especiaes para investigarem e apurarem os factos: serviam para isso os tribunaes ordinarios. $\mathrm{O}$ accusado assistia aos actos do processo, dava-selhe conhecimento de todas as accusações, facilitavam-se-lhe os meios de defesa, e nada se lhe occultava. Era inteiramente o inverso das praxes posteriores; e, ainda assim, póde-se dizer que a igreja era, até certo ponto, extranha á imposição de penas afflictivas e ao derramamento de sangue com que mais de uma vez se manchou a intolerancia religiosa antes do seculo XIII. ${ }^{6}$

Contudo, a necessidade de punir os hereges de maneira mais severa foi aumentando e, em 1179, o terceiro concílio geral de Latrão decretou medidas mais severas contra a heresia. ${ }^{7}$

De acordo com HERCULANO (1960: 31), apesar de o referido concílio ter adotado uma postura mais rígida em relação aos hereges, abandonando a "extrema mansidão $e$ brandura que os antigos padres aconselhavam e seguiam; [...]", não se confundiam e não se misturavam as autoridades eclesiástica e secular. Em outras palavras, cada esfera de poder aplicava suas respectivas penas e ainda não havia juízes ou tribunais específicos para julgar os crimes de heresia. ${ }^{8} \mathrm{O}$ que observamos no processo ora estudado, pois apesar de estar sob o âmbito eclesiástico, se houvesse alguma medida judicial, essa devia ser tomada pela justiça comum. A igreja, como instituição, furtava-se de "sujar suas mãos".

Entretanto, em 1184 foi promulgada uma constituição por Lucio III e alguns estudiosos a consideram como sendo a origem da Inquisição, pois segundo tal documento, ordena-se que os comissários visitem as respectivas dioceses uma ou duas vezes por ano com a finalidade de descobrir os crimes de heresia. Além disso, já consta neste mesmo documento vocabulário específico referente aos hereges:

[...] Aquelle acto do poder papal, expedido de accordo com os principes seculares, ordena aos bispos que, por si, pelos arcediagos, ou por commissarios de sua nomeiação, visitem uma ou duas vezes por anno as respectivas dioceses, afim de descubrir os delictos de heresia, ou por fama publica ou por denuncias particulares. Nessa constituição apparecem já as designações de suspeitos, convencidos, penitentes e relapsos, com que se indicam diversos graus de culpabilidade religiosa, com diversas sancções penaes. $[\ldots] .^{9}$

6 HERCULANO, Idem, pp. 25.26.

7 HERCULANO, Idem, p. 30.

8 Cf. HERCULANO, Idem, pp. 31-32.

9 Ver HERCULANO, 1960, p. 32. 
Contudo, mesmo com a rigidez implementada por Lucio III, a distinção entre os poderes da Igreja e poder secular continuava bem definida. Além disso, HERCULANO (1960: 33) afirma que o que realmente mudou com a constituição de Lucio III é o fato de serem fixadas, de certa maneira, "[...] as formulas do processo ecclesiastico em relação aos dissidentes; [...]" e ter sido estabelecido um sistema específico de processo para o réu acusado de heresia. ${ }^{10}$

Entretanto, segundo a historiografia, o papa Inocêncio III enviou, em 1206, os espanhóis Domingos de Guzmán e o bispo de Osma para auxiliar outros três monges no combate à heresia, que continuava a avançar sobre a França, porém, após dois anos, o bispo de Osma se voltou à sua diocese e a tarefa de lutar contra os hereges ficou a cargo de Domingos de Guzmán. Este, reuniu outros sacerdotes à empresa, o que resultou em uma espécie de congregação em Tolosa e, em 1216, após o papa Honório III ter aprovado seus estatutos, foi criada a ordem dos dominicanos. De acordo com HERCULANO (1960: 35):

[...] Foi então que o inquieto conego hespanhol buscou associar á empreza varios sacerdotes, que, por fim estabeleceram uma especie de congregação em Tolosa, com a qual, sendo os seus estatutos aprovados em 1216 por Honorio III, se constituiu a ordem dos frades prégadores ou dominicanos.

Os frades dominicanos receberam a denominação de "inquisidores da fé", porém, tal designação não possuía o mesmo valor que veio a ter posteriormente e eles não constituíam exatamente um tribunal, nem possuíam regras específicas de processo. Da sua alçada competia basicamente identificar os hereges e combatê-los pela palavra. Ainda assim, os dominicanos ganhavam força, pois eram dotados de independência e certo poder, não sendo mais submissos à autoridade episcopal.

Contudo, as heresias continuavam a correr na França, apesar dos muitos esforços empregados pelos frades dominicanos para exterminá-las e, além disso, os albigenses não cediam às palavras dos inquisidores da fé e nem recorriam à violência, quando possuíam recursos para evitá-la. Os albigenses caracterizavam-se basicamente por todas as seitas daquela região, cujos preceitos iam contra a fé católica. Nas palavras de HERCULANO (1960: 36), os albigenses podem ser descritos da seguinte maneira: "[...] nome com que se designavam, sem sufficiente distincção, todas as seitas que naquellas provincias se

10 Cf. HERCULANO, Op. cit., p. 33. 
affastavam mais ou menos da doutrina catholica [...].”. Ainda referente aos albigenses, MOTA (2016: 24) comenta:

Os albigenses viviam na região do Midi, no sul da França e, devido a conflitos relacionados a dogmas religiosos, "constituíram uma espécie de Igreja contra a Igreja de Roma" (NOVINSKY, 2007: 22), o que culminou com a criação do Tribunal do Santo Ofício medieval.

Todavia, com o objetivo de aniquilar as heresias, reprimindo com mais ferocidade os hereges, os decretos do imperador Frederico II, do Sacro Império Romano-Germânico, foram promulgados entre 1220 e $1224 .{ }^{11}$ Dentre tais decretos, constava a pena de morte aos hereges, que deveriam ser queimados vivos. ${ }^{12}$ Entretanto, a responsabilidade por tal castigo, a pena capital, não poderia recair sobre a Igreja.

Segundo HERCULANO (1960: 38-39), a Santa Inquisição tem sua real origem ainda no século XIII, em 1229, durante a Cruzada Albigense:

O anno de 1229 é a verdadeira data do estabelecimento da Inquisição. Os albigenses tinham sido esmagados, e a lucta fora assás longa e violenta para deverem contar com o exterminio. O legado do Papa Gregorio IX, Romano de S. Angelo, ajunctou nesse anno um concilio provincial em Tolosa. Promulgaram-se ahi quarenta e cinco resoluções conciliares, dezoito das quaes eram especialmente relativas aos herejes ou suspeitos de heresia. [...]

Neste concílio estabeleceu-se que os arcebispos e bispos deveriam nomear um clérigo em cada paróquia, com dois, três ou mais assessores seculares, sendo eles ajuramentados, cuja função seria inquirir da existência de qualquer pessoa suspeita do crime de heresia ou de alguém que seguisse ou protegesse o suspeito. Além disso, os supostos hereges deveriam ser delatados aos respectivos bispos ou aos magistrados seculares, utilizando-se de toda a cautela necessária e tomando as medidas cabíveis para que não fugissem. Acrescenta-se a este quadro que essas comissões formadas por clérigos e assessores eram permanentes.

Além disso, os barões, os senhores de terras e os prelados das ordens monásticas eram obrigados a procurar hereges nos mais diversos territórios e propriedades. ${ }^{13}$

11 Cf. HERCULANO, Op. cit., p. 38.

12 Ver "História da Igreja: a Inquisição (parte 2)". In. Editora Cléofas (website). Disponível em: http://cleofas.com.br/historia-da-igreja-a-inquisicao-parte-2/ . Consultada em 25/8/2018.

13 De acordo com HERCULANO (1960: 39): “[...] Os barões ou senhores das terras e os prelados das ordens monasticas ficavam, além disso, obrigados a procurá-los nos districtos ou territorios da sua dependencia, nos povoados e nas selvas, nas habitações humanas e nos esconderijos e cavernas. [...]." 
Afora todas as disposições mencionadas acima, vale enfatizar que havia penas para quem abrigasse um herege em sua propriedade: o cúmplice poderia perder a propriedade e ser punido corporalmente; e a casa onde fosse encontrado um herege, deveria ser destruída.

Outro fator que agravou a perseguição e as penas dirigidas aos hereges, foi o fato de o rei Luís IX, rei da França, ter promulgado um decreto no qual ordenava o suplício imediato dos hereges condenados, decretando as penas de confisco de bens contra seus protetores.

Deste modo, é necessário lembrar que, a esta altura, a Inquisição já era presente na Itália e na Alemanha, porém, a partir deste momento, as leis do imperador Frederico II passaram a ser difundidas também pela França:

[...] Assim, o espirito da legislação de Friderico II, que dominava já na Allemanha e numa parte da Italia, estendia-se agora a França e tornava muito mais tremendas as providencias tomadas na assembléa de Tolosa. ${ }^{14}$

É importante lembrar que, mesmo com o endurecimento das penas aos hereges, essa Inquisição "em fase inicial” mantinha a distinção entre poder secular e poder eclesiástico, diferentemente da postura que a instituição adotou do século XVI em diante.

Mesmo que nas assembleias eclesiásticas houvesse a imposição de penas temporais aos acusados de heresia, havia uma justificativa para tal intromissão da Igreja no território da autoridade secular, que residia no fato de, muitas vezes, os príncipes decretarem castigos iguais ou ainda mais severos, havendo, portanto, uma convergência entre os dois poderes.

Mais tarde, porém, as fórmulas dos processos contra os hereges tornaram-se mais severas. Depois do concílio geral de Lyon, em 1245, no qual o imperador Frederico II de Alemanha e o rei Sancho II de Portugal foram depostos, foi celebrado um concílio provincial em Béziers, sul da França, durante o qual foi redigido um regulamento definitivo, ordenado pelo papa Inocêncio IV, acerca da maneira de se proceder contra os acusados de heresia. Tal regulamento, distribuído em trinta e sete artigos, além de possuir disposições papais e conciliares mais antigas, trazia outras que eram novas, servindo este documento como alicerce de todos os regulamentos posteriores do Tribunal do Santo Ofício. Dentre os artigos contidos nesse regulamento, consta o seguinte:

[...] chegando os inquisidores a qualquer logar, convoquem o clero e o povo e, depois de fazerem uma practica, leiam a patente da sua nomeiação e exponham os fins que se propõem $[\ldots] .{ }^{15}$

14 HERCULANO, Op. cit., p. 40.

15 HERCULANO, Idem, p. 51. 
Outras disposições presentes no referido regulamento eram que se as pessoas que se achassem em crime de heresia ou conhecessem alguém suspeito, deveriam declarar a verdade, isto é, confessarem ou fazer a denúncia durante um prazo específico, denominado de "tempo do perdão" 16 , período durante o qual ficavam isentos de pena de morte, cárcere perpétuo, desterro e confisco de bens. Além disso, as pessoas que não se apresentassem durante este prazo seriam citadas individualmente, sendo concedido a elas termo para comparecerem e liberdade de defesa, porém, se a defesa não fosse satisfatória e não confessassem os crimes, seriam "[...] condemnados sem misericordia, ainda submettendo-se elles ás decisões da igreja. [...]". ${ }^{17}$ Acrescenta-se ainda que os nomes das testemunhas deveriam permanecer ocultos aos réus; os suspeitos que fugissem seriam julgados como se estivessem presentes e, se voltassem, ficavam suscetíveis à prisão; os réus que recusassem se converter, deveriam confessar-se como hereges publicamente; os hereges já falecidos seriam igualmente condenados, sendo seus herdeiros citados para a defesa. Além de outras medidas, estabeleceuse que os "relapsos" (pessoas que depois de convertidas reincidiam no crime), os fugitivos dispostos a se entregarem e os capturados após o "tempo do perdão" eram condenados a cárcere perpétuo. ${ }^{18}$ Além disso, voltam a ser realizadas as buscas por hereges em todo e qualquer tipo de propriedade, sendo ela pública ou privada e ordena-se o confisco de bens e a destruição das casas, cujos donos poderiam estar abrigando hereges:

[...] Renova-se a instituição dos commissarios de parochia para fazerem continuas pesquizas pelas habitações, cabanas, subterraneos e esconderijos, destruirem estes e colherem ás mãos os dissidentes. Mandam-se arrasar as casas onde qualquer delles se haja occultado, e confiscar os bens dos donos. [...]. ${ }^{19}$

Foi ainda durante o século XIII, por volta de 1255-1256, que o papa Alexandre IV, pelas súplicas do rei Luís IX, generalizou a Santa Inquisição na França. ${ }^{20}$

Já na Itália, a Inquisição havia sido estabelecida com disposições mais absolutas, porém, as resistências eram tantas que os papas viram-se no dever de moderar tais fórmulas. Ainda assim, segundo HERCULANO (1960: 59-60), somente no ano de 1289 a Santa Inquisição conseguiu estabelecer-se na república de Veneza, com muito mais limitações do que na França, ficando sob a ação do poder civil, de maneira que fosse considerada um

16 Alexandre Herculano utiliza o termo "tempo do perdão", porém, autores como Francisco Bethencourt (2000) empregam o termo "tempo de graça".

17 Cf. HERCULANO, Op. cit., p. 52.

18 HERCULANO, Idem, p. 53.

19 HERCULANO, Idem, Ibidem.

20 Cf. HERCULANO, Op. cit., p. 58. 
tribunal do Estado, e não uma delegação pontifícia. Todavia, no século XVI, mais precisamente no ano de 1542, a Inquisição romana passou por uma reforma por meio da bula Licet ab initio, e o protestantismo tornou-se o alvo desse tribunal. ${ }^{21}$

Já no final do século XIII, a Inquisição chegava ao seu apogeu na França para, em breve, entrar em declínio e perder importância até desaparecer. Logo, de acordo com HERCULANO (1960: 60-61), no século XVI a Inquisição já estava extinta na França.

No século XIV, no ano de 1378 , o rei Carlos V declarou fim ao sistema de se derrubarem as casas dos hereges, sistema este estabelecido no concílio de Béziers, e que os ministros da Inquisição recebessem uma remuneração regular, em vez de herdarem uma parte dos bens das vítimas.

Foi ainda no século XIV que foram redigidos os manuais da Inquisição medieval. Segundo BETHENCOURT (2000: 23), o manual de Bernard Gui foi escrito por volta de 1324 e o Directorium Inquisitorum, de Nicolau Eymerich, considerado o grande manual da Inquisição, foi escrito em 1376 e tornou-se objeto de numerosas edições a partir de 1503 , sendo reeditado até o século XVIII. Portanto, em seus manuais, os referidos autores realizaram tentativas de sistematizar o que seria considerado heresia.

[...] O manual de Bernard Gui, por exemplo, está organizado em torno de uma classificação dos hereges da época: cátaros (designados como "novos maniqueus"), valdenses, pseudo-apóstolos, beguinos, judaizantes, feiticeiros, adivinhadores e invocadores de demônios. O manual de Nicolau Eymerich acrescenta outros delitos, como a blasfêmia, a vidência ou o islamismo, propondo uma tipologia mais sutil e abstrata, na qual se inclui a definição de heresia, a graduação dos hereges e a distinção entre diferentes casos suspeitos. [...]. ${ }^{22}$

Contudo, a Inquisição foi fixada como tribunal permanente apenas no fim do século $\mathrm{XV}$, exercendo sua administração sobre tudo aquilo que era considerado desvio da fé católica e apresentando as características que atribuíram uma reputação negativa ao tribunal posteriormente.

$\mathrm{Na}$ Espanha do século XV, reinada por Isabel I e Fernando V, apesar das resistências da rainha, a moderna Inquisição foi fundada pelo monarca e o alvo do tribunal passou a ser os judeus. Segundo HERCULANO (1960: 68-69): “[...] Fernando v teve a triste gloria de ser o

21 A respeito da reforma da Inquisição romana, Francisco Bethencourt (2000: 27) comenta: "A Inquisição romana não foi objeto de uma verdadeira refundação, mas sim de uma reorganização, em 4 de julho de 1542, através da bula Licet ab initio. Ao contrário dos motivos invocados para o estabelecimento das Inquisições na Espanha e em Portugal, onde a difusão do judaísmo justificava a organização do tribunal, aqui era a heresia protestante o alvo da nova configuração do 'Santo Ofício'."

22 BETHENCOURT, 2000, p. 32. 
fundador da moderna Inquisição hespanhola. [...].” Assim, em novembro de 1478, o papa Sisto IV assinou a bula Exigit sincerae devotionis affectus, fundando o Tribunal do Santo Ofício na Espanha. De acordo com BETHENCOURT (2000: 17):

No dia $1^{\circ}$ de novembro de 1478, o papa Sisto IV assinou a bula Exigit sincerae devotionis affectus, através da qual fundou uma nova Inquisição na Espanha. Redigida como resposta às petições dos Reis Católicos, essa bula reproduzia os argumentos régios sobre a difusão das crenças e dos ritos mosaicos entre os judeus convertidos ao cristianismo em Castela e Aragão, atribuía o desenvolvimento dessa heresia à tolerância dos bispos e autorizava os reis a nomear três inquisidores (entre os prelados, religiosos ou clérigos seculares com mais de quarenta anos, bacharéis ou mestres em teologia, licenciados ou doutores em direito canônico) para cada uma das cidades ou dioceses dos reinos. [...].

A nomeação de inquisidores pelos príncipes não era algo corriqueiro, sendo uma tarefa geralmente atribuída ao papa, porém, a referida bula permitia que os Reis Católicos nomeassem, revogassem e substituíssem os inquisidores. Entretanto, o primeiro inquisidorgeral da Espanha fora nomeado pelo próprio papa, cinco anos após a fundação da Inquisição.

[...] Esse poder concedido aos príncipes era um acontecimento inédito: até então, a nomeação dos inquisidores, cuja jurisdição se sobrepunha à jurisdição tradicional dos bispos em matéria de perseguição das heresias, estava reservada ao papa. A bula, com efeito, permitia aos Reis Católicos não apenas a nomeação mas também a revogação e a substituição dos inquisidores. Tratava-se de uma verdadeira transferência de competências, que seria matizada cinco anos mais tarde com a nomeação formal do primeiro inquisidor-geral pelo papa, de acordo com a proposta régia - início de uma prática regular que confirmava e legitimava a Inquisição espanhola como um tribunal eclesiástico, funcionando com poderes delegados pelo papa. [...]. ${ }^{23}$

Além disso, BETHENCOURT (2000: 17-18) comenta acerca da ruptura da Inquisição moderna com a tradição inquisitorial medieval, em termos de união formal das jurisdições civil e eclesiástica:

[...] Contudo, a ruptura com a tradição medieval (na verdade trata-se de uma tradição com apenas dois séculos e meio) era flagrante: pela primeira vez, assistia-se ao estabelecimento de uma ligação formal entre a jurisdição eclesiástica e a jurisdição civil, pois a intervenção do príncipe no processo de nomeação dos inquisidores alterava as relações de fidelidade desses agentes.

Apesar de possuírem a bula de estabelecimento do Santo Ofício, Isabel de Castela e Fernando de Aragão nomearam dois inquisidores somente no ano de 1480, escolhendo os 
dominicanos frei Juan de San Martín e frei Miguel de Morillo, ambos com formação em teologia, para o cumprimento da perseguição contra os hereges.

Munidos desse documento fundador, os Reis Católicos demoraram algum tempo para colocá-lo em prática: esperaram até setembro de 1480 para nomear dois inquisidores, os dominicanos frei Juan de San Martín e frei Miguel de Morillo, respectivamente bacharel e mestre em teologia, para perseguir os crimes de heresia nos seus reinos. É necessário sublinhar duas sutilezas nessa carta: a designação abstrata dos crimes de infidelidade, heresia e apostasia (estendendo a ação dos inquisidores a todos os domínios do comportamento e das crenças desviadas) e a ausência de delimitação geográfica da jurisdição dos novos inquisidores. $[\ldots] .^{24}$

Uma das motivações para a criação do tribunal estava no fato de que uma parte dos bens das vítimas condenadas passava a pertencer aos julgadores, o que era uma excelente justificativa para se “caçar” hereges. De acordo com HERCULANO (1960: 69):

[...] O inquisidor siciliano, frei Philippe de Berberis, vindo a Hespanha pedir aos reis catholicos a confirmação de um antigo privilegio, pelo qual a terça dos bens dos que eram condemnados como herejes ficava pertencendo aos seus julgadores (arbitrio excellente para achar culpados), depois de obter favoravel despacho, tractou de persuadir o principe aragonês de quanto sería conveniente estabelecer na Peninsula o tribunal permanente da Inquisição. [...]

Assim, começaram a surgir casos de desacato às coisas sagradas, casos secretos, porém, segundo HERCULANO (1960: 69), “[...] quasi milagrosamente revelados.” Estas acusações de sacrilégio recaíam sobre famílias judias, e a razão para tais perseguições residia no fato de os judeus constituírem a camada mais rica da Espanha. Assim, quando perseguidos e condenados, seus bens eram confiscados e passavam a pertencer à Igreja. Portanto, a ganância dos inquisidores ficou disfarçada sob o manto do cristianismo e os judeus foram duramente reprimidos. ${ }^{25}$

É de grande importância mencionar que os sentimentos de ódio e inveja pelos judeus eram fenômenos que já vinham se arrastando desde a Idade Média, tanto que, as manifestações de violência contra eles já ocorriam nos séculos XII e XIV.

O Tribunal do Santo Ofício necessitava de regulamentos e instruções para seu bom funcionamento e tais regras já se faziam presentes nos manuais da Inquisição medieval, porém, as Inquisições modernas careciam de instruções mais adequadas à época e ao respectivo contexto social. Assim, os primeiros regulamentos do Santo Ofício espanhol foram 
organizados em 1484, pelo primeiro inquisidor-geral, Tomás de Torquemada. Segundo BETHENCOURT (2000: 41):

[...] Essas regras já estavam esboçadas nos manuais da Inquisição medieval, embora as novas características das Inquisições de Antigo Regime, sobretudo no mundo hispânico, expliquem o desenvolvimento de instruções internas muito mais pormenorizadas. [...]. As primeiras instruções espanholas datam de 1484, isto é, foram organizadas durante o período de fundação do "Santo Ofício", logo após a nomeação do primeiro inquisidor-geral, Tomás de Torquemada. Para esse efeito, ele reuniu em Sevilha os inquisidores da cidade, os de Córdoba, de Ciudad Real e de Jaén, mais dois letrados e dois membros do Conselho Real. $[\ldots]$.

Tais instruções envolviam conteúdos relacionados aos ritos de fundação dos tribunais de distrito, ao comportamento dos inquisidores, à regulamentação da prática de tortura, à publicação de éditos, ao confisco de bens, ao comportamento dos funcionários, entre outros.

[...] As instruções são muito interessantes, pois definem, em primeiro lugar, os ritos de fundação dos novos tribunais de distrito (apresentação dos inquisidores, organização da missa, publicação do édito da graça). Em seguida, elas estabelecem o comportamento dos inquisidores em relação às pessoas que se confessem durante o tempo de graça (interrogatórios, penas, formas de abjuração); o procedimento em face dos acusados fora do tempo de graça, incluindo a regulamentação da prática da tortura e da observação do segredo; a publicação dos éditos; a jurisdição nos territórios dos "grandes" e cavaleiros do Reino; o confisco de bens e a libertação dos escravos pertencentes aos condenados; e, finalmente, as regras de comportamento profissional e pessoal dos funcionários. ${ }^{26}$

O tempo de graça - já referido anteriormente, segundo Alexandre Herculano, como "tempo do perdão" - consistia de um período de geralmente trinta dias durante o qual as pessoas culpadas de crimes de heresia podiam se apresentar espontaneamente para confessar seus delitos aos inquisidores. ${ }^{27}$ Além disso, a proclamação do tempo de graça era realizada na mesma ocasião de publicação de um édito, o édito da graça, documento cujo conteúdo compreendia uma clara descrição dos crimes sob alçada do Santo Ofício, que não era somente lido após o sermão, mas também afixado na porta da igreja, prática que se tornou tradição após o advento da Inquisição espanhola. ${ }^{28}$ De acordo com BETHENCOURT (2000: 156), os éditos da graça conferiam os seguintes benefícios às pessoas que se apresentassem de forma 
espontânea aos inquisidores: perdão da pena de morte, da prisão perpétua e da pena de confisco de bens.

Entretanto, a verdadeira intenção do tribunal com o édito e o tempo de graça era justamente produzir denúncias, buscar e condenar hereges, objetivo oculto por trás de atitudes supostamente piedosas. Segundo BETHENCOURT (2000: 157):

[...] Com efeito, a confissão "espontânea" suscitava interrogatórios, destinados em geral a verificar todas as particularidades dos atos cometidos, não apenas para estabelecer a natureza dos crimes perpetrados, mas também, e sobretudo, para identificar os "cúmplices" desses atos. Em resumo, o édito da graça desencadeava uma engrenagem cujo objetivo era produzir denúncias. A graça era, portanto, uma armadilha que servia para constituir um primeiro arquivo de suspeitos posteriormente submetidos a inquérito (evidentemente, para os inquisidores tratava-se de salvar as almas perdidas). Mesmo aqueles que aproveitavam esse "período de misericórdia" podiam ser condenados a penas menores, $[\ldots]$.

Já em relação a Portugal, durante muito tempo, a convivência entre judeus e cristãos foi relativamente pacífica e harmoniosa; muitos cristãos adotaram práticas judaicas, de forma consciente ou inconsciente; o Antigo Testamento circulava quase que livremente durante o século XV e parte do XVI; festas cristãs e judaicas se misturavam, sendo que muitas das primeiras se inseriam na tradição israelita. ${ }^{29}$

Entretanto, de acordo com SOUZA (2009: 132), o estabelecimento da Inquisição em Portugal e a consequente perseguição aos judeus resultaram em emigrações em massa, o que originou uma colônia portuguesa de origem judia, em Amsterdã. Já em relação ao Oriente, a emigração tornara-se inviável a partir do ano de 1560, quando foi estabelecido o Tribunal do Santo Ofício em Goa, na Índia, único tribunal colonial português. ${ }^{30}$ Assim, segundo afirma SOUZA (2009: 132), além dos Países Baixos, o Brasil também se tornaria o local mais seguro para judeus e cristãos-novos, sendo considerado uma espécie de refúgio pelos que fugiam das perseguições inquisitoriais.

Assim, em Portugal, o Tribunal do Santo Ofício teve sua atuação autorizada somente no ano de 1536, após a publicação da bula Cum ad nihil magis. ${ }^{31}$ Tal bula estabelecia três bispos como inquisidores-gerais e possibilitava que o rei D. João III nomeasse um quarto

29 Laura de Mello e Souza, O diabo e a Terra de Santa Cruz: feitiçaria e religiosidade popular no Brasil colonial. São Paulo: Companhia das Letras, 2009, p. 132.

30 Idem, Ibidem.

31 Cf. MOTA, 2016, p. 27. 
inquisidor-geral, sendo um desses cargos delegado ao bispo de Ceuta, D. Diogo da Silva. Segundo BETHENCOURT (2000: 24):

[...] A bula de estabelecimento do tribunal Cum ad nihil magis, assinada pelo papa em 23 de maio de 1536, nomeava três bispos (de Ceuta, de Coimbra e de Lamego) como inquisidores-gerais, concedendo ao rei d. João III a possibilidade de nomear um quarto inquisidor-geral entre os bispos, religiosos ou clérigos seculares formados em teologia ou direito canônico. Essa bula foi apresentada em 5 de outubro do mesmo ano ao bispo de Ceuta, o franciscano d. Diogo da Silva, confessor do rei e do seu conselho, pelo dr. João Monteiro, do Desembargo Régio. [...].

Assim, em 22 de outubro do mesmo ano (um domingo), deu-se a cerimônia de publicação da bula, assinalando a fundação do Santo Ofício português, realizada na igreja catedral, diante do rei, do cardeal, do cabido, do inquisidor-geral, do clero e contando também com a presença do povo da cidade e dos arredores. ${ }^{32}$ Além disso, no dia 19 de novembro, ao final do tempo de graça, foi publicado um monitório divulgando os delitos que deveriam ser denunciados à Inquisição. De acordo com BETHENCOURT (2000: 25):

[...] No fim do tempo de graça (trinta dias), em 19 de novembro, o inquisidor-geral publicou um monitório com a descrição pormenorizada dos crimes sob jurisdição inquisitorial que deviam ser denunciados ao tribunal. A bula designava o judaísmo dos cristãos-novos, acrescentando o luteranismo, o islamismo, as proposições heréticas e os sortilégios. $[\ldots]$.

Entretanto, no ano de 1539, o bispo D. Diogo da Silva renunciou ao cargo de inquisidor-geral em razão de sua idade avançada e de questões de saúde, sendo o cargo posteriormente concedido ao Infante D. Henrique, irmão do rei D. João III.

[...] Em 3 de julho de 1539 o dr. João Monteiro, juiz do Desembargo do Paço e membro do Conselho Régio, apresentou ao arcebispo de Braga, infante d. Henrique, uma carta do bispo d. Diogo da Silva onde renunciava ao cargo de inquisidor-geral devido à sua idade e a problemas de saúde. Em seguida apresentou uma carta régia de 22 de junho, em que o próprio d. Henrique, irmão do rei, era nomeado inquisidor-geral (nomeação feita com o poder concedido pelo papa na bula de fundação da Inquisição em Portugal). [...]. ${ }^{33}$

Apesar de a bula Cum ad nihil magis ter sido publicada em 1536, o primeiro regimento da Inquisição portuguesa foi publicado somente mais tarde, em 1541. De acordo com MEA (2001: 165):

32 Cf. BETHENCOURT, 2000, p. 25.

33 BETHENCOURT, 2000, p. 26. 
O primeiro Regimento da Inquisição Portuguesa [...] data de 1541, mesmo se o tribunal existia desde a publicação da Bula "Cum ad nihil magis" de 1536. O facto explica-se em virtude da bula se constituir já definidora de certas regras e sobretudo pela nova dinâmica dada à instituição pelo Infante D. Henrique, Inquisidor Mor a partir de 1539, o qual cria, em 1541, tribunais locais no Porto, Coimbra, Lamego e Tomar, pelo que se acentua então a necessidade de existência duma actuação objectiva segundo critérios uniformes.

Entretanto, segundo as palavras de FERNANDES (2014: 200), o primeiro regimento da Inquisição data de 1552 e, além disso, a autora afirma que o Tribunal do Santo Ofício estabeleceu-se em Portugal somente em 1547, apesar de já estar presente no reino desde 1536:

A Inquisição se estabeleceu em Portugal, em 1547, por força da bula Meditati Cordis, de Paulo III. Já em 1536, o rei dom João III havia conseguido que o Tribunal do Santo Ofício atuasse no Reino, fazendo suas primeiras vítimas, apresentadas no primeiro Auto de fé, em 1540. Era regulamentado por um Regimento que foi modificado através dos tempos, conforme os interesses políticos e econômicos da instituição. O primeiro regimento data de 1552 . O segundo data de 1613 e vigorou até 1640, quando entrou em vigor o quarto Regimento, que durou 134 anos. Somente em 1774 o marquês de Pombal o substituiu, elaborando o quinto Regimento do Santo Ofício.

Até 1541, a bula Cum ad nihil magis, segundo afirma MEA (2001: 165), restringiu bastante o poder da Inquisição portuguesa, ao contrário do que ocorria no tribunal espanhol, estipulando que o Tribunal do Santo Ofício processasse de acordo com o direito comum, isto é, as denúncias não eram secretas.

Além disso, de acordo com MEA (2001: 165), entre os anos de 1536 e 1539, o processamento inquisitorial foi conduzido pela moderação, pelo rígido cumprimento da legalidade. Já as visitações do Tribunal do Santo Ofício foram propostas ao rei pelo inquisidor-mór dom Diogo da Silveira, no ano de 1536, a fim de penalizar os hereges, principalmente os acusados de práticas judaizantes.

Entretanto, havia disputas entre a coroa portuguesa e o papado, devido à problemática relacionada a quem teria a jurisdição sobre o tribunal, o que resultou no atraso de seu estabelecimento em Portugal. Contudo, tais divergências dissiparam-se quando D. João III ofereceu ao papa uma grande fortuna, para que pudesse exercer o poder sobre o tribunal, sem a interferência de Roma. ${ }^{34}$ 
Por volta de 1540, segundo MEA (2001: 166), era preso pela Inquisição apenas quem possuía, pelo menos, três denúncias diferentes e as falsas acusações sofriam uma punição exemplar, o que deixa de ocorrer mais tarde.

Todavia, em relação à bula Meditatio cordis, referida anteriormente, MEA (2001: 167) afirma que em 1547 a mesma "[...]confere à Inquisição portuguesa uma jurisprudência particular, permitindo o processo sigiloso, equiparando-a assim à congénere espanhola. [...]”. Além disso, a bula foi precedida de duas medidas substanciais: o perdão geral para os crimes cometidos no passado (exceto no caso de reincidência) e suspensão da pena do confisco de bens por mais dez anos. Contudo, D. João III proibiu a saída do reino aos cristãosnovos durante três anos, a não ser que fosse obtida autorização real.

É importante ressaltar que, no ano de 1548, somente os tribunais de Évora e Lisboa funcionaram e o tribunal de Coimbra foi restaurado somente no ano de $1565 .{ }^{35} \mathrm{~A}$ respeito da criação e localização desses tribunais, SIQUEIRA (1978: 122) comenta:

[...] A presença da corte em Évora, o domínio lisboeta sobre o mundo atlântico, o reduto cultural coimbrão parecem razões mais plausíveis para a fixação dos grandes distritos inquisitoriais. Eram lugares onde, obviamente, a circulação de idéias de procedência estrangeira poderia degenerar em heterodoxia. Pontos de concentração de cristãos-novos de maior destaque na sociedade do tempo: os que estavam ligados à administração central, à burguesia comercial e marítima de caráter internacional, e aos centros de formação profissional. Por esta razão, mereceria o Porto receber um tribunal, mas Coimbra era próxima, e mais culta. E mais corte. Capital teológica do Reino.

A criação do único tribunal em colônia portuguesa, o tribunal de Goa, na Índia, efetivou-se no dia 15 de março de 1560. De acordo com SIQUEIRA (1978: 122):

Aos 15 de março de 1560 foi criada a Inquisição de Goa, com jurisdição sobre todos os domínios portugueses além do Cabo da Boa Esperança: todas as possessões da Ásia e da costa oriental da África.

Além disso, como mencionado anteriormente, o Cardeal D. Henrique, inquisidorgeral, proveu o Santo Ofício português de um verdadeiro regulamento, que garantia uma eficácia maior e controle efetivo, desenvolvendo simultaneamente uma política dinamizadora, com o objetivo de tornar a Inquisição portuguesa uma instituição independente, dotada de meios próprios. ${ }^{36}$ É relevante enfatizar que o que favoreceu o projeto de D. Henrique referente

35 MEA, 2001, p. 167.

36 Ver MEA, 2001, pp. 167-168. 
ao Santo Ofício português foi o fato de ele ter se tornado regente, a partir de 1562, durante o período da menoridade de D. Sebastião e, mais tarde, após a morte do rei. ${ }^{37}$

O Regimento de 1552 deriva da legislação pontifícia referente à Inquisição medieval e "[...] situa-se na esteira dos códigos civis portugueses, as Ordenações Afonsinas e Manuelinas, [...]." ${ }^{38}$ Tal Regimento é um conjunto de ofícios e oficiais, desdobrando-se em artigos enumerando inquisidores, letrados de boa consciência, promotores, notários, meirinhos, entre outros cargos. ${ }^{39}$ Além disso, MEA (2001: 168) também afirma que nos primeiros tempos do tribunal português, houve predominante presença de homens de leis.

Outra característica da Inquisição portuguesa no século XVI é o fato de o tribunal encarar os crimes de blasfêmia e feitiçaria com mais benevolência, porém, dada a especificidade do tribunal, declaravam-se prisões preventivas a tempo indeterminado; sigilo na identidade e dados cronológico-geográficos dos denunciantes, procedimento autorizado pelo papa somente em 1560; e a pena de morte, que se estendia a hereges falecidos e pessoas ausentes, pena esta aplicada pela justiça secular. ${ }^{40}$ Entretanto, a partir da década de 1570, a Inquisição portuguesa deixa de condenar defuntos e ausentes. ${ }^{41}$

De acordo com MEA (2001: 169), os códigos espanhol e português, mas principalmente o português, conferiam uma grande margem de manobra ao arbítrio dos inquisidores, que julgavam para além dos atos, intenções e sentimentos, constituindo-se de uma prática recorrente.

Ainda no ano de 1552, estabeleceu-se o Regimento do Colégio da Doutrina da Fé, cuja função era reinserir os réus na comunidade cristã, por meio do conhecimento da doutrina católica. Nas palavras de MEA (2001: 169):

Ainda em 1552 surge o Regimento do Colégio da Doutrina da Fé, com o objectivo de reinserção dos réus no seio da Igreja, mediante o conhecimento da doutrina, pelo que evidencia grande flexibilidade e tolerância, como o demonstram a possibilidade de comunicar com parentes e amigos. [...].

Ainda durante o mesmo século, o Santo Ofício português sofreu com a falta de funcionários, causada por carência de meios financeiros, questões relacionadas às habilitações

37 Cf. MEA, Op. cit., p. 168 (nota de rodapé).

38 Cf. MEA, Idem, p. 168.

39 MEA, 2001, p. 168.

40 Cf. MEA, Idem, Ibidem.

41 MEA, Idem, Ibidem (nota de rodapé). 
para os cargos, pagamentos atrasados, sobrecarga de trabalho, entre outros fatores. Conforme assegura MEA (2001: 169):

Assim, por uma carência crónica de meios financeiros, problemas ligados às habilitações para os cargos e aos ordenados (em que era habitual o atraso nos pagamentos), sobrecarga de trabalho etc, foi constante o déficit de funcionários a vários níveis, mesmo recorrendo a tarefeiros, pelo que durante o século XVI, é frequente existirem em cada tribunal menos inquisidores e deputados que o estipulado, com todos os perigos e falhas que uma tal situação acarreta. No final do século começam-nos a aparecer altos funcionários familiares de outros, o que era ilegal.

Já em relação ao cargo de procurador, MEA (2001: 169) afirma que tal cargo deveria ser ocupado por um cristão-velho e que fosse "pessoa de confiança", porém, o próprio Regimento não traz uma explicação mais específica a este respeito, sendo problemático o modo como o cargo de procurador é apresentado no documento. Além disso, os inquisidores tinham poder para suspender o procurador, alegando "justa causa". ${ }^{42} \mathrm{O}$ procurador também fazia juramento de sempre defender o réu, podendo, porém, desistir da causa, informando a decisão aos inquisidores:

O cargo de procurador tal como é definido no Regimento é muito discutível, na medida em que para além de cristão-velho devia ser "pessoa de confiança", não se especificando de quem, muito embora os inquisidores tenham poder para o suspender "com justa causa". Fazendo juramento de defender sempre o réu, simultaneamente consigna-se que se "vir e conhecer que não tem justiça, o manifestará à parte e dirá aos inquisidores na Mesa do Santo Ofício e desistirá da causa". [...]. ${ }^{43}$

Na documentação aqui utilizada para análise, consta que o procurador das rés Thereza Leyte e Escholastica Pinta da Sylva é o Doutor Joaó de Saó Payo Peyxoto:

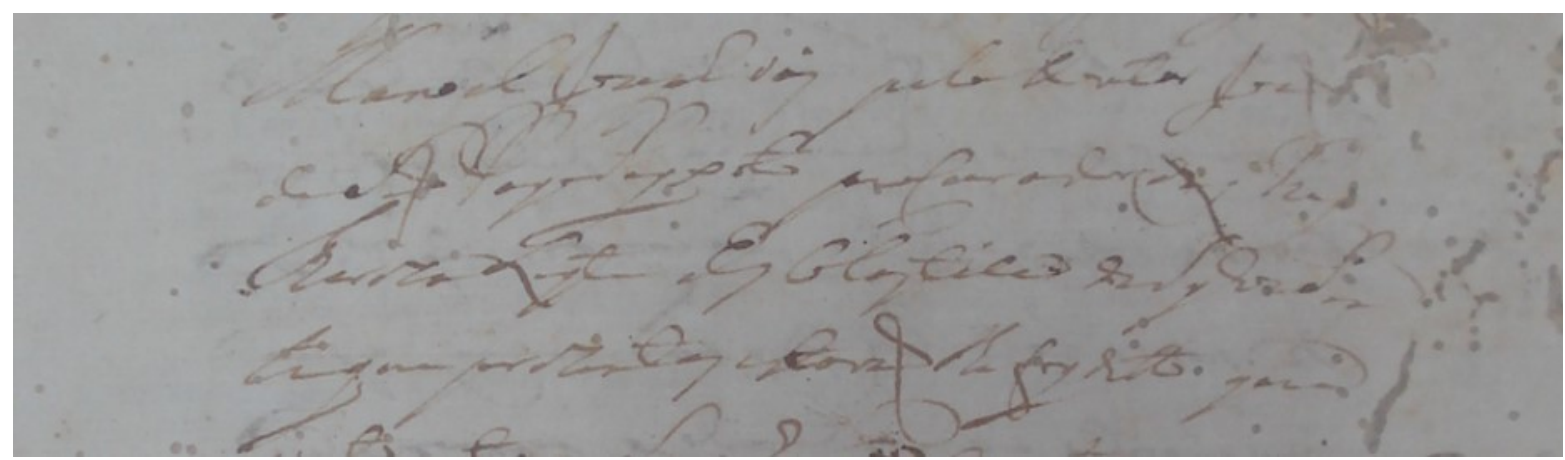

(Fólio 8 r. - Polycarpo de Abreu Nogueyra)

42 MEA, 2001, p. 169

43 MEA, Idem, pp. 169-170. 


\author{
Manoel Jozeph vás peloDoutor Joã̃ \\ deSaõ PayoPeyxoto proCurador das Res \\ Thereza Leyte eEs Colastica daSylvaPin \\ taque preZentes estavaõ lhefoy ditto que
}

O curador, outro funcionário do Santo Ofício, cuja presença era obrigatória para prestar assistência aos réus menores de vinte e cinco anos, nem sempre era nomeado, ou era nomeado somente quando o processo chegava à fase do libelo, podendo ser nomeado até mesmo depois. ${ }^{44}$

As instruções que os inquisidores recebiam eram, em alguns aspectos, indefinidas, o que deixava uma grande margem de critérios a cargo da personalidade de cada inquisidor, visto que ele tinha poder para julgar sentimentos, sinais de estados emocionais, entre outros. ${ }^{45}$ Além disso, MEA (2001: 170) afirma que o inquisidor também era dotado de poder para "[...] apurar como deve parecer "uma boa e verdadeira confissão", precisar objectivamente qual o crédito a dar aos testemunhos, enfim, determinar quando e como actos e intenções se tornam delitos."

Entretanto, as visitações do Santo Ofício eram bastante custosas e incômodas, pois não estavam estabelecidas sua obrigatoriedade e periodicidade, sendo mais frequentes a partir da década de 1560. De acordo com MEA (2001: 171):

Como não estava determinada a obrigatoriedade e periocidade das visitações, eram bastante onerosas e tremendamente incómodas, a sua execução concretizou-se mais a partir dos anos sessenta, mercê da actividade regular do Santo Ofício e da acção do Conselho Geral, dandose-lhe relevo no Regimento do Conselho Geral do Santo Ofício de 1570.

O Regimento do Conselho Geral surgiu como resultado da reformulação do Conselho Geral, em 1569, o que constituiu-se de mais um passo para a estruturação e autonomia da Inquisição portuguesa. ${ }^{46}$ Segundo MEA (2001: 171), o objetivo do Conselho Geral era preencher uma lacuna presente nos procedimentos inquisitoriais, pois, à altura do ano de 1569 era impossível que o Inquisidor geral constituísse última instância, esclarecesse dúvidas, apurasse casos mais complexos, controlasse os tribunais e, principalmente, tornou-se impossível a ele ser “[...] o garante último de idoneidade e isenção. ",47

44 Cf. MEA, 2001, p. 170.

45 Cf. MEA, Idem, Ibidem.

46 MEA, 2001, p. 171 (em nota de rodapé).

47 Cf. MEA, Op cit., p. 171 (em nota de rodapé). 
Além de ser um órgão de consultoria, o Conselho Geral constituía-se de um tribunal de recurso, possuindo poderes para conceder fiança a pessoas presas por heresia, após os inquisidores distritais e o inquisidor-geral terem sido ouvidos; substituir penas; substituir o inquisidor-geral quando este estivesse ausente; e fiscalizar seu desempenho. ${ }^{48}$ Além de todos esses poderes, o Conselho também tinha a função de elaborar róis de livros proibidos, providenciar visitas à livrarias e fornecer autorização para os inquisidores censurarem proposições. $^{49}$

Em relação aos crimes de bigamia, feitiçaria e blasfêmia (considerados crimes menores), MEA (2001: 172) afirma que há problemas, pois, em tese, cabia ao Tribunal do Santo Ofício identificar e julgar a heresia ou intenção herética, porém, na prática, não era tão simples, pois era difícil estabelecer fronteiras entre o que era, de fato, heresia e o que não era, o que podia resultar em contestação por parte da autoridade eclesiástica. Vale lembrar que o cerne do tribunal era a perseguição ao judaísmo, assim, as perseguições recaíram com mais força sobre seus adeptos, o que absorveu tribunais inteiros durante o século XVI. ${ }^{50}$

Outro ponto importante a ser mencionado é o fato de que, segundo afirma MEA (2001: 172), cristãos-velhos e cristãos-novos não recebiam (e nem deviam receber) o mesmo tratamento diante do tribunal, mesmo em função da gravidade do delito denunciado.

No ano de 1583, o Conselho Geral fez várias advertências, com o objetivo de que houvesse cautela em relação ao crédito dado às testemunhas, o que não foi efetivo, exceto nos casos em que se podia identificar falso-testemunho. Nas palavras de MEA (2001: 173): "Em 1583 aparecem várias indicações do Conselho Geral no sentido de haver muito cuidado com o crédito a dar às testemunhas, o que não se verifica, a não ser em casos de perjúrio mais ou menos evidente. [...]."

Já no início do século XVII, o Conselho Geral determinou que antes de se prender pessoas por um único testemunho de parente próximo, o caso deveria ser averiguado pelo próprio Conselho, o que levou, em 1604, os inquisidores de Coimbra a queixarem-se desta providência, pois, de acordo com MEA (2001: 173), na cidade portuguesa de Guimarães muitos cristãos-novos haviam fugido, em razão de não serem imediatamente presos, mesmo em função de uma única denúncia feita por algum estranho.

48 Cf. MEA, Op. cit., p. 171 (em nota de rodapé).

49 Cf. MEA, Idem, Ibidem (em nota de rodapé).

50 Cf. MEA, 2001, p. 172. 
A abolição do Tribunal do Santo Ofício se inicia a partir do século XVIII na Itália e ocorre na Espanha e em Portugal no século XIX. Em relação ao fim da Inquisição na Itália, BETHENCOURT (2000: 377) afirma:

[...] os decretos de abolição da Inquisição nos diferentes Estados italianos sucedem-se entre 1746 e 1800 , quer no quadro da ação de governos "iluminados" - como em Nápoles, em 1746; Parma, em 1768; Milão, em 1775; Toscana e Sicília, em 1782; ou Modena, em 1785 -, quer no quadro das invasões francesas, entre 1796 e 1800, em Veneza, Gênova e Turim. [...].

Especificamente em relação ao caso da abolição do tribunal na Sicília, é importante ressaltar que abolir a Inquisição foi uma decisão do próprio rei Fernando III, aconselhado pelo vice-rei, o marquês de Villamaina Domenico Caracciolo, e apoiada pelos membros de seu governo. ${ }^{51}$ Portanto, apesar das resistências do Senado de Palermo e do inquisidor-geral, em 12 de março, o vice-rei ordenou o encerramento das atividades da Inquisição e o controle dos arquivos, que foram todos selados. Assim, no dia 16 de março de 1782, o rei Fernando III publicou o decreto de abolição do Tribunal do Santo Ofício. ${ }^{52}$

Segundo BETHENCOURT (2000: 381), no caso da Espanha, a abolição da Inquisição resultou da invasão pelas tropas de Napoleão, no ano de 1808. José Bonaparte foi reconhecido como rei e uma nova Constituição foi aprovada. Apesar das tentativas do tribunal de garantir sua sobrevivência por meio do reconhecimento do novo poder, no dia 4 de dezembro de 1808 , o decreto de abolição do Santo Ofício foi assinado pelo próprio Napoleão, quando de sua chegada a Madri. Segundo esse decreto, os bens do tribunal deveriam ser sequestrados e a Coroa deveria se apropriar deles, com a finalidade de pagar a dívida pública. ${ }^{53}$ Em seguida, houve a retomada das instalações do tribunal pelas autoridades civis, houve também uma primeira destruição dos arquivos e os presos foram colocados em liberdade..$^{54}$

Todavia, a corte de José Bonaparte fugiu da Espanha no ano de $1813^{55}$ e, mesmo após essa primeira abolição do Santo Ofício, as cortes estavam reunidas em Cádiz desde 1810, discutindo a problemática da Inquisição, tornada emblema do Antigo Regime. De acordo com BETHENCOURT (2000: 383):

[...] Aqui, o debate sobre a Inquisição começou com a invasão francesa e a ruptura dos mecanismos de censura, mesmo nos territórios que tinham escapado à dominação estrangeira. O futuro do "Santo Ofício" polarizou

51 Cf. BETHENCOURT, 2000, p. 378.

52 Cf. BETHENCOURT, Idem, pp. 378-379.

53 Ver BETHENCOURT, Idem, p. 382.

54 Ver BETHENCOURT, 2000, p. 382.

55 Cf. BETHENCOURT, Op. cit., pp. 383-384. 
as opiniões de todos os que tinham se juntado para expulsar o invasor, debate que se estendeu às cortes reunidas em Cádiz desde 1810, pois os atos dos ocupantes tinham sido julgados nulos. [...].

Assim, a Constituição liberal foi aprovada em 1812 e reorganizou o debate em torno da questão da compatibilidade do tribunal com a nova Constituição. Tal discussão foi fortemente influenciada inclusive pelo exemplo da abolição da Inquisição na Sicília, caso citado de forma explícita durante as discussões da assembleia. ${ }^{56} \mathrm{~A}$ decisão final de abolir o Tribunal do Santo Ofício na Espanha foi tomada em fevereiro de 1813. Nas palavras de BETHENCOURT (2000: 383):

[...] A decisão final de abolir o tribunal, tomada em 22 de fevereiro de 1813, retomou e adaptou o decreto de abolição da Inquisição da Sicília, pois o tribunal foi julgado incompatível com a Constituição e a jurisdição sobre os delitos de heresia foi reconhecida de novo aos bispos, cujo procedimento de inquérito devia ser conforme com as constituições e as leis do Reino. [...].

Entretanto, segundo afirma BETHENCOURT (2000: 383), a situação logo se inverteu: o rei Fernando VII regressou e declarou nulos os decretos das cortes de Cádiz em 4 de maio de 1814, revelando a fragilidade da posição liberal e restabelecendo a Inquisição. Além disso, com o objetivo de tornar tal feito mais explícito, o rei publicou um decreto específico em 21 de julho do mesmo ano, investindo o Santo Ofício de todos os poderes que possuía antes da primeira abolição. ${ }^{57}$ Em seguida, foi nomeado um novo inquisidor-geral e a rede dos tribunais foi reorganizada, sendo suas primeiras tarefas recuperar os bens e reiniciar as atividades contra a maçonaria. Além da metrópole, a América espanhola também foi afetada pelo restabelecimento da Inquisição. De acordo com BETHENCOURT (2000: 384): “[...] $O$ tribunal também foi restabelecido na América espanhola (Lima, México, Cartegena de Índias), por decreto de 31 de julho de 1815."

O Tribunal do Santo Ofício havia se tornado um emblema e sua atividade antes da primeira supressão, em 1808, já era bastante fraca. De acordo com BETHENCOURT (2000: 384):

[...] O "Santo Ofício" tinha se tornado sobretudo um emblema, um objeto simbólico das lutas políticas e sociais da época, não podendo voltar a ser um instrumento eficaz de intervenção e de controle social. É essa função emblemática que explica a violência desencadeada pela revolução liberal de 1820 contra o tribunal. [...].

56 Cf. BETHENCOURT, Op. cit., p. 383.

57 Cf. BETHENCOURT, Idem, Ibidem. 
Consequentemente, os motins que se desencadearam em diversas cidades a favor da Constituição de Cádiz conduziram ao assalto e saque de várias sedes do tribunal, particularmente em Madri, Saragoça, Santiago, Barcelona, Valência, Sevilha e Maiorca. Além disso, tais motins também obrigaram o rei Fernando VII a prestar juramento de fidelidade no dia 7 de março e, dois dias depois, em 9 de março de 1820, o rei publicou um decreto de abolição da Inquisição, declarando-a incompatível com a Constituição do Reino. Todavia, a ação direta dos rebeldes havia se antecipado em relação à ação legislativa. ${ }^{58} \mathrm{~A}$ respeito dessa situação conturbada, BETHENCOURT (2000: 384) comenta:

[...] Trata-se, obviamente, de uma mudança radical da opinião das forças liberais e do resultado de sua reorganização, mas o equilíbrio de forças não tinha sido completamente invertido, pois a invasão da Santa Aliança em apoio aos realistas, em 1823, restabeleceu a situação anterior a 1820. De novo se organizam petições em favor da Inquisição, cuja função emblemática tinha sido sublinhada pelos realistas espanhóis, que gritavam em seus combates: "Rey absoluto y Inquisición! Mueran los negros [liberais]!", mas as forças francesas de ocupação pressionaram o rei a não restabelecer o tribunal, ao mesmo tempo que a ascensão das forças realistas mais radicais, organizadas em torno da figura do irmão mais novo, Don Carlos, convenceram o rei a renunciar ao projeto. [...].

Entretanto, apesar do decreto específico de abolição do Santo Ofício, a nova supressão da Constituição de Cádiz, no ano de 1823, gerou uma situação de ambiguidade a respeito do tribunal. Logo, em 1824 e 1825, essa situação foi explorada por bispos que criaram juntas de fé para perseguir os crimes de heresia, organizações que possuíam como objetivo a retomada do processo inquisitorial. ${ }^{59}$

Todavia, a relação de forças entre liberais e absolutistas se inverteu devido à morte do rei Fernando VII, em 1833, e à ameaça das forças carlistas, o que impôs o esclarecimento acerca da posição do novo governo. Deste modo, em julho de 1834, o Tribunal do Santo Ofício foi finalmente abolido:

[...] Assim, em 15 de julho de 1834, foi publicado o decreto de abolição definitiva da Inquisição na Espanha, sem justificação prévia, exceto a necessidade de assegurar os princípios de justiça, pois a religião era suficientemente protegida pela autoridade dos bispos. [...]. ${ }^{60}$

58 Ver BETHENCOURT, 2000, p. 384.

59 Cf. BETHENCOURT, Idem, Ibidem.

60 BETHENCOURT, 2000, pp. 384-385. 
Finalmente, foi estabelecido que os bens do tribunal e as rendas dos cabidos eclesiásticos (anteriormente recebidas pelo Santo Ofício) deveriam ser destinados ao pagamento da dívida pública. ${ }^{61}$

Já em relação à abolição do Tribunal do Santo Ofício em Portugal, os poderes públicos, principalmente a Coroa, se mostraram dispostos a sacrificar o tribunal colonial de Goa bastante cedo. Portanto, segundo BETHENCOURT (2000: 385), a posição política do poder central a respeito da situação da Inquisição é mais flexível do que a posição espanhola. Além disso, a revolução liberal de 1820 teve um papel fundamental na supressão do Santo Ofício português.

[...] A outra vertente do processo de supressão do "Santo Ofício" em Portugal é a do debate limitado ao quadro da Assembléia Constituinte estabelecida depois da revolução liberal de 1820: não existem confrontos prévios e não existe recuo posterior. A decisão é tomada de uma forma seca, depois de uma discussão pouco dramática em que todos estavam de acordo, mesmo os inquisidores presentes, sobre a inutilidade do tribunal. A Inquisição foi abolida sem motins, tranqüilamente, o que permitiu conservar todos os arquivos e fazer o inventário dos bens. [...]. ${ }^{62}$

Especificamente acerca do tribunal de Goa, a supressão desse tribunal foi proposta pelo inquisidor-geral, Cardeal da Cunha, no dia 6 de abril de 1773 e foi aceita pelo rei no mesmo dia. Em relação aos motivos que levaram à abolição desse tribunal, BETHENCOURT (2000: 385) afirma:

[...] O texto, repetido na provisão de 20 de janeiro de 1774 , invoca a perda de muitos dos territórios portugueses na Ásia e o declínio do comércio desde o século XVII (é feita alusão à "fatal união desses reinos à Monarquia da Espanha"), assim como a redução radical do aparelho do Estado português no Oriente, sobretudo o da administração da Justiça, para justificar a decisão de suprimir o tribunal. A pequena dimensão do distrito é comparada com os territórios do Brasil, sempre sob a jurisdição do tribunal de Lisboa. [...].

Assim, no lugar de um tribunal propriamente dito, haveria um comissário, assim como na América portuguesa, para recolher informações e enviar os suspeitos de heresia a Portugal. Dessa forma, o tribunal de Lisboa assumiria a tarefa de garantir a jurisdição sobre os crimes de heresia em todo o Império português. ${ }^{63}$ No dia 8 de fevereiro de 1774 , o inquisidor-geral ordenou que a provisão anterior fosse executada, que os presos fossem colocados em

61 Cf. BETHENCOURT, Op. cit., p. 385.

62 BETHENCOURT, Idem, Ibidem.

63 Cf. BETHENCOURT, 2000, p. 385. 
liberdade e que os processos ainda em curso fossem enviados para o Conselho Geral. ${ }^{64}$ Além disso, segundo afirma BETHENCOURT (2000: 386), o marquês de Pombal também teve participação no processo de abolição do tribunal de Goa:

[...] Em 10 de fevereiro de 1774, o marquês de Pombal expediu uma carta ao governador da Índia portuguesa, na qual critica a ação anterior dos inquisidores locais e ordena a rápida execução da provisão do inquisidor-geral - em caso de resistência dos inquisidores, o marquês recomenda sua detenção como rebeldes e seu envio no primeiro navio para serem julgados em Lisboa. Uma carta do ouvidor-geral de Goa, datada de 22 de fevereiro de 1775 , dá conta da imediata execução da provisão, com a libertação dos presos e o inventário e seqüestro dos bens do tribunal, sem nenhuma oposição dos inquisidores.

Essa primeira abolição do Santo Ofício em Goa foi formalmente proposta pelo próprio inquisidor-geral e, por isso mesmo, mostrou-se pacífica, aparentando ser uma decisão racional. Segundo BETHENCOURT (2000: 386):

[...] a abolição do tribunal foi formalmente proposta pelo inquisidorgeral, o que simulava uma legitimidade "interna" do processo. Além disso, os argumentos do cardeal da Cunha parecem razoáveis, podendo indicar não uma política seletiva de abolição a longo prazo, mas uma simples racionalização da rede. [...].

Entretanto, a carta do marquês de Pombal gerou dúvidas acerca dos reais motivos da abolição desse tribunal: "[...] os inquisidores de Goa são explicitamente apresentados como desobedientes ao poder régio, e as ordens de prisão em caso de resistência mostram claramente as tensões latentes. [...]." 65

Assim, o tribunal de Goa foi novamente instaurado em 4 de abril de 1778, e seu restabelecimento foi ordenado pelo mesmo inquisidor-geral cerca de um ano após a morte de D. José e da imediata destituição do marquês de Pombal, o que deixa claro que as razões para a supressão do tribunal não eram puramente administrativas. ${ }^{66}$ Em relação aos motivos apresentados para o restabelecimento da Inquisição em Goa, BETHENCOURT (2000: 386) comenta: “[...] As justificações apresentadas - a retomada dos ritos gentílicos, a ofensa contra a religião cristã e as ameaças de recuo dos convertidos - não são convincentes, tanto mais que a abolição ocorrera havia menos de três anos."

Se, por um lado, havia o desejo de se restabelecer o tribunal em Goa - reafirmando o papel da Inquisição na perseguição contra a heresia -, por outro, o Santo Ofício era acusado 
de ser o responsável pela decadência do comércio e da atividade econômica dos estabelecimentos portugueses na Ásia. Portanto, a abolição do Tribunal do Santo Ofício seria uma estratégia para Portugal recuperar seu poder político, militar e econômico na Ásia. ${ }^{67}$

Apesar da resistência do Santo Ofício, o tribunal de Goa se manteve frágil e vulnerável diante de tal circunstância, principalmente após sua primeira abolição. Logo, a referida conjuntura levou o governo português (que já se encontrava refugiado no Brasil, após a invasão francesa) a reconhecer o princípio de tolerância religiosa em Goa no tratado de comércio com a Inglaterra, assinado no ano de 1810. Assim, no dia 16 de junho de 1812, o príncipe regente determinou a supressão do tribunal de Goa e foi estabelecida a tolerância de todos os cultos religiosos nos territórios portugueses da Ásia. ${ }^{68}$ Em relação à influência inglesa nesse cenário, BETHENCOURT (2000: 387) afirma:

[...] Evidentemente, os ingleses encontravam-se em posição de força, pois tutelavam nesse momento os territórios portugueses na Ásia e de seu apoio militar dependia a recuperação do território do Reino na península Ibérica para a Coroa portuguesa, mas os efeitos da nova política esboçada por Pombal contribuíram para a aceitação dessa solução.

Portanto, a abolição do tribunal da Inquisição de Goa resultou de uma soma de fatores, sendo eles: a política do marquês de Pombal, a crise do Império português na Ásia, a dependência em relação à Inglaterra e a invasão francesa.

O caso português apresenta, portanto, traços bastante originais, em que a prevalência da razão de Estado desde o governo de Pombal, conjugada com o aprofundamento da crise do Império português na Ásia, conduziu à supressão de um tribunal periférico mas com enorme atividade, supressão temporária que só se tornou definitiva com a pressão inglesa e com a ocupação do Reino pelas tropas de Napoleão. [...]. ${ }^{69}$

Já precisamente em Portugal, a Inquisição foi abolida no ano de 1821, após a revolução liberal ocorrida em 1820. De acordo com BETHENCOURT (2000: 396):

A abolição definitiva de todos os tribunais da fé em Portugal, em 1821, insere-se já no contexto da revolução liberal, que mudou completamente as relações de poder, introduzindo uma ruptura com os equilíbrios e as articulações políticas anteriores. [...]. Em uma palavra, a Inquisição sofreu uma perda de poder e, sobretudo, de imagem, tendo sido cada vez mais desvalorizada como organismo de controle e como organismo ativo no campo dos poderes.

67 Cf. BETHENCOURT, Idem, Ibidem.

68 Ver BETHENCOURT, Op. cit., p. 387.

69 BETHENCOURT, 2000, p. 387. 
Assim, um mês e meio após a revolução liberal, no dia 6 de outubro de 1820, a junta provisória de governo ordenou ao Conselho Geral da Inquisição e a todos os oficiais do Santo Ofício que prestassem juramento de fidelidade e obediência ao governo instaurado, às cortes convocadas e à futura Constituição. ${ }^{70}$ Em 13 de outubro, tal juramento foi prestado no palácio da Inquisição de Lisboa e os membros do Conselho assinaram o respectivo documento notarial no mesmo dia. A primeira sessão das cortes ocorreu no dia 26 de janeiro de 1821 e, na oitava sessão, ocorrida em 8 de fevereiro, o deputado Francisco Simões Margiocchi propôs um projeto de decreto de abolição do Tribunal do Santo Ofício. Apesar da presença de um membro do Conselho Geral da Inquisição entre os deputados, o projeto não suscitou nenhuma oposição. O referido projeto de abolição do tribunal foi votado no dia 24 de março, devido a um rumor de que a Inquisição havia empregado novos funcionários, que seriam favorecidos pelas pensões de reforma previstas nesse projeto. ${ }^{71}$ Logo, esse boato suscitou uma discussão acalorada acerca dos malefícios da Inquisição. Segundo BETHENCOURT (2000: 388):

[...] Desencadeia-se então uma discussão mais viva, em que intervêm argumentos explícitos sobre os malefícios e a monstruosidade do tribunal - a desmoralização deste é tal que o inquisidor presente limita-se a justificar o estabelecimento do "Santo Ofício" pelo espírito intolerante da época, atribuindo sua persistência em Portugal "às causas morais que retardaram os progressos do entendimento humano". Nesse discurso, o inquisidor sublinha a adaptação do tribunal às "luzes do século" e vota a favor de sua extinção, considerando-a inútil e incompatível com o governo constitucional.

No dia 23 de março, por ordem da regência do Reino, o Conselho Geral da Inquisição foi convocado para participar de uma missa solene, realizada em 29 de março na igreja de São Domingos. $\mathrm{Na}$ ocasião, todas as autoridades civis e militares prestaram juramento de fidelidade às bases da Constituição, que haviam sido aprovadas pelas cortes. ${ }^{72}$

As cortes enviaram o decreto final para a regência do Reino em 31 de março do mesmo ano. Assim, o decreto de abolição do Tribunal do Santo Ofício português foi publicado no dia 5 de abril de $1821 .^{73} \mathrm{O}$ primeiro artigo desse decreto reproduzia a argumentação das cortes de Cádiz, considerando a Inquisição incompatível com as bases da Constituição. Em seguida, a jurisdição espiritual sobre os crimes de heresia foi restituída à Justiça episcopal e as leis e ordens do Santo Ofício foram revogadas. Além disso, os bens do

70 Cf. BETHENCOURT, 2000, p. 388.

71 Cf. BETHENCOURT, Idem, Ibidem.

72 Cf. BETHENCOURT, 2000, p. 389.

73 Ver BETHENCOURT, Op. cit., p. 388. 
tribunal foram integrados ao Tesouro Nacional; os livros, processos e manuscritos foram incorporados à Biblioteca Pública de Lisboa; e pensões de reforma foram concedidas aos funcionários. ${ }^{74}$ De acordo com BETHENCOURT (2000: 388-389):

[...] Com efeito, todo o processo de abolição se desenrola de uma forma pacífica, de onde resulta que a documentação inquisitorial tenha se conservado praticamente intacta, tendo os deputados liberais explicitamente definido o objetivo de guardar a memória da intolerância. $[\ldots]$.

Os últimos ritos de extinção da Inquisição portuguesa se caracterizaram pela abertura das portas dos palácios do tribunal e pela profanação do espaço pelo público, que foi autorizado a percorrer os cárceres e as câmaras secretas. Além disso, “[...] a estátua da fé, colocada na rua, na esquina do palácio, era retirada. [...]. ",75

\subsection{O TRIBUNAL DO SANTO OFÍCIO NA AMÉRICA PORTUGUESA}

De acordo com as palavras de FERNANDES (2014: 143), "a Inquisição esteve presente e atuante na Colônia, interferindo profundamente na vida colonial durante mais de dois séculos, perseguindo portugueses, brasileiros, africanos e índios."

Durante a primeira metade do século XVI, a América portuguesa estava "relativamente a salvo do furor persecutório inquisitorial da segunda metade do século XVI" (VAINFAS, 1997: 6 apud MOTA, 2016: 27). Tal fato influenciou a chegada de muitos cristãos-novos à colônia. Sua presença na colônia estava diretamente relacionada à comercialização de pau-brasil.

Nos primeiros anos da colonização, Portugal não se interessou tanto pelo território americano, pois, à época, o reino português estava empenhado no comércio de especiarias originárias da Índia, como o cravo, a canela, o gengibre e a pimenta. Entretanto, o crescente interesse dos franceses, que também estavam explorando o pau-brasil na colônia portuguesa, fez os portugueses mudarem de posição. Segundo DORIA (2012: 53 apud MOTA, 2016: 28): "[...] os franceses tinham os tupinambás, de Angra dos Reis, Cabo Frio e Guanabara em boa conta. Os nativos faziam fortunas para os normandos [...]”.

O tráfico e comércio do pau-brasil por parte dos franceses preocupavam Portugal. A presença francesa representava, portanto, uma ameaça à Coroa portuguesa, levando Portugal a 
intensificar o povoamento e a defesa nas terras recém-colonizadas. Além disso, a fundação da França Antártica pelos franceses, no ano de 1555, na Baía de Guanabara foi, de acordo com MOTA (2016: 28), um “fator que exerceu grande influência para a metrópole legitimar o processo de colonização”.

Apesar da crescente preocupação em ocupar as terras do Brasil, organizar e estabelecer o cristianismo na colônia ainda não eram prioridades da Coroa (nem da Igreja Católica). Assim, tal tarefa ficou a cargo dos padres jesuítas. Segunda SOUZA (2009: 118119):

Sujeito por mais de meio século à jurisdição do bispado de Funchal, contando, nos subsequentes cem anos, com um único bispado - o da Bahia -, o Brasil colônia teria nos jesuítas os primeiros organizadores do seu catolicismo. A instituição do Padroado, anterior à descoberta, fazia da Coroa portuguesa o patrono das missões católicas e instituições eclesiásticas na África, Ásia e, depois, no Brasil. Foi o Padroado que incentivou e sustentou missionários em terras coloniais, antecipando-se à Igreja romana e ocupando um espaço vago.

A criação do bispado da Bahia deu-se no ano de 1551, período durante o qual ocorria o Concílio de Trento, cujas prioridades também não abarcavam o mundo ultramarino, compreendendo apenas a Europa. As preocupações da Igreja, portanto, voltaram-se para a colônia apenas no século XVII. De acordo com SOUZA (2009: 119):

[...] Por ocasião da criação do bispado da Bahia (1551), desenrolava-se o Concílio de Trento (1545-1563); entretanto, apesar de este ter representado, de certa forma, o triunfo da cristandade meridional, não colocou o mundo ultramarino no centro de suas preocupações imediatas. Voltado para a Europa, não teve sequer um prelado colonial que assistisse às suas sessões. Só no século XVII é que Roma passaria a se preocupar com a evangelização do mundo colonial, $[\ldots]$.

A primeira visita do Tribunal do Santo Ofício ocorreu somente em 1591, o que evidencia o pouco interesse que Portugal possuía na colônia, tendo em vista que a autorização para a criação do Santo Ofício ocorreu no ano de 1536, em Portugal. FERNANDES (2014: 143) afirma:

No Brasil, o Tribunal da Inquisição iniciou suas atividades em 12 de fevereiro de 1579, durante o reinado do cardeal dom Henrique, quando dom Antonio Barreiros, bispo e governador da Bahia, foi designado comissário do Santo Ofício. Permaneceu até às vésperas da Independência, atuando por intermédio de seus comissários e familiares. 
Devido à ausência de um tribunal oficial na Bahia, os casos de foro religioso deveriam ser analisados pelo bispo, à época, dom Antônio Barreiros. Segundo Frei Vicente do Salvador (1982: 202 apud MOTA, 2016: 29): “Até a vinda do visitador o bispo da Bahia era o comissário do tribunal com apelação para a metrópole”. Portanto, o Tribunal do Santo Ofício estava presente na colônia, mesmo não havendo inquisidores oficiais. Ainda segundo MOTA (2016: 29):

A responsabilidade atribuída à autoridade episcopal revela que as lentes do Santo Ofício estavam representadas na colônia, mesmo sem a presença oficial de inquisidores. Em contrapartida, o fato de não haver representantes legais permitiu que pairasse certa tranquilidade aos cristãos-novos, que vieram para o Brasil fugidos das perseguições implantadas em Portugal.

Segundo FERNANDES (2014: 143): "O Tribunal do Santo Oficio nunca foi oficialmente implantado no Brasil como o foi em Portugal. Nem precisava. Qualquer religioso regional fazia o papel de Inquisidor.”

Devido ao fato de que não havia representantes oficiais do Santo Ofício na colônia, os casos de heresia ficavam a cargo dos comissários, no caso da Bahia, de dom Antonio Barreiros. FERNANDES (2014: 144) afirma:

Comissários eram homens do clero, representantes do Tribunal. Tinham o poder de prender e o dever de informar tudo à Lisboa, encarregada dos casos brasileiros. Para o julgamento dos casos especiais, os comissários poderiam contar com os visitadores oficiais. Eram, portanto, os inquisidores da Colônia, podendo agir e tomar todas as atitudes que os inquisidores tomavam, inclusive examinar os pertences pessoais do preso, contas, livros de razão, etc.

Além dos comissários, havia também os familiares do Santo Ofício, que, de acordo com FERNANDES (2014: 144), eram homens leigos e de influência, cuja função era colher denúncias, investigar, confiscar os bens e prender. Em outras palavras, a função dos familiares era semelhante à dos comissários e é importante ressaltar que eles não eram assalariados, porém, eram isentos do pagamento de impostos:

[...] "familiares" [são] funcionários não assalariados do Santo Ofício que recebiam gratificação pelas diligências realizadas. Comunicavam aos inquisidores atos e discursos contrários a fé e podiam confiscar e prender infratores. Gozavam da garantia de serem "limpos de sangue" e de uma posição social privilegiada. Os "familiares" eram isentos do pagamento de impostos e da obrigação de exercer cargos municipais, e ainda tinham 
direito de andar armados. Distribuídos por todo o reino e domínios, os familiares eram um elo entre as regiões distantes e os Tribunais. ${ }^{76}$

É importante enfatizar que os familiares eram homens de "sangue limpo", isto é, cristãos-velhos. A respeito da "pureza de sangue", MOTA (2016: 104) destaca que " $A$ Inquisição não criou os estatutos de pureza de sangue, nem foi a invenção sua a exclusão dos descendentes de judeus de toda participação na sociedade. Desde o concílio de Latrão, em 1215, os judeus deviam ser excluídos de todas as funções públicas."

De acordo com informações contidas no Regimento dos Superintendentes, Guardasmores e Oficiais (1702), elaborado especificamente para a região das minas de ouro, no século XVIII, a repressão política, econômica e principalmente a repressão religiosa aumentaram na América portuguesa devido ao grande número de pessoas que se dirigia às Minas Gerais, por ocasião da descoberta do ouro. ${ }^{77}$ Consequentemente, os exames de "pureza de sangue" - que eram realizados com o objetivo de verificar se havia vestígios de sangue mouro ou judeu ${ }^{78}$ tornaram-se mais rígidos e o número de familiares aumentou. ${ }^{79}$

Havia regiões onde nem os familiares nem os comissários faziam-se presentes. Nestes casos, os bispos substituíam os inquisidores, cumprindo suas funções e organizando as visitas diocesanas. ${ }^{80}$ Além disso, segundo FERNANDES (2014: 145), quando o bispo se sentia incapaz de julgar a culpa do preso ou mesmo sentenciá-lo, poderia recorrer aos visitadores oficiais. Portanto, apesar de as visitas diocesanas constituírem-se na esfera episcopal, contaram com a participação direta do Santo Ofício, de comissários do tribunal da Inquisição que acompanhavam os processos das devassas.

Os comissários residentes na colônia poderiam ser encarregados de "inquirir" em determinadas regiões. Tais visitas constituíam uma Mesa mais simplificada que as Mesas oficias do Tribunal do Santo Ofício, com menor número de agentes eclesiais. As Mesas instituídas na colônia funcionavam mais rapidamente, uma vez que os moradores eram convocados a prestar depoimento. Consequentemente, permaneciam nas freguesias, vilas e povoados somente o tempo necessário para coletar as denúncias e montar o processo que,

76 NOVINSKY, 2015: 48 apud MOTA, 2016: 104.

77 Ver FERNANDES, 2014, p. 144.

78 Cf. FERNANDES, 2014: 200

79 Cf. FERNANDES, idem, p. 144

80 Cf. FERNANDES, idem, p. 145. 
posteriormente, era enviado a Lisboa. Assim, as curtas estadas de tais visitas podiam abranger um número maior de vilas. ${ }^{81}$

Como dito anteriormente, a primeira visitação do Tribunal do Santo Ofício em terras americanas ocorreu no ano de 1591 e possuía como destino Salvador, capital da colônia desde 1549. A visita foi autorizada pelo vice-rei Alberto d'Áustria, que foi instituído como inquisidor-geral pelo papa Sisto V, em 28 de janeiro de 1586. No dia 2 de março de 1591, Heitor Furtado de Mendonça foi nomeado por Alberto d'Áustria para a função de visitador dos bispados de Cabo-Verde, São Thomé, Brasil e administração de São Vicente ou Rio de Janeiro. Assim, o visitador Heitor Furtado de Mendonça chegou a Salvador juntamente com o governador D. Francisco de Sousa no dia nove de junho de 1591, domingo da Santíssima Trindade. ${ }^{82}$

Todavia, a visita de Heitor Furtado de Mendonça, no final de 1595, havia ultrapassado o prazo estabelecido, limitando-se à América portuguesa, não sendo, portanto, possível a realização da visita aos outros bispados.

De acordo com MOTA (2016: 30), a segunda visita do Tribunal do Santo Ofício também ocorreu na Bahia, entre os anos 1618 e 1620, visita esta conduzida pelo inquisidor Marcos Teixeira. A terceira visitação deu-se entre 1763 e 1769, abarcando a capitania do Grão Pará e Maranhão. Esta visitação foi realizada pelo visitador Pires da Veiga.

Desde o século XVI, a espionagem possuía forte presença em Portugal, sendo implantada também no Brasil. FERNANDES (2014: 143) afirma que todos informavam e delatavam: bispos, padres e párocos. Quando um processo era aberto, o escrivão colocava, com riqueza de detalhes, sua opinião pessoal na sinopse do mesmo. Tais detalhes eram fornecidos pela rede de delatores, ou espiões, que o clero mantinha na colônia, nas paróquias e capelas. Ainda nas palavras de FERNANDES (2014: 143):

\footnotetext{
Documentos pertencentes ao Arquivo Nacional da Torre do Tombo, como os Livros dos Culpados e os processos da Inquisição de Lisboa, revelam que cerca de 2 mil brasileiros foram presos, julgados e condenados em Portugal, até o século XIX. O maior número de denunciados vivia no Rio de Janeiro, Bahia, Paraíba e Minas Gerais.
}

Como já mencionado, não houve a instalação de tribunais do Santo Ofício nas colônias portuguesas, com exceção de Goa. Houve, nas colônias, somente visitações, como é o caso da América portuguesa. Segundo MARQUILHAS (2000 apud MOTA, 2016: 31), 
havia dois modos de atuação do Santo Ofício: o estável (ligado às sedes dos tribunais) e o ambulante (derivado das visitações dos inquisidores a diversos locais do território sob sua jurisdição). Na América portuguesa, o tribunal atuou de modo ambulante, sob a influência do tribunal de Lisboa.

Quando ocorria a visitação, era realizada, inicialmente, a apresentação da comitiva do Santo Ofício, que era acompanhada de procissão solene, pompa e festividade. Além disso, já estavam estabelecidos nos Regimentos da Inquisição todos os rituais a serem seguidos durante a visitação:

[...] no primeiro dia santo, que houver mandará publicar nas igrejas do lugar, o dia em que se há de fazer a publicação da visita, com o sermão da Fé, que sempre será domingo, ou dia santo; e que portanto encomenda muito ao povo Cristão se ache presente; e mandará por autoridade Apostólica, que nesse dia não haja outra provisão, nem pregação em alguma Igreja; e aos Religiosos, Priores, Curas, e mais Clero da Cidade, vila, ou lugar, acompanhem a procissão, que se há de fazer, nomeando as Igrejas, de que se há de sair, e onde a visita se há de publicar, que serão as que lhe parecer convenientes; e avisará as justiças da Câmara, para que na procissão o acompanhem, e ao saber da terra, ou Alcaide-mor, para que na publicação se achem presentes. ${ }^{83}$

O início da primeira visitação do Santo Ofício deu-se no dia 28 de julho de 1591, domingo de pentecostes. O visitador Heitor Furtado de Mendonça foi levado para a Catedral da Sé de Salvador. Além disso, foi declarado que, ao redor de uma légua, todas as pessoas poderiam confessar-se diante do visitador, durante os já mencionados trinta dias da graça que, segundo MOTA (2016: 35), é o período “de trinta dias, contados a partir da publicação do Édito, para que o depoente se apresente perante o Tribunal do Santo Oficio e possa receber perdão pelos pecados confessados." Foi publicado na Sé o édito de ação da graça que, como dito anteriormente, consistia em um documento onde constavam todos os crimes perseguidos pelo Tribunal do Santo Ofício ${ }^{84}$, e a transcrição do alvará de Sua Majestade, com o objetivo de fazer com que as pessoas confessassem suas culpas, de maneira espontânea, no período estabelecido. Tanto o édito quanto o alvará foram afixados na porta da Catedral da Sé. ${ }^{85}$

Tendo a primeira visitação do Santo Ofício à colônia portuguesa durado quatro anos (1591-1595), a segunda dois anos (1618-1620) e a terceira visita seis anos (1763-1769), percebe-se que as visitações oficiais do tribunal permaneciam muito mais tempo em um único local, como afirma FERNANDES (2014: 145):

83 SANTO OFÍCIO, 1640: 718 apud MOTA, 2016: 31.

84 Ver MOTA, 2016, p. 35.

85 Idem, Ibidem. 
[...] As visitas inquisitoriais do Santo Ofício à Colônia, ao contrário, permaneciam muito mais tempo num determinado local. A visitação do Grão-Pará, por exemplo, permaneceu na cidade de 1763-1769, levantando os acusados e ouvindo os depoimentos das pessoas que tinham sido delatadas pelos presos, não convocadas. [...]

Todavia, como já referido, as visitas episcopais eram mais rápidas e eficientes, permanecendo apenas nas freguesias, vilas e povoados. Nelas, predominaram as acusações de concubinato e as acusações de judaísmo foram julgadas pelos próprios visitadores do Tribunal da Inquisição. ${ }^{86}$

Além dos bispos, familiares do Santo Ofício e comissários, o trabalho inquisitorial requisitava um grande número de funcionários, dentre os quais clérigos seculares e regulares. Contudo, os visitadores eram o principal instrumento da política religiosa na colônia. Acompanhados de um escrivão, percorriam as freguesias, onde era oficializada a Mesa da visitação, com o objetivo de abrir os processos.

As visitas eram prenunciadas por um ritual preparado por clérigos locais e podiam acontecer anualmente. $\mathrm{Na}$ ocasião da chegada do visitador, toda a população era convocada a delatar aqueles considerados "hereges":

[...] Quando da chegada do visitador, toda a população era convocada, através de edital, para delatar pessoas consideradas heréticas e responder interrogatórios preliminares, com quarenta quesitos, abrangendo todos os crimes e transgressões religiosas, como heresias, blasfêmias, feitiçarias, bigamias, solicitações, sacrilégios, simonias, sodomias, incestos, bestialidades, judaísmo, corrupção, empréstimos, dívidas, usuras, concubinatos, falsos juramentos, vinganças e muitos outros. Pode-se concluir que os interrogatórios das visitas diocesanas especulavam profundamente os costumes, radiografando toda a vida social da paróquia. ${ }^{87}$

Com o objetivo de nortear o julgamento do visitador, o escrivão, após a convocação, anotava o número de depoentes, as denúncias que eles faziam e elaborava uma síntese dos fatos narrados. ${ }^{88}$

Após ouvir os depoimentos, o secretário do visitador elaborava o termo de encerramento e escriturava as sentenças, que deveriam ser declaradas pelo visitador a cada uma das pessoas confessas ou delatadas:

86 Cf. FERNANDES, 2014, p. 145.

87 FERNANDES, 2014: 146.

88 Cf. FERNANDES, idem, p. 146. 
Depois de ouvir os depoimentos, o secretário do visitador lavrava o termo de encerramento e escriturava as províncias das devassas, isto é, sentenças que o visitador dava para cada uma das pessoas confessas ou denunciadas, por meio de listas com os nomes dos culpados, ou separadamente, por crime e delito. Em nenhuma fase do trabalho o visitador interrogava as testemunhas, procurava conhecer as relações entre o acusador e o acusado, não verificava a veracidade das denúncias nem a idoneidade moral do denunciante. Procedia-se, apenas, às diligências indispensáveis. Dessa maneira, os termos das denúncias se tornavam definitivos libelos acusatórios, enviados à Metrópole. ${ }^{89}$

\section{O PROCESSO INQUISITORIAL}

Segundo MEA (2001: 166), durante o século XVI, em Portugal, os inquisidores eram auxiliados por outros funcionários: era estabelecido que em cada tribunal houvesse dois inquisidores, um promotor, um notário, um meirinho, um solicitador e um carcereiro.

O Regimento do Santo Ofício de 1541, segundo afirma MEA (2001: 166), “[...] é omisso quanto ao número de testemunhos acusatórios necessários para se proceder a prisão; [...]." Todavia, confirmada a prisão, o preso deveria permanecer incomunicável durante os interrogatórios, que ocorreriam em três sessões. ${ }^{90}$ Além disso, MEA (2001: 166) comenta que "[...] depois de se identificar o implicado e averiguar o grau de conhecimento das orações, doutrina cristã e participação nos sacramentos, [o suspeito] era amoestado e perguntado acerca das suas culpas, primeiro na generalidade, depois em pormenor." Ainda segundo MEA (2001: 166), após as três sessões, caso o suspeito ainda não houvesse feito nenhuma confissão, era pronunciado um libelo ${ }^{91}$ acusatório. Na segunda sessão após o libelo, o réu adquiria direito à defesa, podendo escolher o procurador, desde que este não fosse pessoa suspeita, isto é, desde que o procurador fosse um cristão-velho. ${ }^{92}$ Entretanto, MEA (2001: 166) enfatiza que a escolha de um procurador era difícil para quem estava detido, isolado e principalmente era desprovido de posses. Além do mais, ficava a critério do réu decidir se queria uma devassa ${ }^{93}$ judicial, o que prolongava mais o caso:

89 FERNANDES, 2014, pp. 146-147.

90 MEA, 2001, p. 166.

91 Segundo o dicionário Caldas Aulete Digital, o libelo constituía-se de uma acusação por escrito. Disponível em: http://www.aulete.com.br/libelo

92 Cf. MEA, Op. cit., p. 166.

93 De acordo com o Caldas Aulete Digital, uma devassa pode ser uma "Investigação e apuração rigorosa de ato(s) criminoso(s)" e/ou "Processo em que constam os resultados de tal investigação.". Disponível em: http://www.aulete.com.br/devassa 
[...] Cabia ao implicado escolher se queria uma devassa judicial, o que tornava o caso mais moroso, conhecendo-se então o teor das acusações e sua proveniência, de modo a poder indicar contraditas. Requeria-se apenas no despacho e sentença final a presença do Ordinário, o qual com os "letrados de consciência", ajudavam os inquisidores a decidir o grau de culpabilidade e sentença. Depois do despacho podia apelar-se ao Inquisidor Geral. ${ }^{94}$

Segundo MEA (2001: 167), não havia critérios para a seleção das denúncias, ficando tal seleção sujeita a situações, momentos e variando ainda de acordo com os inquisidores: "Dum modo geral a triagem das denúncias não parece estar sujeita a critérios, mas a situações, a momentos, variando ainda em função dos inquisidores, o que acontece também com o próprio processamento, [...]."

Ainda no século XVI, mais da metade das penas de cárcere e degredo eram perdoadas antecipadamente e substituídas por participação obrigatória dos réus em determinadas celebrações da doutrina católica, o que reforçava a propaganda inquisitorial, permitindo que a Igreja controlasse a vida religiosa das pessoas. Nas palavras de MEA (2001: 167):

Uma outra constante desta época é a comutação de penas de cárcere e de degredo (mais de metade são perdoadas antecipadamente), substituindose por participação obrigatória (comunhão) dos réus em determinadas festas do ano, o que por um lado reforça a propaganda inquisitorial, a sua pedagogia do medo e por outro o imperativo da Igreja em regular e controlar a prática devocional dos leigos.

De acordo com FERNANDES (2014: 147), durante o século XVIII, período no qual se insere a documentação estudada nesta pesquisa, entre os anos 1700 e 1778, o Tribunal do Santo Ofício da Inquisição de Lisboa condenou cerca de 2.636 pessoas, das quais 214 foram condenadas entre 1750-1759.

Além disso, é relevante salientar que não se pode considerar os processos como fontes fidedignas, devido ao fato de que o tribunal se alimentava da delação. ${ }^{95}$ Nas palavras de FERNANDES (2014: 157):

Nos processos eram consideradas as denúncias, sem prova, valendo apenas a palavra do denunciante. Comuns foram as acusações "por ouvir dizer", "pelo ver e ouvir", "pelo ver e ser público", "por ser público e notório", sem precisar nenhuma referência.

94 MEA, 2001, pp. 166-167.

95 Cf. FERNANDES, 2014, p. 148. 
A acusação feita às rés Thereza Leyte e Escholastica Pinta da Sylva segue o perfil de denúncia descrito acima, isto é, acusações por "ouvir dizer” e "por ser público":

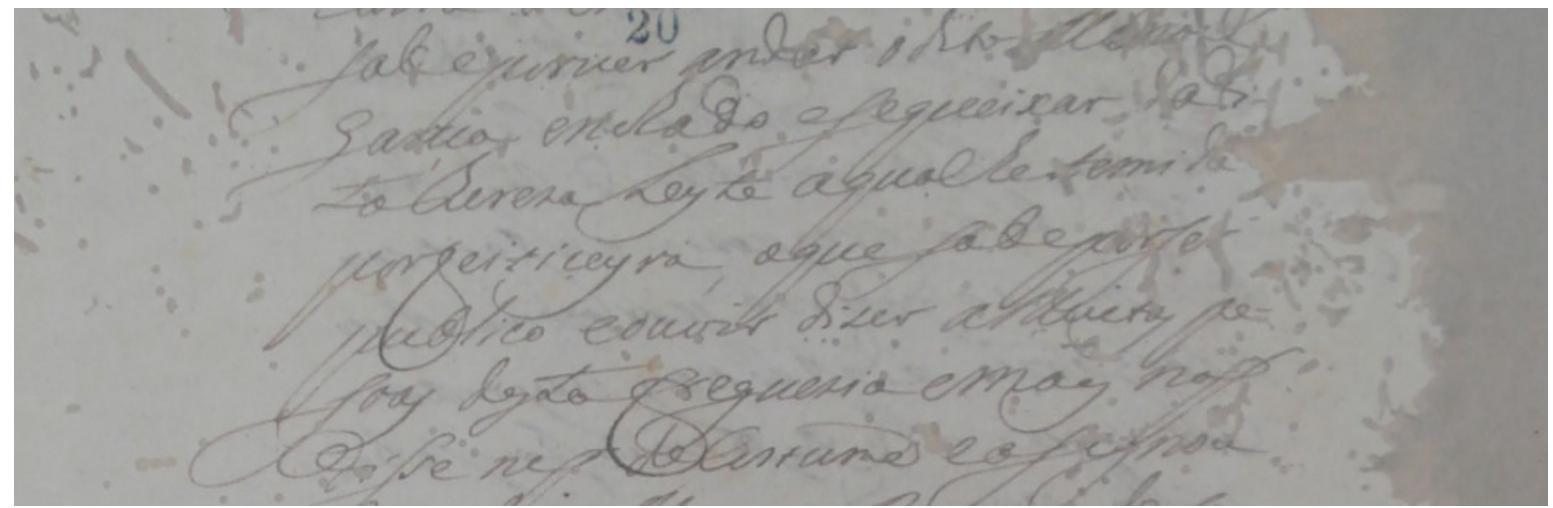

(Fólio 40 r. - Fernando Pinto de Almeyda)

$$
\begin{gathered}
\text { sabeporuer }<\uparrow 20>\text { andar o ditoManoel } \\
\text { Garçia enchado esequeixar dadi - } \\
\text { taTherezaLeyte aqualhetemida } \\
\text { por feitiçeyra, oquesabeporser } \\
\text { publico eouvir dizer aMuitas pe- } \\
\text { soas destafreguezia emais naõ } \\
\text { disse nẽ docostume easignou }
\end{gathered}
$$

A diferença entre os processos inquisitoriais e os processos jurídicos residia no fato de que os processos inquisitoriais eram compostos por duas partes:

Da primeira, constavam as acusações iniciais, os mandatos de captura e de entrega, seguidos do pedido formal de prisão. $\mathrm{Na}$ segunda parte, realizava-se o sequestro de bens, quando tudo era tomado do acusado: propriedades, dinheiro, mercadorias, utensílios, créditos e até os animais domésticos. ${ }^{96}$

Ainda nessa segunda fase eram realizados o inventário e as sessões de interrogatório, que podiam ser in genere (em várias sessões, com perguntas gerais) ou in specie (com perguntas específicas a respeito das acusações atribuídas ao "réu"). ${ }^{97}$

Durante os interrogatórios, o Tribunal do Santo Ofício podia fazer uso do "tormento", isto é, métodos de tortura. Conforme assegura MEA (2001: 167): “Consignava-se o tormento, como meio de apurar a verdade nos casos previstos pelo Direito civil, podendo repetir-se, sendo então passível de apelo.[...]." Entretanto, antes da tortura, o "réu" deveria ser 
examinado por um médico, para que sua resistência fosse avaliada e, além disso, o acusado deveria assinar um documento, no qual assumia a culpa caso sofresse alguma fratura ou qualquer outro dano durante as sessões de tortura. ${ }^{98}$

FERNANDES (2014: 156) afirma que os tipos de tormento eram muito variados, dentre eles pode-se citar o potro e a polé, estabelecidos pelo regimento de 1640. Segundo AZEVEDO (apud FERNANDES, 2014: 156), o potro era uma "espécie de cama de ripas onde, ligado o paciente com diferentes voltas de corda nas pernas e braços, se apertavam aquelas com um arrocho, cortando-lhes as carnes". Já a polé constituía-se de um “moitão seguro no teto, onde era suspensa a vítima, com pesos aos pés, deixando-a cair em brusco arranco sem tocar no chão", ${ }^{99}$

Após as referidas etapas, seguia-se a acusação ou libelo, ocasião na qual o processo esclarecia o objetivo das provas. FERNANDES (2014: 157) assevera que o réu possuía o direito de defesa e que a tarefa de contestar a defesa cabia ao próprio Tribunal do Santo Ofício:

\begin{abstract}
A contestação cabia ao Tribunal, que respondia com os depoimentos de acusação formadores de uma sessão processual denominada "publicação de prova de justiça". A defesa continuava com as "contraditas", conjunto de provas que o réu reunia para anular as acusações recebidas. E, finalizando o processo, a sentença era anunciada. Tudo era secreto. Os acusados não conheciam os denunciantes, nem as testemunhas, nem as circunstâncias de tempo e de lugar das acusações que lhes eram imputadas.
\end{abstract}

Geralmente, os processos prolongavam-se por muito tempo, com perguntas e relatórios repetidos, cuja finalidade também era a de sacrificar ainda mais os presos, submetendo-os às torturas para que confessassem o que sabiam e até mesmo o que não sabiam, além de denunciarem outras pessoas, como amigos, parentes e conhecidos. ${ }^{100}$

As sentenças eram proclamadas de maneira solene, nos chamados autos de fé, que consistiam em grandes festas populares e públicas, que se caracterizavam por verdadeiras cerimônias solenes, nas quais as sentenças eram lidas e executadas. Nos autos de fé compareciam reis, nobres, pessoas ilustres, além do próprio povo.

98 Cf. FERNANDES, 2014: 156

99 AZEVEDO apud FERNANDES, 2014: 156.

100 Cf. FERNANDES, 2014: 157. 
Essa cerimônia recebia o nome de "auto" devido a sua dimensão teatral, relacionada ao teatro de caráter religioso. De acordo com BETHENCOURT (2000: 227):

Auto da fé significa literalmente "ato da fé", o que quer dizer nessa época efeito moral e representação (teatral) da fé. Essa representação, que é possível situar no conjunto das manifestações de teatro religioso da península Ibérica - por exemplo, os autos sacramentales, os autos da paixão ou os quadros vivos de cenas bíblicas incluídos nas procissões do Corpus Christi -, tem a particularidade de ser produzida com acusados verdadeiros, que seguramente conhecem o seu papel, mas que não são atores no sentido literal do termo e não fazem ensaios: o espetáculo é definitivo e único para eles. [...].

Havia dois tipos de autos de fé: aqueles que eram realizados no Palácio da Inquisição ou no Convento de São Domingos, destinados às pessoas que eram readmitidas na Igreja, cujas penas variavam entre penitências espirituais até prisão ou desterro; e os autos de fé que eram realizados em praças públicas, geralmente aos domingos e que podiam durar dias inteiros. ${ }^{101}$ Acerca da importância e do significado de tal cerimônia, BETHENCOURT (2000: 220) comenta:

[...] Exigência de uma sociedade sequiosa de representações fortes nas quais a palavra não é suficiente, o auto da fé fornece hoje, paradoxalmente como no passado, o suporte visual da argumentação vitoriosa. [...]. Contudo, ao nos referirmos à cerimônia que se tornou o símbolo da intolerância, utilizado em todos os desenvolvimentos literários e políticos, raramente ultrapassamos um nível descritivo estereotipado, centrado na queima dos condenados. [...].

Antes dos autos de fé, era publicado o édito de anúncio dessa cerimônia e esse documento, em Portugal, era distribuído pela cidade e lido durante a missa:

O édito de anúncio do auto da fé devia ser publicado pelo menos oito dias antes da realização da cerimônia. No caso português, o édito era distribuído pelos familiares junto ao clero paroquial da cidade, que devia lê-lo durante a missa do domingo imediatamente anterior ao ato, exortando os fiéis a estarem presentes. O édito devia ainda ser afixado nos locais habituais. Em Lisboa, no próprio dia da publicação, o rei devia ser informado pessoalmente pelo inquisidor mais antigo da realização do auto e ser convidado a assistir. [... $]^{102}$

Entretanto, na Espanha, o anúncio dos autos de fé se caracterizava por verdadeiras cerimônias: funcionários do Santo Ofício (incluindo os familiares da Inquisição) percorriam as ruas e praças das cidades, a pé ou a cavalo, divulgando a data de realização dos autos. ${ }^{103}$ 
Além disso, no período anterior à realização do auto de fé, era iniciada a construção do cadafalso - pois, como já mencionado, o auto de fé era caracterizado como sendo uma grande representação teatral -, os processos eram concluídos, os hereges eram informados acerca de suas sentenças e um pintor era contratado. Segundo BETHENCOURT (2000: 226):

[...] Para que tudo esteja pronto, os processos devem ser concluídos (por vezes alguns dias antes do auto da fé) e os presumidos hereges advertidos quinze dias antes do ato (os relaxados, três dias), para que possam se arrepender ou resolver seus problemas temporais antes da execução. [...]. Durante a última semana, os hábitos penitenciais são preparados e um pintor é chamado na véspera do auto para desenhar os rostos dos relaxados sobre os respectivos hábitos. [...].

Os relaxados eram as pessoas entregues à justiça secular, isto é, os condenados à morte. Já os hábitos penitenciais eram os sambenitos e a mitra. O sambenito era um traje que o herege usava durante o auto de fé, e que, segundo BETHENCOURT (2000: 240), era feito de linho cru e pintado de amarelo, com a cruz vermelha de Santo André, que simbolizava a reconciliação com a Igreja, ou mesmo com o retrato do acusado rodeado por chamas e por grifos, que simbolizava a condenação, no caso dos condenados à morte. ${ }^{104}$ Já a mitra era uma espécie de chapéu, feita de papel e utilizada pelo herege relaxado à justiça secular. De acordo com BETHENCOURT (2000: 241):

[...] A mitra fazia parte dos ritos de degradação, pois representava a falsidade do heresiarca. A sua origem pode ser encontrada nos ritos de inversão da festa dos loucos, em que a mitra do bispo era reproduzida em papel com um objetivo de escárnio. [...].

O auto de fé era uma celebração cuja duração podia se estender de dois a três dias, não somente devido à complexidade da cerimônia, mas também por conta da quantidade de sentenciados, que podia alcançar um número de até duzentas pessoas. ${ }^{105}$

No dia de realização do auto de fé, o local da cerimônia era decorado como nos dias de festa, a circulação de pessoas era controlada pelos guardas reais e os dignatários da corte, os nobres e os notáveis da cidade ocupavam as janelas dos palácios com o objetivo de assistir ao auto. ${ }^{106}$ Já o povo assistia à cerimônia de pé, em volta do palco, portanto, viam a cena de baixo. Contudo, se no século XVI o acesso ao palco era permitido somente aos juízes,

104 Francisco Bethencourt (2000: 241) comenta acerca dos significados das cores e dos símbolos retratados nos sambenitos: "[...] o amarelo como cor de fundo simboliza a traição dos hereges e é sobre ele que estão pintados a cruz vermelha de Santo André para os reconciliados ou os grifos e as chamas do inferno para os excluídos. O vermelho da cruz simboliza o sangue vertido por Cristo e pelos santos mártires. [...]."

105 Ver BETHENCOURT, Op. cit., p. 249.

106 Ver BETHENCOURT, 2000, p. 230. 
condenados, familiares da Inquisição e religiosos escolhidos, a partir do século XVII essa relação se altera e autoridades, nobres, religiosos e notáveis da cidade ganham acesso a esse espaço. Assim, de tribunal religioso, o Santo Ofício adquire um caráter de tribunal de corte. ${ }^{107}$

Segundo FERNANDES (2014: 154), no dia do auto de fé, as procissões saíam de manhã e percorriam uma parte da cidade antes de chegar à praça onde seria realizada a leitura das sentenças. A procissão dos penitentes e dos condenados era organizada no palácio da Inquisição, ainda de madrugada ${ }^{108}$ e havia uma hierarquia a ser seguida nas procissões: à frente, vinham os frades dominicanos, levando a bandeira da Santa Inquisição. ${ }^{109}$ Em seguida, vinham os hereges, todos vestindo os sambenitos, seguindo em ordem de gravidade de culpa os acusados de crimes menos graves estavam à frente e os acusados de crimes mais graves, atrás - e eram acompanhados por guardas. Os penitentes vinham descalços e levavam uma vela na mão. Logo atrás, seguiam os condenados à morte, portando uma mitra de papel pintada com os mesmos motivos do sambenito, acompanhados dos familiares e confessores jesuítas. Por último, eram transportadas as estátuas de madeira (no caso dos fugitivos), que seriam queimadas em efígie, e os caixões, no caso dos condenados já mortos, que também seriam queimados. O fechamento da procissão dava-se com uma tropa de familiares a cavalo, a cúpula da Santa Inquisição e, finalmente, o inquisidor-geral, que vinha escoltado por nobres. ${ }^{110}$

Quando a procissão chegava finalmente ao palco, os inquisidores tomavam seus lugares no cadafalso, os sentenciados geralmente se sentavam do lado oposto do palco ficando os juízes e os acusados frente a frente - e, na zona central do palco, era instalado o altar da abjuração. ${ }^{111}$ Após todos estarem devidamente acomodados, a solenidade era iniciada com um sermão realizado por um frade dominicano, a respeito da Inquisição, heresias e judaísmo.

Em seguida, as sentenças eram então lidas, em voz alta, para cada acusado. Havia os penitentes que abjuravam, isto é, se arrependiam e se retratavam publicamente, no altar 107 Cf. BETHENCOURT, Op. cit., pp. 233-234.

108 Cf. BETHENCOURT, Op. cit., p. 239.

109Entretanto, Francisco Bethencourt (2000: 240), oferece uma informação distinta acerca dos clérigos que iniciavam a procissão: "[...] À frente da procissão estava um grupo de clérigos seculares organizados em torno do padre responsável pela paróquia principal da cidade, que levava, velada, a cruz à sua igreja. [...]."

110 Em relação ao fechamento das procissões, Francisco Bethencourt (2000: 240) também fornece uma informação diversa: "[...] O cortejo era aberto, no século XVII, por quatro familiares a cavalo com as varas da Justiça, e fechado pelo alcaide e pelo meirinho da Inquisição, igualmente a cavalo e levando também as varas da Justiça. [...]."

111 Ver BETHENCOURT, 2000, p. 231. 
construído no palco especialmente para este fim, sendo readmitidos no seio da Igreja. Segundo BETHENCOURT (2000: 249), a abjuração é “[...] o ato de expressão pública e formal do arrependimento do penitente, de recusa das heresias cometidas e de compromisso renovado com a Igreja católica." Além disso, as penas previstas aos reconciliados variavam consideravelmente:

[...] Existia toda uma tipologia de penas, desde as penas espirituais às corporais (geralmente açoites públicos; não existem indícios de mutilações), passando pela condenação às galés, a deportação, o exílio temporário do termo ou do bispado, a prisão temporária (entendida no sentido da época, quer como detenção num convento ou no colégio da fé criado pela Inquisição para o ensino da doutrina religiosa aos penitentes, quer como proibição de sair de casa, do bairro ou da cidade sem autorização inquisitorial). [...]. ${ }^{112}$

Já o espetáculo da execução dos relaxados à justiça secular era realizado imediatamente após o auto de fé, sob a responsabilidade de autoridades civis, sempre vigiadas pelos agentes do Tribunal do Santo Ofício. ${ }^{113}$ A respeito dessa transferência de responsabilidade, BETHENCOURT (2000: 254) comenta:

[...] Essa distribuição de responsabilidades é explicável, pois os inquisidores, enquanto clérigos, não podiam condenar ninguém à morte (uma prática proibida pelo direito canônico). Daí o artifício de "relaxar" o excomungado à Justiça secular, que reconhecia a validade do processo inquisitorial, aceitando suas conclusões e ordenando imediatamente a execução da pena capital. [...].

Os condenados à morte eram então conduzidos, em mais um cortejo, até o local da execução (geralmente áreas destinadas às execuções civis), fora dos limites da cidade, pois aquele derramamento de sangue não poderia ocorrer dentro da cidade e muito menos no palco onde era realizado o auto de fé, que era considerado um local sagrado que preservava a santidade e pureza da Igreja católica. ${ }^{114}$ Esse desfile dos relaxados e o espetáculo da execução eram acompanhados pelo povo, que demonstrava suas emoções diante dos condenados, apiedando-se deles ou mesmo zombando ou ofendendo-os.

A construção dos locais de execução ficava a cargo das autoridades civis, porém, o local era consagrado pela presença de uma cruz, que geralmente pertencia à confraria que adquiria o privilégio de acompanhar os condenados à morte até o último instante. ${ }^{115}$ Os locais 
de execução não eram preparados da mesma forma em todas as regiões, mas na maioria dos casos, a construção seguia um padrão. De acordo com BETHENCOURT (2000: 256):

[...] Esse local não era preparado da mesma maneira em todos os lugares. Na maior parte dos casos, as bases das fogueiras eram bastante simples: cada uma era um cubo formado com toras cruzadas sobre as quais se colocava um banco apoiado no tronco vertical. Nesse tronco a vítima podia ser estrangulada antes da fogueira, caso manifestasse seu arrependimento e quisesse morrer como católica. [...].

O primeiro auto de fé foi realizado no ano de 1540 e o último, em 1765. Segundo afirma FERNANDES (2014: 155), nos primeiros autos de fé, realizados em Lisboa, já haviam cristãos-novos da América portuguesa. A partir do início do século XVIII, com a perseguição inquisitorial em Minas Gerais, cristãos-novos começaram a aparecer em diversos autos de fé, a exemplo de João Lopes Nunes e Alexandre Rodrigues, dois mercadores, residentes na capitania do Rio de Janeiro que, em 1704, foram presos acusados de judaísmo. Além desses dois casos, a autora ainda cita outros, todos ocorridos no século XVIII:

No auto de 1713, presentes estavam 14 cristãos-novos. No de 16 de outubro de 1729, encontravam-se três mineiros condenados por judaísmo, entre os 15 que foram penitenciados: José da Cruz Henriques, José Roiz da Costa e Manoel Nunes da Paz. Entre os 19 que saíram no auto de fé de 17 de junho de 1731, dois eram de Minas Gerais: Luiz Vaz de Oliveira e Pedro Nunes Miranda. No auto de fé de 6 de junho de 1732, o número de mineiros aumentou. Entre 24 judaizantes penitenciados, seis eram de Minas Gerais. Domingos Nunes foi o primeiro condenado à fogueira. Diogo Correa do Vale e seu filho Luís Miguel Correa sofreram pena capital, sendo garroteados e queimados. ${ }^{116}$

FERNANDES (2014: 155) ainda assegura que, até o ano de 1769, cristãos-novos mineiros faziam-se presentes nos autos de fé:

Em 1733 foi condenado à morte um cristão-novo de Minas Gerais. No auto de fé de 10 de setembro de 1737, foi condenado à morte Manoel da Costa Ribeiro, de Ouro Preto, Minas Gerais. Outros três cristãos-novos das cidades auríferas de Minas foram condenados no auto de fé de 18 de outubro de 1739. Em 1744, foi condenado à morte um cristão-novo de Paracatu, João Henriques, junto com Pedro Rates Henequim, que, depois de viver vinte anos em Minas, foi denunciado à Inquisição como cabalista, "afogado no Tejo e depois queimado". ${ }^{117}$

É de grande relevância ressaltar que, segundo afirma FERNANDES (2014: 155), as mulheres consistiam em metade dos presos luso-americanos, já que eram consideradas “competentes transmissoras das heresias, bruxarias e judaísmo”, pois era no interior das 
casas que os rituais religiosos eram praticados. Em relação aos cristãos-novos condenados por crimes menores (homossexualismo, sodomia, bigamia, heresia, bruxaria), estes receberam sentenças e penas mais brandas. ${ }^{118}$

\subsection{A LEGISLAÇÃO DA ÉPOCA: AS ORDENAÇÕES FILIPINAS}

No século XVIII vigoravam na América portuguesa as Ordenações Filipinas (ou Código Filipino), que eram uma espécie de reforma das Ordenações Manuelinas. As Ordenações Filipinas começaram a ser elaboradas por ordem de Filipe I, ainda no século XVI, mas entraram em vigência somente no século seguinte. Em sua nota de apresentação elaborada para uma reedição das Ordenações, Mario Júlio de Almeida Costa (1985: 6-7), afirma:

As novas Ordenações estavam concluídas em 1595, recebendo aprovação por Lei de 5 de Junho desse ano, mas que não chegou a produzir efeito. Só no reinado de Filipe II, através de Lei de 11 de Janeiro de 1603, iniciaram a sua vigência - a mais duradoura que um monumento legislativo conseguiu em Portugal. [...]

Almeida Costa (1985: 8) comenta também a respeito da longa vigência do Código Filipino na América portuguesa: "As Ordenações Filipinas tiveram múltiplas edições, o que não admira pela longa vigência, já salientada, que conheceram em Portugal e no Brasil." O autor ainda se refere à problemática envolvendo a vigência das Ordenações em pleno século XX:

[...] Na verdade, se, em 1850, o Brasil teve um Código Penal que substituiu o obsoleto livro $\mathrm{V}$ das Ordenações, a promessa paralela da rápida elaboração de um Código Civil, avançada pelo legislador constituinte, protelou-se até 1916. Entretanto, vigoravam os preceitos filipinos, com alterações profundas devidas a numerosos diplomas avulsos, mais ou menos dispersos. Tornara-se embaraçoso e inseguro o conhecimento exato do direito vigente. ${ }^{119}$

Como dito anteriormente, as penas dirigidas a hereges incluíam confisco de bens, multas, excomunhão, exílio e pena de morte, como consta no Livro V das Ordenações Filipinas (1985: 1148), Título I, "Dos Hereges e Apóstatas":

E além das penas corporaes, que aos culpados no dito maleficio forem dadas, serão seus bens confiscados, para se delles fazer o que nossa mercê fôr, postoque filhos tenhão.

118 Ver FERNANDES, Op. cit., p. 155.

119 Cf. Mario Júlio de Almeida Costa. In.: ALMEIDA, Candido Mendes de. Ordenações Filipinas Código Phillipino ou Ordenações e Leis do Reino de Portugal. Volume I. Livro I. Rio de Janeiro, 1870. Edição por reprodução em fac-símile da Fundação Calouste Gulbenkian 1985, p. 10. 
Ainda tendo em mente que o Código Filipino vigorava também na América portuguesa, é de fundamental importância ter conhecimento das penas aplicadas aos condenados por feitiçaria, o que ocorreria às rés Thereza Leyte e Escholastica Pinta da Sylva, caso fossem condenadas. Tais penas são explicitadas no mesmo Livro V das Ordenações (1985: 1150), Título III, “Dos Feiticeiros":

1. E isso mesmo, qualquer pessoa, que em circulo, ou fóra delle, ou em encruzilhada invocar spiritos diabolicos, ou der a alguma pessoa a comer ou a beber qualquer cousa para querer bem, ou mal a outrem, ou outrem a elle, morra por isso morte natural. ${ }^{120}$

Porém em estes dous casos, primeiro que se faça execução, nol-o farão saber, para vermos a qualidade da pessoa, e modo, em que se taes cousas fizeram, e sobre isso mandarmos o que se deve fazer.

O Título III (“Dos Feiticeiros”) do Livro V das Ordenações (1985: 1150-1151), também faz menção às práticas consideradas supersticiosas:

2. Outrosi não seja alguma pessoa ousada que para adivinhar lance sortes, nem varas para achar thesouro, nem veja em agoa, crystal, spelho, spada, ou em outra qualquer couza luzente, nem em spadoa de carneiro, nem faça para adivinhar figuras, ou imagens algumas de metal, nem de qualquer outra cousa, nem trabalhe de adivinhar em cabeça de homem morto, ou de qualquer alimaria, nem traga comsigo dente, nem baraço ${ }^{121}$ de enforcado, nem membro de homem morto, nem faça com cada huma das ditas cousas, nem com outra (postoque aqui não seja nomeada) specie alguma de feitiçaria, ou para adivinhar, ou para fazer dano a alguma pessoa, ou fazenda, nem faça cousa, per que huma pessoa queira bem, ou mal a outra, nem para legar homem, nem mulher para não poderem haver ajuntamento carnal. E qualquer, que as ditas cousas, ou cada huma dellas fizer, seja publicamente açoutado com baraço e pregão ${ }^{122}$ pela Villa ou lugar, onde tal crime acontecer, e mais seja degredado para sempre para o Brazil, e pagará trez mil reis para quem o accusar.

Neste mesmo Título III, há a descrição das punições para outras práticas também tidas como supersticiosas e, consequentemente, como feitiçaria. Além disso, as penas variavam de acordo com o nível da hierarquia social ao qual o acusado pertencia:

E porque taes abusões ${ }^{123}$ não devemos consentir, defendemos, que pessoa alguma não faça as ditas cousas, nem cada huma dellas; e qualquer, que a

120 A pena de "morte natural" era aplicada por meio de veneno, golpe, sufocamento ou decapitação. Havia também a "morte natural de fogo", que envolvia a queima do condenado ainda vivo. João M. Brandão N.: "As Penas e o Processo Penal nas Ordenações Filipinas". In.: "Direito Brasocêntrico - Direito, Sociedade e Política". Disponível em: brasocentrico.blogspot.com.br/2010/03/ as-penas-e-o-processopenal-nas.html?m=1.

121 Segundo João M. Brandão N., o "baraço" era o laço com o qual se apertava a garganta do enforcado.

122 João M. Brandão N. afirma que o "pregão" era a descrição da culpa e da pena.

1230 termo "abusões" significa práticas supersticiosas. Neste caso, as Ordenações referem-se às práticas "de feitiçaria" que envolvem plantas, ervas, objetos, animais, entre outros. 
fizer, se for peão, seja publicamente açoutado com baraço e pregão pela Villa, e mais pague dous mil réis para quem o accusar.

E se for Scudeiro, e dahi para cima, seja degredado para Africa, per dous annos; e sendo mulher da mesma qualidade, seja degredada trez annos para Castro-Marim, e mais paguem quatro mil réis para quem os accusar. $^{124}$

Como fora anteriormente mencionado, as Ordenações Filipinas vigoraram não só em Portugal, mas também na América portuguesa. Portanto, se as rés Thereza Leyte e Escholastica Pinta da Sylva, mãe e filha, fossem condenadas por prática de feitiçaria, seriam punidas de acordo com o Código Filipino. Contudo, isso não ocorreu e é o que veremos com a transcrição completa desse processo.

\section{A SÃO PAULO COLONIAL}

No período colonial, a capitania de São Paulo era menos importante e menos rica que o Nordeste açucareiro, tendo sua fundação no ano de 1554, como afirmam MAIA \& MIRANDA (2006: 8):

Sua fundação, em 25 de janeiro de 1554, foi efetivada por treze missionários jesuítas, que a inauguraram construindo a sede do colégio de catequese de meninos. O local era formado por uma enorme clareira natural em meio a áreas de intensa cobertura vegetal, os campos de Piratininga. O solo saudável da região e o clima temperado (mais próximo daquele a que os jesuítas e demais europeus estavam acostumados) favoreceram o povoamento.

Depois de realizado o estabelecimento da Vila de São Vicente, a Coroa percebeu que o que impediria as ameaças estrangeiras, que eram constantes, seria somente a posse efetiva do território. Deste modo, concessões de terras foram feitas a um grupo de capitães-mores que possuíam boas relações na Corte, constituindo catorze capitanias hereditárias na América portuguesa. Martim Afonso de Sousa e seu irmão Pero Lopes de Sousa (1501-1539) receberam a capitania de São Vicente e a de Santo Amaro, respectivamente. Juntas, em 1709, elas formaram, oficialmente, a capitania de São Paulo e Minas Gerais.

A capitania de São Vicente, que passou a ser conhecida como capitania de São Paulo, tinha no aprisionamento de indígenas o seu principal meio de sustento econômico. Contudo, a

124 Ver ALMEIDA, Candido Mendes de. Ordenações Filipinas - Código Phillipino ou Ordenações e Leis do Reino de Portugal. Volume III. Livros IV e V. Rio de Janeiro, 1870. Edição por reprodução em facsímile da Fundação Calouste Gulbenkian. Coimbra. 1985, p. 1151. 
Coroa portuguesa não contava que os moradores da colônia tentassem dirigir-se para o interior do território, conhecido como sertão. O interesse de Portugal era povoar e proteger a costa, pois a ameaça de estrangeiros era constante. Martim Afonso de Sousa proibiu que os habitantes locais se dirigissem para o sertão, porém, sua decisão não obteve êxito:

\begin{abstract}
Martim Afonso de Sousa chegou a proibir que os moradores locais se dirigissem para os sertões, mas a pressão pela liberação foi tamanha, que sua esposa e procuradora, dona Ana Pimentel, acabou por permitir a movimentação das pessoas serra acima. $\mathrm{O}$ aprisionamento e a escravização de indígenas em São Paulo, principais ocupações econômicas da capitania até o século XVIII, possibilitaram que a criação de animais prosperasse na região de Sorocaba. Então, feiras baseadas nessa atividade passaram a vender os animais para outras áreas da colônia. A capitania de São Paulo firmou-se como abastecedora de gêneros agrícolas de outras áreas da colônia e como núcleo fundador de outras vilas da América portuguesa. ${ }^{125}$
\end{abstract}

Além disso, havia o colégio da vila de São Paulo, cujas aulas eram frequentadas pelos jesuítas, por estudantes portugueses e mamelucos (filhos de português e indígena), que vinham de vilas próximas, e pelos próprios índios. Segundo MAIA \& MIRANDA (2006: 12): "No primeiro século de sua existência, a vila de São Paulo firmou-se como uma referência graças ao colégio jesuítico e por ser ponto de partida para o desbravamento do interior da colônia."

Na passagem do século XVII para o XVIII, a história de São Paulo esteve diretamente relacionada à descoberta do ouro pelos paulistas, o que levou Portugal a redesenhar o mapa da América portuguesa, criando novas capitanias, além de desmembrar e extinguir outras. No ano de 1709, as capitanias de São Vicente e Santo Amaro foram extintas, dando origem à capitania de São Paulo e Minas do Ouro.

Depois de nomear um governador para a nova capitania, a Coroa voltou sua atenção para a exploração e proteção da descoberta do ouro. Os conflitos ocorridos entre paulistas (que haviam descoberto as minas) e as pessoas que se dirigiam para lá em busca de fortuna fácil trouxeram, como consequência, uma nova alteração do mapa administrativo da colônia, por parte da Coroa portuguesa, anos mais tarde. Assim, São Paulo (elevada à condição de cidade em 1711) foi separada de Minas Gerais, firmando-se, segundo MAIA \& MIRANDA (2006: 13), como centro abastecedor de gêneros de primeira necessidade das regiões mineiras. 
Outra questão relevante a ser abordada é a prática comum na São Paulo colonial de se deixar índios como herança:

Comentemos, a título de exemplo, o caso de Cristóvão da Cunha, morador da vila de São Paulo. Em 1664 deixou expresso em seu testamento que sua filha Catarina de Unhate, por ocasião de seu casamento com Antonio Lopes, receberia "oito peças do gentio da terra". Afirmava também que ainda havia dado como dote a sua outra filha, Maria da Cunha, "oito peças do gentio da terra". O próprio Cristóvão declarava ter vinte escravos adultos, seis rapazinhos e uma "rapariguinha". ${ }^{126}$

No processo de feitiçaria aqui estudado, as duas rés, Thereza Leyte e Escholastica Pinta da Sylva, estavam envolvidas em um conflito com os parentes de Manoel Garcia, pois, antes de falecer, Manoel não havia feito testamento informando quem herdaria os escravos indígenas que ele possuía, se seria Escholastica (sua esposa) ou seus familiares. Esse conflito será detalhadamente explorado mais adiante, porém, há nos manuscritos, mais especificamente em apenas um dos fólios, menção explícita ao grupo indígena ao qual pertenciam os escravos em questão. Tratava-se de índios Carijós.

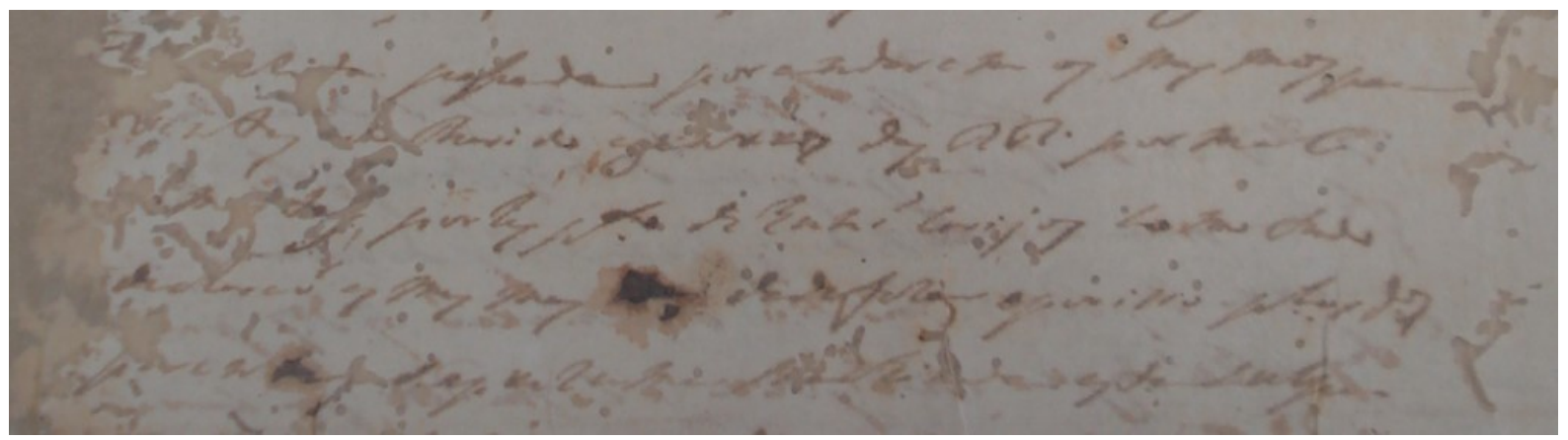

(Fólio 44 v.)

[corroído] [v]ezita passada por andarem os mesmos pa rentes d[o] Marido egenrros das Rés por mal [corroído]m[corroído]tas, por respeito de hunś carijos como tudo declaraó as mesmas [testemunhas] dadefeza epor isso pelos ditos parentes sepreZumiss[e]ahi[n]da estaculp[a] - 
Além das atividades de captura dos indígenas, nas vilas e nos povoados da capitania a população livre pobre ${ }^{127}$ também trabalhava, exercendo diversas atividades com o objetivo de sobreviver. Há muitos relatos registrados pela Câmara Municipal da cidade no século XVIII a respeito da atividade das padeiras. Nas palavras de MAIA \& MIRANDA (2006: 29): "Durante o período colonial, a Câmara fiscalizava a venda de alimentos, seus pesos e medidas, assim como as condições sanitárias dos produtos. Além disso, ela tinha poder para multar e mandar prender os infratores". As padeiras eram mulheres pobres que vendiam, pelas ruas, o pão consumido pela população, às vezes com o auxílio de uma ou duas escravas.

Um outro grupo cuja presença era constante nas ruas paulistas eram as lavadeiras, mulheres que lavavam as roupas nos córregos e rios. As lavadeiras viviam de seu trabalho e muitas vezes sustentavam sozinhas os seus filhos.

Além das lavadeiras, haviam também as quitandeiras, que não comercializavam somente quitutes, mas também toucinho e fumo, o que, segundo alguns comerciantes, prejudicava muito as vendas em suas tavernas. Não apenas as mulheres, mas também os homens participavam do comércio ambulante da cidade, vendendo aguardente, açúcar e carne pelas ruas.

Os pescadores representavam um outro grupo de livres pobres de São Paulo. Esses trabalhadores pescavam nos rios que cortavam a cidade e depois dirigiam-se para diversos pontos da cidade, oferecendo a mercadoria. Segundo MAIA \& MIRANDA (2006: 30), “[ ...] O recenseamento populacional realizado em 1765 pelo governador da capitania mostrou que a maioria dos pescadores de São Paulo concentrava-se no bairro do Pari e em Santana". Com a finalidade de aumentar a pesca, muitos pescadores utilizavam de plantas venenosas, jogando-as nos rios, que eram tóxicas para os peixes, mas inofensivas aos seres humanos. Entretanto, este sistema trazia uma desvantagem: muitas vezes, a quantidade de peixes obtidos era superior ao que se conseguia vender. Assim, os peixes excedentes deterioravam a céu aberto.

Um grupo de livres pobres muito comum em São Paulo eram os tropeiros, homens responsáveis por conduzir tropas de animais e também pela venda de mercadorias. Antes de chegarem a seu destino, os tropeiros faziam paradas para descansar e cuidar dos animais, período durante o qual realizavam a compra e venda de mercadorias. A função dos tropeiros

127 Segundo MAIA \& MIRANDA (2006: 26), "livres pobres” era a denominação para as pessoas dotadas de liberdade jurídica, porém desprovidas de posses ou riquezas. 
era fundamental, pois colaborava para que as mercadorias percorressem o vasto território que era a América portuguesa.

Além dos ofícios descritos, diversos homens e mulheres pobres de São Paulo ainda cultivavam pequenas roças de alimentos e também criavam animais. ${ }^{128} \mathrm{Um}$ exemplo de morador da São Paulo colonial, mais especificamente de Jundiaí, que cultivava sua roça como meio de subsistência, era Norberto de Oliveyra Garçia, sobrinho de Manoel Garcia e testemunha no processo inquisitorial contra Escholastica Pinta da Sylva e Thereza Leyte.

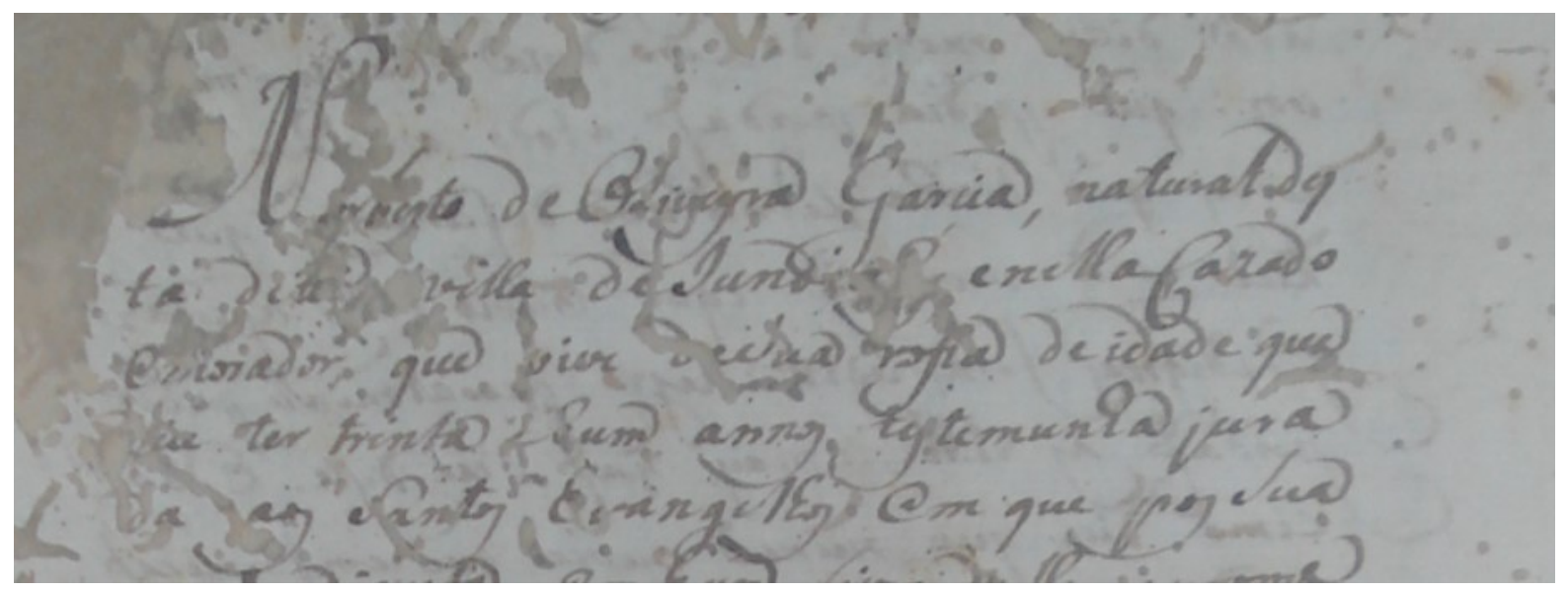

(Fólio 29 v.)

Norberto deOliveyra Garçia, natural des ta dit[ta] villa deIund[i]ahy enellaCazado emorador, que vive deSua rossa deidade que [d]ice ter trinta ehum annos testemunha jura da aos Santos Evangelhos em que pos Sua

São Paulo e toda a colônia eram extremamente carentes de recursos médicos e nos primeiros séculos da colonização, os enfermos recorriam aos jesuítas para cuidar do corpo e da alma. No século XVIII, foi instalado em São Paulo um hospital a cargo da Santa Casa de Misericórdia. Nas palavras de MAIA \& MIRANDA (2006: 38): “[...] O primeiro médico diplomado de que se tem notícia na colônia, o doutor João Rodrigues de Abreu, apenas passou por São Paulo, uma vez que se fixou em terras americanas por pouco tempo, só até 1714." 
No ano de 1721 a cidade de São Paulo contava apenas com dois cirurgiões ${ }^{129}$ e a figura do boticário já se fazia presente na colônia:

[...] No censo realizado pelo governador da capitania em 1765, aparecem listados Jerônimo Roiz, como cirurgião-mor, e Sebastião Teixeira de Miranda, como boticário (equivalente ao farmacêutico dos nossos dias). Ambos contavam com posses medianas. Por sua vez, o boticário Francisco Coelho Aires estava em melhores condições e vivia na rua Direita, onde se localizavam os mais ricos habitantes da cidade. No Rio de Janeiro, sede da Corte, as boticas eram mais bem fiscalizadas e contavam com boticários formados, enquanto em outras paragens, como São Paulo, isso não acontecia. ${ }^{130}$

Os dados fornecidos pelo recenseamento da cidade ainda apontam que, no ano de 1765, São Paulo contava, no total, com três cirurgiões, três boticários e um barbeiro. ${ }^{131}$ Além disso, já fazia-se presente e também era muito comum a figura do barbeiro profissional, à época, vinculado às atividades médicas e responsável não apenas por cortar barba e cabelo, mas também por extrair dentes e aplicar ventosas.

Esse mesmo censo ainda revelou que a capitania de São Paulo contava apenas com um advogado diplomado. Como não havia universidades na América portuguesa, a educação superior era possível apenas no reino de Portugal. Somente no século XIX passou a existir algum tipo de instrução superior em São Paulo, a partir da elaboração de cursos de Matemática, Filosofia e Direito, ministrados por homens como Martim Francisco e José Bonifácio de Andrada e Silva e o padre Diogo Antônio Feijó. A São Paulo colonial não desenvolveu outros centros de ensino, além do colégio jesuítico, único em São Paulo até o século XVIII. De acordo com MAIA \& MIRANDA (2006: 39): “A questão da instrução nunca fora tema fundamental na colonização portuguesa, ao contrário do que se processou na América espanhola, que desde cedo contou com universidades."

No colégio jesuítico, ensinavam-se os índios e, mais tarde, passou-se a ensinar todos os meninos da vila. Além disso, faziam parte do colégio dos jesuítas a igreja e o convento. Dentre os onze colégios jesuíticos estabelecidos na América portuguesa, no século XVII,

129 De acordo com MAIA \& MIRANDA (2006: 31), em Portugal, isto é, na metrópole, havia distinção entre as categorias de médico e cirurgião. O médico deveria ter formação teórica e universitária, enquanto o cirurgião era responsável por tarefas mais simples, como as sangrias, a aplicação de ventosas e sanguessugas e a realização de curativos. Entretanto, tal distinção não foi inteiramente respeitada na colônia, pois como praticamente não havia médicos, os cirurgiões realizavam tarefas muito mais complexas do que sua formação lhes permitia.

130 MAIA \& MIRANDA, 2006, pp. 38-39.

131 Cf. MAIA \& MIRANDA, Idem, p. 39. 
havia o Santo Inácio, localizado em São Paulo, onde se lecionava Gramática, Humanidades e Retórica.

No século seguinte, mais especificamente em 1754, estabeleceu-se uma escola de latim para os meninos do coro e para os capelães da Sé, evidenciando maior preocupação em melhorar a educação oferecida na colônia. Entretanto, no ano de 1759, em vista dos conflitos entre a Coroa e os jesuítas, a ordem religiosa foi expulsa do império português e os seus bens foram confiscados. Assim, "A instrução ficou a cargo de outras ordens religiosas e do próprio Estado." 132

O então governador, dom Luís Antônio de Sousa, em 1768, organizou um estatuto para que houvesse um mestre de meninos na cidade. MAIA \& MIRANDA (2006: 39) explicitam a razão deste fato: "A ideia surgiu porque ele teve grande dificuldade em encontrar uma pessoa que 'tivesse letra' para ocupar um cargo na Secretaria de Governo”. Além disso, após algum tempo, o mesmo governador instituiu um curso de Geometria, porém, pouquíssimos alunos realizaram inscrição no mesmo. Outro fator que evidenciava a precariedade da educação era a quase total falta de livros em São Paulo.

Segundo afirmam MAIA \& MIRANDA (2006: 40), na sociedade colonial os homens mais bem colocados social e financeiramente investiam na compra de terras e escravos, na tentativa de ascender socialmente e constituir fortunas que seriam, no futuro, deixadas de herança para suas famílias.

\subsection{VILA DA NOSSA SENHORA DO DESTERRO: JUNDIAÍ}

O nome Jundiaí é de origem tupi e vem da palavra "jundiá", que significa "bagre" e "y" que significa "rio". Entretanto, alguns estudiosos consideram também o termo "yundiaí", que quer dizer "alagadiços de muita folhagem e galhos secos". ${ }^{133}$

A região de Jundiaí, até o século XVII, foi habitada por povos indígenas que se dedicavam à produção de milho e mandioca. Boa parte da cultura indígena foi incorporada pelos brancos colonizadores, como a técnica de construção e a utilização de queimadas na lavoura.

Segundo MARQUES (2008: 31), Jundiaí fazia parte da vila de Parnaíba (atual Santana do Parnaíba):

132Cf. MAIA \& MIRANDA, 2006, p. 39.

133 História de Jundiaí. Disponível em: https://www.jundiai.sp.gov.br/a-cidade/historia/ . Último acesso em 10 de março de 2017. 
[...] No caso de Jundiaí existem provas documentais de fonte secundária, que comprovam ter a vila de Jundiaí sido desmembrada da vila de Parnaíba, atual Santana do Parnaíba, pois o seu território encontrava-se no termo desta vila. [...].

Em relação à fundação de Jundiaí, MARQUES (2008: 32) afirma que a obra do autor Azevedo Marques foi contestada por outros estudiosos. Portanto, Jundiaí teria sido fundada no ano de 1651, e não em 1615, como teria colocado Azevedo Marques. Além disso, esse autor teria afirmado que o fundador de Jundiaí havia sido Rafael de Oliveira, o velho (pai). Todavia, MARQUES (2008: 33) esclarece que o fundador de Jundiaí foi, na verdade, Rafael de Oliveira, o moço (filho), pois Rafael de Oliveira, o velho, havia falecido no ano de 1648 (em seu sítio, no Jaraguá), um ano antes do início da construção da capela de Jundiaí. ${ }^{134}$

Além de tais equívocos, MARQUES (2008: 33) ressalta que o motivo da fundação de Jundiaí, na obra de Azevedo Marques, também foi questionado:

O terceiro equívoco, segundo Campanhole, deve-se ao fato de Azevedo Marques apontar como motivo dos sertanistas desbravarem sertão um crime amoroso praticado por Rafael de Oliveira, o velho, e Petronilha Antunes. Campanhole afirma que o motivo jamais seria o crime amoroso, pois Rafael de Oliveira, o velho, e Petronilha Antunes não foram amantes e muito menos se casaram. Rafael de Oliveira, o velho, casou-se pela segunda vez, em 1616, com Catarina Figueiredo d'Horta e Petronilha Antunes casou-se, em 1614, com Antônio Jorge. [...].

De acordo com MARQUES (2008: 34), a povoação de Jundiaí passou a ser reconhecida a partir de 1651:

A povoação de Jundiaí começou a ser reconhecida a partir de 1651, com o término da construção da capela dedicada a Nossa Senhora do Desterro. Era com a existência de uma "capela curada" que um pequeno povoado ou arraial obtinha o reconhecimento da presença de uma comunidade.

Era somente com a existência de uma capela curada que um povoado adquiria reconhecimento como sociedade organizada não apenas pois tinha acesso mais próximo à assistência religiosa (batismo, casamento, sacramentos na morte), mas também pois obtinha o reconhecimento de pertencer à Igreja oficial, portanto, de pertencer ao próprio Estado,

134 Acerca da fundação de Jundiaí, Juliano Ricardo Marques (2008) utiliza a seguinte obra como referência: CAMPANHOLE, Adriano; SANTOS, Wanderley e GICOVATE, Moisés. Aditamento à história da fundação de Jundiaí. Instituto Histórico e Geográfico. Jundiaí/SP. Ed. Literarte, 1994. 
garantindo acesso aos registros de nascimento, matrimônio, óbito e outros registros oficiais, com todas as implicações jurídicas e sociais necessárias. ${ }^{135}$

Mais tarde, segundo MARQUES (2008: 29), em quatorze de dezembro de 1655, Jundiaí foi elevada à categoria de vila. Contudo, o cientista social e professor Samuel Vidilli divulgou, no dia vinte de julho de 2018, um documento histórico do Arquivo Nacional da Torre do Tombo, no qual consta a informação de que, na verdade, Jundiaí foi tornada vila em quatorze de dezembro de 1656. Segundo Samuel Vidilli, oitenta famílias - dentre elas as famílias de Paschoal Ribeiro de Faria, Manoel Fernandes, Salvador Ribeiro, José Leme do Prado e Pedro Ferreira - organizaram um abaixo-assinado, enviado, na época, ao responsável pela capitania de São Vicente, contendo tal solicitação. O objetivo dessas oitenta famílias com o pedido de elevação de Jundiaí à categoria de vila era obter um ouvidor-mor, um provedormor e um sargento-mor, consideradas autoridades de grande importância na época. ${ }^{136}$

Ao longo dos séculos XVII, XVIII e início do XIX, a economia de Jundiaí limitava-se a pequenas lavouras de subsistência, que abasteciam moradores da vila, tropeiros e bandeirantes. É relevante destacar que algumas das pessoas que forneceram seus testemunhos à Justiça Eclesiástica no processo-crime em questão, sobreviviam de suas lavouras, a exemplo de Francisco Pereyra Rodrigues, Ioze Cordeyro de Abreu e Manoel Affonço Taborda:

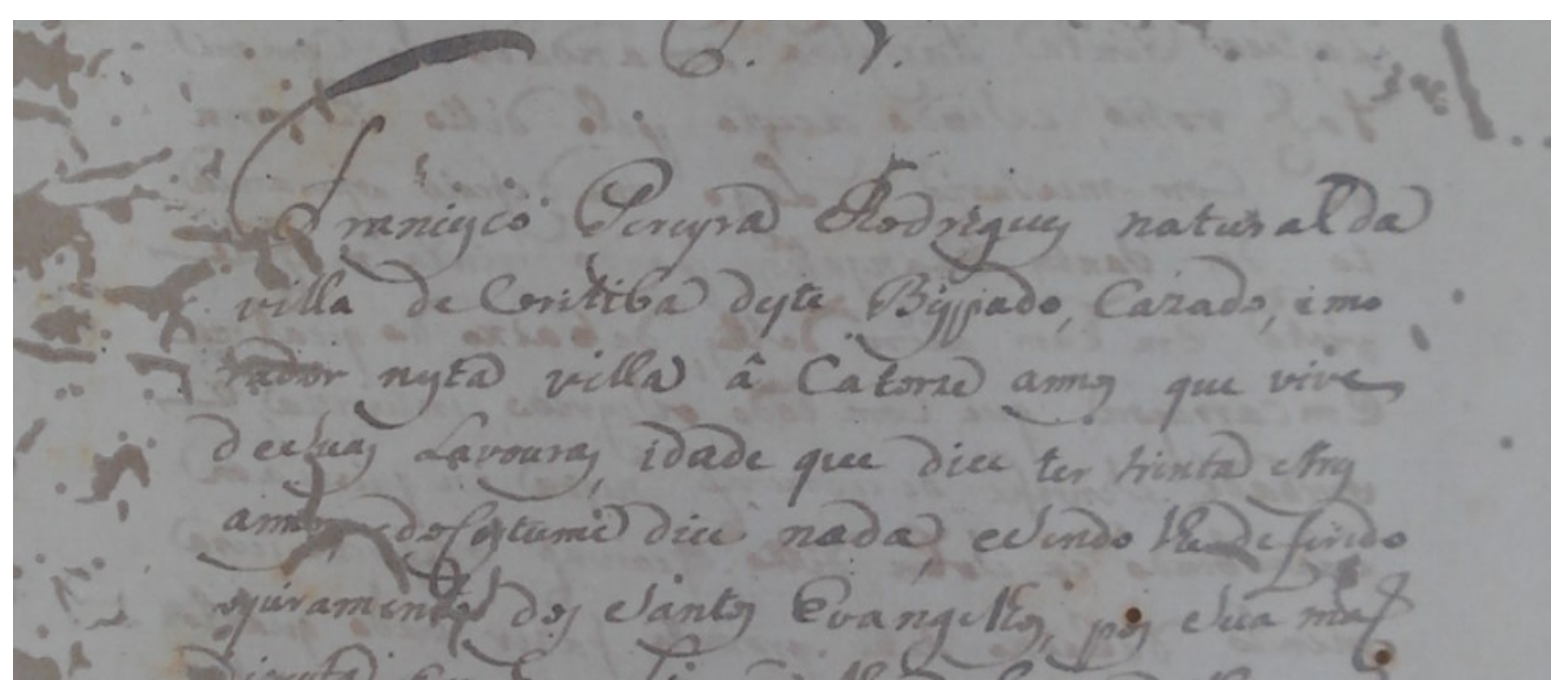

(Fólio $26 \mathrm{v}$.)

135Cf. MARQUES, 2008, pp. 34-35.

136Cf. "Abaixo-assinado foi responsável pela elevação de Jundiaí à vila". In.: Portal tudo.com.você. Disponível em: https://tudo.com.vc/abaixo-assinado-foi-responsavel-pela-elevacao-de-jundiai-vila/ Consultada em 18/02/2019. 
Francisco Pereyra Rodrigues natural da villa decoritiba deste Bispado, Cazado, e mo rador nesta villa â Catorze annos que vive

deSuas Lavouras, idade que dice ter trinta etres annos, edoCostume dice nada, eSendo the deferido ojuramento dos Santos Evangelhos, pos Sua maõ

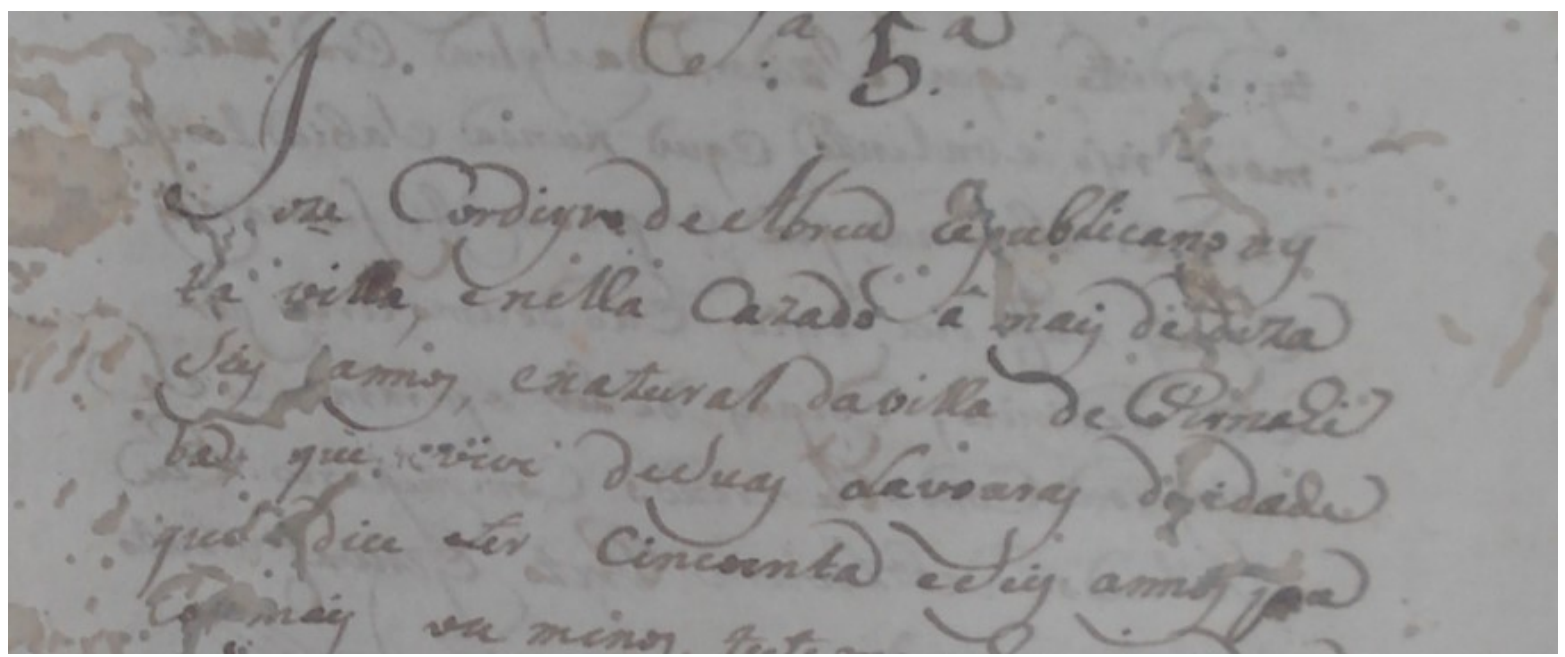

(Fólio 32 v.)

Ioze Cordeyro deAbreu repubLicano nes ta villa, enella cazado â mais de diza Seis annos, enatural davilla de Pernahi ba que vive deSuas Lavouras $d[e]$ idade que dice ter cincoenta eSeis annos pa $\mathrm{co}^{137}$ mais ou menos [...] 


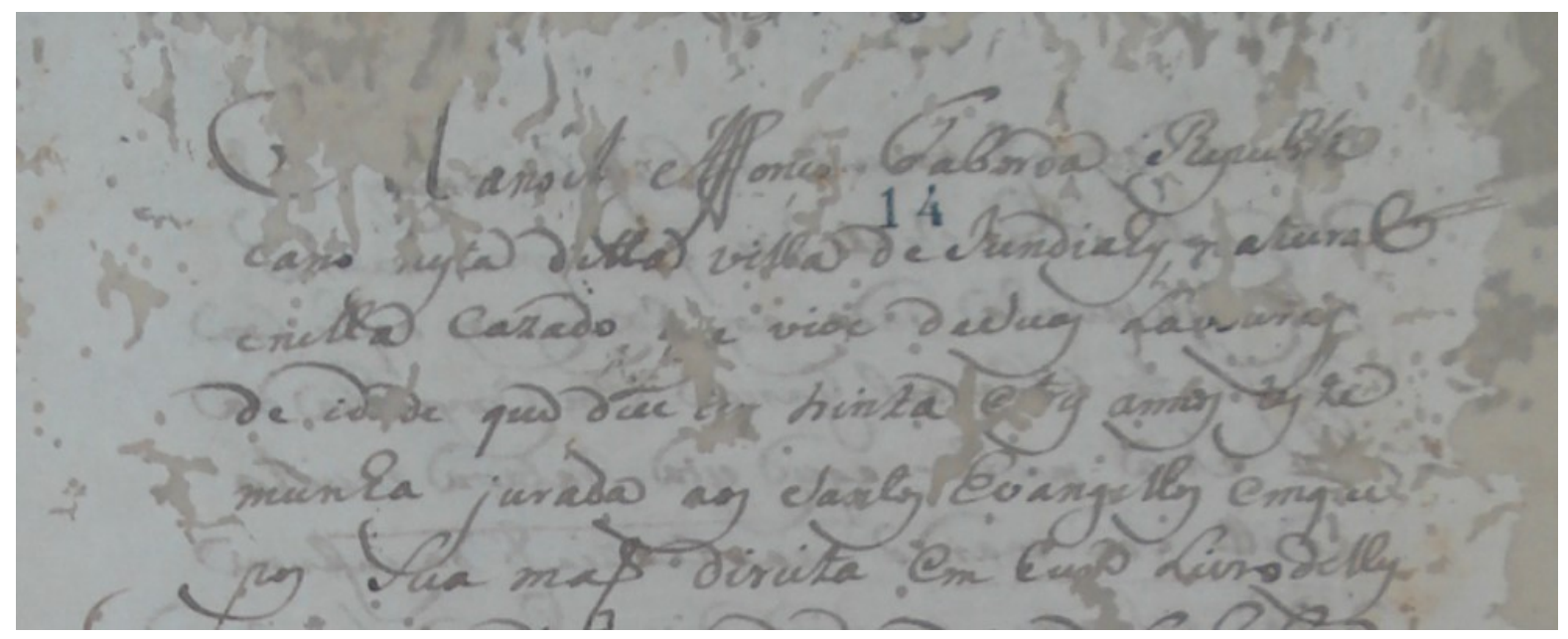

(Fólio 34 r.)

\begin{abstract}
Manoel Affonço $<\downarrow 14>$ Taborda Republi cano nesta ditta villa deIundiahy, natural enella cazado, $\mathbf{q}[\mathbf{u}] \mathbf{e}$ vive deSuas Lav[o]uras, de id[a]de que dice te[r] trinta etres annos teste munha jurada aos Santos Evangelhos emque pos Sua maõ direita em hum Livro delles
\end{abstract}

$\mathrm{Na}$ época, a região era formada por muitas sesmarias pertencentes à capitania de São Vicente, conhecida como "Portão do Sertão" e que era o caminho de numerosas entradas e bandeiras. Além disso, embora proibida por lei, a mão de obra indígena foi, durante um longo período, a base da força de trabalho local.

Ainda naquela época, a cidade possuía quatro ruas centrais, a Rua Direita (atualmente Barão de Jundiaí), Rua do Meio (Rua do Rosário), Rua Nova (Senador Fonseca) e Rua Boa Vista (Zacarias de Góes). As melhores casas eram construídas com taipa e terra, enquanto as moradias das pessoas mais humildes eram construídas com o pau a pique, cobertas por sapé. Na localidade havia a Capela de Nossa Senhora do Rosário - onde atualmente está localizado o Gabinete de Leitura Rui Barbosa -, o Hospício dos Beneditinos e o Mosteiro de São Bento, um dos poucos monumentos sobreviventes.

Na Jundiaí colonial, o abastecimento de água era realizado de modo rudimentar, por meio de bicas públicas. A iluminação se dava por candeeiros que ficavam suspensos nas paredes, sendo acesos ao final da tarde e apagados logo ao nascer do sol. 
Um dos pontos comerciais mais movimentados à época era o Largo do Rocio, que deu lugar à Praça da Bandeira. Além disso, a cana-de-açúcar destacava-se como principal atividade agrícola, porém, a produção era voltada para a fabricação de aguardente.

Em meados do século XVIII, o número de escravos indígenas e de origem africana era praticamente o mesmo, porém, a partir da segunda metade do mesmo século, a quantidade de escravos provenientes da África aumentou, até a mão de obra indígena ser abandonada por completo. Contudo, à medida que o número de escravos africanos aumentava, cresciam também os focos de resistência.

Já no século XIX, em 28 de março de 1865, Jundiaí foi elevada à categoria de cidade. $^{138}$

\section{O PROCESSO: AS RÉS, O FALECIDO, A ACUSAÇÃO E DEMAIS ENVOLVIDOS}

O processo em questão foi aberto pela Justiça Eclesiástica paulista, na então "Villa da Nossa Senhora do Desterro de Iundiahy”, no ano de 1754. Thereza Leyte (casada com Joaõ da Sylva Moraes $^{139}$ ) e Escholastica Pinta da Sylva (mãe e filha, respectivamente) foram acusadas de matar o ex-marido de Escholastica, Manoel Garcia de Oliveira, fazendo o uso de feitiçaria e de terem pacto com o demônio. Além disso, as duas mulheres também foram acusadas de matar outros homens - um deles, por ter se negado a casar com uma irmã das rés, porém, o documento não explicita de quem exatamente era a irmã, se de Thereza ou Escholastica.

O falecido marido de Escholastica, Manoel Garcia, foi Capitão Mor das almas de "Alagoa de Juruoca" (Município de Alagoa, Minas Gerais). O documento mais antigo encontrado a respeito desse município data de 21 de maio de 1723 , sendo a carta patente do governo de Minas Gerais enviada a Manoel Garcia de Oliveira, conferindo-lhe o referido cargo. $^{140}$

As rés do processo em questão, duas mulheres, exemplificam o que seria o estereótipo da feitiçaria, frequentemente associada a mulheres e mais raramente a homens, como afirma SOUZA (2009: 212): “[...] estigmatizar mulheres - e, mais raramente, homens - era andar meio caminho no sentido de construir coletivamente um estereótipo de feitiçaria."

138Este histórico foi feito a partir das informações contidas no site oficial da Prefeitura de Jundiaí. Disponível em: https://jundiai.sp.gov.br/a-cidade/historia/

139 “Joaõ da Sylva Moraes", de acordo com o punho do escrivão Polycarpo de Abreu Nogueyra, porém o escrivão Fernando Pinto de Almeyda escreve "Ioam/Ioaõ da Silua de Moraes".

140Cf. página oficial da Prefeitura Municipal de Alagoa. Disponível em: http://www.alagoa.mg.gov.br/novo_site/index.php?exibir=noticias\&ID=273. 
Em relação ao pacto com o demônio atribuído às rés, é possível inferir que tal boato tenha sido criado justamente para reforçar a acusação de feitiçaria contra mãe e filha, resultando, assim, em uma possível condenação, pois, de acordo com SOUZA (2009: 336): "[...]Como diz Mandrou [...], é o pacto que, quase sempre, define a condição de feiticeiro. $[\ldots] "$

As testemunhas, entretanto, alegaram que as rés não haviam cometido crime algum, pois, antes mesmo de se casar com Escholastica, Manoel Garcia já estava doente, tendo contraído, em uma de suas viagens ao "Certam do Cuyaba", o "mal de Sam Lazaro", outro termo para lepra. ${ }^{141}$ Portanto, as testemunhas afirmaram que a doença foi a causa da morte de Manoel. As testemunhas também alegaram que as duas mulheres eram tementes a Deus, sendo mulheres "de boa conciencia", "boas christans" e que amavam muito ao falecido. Além disso, em um dos testemunhos consta a informação de que Escholastica e Manoel Garcia tinham um casal de filhos:

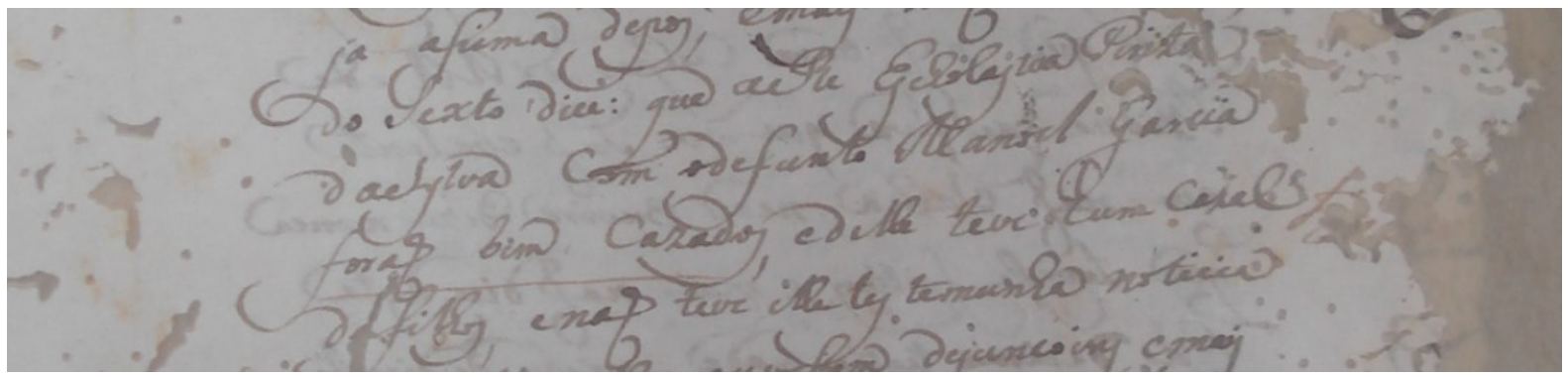

(Fólio 33 r.)

do Sexto dice: que aRe Escholastica Pinta daSylva com odefunto Manoel Garcia foraõ bem cazados, e delle teve hum cazal d[e]filhos, e naõ teve elle testemunha noticia

$\mathrm{Na}$ documentação há testemunhos de que os parentes de Manoel Garcia não simpatizavam com as rés e que, além disso, estavam em conflito com elas por conta de uns “administrados", que, segundo SILVA (2009: 115 - 116), seriam escravos indígenas:

Quando, por volta de 1730 , se fez um levantamento da população da cidade de São Paulo e seu termo para fins de cobrança do donativo real,

141 Segundo Raphael Bluteau (Vocabulario portuguez \& latino: aulico, anatomico, architectonico ..., 1712 - 1728, vol. 5, p. 59), "Lázaro" seria "pobre mendigo" ou "leproso". Antonio de Moraes Silva, em seu Dicionário da Lingua Portuguesa (Diccionario da lingua portugueza - recompilado dos vocabularios impressos ate agora, e nesta segunda edição novamente emendado e muito acrescentado, por ANTONIO DE MORAES SILVA. Lisboa, 1813, vol. 2, p. 210), afirma que "Lázaro" (também chamado de "mal de São Lázaro") é a lepra ou o portador da doença em si. 
os habitantes foram distribuídos em quatro classes, segundo um critério que era simultaneamente jurídico e racial: brancos, administrados, servos e escravos. Não há dúvida de que os administrados eram índios e os escravos eram negros, mas quem compunha a classe dos servos?

MONTEIRO (1994: 137) justifica a condição de "administrados" dos índios, pois os colonos paulistas não os consideravam capazes de administrar a si próprios:

[...] Apesar da legislação contrária ao trabalho forçado dos povos nativos, os paulistas conseguiram contornar os obstáculos jurídicos e moldar um arranjo institucional que permitiu a manutenção e reprodução de relações escravistas. Assumindo o papel de administradores particulares dos índios - considerados como incapazes de administrar a si mesmos -, os colonos produziram um artifício no qual se apropriaram do direito de exercer pleno controle sobre a pessoa e propriedade dos mesmos sem que isso fosse caracterizado juridicamente como escravidão.

Ainda em relação ao termo "administrados", o autor afirma que os índios viviam em condição análoga à escravidão, sendo a "administração particular" praticamente outro nome para encobrir um regime escravista:

[...] De acordo com um relato histórico do início do século XIX, tratavase apenas de uma questão de terminologia: "Os Paulistas, posto que não davam aos índios domesticados o nome de cativos, ou escravos, mas só o de administrados, contudo dispunham deles como tais, dando-os em dotes de casamentos, e a seus credores em pagamento de dívidas" [... $]^{142}$

Assim, como dito anteriormente, havia uma disputa entre os parentes do falecido Manoel Garcia e as rés, por conta de "administrados", isto é, escravos indígenas. Tal conflito por posse, pelo direito de propriedade de escravos, leva a crer que, muito provavelmente, Thereza Leyte e Escholastica Pinta da Sylva fossem brancas, embora não haja nenhuma referência explícita, na documentação, a respeito da cor da pele de ambas. ${ }^{143}$

Outro elemento que reforça a ideia de que mãe e filha fossem brancas é o fato de que Thereza Leyte era proprietária de um sítio, como é possível verificar nos seguintes trechos da documentação:

142 MONTEIRO, Idem, p. 147.

143 Laura de Mello e Souza (2009: 141) menciona um processo inquisitorial brasileiro do século XVIII e afirma que o réu, Isidoro da Silva, provavelmente fosse branco, pois não havia, no processo, "alusão à mestiçagem ou origem negra". Isso nos leva a crer que as rés do processo aqui analisado, Thereza e Escholastica, também fossem brancas, pois, assim como no caso de Isidoro, no processo não há menção à mestiçagem, origem negra e nem mesmo à cor da pele. 


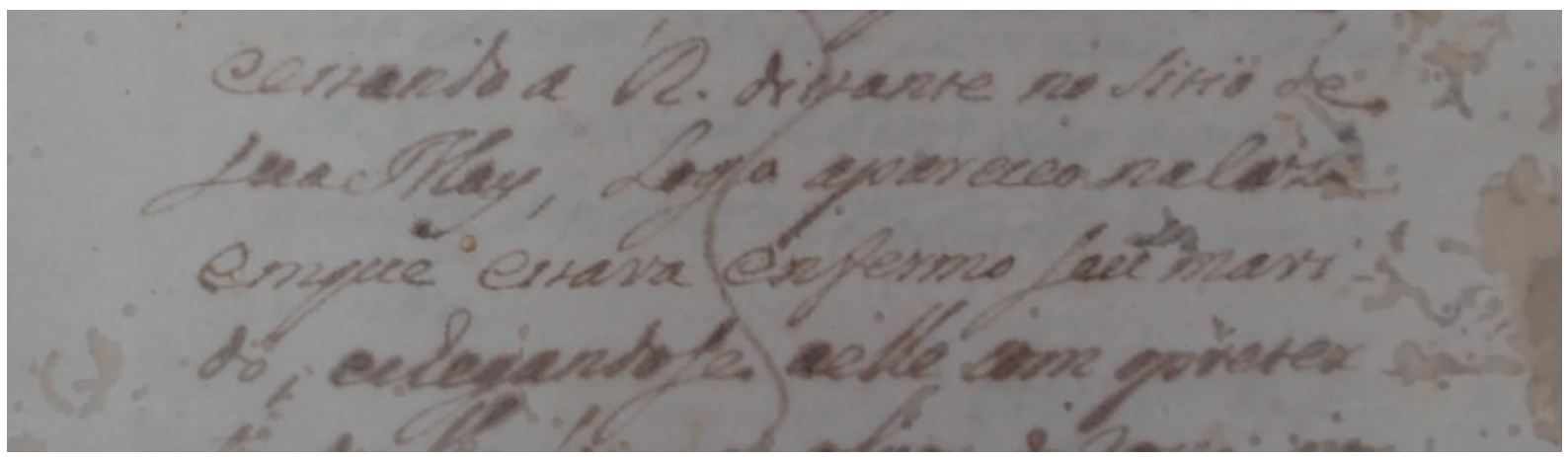

(Fólio 12 r.)

\section{eestando a Ré distante no Sitio de}

suaMay, Logo apareceo nacaza

emque estava enfermo seu mari -

do, echegandose aelle com opretex -

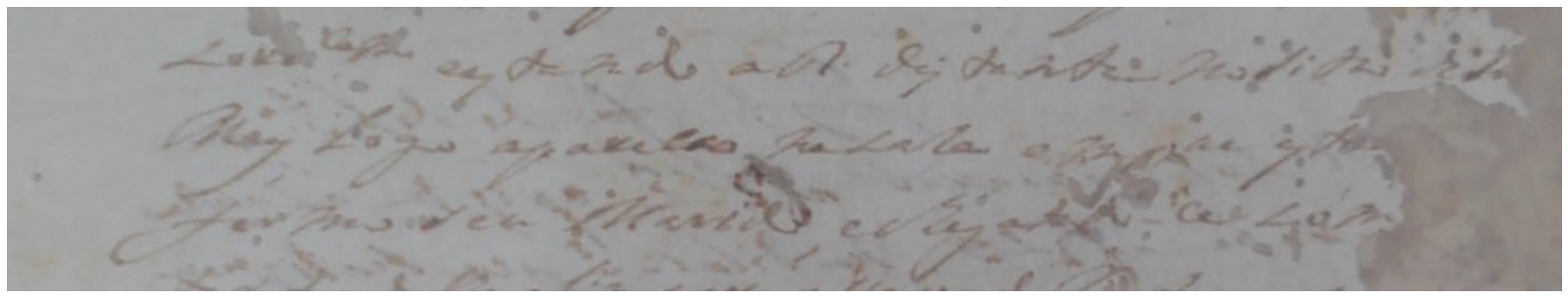

(Fólio 43 r.)

cor[r]eicam eestando aRé distante no sitio des[ua]

May, Logo apareceo nacaZa emque est[corroído]

fermo seu Marido, echegando-ce com [corroído]

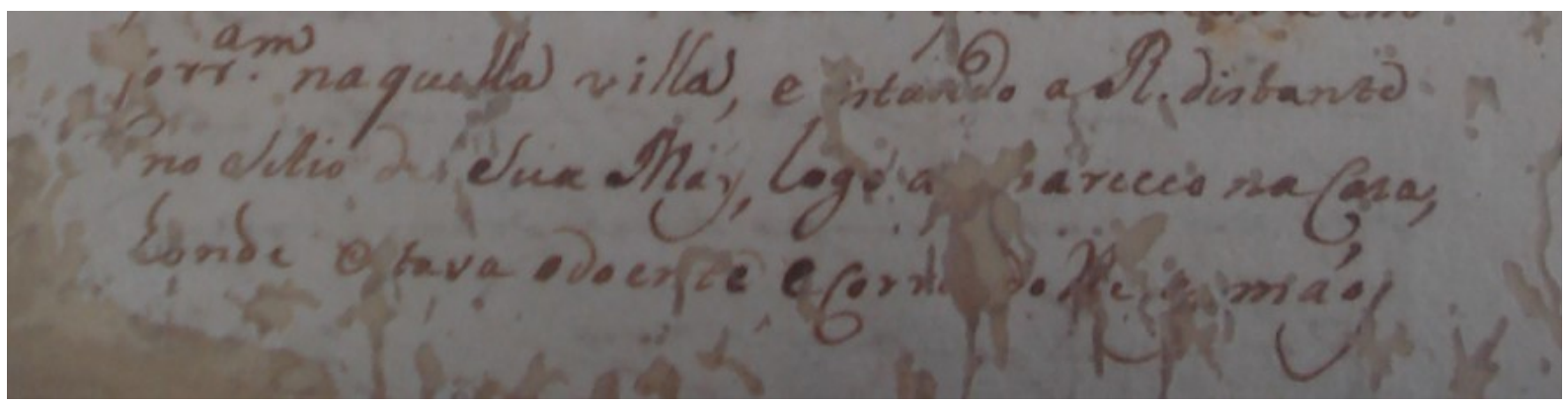

(Fólio 46 v.)

Correiçam ${ }^{144}$ naquella villa, e [e]stando aRé distante

no sitio de sua May, logo a[corroído][p]areceo naCaza, honde e[s]tava o doente eCorr[en]do lhe as máos

144 "Corr"am" por "Correiçam", segundo FLEXOR. Ibidem, p. 100. 
Portanto, apesar de a cor da pele das rés não ser explicitamente mencionada na documentação, há fatores que indicam que Thereza e Escholastica eram, de fato, brancas.

Outro elemento que pode ter agravado o conflito entre os parentes do falecido e as rés é o fato de que Manoel Garcia não havia feito testamento, portanto, não havia registro escrito a respeito de quem ficaria de posse dos escravos, após a sua morte.

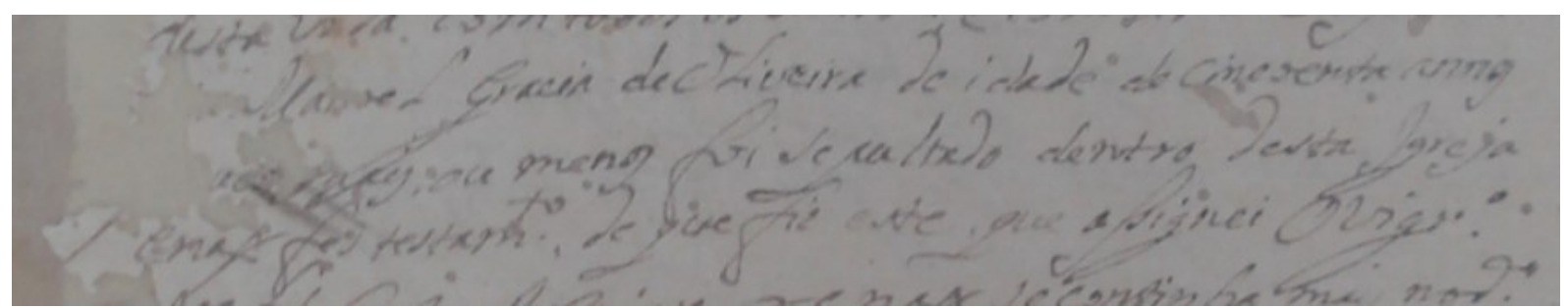

(Fólio 18 v.)

[cia]Ma[n]oel Gracia de OLiveira de idade de cincoenta annos [corroído]ue[corroído] mais ou menos foi se pultado dentro desta Igreja

Enaõ fes testamento de que fiz este que assignei O vigario

Ainda em razão deste conflito, provavelmente porque os parentes do defunto desejavam obter a posse dos escravos indígenas, os mesmos chamaram a um "negro feiticeyro" de nome Francisco (já falecido à época do processo) para que curasse Manoel e também para espalhar boatos, acusando as rés de o terem matado por meio de feitiços.

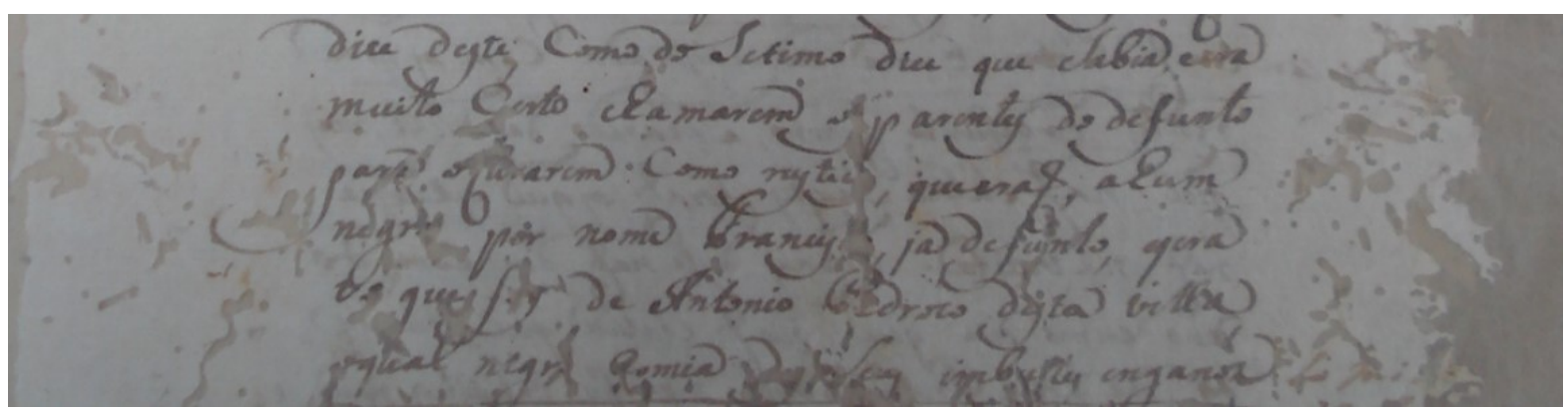

(Fólio 27 r.)

dice deste, Como doSetimo dice que Sabia era muito Certo chamarem os parentes do defunto para oCurarem Como rustic[o]s, queeraõ, ahum negro por nome Francis[co], ja defunto, escra vo que $\mathrm{f}[\mathrm{o}] \mathrm{y}$ de Antonio $\mathrm{P}[\mathrm{e}]$ drozo desta villa, oqual negr[o] comia $\mathrm{d}[\mathrm{os}]$ seus imbu[s]tes enganoz 
Os parentes contrataram o feiticeiro com o objetivo de curar Manoel da lepra e/ou dos feitiços, o que consistia em uma prática comum: recorrer a feiticeiros para tratar não apenas doenças, mas também feitiços. Nas palavras de SOUZA (2009: 224):

Procurar obter curas por meios sobrenaturais aproximava pois esta terapêutica popular da feitiçaria. Curavam-se doenças, insolações, incômodos como dores de dentes; mas também se curavam feitiços.

Além de buscar uma cura, é possível afirmar que, ao contratar o escravo Francisco, os parentes de Manoel Garcia desejavam eliminar a "concorrência", pois, se as rés fossem condenadas por feitiçaria, eles obteriam a posse dos administrados. As denúncias de feitiçaria se tornaram, assim, um modo de eliminar inimigos e resolver problemas internos à comunidade.

Denúncias de feitiçaria frequentemente refletiam tensões entre vizinhos, conhecidos, inimigos. [...]. Como na Europa, questões miúdas, falatórios de vilarejo acabavam servindo de base a denúncias e à constituição de testemunhos. Construindo-se coletivamente o estereótipo da bruxa, encontrava-se um meio de resolver conflitos internos à vida da comunidade, "identificando e excluindo o responsável pelas desgraças." $[\ldots]]^{145}$

Segundo consta nos manuscritos redigidos pelo promotor Paulo de Souza Rocha, a ré Escholastica da Sylva era acusada de ter causado feridas nas pernas do ex-marido; de fazê-lo sentir enjoos e dores no estômago após mexer, com as mãos, em um prato de comida do qual ele estava comendo; e de deixá-lo cego, sendo essas consideradas práticas de feitiçaria.

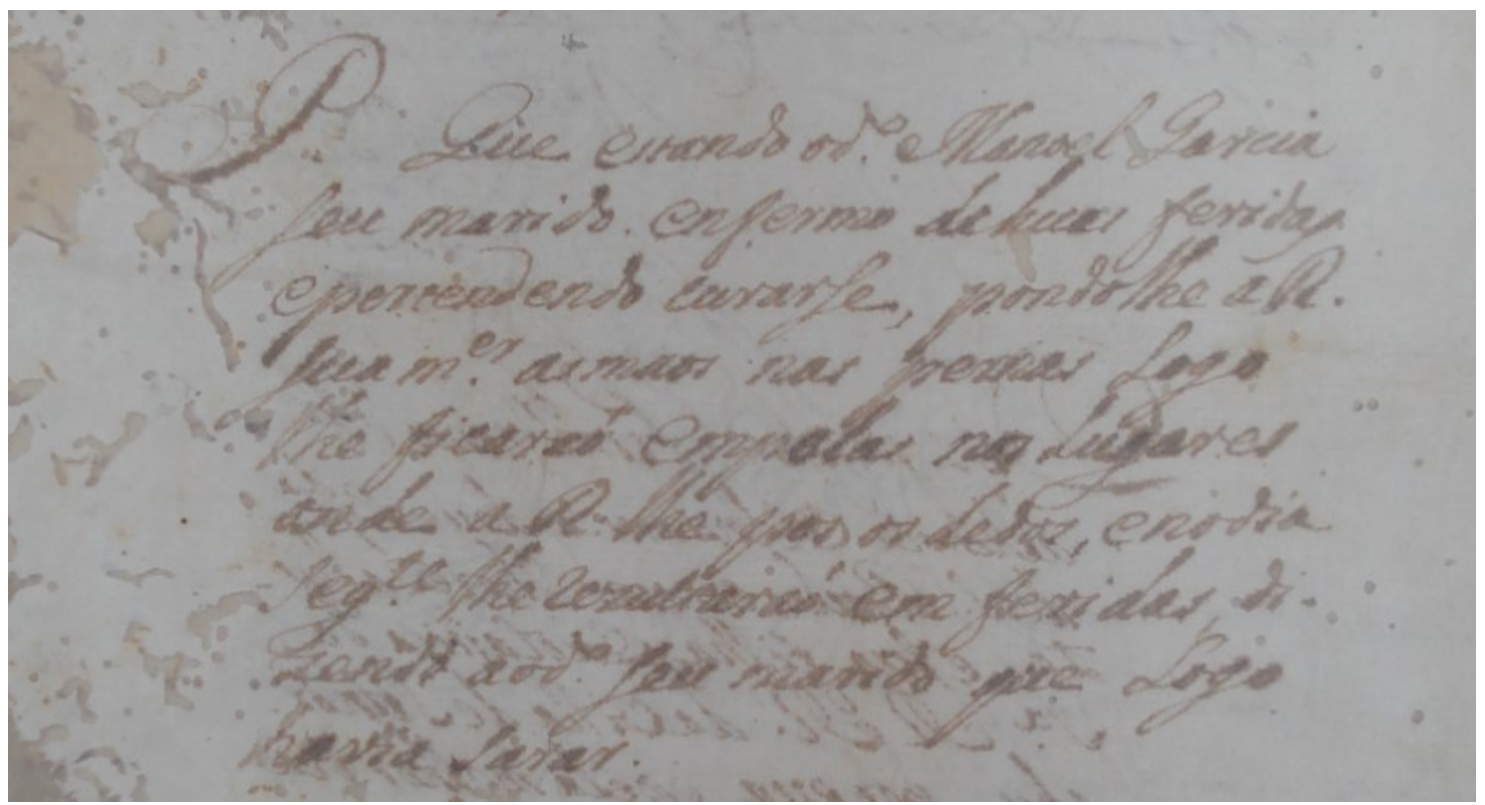

(Fólio 11 v.)

145 Ver SOUZA, 2009, p. 262. 
Provara [espaço] Que estando odito Manoel Garcia seu marido enfermo dehuas feridas epertendendo curarse, pondolhe a Ré sua mulher as maos nas pernas Logo

lhe ficaraó Empolas nos Lugares onde a Ré lhe pos os dedos, e nodia Seguinte lhe rezultaraó em feridas, di zendo aodito seu marido que Logo havia Sarar.

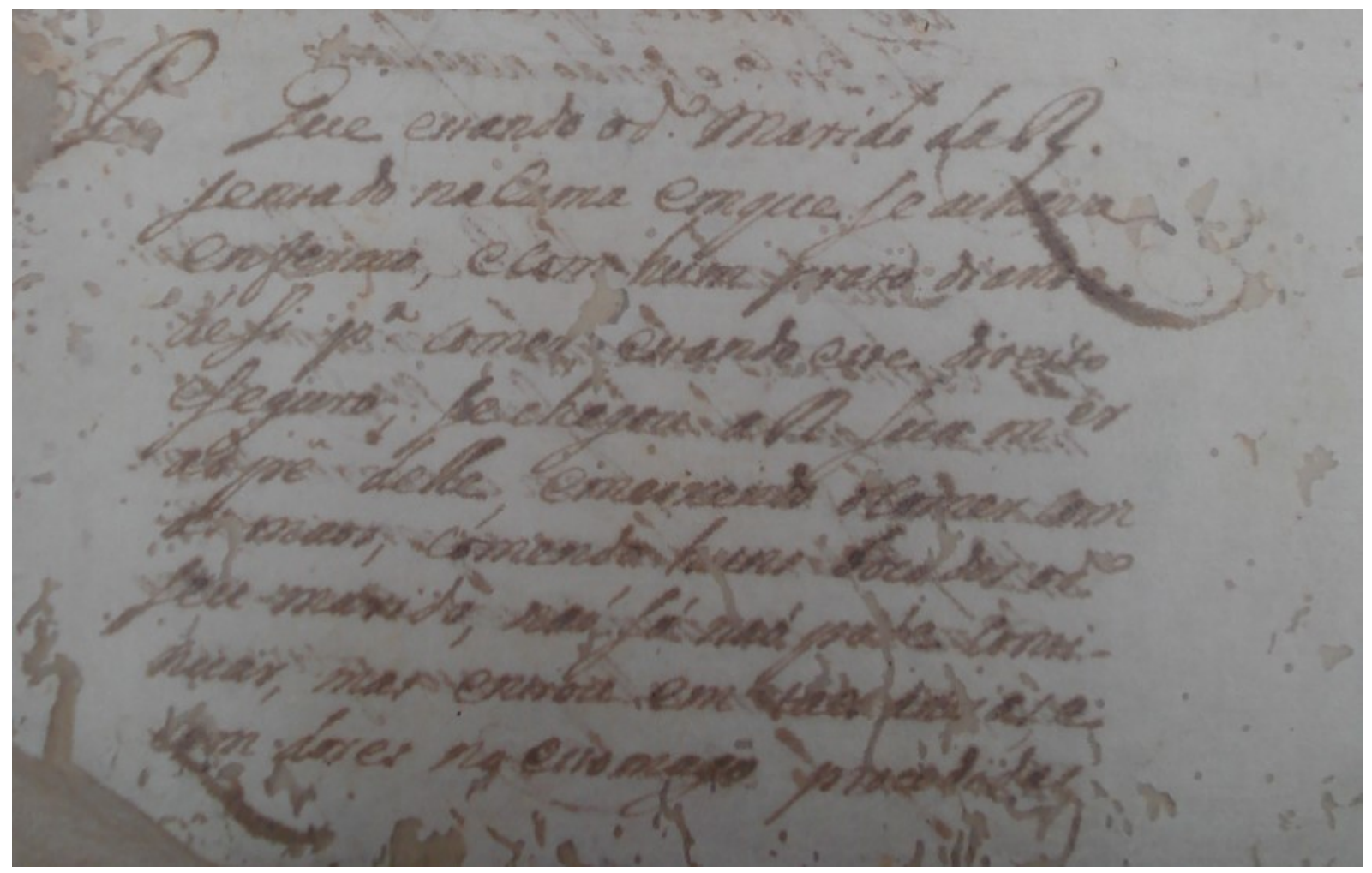

(Fólio 11 v.)

Provara [espaço] Que estando odito marido daRé sentado nacama em que se achava enfermo, ecom hum prato diante desi para comer, estando este direito eseguro, se chegou aRé sua mulher aopê delle, emeixendo ocomer com as maos, comendo $\mathrm{h}[\mathrm{u}] \mathrm{ns}$ bocados odito seu marido, naó só naó pode conti nuar, mas entrou em tae[s] an[c]ias e com dores no estomago procedidas 


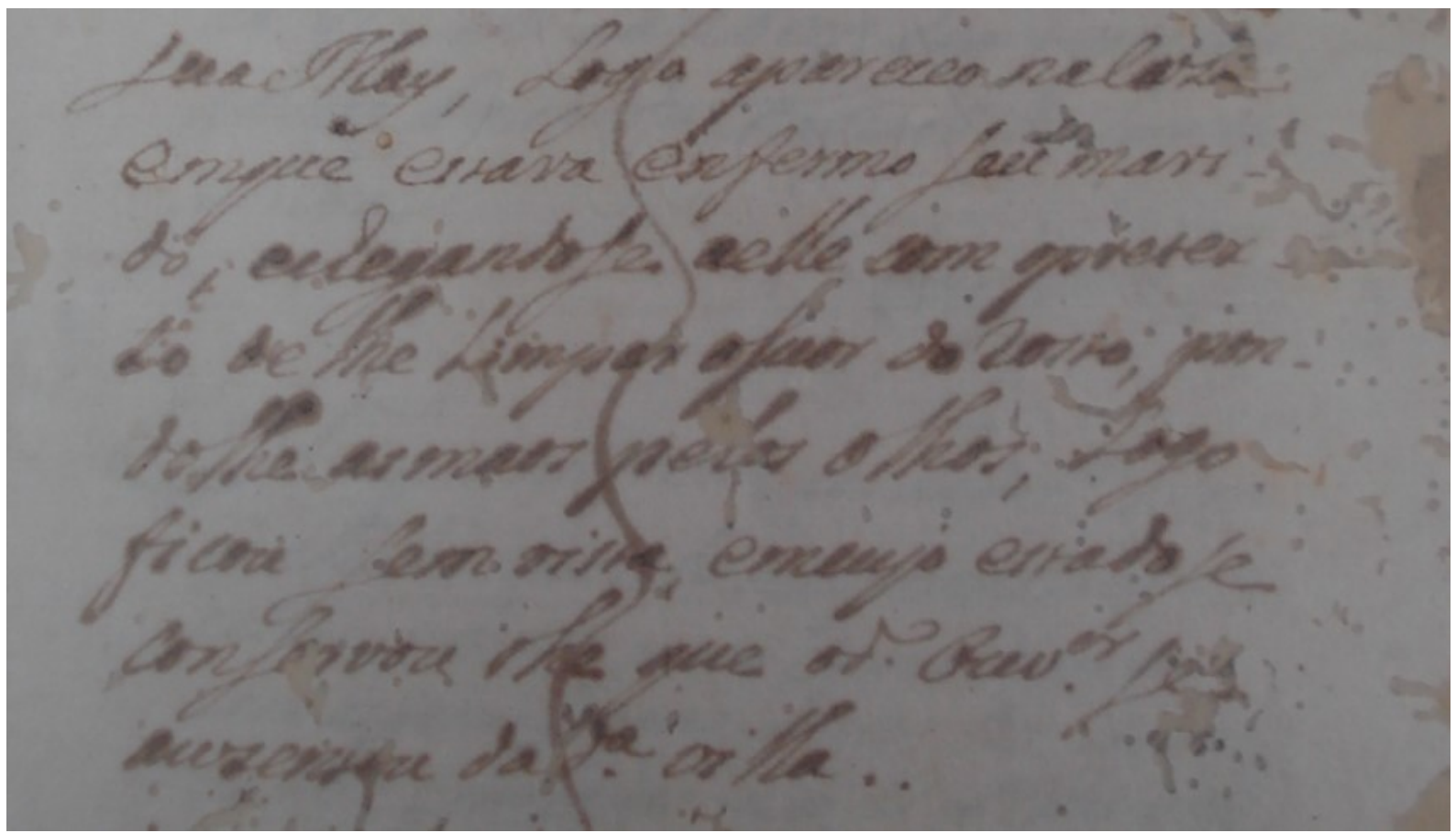

(Fólio 12 r.)

suaMay, Logo apareceo nacaza emque estava enfermo seu mari do, echegandose aelle com opretex to de lhe Limpar osuor do rosto, pon dolhe as maos pelos olhos, Logo ficou sem vista, emcujo estado se conservou the que odito Ouvidor se auzent[o]u da dita villa.

Nos manuscritos ainda há a informação de que, após Escholastica ter "enfeitiçado" o prato de comida de Manoel, fazendo-o sentir enjoos e dores no estômago, foi necessário ao defunto beber azeite para vomitar. 


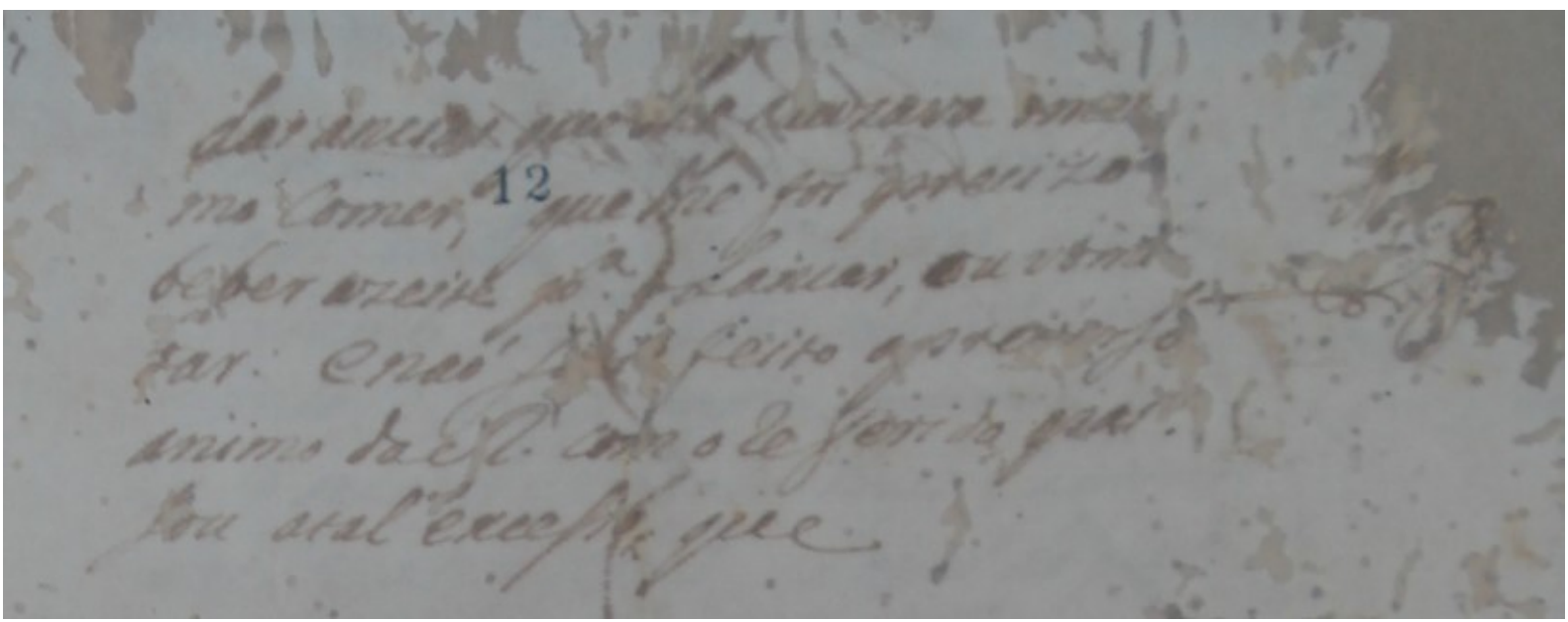

(Fólio 12 r.)

das ancias que lhe cauzava ome[s] mo comer, $<\uparrow 12>$ que the foi precizo

beber azeite para [o]Lancar, ou vomi -

tar E naó s[corroído] feito opre[ve]rso

animo daRé com o referido pas -

sou atal excesso que

A prática de beber azeite, mencionada acima, foi realizada com a finalidade de eliminar, de expulsar o feitiço do corpo de Manoel, pois havia o entendimento de que, vomitando ou defecando, podia-se expulsar energias negativas do corpo do enfeitiçado ou do doente.

[...] Chupar, assoprar, vomitar, defecar, desenterrar eram portanto procedimentos norteados por um princípio comum: expelir, fazer expelir, neutralizar uma espécie de energia negativa, destruidora, responsável por doenças e desgraças. ${ }^{146}$

Ainda nos manuscritos redigidos por Paulo de Souza Rocha, há informações e descrições a respeito de alguns "rituais": Manoel Garcia havia encontrado, em sua casa, seus sapatos enterrados e com pedaços cortados de uma camisa sua dentro deles, ato que foi atribuído à Escholastica. Segundo SOUZA (2009: 230-231): "Provocar malefícios por meio de feitiços enterrados era procedimento comum no Brasil colônia.[...].” 


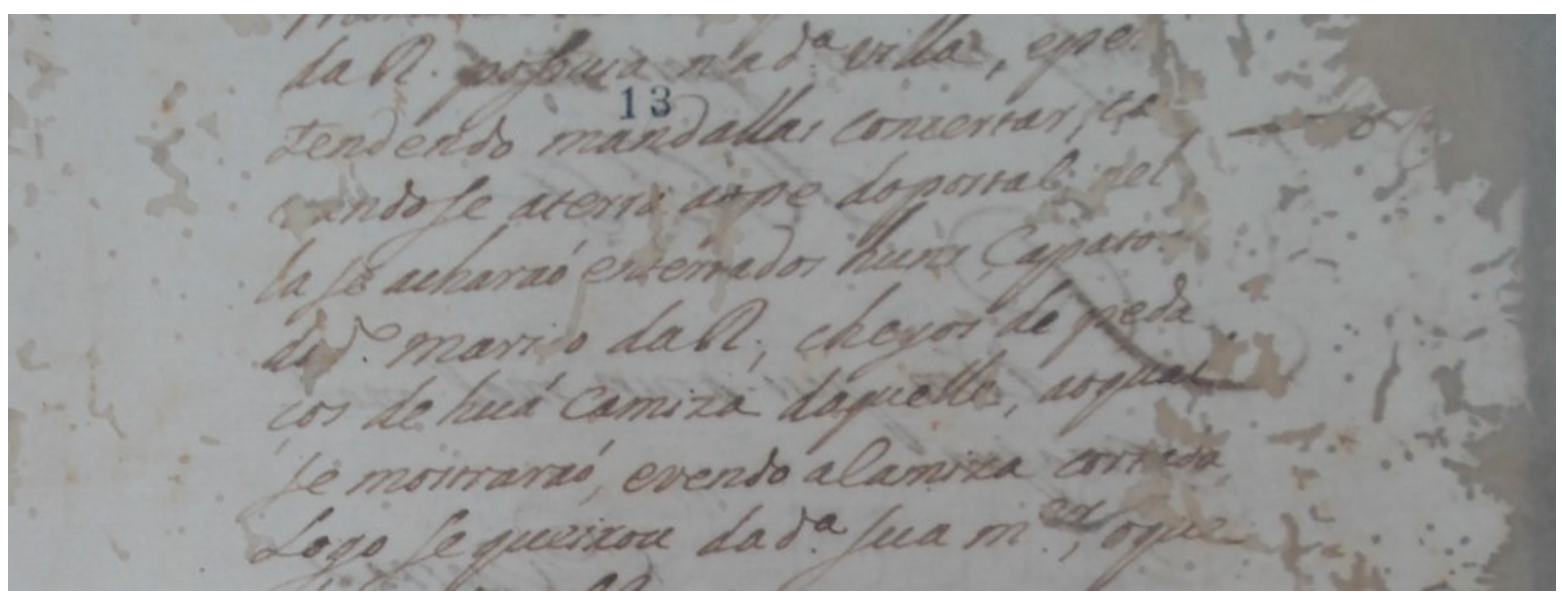

(Fólio 13 r.)

\begin{abstract}
daRé possuia $<\downarrow 13>$ na dita villa, epe[r] tendendo mandallas concertar, ca

vandose aterra aope doportal nel la se acharaó enterrados huns çapatos do dito mari[d]o daRé, cheyos de peda ços de huá camiza daquelle, aoqual se mostraraó, evendo acamiza cortada Logo se queixou da dita sua mulher, oque
\end{abstract}

Como já mencionado acima, os parentes de Manoel Garcia contrataram o então falecido escravo de nome Francisco para que o curasse. Entretanto, testemunhas alegaram que o feiticeiro também possuía fama de enganador, mas recorrer a feiticeiros era uma prática recorrente, como também foi dito anteriormente. As soluções propostas pelas feiticeiras e feiticeiros variavam entre magia invocativa, na qual os demônios ocupavam um importante papel, e curandeirismo de origem africana, transformando a colônia em um repositório de sincretismo religioso. Conforme assegura SOUZA (2009: 229):

[...] no início do século XVIII, as práticas mágicas sincréticas se achavam arraigadas na vida cotidiana das populações coloniais. Recorriase a curandeiros e feiticeiras para resolver questões amorosas e achaques; as soluções mágicas encontradas variavam da magia invocativa de cunho mais acentuadamente europeu - onde os demônios eram ainda soldados valorosos de sabor medieval - ao curandeirismo corrente entre populações africanas, passando por tradições populares extremamente antigas $[\ldots]$. 
Algumas das testemunhas também descreveram o tipo de feitiço realizado por Francisco: afirmaram que o "negro feiticeyro" via, dentro de um copo com aguardente e dinheiro, a sombra de quem havia feito algum malefício ou feitiço:

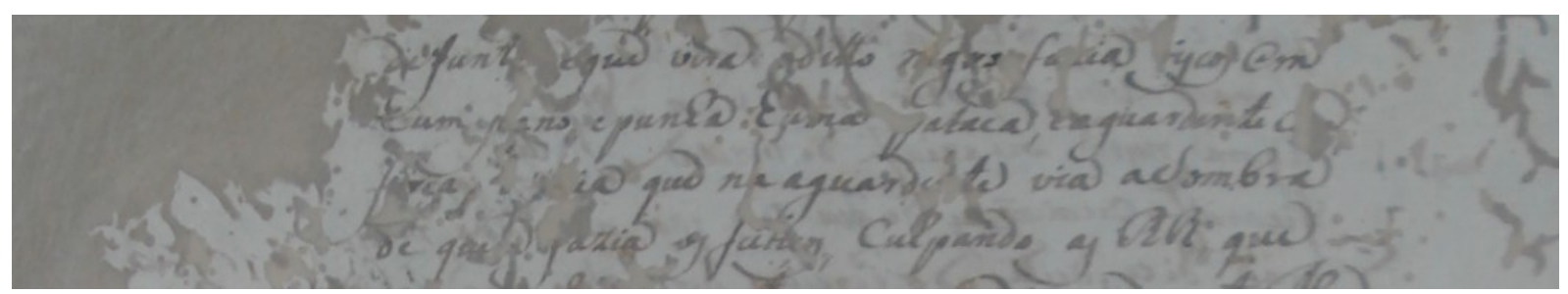

(Fólio 27 v.)

\section{defunt[o] eque vira oditto $\mathbf{n}[\mathbf{e}]$ gro fazia [r]iscos em hum pano epunha huma pataca, eaguardente [com] f[o]rça [corroído]ia que na aguarde[n]te via aSombra de quem fazia os feitiços, culpando as Rés que}

A prática de se fazer adivinhações foi muito difundida pelo Ocidente cristão, porém, foi também frequentemente associada ao diabo. ${ }^{147}$ Logo, até mesmo as leis civis associariam as adivinhações ao demônio, a exemplo das já referidas Ordenações Filipinas que, como se viu anteriormente, condenavam as práticas divinatórias:

[...] Em Portugal, o título III das Ordenações Filipinas, referente aos feiticeiros, atém-se também às adivinhações: ver em água, cristal, espelho, espada, espádua de carneiro, imagens de metal, adivinhar em cabeça de alimárias ou homem morto. As penas impostas eram duras: açoites com baraço e pregão pelas ruas da vila em que ocorrera o crime, três mil-réis pagos ao acusador e, curiosamente, degredo para o Brasil. ${ }^{148}$

O tipo de feitiço praticado pelo "negro feiticeyro" Francisco reflete a cultura e religião africanas trazidas pelos escravos para a colônia. Logo, o cristianismo se misturou às religiões africanas e dos nativos, promovendo um sincretismo religioso próprio da colônia. De acordo com SOUZA (2009: 128-129):

Uma colônia escravista estava, pois, fadada ao sincretismo religioso. Outorgado, talvez, num primeiro momento, pela camada dominante, o sincretismo afro-católico dos escravos foi uma realidade que se fundiu com a preservação dos próprios ritos e mitos das primitivas religiões africanas. Cultuava-se são Benedito, mas cultuava-se também Ogum, e batiam-se atabaques nos calundus da colônia: nas estruturas sociais que lhes foram impostas, os negros, através da religião, procuraram "nichos" 
em que pudessem desenvolver integradamente suas manifestações religiosas. [...].

Portanto, verifica-se que a feitiçaria, na colônia, possuiu dois "campos" de atuação, um contrapondo-se ao outro, pois, se as rés do processo em questão foram acusadas de matar Manoel Garcia utilizando-se de feitiços, o escravo Francisco foi solicitado para que o curasse também por meio de feitiços. Logo, a feitiçaria tinha ação positiva, mas também negativa:

Numa sociedade escravista como a do Brasil colonial, a tensão era permanente, constitutiva da própria formação social, e refletia-se em muitas das práticas mágicas e de feitiçaria exercidas pelos colonos. Através delas, buscava-se ora preservar a integridade física, ora provocar malefícios a eventuais inimigos. Tinham portanto função dupla: ofensiva, visando agredir; defensiva, visando preservar, conservar. ${ }^{149}$

Até o terror inquisitorial se instaurar e conferir características negativas à determinadas práticas religiosas, a comunidade cristã ocidental recorria a elas com naturalidade, o que não foi diferente na colônia:

[...] as orações usadas para a obtenção de fins concretos ligavam-se antes à religião folclorizada do que à magia ritual ou à feitiçaria. [...] As populações do Ocidente cristão recorriam a elas com naturalidade, e só passaram a olhá-las com temor quando os aparelhos de poder identificaram-nas com crimes contra a fé. No contexto colonial, coube à Inquisição desempenhar esse papel. ${ }^{150}$

Contudo, o pai de Escholastica exercia a posição de juiz ordinário na vila e ordenou que o "negro feiticeyro" fosse preso, por ter disseminado os boatos contra as rés:

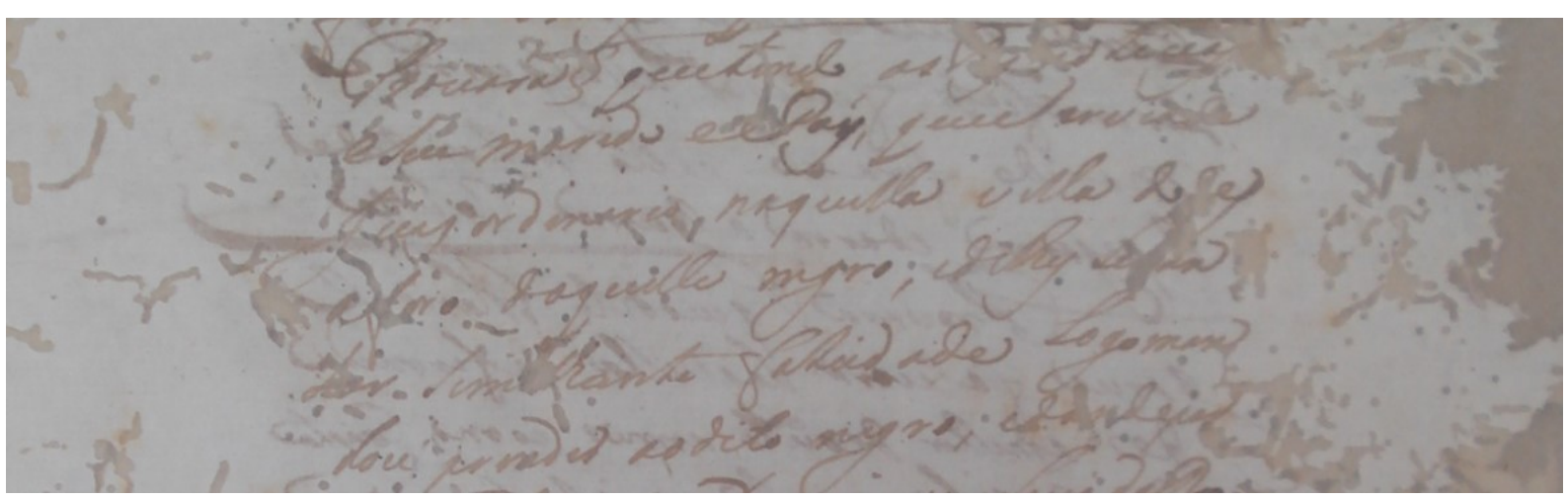

(Fólio 23 r. - Punho desconhecido 2)

Prouarâ § quetendo as R[e]s [n]oticias

eSeu marido eePay, queServiade

149 SOUZA, 2009, pp. 258-259.

150 SOUZA, Op. cit., pp. 217-218. 
Juis ordinario naquella villa do $[\mathrm{d}] \mathrm{es}$ aforo daquelle negro, edelhes Le[v]an tar Sem[e]lhante faLcidade Logo man dou prender ao dito negro, edandopar

Como punição por ter espalhado os boatos, o "feiticeiro" também foi açoitado no pelourinho $^{151}$ e, depois, devolvido a seu dono. Todavia, as testemunhas afirmaram que o feiticeiro pediu desculpas, publicamente, às rés.

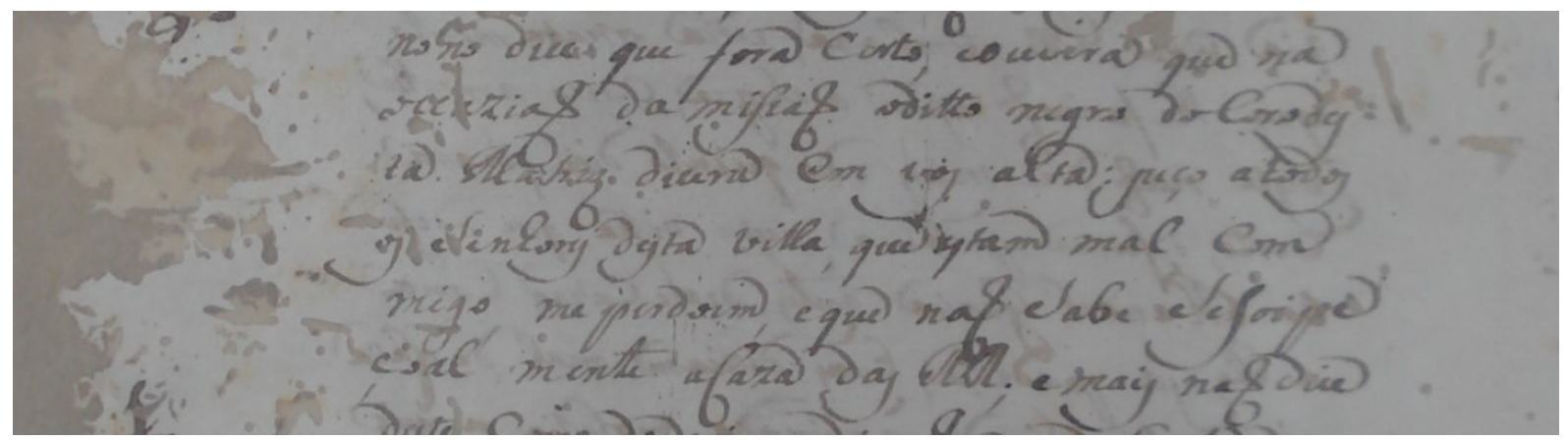

(Fólio 27 v.)

nono dice que fora certo, eouvira que na occaziaõ da missaõ oditto negro docoro des ta Matriz dicera em vos alta: peço a todos os Senhores desta villa, que estam mal com migo, me perdoem, eque naõ Sabe Sefoi pe çoal mente aCaza das Rés; e mais naõ dice

151 Segundo Raphael Bluteau (1728: 383), o "pelourinho" é uma espécie de coluna, em local público (da cidade ou vila) onde, em final de jurisdição, se exerce a justiça com pena de morte. O autor também afirma que, no pelourinho, os "delinquentes" ficavam presos por argolas, expostos ao escárnio do povo. Já Antonio de Moraes Silva (1813: 424) afirma que o "pelourinho" é uma coluna de pedra, posta em alguma praça de vila ou cidade, onde se prende o criminoso pela cintura, expondo-o à vergonha ou onde ele pode também receber açoites. SILVA afirma também que o pelourinho possui argolas, onde se pode enforcar e ponta de ferro de por cabeças. Além disso, é um local onde éditos são afixados. 


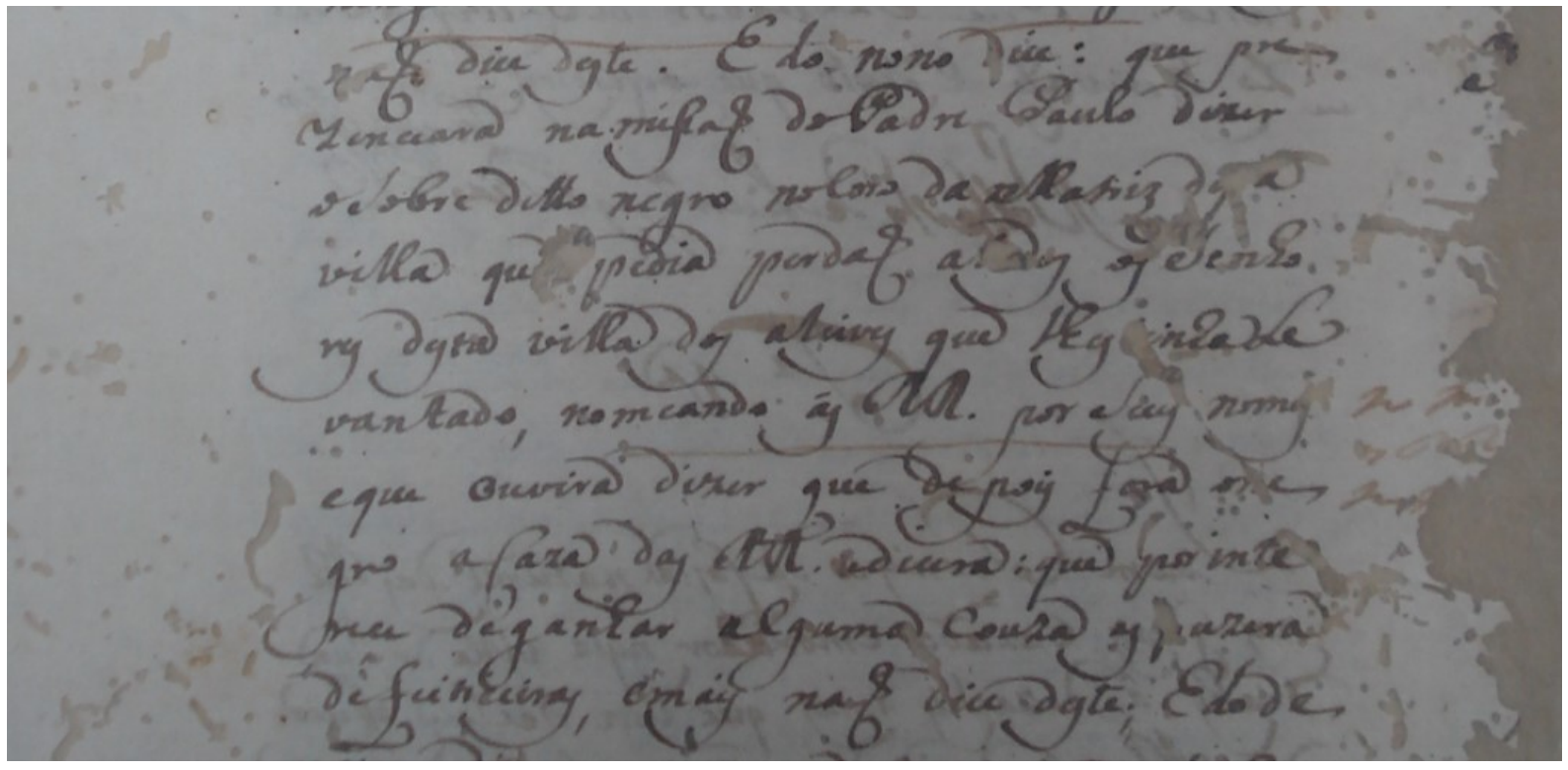

(Fólio 30 r.)

naõ dice deste. E do nono dice: que pre zenciara na missaõ doPadre Paulo dizer osobre ditto negro nocoro da Matriz des[t]a villa qu[e] pedia perdaõ at[o]dos os Senho res desta villa dos aleives que lhes [t]inha Le vantado, nomeando ās Rés por Seus nomes eque ouvira dizer que depois fora one gro aCaza das Rés edicera: que por inte reçe de ganhar alguma couza as puzera defeiticeiras, emais naõ dice deste; E do de

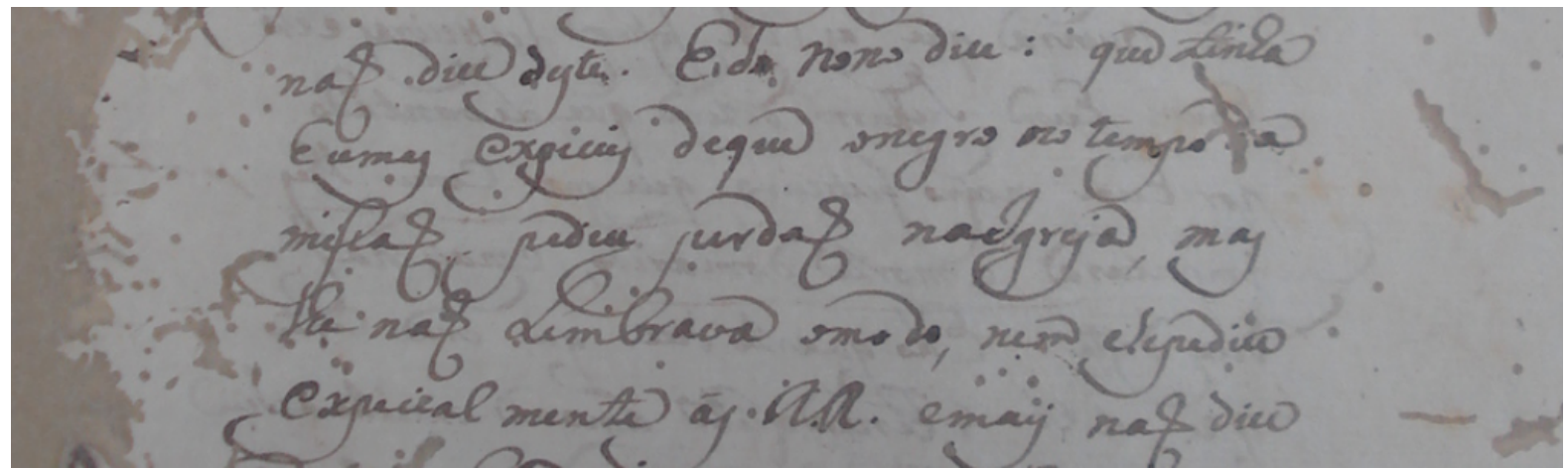

(Fólio 34 v. - Salvador de Oliveyra Preto)

naõ dice deste. E do nono dice: que tinha humas expecies deque onegro no tempo da missaõ pediu perdaõ naIgreja, mas 
lhe naõ Lembrava omo do, nem Sepediu

expecial mente ās Rés emais naõ dice

Em nota de rodapé do Livro II do Código Filipino, define-se o juiz ordinário (função exercida pelo pai de Escholastica) como "[...] o Magistrado eleito annualmente pelos Povos e Camaras, tendo no mesmo lugar domicilio e estabelecimento. ${ }^{\prime 152}$

Ainda no Livro II do Código Filipino, consta a seguinte informação acerca do papel dos juízes ordinários: "Os Juizes ordinarios e outros, que Nós de fóra mandarmos, devem trabalhar, que nos lugares e seus termos, onde forem Juizes, se não façam maleficios, nem malfeitorias. E fazendo-se, provejam nisso, e procedam contra os culpados com diligencia. " 153

Segundo FERREIRA (1937: 5), os juízes ordinários "Tinham por circumscripção o concelho e eram eleitos em segredo, dois para cada anno do triennio, por seis eleitores do segundo gráo na fôrma da Ordenação I, 67, e do alvará de 12 de novembro de 1611." Além disso, o juiz ordinário era responsável por:

\footnotetext{
Processar e julgar os feitos civeis e crimes;

Exercer as funcções de juiz de orphãos onde não houvesse;

Proceder a devassas especiaes pelos crimes indicados na Ordenação, I, 65,31 , e tirar devassas geraes na fórma da mesma Ordenação, $\S \S 39$ e seguintes;

Processar e julgar com os vereadores, sem recurso, as injurias verbaes, julgando-as por si, mas com recurso, quando alguma das partes fosse fidalgo ou cavalleiro;

Processar e julgar com os vereadores, sem recurso, os furtos commettidos por escravos até a quantia de mil e duzentos réis;

Conhecer das appellações e aggravos interpostos das decisões dos almotacés nas causas de valor até dezoito mil réis por si ou com os vereadores, si a causa passasse de mil e oitocentos réis. ${ }^{154}$
}

Em outra nota de rodapé do mesmo Livro II das Ordenações Filipinas, afirma-se que o juiz ordinário "[...] era um Juiz independente da Realeza, e a legislação que executava estava fóra do alcance do mesmo poder, e só o costume podia altera-la."

152 Codigo Phillippino, ou Ordenações e Leis do Reino de Portugal: recopiladas por mandado D'El-Rey Phillippe I. Edição comentada por Cândido Mendes de Almeida. Rio de Janeiro: Typographia do Instituto Philomatico, 1870. Livros I e II, p. 134 (Livro II).

153 Idem, pp. 134-135 (Livro II).

154Fernando Luis Vieira Ferreira. Juizes e tribunaes do Primeiro Imperio e da Regencia - pelo dezembargador Vieira Ferreira. Boletim do Instituto Historico e Geographico Brasileiro. Rio de Janeiro: Imprensa Nacional, 1937, p. 5.

155 Codigo Phillippino, ou Ordenações e Leis do Reino de Portugal. Livro II, p. 135. 
Ainda de acordo com FERREIRA (1937: 5), os juízes ordinários também eram os juízes das sisas, que consistiam em um antigo imposto sobre compras e vendas, principalmente de bens imóveis, sendo atualmente chamado de imposto de transmissão. ${ }^{156}$

O autor ainda afirma, acerca desses mesmos juízes, que "Sua alçada era de tres mil réis nos logares de população superior a duzentas almas e de mil e oitocentos réis em moveis e mil e duzentos em bens de raiz nos logares menos populosos. "157

É importante ressaltar que os juízes e oficiais costumavam portar varas como símbolo de seu poder como agente da lei: "A vara era, e ainda he, a insignia que trazião os Juizes e Officiaes seculares em signal de jurisdicção, para que fossem conhecidos, e não soffressem em suas ordens resistencia." "158

Em alguns casos, entretanto, a tarefa do juiz ordinário poderia ser encaminhada a uma instância superior, como o ouvidor de comarca ${ }^{159}$ : "Nas causas que a excedessem de suas sentenças havia appellação ou aggravo para o ouvidor da comarca ou para a Relação competente, conforme o valor coubesse ou não na alçada do ouvidor." $" 160$

Os ouvidores, segundo o mesmo Livro II das Ordenações, eram os juízes nas terras de donatários e nobres:

Chamava-se assim outr'ora os Juizes nas terras dos Donatarios e Nobres; e he por isso que os Juizes no Brazil e outras colonias portuguezas, a principio pertencentes á Donatarios, tambem se chamavão - Ouvidores, e tinhão em cada Capitania os seus Regimentos.

A C. R. de 22 de janeiro de 1623 declarou que os Governadores da America não podião suspender os Ouvidores; e a de 24 de Março de 1708 tambem declarou que os Ouvidores das Capitanias do Brazil erão Juizes

156 Cf. Dicionário Caldas Aulete Digital. Disponível em: http://www.aulete.com.br/sisa

157 FERREIRA, Op. cit., p. 5.

158 Cf. Codigo Phillippino, ou Ordenações e Leis do Reino de Portugal. Livro II, p. 135 (em nota de rodapé).

159 Segundo FERREIRA, Op. cit., pp. 7-8, os ouvidores de comarca eram nomeados pelo Rei por três anos e correspondiam aos corregedores de Portugal e Algarves. Suas funções compreendiam: conhecer as causas pertencentes à competência dos juízes ordinários; conhecer os agravos dos juízes ordinários e suas apelações nas causas que não excedessem a sua alçada; tirar devassas; ordenar a prisão de criminosos; dar cartas de seguro; inspecionar as prisões; fazer correição nos julgados de sua comarca; zelar pela observação dos regimentos dados aos juízes e funcionários da justiça; anular as posturas feitas pelas câmaras sem a forma das Ordenações, dentre outras.

No volume dois de seu Vocabulario Portuguez \& Latino, Raphael Bluteau (1728: 386), define "comarca" como o espaço de terra da jurisdição de um corregedor. Além dele, Antonio de Moraes Silva (1813: 416-417), no volume um de seu Diccionario da lingua portugueza, afirma basicamente o mesmo, definindo "comarca" como: "Um numero de Villas com seus territorios, cuja justiça é administrada pelo Corregedor, e mais Ministros, que residem na Cabeça da Commarca, que é Cidade, ou Villa notavel. [...] Tambem há Comarcas Ecclesiasticas, em que os Bispados se dividem á imitação das Provincias em Comarcas Civís."

160 FERREIRA, 1937, p. 5. 
da Corôa, para a decisão dos Recursos interpostos das Justiças Ecclesiasticas $[\ldots]{ }^{161}$

Além disso, em situações de ausência, por exemplo, o juiz ordinário era substituído pelo ouvidor de comarca e o contrário também ocorria. Contudo, em caso de ausência prolongada de algum deles ou de morte, a câmara de homens bons decidia quem ocuparia o cargo.

Nas ausencias ou impedimentos passageiros um era substituido pelo outro e ambos pelo vereador mais velho. No caso de morte, impedimento ou ausencia prolongada de qualquer delles, a camara com os homens bons escolhia quem o substituisse. ${ }^{162}$

É de fundamental importância ressaltar que, à época do processo, Escholastica da Sylva estava casada com Antonio Marques Barboza, isto é, em seu segundo casamento. Em um dos fólios, redigido pelo pároco Francisco Iozeph Guedes, consta a informação de que Manoel Garcia, primeiro marido de Escholastica, havia falecido no ano de 1746.

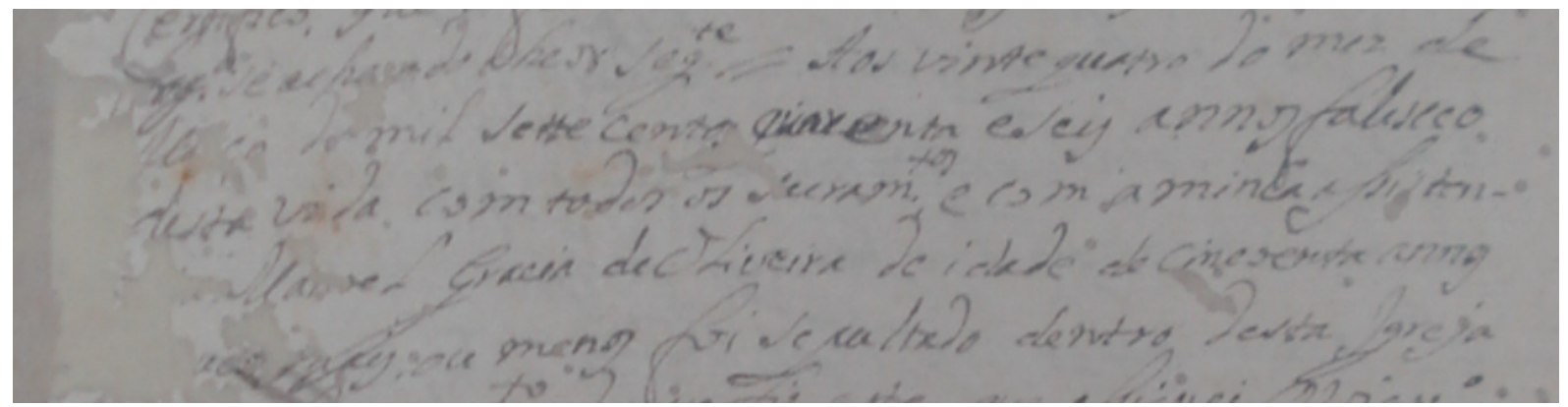

(Fólio 18 v.)

[...] Aos vinte quatro do mez de

$\mathrm{Ma}[\mathrm{r}]$ ço do mil sette centos quarenta ${ }^{163}$ eseis annos falesceo desta vida com todos os $\mathbf{s}[\mathbf{a}]$ cramentos e com a minha assisten -

[cia]Ma[n]oel Gracia de OLiveira de idade de cincoenta annos

[corroído]ue[corroído] mais ou menos foi se pultado dentro desta Igreja

Além de Escholastica estar casada pela segunda vez, é importante enfatizar que, em um dos fólios, onde seriam necessárias as assinaturas das duas rés, pois se tratava de uma

161 Codigo Phillippino, ou Ordenações e Leis do Reino de Portugal. Livro II, p. 468.

162 FERREIRA, Op. cit., p. 5.

163 Aparentemente, o "e" em "quarenta" foi escrito por cima de outra letra. 
procuração, quem assina o documento é o marido de Escholastica, Antonio Marques Barboza. A razão para isso se encontra no fato de que Escholastica Pinta da Sylva e Thereza Leyte não sabiam ler ou escrever, como é possível observar pelos trechos a seguir, retirados do documento redigido pelo escrivão Polycarpo de Abreu Nogueyra.

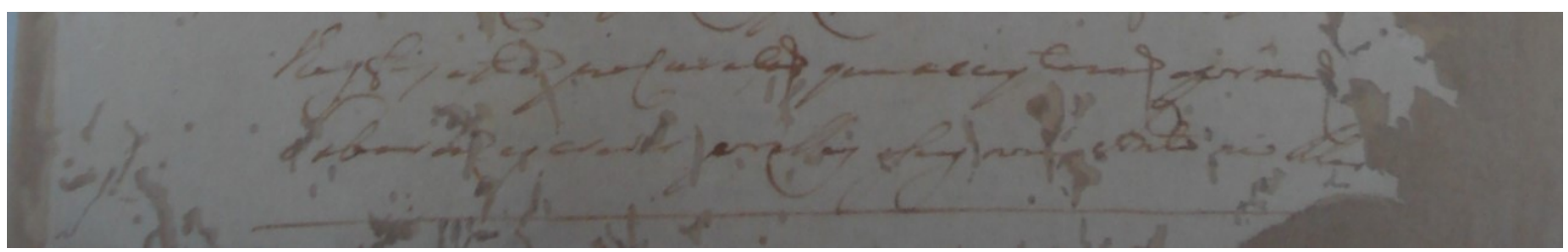

(Fólio 7 r.)

lhes fis esta proCuraçaõ queacceytaraõ epor nã̃

Saberem escrev[e]r porellas assig nou Anto nio Mar

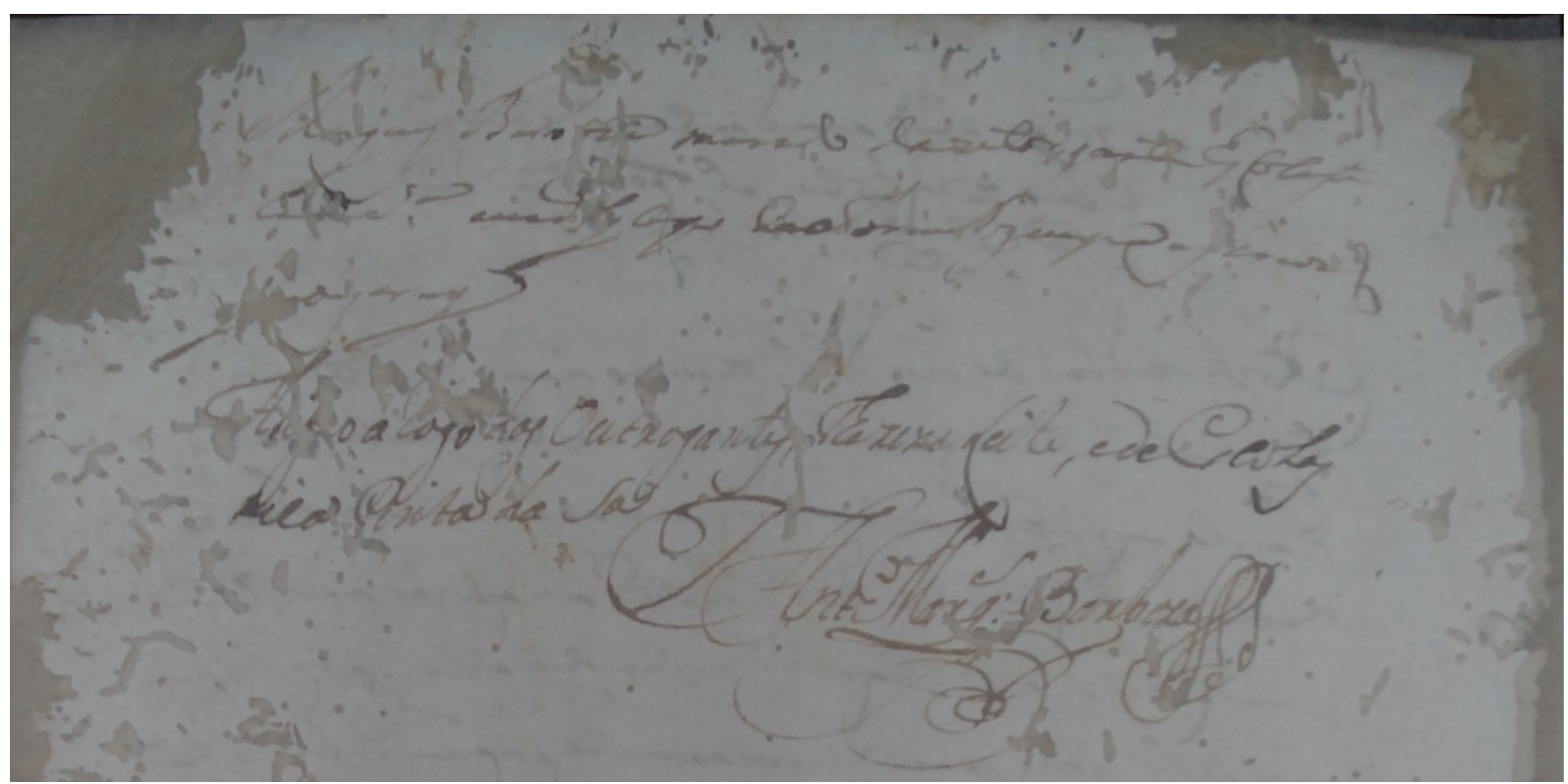

(Fólio 7 v.)

$[[\mathrm{M}[\mathrm{a}] \mathrm{r}]]$ ques Barb[o]za marido daoutorgante EsColasti

Ca[da]Silva eeuPolycarpo deAbreuNogueyra escrivaõ

[que]oescrevy

[espaço]

A[sign $]$ o a rogo das Outrogantes, Thereza Leite, edeEscolas

tica Pinta da Silva

AntonioMarques Barboza[sinal público] 
Vale enfatizar também que as testemunhas que forneceram depoimentos neste processo-crime eram somente homens (alfaiates, donos de lavouras), não havendo, assim, nenhuma mulher dentre as testemunhas, como demonstram os seguintes excertos dos manuscritos:

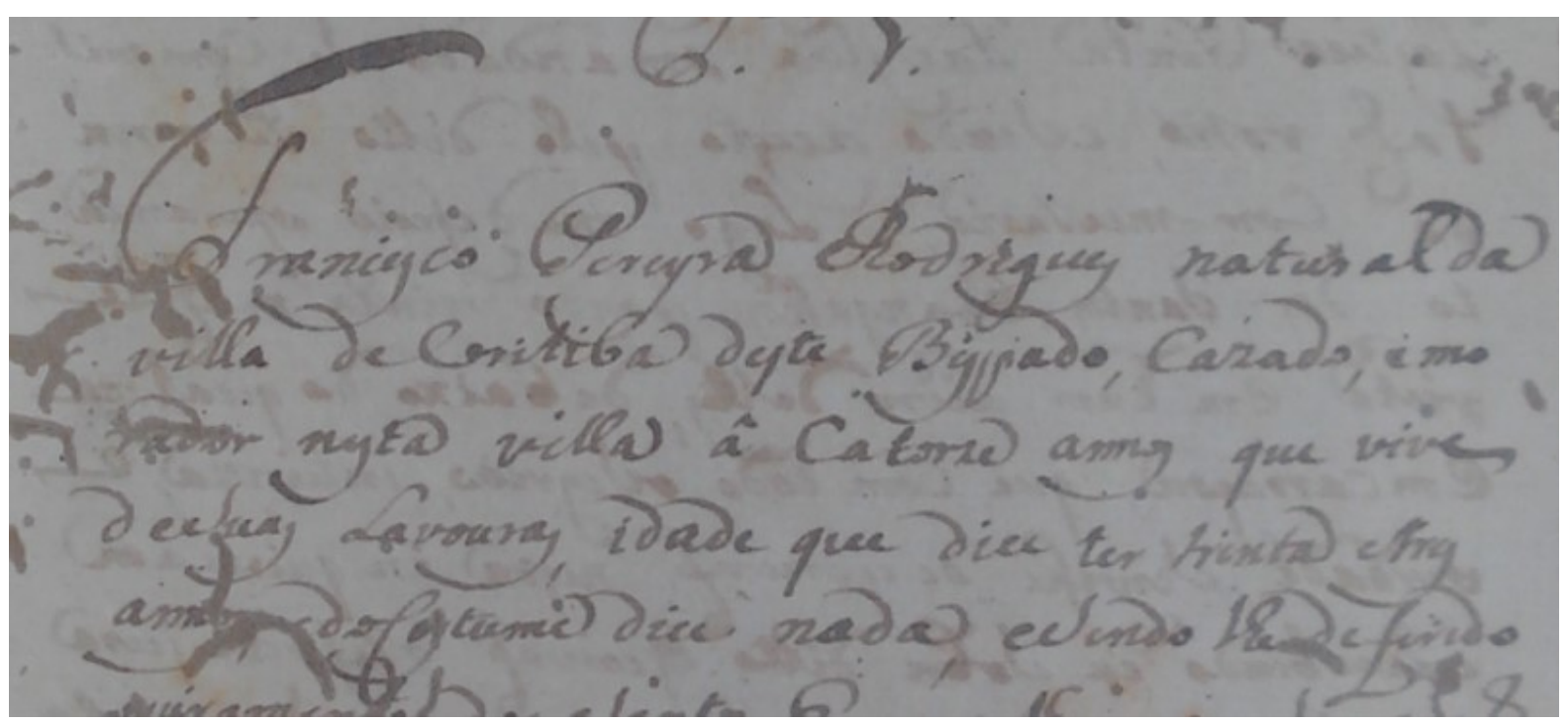

(Fólio 26 v.)

Francisco Pereyra Rodrigues natural da villa decoritiba deste Bispado, Cazado, e mo rador nesta villa â Catorze annos que vive deSuas Lavouras, idade que dice ter trinta etres annos, e doCostume dice nada, eSendo lhe deferido

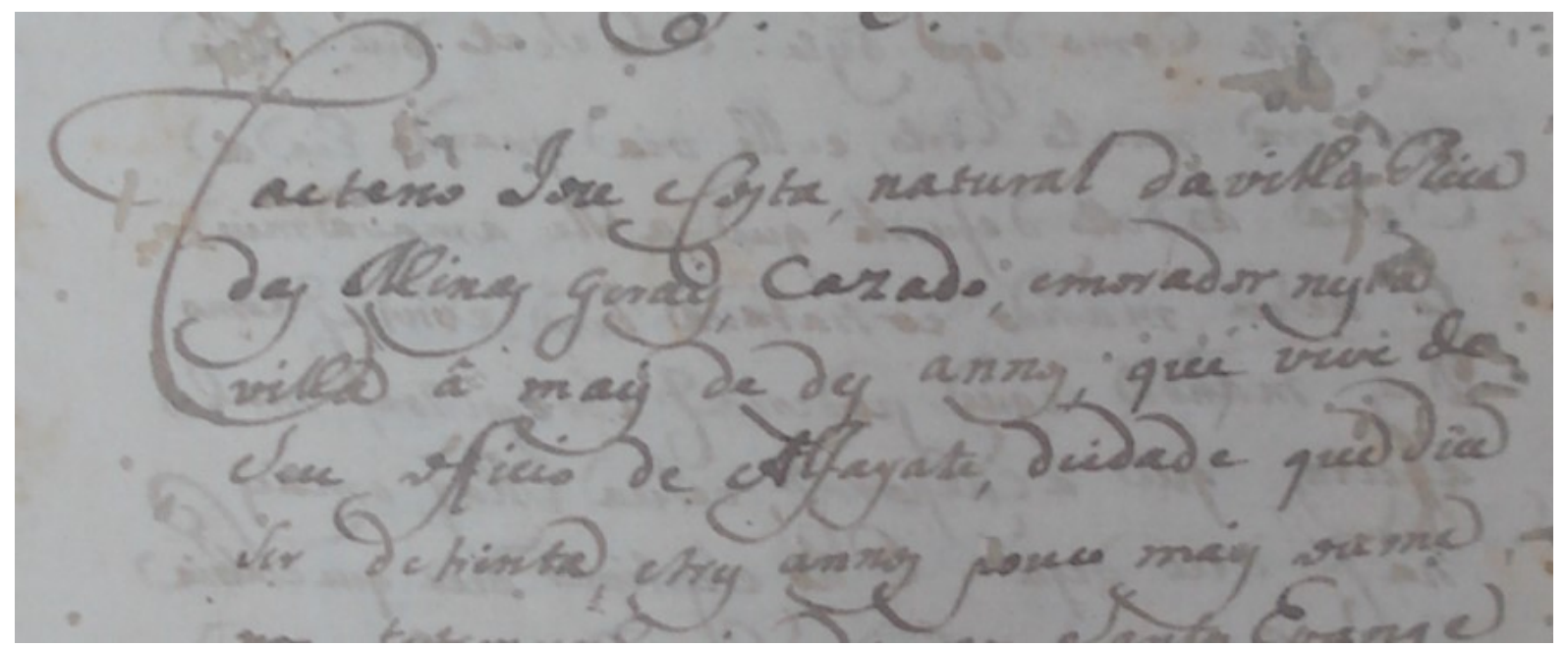

(Fólio 28 r.) 
Caetano Ioze Costa, natural da villa Rica

das Minas Gerais, cazado, emorador nes $[\mathrm{t}] \mathrm{a}$

villa â mais de des annos, que vive de

Seu officio de Alfayate, deidade que dice

ser de trinta etres annos pouco mais ou me

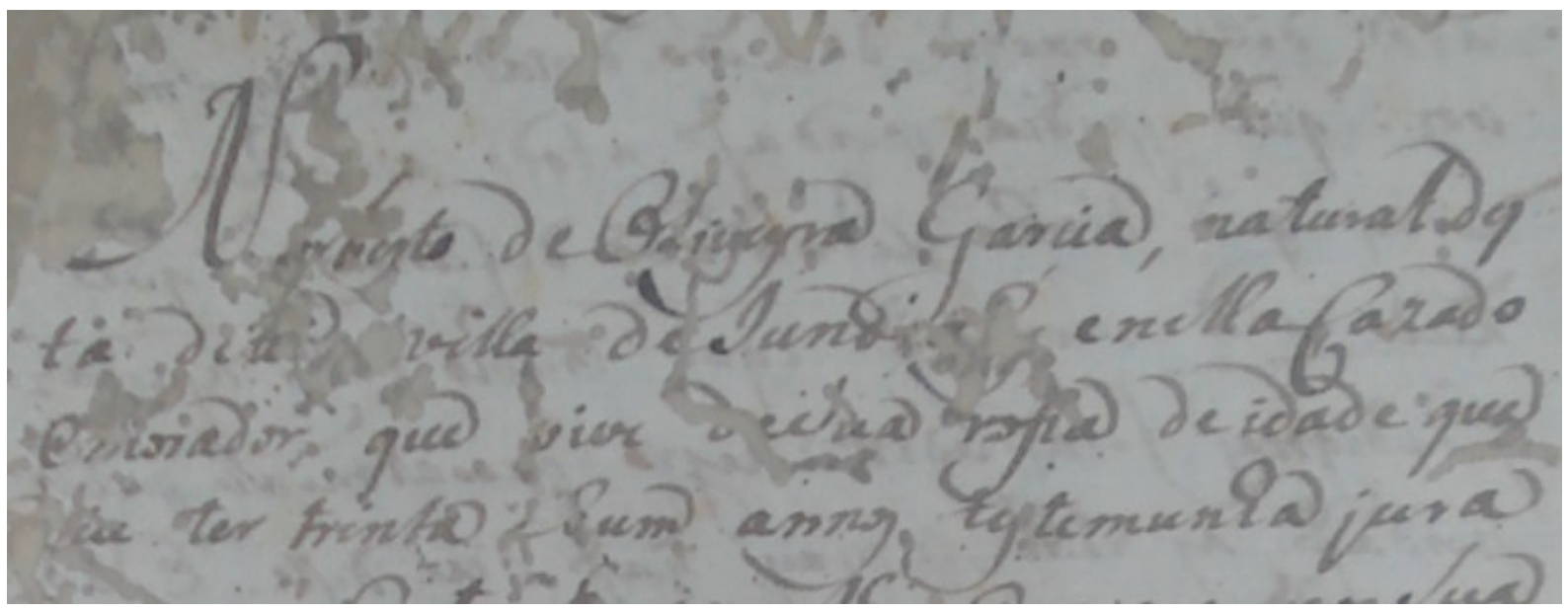

(Fólio 29 v.)

Norberto deOliveyra Garçia, natural des

ta dit[ta] villa deIund[i]ahy enellaCazado

emorador, que vive deSua rossa deidade que

[d]ice ter trinta ehum annos testemunha jura

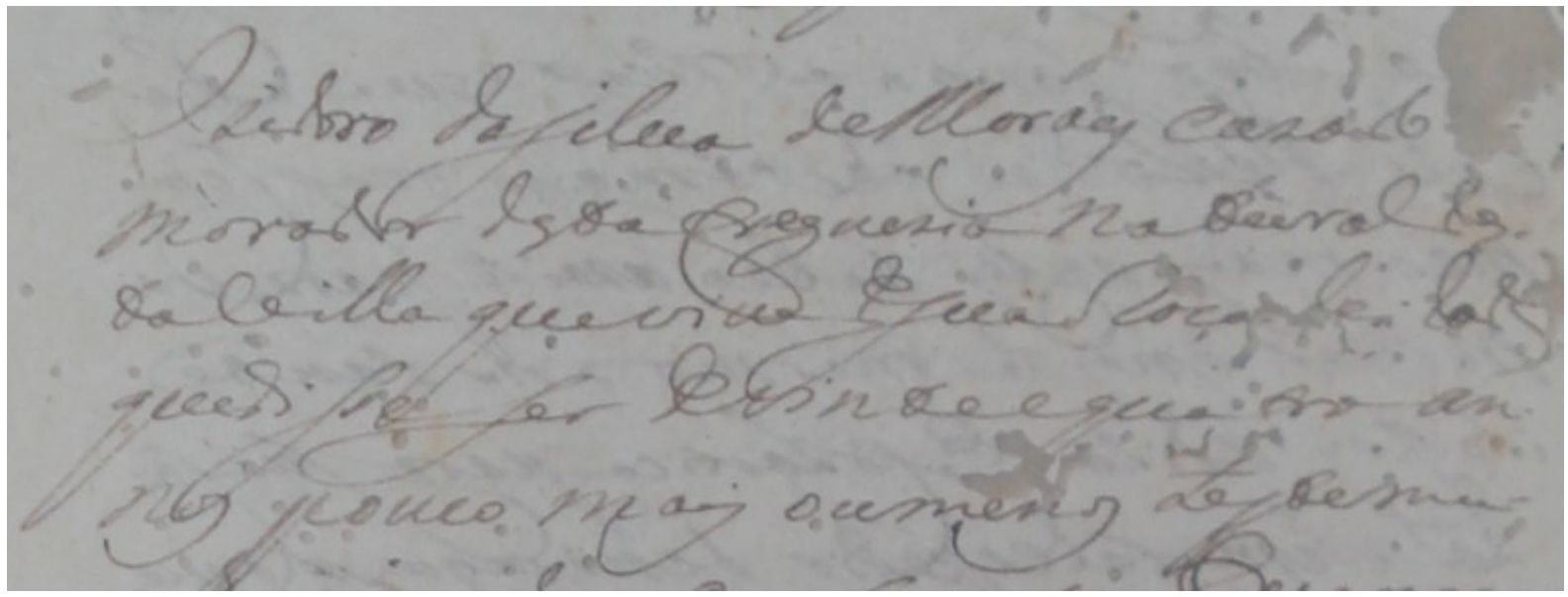

(Fólio 37 r.)

Izidoro dasilua deMoraes cazado

morador destafreguezia naturaldes- 
taVilla queviuedesuaRoça deidade

quedisseser devinteequatroan-

nos pouco mais oumenos testemu -

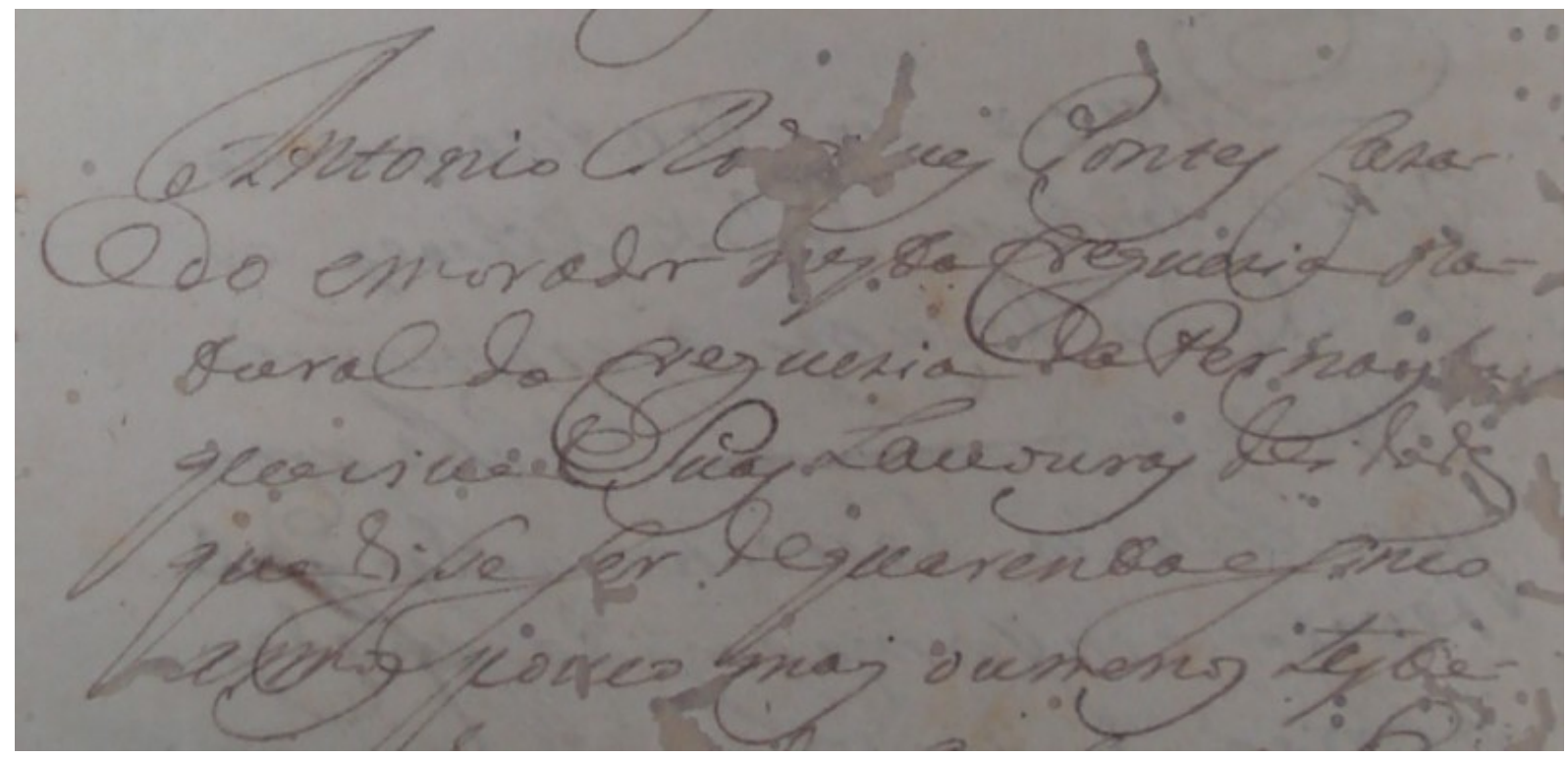

(Fólio 40 r.)

\begin{abstract}
Antonio Ro[drig]ues Pontes Caza-
do emorador nestaFreguezia naturaldafreguezia daPernayba queviuedeSuas Lauouras deidade quedisseser dequarentaesinco annos pouco mais oumenos teste-
\end{abstract}

Outro ponto a ser mencionado é um testemunho afirmando que Manoel Garcia e Escholastica da Sylva participavam de rituais de exorcismo.

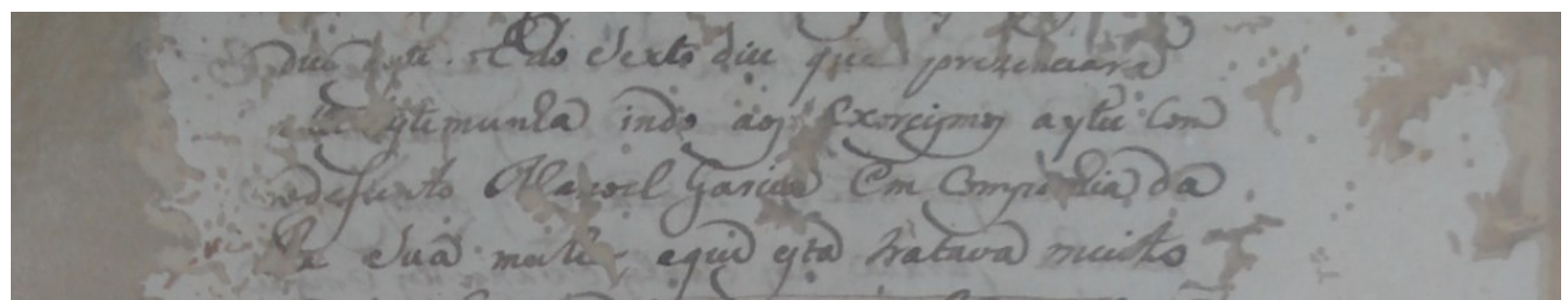

(Fólio 34 v.)

dice deste. E do Sexto dice que prezenciara elle $[\mathrm{t}$ ] estemunha indo aos exorcismos a ytu com 


\section{odefunto Manoel Garcia emcompa[n]hia da \\ Re Sua mulh[e]r, eque esta tratava mu[i]to}

Finalmente, o processo foi concluído em maio de 1755, sendo as rés absolvidas das acusações de feitiçaria. Além disso, se estabeleceu que fosse pago a elas as "custas" do processo, isto é, quem as processou, levantando falso testemunho (injúria) contra mãe e filha, deveria "reembolsá-las" pelo valor que Thereza e Escholastica gastaram com a defesa.

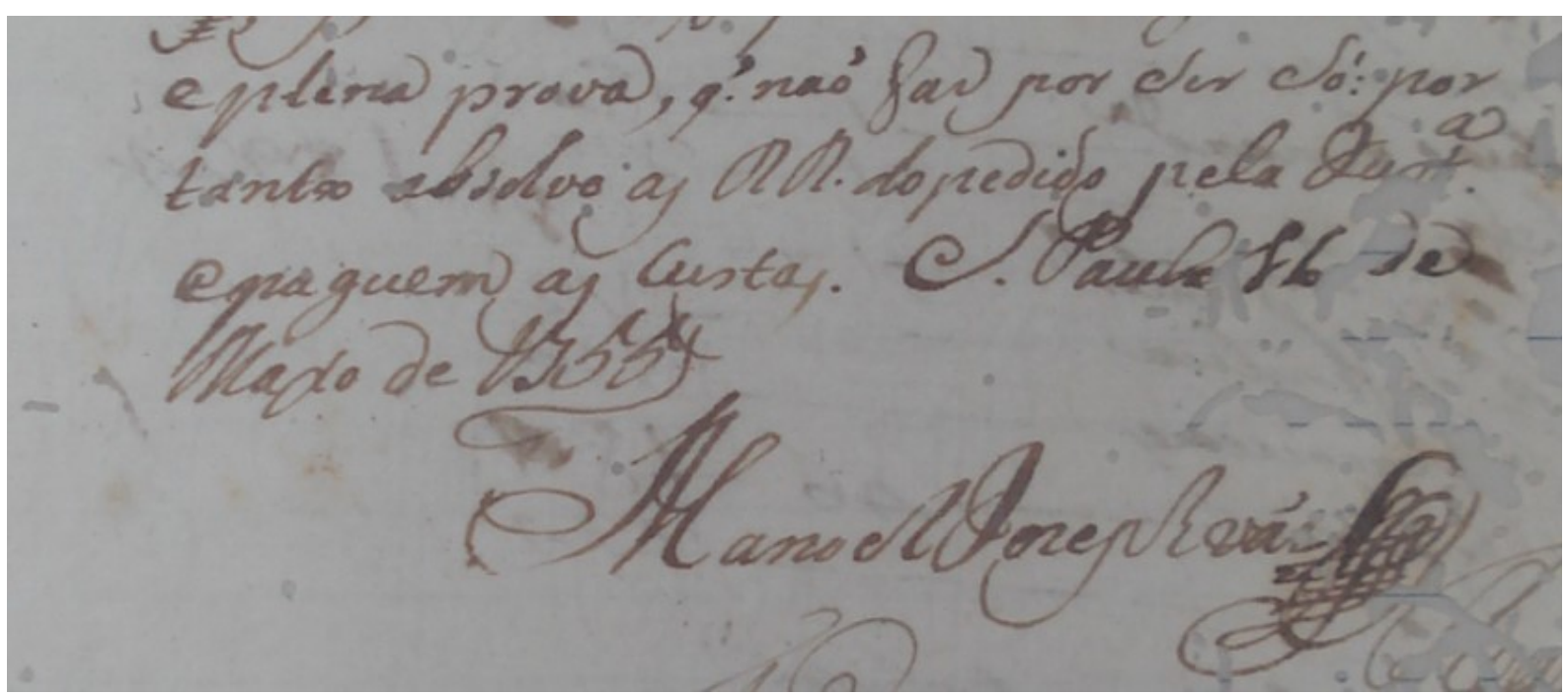

(Fólio 48 r.)

e plena prova, que naó faz por ser só: por tanto absolvo as Rés do pedido pela Iustiça epaguem as custas. Saó Paulo 16 de

Mayo de 1755

\section{Manoel Iozeph váz[sinal público]}

Além das rés, do falecido (Manoel Garcia) e de outras pessoas envolvidas neste processo-crime, há também a presença de figuras de autoridade (escrivães, promotores, clérigos, meirinhos, dentre outros) que redigiram ou foram somente mencionadas ao longo da documentação. A seguir, apresenta-se informações acerca de algumas dessas pessoas, pois, infelizmente, não foi possível localizar dados sobre todas elas. 
- Escrivão Polycarpo de Abreu Nogueyra: exerceu os cargos de padre e visitador, tendo realizado visitas pastorais no Bispado de São Paulo, no período compreendido entre os anos de 1765 e $1771 .^{164}$

- Promotor Paulo de Souza Rocha: exercia as funções de cônego, arcipreste do cabido $^{165}$ paulista e vigário-geral da diocese de São Paulo. ${ }^{166} \mathrm{O}$ cônego seria um padre do clero secular, que possuía alguma função religiosa, como rezar ofícios. ${ }^{167} \mathrm{Em}$ relação ao arcipreste, esse seria um título de dignidade concedido aos párocos de determinadas igrejas, conferindo-lhes preeminência e jurisdição sobre os demais párocos; o arcipreste também poderia ser um sacerdote idoso que participava das decisões relacionadas à diocese; e pode também ser entendido com um título honorífico concedido aos párocos em determinados países da Europa. ${ }^{168}$ Já o vigáriogeral seria um "prelado que representa o bispo na administração da diocese. "169

- Manoel Iozeph váz: D. Bernardo Rodrigues Nogueira foi nomeado bispo de São Paulo no ano de 1745, porém, ao chegar à colônia, permaneceu em Salvador, com o objetivo de resolver questões burocráticas em relação à instituição da nova diocese. Por este motivo, D. Bernardo expediu uma procuração para que Manoel Iozeph váz assumisse, temporariamente, o bispado em seu nome. À época, Manoel exercia a função de vigário de vara da comarca da Sé, entretanto, a partir de 1746, passou a ocupar o cargo de governador do bispado de São Paulo. ${ }^{170}$

- Dom Frei Antonio da Madre de Deos (mencionado nos fólios 3 r. e 6 r.): Após o falecimento de D. Bernardo, em 1748, a diocese de São Paulo entrou em seu primeiro período de vacância. Segundo o Concílio de Trento, em caso de sé vacante, um vigário capitular (eleito pelo Cabido) deveria assumir a função do prelado. ${ }^{171}$ Assim, em 10 de

164Cf. MOTT, Luiz. "Paulistas e colonos de São Paulo nas garras da Inquisição portuguesa". In.: Revista USP. São Paulo, $\mathrm{n}^{\circ}$ 45, março/maio, 2000, pp. 118 e 119. Disponível em: https://www.revistas.usp.br/revusp/article/download/30120/32005/. Consultado em 18/10/18.

165 De acordo com Aldair Carlos Rodrigues (2012: 11), o cabido consistia em uma "corporação que abrigava a elite eclesiástica das dioceses."

166Cf. RODRIGUES, Aldair Carlos (Universidade de São Paulo). Poder eclesiástico e Inquisição no século XVIII luso-brasileiro: agentes, carreiras e mecanismos de promoção social. Tese de doutorado. São Paulo, 2012, pp. 166 e 252. Disponível em: http://www.teses.usp.br/teses/disponiveis/8/8138/tde27092012-114557/pt-br.php. Consultado em 18/10/18.

167 Ver Caldas Aulete Digital. Disponível em: http://www.aulete.com.br/c\%C3\%B4nego

168 Ver Caldas Aulete Digital. Disponível em: http://www.aulete.com.br/arcipreste

169 Ver Caldas Aulete Digital. Disponível em: http://www.aulete.com.br/vig\%C3\%A1rio-geral

170 Cf. ZANON. Dalila. "Os bispos e o poder secular na capitania de São Paulo setecentista". Unicamp, p. 212. Disponível em: http://www.humanas.ufpr.br/portal/cedope/files/2011/12/Os-bispos-e-o-podersecular-na-capitania-de-S\%C3\%A3o-Paulo-setecentista-Dalila-Zanon.pdf. Consultado em 18/10/2018.

171 Cf. ZANON, Idem, Ibidem. 
novembro de 1748, o cônego Lourenço Leite Penteado foi eleito vigário capitular. Entretanto, o período de vacância terminou somente quando Dom Frei Antonio da Madre de Deos Galrão foi nomeado segundo bispo de São Paulo, em 24 de novembro de 1749. Dom Frei Antonio nasceu em Lisboa, em maio de 1697. Após concluir os estudos preliminares, tornou-se franciscano da província de Arrábia. ${ }^{172}$ Ainda em Lisboa, expediu uma procuração, datada de 15 de julho de 1750, para que o arcediago Mateus Lourenço de Carvalho assumisse a diocese. No dia 24 de março de 1751, Dom Frei Antonio partiu de Portugal e sua entrada solene em São Paulo deu-se em 28 de junho do mesmo ano, quando tinha cerca de 54 anos de idade. Dom Frei Antonio da Madre de Deos administrou a diocese de São Paulo por um período de treze anos, falecendo em 19 de março de 1764, aos 67 anos. ${ }^{173}$

- Reverendo Visitador Miguel Dias Ferreyra (mencionado nos fólios 17 r., 18 r., 18 v., 23 v. e 27 v.): ocupava o cargo de padre vigário da Vila de Itu $^{174}$ e já havia exercido a função de comissário do Tribunal do Santo Ofício, em $1743 .{ }^{175}$

- Doutor Ouvidor Domingos Luis da Rocha (mencionado nos fólios 16 v. e 23 r.): exercia a função de Ouvidor Geral, isto é, representante do poder da Coroa. Durante a década de 1740, mais especificamente no final de 1744, estabeleceu-se um conflito entre Domingos Luis da Rocha e os membros da Câmara municipal de São Paulo, devido à posição que o Ouvidor Geral deveria ocupar não apenas nas festividades religiosas, mas também nas funções públicas. Essa discórdia entre o poder real e autoridades coloniais influenciou diretamente a vida jurídica da aldeia de São Miguel. ${ }^{176}$ Domingos Luis da Rocha não aceitava ocupar o segundo lugar nas cerimônias religiosas, o que “consistia realmente numa denúncia da negação de sua autoridade como hierarquicamente superior no âmbito municipal. "177

172 Geralmente escrito "Arrábida", região de Portugal.

173 Cf. ZANON, Op. cit., p. 212.

174 Ver página oficial da Paróquia Nossa Senhora de Monte Serrat (Diocese de Jundiai - Salto/SP), "História da Paróquia". Disponível em: http://paroquiamonteserrat.com.br/a-paroquia/. Consultado em $18 / 10 / 18$.

175 Cf. MOTT, Op. cit., p. 118.

176 Cf. MACEDO, Camilla de Freitas (Universidad del País Vasco). "Sesmarias indígenas na São Paulo colonial: uma interseção entre estatutos pessoais e situações reais". In.: Dimensões - Revista de História da Ufes, n. 39, 2017, pp. 127 e 129. Disponível em: http://periodicos.ufes.br/dimensoes/article/view/18629/0. Consultado em 18/10/18.

177 Idem, Ibidem, p. 127. 


\section{ETIMOLOGIA DAS PALAVRAS "BRUXARIA" E "FEITIÇARIA"}

Observa-se, ao longo do referido processo-crime, datado de 1754, que as duas rés, mãe e filha, são acusadas de "feitiçaria". Entretanto, este termo é o único utilizado para se referir às ações "maléficas" de Thereza Leyte e Escholastica Pinta da Sylva: são acusadas de realizarem "feitiços", de serem "feiticeiras". Em outras palavras, nota-se que somente termos relacionados à "feitiçaria" são utilizados e não há ocorrência dos termos "bruxaria" ou "bruxa", o que traz uma reflexão a ser feita: por que "feitiçaria" é usado em detrimento de "bruxaria" sendo que, atualmente, ambos possuem o mesmo significado?

Abaixo, estão alguns trechos da documentação onde foram utilizados os termos apresentados, isto é, "feitiço" e "feiticeira":

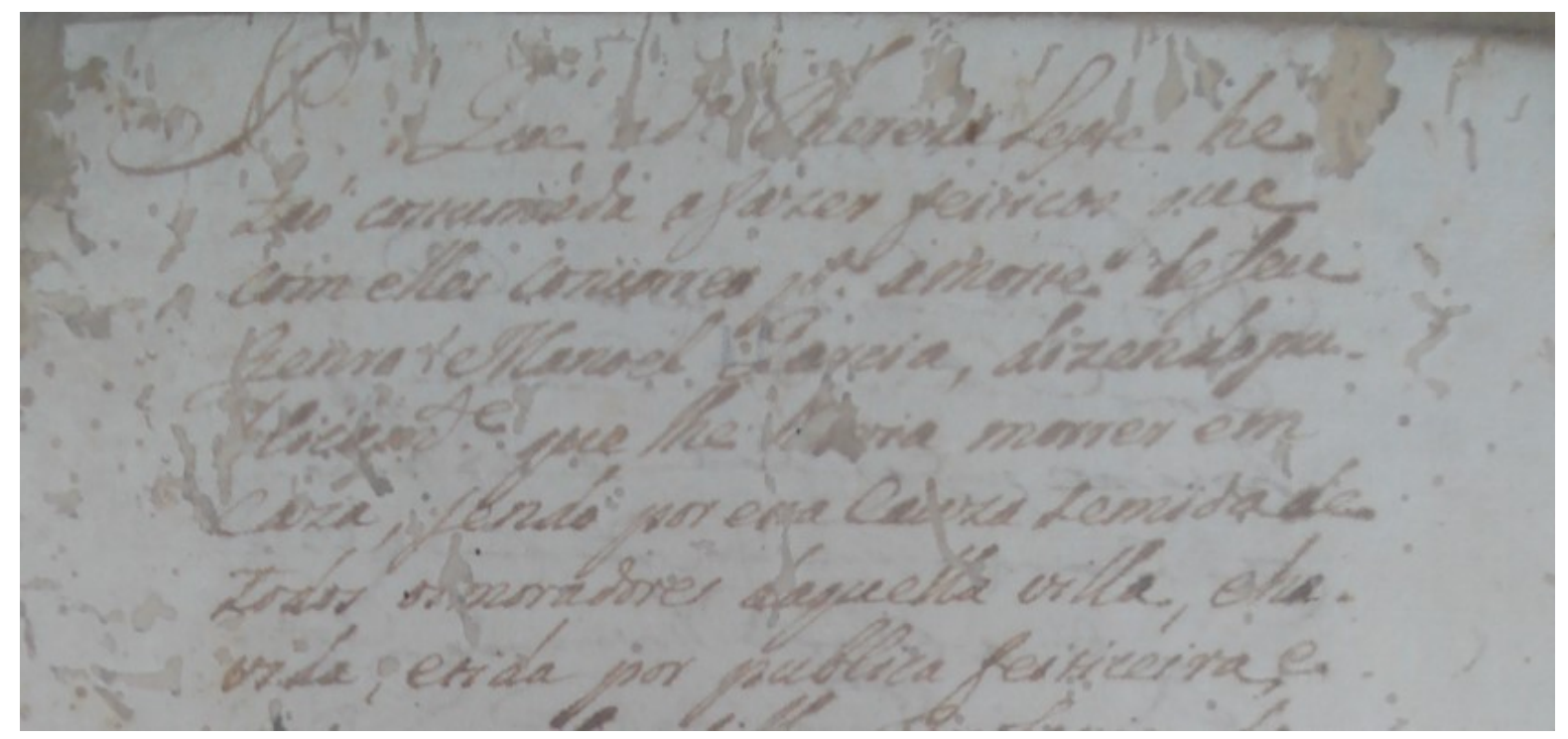

(Fólio 11 v.)

Provara [espaço] Que adita TherezaLeyte he taó costumada afazer feitiços que com elles concorreo para amorte deseu genro Manoel Garcia, dizendo pu [b]licamente que lhe [ha]via morrer em caza, sendo por es[t]acauza temidade todos o[s] moradores daquella villa, eha vida, etida por publica feiticeira e 


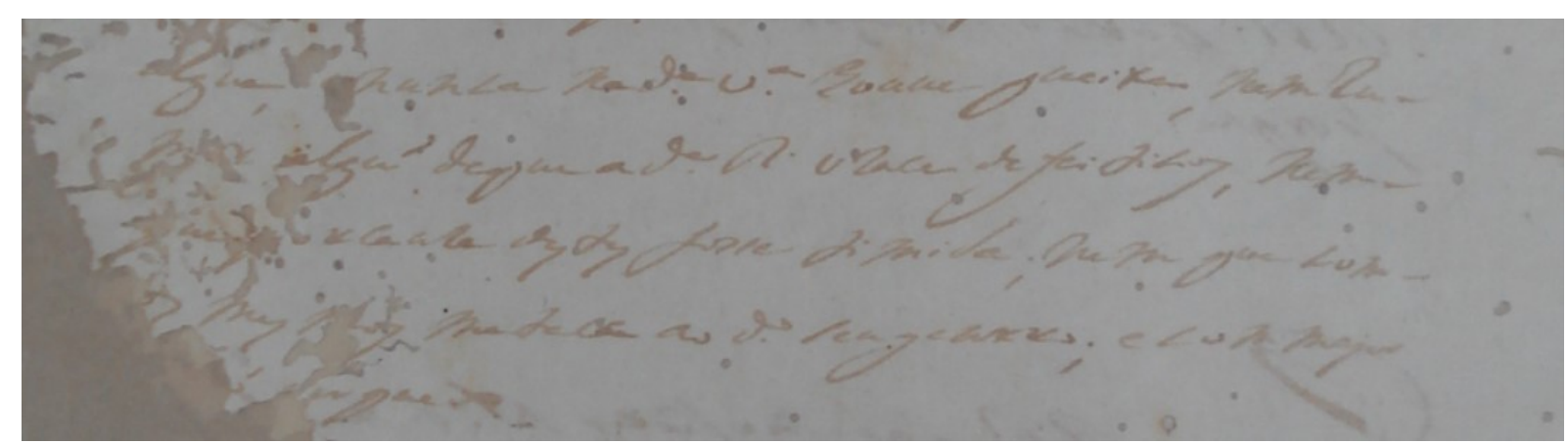

(Fólio 15 v.)

algúa, [e]nunca nadita vila houue queixa, nemru -

$\mathrm{m}[\mathrm{o}] \mathrm{r}$ algú deque a dita Re uZace defeiticos, nem -

[q]ue [p]or cauZa destes fosse timida; nem que com -

[corroído]os mesmos matasse ao dito seu genrro; e com major

[corroído]ó [p]or qu[ilegível]

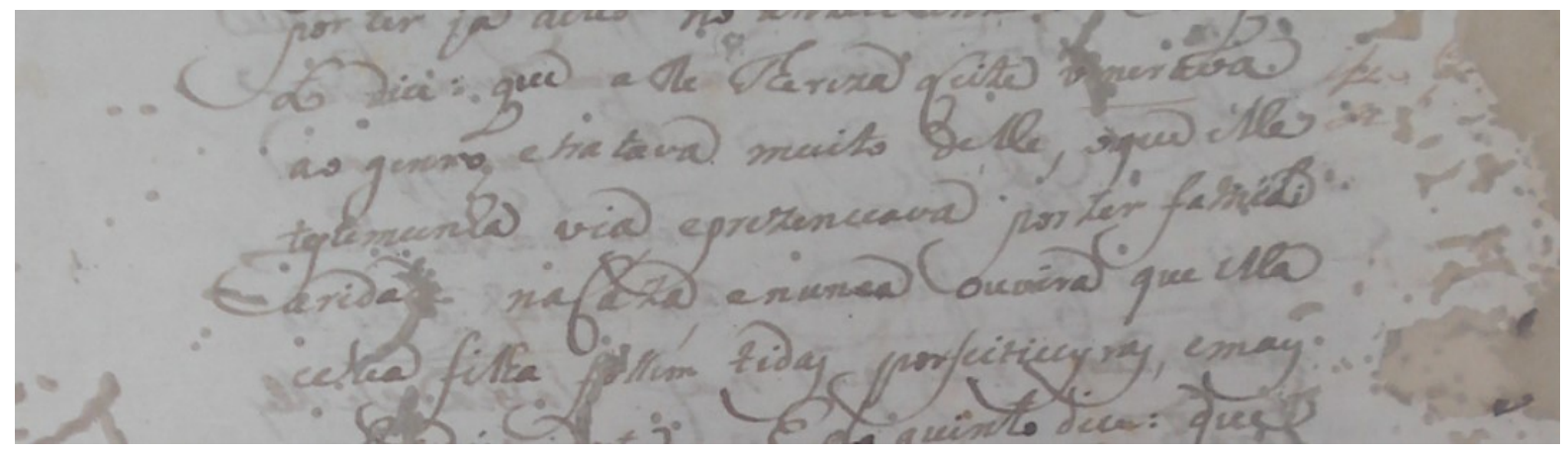

(Fólio 33 r.)

to dice: que aRe Thereza Leite v[e]nerava ao genro, etratava muito delle, oque elle testemunha via eprezenciava por ter famiLi aridad[e] naCaza, enunca ouvira que ella eSua filha fossem tidas por feiticeyras, emais 


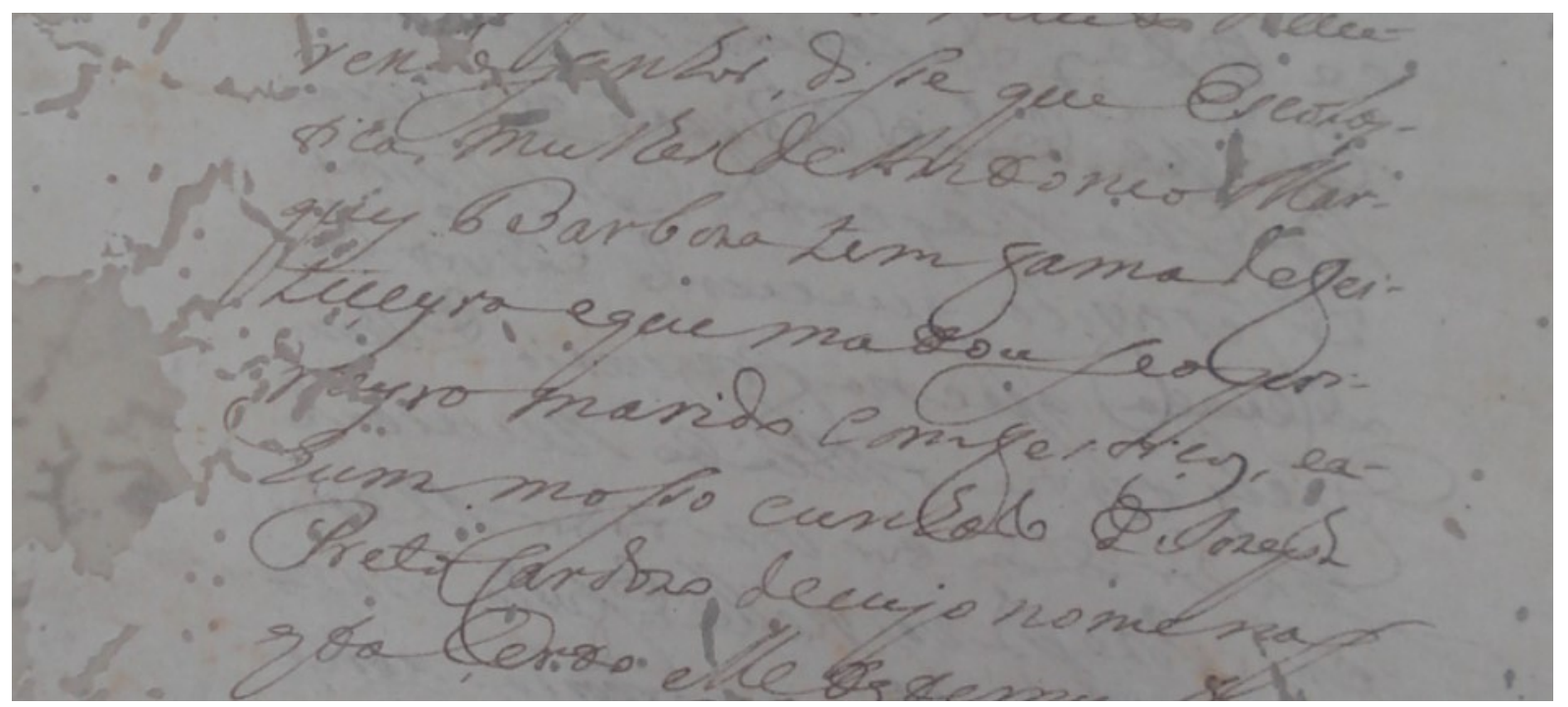

(Fólio 36 v.)

rendosenhor, disse queEscoLas tica mulher deAntonioMar ques Barboza tem famadefei tiçeyra equematouseopri meyromarido comfeitiços, ea hummosso cunhado de Iozeph PretoCardozo decujo nomenaõ estaçerto elletestemunha $[\ldots]$

Atualmente, a palavra "feitiçaria" e a palavra "bruxaria" são utilizadas como sinônimos. Segundo o dicionário Caldas Aulete, cuja primeira edição é datada de 1881, o termo "feitiçaria" é definido como "malefício de feiticeiro, bruxaria, arte mágica, sortilégio [...]. (Fig.) Fascinação, encanto, enlevo, faculdade de cativar os corações. [...]." ${ }^{178}$ Em relação ao significado do termo "bruxaria", o mesmo dicionário o define da seguinte maneira: "maleficio que se atribui às bruxas; sortilégio; feitiçaria”. Assim, observa-se que o dicionário Caldas Aulete considera ambas as palavras como sendo sinônimas.

Consultando-se o dicionário Michaelis (disponível online) a respeito dos significados dos mesmos termos, tem-se que "feitiçaria" significa: "Ação própria de feiticeiro ou

178 Caldas Aulete, Dicionário Contemporâneo da Língua Portuguesa. $2^{\mathrm{a}}$ edição brasileira. Rio de Janeiro: Editora Delta, 1964, p. 1743. 
feiticeira. V bruxaria" ${ }^{179}$. Já a acepção de "bruxaria" é definida da seguinte maneira pelo mesmo dicionário:

1. Ação própria de bruxa ou bruxo; bruxedo, coisa-feita, feitiçaria, feitiço, tanglomanglo. 2. Conjunto de práticas que, segundo a crendice popular, permitem à bruxa ou ao bruxo usar de poderes sobrenaturais de modo a prever o futuro e atuar negativamente sobre a vida de uma pessoa, causando-lhe danos ou malefícios ou, até mesmo, levando-a à morte. 3. O suposto efeito de tais práticas divinatórias e maléficas; bruxedo, coisafeita. 4. Acontecimento que, por não ter explicação lógica, acaba tendo sua ocorrência atribuída à atuação de forças sobrenaturais; bruxedo, coisa-feita. 5. Atração incontrolável; fascínio, magnetismo, sedução. ${ }^{180}$

Como pode ser visto, o dicionário Michaelis também considera estes dois vocábulos como sinônimos, não havendo, portanto, divergências semânticas entre eles.

Para Raphael Bluteau, a origem do termo "bruxa" está em Brugis, região da Macedônia, ou em Bruges, Cidade de Flandes, ou ainda que "bruxa" vem de Bruex, que em uma língua setentrional significa "irmão" e "irmandade", pois, segundo o autor, as bruxas são como irmãs do demônio. ${ }^{181}$

Já Francisco da Silveira Bueno afirma que "bruxa" é um termo cuja origem está ainda em discussão, mas que pode ter se originado do celta *bruskja, ampliação de *bruska, que significa "camada de neve":

Feiticeira. Origem ainda em discussão. Para J. Hubschmid vem do celta *bruskja, ampliação de * bruska, camada de neve. Não se compreende bem como é que camada de neve passou a significar feiticeira. Para Rohlfs o étimo provável é *bruxa. Para Corominas a fonte está em *brouxa, de origem celta, com o significado de altura porque as bruxas se reúnem sempre em montanhas, andam voando pelas alturas, etc. Até que novos estudos esclareçam o assunto, parece-nos que a maior soma de probabilidades esteja com Juan Corominas. [...] ${ }^{182}$

Portanto, ao que tudo indica, talvez "bruxaria" significasse uma prática realizada ao ar livre, mantendo proximidade com a natureza. Além disso, Bluteau afirma que as bruxas sugavam sangue de crianças, buscando o rejuvenescimento:

179Para "feitiçaria", ver Michaelis: http://michaelis.uol.com.br/busca? $\mathrm{r}=0 \& \mathrm{f}=0 \& \mathrm{t}=0 \&$ palavra=feiti $\% \mathrm{C} 3 \% \mathrm{~A} 7$ aria

180 Para "bruxaria", ver Michaelis: http://michaelis.uol.com.br/busca? $\mathrm{r}=0 \& \mathrm{f}=0 \& \mathrm{t}=0 \&$ palavra=bruxaria

181 Raphael Bluteau. Vocabulario portuguez \& latino: aulico, anatomico, architectonico ... Coimbra: Collegio das Artes da Companhia de Jesu, 1712-1728. 8 v., vol. 2, p. 200. Disponível em: http://dicionarios.bbm.usp.br/en/dicionario/1/bruxa

182 Francisco da Silveira Bueno. Grande dicionário etimológico-prosódico da íngua portuguesa vocábulos, expressões da língua geral e científica - sinônimos, contribuições do tupi-guarani. Vol. 2. São Paulo: Edição Saraiva, 1964. pp. 554-555. 
[...] Em Portuguez chamamos Bruxas humas mulheres, que se entende, que matão as crianças, chupandolhe o sangue [...]. Bruxa em Latim se pode chamar Strix, strigis. Fem. que he o nome de huma ave infausta, \& nocturna, da qual diz Ovidio [...] E o mesmo Plinio em outro lugar chama a esta ave Caprimulgus $; \&$ he opinião de graves Authores, que esta mesma ave, quando se lhe offerece a occasião, tambem chupa aos meninos o sangue [...] Que esta ave Caprimulgus, seja a mesma, Strix, não o affirmo, mas he certo, que antigamente foram chamadas Striges, humas bruxas, que para remoçarem, chupavão aos meninos o sangue, [...]. No commento do verso 14 do cap. 34 do Propheta Isaias, que diz Ibi cubavit lamia, diz Cornelio Alapide, que hà versoens, em que se lè strix em lugar de Lamia, \& que por esta palavra strix se entende a molher, que chupa o sangue aos meninos, ou com outros maleficios os mata, que he o mesmo, que entre nos Bruxa. [...]. ${ }^{183}$

Um outro dicionário antigo, também do século XVIII, que pode ser consultado acerca de tais palavras é o Diccionario da lingua portugueza, de Antonio de Moraes Silva, publicado pela primeira vez em 1789, isto é, publicado algumas décadas depois da ocorrência do processo contra Thereza Leyte e Escholastica Pinta da Sylva. ${ }^{184}$

Neste dicionário, a palavra "bruxa" (grafada "brúxa") é definida como "Mulher, que inculca ter pacto com o demonio, em cujo poder faz coisas maravilhosas, e de ordinario $m a l$ "185. Já o significado do substantivo masculino "bruxo" (escrito "brúxo") é dado por "O que se attribue o poder de fazer bruxarias" ${ }^{186}$. E a acepção da palavra "bruxaria" (grafada "bruxaría”) é "Acção, ou effeito causado por bruxa, ou bruxo"187.

Já em relação à palavra "feitiço", BUENO (1964-1965: 1363) afirma que sua origem está no latim factício, que significa coisa preparada de modo artificial.

O significado do vocábulo "feitiço" (escrito "feitíço") é dado por Antonio de Moraes Silva como "Veneno, ou drogas preparadas por arte diabolica para fazer criar amor, ou odio. Coisa que em belleza encanta" 188 e ainda "Não natural, feito por artificio [...] fingido, e não verdadeiro" 189 . Além disso, neste mesmo dicionário, a palavra "feiticeira" (grafada "feiticèira") significa "Mulher que faz feitiços" 190 . Contudo, o autor oferece uma acepção

183 Ver BLUTEAU, Op. cit., pp. 200-201.

184 A primeira edição deste dicionário data de 1789, porém, a edição utilizada nesta pesquisa é de 1813 .

185 Antonio de Moraes Silva. Diccionario da lingua portugueza - recompilado dos vocabularios impressos ate agora, e nesta segunda edição novamente emendado e muito acrescentado, por ANTONIO DE MORAES SILVA. Vol. 1. Lisboa: Typographia Lacerdina, 1813. p. 305. Disponível em: $\mathrm{http} / / /$ dicionarios.bbm.usp.br/dicionario/edicao/2

186 Idem, Ibidem.

187 Cf. Antonio de Moraes Silva, Op. cit., p. 305.

188 Cf. Antonio de Moraes Silva, 1813, vol. 2, p. 20.

189 Ver Antonio de Moraes Silva, Op. cit., p. 20.

190 Idem, p. 19. 
mais detalhada da palavra "feiticeiro" (grafada "feiticèiro") em seu dicionário: "Homem que faz maleficios, ou doenças com hervas venenosas, e outras drogas; e talvez intervindo obra diabolica. Encantador, fascinador" $"$. Aqui, pode-se relacionar essa definição de "feiticeiro" à figura do já referido escravo de nome Francisco, contratado pela família de Manoel Garcia para curá-lo e que, segundo testemunhas, fazia feitiços utilizando aguardente e dinheiro. Além de todas essas definições, no dicionário de Antonio de Moraes Silva é apresentado o seguinte significado para a palavra "feitiçaria" (escrita "feiticería"): "O maleficio, ou veneficio feito pela feiteceira, ou feiticeiro; magia, encanto, fascinação" ${ }^{\prime 192}$.

Assim, pode ser este o motivo pelo qual são utilizados os termos "feitiço", "feitiçaria", "feiticeira" e "feiticeiro" no processo inquisitorial de Escholastica Pinta da Sylva e Thereza Leyte, pois, apesar de as palavras "feitiçaria" e "bruxaria" serem ambas associadas ao demônio e de as rés serem acusadas de terem pacto - além de serem acusadas de outros malefícios -, no processo não há menção de práticas realizadas em meio à natureza. Além disso, vale lembrar que, para Bluteau, o "feitiço" está muito mais associado ao demônio do que a "bruxaria":

He huma cousa, que em si naturalmente naõ tem o effeyto, que obra, causando-o só o Demonio, com aquillo, que por permissaõ Divina lhe ajunta, paraque possa obrar. E assi a lagartixa, que certo feiticeiro poz na couceira da porta de hum lavrador, a qual em todo o tempo, que ali esteve, nem a molher, nem animal algum de casa paria, era feitiço, porque nenhuma virtude natural tem huma lagartixa, mettida na couceira de huma porta, para produzir estes effeytos; mas poemlhe o Demonio a virtude malefica, \& esta he a razaõ, porque (como adverte Philo Hebreo) contra este genero de males, causados pelo Demonio, nenhum poder tem remedios naturaes.[...]\& desta maneira sempre o feitiço he mais obra do Demonio, que effeyto da natureza. $[\ldots]^{193}$

Portanto, a denominação de "feiticeiras" caberia melhor à Escholastica Pinta da Sylva e à Thereza Leyte, pois, além da acusação de pacto com o demônio, testemunhas alegaram que Manoel Garcia havia se queixado da esposa, acusando-a de enterrar seus sapatos com pedaços de uma camisa do próprio falecido dentro deles. Assim, Escholastica teria utilizado de objetos, "artifícios", portanto, feitiços - que não são considerados naturais, e sim produzidos, de acordo com Francisco da Silveira Bueno, Antonio de Moraes Silva e Raphael Bluteau - para matar seu primeiro marido. Além disso, não há referência à nenhuma prática 
realizada ao ar livre, em meio à natureza, que possa relacionar Thereza e Escholastica às bruxas descritas anteriormente por Francisco da Silveira Bueno.

\section{MATERIAIS E MÉTODOS}

Os materiais utilizados para a realização da pesquisa são fac-símiles do já citado processo contra feitiçaria, que é composto por quarenta e oito fólios e encontra-se, em sua maior parte, em razoável estado de conservação. Entretanto, há também muitos fólios deteriorados (pela ação do tempo ou de traças).

Os métodos empregados para a transcrição de tal processo serão as normas estabelecidas pela Comissão de elaboração de Normas para transcrição de documentos manuscritos para a História do Português do Brasil, em 1998. Trata-se de um conjunto de dezesseis normas para a elaboração de edições semidiplomáticas.

De acordo com MEGALE \& TOLEDO NETO (2005: 147-148), tais normas são:

- A transcrição do manuscrito será conservadora, isto é, será o mais próxima possível do documento original;

- As abreviaturas deverão ser desenvolvidas e as letras omitidas na mesma serão assinaladas em itálico;

- Quando houver palavras escritas juntas no documento original, será mantida a mesma estrutura na transcrição. Além disso, hifens ou apóstrofos não serão inseridos caso não estejam presentes no original;

- A pontuação presente no documento original deverá ser fielmente reproduzida na transcrição. E nos locais em que houver maior espaço intervalar, deverá ser marcado na transcrição: [espaço];

- A acentuação do documento original deverá ser reproduzida com rigor;

- O emprego de letras maiúsculas e minúsculas deverá ser fielmente mantido tal qual se encontra nos manuscritos;

- Serão inseridos em notas de rodapé eventuais erros cometidos pelo escriba ou copista;

- Na transcrição, serão inseridas entre os sinais $<>$ as inserções realizadas por parte do escriba ou copista, na mesma localização nas quais se encontram no documento original; 
- As supressões realizadas pelo escriba ou copista deverão ser tachadas. Já em relação às repetições não suprimidas pelos mesmos no manuscrito, elas deverão, na transcrição, ser colocadas entre colchetes duplos [[ ]];

- As intervenções realizadas por terceiros no manuscrito deverão ser informadas ao final da transcrição com a localização indicada;

- Serão raras as intervenções por parte do editor, ocorrendo somente em situações de absoluta necessidade e devem, quando realizadas, ser inseridas entre colchetes;

- Quando alguma letra ou palavra estiver ilegível por deterioração, deve ser indicada entre colchetes da seguinte maneira: [ilegível];

- Se houver ocorrência de trecho ilegível por deterioração que seja mais longo, de trecho riscado ou completamente anulado, deverá ser inserida a informação pertinente entre colchetes e sublinhada;

- Deverá ser mantida, na transcrição, a divisão das linhas tal qual apresenta-se no documento original e a mudança de fólio deverá ser marcada com o respectivo número entre duas barras verticais, por exemplo: ||1r.|| ||1v.|| ||2r.|| ||2v.||. Todavia, já consta uma enumeração impressa de maneira quase centralizada, na parte superior do anverso (reto) dos fólios, porém, a enumeração repete-se a partir do fólio 21 r.. Assim, os fólios 1 r. e 21 r. contêm o número um (1) impresso no papel, mantendo-se a seguinte sequência numérica nos manuscritos:

\begin{tabular}{|c|c|}
\hline Fólios & Enumeração de página impressa no papel \\
\hline 1 r. -20 v. & $1-20$ \\
\hline 21 r. -48 v. & $1-28$ \\
\hline
\end{tabular}

Portanto, com o objetivo de estabelecer uma linearidade na sequência numérica dos manuscritos e possibilitar que o leitor se localize mais facilmente na documentação, os fólios foram renumerados, do 1 r. ao 48 v., desconsiderando a enumeração já impressa no papel.

- As linhas, na transcrição, deverão ser enumeradas de cinco em cinco a partir da quinta linha. $\mathrm{Na}$ transcrição do processo de feitiçaria aqui utilizado para estudo, manteve-se a enumeração de cinco em cinco linhas, porém, optou-se pela transcrição justalinear;

- Serão sublinhadas as assinaturas simples ou as rubricas de quem assinou o documento e os sinais públicos deverão ser colocados entre colchetes. 
Além dos critérios expostos acima, CAMBRAIA (2005: 129-130) ressalta que é também de muita relevância desenvolver as notas tironianas (representadas pelo número 2) presentes no texto e que operam como a conjunção aditiva “e”. É necessário também informar em notas de rodapé elementos como mudança de punho, isto é, quando mais de uma pessoa escreveu o texto, o que implica discrepâncias em relação à escrita e à tinta - o que acarreta divergências em relação à cor e composição da mesma.

Outra observação em relação ao método empregado na transcrição dos manuscritos é digna de nota: alguns dos escrivães (Polycarpo de Abreu Nogueyra, escrivão desconhecido 2, Salvador de Oliveyra Preto e Fernando Pinto de Almeyda) utilizaram de linhas horizontais ao final das páginas redigidas (rodapé), o que pode ser indicativo de que tais páginas estão completas e que não se deve acrescentar mais nada às mesmas. Estes sinais de preenchimento de espaço em branco, na transcrição, foram indicados por linhas horizontais tracejadas, com a finalidade de não se fazer confusão com as linhas inseridas embaixo das assinaturas, rubricas e sinais públicos. Seguem-se alguns exemplos dos punhos dos próprios escrivães:

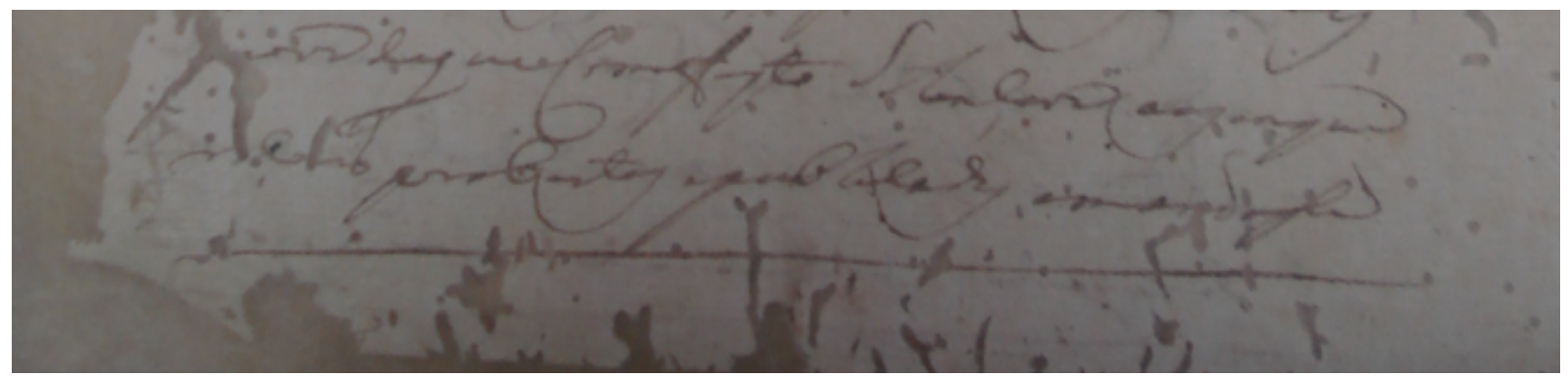

(Fólio 19 v. - Polycarpo de Abreu Nogueyra)

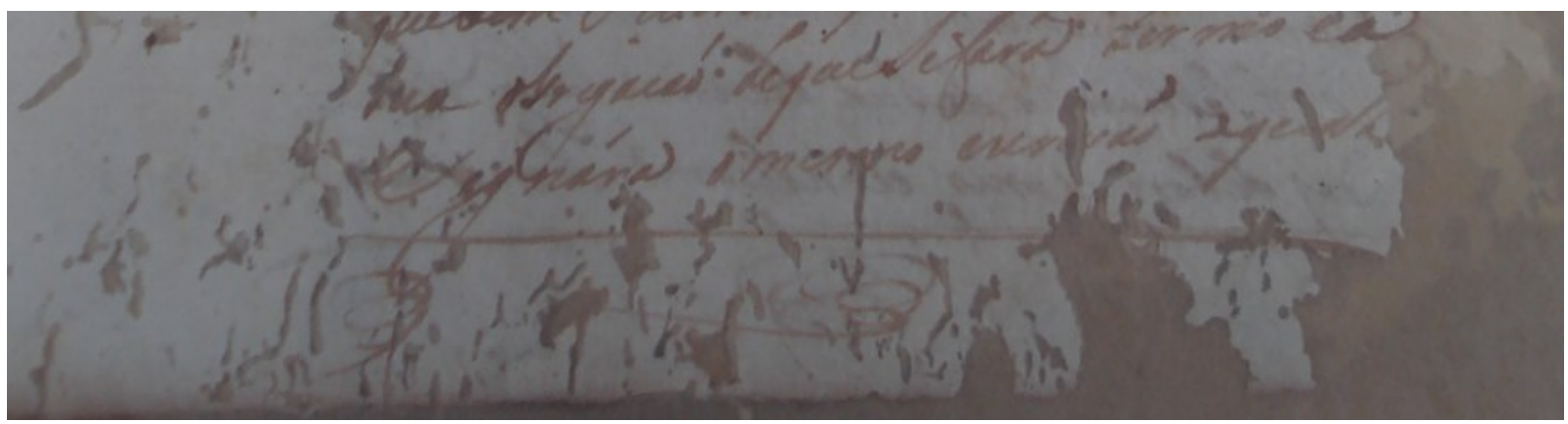

(Fólio 21 r. - Punho desconhecido 2) 


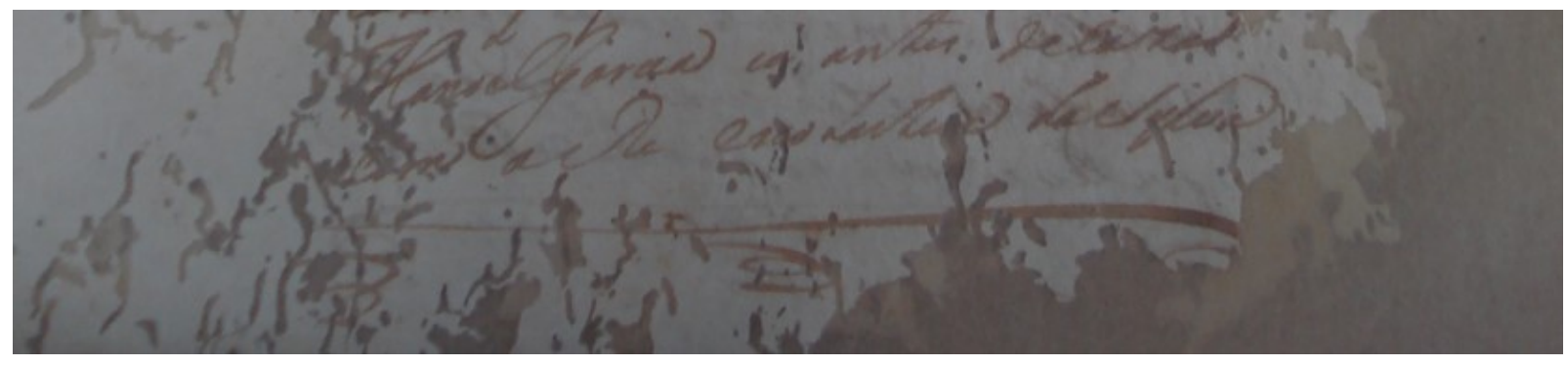

(Fólio 22 r. - Punho desconhecido 2)

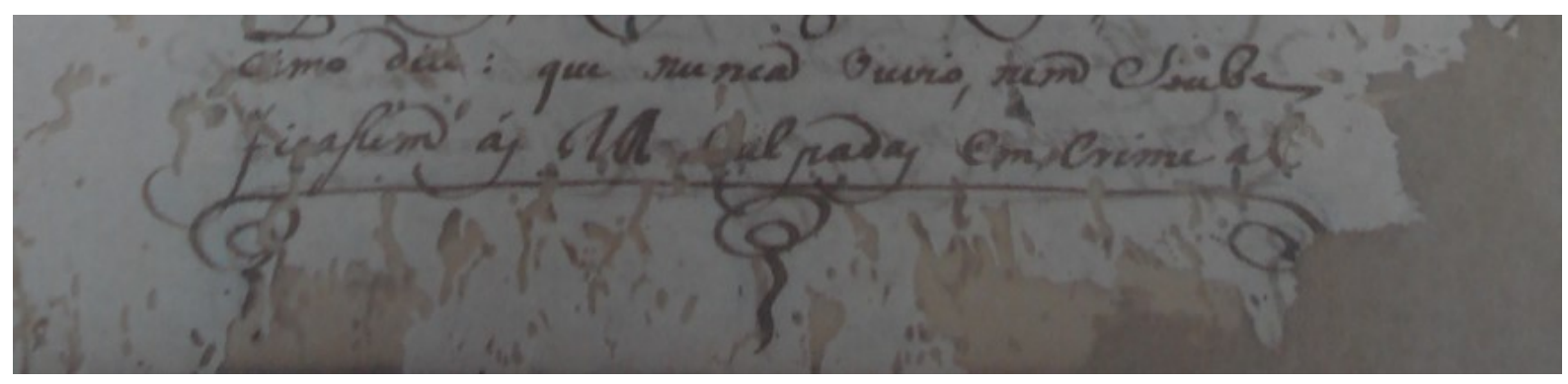

(Fólio 30 r. - Salvador de Oliveyra Preto)

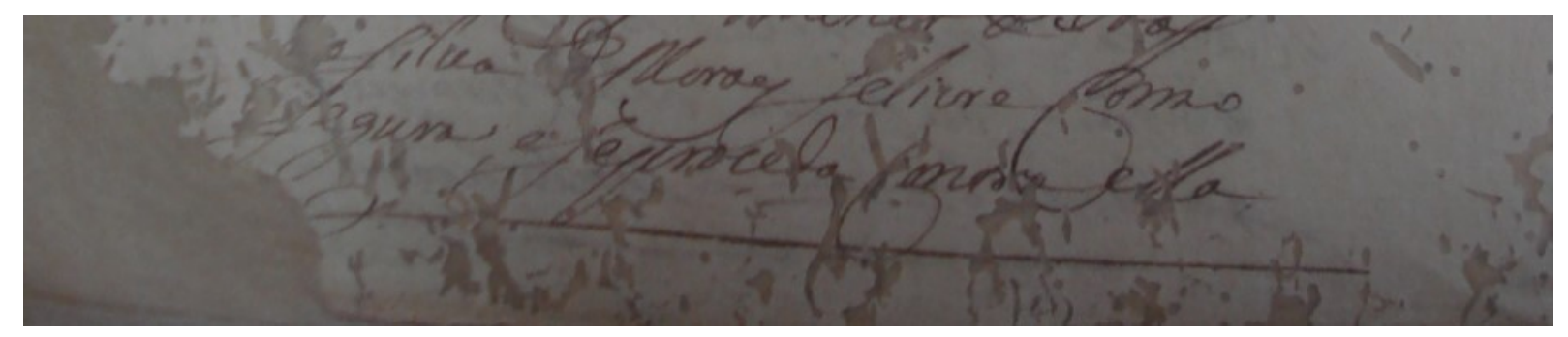

(Fólio 40 v. - Fernando Pinto de Almeyda)

\subsection{ESTUDO FILOLÓGICO DA DOCUMENTAÇÃO}

A filologia possui o texto como seu principal objeto de estudo e busca não apenas torná-lo acessível para os leitores, mas, além disso, busca também desvendar a história por trás daquele texto, revelando aspectos linguísticos, históricos, culturais, entre outros, da sociedade que o produziu. De acordo com SPINA (1977: 74): 
O texto, manuscrito ou impresso, é o objeto fundamental da investigação histórica, filológica e literária. Se a História dispõe de outros documentos - como a tradição oral, a tradição pictórica e os chamados "restos" (subministrados pela Paleontologia, pela Arqueologia, pela Lingüística, pela Etnologia e pelo Folclore), a Literatura e a Filologia só dispõem do texto. Entretanto é preciso distinguir: o corpus textual em que se exerce fundamentalmente a História é constituído pelos textos históricos, jurídicos, religiosos, políticos, diplomáticos; os textos literários, que podem muitas vezes fornecer informações de natureza histórica, formam seu corpus secundário; ao passo que a Filologia, se tem como corpus fundamental o texto literário, e como corpus secundário os textos históricos, jurídicos, religiosos e filosóficos, a Literatura escrita tem no texto literário o seu único objeto.

Assim, a filologia se serve de disciplinas auxiliares para trabalhar e explicitar os diversos aspectos de um texto, sendo algumas dessas disciplinas a codicologia, a paleografia e a história. Segundo SPINA (1977: 74): “A História é, sem dúvida, a disciplina que maiores pontos de contacto apresenta com a Filologia, pois o objeto e o método de ambas são os mesmos: o texto e o método crítico. [...].” Segismundo Spina (1977: 75) ainda afirma:

A Filologia concentra-se no texto, para explicá-lo, restituí-lo à sua genuinidade e prepará-lo para ser publicado. A explicação do texto, tornando-o inteligível em toda a sua extensão e em todos os seus pormenores, apela evidentemente para disciplinas auxiliares a (literatura, a métrica, a mitologia, a história, a gramática, a geografia, a arqueologia, etc.), a fim de elucidar todos os pontos obscuros do próprio texto. [...].

As referidas áreas do conhecimento, além da área de Direito, foram fundamentais para se obter um nível de compreensão satisfatório acerca do processo-crime de Thereza Leyte e Escholastica Pinta da Sylva.

Portanto, a filologia se preocupa não apenas com o estabelecimento do texto, isto é, com questões puramente técnicas que visam a publicação de uma obra, mas também preocupa-se em estudar os demais elementos que compõem o texto.

Há uma ordem de problemas, com os quais a Filologia também se preocupa; são problemas que não estão no texto, mas se deduzem dele: a sua autoria, a sua datação e a sua importância (valorização) perante os textos da mesma natureza. Esta seria a função adjetiva da Filologia. ${ }^{194}$

Com o objetivo de resumir a atividade filológica para um melhor entendimento do leitor, Segismundo Spina (1977: 77) apresenta uma síntese do que seriam as funções substantiva, adjetiva e transcendente da filologia, abordando desde questões puramente 
técnicas de edição do texto para publicação até as contribuições histórica/cultural/linguística fornecidas pelo filólogo:

Resumindo: três são as funções da atividade filológica: $1 .^{\mathrm{a}}$ ) Função substantiva, em que ela se concentra no texto para explicá-lo, restituí-lo à sua forma genuína e prepará-lo tecnicamente para publicação; $2 .^{a}$ ) Função adjetiva, em que ela deduz, do texto, aquilo que não está nele: a determinação de autoria, a biografia do autor, a datação do texto, a sua posição na produção literária do autor e da época, bem como a sua avaliação estética (valorização); $3 .^{\mathrm{a}}$ ) Função transcendente, em que o texto deixa de ser um fim em si mesmo da tarefa filológica, para se transformar num instrumento que permite ao filólogo reconstituir a vida espiritual de um povo ou de uma comunidade em determinada época. $[\ldots]$.

A filologia dispõe de diversos tipos de edições de texto, sendo elas maneiras diversas de se trabalhar, analisar, editar e apresentar o texto ao leitor. Cada edição oferece um resultado diferente (com características diferentes), mais fácil ou mais difícil de ser lido e compreendido por determinado perfil de leitor.

Os tipos de edição de que pode se servir o filólogo para editar um texto e torná-lo acessível podem ser divididos em dois grupos: as edições monotestemunhais e as edições politestemunhais. A edição monotestemunhal é baseada somente em um testemunho ${ }^{195}$ do texto, ao passo que a edição politestemunhal é baseada no confronto de dois ou mais testemunhos do mesmo texto. ${ }^{196}$ As edições monotestemunhais são: edição mecânica ou facsimilar, edição diplomática, edição semidiplomática, edição interpretativa, edição modernizada. Já as edições politestemunhais são: a edição crítica e a edição genética.

A edição fac-similar, descrita detalhadamente mais adiante, não apresenta nenhuma intervenção por parte do editor, sendo apresentadas ao leitor apenas as cópias dos textos originais, cópias essas obtidas por meio de fotografia, xerografia, dentre outros meios. ${ }^{197}$

Já a edição diplomática apresenta o primeiro grau de intervenção por parte do editor, isto é, apresenta um "grau baixo de mediação." 198 Segundo CAMBRAIA (2005: 93):

[...] Neste tipo de edição, faz-se uma transcrição rigorosamente conservadora de todos os elementos presentes no modelo, tais como

195 "Testemunho" é o termo utilizado para denominar uma edição de uma dada obra. Em seu manual Introdução à crítica textual, César Nardelli Cambraia (2005: 98), afirma que o termo tradicional latino geralmente empregado como referência seria codex (códice). Todavia, o autor adaptou o termo para o português adotando, em sua obra, o termo "testemunho", com o objetivo de abarcar tanto os códices (livros manuscritos) quanto os livros impressos.

196 Cf. CAMBRAIA, 2005, p. 91.

197 Cf. CAMBRAIA, Idem, pp. 91-93.

198 CAMBRAIA, 2005, p. 93. 
sinais abreviativos, sinais de pontuação, paragrafação, translineação, separação vocabular, etc.

A vantagem oferecida pela edição diplomática é a facilitação de leitura do texto, pois a transcrição não exige do leitor muitas habilidades paleográficas para a decifração da escrita original do texto, tratando-se principalmente de manuscritos. Entretanto, apesar da facilitação de leitura oferecida pela transcrição diplomática, esse tipo de edição, ao manter, por exemplo, uma transcrição rigorosa dos sinais abreviativos, possui a desvantagem de ser consultada quase que exclusivamente por especialistas, pois exige um certo grau de conhecimento paleográfico, não dominado pela grande maioria das pessoas. ${ }^{199}$

Um nível acima de intervenção por parte do editor encontra-se na edição semidiplomática, também descrita detalhadamente mais adiante. Esse tipo de edição, ao contrário da diplomática, oferece ao leitor um texto mais fácil de ser lido, pois o editor realiza modificações ao reproduzir o texto do manuscrito, como o desenvolvimento de sinais abreviativos, tornando o texto acessível a um público mais amplo, em comparação com o público leitor da edição diplomática. ${ }^{200}$

Já a edição interpretativa apresenta um nível a mais de intervenção, isto é, o grau máximo de mediação por parte do editor. Além do desenvolvimento de abreviaturas, esse tipo de edição promove um grande processo de uniformização gráfica do texto, como de pontuação e paragrafação. Assim, uma edição interpretativa oferece ao leitor um texto muito mais acessível e apurado. ${ }^{201}$ De acordo com CAMBRAIA (2005: 97):

\footnotetext{
Não se pode deixar de esclarecer que, neste tipo de edição, a uniformização é essencialmente gráfica: não se uniformizam variantes fonológicas, morfológicas, sintáticas e lexicais [...]. É evidente, porém, que certas uniformizações (de pontuação, paragrafação, etc.) acabam por fixar apenas uma das leituras possíveis do testemunho, razão pela qual esse tipo recebe justamente o nome de interpretativa. Como se vê, sua maior qualidade - a acessibilidade - determina igualmente seu maior defeito - a subjetividade.
}

O último tipo de edição monotestemunhal é a edição modernizada, que diferentemente da edição interpretativa (e das demais) apresenta uniformizações fonológicas, morfológicas, sintáticas e lexicais. Em outras palavras, a edição modernizada disponibiliza ao público um texto que passou por um processo de modernização linguística. ${ }^{202}$

199 Cf. CAMBRAIA, 2005, p. 94.

200 Cf. CAMBRAIA, Idem, pp. 95-96.

201 Cf. CAMBRAIA, 2005, pp. 96-98..

202 Cf. CAMBRAIA, 2005, p. 103. 
Já a edição crítica, que seria uma edição politestemunhal, é o resultado do confronto de diversos testemunhos não-autorais (apógrafos), cuja finalidade é estabelecer a forma genuína do texto, isto é, tentar se aproximar o máximo possível da forma que o autor teria dado à sua obra, ao texto original. ${ }^{203} E$ de fundamental importância enfatizar que uma edição crítica é realizada quando não há a possibilidade de se trabalhar com o texto original de determinada obra, pois geralmente o testemunho se perdeu, não sobrevivendo ao tempo. ${ }^{204}$

Para a elaboração deste tipo de edição, o confronto de diferentes testemunhos (sejam eles manuscritos e/ou impressos) é necessário para se identificar erros de cópia, modificações voluntárias ou involuntárias, que alteraram e deturparam a forma original do texto. Segundo CAMBRAIA (2005: 104):

A consulta a mais de um testemunho permite ao crítico textual identificar e separar, na medida do possível, os elementos de um texto que não seriam genuínos, pois, como os copistas não erram sempre no mesmo ponto do texto que reproduzem, uma forma genuína pode ser adulterada em um ou em outro testemunho, mas geralmente mantém-se intacta em outros. [...].

A edição crítica é fruto da crítica textual, que se caracteriza por um conjunto de técnicas que compõem o método de estabelecimento da forma genuína do texto. Assim, o principal objetivo da crítica textual é a busca pelo texto original, já perdido. A crítica textual se utilizou de diferentes abordagens ao longo de sua história, compreendendo desde a Antiguidade, passando pela Idade Média e Idade Moderna. Além disso, as técnicas empregadas pelos críticos textuais também passaram por modificações e foram aperfeiçoadas ao longo dos séculos, até serem estabelecidas - constituindo, de fato, um método científico por figuras como a do alemão Karl Lachmann (1793-1851) e do italiano Giorgio Pasquali (1885-1952). ${ }^{205}$ Vale ressaltar aqui que a crítica textual é, algumas vezes, considerada como sinônimo de filologia. ${ }^{206}$

Outra edição politestemunhal e a última de que trataremos aqui é a edição genética que, assim como a edição crítica, também é resultado do confronto de mais de um testemunho, porém, desta vez, são utilizados testemunhos autógrafos e/ou idiógrafos

203 Cf. CAMBRAIA, Idem, p. 104.

204Para um estudo mais aprofundado acerca deste tipo de edição, ver CAMBRAIA (2005: 133-174), capítulo 6, "Edição crítica".

205 Para um histórico da crítica textual, ver CAMBRAIA (2005: 37-62), capítulo 2, "Breve histórico da crítica textual" e SPINA (1977: 66-72), seção 3, "A crítica textual moderna e seus métodos: Karl Lachmann e Giorgio Pasquali".

206Cf. CAMBRAIA (2005: 13-19), seção 1.3, "Crítica textual, ecdótica e filologia", do capítulo 1 ("Introdução"). 
(originais). O objetivo desse tipo de edição é identificar e registrar todas as divergências entre as primeiras redações de um texto e a forma final dada pelo autor, comparando os já referidos testemunhos originais. ${ }^{207}$ De acordo com CAMBRAIA (2005: 105):

A edição genética é fruto do desenvolvimento de uma abordagem de crítica do texto literário baseada no estudo da sua gênese, abordagem a que se chama de crítica genética. [...].

Durante o processo de elaboração de uma edição genética, o crítico genético faz uso de diversas fontes, de diversos testemunhos. Segundo CAMBRAIA (2005: 105):

\footnotetext{
Para delinear o percurso criativo de um texto, o crítico genético utiliza uma gama heterogênea de fontes: de acordo com Hay (1991: 23), elas podem ser as marcas dos impulsos iniciais (p. ex., notas, cadernos, diários), os documentos das operações preliminares (p. ex., projetos, planos, roteiros) e ainda os instrumentos do trabalho redacional (p. ex., esboços, primeiras redações, rascunhos).
}

Assim, uma edição genética deve oferecer ao público a forma final de determinada obra, isto é, a forma que o autor havia considerado como definitiva. A edição deve apresentar também o aparato genético ${ }^{208}$, que seria o registro das informações (variantes) referentes à gênese do texto, contidas nos testemunhos consultados, como as notas, diários, roteiros, rascunhos e demais fontes mencionadas acima. ${ }^{209}$

Para a edição dos manuscritos que compõem o processo-crime de Thereza Leyte e Escholastica Pinta da Sylva foi escolhida a edição semidiplomática, com a finalidade de preservar as características linguísticas do texto e as características pessoais da escrita de cada redator, reproduzindo fielmente todos esses elementos e mantendo a transcrição o mais próxima possível do documento original, modificando apenas alguns elementos, como as abreviaturas, para tornar o texto mais inteligível ao leitor. Portanto, a edição semidiplomática foi escolhida em detrimento das outras para levar ao leitor uma amostra do que teria sido a língua portuguesa escrita (e de suas demais particularidades) no século XVIII, período no qual essa documentação está inserida. Contudo, uma edição fac-similar também será apresentada com as respectivas transcrições dos manuscritos, para que seja possível ao leitor consultar os manuscritos originais do processo-crime em questão.

207 Cf. CAMBRAIA, 2005, pp. 104-105.

208 A expressão "aparato genético" é empregada por CAMBRAIA (2005: 106), no capítulo 4, "Tipos de edição".

209 Cf. CAMBRAIA, Idem, p. 105. 
O estudo filológico do processo inquisitorial contra Thereza Leyte e Escholastica Pinta da Sylva será dividido em estudo codicológico e estudo paleográfico, tendo como base as edições fac-similar e semidiplomática da documentação.

A edição fac-similar caracteriza-se, principalmente, pelo grau zero de mediação, pois é somente reproduzida a imagem de determinado documento por meio de fotografia, xerografia, escanerização, entre outros. A vantagem deste tipo de edição é que permite o acesso ao documento original. Por outro lado, exige do leitor a habilidade para se ler o texto na escrita original, isto é, exige habilidades paleográficas.

Este tipo de edição tem como vantagem permitir o acesso ao texto de forma praticamente direta, o que confere ao consulente grande autonomia e liberdade na interpretação do testemunho. Por outro lado, tem a desvantagem de poder ser consultada apenas por especialistas, porque pressupõe a capacidade de se ler um texto na escrita original $[\ldots . . .210$

Portanto, pode-se perceber que a edição fac-similar é importante para que o leitor conheça de fato o manuscrito original. Entretanto, o autor também enfatiza ser necessário possuir noções de paleografia (estudo das escritas antigas), para obter êxito na leitura de tais documentos e é por essa razão que uma transcrição (semidiplomática) dos mesmos se faz necessária.

Já na edição semidiplomática (ou paleográfica) há um grau médio de mediação por parte do editor, o que significa que ele realiza modificações ao reproduzir o modelo, com o propósito de facilitar a leitura e compreensão dos leitores, que podem não possuir habilidades paleográficas.

[...] já na [edição] paleográfica o editor atua de forma mais interventiva, através de operações como desenvolvimento de sinais abreviativos, inserção ou supressão de elementos por conjectura, dentre outras (embora qualquer uma dessas operações fique explicitamente assinalada na reprodução): os principais objetivos de todas essas operações são (1) o de facilitar ainda mais a leitura do texto e torná-lo acessível a um público menos especializado [...]; e (2) o de tentar retificar falhas óbvias no processo de cópia do texto, tais como supressão ou repetição de letras, etc. $^{211}$

Além disso, é importante enfatizar o caráter não-literário da documentação aqui estudada, sendo ela, portanto, composta por manuscritos de caráter documental. Por esta razão, CAMBRAIA (2005: 96) afirma que a edição semidiplomática é utilizada 
principalmente na transcrição de documentos jurídicos. A razão disso está no fato de a diplomática ser a disciplina responsável por estudar os documentos caracterizados como tais. De acordo com SPINA (1977: 19):

Se eliminarmos os documentos que não visam à preservação de um direito qualquer, tais como as cartas missivas (entre entidades públicas ou particulares), e os chamados simplesmente escritos (como minutas, relatórios, memórias, documentos contábeis, etc.), os demais documentos são rotulados via de regra de documentos jurídicos, cuja legitimidade ou grau de probabilidade como genuínos ou suspeitos é objeto da ciência Diplomática ou Diplomatística.

Portanto, um dos principais objetos de estudo da diplomática são os documentos histórico-jurídicos, que é o caso dos manuscritos aqui analisados, isto é, o processo-crime de Thereza Leyte e Escholastica Pinta da Sylva.

[...] Entretanto, atualmente a Diplomática restringe-se ao estudo dos documentos das chancelarias, documentos histórico-jurídicos - régios, pontifícios, consulares. [...] Theodor Sickel, o fundador da diplomática moderna, definia o documento diplomático, isto é, no seu sentido específico, como "um testemunho escrito de um fato de natureza jurídica, coligido com a observância de certas formas determinadas, destinadas a conferir-lhe fé e dar-lhe força de prova." ${ }^{12}$

\subsubsection{ESTUDO CODICOLÓGICO}

A codicologia é a ciência que estuda o material utilizado na produção de manuscritos, como o pergaminho e o papel, por exemplo. Nas palavras de SPINA (1977: 22): “ $A$ Codicologia é atinente exclusivamente ao conhecimento do material empregado na produção do manuscrito (Scriptoria) e das condições materiais em que esse trabalho se verificou; [...]". Além disso, a codicologia também se concentra no estudo das tintas usadas na redação dos manuscritos, bem como em outros elementos que constituem os mesmos.

[...] A Codicologia, que tem sob seu domínio toda a produção manuscrita medieval, já vai fixando seu campo de conhecimento: procurando situar no tempo e no espaço os manuscritos, determinar as características regionais desta ou daquela escola, deste ou daquele centro de artesanato bibliográfico (Scriptoria), a identidade do copista, do decorador, a Codicologia estuda a qualidade e a preparação do pergaminho, a natureza e a origem do papel, a composição das tintas e das cores utilizadas na decoração, os mínimos detalhes da encadernação (dimensão, composição dos cadernos), modos de numeração, entrelinhamento, colunas, margens, 
reclamos, dimensões das letras, os motivos iconográficos, a própria escritura. $[\ldots]^{213}$

O processo inquisitorial de Thereza Leyte e Escholastica Pinta da Sylva encontra-se armazenado em pasta plástica polionda ${ }^{214}$ e possui, como "capa" uma folha branca de papel pautado contendo informações básicas a respeito da documentação, como o tipo de crime (feitiçaria); data do processo; o nome das acusadas; o nome do falecido; local de origem do documento; duas observações; data de quando, provavelmente, a documentação chegou ao Arquivo da Cúria; e a assinatura do diretor do Arquivo, Jair Mongelli Júnior.

213 Segismundo Spina, em nota de rodapé de seu manual Introdução à edótica: crítica textual. São Paulo: Cultrix, ed. da Universidade de São Paulo, 1977, pp. 22-23.

2140 plástico corrugado, ou poliondas, é um material resistente à água, calor, umidade, além de ser anticorrosivo e impedir a formação de mofo. In.: PLASTIFILME - Embalagens Plásticas. Disponível em: http://www.plastifilme.com.br/oque-e-corrugado. Consultado em 19/10/18. 


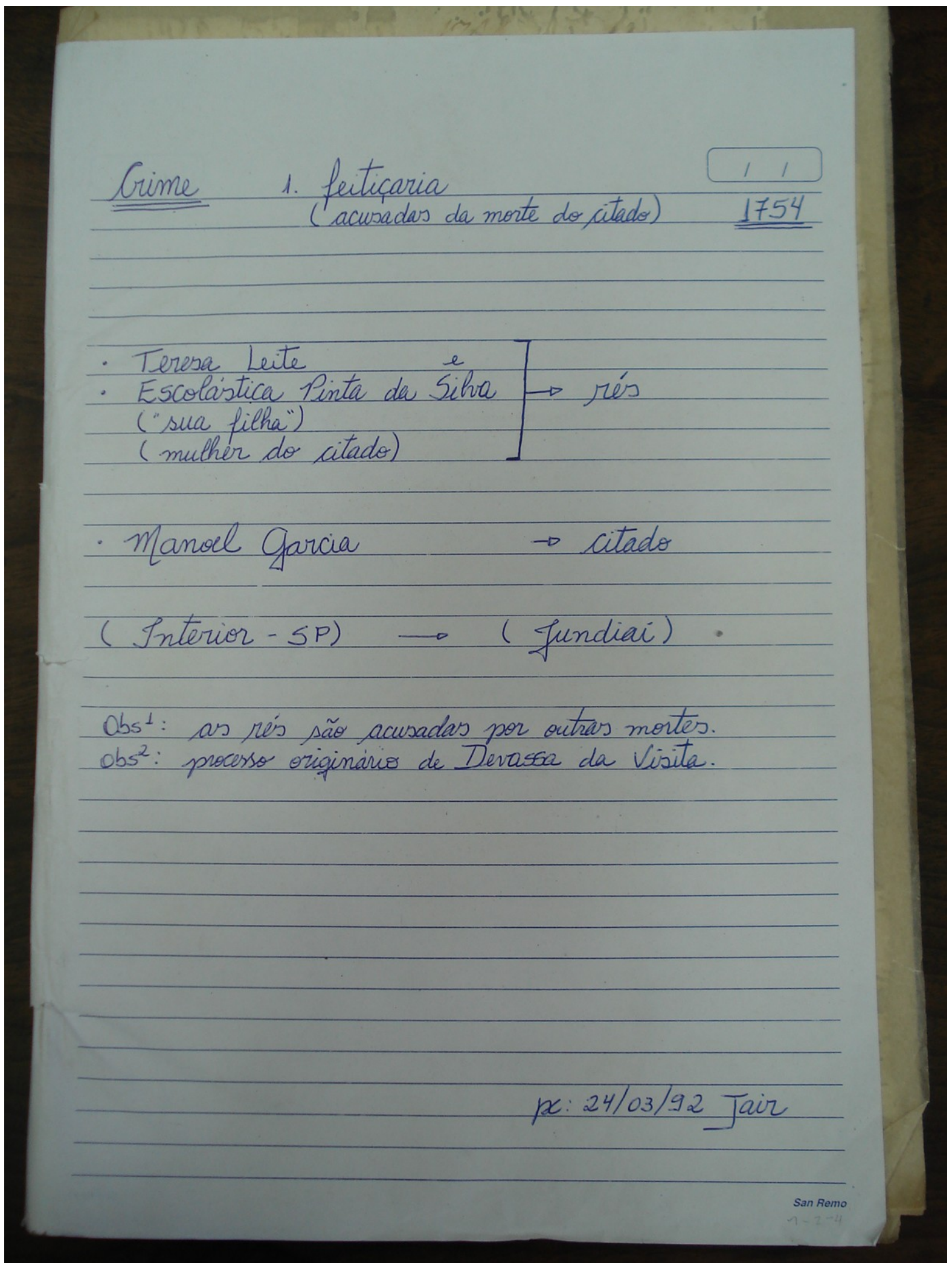

("capa" do processo-crime contra Thereza Leyte e Escholastica Pinta da Sylva) 
Além disso, este mesmo processo-crime é composto por 48 fólios $^{215}$ (frente e verso), sendo que, o verso de quatro deles está em branco (fólios \|2 v. $\|\| ,5 \mathrm{v} .\|\| ,25 \mathrm{v} . \|$ e $\|35 \mathrm{v}\|$.$) .$

$\mathrm{O}$ suporte material ${ }^{216}$ utilizado para a elaboração da documentação constitui-se de papel não pautado e, acerca de tal material, diz CAMBRAIA (2005: 66-67):

O papel constitui um suporte de natureza vegetal: sua fabricação dava-se no passado através de um processo de maceramento de elemento vegetal (como, p. ex., trapos de linho) colocado em água até a obtenção de uma pasta fina, à qual podem ser acrescentadas substâncias aglutinantes e branqueadoras. Uma porção dessa pasta era colocada sobre uma tela formada de moldura de madeira com trançado de fios de metal mais grossos e distantes uns dos outros na direção vertical (os pontusais) e de outros mais finos e próximos entre si na direção horizontal (as vergaturas). Escorrida a água, a lâmina de pasta que se formava era posta sobre um feltro para secar; uma pilha de lâminas sobre o feltro poderia ser colocada em uma prensa para serem alisadas. [...]

Outra informação de valor é que, aparentemente, os fólios do processo inquisitorial contra Thereza Leyte e Escholastica Pinta da Sylva não possuem marca d'água (filigrana) que, de acordo com CAMBRAIA (2005: 67), trata-se de figuras em forma de mão, estrela, âncora, entre outras que, por volta de 1280, passaram a ser entrelaçadas no trançado da tela de fios utilizada na fabricação do papel, deixando sobre a lâmina do mesmo uma marca perceptível contra a luz. A marca d'água, ainda segundo o autor, constitui um elemento de alta relevância na datação e localização dos testemunhos registrados em papel. ${ }^{217}$ Em relação aos suportes materiais dos manuscritos redigidos em língua portuguesa, CAMBRAIA (2005: 67) afirma: "Em se tratando de manuscritos lavrados em língua portuguesa (que começam a aparecer por volta dos sécs. XII-XIII), as matérias subjetivas básicas são o pergaminho e o papel."

Em relação à tinta utilizada na redação de um manuscrito, dá-se o nome de "matéria aparente", composta por corante, solvente, aglutinante e fixador.

A matéria aparente consiste propriamente na tinta. Esta compõe-se basicamente de elementos com as seguintes propriedades: corante (responsável pela cor do pigmento), solvente (responsável pela liberação

215 Atribui-se a denominação de "fólio" a uma folha frente e verso. Todavia, na presente pesquisa, quando trata-se apenas da frente ou do verso, é utilizado o termo "página".

216 Nesta dissertação de mestrado, optou-se por utilizar o termo "suporte material", empregado por CAMBRAIA (2005), em detrimento de "material base", utilizado por Ubirajara Dolácio Mendes, em seu manual Noções de paleografia (1953). A razão disso reside unicamente no fato de o manual de CAMBRAIA ser mais atual, publicado em 2005. Em suas palavras: "A matéria subjetiva constitui o suporte material para a escrita. Pode-se dizer que, de forma geral, os livros manuscritos têm como suporte uma (ou mais) das três seguintes matérias subjetivas: papiro, pergaminho e papel." (2005: 65).

217 Cf. CAMBRAIA, Op. cit., p. 67. 
do pigmento em uma solução líquida), aglutinante (responsável pelo ligamento homogêneo dos componentes da solução líquida) e fixador (responsável pela adesão da solução sobre o suporte). ${ }^{218}$

De acordo com CAMBRAIA (2005: 68), os elementos presentes na tinta podiam ser de origem vegetal, mineral e animal: "Os elementos que faziam parte da tinta poderiam ser de origem vegetal (p. ex., noz-de-galha ${ }^{219}$, azeite de oliva, vinho branco, goma-arábica), mineral (p. ex., sulfato de ferro) e animal (p. ex., mel, clara de ovo).[...]”. Entretanto, MENDES (1953: 52), inclui outros componentes na composição das tintas: ele afirma que as tintas vegetais são compostas à base de tanino ${ }^{220}$, corantes vegetais, entre outros; as tintas de origem animal podiam conter, em sua composição, ciba $^{221}$ e fuligem proveniente da queima de materiais animais; e as tintas minerais podiam ter ouro, prata e outras combinações químicas, em sua composição.

Especificamente em relação à tinta preta, MENDES (1953: 50) afirma que o método de fabricação majoritariamente utilizado era o de misturar fuligem com gordura dissolvida. Além disso, era adicionada uma pequena quantidade de vinagre à composição, com o objetivo de repelir os insetos que pudessem avançar pelo texto, por conta da gordura. ${ }^{222}$

O processo inquisitorial de Thereza Leyte e Escholastica Pinta da Sylva encontra-se corroído principalmente nas margens, devido à utilização de tinta ferro-gálica na redação dos manuscritos, dificultando o avanço das traças sobre o texto, provavelmente em razão da pequena quantidade de vinagre ou de vitríolo presente na composição da tinta. CAMBRAIA (2005: 68-69) comenta a respeito das tintas ferro-gálica e de carbono:

[...] Havia no passado dois tipos básicos de tinta: a de carbono e a ferrogálica; mas era também possível um tipo misto, composto de elementos comuns a essas duas. A tinta de carbono tinha base orgânica, por isso não sofria oxidação nem redução, mas, pelo fato de não reagir nem penetrar profundamente no suporte material, borrava com facilidade. Já a tinta ferro-gálica, que parece ter predominado na Europa ocidental na Idade Média, compunha-se geralmente de elementos como noz-de-galha (resina liberada por certas árvores), vitríolo (sulfato de cobre ou ferro) e goma.

218CAMBRAIA, 2005, p. 68.

219Em nota de rodapé de seu manual Introdução à edótica, Segismundo Spina (1977: 31) afirma: "A 'galha' é uma resina do carvalho, formada por excrescência da casca machucada."

220 Conforme consta no dicionário Caldas Aulete Digital, o tanino é um ácido adstringente extraído de vegetais, usado para tratar queimaduras, curtir couro, produzir corantes, tintas, entre outros. Disponível em: http://www.aulete.com.br/tanino

221 Segundo Ubirajara Dolácio Mendes (1953: 50), a ciba era uma secreção produzida por certos moluscos, utilizada pelos romanos na fabricação de tintas. Contudo, a tinta que possuía essa secreção em sua composição não produzia uma escrita totalmente preta, mas sim um tom da cor sépia (proveniente de "ciba").

222 MENDES, Idem, Ibidem. 
Esse segundo tipo de tinta, por apresentar propriedade cáustica, soía corroer a matéria subjetiva, o que era ainda favorecido pela sua oxidação.

O vitríolo, mencionado acima, era utilizado com a função de fixador e inseticida (como o vinagre), porém, proporcionava a oxidação dos manuscritos.

[...] Por vezes juntavam à composição pequena quantidade de vitríolo, com fim duplo: como fixador e como inseticida. Provàvelmente êste é o motivo por que muitos documentos, hoje existentes pelos arquivos, sofreram corrosão ao longo do tracejado da escrita. Tais documentos se transformaram em verdadeiras rendas cujas franjas são as bordas das letras que o antigo escriba traçou. São documentos que não resistem ao manusêio e que nem sempre se tornam elegíveis para um trabalho de restauração, perdendo-se portanto. ${ }^{223}$

Assim, como foi dito, a documentação de feitiçaria aqui analisada está corroída sobretudo nas margens dos manuscritos, mantendo-se majoritariamente mais preservada onde há texto escrito, isto é, na mancha ${ }^{224}$ dos fólios, o que se deve ao fato de provavelmente haver vinagre ou vitríolo na composição das tintas utilizadas, afastando, deste modo, a ação de insetos.

Com o objetivo de informar o leitor acerca das cores das tintas presentes nos manuscritos, segue-se uma tabela elencando a cor de tinta utilizada por cada redator da documentação, lembrando que as cores listadas são apenas hipóteses, uma vez que as tintas também sofreram corrosão e as cores desbotaram ao longo do tempo.

\begin{tabular}{|c|c|}
\hline Nome & Cor da tinta utilizada \\
\hline Polycarpo de Abreu Nogueyra & Marrom claro/ Marrom/ Preta \\
\hline Padre Bento Joze Leyte & Marrom claro \\
\hline Phelippe vas Lima & Marrom claro \\
\hline Fernando Pinto de Almeyda & Marrom claro/ Marrom \\
\hline $\begin{array}{c}\text { Promotor Paulo de Souza } \\
\text { Rocha }\end{array}$ & Marrom (um pouco avermelhado) \\
\hline Joaó de Saó Payo Peyxoto & Marrom claro \\
\hline Punho desconhecido 1 & Preta \\
\hline
\end{tabular}

223 MENDES, 1953, pp. 50-51.

224De acordo com o Caldas Aulete Digital, a mancha consiste na "parte impressa de uma página de livro, jornal etc.". Logo, no caso do processo-crime aqui estudado, a mancha seria a parte escrita dos fólios, onde há texto. Disponível em: http://www.aulete.com.br/mancha 


\begin{tabular}{|c|c|}
\hline Manoel Iozeph váz & Marrom (um pouco avermelhado) \\
\hline Francisco Iozeph Guedes & Preta \\
\hline Punho desconhecido 2 & Marrom claro \\
\hline Salvador de Oliveyra Preto & Marrom/ Preta \\
\hline
\end{tabular}

Todavia, foram realizados restauros em papel-arroz na documentação justamente pelo fato de as tintas conterem propriedade cáustica em sua composição, o que favorece a corrosão do documento. A folha de papel-arroz possui propriedades que neutralizam o $\mathrm{pH}$ das tintas empregadas na redação dos manuscritos, evitando que a acidez das mesmas possa corroer ainda mais o papel. É possível visualizar, nos fac-símiles utilizados para a presente pesquisa, que, embaixo de cada fólio, foi inserida uma folha de papel-arroz. 


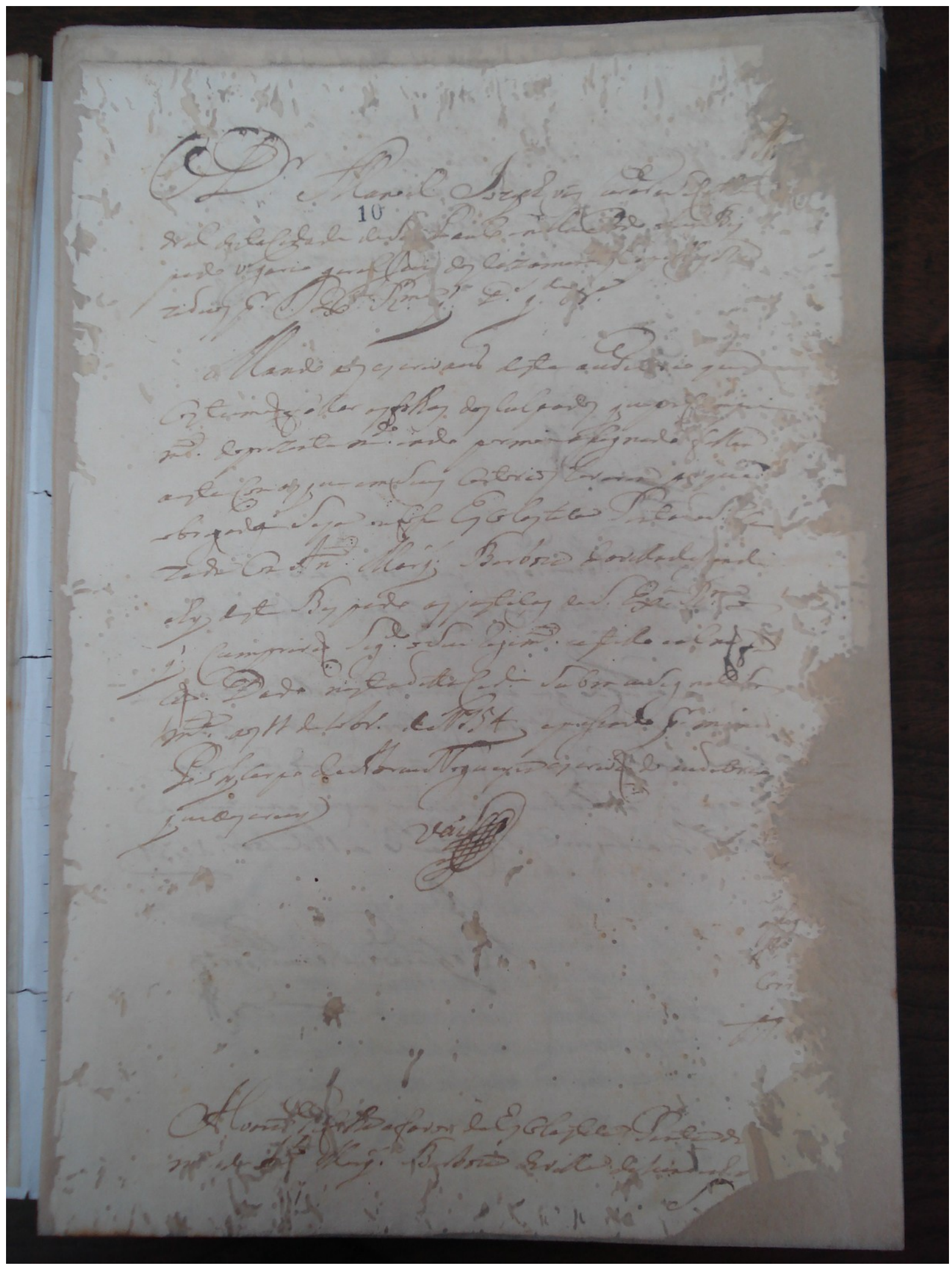

(Fólio 10 r. - É possível ver a folha de papel-arroz embaixo do manuscrito) 
Acerca do punho do escrivão Salvador de Oliveyra Preto, nota-se alguns números localizados à margem dos fólios - lado direito ou esquerdo, dependendo se é o reto ou o verso do fólio -, indicando o número dos artigos citados no texto. É interessante observar que, ao longo dos fólios escritos pelo referido escrivão, há algumas frases sublinhadas com uma tinta mais clara (vermelha ou marrom) e algumas anotações feitas ao lado de tais frases. Essas anotações constituem-se de uma reprodução do conteúdo das frases sublinhadas e localizamse na margem da página, entre os já mencionados números indicadores dos artigos. Além disso, é importante enfatizar que o punho, isto é, a caligrafia utilizada em tais anotações é de outra pessoa (do promotor das rés, Joaó de Saó Payo Peyxoto) e encontra-se em uma letra de módulo menor, não obedecendo exatamente a pauta "imaginária" da página.

É possível inferir que o procurador Joaó de Saó Payo Peyxoto tenha sublinhado as informações mais importantes do texto, copiando-as na margem com o objetivo de utilizá-las como referência futura, isto é, com o objetivo de tornar as informações mais facilmente localizáveis, caso o texto necessitasse ser consultado futuramente ou por outra pessoa. Seguem-se alguns exemplos retirados da documentação:

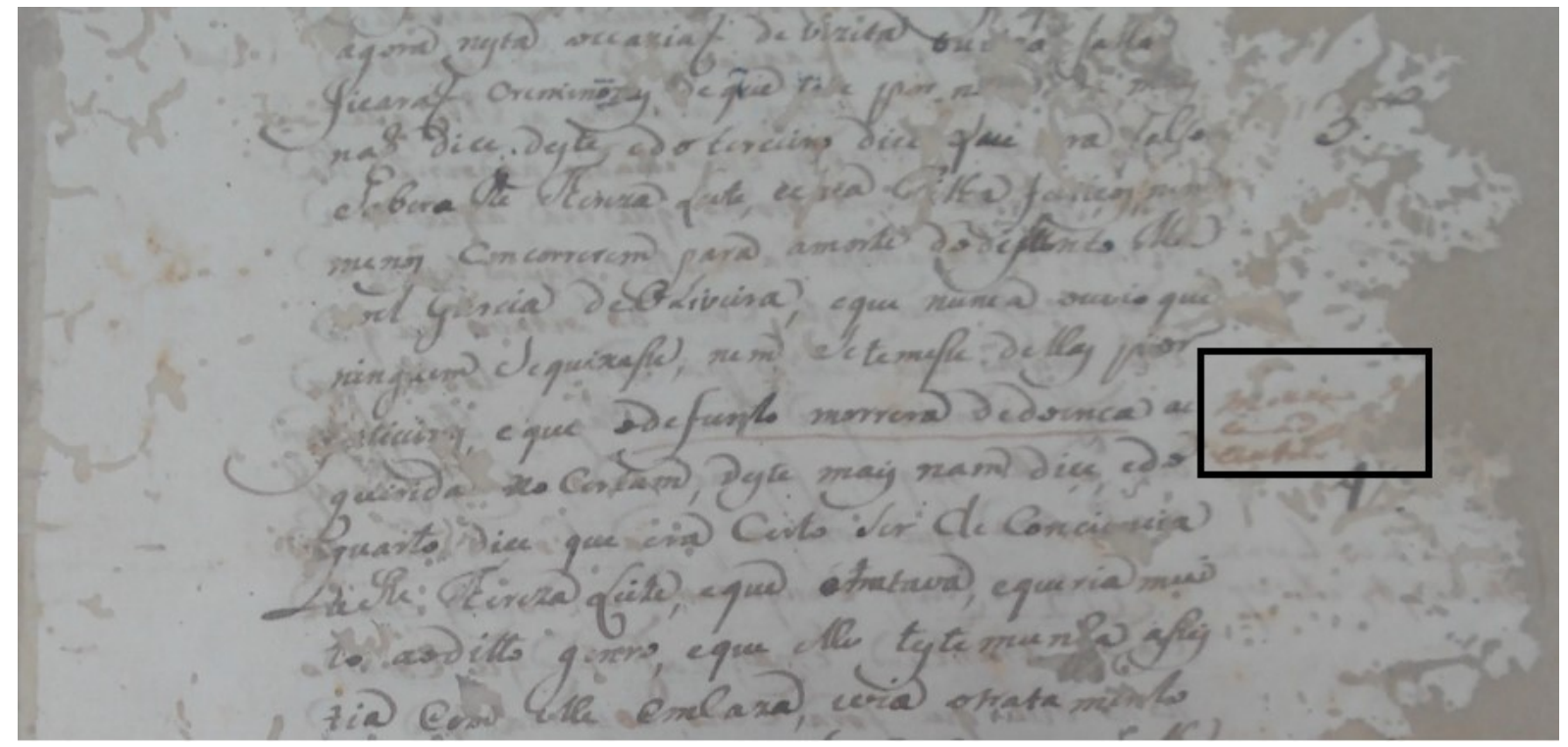

(Fólio 27 r. - Salvador de Oliveyra Preto e Joaó de Saó Payo Peyxoto) 


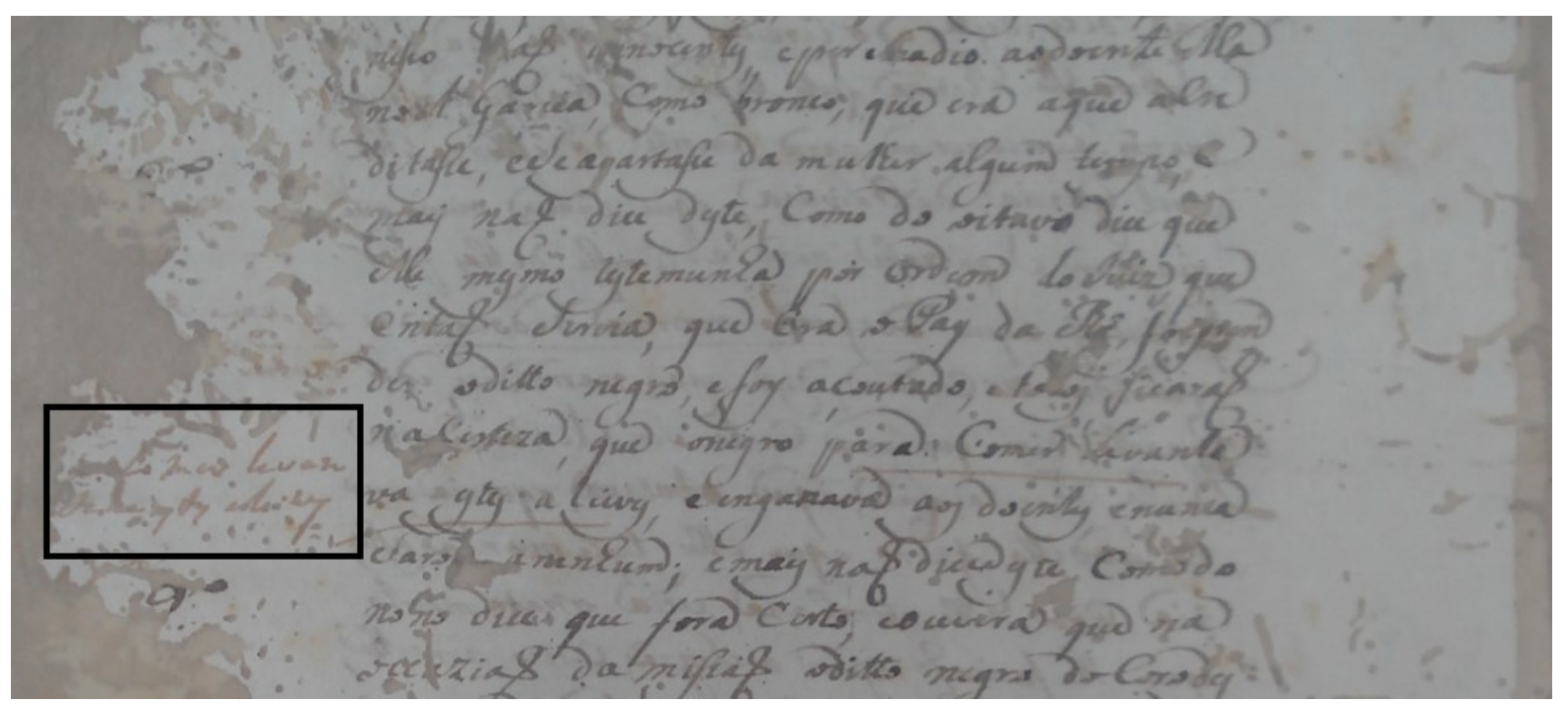

(Fólio 27 v. - Salvador de Oliveyra Preto e Joaó de Saó Payo Peyxoto)

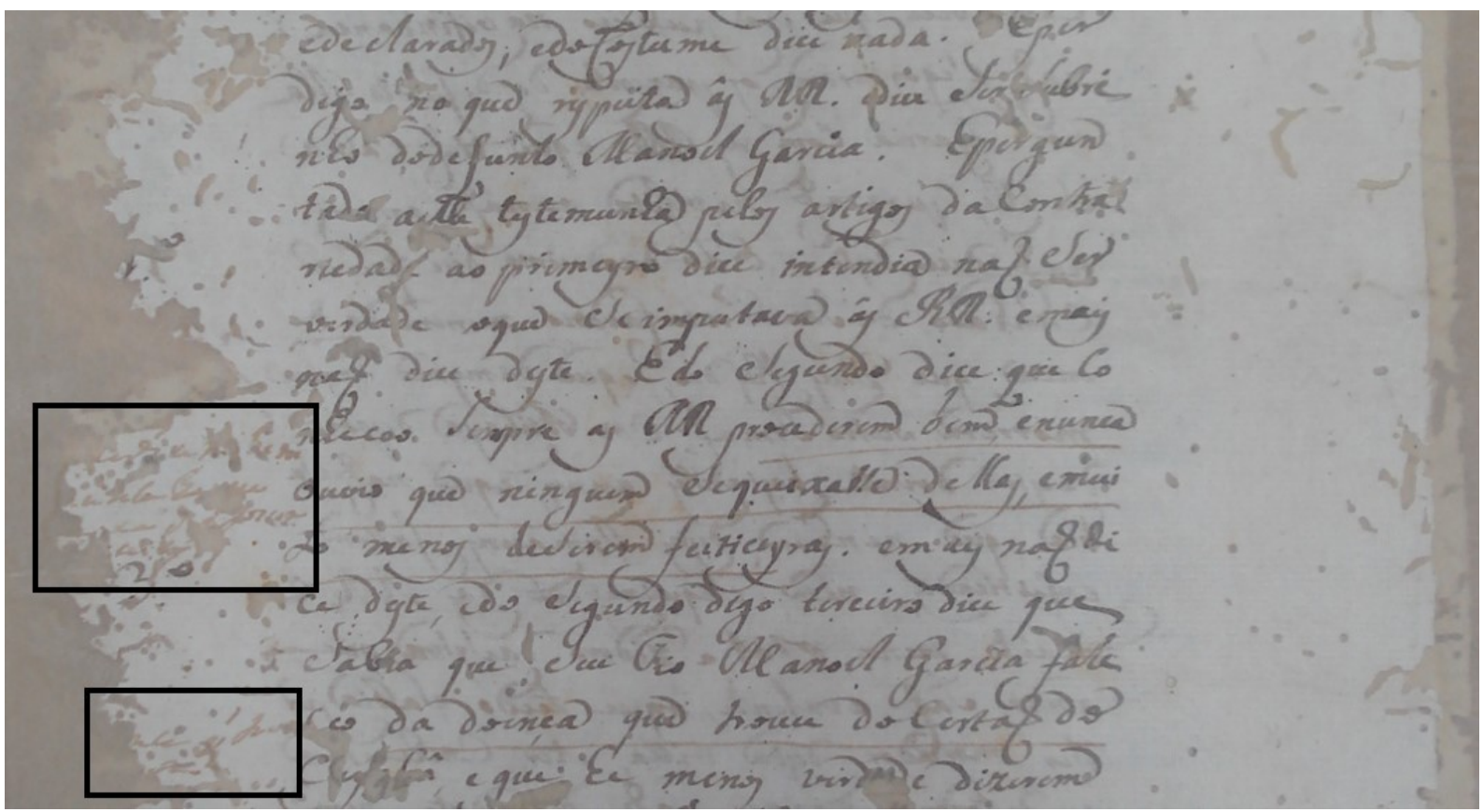

(Fólio 29 v. - Salvador de Oliveyra Preto e Joaó de Saó Payo Peyxoto) 


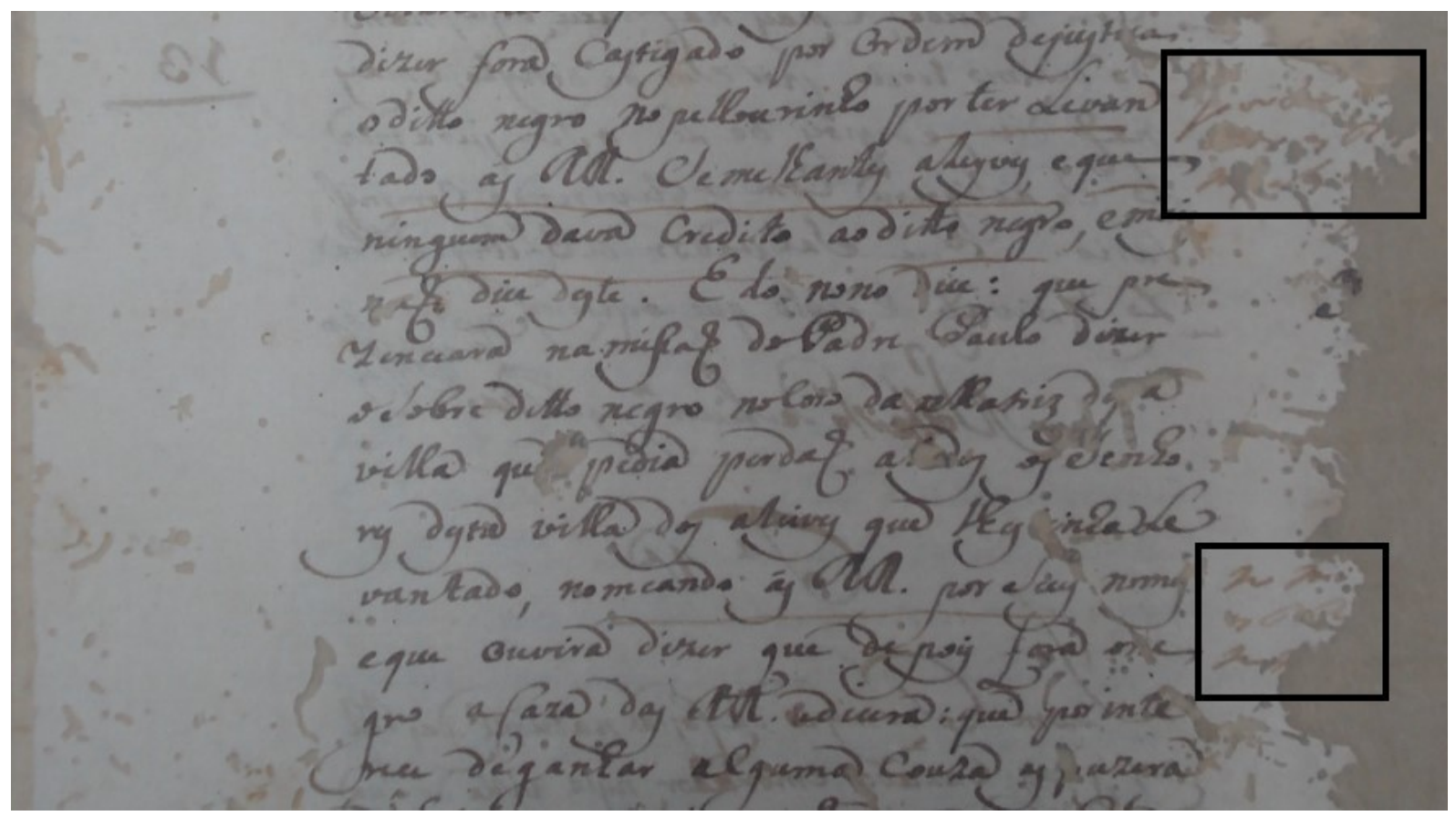

(Fólio 30 r. - Salvador de Oliveyra Preto e Joaó de Saó Payo Peyxoto)

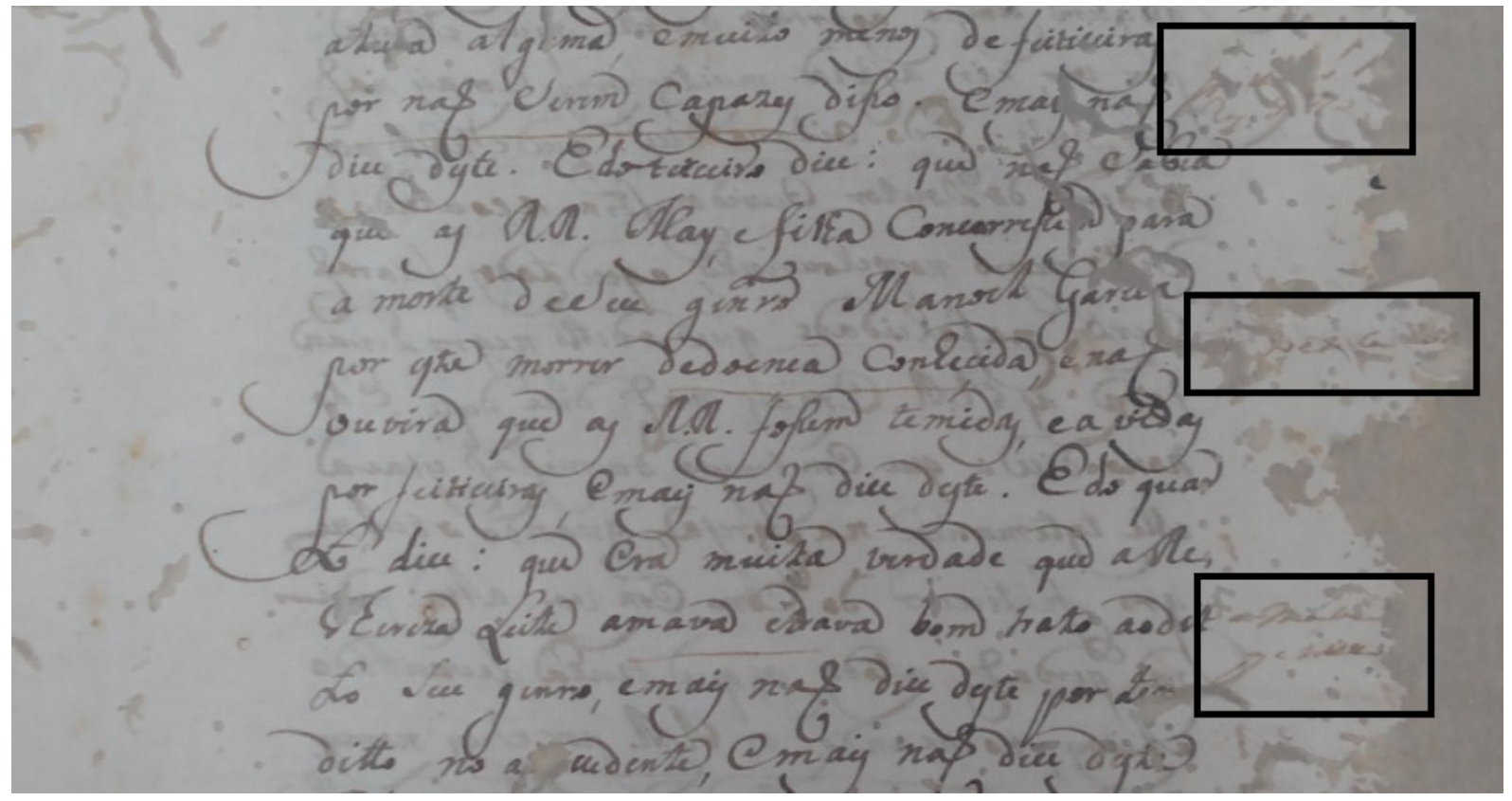

(Fólio 31 r. - Salvador de Oliveyra Preto e Joaó de Saó Payo Peyxoto)

Outro elemento presente na documentação é o "reclamo" (ou "reclame"), que consiste em uma ou mais palavras que estão localizadas ao final da página e que são repetidas no 
início da página seguinte, indicando a continuação do texto, sendo um recurso útil na organização da sequência dos fólios. ${ }^{225}$

[...] O reclamo consistia na parte de uma palavra, em uma palavra inteira ou ainda em um grupo de palavras que se colocava, fora da mancha, à direita da margem de pé da página, repetindo o que deveria estar no início da coluna, página ou caderno que se seguiria $[\ldots]^{226}$

A única diferença, porém, entre o "reclamo" descrito acima por CAMBRAIA e os "reclamos" presentes no processo-crime em questão é que estes encontram-se dentro da mancha. Seguem-se alguns exemplos extraídos dos manuscritos utilizados nas transcrições:

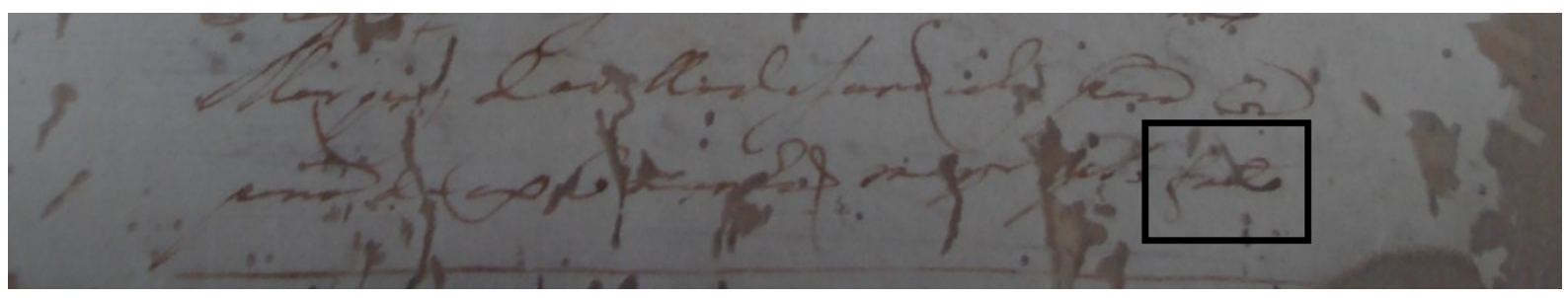

(Fólio 4 r. - Polycarpo de Abreu Nogueyra)

Marqu[e]s dav[i]lladeJundiahy para com

pena, de ex Comunhaõ mayor pelo facto

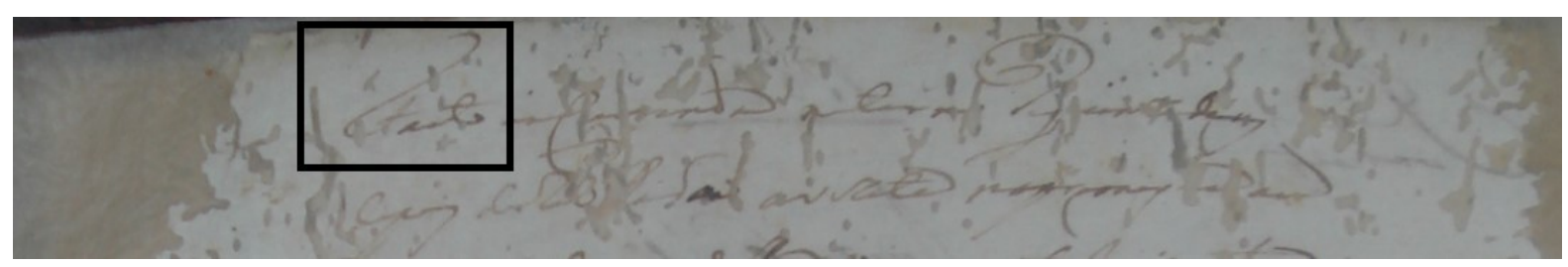

(Fólio 4 v. - Polycarpo de Abreu Nogueyra)

[[Facto]] inC[urr]endo noter[mo] deq[u]in[ze]dias

depois dereco[lh]ida avizita naprimey $[\mathrm{r}] \mathrm{a}$ au

225 Para maiores detalhes acerca do estudo dos "reclamos" (ou "reclames"), ver a dissertação de mestrado de Elizangela Nivardo Dias: Subsídios para um estudo do reclame em documentos manuscritos e impressos em português (séculos XVI a XVIII), 2007.

226 CAMBRAIA, 2005, p. 73. 


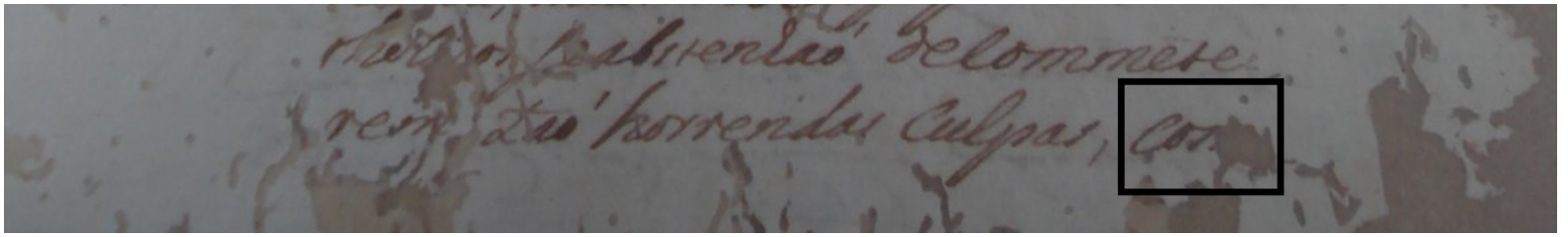

(Fólio 13 r. - Promotor Souza)

thol[i] $\cos \mathrm{s}[\mathrm{e}]$ abstenhaó decommete -

rem taó horrendas culpas, co[m]

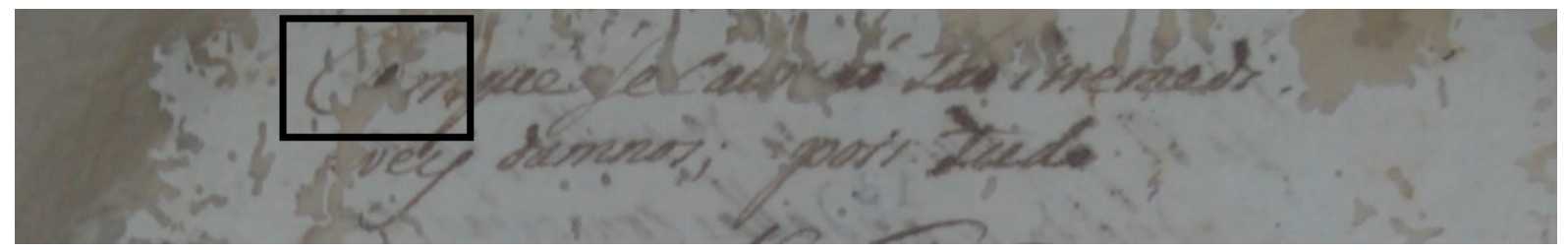

(Fólio 13 v. - Promotor Souza)

[[Com]lque seca[uzar]aó ta[ó] irremedi -

[a]veis damnos; [espaço] pois tudo

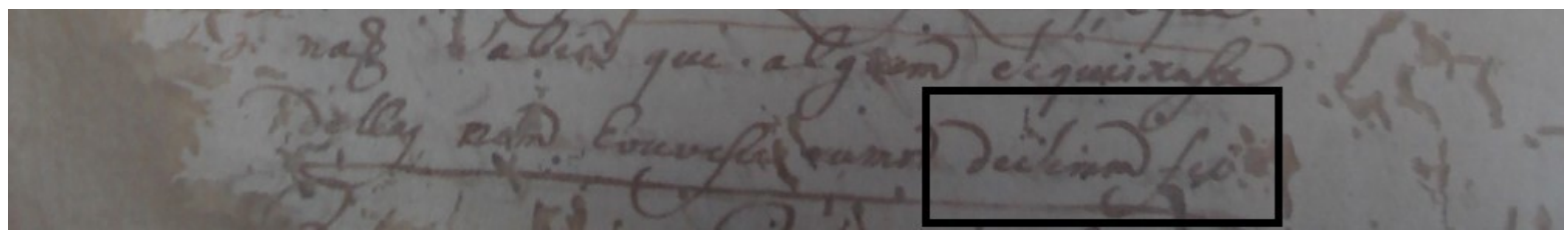

(Fólio 32 v. - Salvador de Oliveyra Preto)

naõ Sabia que alg[u]em Sequeixasse

dellas, nem houvesse rumor deSerem fei

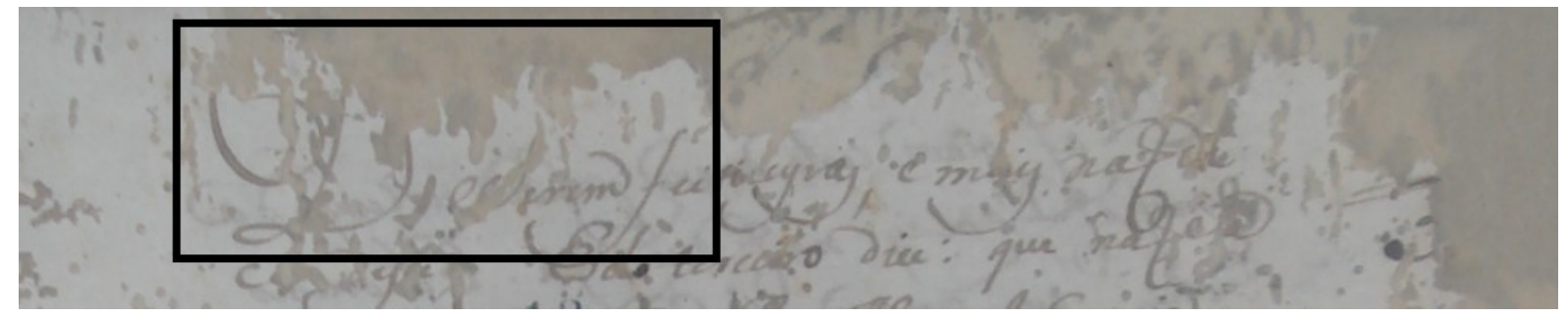

(Fólio 33 r. - Salvador de Oliveyra Preto)

[[DeSerem fei]]ticeyras, emais naõ di

$\mathrm{c}[\mathrm{e}] \operatorname{des}[\mathrm{t}] \mathrm{e}<\downarrow 13>\mathrm{E}$ do terceiro dice: que naõ Sa 


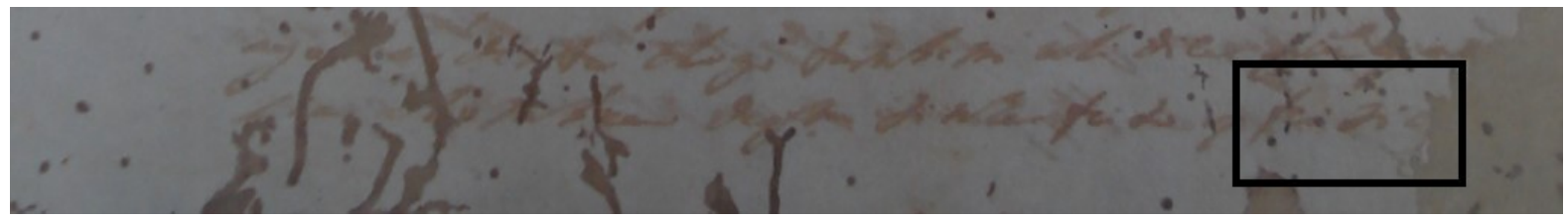

(Fólio 16 r. - Joaó de Saó Payo Peyxoto)

ago[a] a[r]dente Logo tambem ali dice que [a]pa[corroído]

c[i]a aSombra dequem tinha feito os feitic[os]

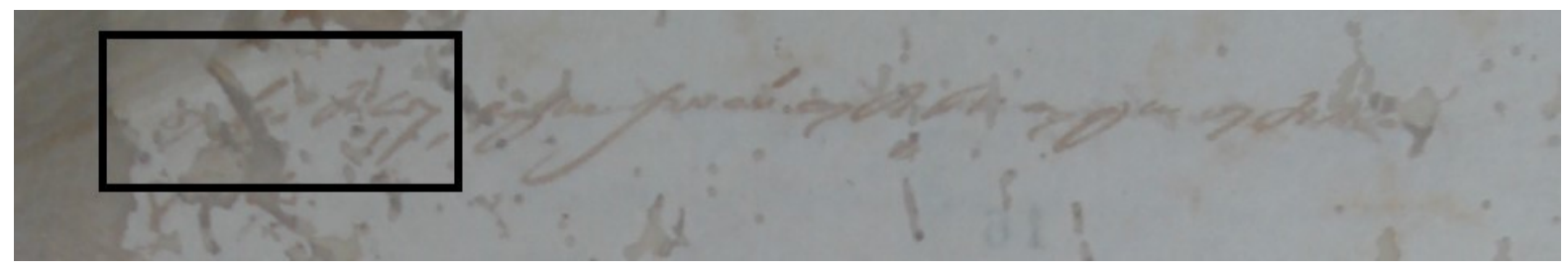

(Fólio 16 v. - Joaó de Saó Payo Peyxoto)

[[os feitiços]], equeforaó as Rés as que os t[corroído] [corroído]o.

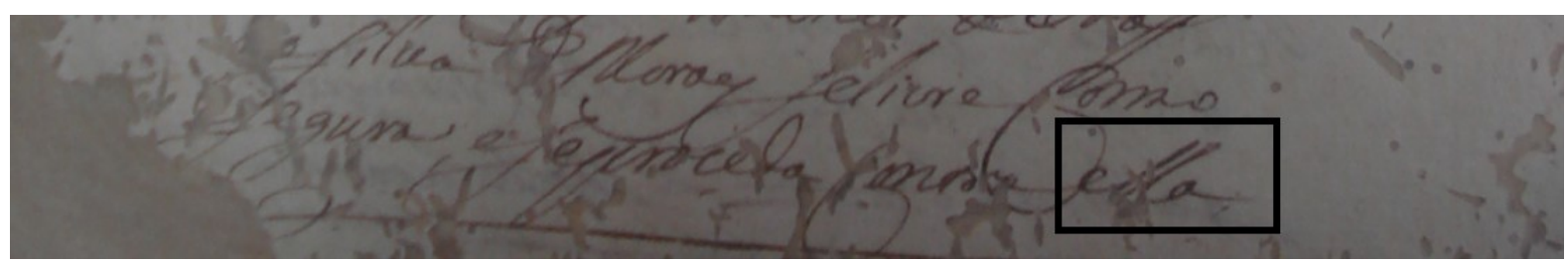

(Fólio 40 v. - Fernando Pinto de Almeyda)

dasilua deMoraes selivreComo

segura, eseproçeda Contraella

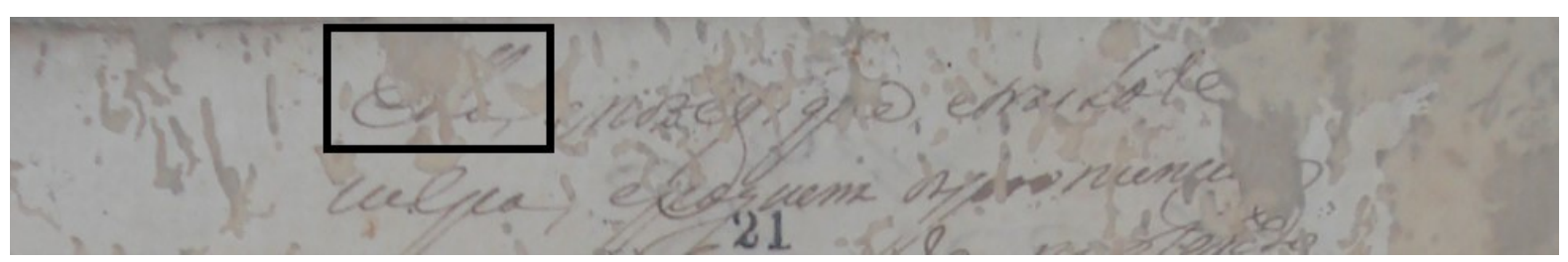

(Fólio 41 r. - Fernando Pinto de Almeyda)

[[Ella]], enotefique etra[s] Lade [corroído] culpa, epaguem $<\downarrow 21>$ azpronunci[ada]s 


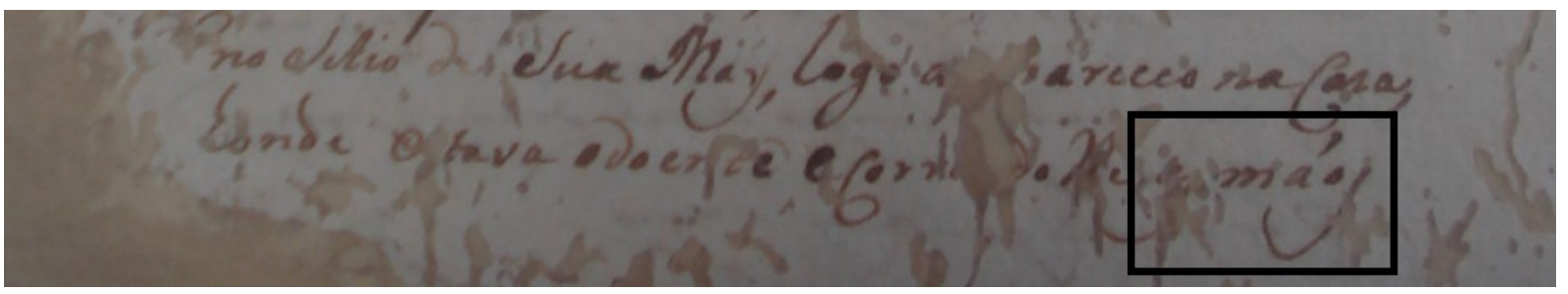

(Fólio 46 v. - Manoel Iozeph váz)

no sitio de sua May, logo a[corroído][p]areceo naCaza,

honde e[s]tava o doente eCorr[en]do lhe as máos

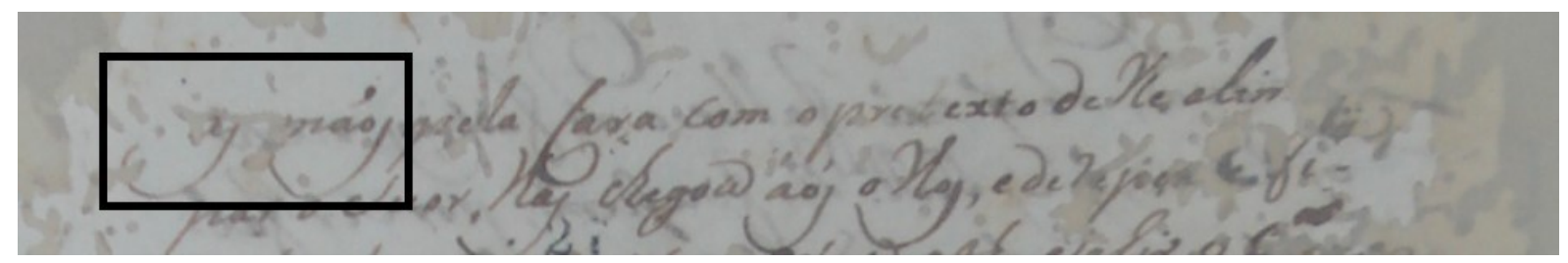

(Fólio 47 r. - Manoel Iozeph váz)

[[as máos]] pela Cara com o pretexto de lhe alim par o suor, lhas $<\downarrow 27>$ chegou aos olhos, e de repe[nt]e fi -

Finalmente, é importante ressaltar que, no corpus da pesquisa, há fólios mais deteriorados do que outros, tornando a leitura e a transcrição dos manuscritos tarefas ainda mais árduas. A seguir, segue-se um fac-símile de um dos fólios mais corroídos da documentação: 


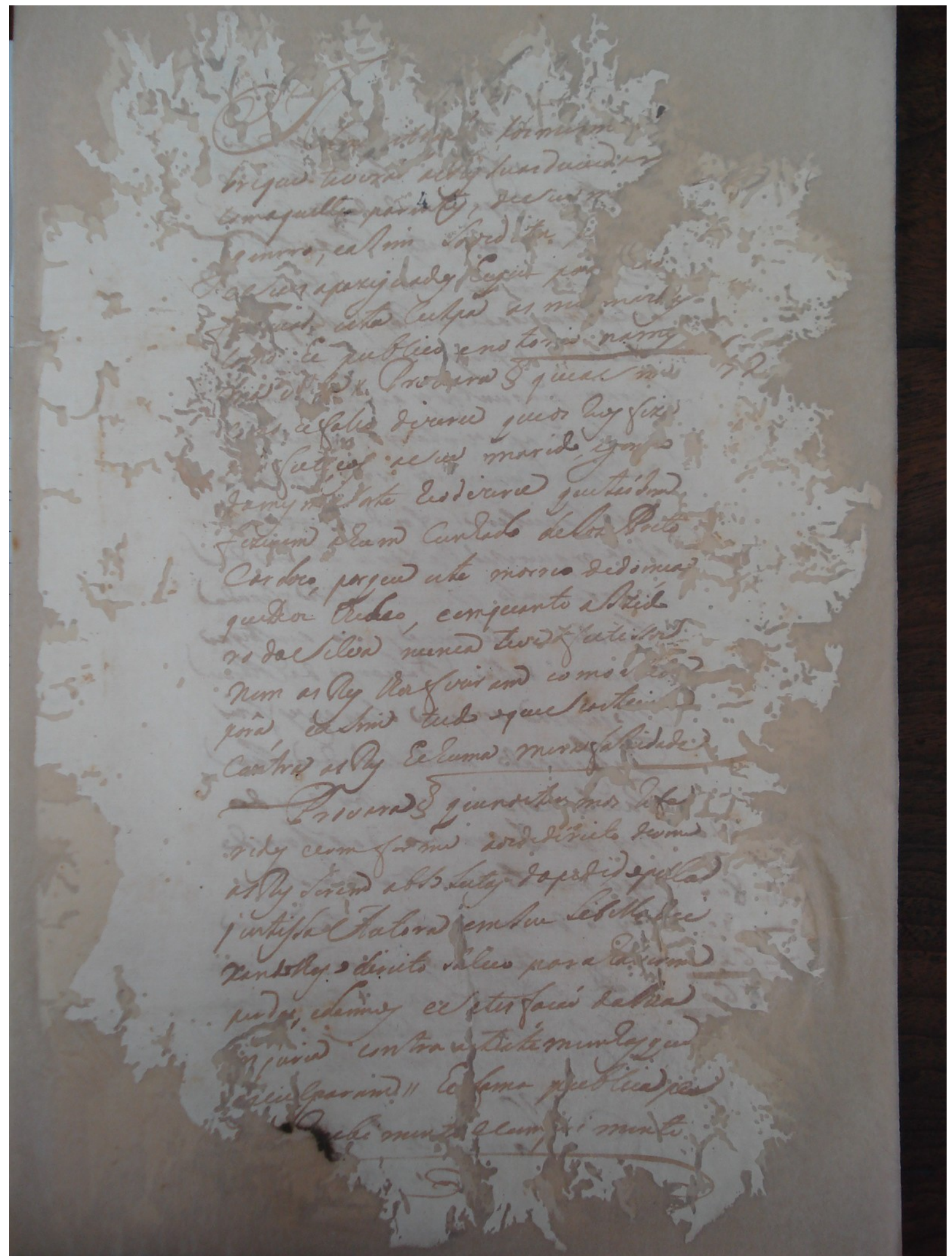

(Fólio 24 r. - Punho desconhecido 2) 


\subsubsection{ESTUDO PALEOGRÁFICO}

O processo-crime de Thereza Leyte e Escholastica Pinta da Sylva é composto por onze punhos, isto é, onze pessoas diferentes redigiram a documentação, sendo elas escrivães, um promotor, um meirinho da visita, um reverendo vigário $\left(\right.$ pároco $^{227}$ ) e um reverendo visitador. Contudo, é de fundamental importância ressaltar que, nesta pesquisa, as assinaturas das testemunhas que prestaram depoimento no decorrer do processo não foram consideradas como punhos. Abaixo, encontra-se uma tabela, cuja finalidade é auxiliar o leitor a localizar e reconhecer os punhos (dos redatores do processo) na documentação, uma vez que alguns deles se alternam, não havendo, portanto, uma sequência exata, linear dos punhos, nos manuscritos.

\begin{tabular}{|c|c|c|}
\hline Nome & Função & Fólios \\
\hline \multirow{3}{*}{ Polycarpo de Abreu Nogueyra } & \multirow{3}{*}{ Escrivão } & 1 r. -2 r./ 4 r. -5 r. $/ 7$ r. -11 r./ \\
\hline & & 13 r. -14 v./ 19 r. -20 v./ 41 v. \\
\hline & & 42 r./ 45 r. -46 r./ 48 r. -48 v. \\
\hline Padre Bento Joze Leyte & Escrivão & 3 r. -3 v./ 6 r. -6 v. $/ 48$ v. \\
\hline Phelippe vas Lima & Meirinho da visita & 3 v. e 8 v. \\
\hline Fernando Pinto de Almeyda & $\begin{array}{l}\text { Escrivão da Câmara } \\
\text { Episcopal }\end{array}$ & 9 v./ 10 v./ 24 v./ 36 r. -41 r. \\
\hline $\begin{array}{c}\text { Promotor Paulo de Souza } \\
\text { Rocha }\end{array}$ & Promotor & 11 r. -13 v./ 41 v. \\
\hline Joaó de Saó Payo Peyxoto & Procurador das rés & $14 \mathrm{v} .-17 \mathrm{r} . / 42 \mathrm{v} .-44 \mathrm{v}$. \\
\hline Punho desconhecido 1 & Não informado & $18 \mathrm{r}$. \\
\hline Manoel Iozeph váz & Reverendo visitador & 18 r./ 45 r./ 46 v. -48 r. \\
\hline Francisco Iozeph Guedes & Reverendo vigário/pároco & $18 \mathrm{v}$ \\
\hline Punho desconhecido 2 & Escrivão do auditório & 21 r. -24 v. \\
\hline Salvador de Oliveyra Preto & Escrivão & 26 r. -35 r. \\
\hline
\end{tabular}

Como já fora mencionado anteriormente e de forma breve, a paleografia seria, de modo geral, o estudo das escritas antigas.

A paleografia pode ser definida, de uma forma bastante básica, como o estudo das escritas antigas. Modernamente, apresenta finalidade tanto teórica quanto pragmática. A finalidade teórica manifesta-se na preocupação em se entender como se constituíram sócio-historicamente os sistemas de escrita; já a finalidade pragmática evidencia-se na

227 Segundo o dicionário Caldas Aulete Digital, o pároco é um padre responsável por uma paróquia, sendo equivalente a um vigário, cura ou abade. Disponível em: http://www.aulete.com.br/pároco 
capacitação de leitores modernos para avaliarem a autenticidade de um documento, com base na sua escrita, e de interpretarem adequadamente as escritas do passado. ${ }^{228}$

Outra definição bastante útil e clara do termo paleografia é dada por SPINA (1977: 18): "[...] estudo das antigas escritas e evolução dos tipos caligráficos em documentos, isto é, em material perecivel (papiro, pergaminho, papel).” Entretanto, foi apenas no século XVIII que tal termo passou a ser utilizado, após uma publicação de autoria de um beneditino.

[...] em 1708 é outro beneditino, Bernard de Montfaucon, que, dirigindo as suas pesquisas sobre textos gregos, publica a Palaeographia graeca, pondo em voga o termo inventado para designar a ciência das escrituras antigas. ${ }^{229}$

A paleografia torna-se indispensável no tratamento desta documentação por tratar-se de manuscritos antigos, redigidos com uma escrita também antiga, inserida em uma tradição de escrita muito divergente da atual.

A escrita que compõe este documento é chamada de humanística, uma escrita surgida no século XIV através da imitação da letra carolina por parte dos humanistas, que rejeitavam a escrita gótica e buscavam mimetizar o modelo de escrita greco-romano, recuperando também outros valores da Antiguidade clássica. SPINA (1977: 35) afirma que a escrita gótica degenerou-se em confusão e rebuscamento ${ }^{230}$, portanto, havia uma necessidade por parte dos humanistas de buscar uma escrita cujo traçado fosse mais "limpo" e claro, utilizando e reproduzindo uma escrita que fosse completamente o oposto da escrita gótica.

[...] O Renascimento, que se caracterizou por uma adesão incondicional ao mundo clássico antigo e postulou um conceito pejorativo contra a Idade Média (identificando a imperfeição com o goticismo), relegou o estilo gótico pela sua profusão de artifícios, e voltou as suas simpatias para um tipo de letra mais simples e mais pura, adequada à cópia dos clássicos latinos; daí a reabilitação da antiga minúscula carolina, que supunham genuinamente romana. $\mathrm{O}$ novo estilo caligráfico redundou na

228CAMBRAIA, Op. cit., p. 23.

229 SPINA, 1977, p. 21.

230Segundo SPINA (1977: 34-35): "Desde o início do reinado carolíngio, entretanto, todas essas modalidades da escritura greco-romana dão lugar à chamada minúscula carolina, que se torna dominante nos três séculos que sucedem ao reinado carolíngio; mas é de observar que a minúscula carolina, já desde o século X, manifesta evidente inclinação para as formas modernas; e no século seguinte evolui, numa verdadeira inversão da sua simplicidade e elegância, para a chamada letra gótica, que a partir do século XII segue triunfante pela Europa até a aparição da imprensa, quando, diversificada já na sua evolução com as diferentes particularidades nacionais, degenera em confusão e rebuscamento. [...]" 
chamada escrita humanística ou italiana, que entrou pelos séculos seguintes. ${ }^{231}$

Além da escrita humanística, o processo-crime contra Thereza Leyte e Escholastica Pinta da Sylva foi redigido fazendo-se o uso da escrita cursiva que, segundo CONTRERAS (1994: 45), é aquela na qual predomina a rapidez na execução das letras, o que gera um distanciamento cada vez maior do modelo "padrão" das mesmas. ${ }^{232}$ Além disso, SPINA (1977: 34) assegura que a letra cursiva era mais utilizada por escrivães, pois havia a necessidade de utilizarem uma letra cujo traçado fosse mais rápido e corredio, em função de seu trabalho.

[...] A letra cursiva, usada desde o século II a.C., tornou-se escrita popular e largamente utilizada pelos notários e escrivães, que necessitavam de um tipo caligráfico mais rápido e mais correntio na redação de documentos. [...].

Outro aspecto relacionado à escrita da documentação aqui analisada é o fato de, além de cursiva, a escrita ser encadeada, isto é, há traços entre as letras, conectando-as. A diversidade de punhos contidos no processo de Thereza e Escholastica resulta em uma variedade de tipos de escrita, cada uma trazendo características próprias de cada escrivão, sendo umas mais encadeadas do que outras e revelando um maior ou menor domínio sobre a escrita e sobre o sistema abreviativo.

231 SPINA, 1977, p. 35.

232 De acordo com CONTRERAS (1994: 45): "[La escritura cursiva] Es aquélla en la que priva la rapidez en su trazado; a la rapidez se sacrifica, en los límites de lo posible, la exactitud y correspondencia al modelo de las formas de los signos." 


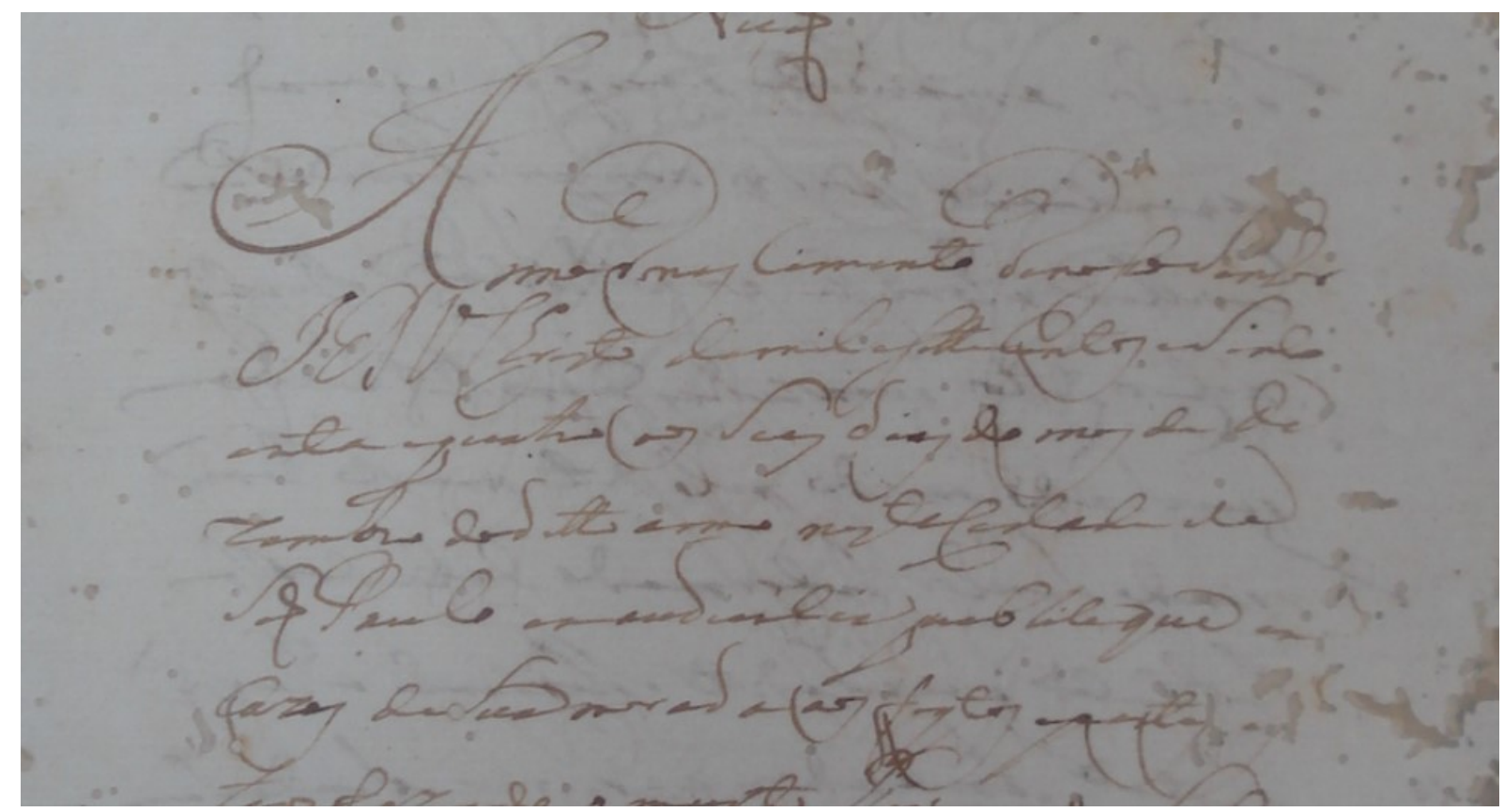

(Fólio 4 r. - Punho mais encadeado de Polycarpo de Abreu Nogueyra)

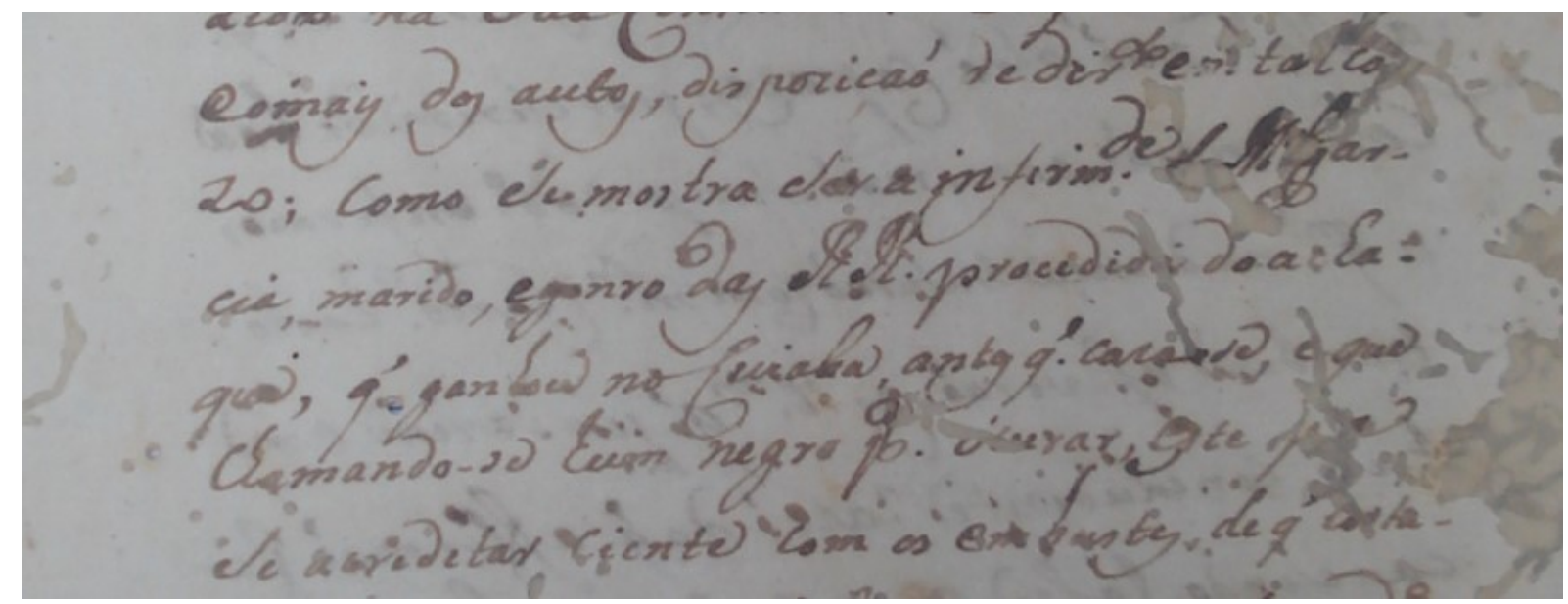

(Fólio 47 r. - Punho menos encadeado de Manoel Iozeph váz)

Os referidos traços que conectam as letras, isto é, as ligaduras, são, de acordo com CONTRERAS (1994: 43), linhas que unem os traços de letras próximas, que, na verdade, deveriam ser executadas separadamente, erguendo-se o instrumento gráfico. As ligaduras são produzidas quando, depois de executado o traçado de uma letra, o instrumento gráfico segue movendo-se para a direita em sentido ascendente, descendente ou sobre a própria pauta, para 
produzir o traçado da letra seguinte. ${ }^{233}$ Além disso, as ligaduras podem ocorrer em uma letra, em letras da mesma palavra ou entre duas ou mais palavras consecutivas, quando há união da última letra de uma palavra com a primeira letra da palavra seguinte. ${ }^{234}$

No processo-crime contra Thereza Leyte e Escholastica Pinta da Sylva, o punho que apresenta as ligaduras como elemento predominante da escrita é o do escrivão Fernando Pinto de Almeyda (fólios 9 v./ 10 v./ 24 v./ 36 r. - 41 r.).

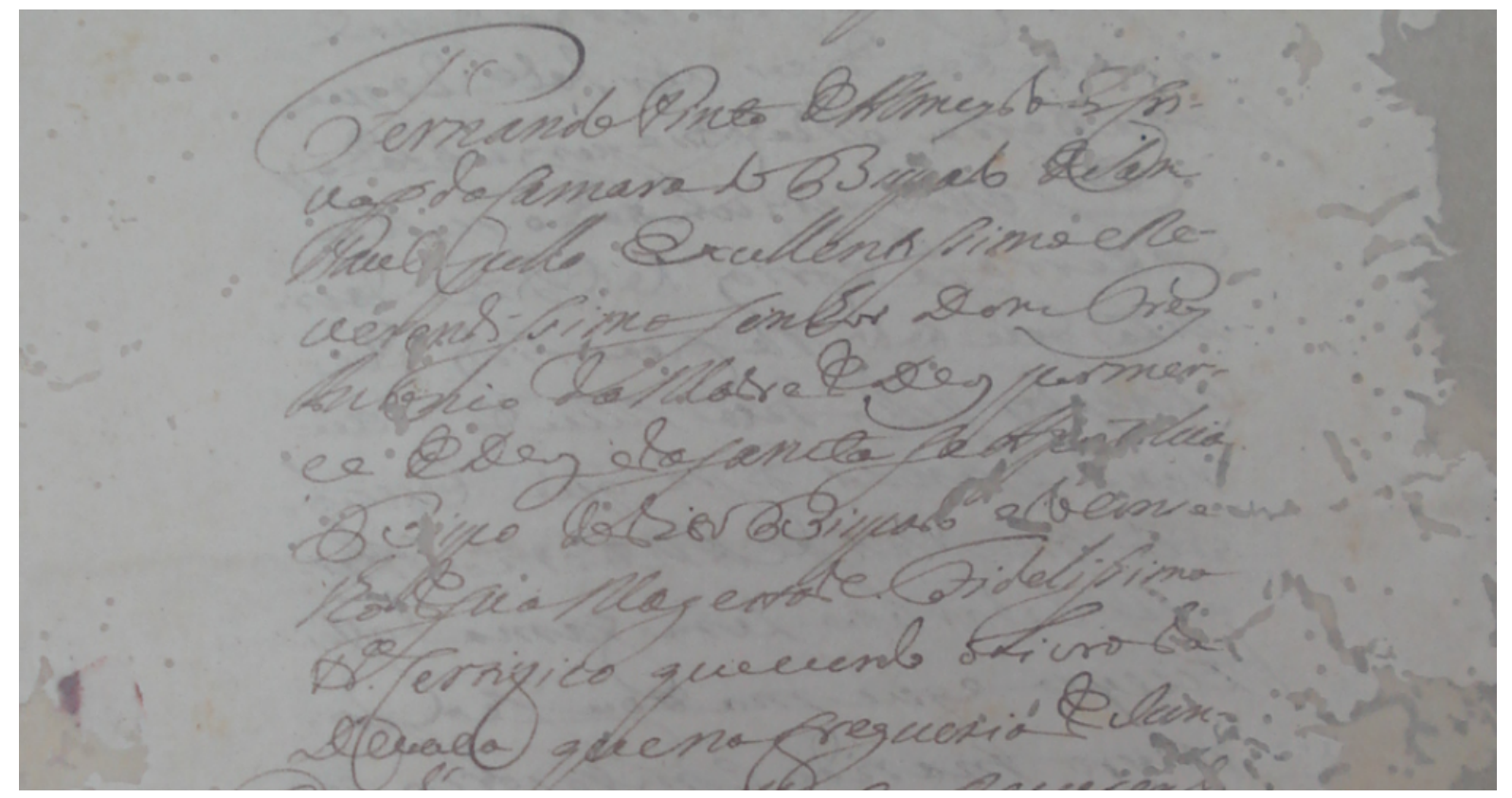

(Fólio 36 r.)

FernandoPinto $d \boldsymbol{e A l m e y d a E s C r i ~ - ~}$ uaõ daCamaradoBis[p]ado deSam Paul[o]pello ExcellentissimoRe uerendissimosenhor DomFrey Antonio daMadredeDeos pormer ce $d e$ Deosedasancta feAp[os]t[o]lica doBispo doditoBispado edoconse lhodesuaMagestadeFidelissima menteCertifico queuendo oLivroda

Deuaça quenafregueziade Iun -

233 Segundo CONTRERAS (1994: 43): "[Ligados] Son tracitos o incluso simples rasgos cursivos que unen trazos de una o dos letras próximas que por su naturaleza tenían de ejecutarse levantando el instrumento gráfico. Se producen cuando después de ejecutado un trazo de una letra, el instrumento sigue moviéndose hacia la derecha en sentido ascendente, descendente o sobre la línea de escritura para hacer un trazo de la letra siguiente."

234 De acordo com CONTRERAS (1994: 43): "[La ligadura] Se produce en una letra, en letras de la misma palabra o entre dos o más palabras consecutivas cuando la unión es entre la última de las letras de una y la primera de la otra." 


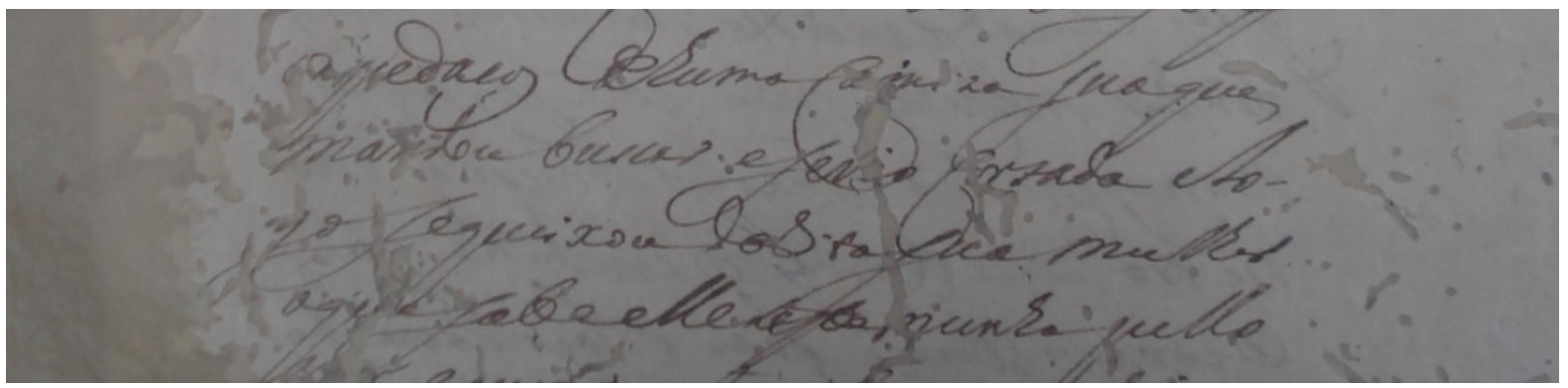

(Fólio 37 v.)

o[z]pedaços dehumaCamiza suaque

mandoubuscar esev[i]o Cortada eLo -

gosequeixoudaditasuamulher

oquesabeelletestemunha pello

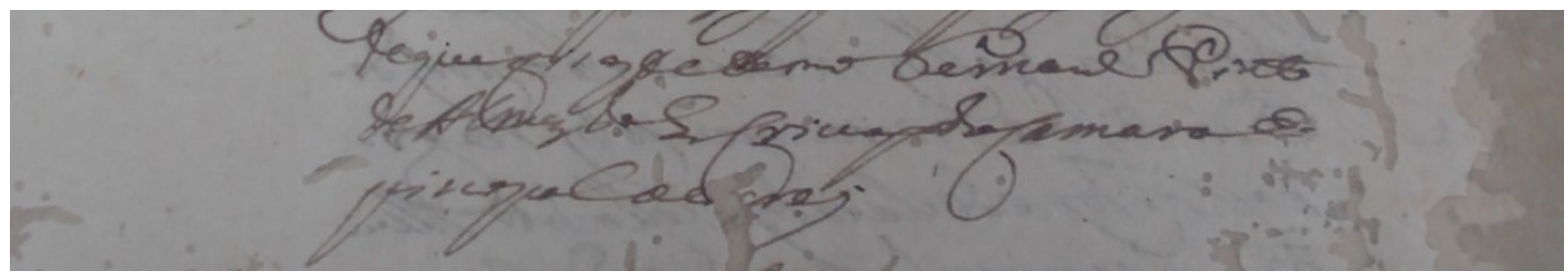

(Fólio 39 r.)

dequefis estetermoFernandoPinto

deAlmeydaEsCriua õdaCamaraE piscopaloe $[\mathrm{s}] \mathrm{crevj}$

Observe-se também, principalmente em outros punhos que compõem a documentação, o espaçamento entre palavras e a divisão de palavras em duas partes, quando não é possível redigi-las por inteiro na mesma linha. 


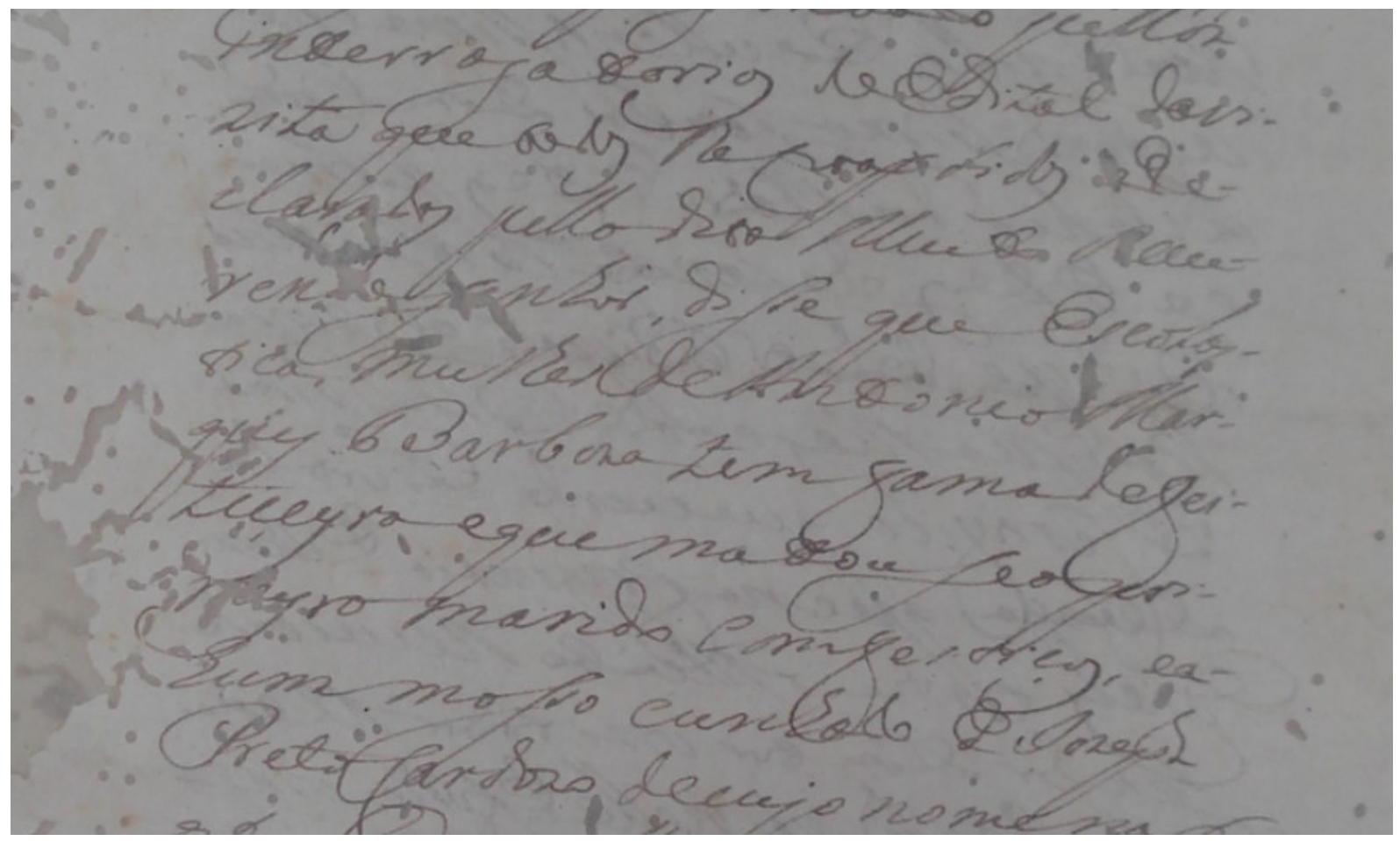

(Fólio 36 v. - Fernando Pinto de Almeyda)

interrogatorios doEdital davi zita quetodos lheforaõ lidos ede clarados pellodito Muito Reue rendosenhor, disse queEscoLas tica mulher deAntonioMar ques Barboza tem famadefei tiçeyra equematouseopri meyromarido comfeitiços, ea hummosso cunhado de Iozeph PretoCardozo [...] 


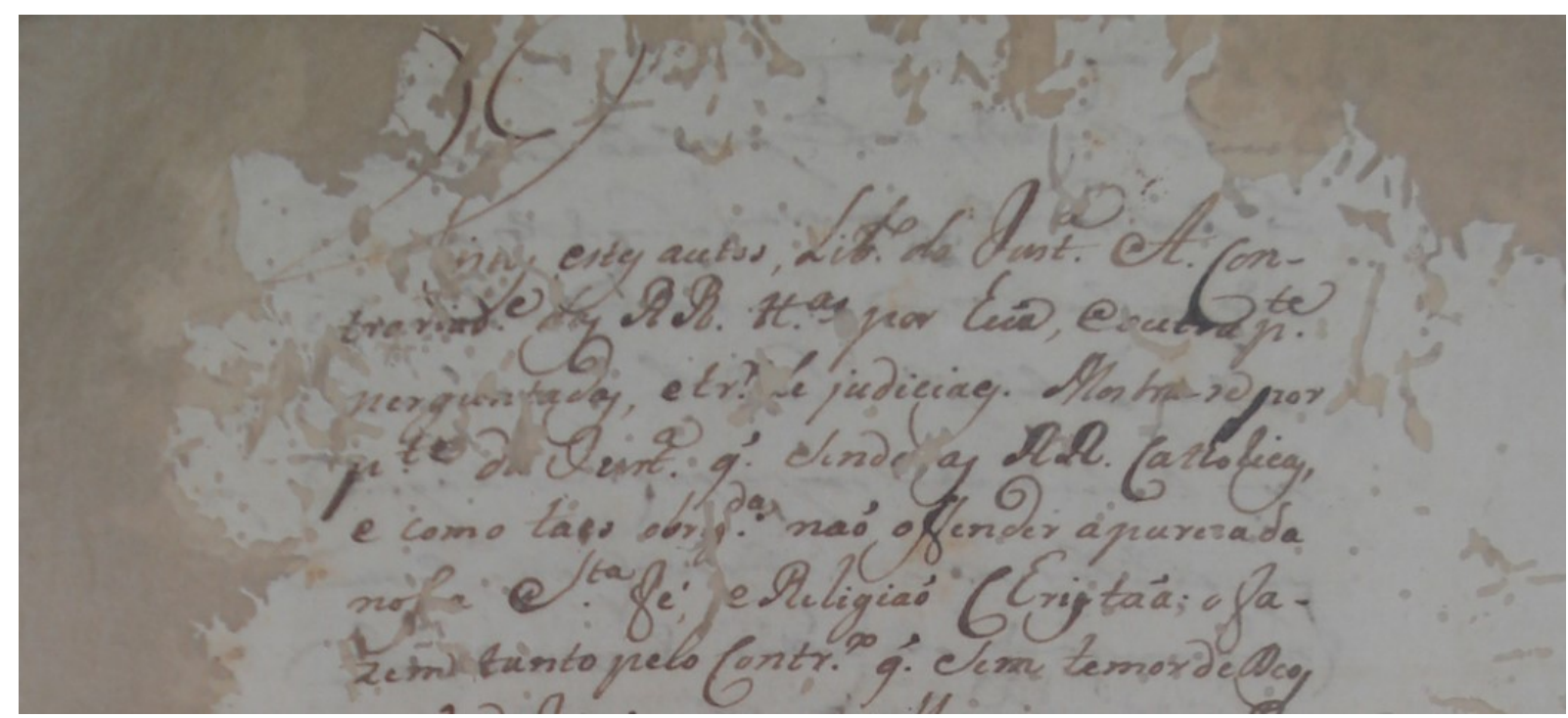

(Fólio 46 v. - Manoel Iozeph váz)

\author{
Vistos estes autos, Libelo ${ }^{235}$ da Iustiça Autora Con $^{236}$ - \\ trariadade $\mathrm{e}^{237}$ das Rés testemunhas por huã, eoutra parte \\ perguntadas, e tr?[corroído]Le judiciaes. Mostra-se por \\ parte da Iustiça que sendo as Rés Catholicas, \\ e como taes obr[i]gadas naó offender a pureza da \\ nos[s]a Santa fé, e Religiaó Christaã; o fa - \\ zem tanto pelo Contrario que sem temor de Deos
}

Assim, SPINA (1977: 42) assegura que até o final do século VIII, praticamente não havia a presença de espaço intervocabular em códices e diplomas primitivos, situação que começou a mudar principalmente no início do século IX, surgindo também a divisão de palavras, em duas ou mais partes.

Já a paragrafação só é presente em um dos punhos que compõem a documentação aqui estudada, sendo ele o punho desconhecido 2, apenas no fólio $21 \mathrm{r}$.. 


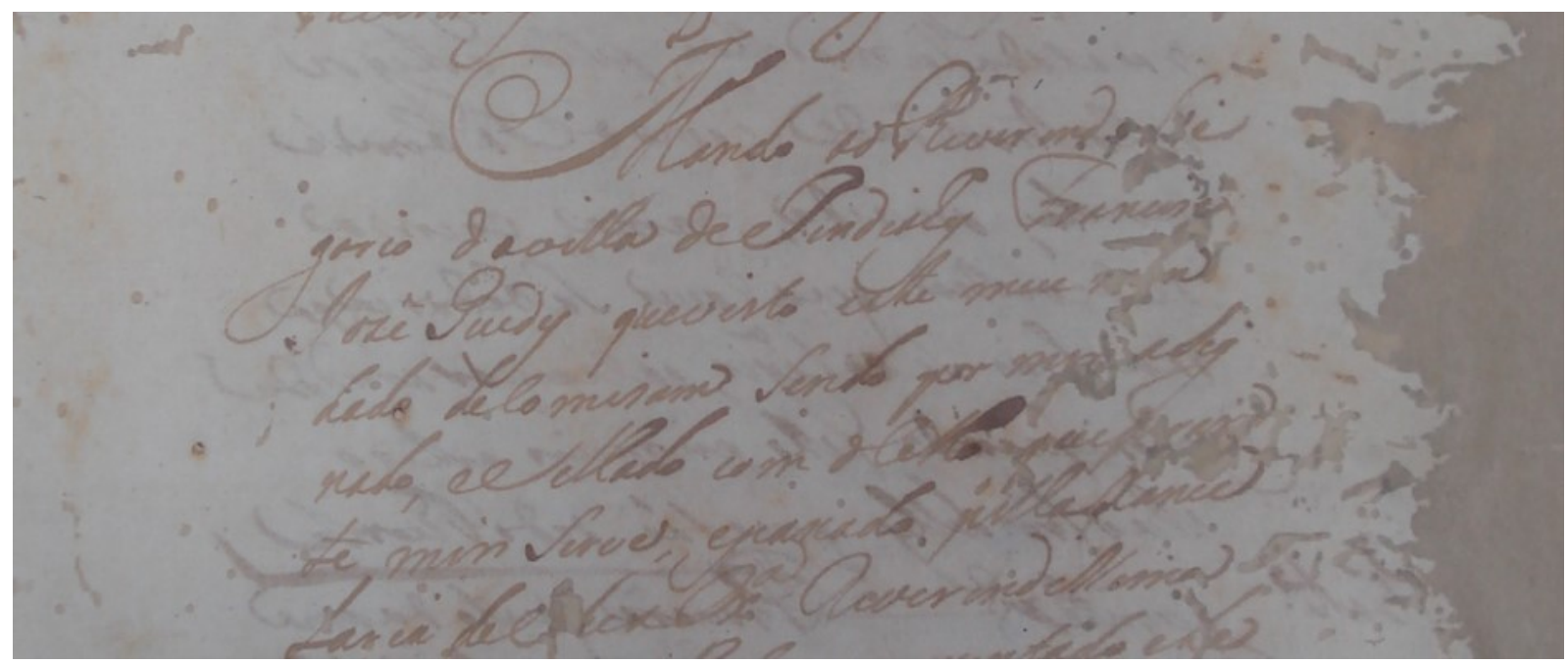

(Fólio 21 r. - punho desconhecido 2)

\author{
Mando aoReverendo [Vi] \\ gario davilla deIindiahy ${ }^{238}$ Francis[co] \\ Iozê Guedes quevisto este meu [ma]n \\ dado decomisam Sendo por $\mathrm{m}$ [in] aSig \\ nado, eSellado com ocello quep[o]r [ar] \\ te min Serve, epassado pellaXance \\ Laria deSuaExcelenci $\mathrm{a}^{239}$ Reverendissima
}

Sobre a paragrafação, SPINA (1977: 43) afirma que em diplomas e documentos diversos os parágrafos eram raros, sendo utilizados com mais frequência na inserção de datas e assinaturas, como ocorre no processo contra Thereza e Escholastica.

Relativamente ao parágrafo, os antigos documentos representavam-no por um espaço de uma polegada, iniciando a nova linha com minúscula - se o documento é anterior ao século VIII -, e com maiúscula - se posterior a essa época. Muitas vezes se designava o parágrafo mediante uma figura semelhante ao 2 ou ao 5 , ou então a pontos de interrogação deitados. Entretanto, nos diplomas e demais documentos, rarissimamente se usam os parágrafos, a não ser no caso das datas e das assinaturas que abrem nova linha.

A seguir, apresentam-se alguns exemplos, extraídos dos manuscritos em questão, de paragrafação utilizada antes de assinaturas:

238 "Iindiahy" por "Iundiahy". Provavelmente a troca de "u" por "i" tenha sido resultado de um erro por parte do escrivão.

239 "Ex" por "Excelência", segundo FLEXOR, Ibidem, p. 172. 


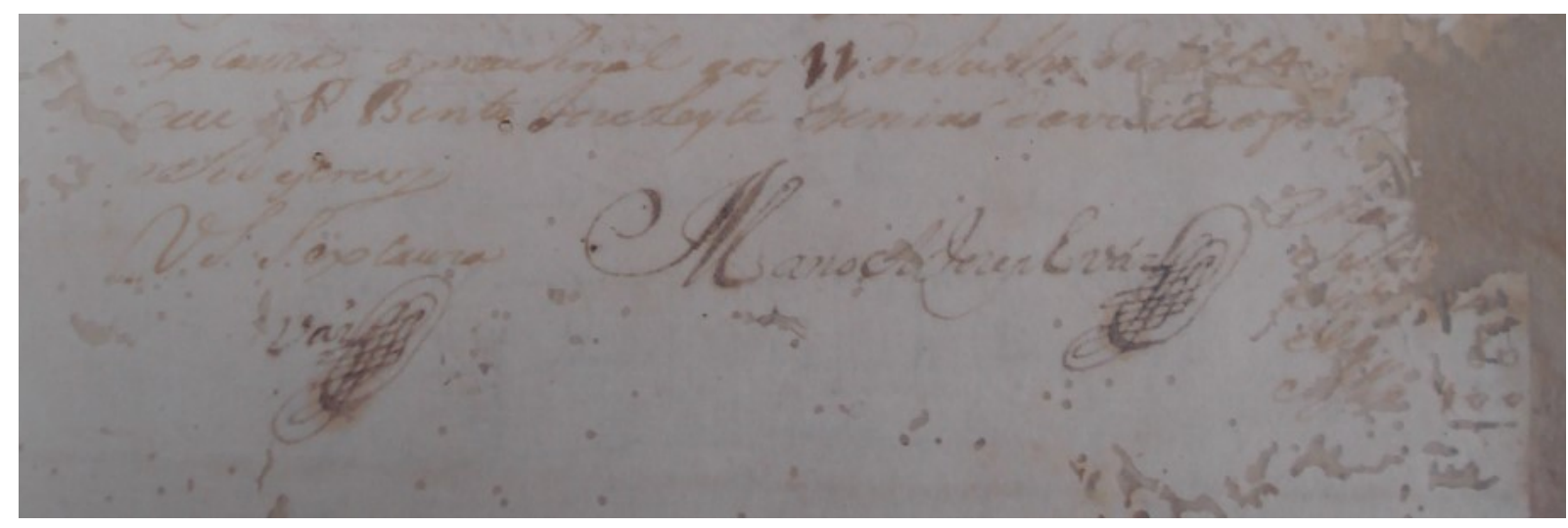

(Fólio 3 r. - Padre Bento Joze Leyte com assinaturas e sinais públicos de Manoel Iozeph váz)

ex causa omeuSinal aos 11 deIulho de1754

eeu [o]Padre Bento IoseLeyte Escrivaó davi[s]ita of[i]z

eSob escrevj

VoSsa Senhoria ex cauza Manoel Iosephváz[sinal público]

váz[sinal público]

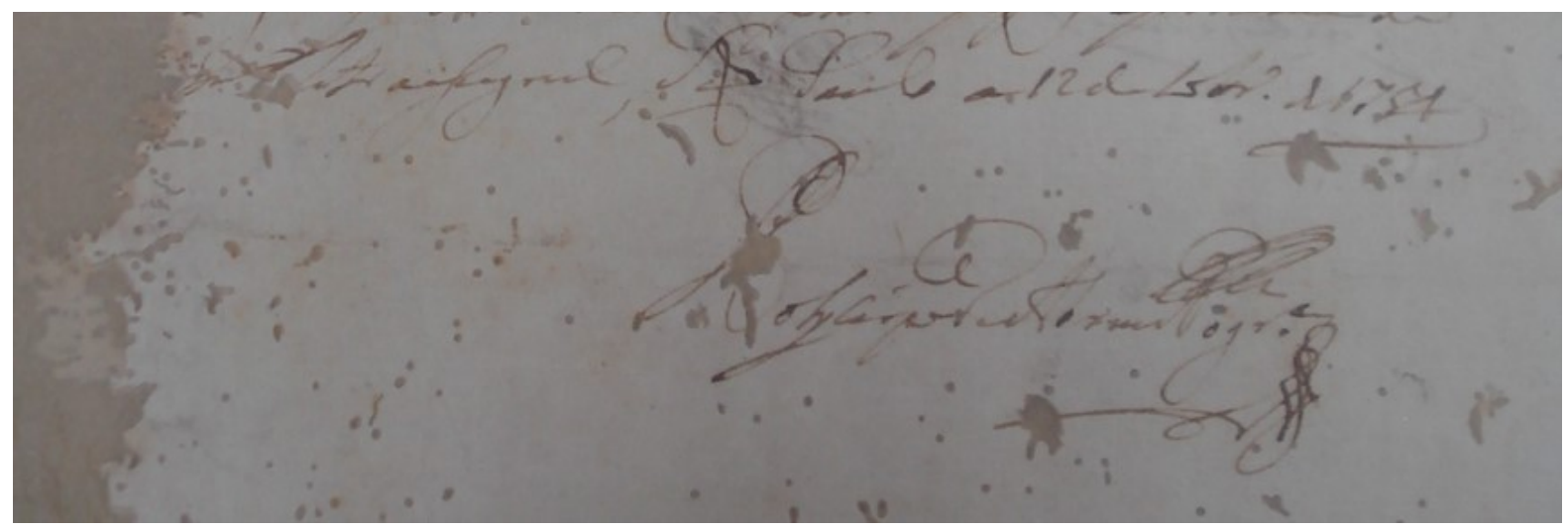

(Fólio 10 v. - Polycarpo de Abreu Nogueyra)

minhaLetraessignal, Saõ Paulo a12dedezembro de1754

[espaço]

[sinal público]

PolycarpodeAbreuNogueyra

[sinal público] 


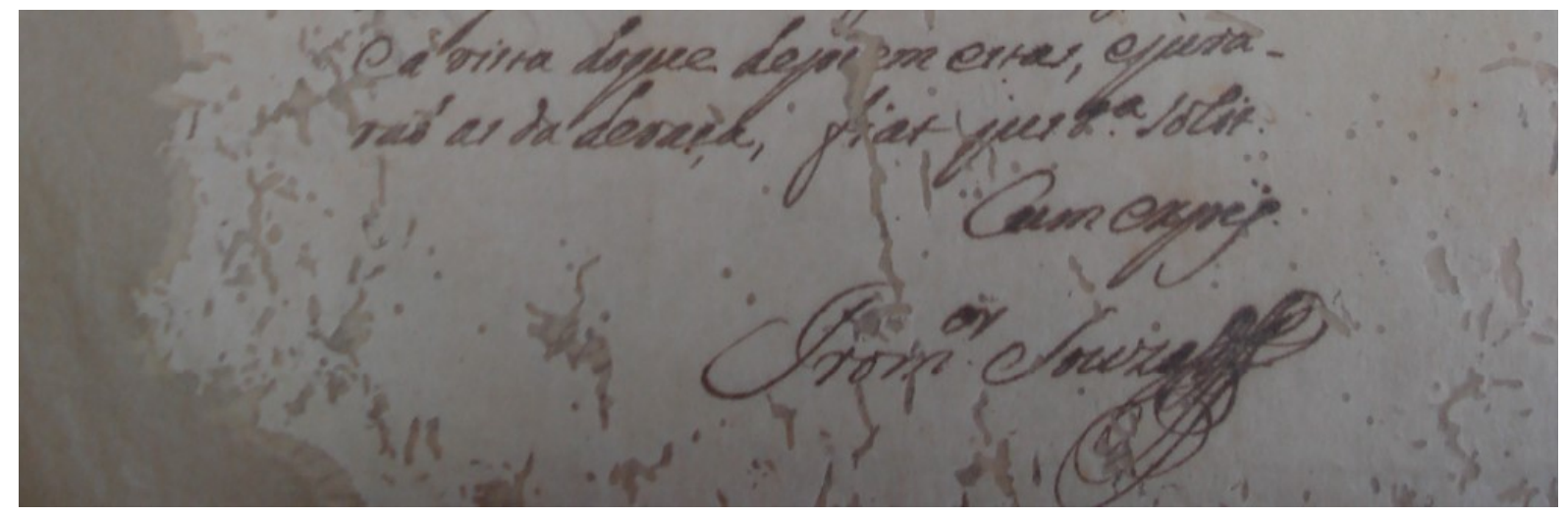

(Fólio 41 v. - Promotor Souza)

ea vista doque dep[o]em estas, ejura -

raó as da devaça, fiat justiça solit.

Cum expis

Promotor Souza[sinal público]

No que diz respeito à pontuação contida na documentação, esta é empregada de maneira um pouco diversa da usada atualmente. Um exemplo disso está em um excerto de um dos manuscritos redigidos pelo escrivão Salvador de Oliveyra Preto, no qual o uso das aspas (“ ”) ou do travessão ( - ) seria necessário por se tratar de transcrição de discurso direto, porém, não é utilizado.

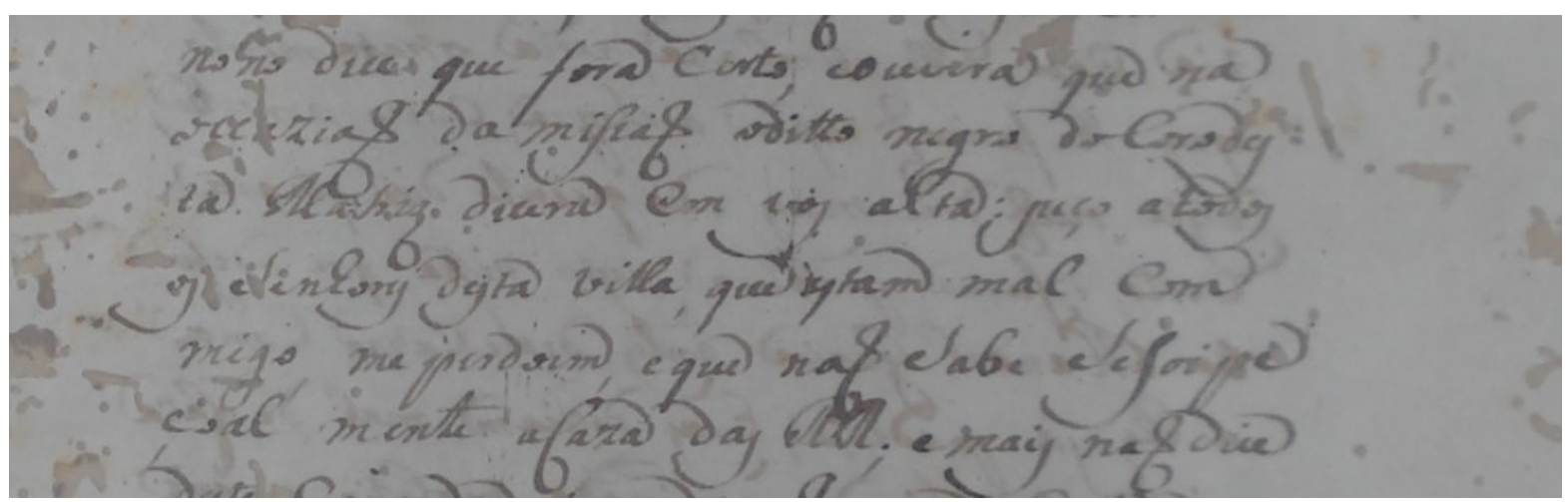

(Fólio 27 v. - Salvador de Oliveyra Preto)

nono dice que fora certo, eouvira que na occaziaõ da missaõ oditto negro docoro des ta Matriz dicera em vos alta: peço a todos os Senhores desta villa, que estam mal com migo, me perdoem, eque naõ Sabe Sefoi pe çoal mente aCaza das Rés; e mais naõ dice 
Assim, é possível observar que a pontuação não foi utilizada como é atualmente, apesar de sua fixação ter se iniciado no século anterior à redação do processo, segundo afirma SPINA (1977: 43): “[...] a pontuação como nós a conhecemos só se fixou a partir do século XVII.". No trecho anterior, a pontuação pode não ter sido empregada corretamente pelo escrivão devido aos seguintes fatores: a) a pressa do escrivão ao redigir a documentação, simultaneamente ao ouvir os depoimentos das testemunhas; b) provavelmente a pontuação estava mais bem fixada na Europa do que na colônia (ainda mais no interior de São Paulo); e c) o grau de instrução do escrivão.

Portanto, pode-se dizer que a pontuação incorreta e a não utilização de sinais que indicam discurso direto resultam da própria situação na qual o escrivão se encontrava, isto é, a pressa é um elemento que afeta a transcrição do depoimento. Todavia, esse fator é uma característica comum de documentação judicial - mesmo que o processo aqui tratado seja de caráter inquisitorial. De acordo com FERNANDES (2012: 54):

Porém, para o estudo linguístico histórico, tanta ênfase na forma escrita pode ser um indício de que o depoimento constitua uma fonte bastante segura para aferir dados linguísticos. Nele, o oral precede o escrito, e certas circunstâncias podem ter influência sobre o texto resultante da transcrição - no caso, o confronto entre a pressa para registrar tudo o que está sendo dito e as exigências do sistema processual com relação a esse registro, $[\ldots]$.

Além da pressa, há outro fator que deve ser considerado: o escrivão redigia tudo à mão. Logo, tal fato, segundo FERNANDES (2012: 55), concedia ao escrivão muito menos tempo para pensar durante a transcrição de um depoimento.

Ainda assim, é possível verificar, nos manuscritos, o uso de alguns sinais básicos de pontuação, como a vírgula (,), o ponto e vírgula (;), os dois pontos (:) e o ponto final (.).

Além disso, outro elemento importante da escrita a ser examinado em documentação antiga é o uso da cedilha.

[...] A cedilha, que entre os latinos se colocava sob a letra $e$, denotava o ditongo $\alpha$; seu uso na parte inferior da letra $c$ para designar o som fricativo tornou-se tão geral que durante a Baixa Idade Média e até bem depois do Renascimento encontramo-lo cedilhando a letra c sem necessidade (çe, çi). [...]. ${ }^{240}$

No processo que acusa Thereza Leyte e Escholastica Pinta da Sylva de praticarem feitiçaria, encontram-se algumas ocorrências do uso de cedilha sem necessidade, antecedendo 
as letras "e" e "i" e ocupando, até mesmo, a posição do "s", dos dois "ss" e do "x". Abaixo, apresentam-se alguns destes exemplos:

\begin{tabular}{|c|c|c|c|}
\hline Localização & Punho & Fac-símile & Transcrição \\
\hline $6 \mathrm{v}$ & Phelippe vas Lima & & Reverendiçima \\
\hline $6 \mathrm{v}$ & Phelippe vas Lima & & de/Ligençia \\
\hline $15 \mathrm{v}$. & $\begin{array}{c}\text { Joaó de Saó Payo } \\
\text { Peyxoto }\end{array}$ & & çertaó \\
\hline $16 \mathrm{v}$ & $\begin{array}{c}\text { Joaó de Saó Payo } \\
\text { Peyxoto }\end{array}$ & & emtregaçe \\
\hline $18 \mathrm{r}$. & Punho desconhecido & & faLeçeo \\
\hline $18 \mathrm{r}$. & $\begin{array}{c}\text { Punho desconhecido } \\
1\end{array}$ & & Garçia \\
\hline $18 \mathrm{r}$. & $\begin{array}{c}\text { Punho desconhecido } \\
1\end{array}$ & & Çertida[õ] \\
\hline $30 \mathrm{r}$. & $\begin{array}{c}\text { Salvador de Oliveyra } \\
\text { Preto }\end{array}$ & & [tro]uçe \\
\hline $30 \mathrm{r}$. & $\begin{array}{c}\text { Salvador de Oliveyra } \\
\text { Preto }\end{array}$ & & inte/reçe \\
\hline $30 \mathrm{v}$ & $\begin{array}{c}\text { Salvador de Oliveyra } \\
\text { Preto }\end{array}$ & & feitiçeiras \\
\hline
\end{tabular}




\begin{tabular}{|c|c|c|c|}
\hline $31 \mathrm{r}$. & $\begin{array}{c}\text { Salvador de Oliveyra } \\
\text { Preto }\end{array}$ & conheçida \\
\hline $35 \mathrm{r}$. & $\begin{array}{c}\text { Salvador de Oliveyra } \\
\text { Preto }\end{array}$ & $\begin{array}{c}\text { Fernando Pinto de } \\
\text { Almeyda }\end{array}$ & emçerramento \\
\hline $36 \mathrm{v}$. & $\begin{array}{c}\text { Fernando Pinto de } \\
\text { Almeyda }\end{array}$ & fei-/tiçeyra \\
\hline $36 \mathrm{v}$. & $\begin{array}{c}\text { Fernando Pinto de } \\
\text { Almeyda }\end{array}$ & p̧erto \\
\hline $38 \mathrm{v}$. & pronunçias \\
\hline $44 \mathrm{v}$. & $\begin{array}{c}\text { Joaó de Saó Payo } \\
\text { Peyxoto }\end{array}$ & & Mostraçe \\
\hline
\end{tabular}

O estudo das abreviaturas presentes na documentação é fundamental, pois elucida aspectos relevantes da tradição manuscrita do período mencionado, para que o leitor possa examinar e refletir a respeito da grafia e de outras particularidades da escrita no século XVIII. Segundo CRUZ (1987: 87):

Entende-se por abreviatura a redução do número de letras que compõem uma palavra, sem prejuízo da sua interpretação. Foi essa uma prática normal da parte dos romanos e também da parte de todos os povos que, por eles dominados, adotaram a sua escrita.

As abreviaturas constituem elementos predominantes nestes manuscritos, utilizadas mais por alguns escrivães (a exemplo de Polycarpo de Abreu Nogueyra e Padre Bento Joze Leyte) do que por outros (como Salvador de Oliveyra Preto). BERWANGER \& LEAL (1991: 91-92) comentam acerca do uso das abreviaturas ao longo da história:

O código de Justiniano proibiu a sua utilização em documentos jurídicos. Após o século IX d.C. há um modismo em abreviar palavras, mas nos séculos XII e XIII tomaram-se providências no sentido de proibir as abreviaturas. Com o Renascimento, dá-se um novo surto de seu uso, criando-se, inclusive, tabelas de abreviaturas no século XVI. No reinado 
de D. Diniz, fez-se uma lei interditando as abreviaturas na documentação oficial [...].

É importante enfatizar que a implantação da escrita cursiva (utilizada nos manuscritos do presente trabalho) está relacionada à diminuição do uso de abreviaturas, na tradição manuscrita. Segundo SPINA (1977: 45): “[...] O abuso começou a diminuir à medida que se implantava a utilização da letra cursiva, que não permitia a profusão das abreviaturas; $[\ldots] . ”$

As abreviaturas dividem-se em categorias e seu estudo será realizado de acordo com cada uma delas.

\section{Siglas}

Segundo CRUZ (1987: 90), uma das formas mais antigas do sistema de abreviaturas (sistema braquigráfico) são as siglas (litterae singulares).

A mais antiga dessas formas, exemplificada através de inscrições, consistia no uso das letras iniciais para a representação de palavras. Assim: C = Cônsul; D. M. S. = Diis Manibus Sacrum; S. P. Q. R. = Senatus Populus Que Romanus. Quando se agrupavam duas letras iguais, pretendia-se indicar o plural: $\mathrm{CC}=$ Consules $[\ldots] .{ }^{241}$

É importante também mencionar que, além de significar palavra no plural, se a letra inicial da palavra vier dobrada, pode também indicar o superlativo. ${ }^{242}$ Além disso, vale ressaltar que "expressões" inteiras também podem ser representadas por siglas.

[...] duas ou mais palavras, que pelo sentido formam um todo, podem também reduzir-se às suas iniciais, e nesse caso é utilizado o ponto em cada sigla: C.A. $=$ Caesar Augustus, D.N. $=$ Dominus noster. $[\ldots]^{243}$

\begin{tabular}{|c|c|c|c|}
\hline \multicolumn{5}{|c|}{ POLYCARPO DE ABREU NOGUEYRA } \\
\hline Localização & Abreviatura & Transcrição & $\begin{array}{c}\text { Abreviatura } \\
\text { desenvolvida }\end{array}$ \\
\hline $1 \mathrm{r}$. & & $\mathrm{R}$ & Reverendo \\
\hline
\end{tabular}




\begin{tabular}{|c|c|c|c|}
\hline $10 \mathrm{r}$. & & q' & que \\
\hline $14 \mathrm{r}$. & & S. & $\mathrm{S} a \tilde{o}$ \\
\hline \multicolumn{4}{|c|}{ PADRE BENTO JOZE LEYTE } \\
\hline Localização & Abreviatura & Transcrição & $\begin{array}{r}\text { Abreviatura } \\
\text { desenvolvida }\end{array}$ \\
\hline $3 \mathrm{r}$. & & D. & Dom \\
\hline $6 \mathrm{r}$. & & M & Muyto \\
\hline $6 \mathrm{r}$. & & P. & Padre \\
\hline \multicolumn{4}{|c|}{ PHELIPPE VAS LIMA } \\
\hline Localização & Abreviatura & Transcrição & $\begin{array}{l}\text { Abreviatura } \\
\text { desenvolvida }\end{array}$ \\
\hline $6 \mathrm{v}$ & & q & que \\
\hline \multicolumn{4}{|c|}{ FERNANDO PINTO DE ALMEYDA } \\
\hline Localização & Abr & Transcrição & $\begin{array}{l}\text { Abreviatura } \\
\text { desenvolvida }\end{array}$ \\
\hline $39 \mathrm{r}$. & & q & que \\
\hline \multicolumn{4}{|c|}{ PROMOTOR PAULO DE SOUZA ROCHA } \\
\hline Localização & Abreviatura & Transcrição & $\begin{array}{l}\text { Abreviatura } \\
\text { desenvolvida }\end{array}$ \\
\hline $11 \mathrm{v}$ & & $\mathrm{R}$. & Ré \\
\hline $13 \mathrm{r}$. & & P. & Provara \\
\hline $41 \mathrm{v}$ & & R.R. & Rés \\
\hline \multicolumn{4}{|c|}{ JOAÓ DE SAÓ PAYO PEYXOTO } \\
\hline Localização & Abreviatura & Transcrição & $\begin{array}{l}\text { Abreviatura } \\
\text { desenvolvida }\end{array}$ \\
\hline $15 \mathrm{r}$. & & A & Autora \\
\hline
\end{tabular}




\begin{tabular}{|c|c|c|c|}
\hline $16 \mathrm{r}$. & & $\mathrm{R}$. & Ré \\
\hline $17 \mathrm{r}$. & & P. & Provara \\
\hline \multicolumn{4}{|c|}{ PUNHO DESCONHECIDO 1} \\
\hline Localização & Abreviatura & Transcrição & $\begin{array}{l}\text { Abreviatura } \\
\text { desenvolvida }\end{array}$ \\
\hline $18 \mathrm{r}$. & & $\mathrm{q}$ & que \\
\hline \multicolumn{4}{|c|}{ MANOEL IOZEPH VÁZ } \\
\hline Localização & Abr & Transcrição & $\begin{array}{l}\text { Abreviatura } \\
\text { desenvolvida }\end{array}$ \\
\hline $45 \mathrm{r}$. & & $\mathrm{S}$. & Saó \\
\hline $46 \mathrm{v}$ & & A. & Autora \\
\hline $47 \mathrm{r}$. & & q'. & que \\
\hline \multicolumn{4}{|c|}{ FRANCISCO IOZEPH GUEDES } \\
\hline Localização & Abreviatura & Transcrição & $\begin{array}{l}\text { Abreviatura } \\
\text { desenvolvida }\end{array}$ \\
\hline $18 \mathrm{v}$. & & N. & Nossa \\
\hline $18 \mathrm{v}$. & & $\mathrm{f}$ & folha \\
\hline $18 \mathrm{v}$ & $\because$ & $\mathrm{v}$. & verso \\
\hline \multicolumn{4}{|c|}{ PUNHO DESCONHECIDO 2} \\
\hline Localização & Abreviatura & Transcrição & $\begin{array}{l}\text { Abreviatura } \\
\text { desenvolvida }\end{array}$ \\
\hline - & - & - & - \\
\hline \multicolumn{4}{|c|}{ SALVADOR DE OLIVEYRA PRETO } \\
\hline Localização & Abreviatura & Transcrição & $\begin{array}{l}\text { Abreviatura } \\
\text { desenvolvida }\end{array}$ \\
\hline $29 \mathrm{v}$ & $\mathbb{Q R}$. & R.R. & Rés \\
\hline
\end{tabular}




\section{Abreviatura por suspensão ou apócope}

Segundo SPINA (1977: 46), as abreviaturas por apócope remontam aos gregos e romanos e houve maior desenvolvimento de tal categoria a partir da divulgação da escrita carolíngia pela Europa. De acordo com BERWANGER \& LEAL (1991: 92), nas abreviaturas por suspensão ou apócope "corta-se o final da palavra ou final da sílaba, que, assim, fica inacabada.". Seguem-se alguns exemplos encontrados na documentação de Thereza Leyte e Escholastica Pinta da Sylva:

\begin{tabular}{|c|c|c|c|}
\hline \multicolumn{4}{|c|}{ POLYCARPO DE ABREU NOGUEYRA } \\
\hline Localização & Abreviatura & Transcrição & $\begin{array}{l}\text { Abreviatura } \\
\text { desenvolvida }\end{array}$ \\
\hline- & - & - & - \\
\hline \multicolumn{4}{|c|}{ PADRE BENTO JOZE LEYTE } \\
\hline Localização & Abreviatura & Transcrição & $\begin{array}{l}\text { Abreviatura } \\
\text { desenvolvida }\end{array}$ \\
\hline $3 \mathrm{r}$. & & Fr. & Frei \\
\hline $48 \mathrm{v}$ & & 2evel & revelia \\
\hline \multicolumn{4}{|c|}{ PHELIPPE VAS LIMA } \\
\hline Localização & Abreviatura & Transcrição & $\begin{array}{l}\text { Abreviatura } \\
\text { desenvolvida }\end{array}$ \\
\hline- & - & - & - \\
\hline \multicolumn{4}{|c|}{ FERNANDO PINTO DE ALMEYDA } \\
\hline Localização & Abreviatura & Transcrição & $\begin{array}{l}\text { Abreviatura } \\
\text { desenvolvida }\end{array}$ \\
\hline $10 \mathrm{v}$ & & porq & porque \\
\hline \multicolumn{4}{|c|}{ PROMOTOR PAULO DE SOUZA ROCHA } \\
\hline Localização & Abreviatura & Transcrição & $\begin{array}{l}\text { Abreviatura } \\
\text { desenvolvida }\end{array}$ \\
\hline $13 \mathrm{v}$. & & adm. & administrare \\
\hline
\end{tabular}




\begin{tabular}{|c|c|c|c|}
\hline $13 \mathrm{v}$. & & just. & justitia \\
\hline $13 \mathrm{v}$. & & mel. & melius \\
\hline $13 \mathrm{v}$. & & mod. & $\bmod u s$ \\
\hline \multicolumn{4}{|c|}{ JOAÓ DE SAÓ PAYO PEYXOTO } \\
\hline Localização & Abreviatura & Transcrição & $\begin{array}{l}\text { Abreviatura } \\
\text { desenvolvida }\end{array}$ \\
\hline $17 \mathrm{v}$. & > & porq & porque \\
\hline \multicolumn{4}{|c|}{ PUNHO DESCONHECIDO 1} \\
\hline Localização & Abreviatura & Transcrição & $\begin{array}{l}\text { Abreviatura } \\
\text { desenvolvida }\end{array}$ \\
\hline - & - & - & - \\
\hline \multicolumn{4}{|c|}{ MANOEL IOZEPH VÁZ } \\
\hline Localização & Abreviatura & Transcrição & $\begin{array}{l}\text { Abreviatura } \\
\text { desenvolvida }\end{array}$ \\
\hline - & - & - & - \\
\hline \multicolumn{4}{|c|}{ FRANCISCO IOZEPH GUEDES } \\
\hline Localização & Abreviatura & Transcrição & $\begin{array}{l}\text { Abreviatura } \\
\text { desenvolvida }\end{array}$ \\
\hline - & - & - & - \\
\hline \multicolumn{4}{|c|}{ PUNHO DESCONHECIDO 2} \\
\hline Localização & Abreviatura & Transcrição & $\begin{array}{l}\text { Abreviatura } \\
\text { desenvolvida }\end{array}$ \\
\hline $21 \mathrm{r}$. & con & cazam & cazamentos \\
\hline \multicolumn{4}{|c|}{ SALVADOR DE OLIVEYRA PRETO } \\
\hline Localização & Abreviatura & Transcriçãa & $\begin{array}{l}\text { Abreviatura } \\
\text { desenvolvida }\end{array}$ \\
\hline - & - & - & - \\
\hline
\end{tabular}

\section{Abreviatura por contração ou síncope}

Segundo BERWANGER \& LEAL (1991: 92), nesta categoria "a palavra é composta de elementos do início e fim da palavra.". Todavia, identificar a palavra abreviada somente a 
partir da letra inicial e da letra final do vocábulo pode ser uma tarefa difícil. Portanto, para tornar as abreviaturas mais inteligíveis, muitas vezes, conservam-se letras do meio da palavra (intermediárias), denominadas características. ${ }^{244}$

Além disso, CRUZ (1987: 94) divide as abreviaturas por contração ou síncope em simples (quando há suspensão de letras contíguas na palavra); duplas (quando houver dois grupos de letras suprimidos, separados por uma ou mais letras) e tríplices (quando houver três grupos de letras suprimidos, separados por uma ou mais letras). Seguem-se, abaixo, alguns exemplos:

\begin{tabular}{|c|c|c|c|}
\hline \multicolumn{4}{|c|}{ POLYCARPO DE ABREU NOGUEYRA } \\
\hline Localização & Abreviatura & Transcrição & $\begin{array}{l}\text { Abreviatura } \\
\text { desenvolvida }\end{array}$ \\
\hline - & - & - & - \\
\hline \multicolumn{4}{|c|}{ PADRE BENTO JOZE LEYTE } \\
\hline Localização & Abreviatura & Transcrição & $\begin{array}{l}\text { Abreviatura } \\
\text { desenvolvida }\end{array}$ \\
\hline $6 \mathrm{r}$. & (2.). & VS. & VoSsa (dupla) \\
\hline \multicolumn{4}{|c|}{ PHELIPPE VAS LIMA } \\
\hline Localização & Abreviatura & Transcrição & $\begin{array}{l}\text { Abreviatura } \\
\text { desenvolvida }\end{array}$ \\
\hline - & - & - & - \\
\hline \multicolumn{4}{|c|}{ FERNANDO PINTO DE ALMEYDA } \\
\hline Localização & Abreviatura & Transcrição & $\begin{array}{l}\text { Abreviatura } \\
\text { desenvolvida }\end{array}$ \\
\hline- & - & - & - \\
\hline \multicolumn{4}{|c|}{ PROMOTOR PAULO DE SOUZA ROCHA } \\
\hline Localização & Abreviatura & Transcrição & $\begin{array}{l}\text { Abreviatura } \\
\text { desenvolvida }\end{array}$ \\
\hline - & - & - & - \\
\hline \multicolumn{4}{|c|}{ JOAÓ DE SAÓ PAYO PEYXOTO } \\
\hline Localização & Abreviatura & Transcrição & $\begin{array}{l}\text { Abreviatura } \\
\text { desenvolvida }\end{array}$ \\
\hline $15 \mathrm{v}$ & & Mel & Manoel (simples) \\
\hline
\end{tabular}




\begin{tabular}{|c|c|c|c|}
\hline $16 \mathrm{r}$. & & tpo & tempo (simples) \\
\hline $42 \mathrm{v}$ & 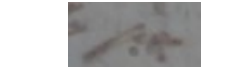 & pa & para (simples) \\
\hline \multicolumn{4}{|c|}{ PUNHO DESCONHECIDO 1} \\
\hline Localização & Abreviatura & Transcrição & $\begin{array}{l}\text { Abreviatura } \\
\text { desenvolvida }\end{array}$ \\
\hline - & - & - & - \\
\hline \multicolumn{4}{|c|}{ MANOEL IOZEPH VÁZ } \\
\hline Localização & Abreviatura & Transcrição & $\begin{array}{l}\text { Abreviatura } \\
\text { desenvolvida }\end{array}$ \\
\hline - & - & - & - \\
\hline \multicolumn{4}{|c|}{ FRANCISCO IOZEPH GUEDES } \\
\hline Localização & Abreviatura & Transcrição & $\begin{array}{l}\text { Abreviatura } \\
\text { desenvolvida }\end{array}$ \\
\hline - & 一 & - & - \\
\hline \multicolumn{4}{|c|}{ PUNHO DESCONHECIDO 2} \\
\hline Localização & Abreviatura & Transcrição & $\begin{array}{l}\text { Abreviatura } \\
\text { desenvolvida }\end{array}$ \\
\hline - & - & - & - \\
\hline \multicolumn{4}{|c|}{ SALVADOR DE OLIVEYRA PRETO } \\
\hline Localização & Abreviatura & Transcrição & $\begin{array}{l}\text { Abreviatura } \\
\text { desenvolvida }\end{array}$ \\
\hline- & - & - & - \\
\hline
\end{tabular}

\section{Abreviaturas por letras sobrepostas}

As abreviaturas por letras sobrepostas caracterizam-se por uma ou mais letras menores, inseridas ao lado superior direito de uma sílaba, que correspondem a letras do meio ou do final da palavra.

\footnotetext{
A abreviatura por letra sobreposta é aquela que se representa pela colocação, acima da letra determinante, de outra ou outras letras, regra geral, de módulo menor, correspondentes a letras intermédias ou finais da palavra abreviada. ${ }^{245}$
}

As abreviaturas por sobreposição generalizaram-se a partir do século XII, com a escrita visigótica. 
O uso das abreviaturas por letras sobrepostas, muito raro entre os romanos, bem como nos documentos da Península Ibérica anteriores ao século XII, generalizou-se a partir dessa época com a escritura visigótica $[\ldots] \cdot{ }^{246}$

Ainda referente às abreviaturas por letras sobrepostas, CRUZ (1987: 98) afirma que as mesmas remontam ao sistema de abreviaturas jurídicas e que, via de regra, as vogais são mais utilizadas na sobreposição.

A abreviatura por letra sobreposta, remontando embora ao sistema das notae juris, foi usada, sobretudo, a partir do século onze. Regra geral, são as vogais as usadas, posto que também se registrem casos do emprego de consoantes, na sobreposição com valor abreviativo, quer isoladas, quer associadas às vogais.

Em relação às notae juris mencionadas acima, estas constituem-se, em linhas gerais, de abreviaturas por suspensão, cuja finalidade é a fixação de vocabulário técnico (jurídico). ${ }^{247}$

Desta forma, lista-se abaixo alguns exemplos de abreviaturas por sobreposição, extraídas do processo contra Thereza e Escholastica:

\begin{tabular}{|c|c|c|c|}
\hline \multicolumn{5}{|c|}{ POLYCARPO DE ABREU NOGUEYRA } \\
\hline Localização & Abreviatura & Transcrição & $\begin{array}{r}\text { Abreviatura } \\
\text { desenvolvida }\end{array}$ \\
\hline $4 \mathrm{r}$. & Eccles $^{\text {o }}$ & Ecclesiastico \\
\hline $10 \mathrm{r}$. & & Marq $^{\text {s. }}$ & Marques \\
\hline $19 \mathrm{v}$. & & & Lançam \\
& & & \\
\end{tabular}

246 SPINA, 1977, p. 46.

247 Conforme assegura CRUZ (1987: 91): “As notae juris, regra geral, são abreviaturas por suspensão e podem representar, apesar da sua remota origem, uma forma de fixação de um vocabulário técnico, neste caso o jurídico, através do uso do modo abreviado de escrever palavras ou expressões de uso mais corrente. Sabe-se do seu emprego antes do século IV, fixando-lhe esse terminus a quo o facto de Teodosio as ter proibido em 348. Mais tarde, a mesma proibição foi renovada por Justiniano." 


\begin{tabular}{|c|c|c|c|}
\hline \multicolumn{4}{|c|}{ PADRE BENTO JOZE LEYTE } \\
\hline Localização & Abreviatura & Transcrição & $\begin{array}{l}\text { Abreviatura } \\
\text { desenvolvida }\end{array}$ \\
\hline $3 \mathrm{r}$. & & Ap. ${ }^{\text {ca }}$ & Apostolica \\
\hline $6 \mathrm{r}$ & & Meyr. $^{\circ}$ & Meyrinho \\
\hline $6 \mathrm{r}$. & & Escr. $^{\text {am }}$ & Escrivam \\
\hline \multicolumn{4}{|c|}{ PHELIPPE VAS LIMA } \\
\hline Localização & Abrevi & Transcrição & $\begin{array}{l}\text { Abreviatura } \\
\text { desenvolvida }\end{array}$ \\
\hline $3 \mathrm{v}$. & & $e^{a}$ & excelencia \\
\hline $6 \mathrm{v}$. & & $\mathrm{S}^{\mathrm{a}}$ & Silva \\
\hline $6 \mathrm{v}$ & & $\mathrm{m}^{\text {to }}$ & muyto \\
\hline \multicolumn{4}{|c|}{ FERNANDO PINTO DE ALMEYDA } \\
\hline Localização & Ira & Transcrição & $\begin{array}{r}\text { Abreviatura } \\
\text { desenvolvida }\end{array}$ \\
\hline $9 \mathrm{v}$. & & freg $^{\mathrm{a}}$ & freguesia \\
\hline $10 \mathrm{v}$ & & Alm ${ }^{\mathrm{da}}$ & Almeyda \\
\hline $39 \mathrm{r}$. & & D. ${ }^{r}$ & Doutor \\
\hline \multicolumn{4}{|c|}{ PAULO DE SOUZA ROCHA } \\
\hline Localização & tura & Transcrição & $\begin{array}{r}\text { Abreviatura } \\
\text { desenvolvida }\end{array}$ \\
\hline $11 \mathrm{v}$ & & $\mathrm{m} .^{\text {er }}$ & mulher \\
\hline $13 \mathrm{v}$. & & Prom. ${ }^{\text {or }}$ & Promotor \\
\hline $41 \mathrm{v}$ & & Iust. $^{\mathrm{a}}$ & Iustiça \\
\hline \multicolumn{4}{|c|}{ JOAÓ DE SAÓ PAYO PEYXOTO } \\
\hline
\end{tabular}




\begin{tabular}{|c|c|c|c|}
\hline Localização & Abreviatura & Transcrição & $\begin{array}{l}\text { Abreviatura } \\
\text { desenvolvida }\end{array}$ \\
\hline $16 \mathrm{r}$. & & imfirmid. $^{\mathrm{e}}$ & imfirmidade \\
\hline $17 \mathrm{v}$. & & $\operatorname{lib}^{\circ}$ & libello \\
\hline $42 \mathrm{v}$. & & $\mathrm{p} \cdot{ }^{\mathrm{ca}} \mathrm{m}^{\mathrm{te}}$ & publica mente \\
\hline \multicolumn{4}{|c|}{ PUNHO DESCONHECIDO 1} \\
\hline Localização & Abreviatura & Transcrição & $\begin{array}{l}\text { Abreviatura } \\
\text { desenvolvida }\end{array}$ \\
\hline $18 \mathrm{r}$. & & $\mathrm{R} .^{\text {do }}$ & Reverendo \\
\hline $18 \mathrm{r}$. & & $\mathrm{v}^{\mathrm{a}}$ & villa \\
\hline $18 \mathrm{r}$. & & d. ${ }^{\text {a }}$ & dita \\
\hline \multicolumn{4}{|c|}{ MANOEL IOZEPH VÁZ } \\
\hline Localização & Abreviatura & Transcrição & $\begin{array}{l}\text { Abreviatura } \\
\text { desenvolvida }\end{array}$ \\
\hline $46 \mathrm{v}$. & & $\mathrm{L} .{ }^{\text {te }}$ & Leyte \\
\hline $47 \mathrm{r}$. & & eff..$^{\text {to }}$ & effeito \\
\hline $47 \mathrm{v}$ & & $\mathrm{q} \cdot{ }^{\mathrm{m}}$ & quem \\
\hline \multicolumn{4}{|c|}{ FRANCISCO IOZEPH GUEDES } \\
\hline Localização & Abreviatura & Transcrição & $\begin{array}{l}\text { Abreviatura } \\
\text { desenvolvida }\end{array}$ \\
\hline $18 \mathrm{v}$ & & desp. $^{\circ}$ & despacho \\
\hline $18 \mathrm{v}$ & ver & verd. ${ }^{\mathrm{e}}$ & verdade \\
\hline $18 \mathrm{v}$ & & Igr. $^{\text {a }}$ & Igreja \\
\hline \multicolumn{4}{|c|}{ PUNHO DESCONHECIDO 2} \\
\hline
\end{tabular}




\begin{tabular}{|c|c|c|c|}
\hline Localização & Abreviatura & Transcrição & $\begin{array}{l}\text { Abreviatura } \\
\text { desenvolvida }\end{array}$ \\
\hline $21 \mathrm{r}$ & & $\operatorname{Exc}^{\mathrm{a}}$ & Excelencia \\
\hline $21 \mathrm{r}$. & & $g^{\text {de }}$ & guarde \\
\hline $22 \mathrm{v}$ & & oq. ${ }^{\text {al }}$ & oqual \\
\hline \multicolumn{4}{|c|}{ SALVADOR DE OLIVEYRA PRETO } \\
\hline Localização & Abreviatura & Transcrição & $\begin{array}{l}\text { Abreviatura } \\
\text { desenvolvida }\end{array}$ \\
\hline $26 \mathrm{v}$ & & $\mathrm{T}^{\mathrm{a}}$ & Testemunha \\
\hline $35 \mathrm{r}$. & & emçerram $^{\text {to }}$ & emçerramento \\
\hline
\end{tabular}

\section{Abreviatura por sinal especial}

Em relação a esse tipo de abreviatura, CRUZ (1987: 94) assinala que o sinal especial representa as letras que foram eliminadas no processo de abreviação.

A abreviatura por sinal especial é aquela em que o mesmo sinal não se limita a assinalá-la, pois que representa as letras eliminadas, tendo assim e como tal um significado próprio e absoluto ou um significado relativo. ${ }^{248}$

São listados abaixo alguns exemplos das abreviaturas por sinal especial, encontradas nos manuscritos analisados:

\begin{tabular}{|c|c|c|c|}
\hline \multicolumn{4}{|c|}{ POLYCARPO DE ABREU NOGUEYRA } \\
\hline Localização & Abreviatura & Transcrição & $\begin{array}{c}\text { Abreviatura } \\
\text { desenvolvida }\end{array}$ \\
\hline- & - & - & - \\
\hline \multicolumn{4}{|c|}{ PADRE BENTO JOZE LEYTE } \\
\hline
\end{tabular}

248 CRUZ, Op. cit., p. 94. 


\begin{tabular}{|c|c|c|c|}
\hline Localização & Abreviatura & Transcrição & $\begin{array}{l}\text { Abreviatura } \\
\text { desenvolvida }\end{array}$ \\
\hline $48 \mathrm{v}$. & db & $U$ & réis \\
\hline \multicolumn{4}{|c|}{ PHELIPPE VAS LIMA } \\
\hline Localização & Abreviatura & Transcrição & $\begin{array}{l}\text { Abreviatura } \\
\text { desenvolvida }\end{array}$ \\
\hline $3 \mathrm{v}$. & $\infty$ & @) & assinado \\
\hline \multicolumn{4}{|c|}{ FERNANDO PINTO DE ALMEYDA } \\
\hline Localização & Abreviatura & Transcrição & $\begin{array}{l}\text { Abreviatura } \\
\text { desenvolvida }\end{array}$ \\
\hline $36 \mathrm{r}$. & & - & $d e$ \\
\hline \multicolumn{4}{|c|}{ PROMOTOR PAULO DE SOUZA ROCHA } \\
\hline Localização & Abreviatura & Transcrição & $\begin{array}{l}\text { Abreviatura } \\
\text { desenvolvida }\end{array}$ \\
\hline - & - & - & - \\
\hline \multicolumn{4}{|c|}{ JOAÓ DE SAÓ PAYO PEYXOTO } \\
\hline Localização & Abreviatura & Transcrição & $\begin{array}{l}\text { Abreviatura } \\
\text { desenvolvida }\end{array}$ \\
\hline - & - & - & - \\
\hline \multicolumn{4}{|c|}{ PUNHO DESCONHECIDO 1} \\
\hline Localização & Abreviatura & Transcrição & $\begin{array}{l}\text { Abreviatura } \\
\text { desenvolvida }\end{array}$ \\
\hline - & - & - & - \\
\hline \multicolumn{4}{|c|}{ MANOEL IOZEPH VÁZ } \\
\hline Localização & Abreviatura & Transcrição & $\begin{array}{l}\text { Abreviatura } \\
\text { desenvolvida }\end{array}$ \\
\hline - & - & - & - \\
\hline \multicolumn{4}{|c|}{ FRANCISCO IOZEPH GUEDES } \\
\hline Localização & Abreviatura & Transcrição & $\begin{array}{l}\text { Abreviatura } \\
\text { desenvolvida }\end{array}$ \\
\hline $18 \mathrm{v}$ & $x^{2}$ & - & $d e$ \\
\hline \multicolumn{4}{|c|}{ PUNHO DESCONHECIDO 2} \\
\hline Localização & Abreviatura & Transcrição & $\begin{array}{l}\text { Abreviatura } \\
\text { desenvolvida }\end{array}$ \\
\hline
\end{tabular}




\begin{tabular}{|c|c|c|c|}
\hline- & - & - & - \\
\hline \multicolumn{3}{|c|}{ SALVADOR DE OLIVEYRA PRETO } \\
\hline Localização & Abreviatura & Transcrição & $\begin{array}{c}\text { Abreviatura } \\
\text { desenvolvida }\end{array}$ \\
\hline- & - & - & - \\
\hline
\end{tabular}

\title{
Notas tironianas
}

A próxima categoria de abreviaturas a ser apresentada são as notas tironianas. BERWANGER \& LEAL (1991: 93) fazem o seguinte comentário acerca da história desses sinais abreviativos:

\begin{abstract}
Inventadas por um escravo liberto que pertencia a Cícero, de nome Tiro, que anotava seus discursos através de sinais. As notas tironianas (ou taquigrafia) foram usadas desde o Império Romano até o século $\mathrm{X}$, quando entraram em decadência. É muito raro encontrá-las em documentação brasileira [...].
\end{abstract}

CRUZ (1987: 91) comenta que as notas tironianas têm sua origem no alfabeto latino e que foi Ennio quem primeiro fez seu uso, porém, Tiro as teria sistematizado e estruturado.

Entretanto, como foi dito acima, é raro encontrar notas tironianas em documentação brasileira. Assim, os manuscritos aqui estudados não apresentam essa categoria de sinais abreviativos.

Há ainda abreviaturas denominadas nomina sacra, isto é, termos exclusivamente relacionados à religiosidade cristã, que trazem uma herança latina e grega, em sua composição.

Um tipo especial de abreviaturas são os chamados nomina sacra. Sua forma em textos em língua portuguesa, composta efetivamente de caracteres latinos, só se entende em sua história: tendo sido transmitidos de textos gregos cristãos para traduções latinas, mantêm ainda marcas de sua origem, pois, em casos como xpo (= christo) e ihu (=iesu), tem-se reflexo da abreviatura original em caracteres gregos: $x$ latino $=\chi$ grego $\mathrm{e}$ $p$ latino $=\rho$ grego, no primeiro caso $h$ latino $=\eta$ grego, no segundo ${ }^{249}$

Entretanto, assim como ocorre com as notas tironianas, também não se encontram nomina sacra no processo-crime de Thereza Leyte e Escholastica Pinta da Sylva.

Outra categoria de abreviaturas presente na documentação é a abreviatura por indicação numérica, utilizada uma única vez e somente pelo pároco Francisco Iozeph Guedes. 


\begin{tabular}{|c|c|c|c|}
\hline \multicolumn{5}{|c|}{ FRANCISCO IOZEPH GUEDES } \\
\hline Localização & Abreviatura & Transcrição & $\begin{array}{r}\text { Abreviatura } \\
\text { desenvolvida }\end{array}$ \\
\hline $18 \mathrm{v}$. & $8 \mathrm{br}^{\circ}$ & Outubro \\
\hline
\end{tabular}

Além das categorias de abreviaturas listadas acima, há uma última a ser aqui abordada que se constitui, na verdade, de uma combinação das abreviaturas por síncope e das abreviaturas por letras sobrepostas. Essa combinação foi estabelecida a partir da identificação de uma síncope já na sílaba que constitui a base da abreviatura ou de uma síncope presente mesmo nas letras sobrepostas. Tal mescla de categorias abreviativas foi denominada, nesse trabalho, de "abreviaturas mistas". Seguem-se alguns exemplos extraídos do processo de feitiçaria contra Thereza Leyte e Escholastica Pinta da Sylva:

\begin{tabular}{|c|c|c|c|}
\hline \multicolumn{4}{|c|}{ POLYCARPO DE ABREU NOGUEYRA } \\
\hline Localização & Abreviatura & Transcrição & $\begin{array}{l}\text { Abreviatura } \\
\text { desenvolvida }\end{array}$ \\
\hline $9 \mathrm{r}$. & & Debr. $^{\circ}$ & Dezembro \\
\hline $10 \mathrm{v}$ & & Nogr. $^{\text {a }}$ & Nogueyra \\
\hline $14 \mathrm{v}$ & & Px..$^{\text {to }}$ & Peyxoto \\
\hline \multicolumn{4}{|c|}{ PADRE BENTO JOZE LEYTE } \\
\hline Localização & Abreviatura & Transcrição & $\begin{array}{l}\text { Abreviatura } \\
\text { desenvolvida }\end{array}$ \\
\hline $3 \mathrm{r}$. & & $\operatorname{chan}^{\text {ca }}$ & chancelaria \\
\hline $6 \mathrm{r}$ & & ordinr $^{\circ}$ & ordinario \\
\hline
\end{tabular}




\begin{tabular}{|c|c|c|c|}
\hline $6 \mathrm{r}$. & & Auditr. ${ }^{\circ}$ & Auditorio \\
\hline \multicolumn{4}{|c|}{ PHELIPPE VAS LIMA } \\
\hline Localização & Abreviatura & Transcrição & $\begin{array}{l}\text { Abreviatura } \\
\text { desenvolvida }\end{array}$ \\
\hline 一 & - & 一 & - \\
\hline \multicolumn{4}{|c|}{ FERNANDO PINTO DE ALMEYDA } \\
\hline Localização & Abreviatura & Transcrição & $\begin{array}{l}\text { Abreviatura } \\
\text { desenvolvida }\end{array}$ \\
\hline $9 \mathrm{v}$. & & $\operatorname{proximan}^{\text {te }}$ & proximamente \\
\hline $37 \mathrm{r}$. & & $\mathrm{Tes}^{\mathrm{ta}}$ & Testemunha \\
\hline \multicolumn{4}{|c|}{ PROMOTOR PAULO DE SOUZA ROCHA } \\
\hline Localização & Abreviatura & Transcrição & $\begin{array}{l}\text { Abreviatura } \\
\text { desenvolvida }\end{array}$ \\
\hline $11 \mathrm{r}$. & & $\mathrm{Bp}^{\mathrm{do}}$ & Bispado \\
\hline \multicolumn{4}{|c|}{ JOAÓ DE SAÓ PAYO PEYXOTO } \\
\hline Localização & Abreviatura & Transcrição & $\begin{array}{l}\text { Abreviatura } \\
\text { desenvolvida }\end{array}$ \\
\hline $15 \mathrm{r}$. & & verdadr $^{\mathrm{a}}$ & verdadeyra \\
\hline $16 \mathrm{v}$ & & {$[\mathrm{T}]$ eixr. $^{\text {a }}$} & [T] eixeyra \\
\hline $43 \mathrm{v}$ & & $\mathrm{tt}^{\text {as }}$ & testemunhas \\
\hline \multicolumn{4}{|c|}{ PUNHO DESCONHECIDO 1} \\
\hline Localização & Abreviatura & Transcrição & $\begin{array}{l}\text { Abreviatura } \\
\text { desenvolvida }\end{array}$ \\
\hline
\end{tabular}




\begin{tabular}{|c|c|c|c|}
\hline $18 \mathrm{r}$. & & vigr $^{\circ}$ & vigario \\
\hline \multicolumn{4}{|c|}{ MANOEL IOZEPH VÁZ } \\
\hline Localização & Abreviatura & Transcrição & $\begin{array}{l}\text { Abreviatura } \\
\text { desenvolvida }\end{array}$ \\
\hline $18 \mathrm{r}$. & & $\mathrm{Pl}^{\circ}{ }^{\circ}$ & Paulo \\
\hline $46 \mathrm{v}$. & & $\mathrm{tt}^{\text {as }}$ & testemunhas \\
\hline $48 \mathrm{r}$. & 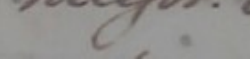 & necessr. ${ }^{\mathrm{a}}$ & necessaria \\
\hline \multicolumn{4}{|c|}{ FRANCISCO IOZEPH GUEDES } \\
\hline Localização & Abreviatura & Transcrição & $\begin{array}{r}\text { Abreviatura } \\
\text { desenvolvida }\end{array}$ \\
\hline $18 \mathrm{v}$. & & Snar $^{\mathrm{a}}$ & Senhora \\
\hline $18 \mathrm{v}$. & & O vigr. ${ }^{\circ}$ & O vigario \\
\hline \multicolumn{4}{|c|}{ PUNHO DESCONHECIDO 2} \\
\hline Localização & Abreviatura & Transcrição & $\begin{array}{r}\text { Abreviatura } \\
\text { desenvolvida }\end{array}$ \\
\hline- & - & - & - \\
\hline \multicolumn{4}{|c|}{ SALVADOR DE OLIVEYRA PRETO } \\
\hline Localização & Abreviatura & Transcrição & $\begin{array}{r}\text { Abreviatura } \\
\text { desenvolvida }\end{array}$ \\
\hline $32 \mathrm{r}$. & & $\operatorname{Tr}^{\circ}$ & Termo \\
\hline
\end{tabular}

Vale lembrar que o uso das abreviaturas predominou na Idade Média, período de maior disseminação, desenvolvimento e profusão das mesmas. Portanto, apesar de as abreviaturas serem recorrentes na documentação de feitiçaria aqui estudada, seu uso já era bem menos frequente em manuscritos do século XVIII do que em manuscritos medievais. 
[...] Desde fins da república romana a abreviação começou a tornar-se complicada, chegando a suscitar - sem que tais medidas surtissem efeito - a intervenção do senado e dos imperadores proibindo o seu emprego. A partir do reinado carolíngio, cujas reformas pedagógicas atingiram também os processos caligráficos, o abuso das abreviaturas começou a saturar os documentos, e a moda degenerou de tal forma que nos séculos XII e XIII várias disposições foram baixadas com o intuito de conter o mal. $\mathrm{O}$ abuso começou a diminuir à medida que se implantava a utilização da letra cursiva, que não permitia a profusão das abreviaturas $[\ldots] .{ }^{250}$

Outro aspecto importante a ser observado no texto deste processo de feitiçaria é o fato de, em muitos casos, a mesma letra ser grafada de formas diferentes, e aqui se faz necessário compreender os conceitos de grafema e alógrafo.

[...] Os grafemas e, consequentemente, os caracteres podem ser alfabéticos, quando fazem parte de um conjunto fixo de unidades que geralmente representam fonemas, como no caso das letras, ou nãoalfabéticos, quando têm função distinta, como no caso dos números, dos sinais de pontuação, dos sinais abreviativos, etc. Os grafemas alfabéticos formam um conjunto coeso de formas numericamente restritas: o alfabeto. ${ }^{251}$

Assim, em outras palavras, dá-se o nome de alógrafo aos mesmos grafemas alfabéticos, isto é, às mesmas letras, que são escritos de formas distintas em uma documentação, sendo, portanto, variantes da mesma letra.

Em alguns poucos casos, um mesmo grafema pode realizar-se como duas diferentes formas (dois caracteres distintos) de um mesmo alfabeto, de um mesmo tipo e de um mesmo módulo: trata-se, nesse caso, dos alógrafos contextuais. No passado era muito comum o grafema $s$ realizarse em módulo minúsculo como uma forma de dupla curva, o $<\mathrm{s}>$, ou como uma forma longa, $\mathrm{o}<\int>[\ldots]^{252}$

Tendo em vista os conceitos explicitados acima, são apresentados, a seguir, alguns exemplos de alógrafos encontrados na documentação estudada, os quais foram selecionados por serem os grafemas que mais apresentam variantes em um mesmo punho e em punhos diferentes. São eles os alógrafos das letras "b", “d”, “f”, "h", "s" (incluindo o "s" duplo) e do ditongo "-ão". Além disso, nas tabelas a seguir, são elencados os referidos grafemas em posições inicial, medial e final, com o objetivo de demonstrar ao leitor que os alógrafos 
ocorrem não somente em função de mudança de punho, mas também em função da posição que a letra ocupa na palavra.

\begin{tabular}{|c|c|c|}
\hline \multicolumn{3}{|c|}{ LETRA B } \\
\hline \multicolumn{3}{|c|}{ POLYCARPO DE ABREU NOGUEYRA } \\
\hline$B$ inicial & B medial & B final \\
\hline \multicolumn{3}{|c|}{ PADRE BENTO JOZE LEYTE } \\
\hline B inicial & B medial & B final \\
\hline \multicolumn{3}{|c|}{ PHELIPPE VAS LIMA } \\
\hline $\mathrm{B}$ inicial & B medial & B final \\
\hline & - & - \\
\hline \multicolumn{3}{|c|}{ FERNANDO PINTO DE ALMEYDA } \\
\hline B inicial & B medial & B final \\
\hline \multicolumn{3}{|c|}{ PROMOTOR PAULO DE SOUZA ROCHA } \\
\hline B inicial & B medial & B final \\
\hline & & - \\
\hline \multicolumn{3}{|c|}{ JOAÓ DE SAÓ PAYO PEYXOTO } \\
\hline$B$ inicial & B medial & B final \\
\hline \multicolumn{3}{|c|}{ PUNHO DESCONHECIDO 1} \\
\hline$B$ inicial & B medial & B final \\
\hline & - & - \\
\hline \multicolumn{3}{|c|}{ MANOEL IOZEPH VÁZ } \\
\hline$B$ inicial & B medial & B final \\
\hline
\end{tabular}




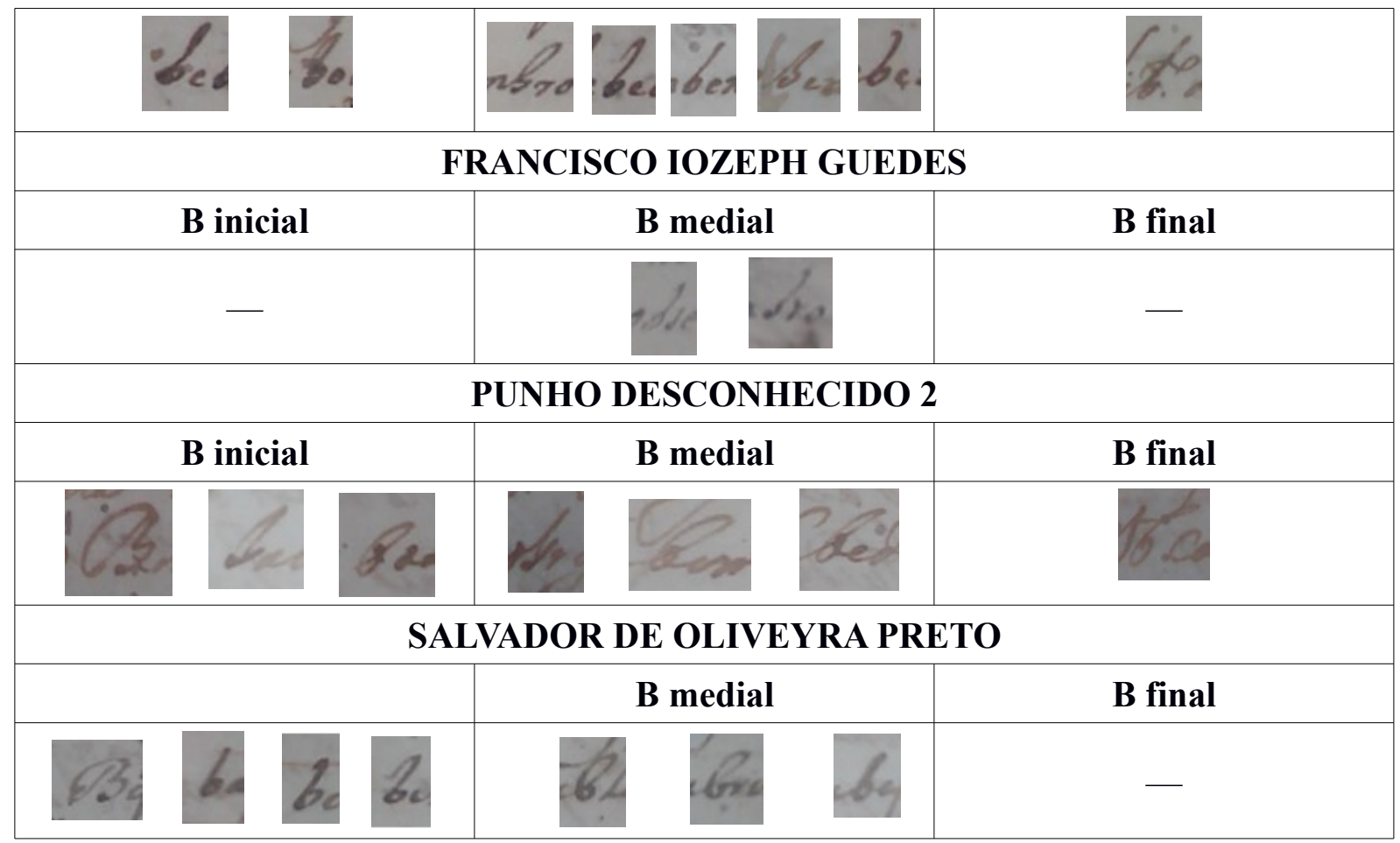

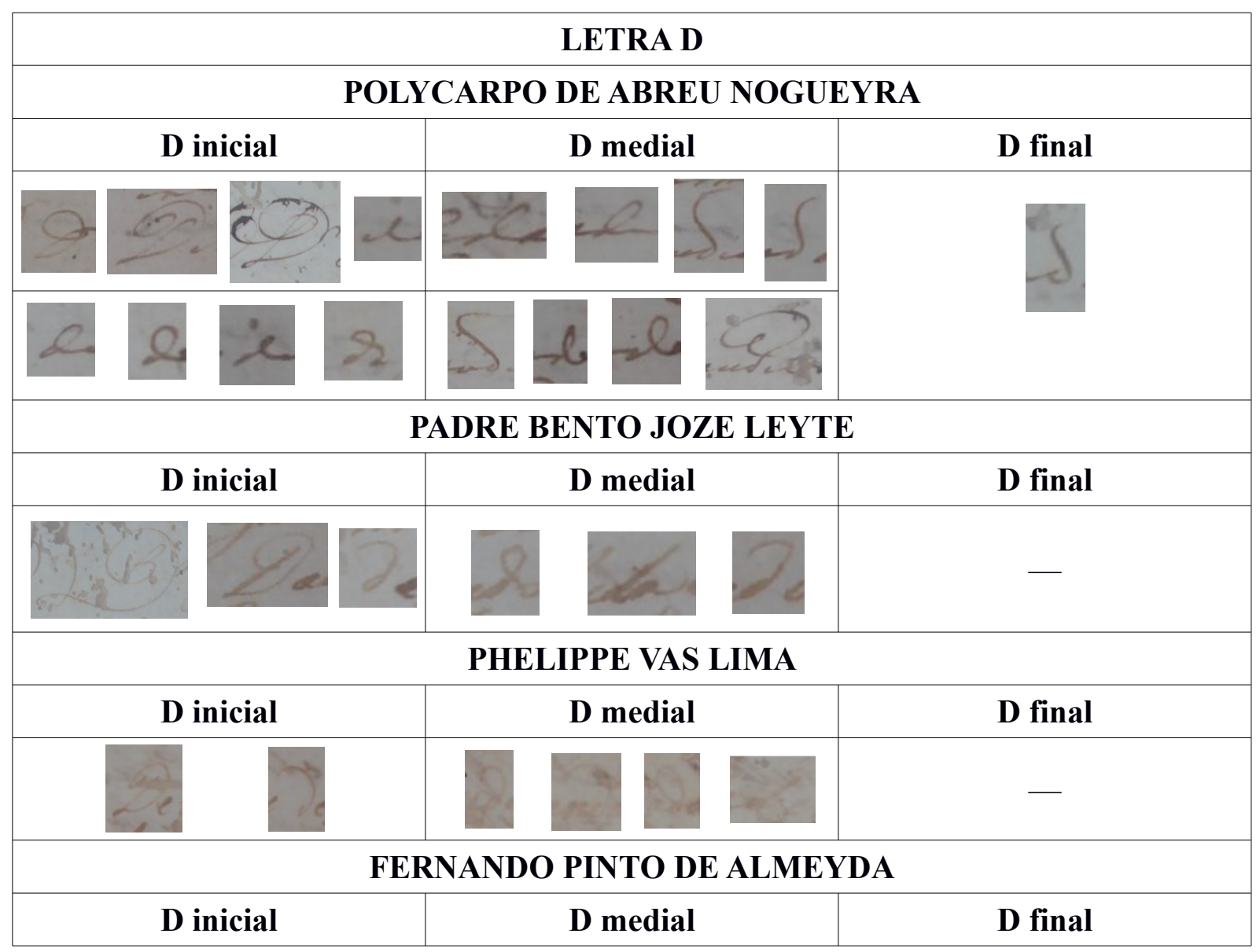




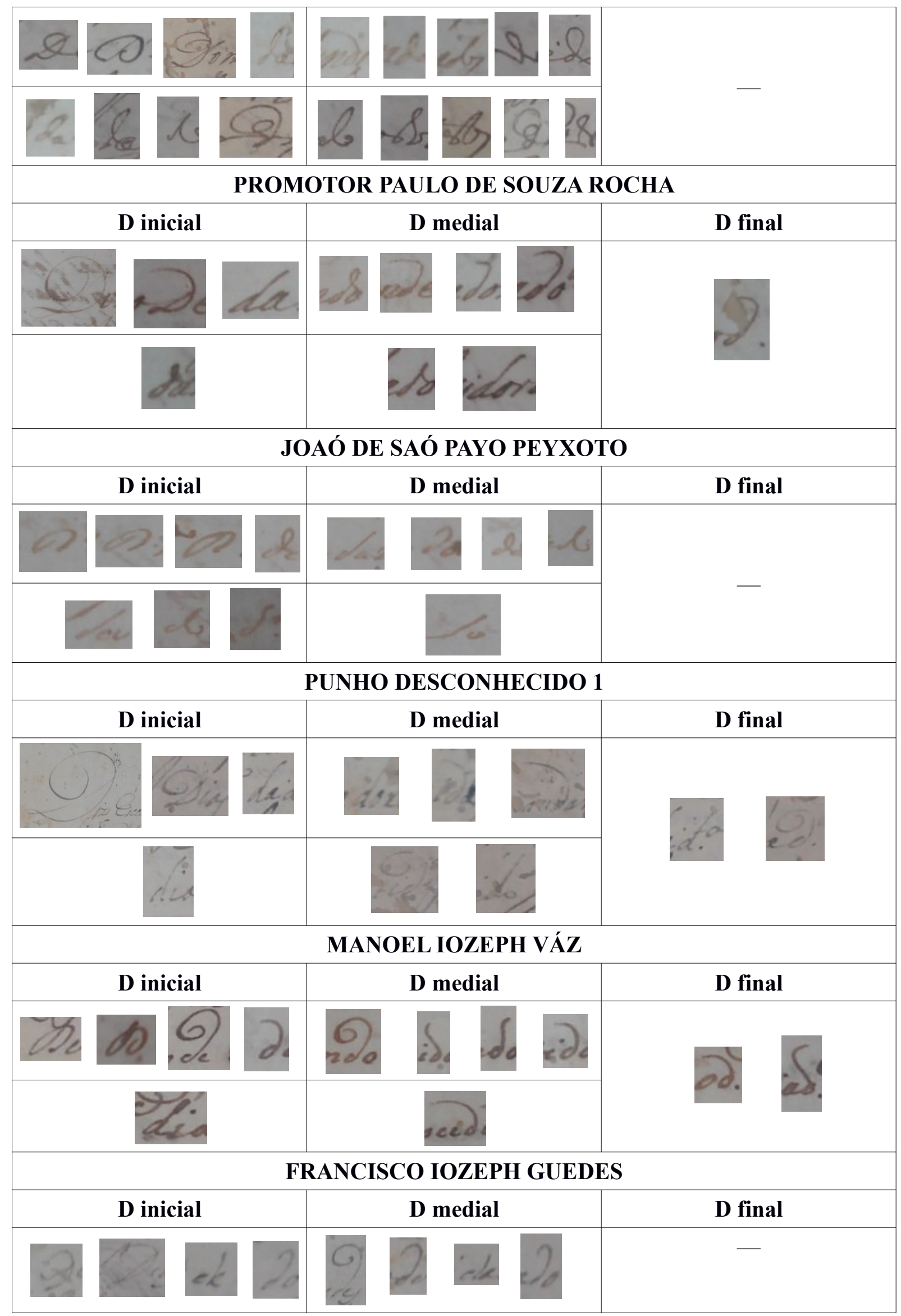




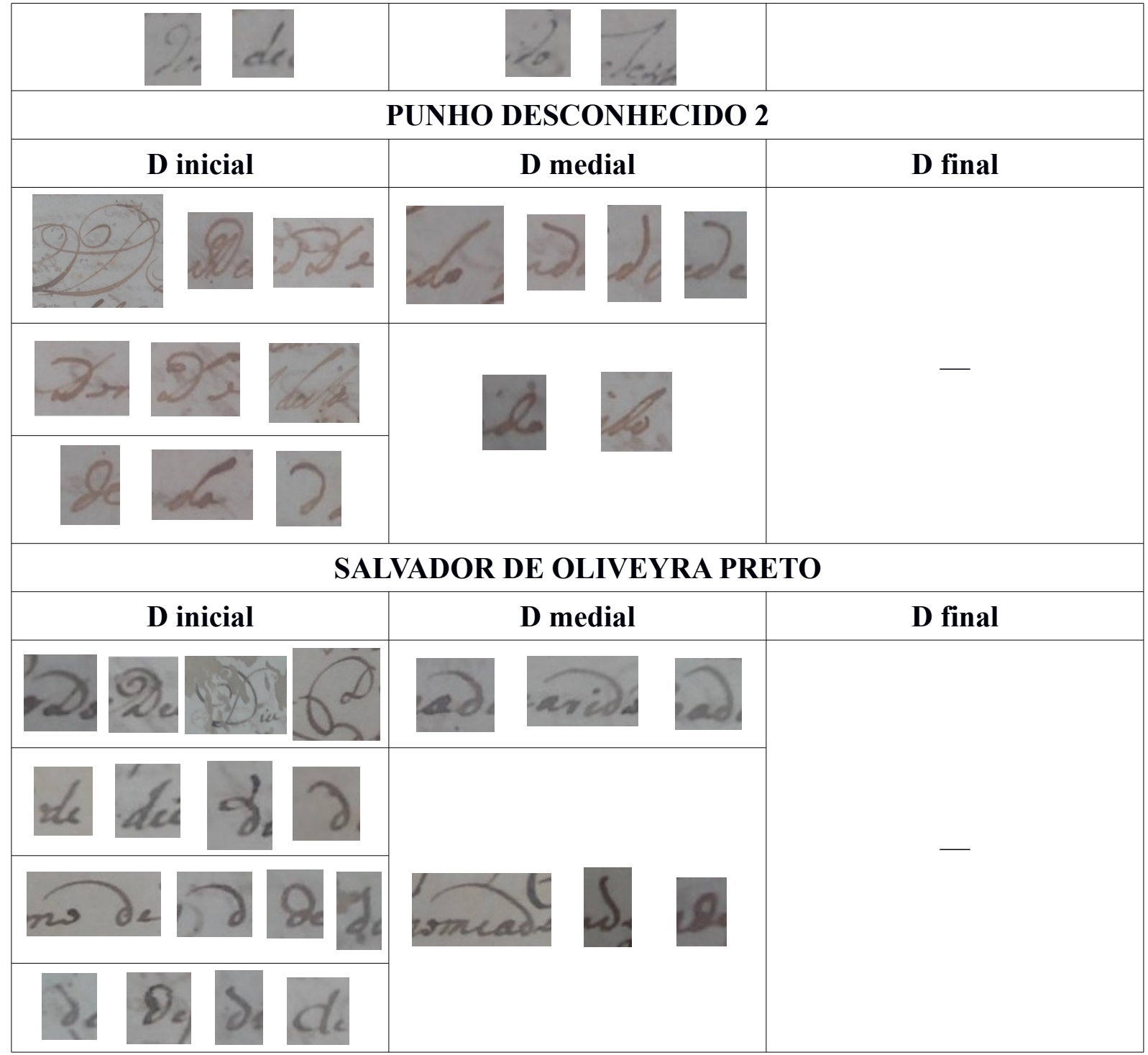

\begin{tabular}{|c|c|c|}
\hline \multicolumn{5}{|c|}{ LETRA F } \\
\hline \multicolumn{3}{|c|}{ POLYCARPO DE ABREU NOGUEYRA } \\
\hline F inicial & F medial & F final \\
\hline & & \\
\hline & & \\
\hline
\end{tabular}




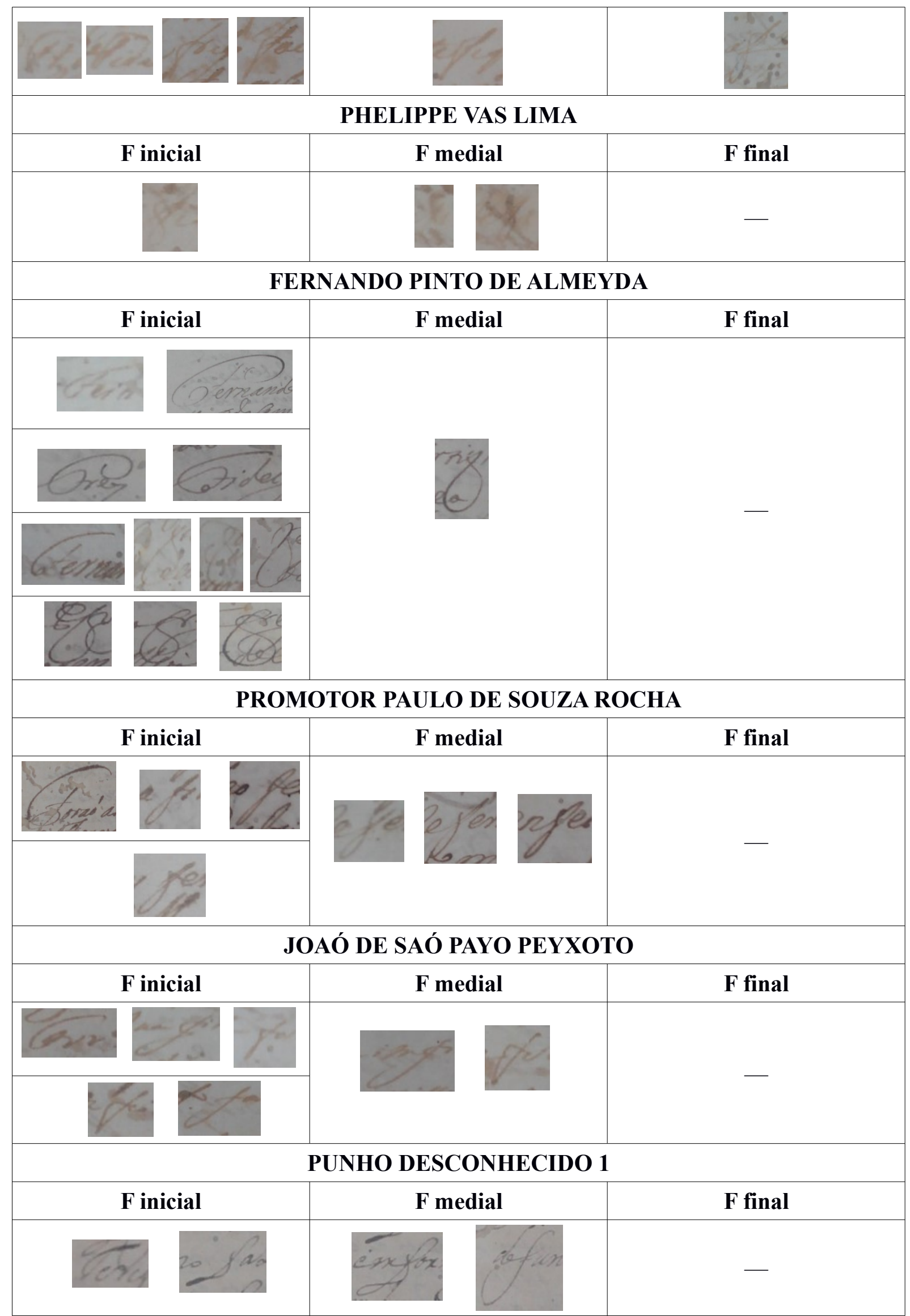




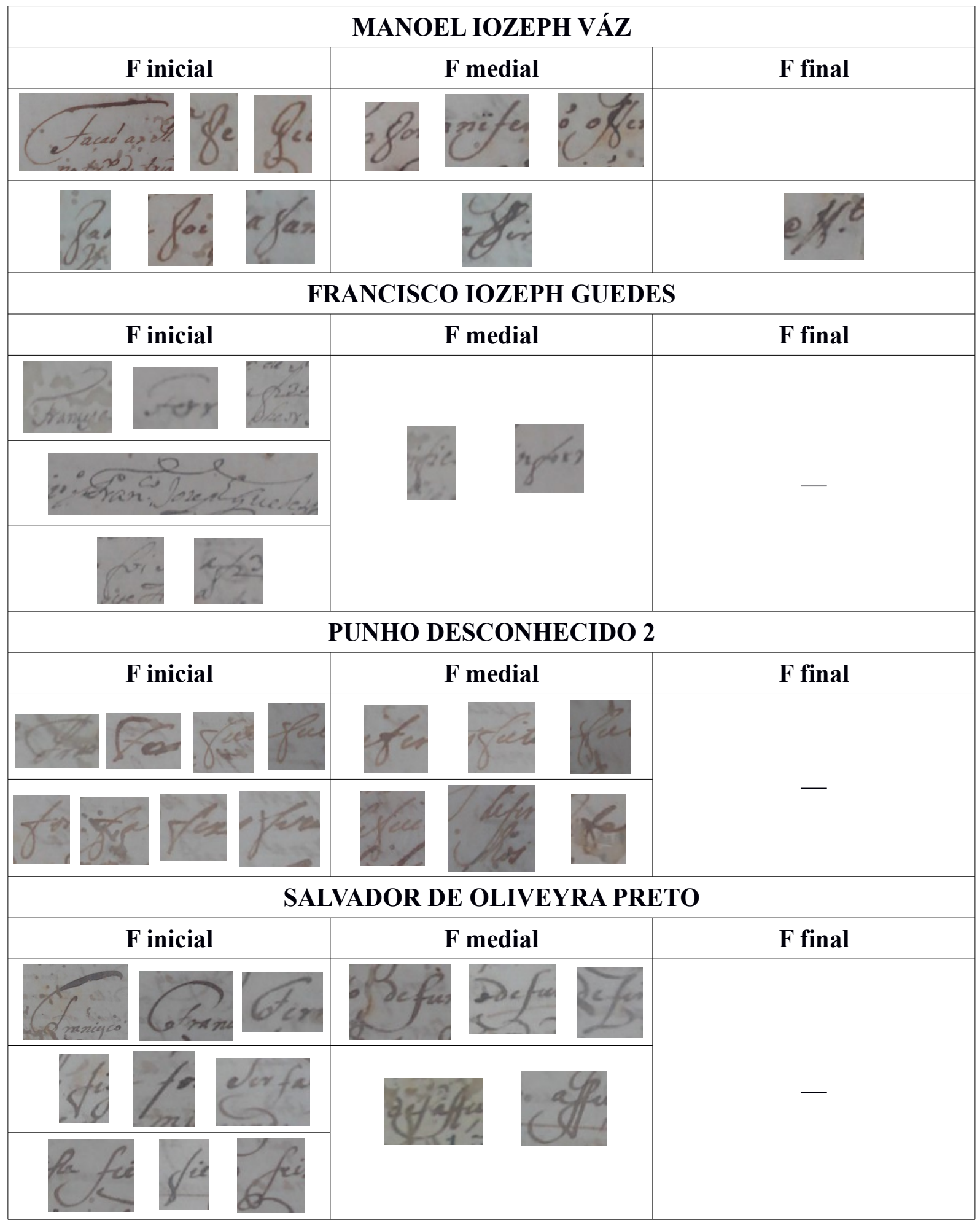

LETRA H

POLYCARPO DE ABREU NOGUEYRA

\begin{tabular}{l|l|l} 
H inicial & H medial & H final \\
\hline
\end{tabular}




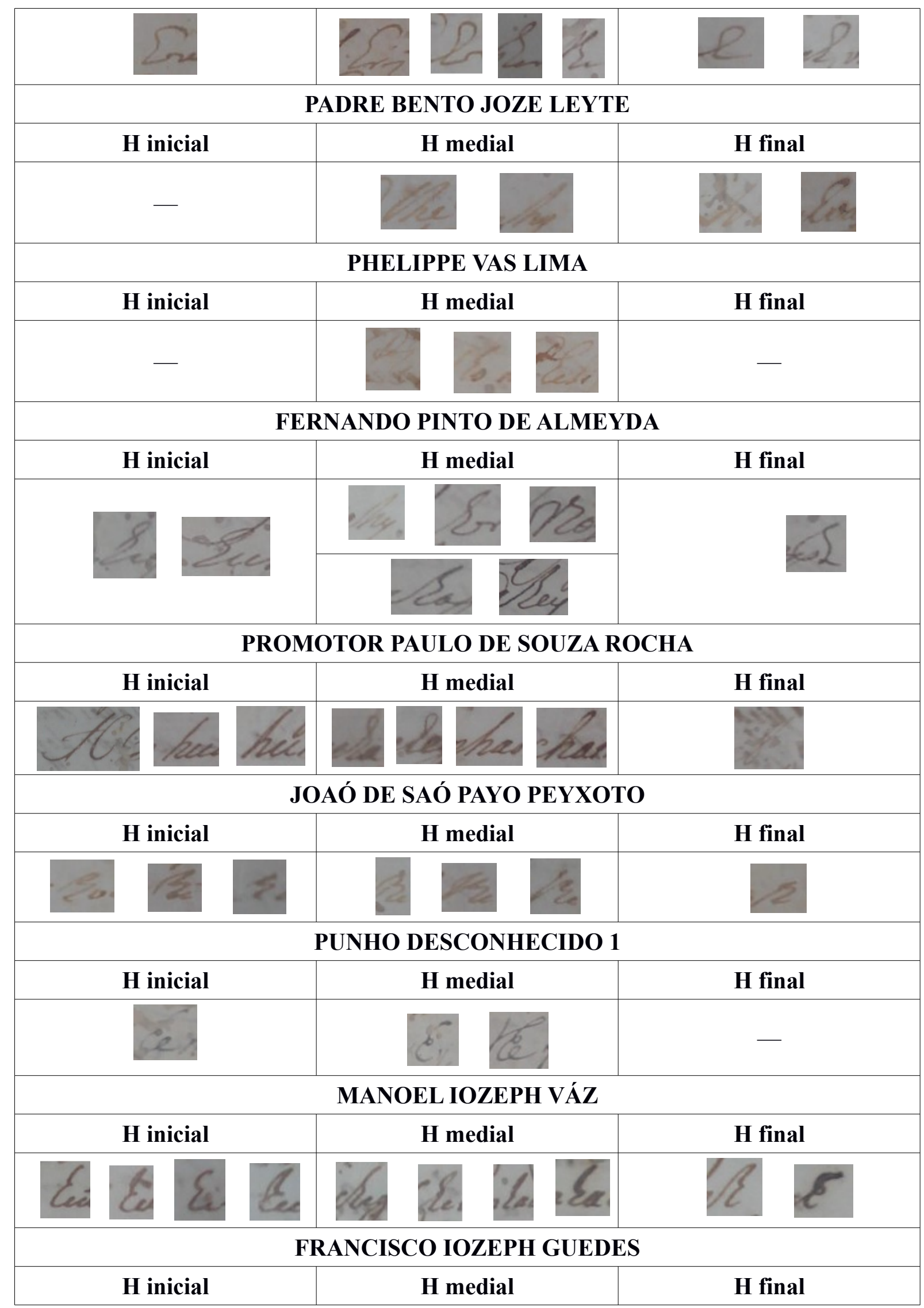




\begin{tabular}{|c|c|c|c|}
\hline & & \\
\hline \multicolumn{5}{|c|}{ PUNHO DESCONHECIDO 2 } \\
\hline H inicial & H medial & H final \\
\hline & & & - \\
\hline & SALVADOR DE OLIVEYRA PRETO & H final \\
\hline
\end{tabular}

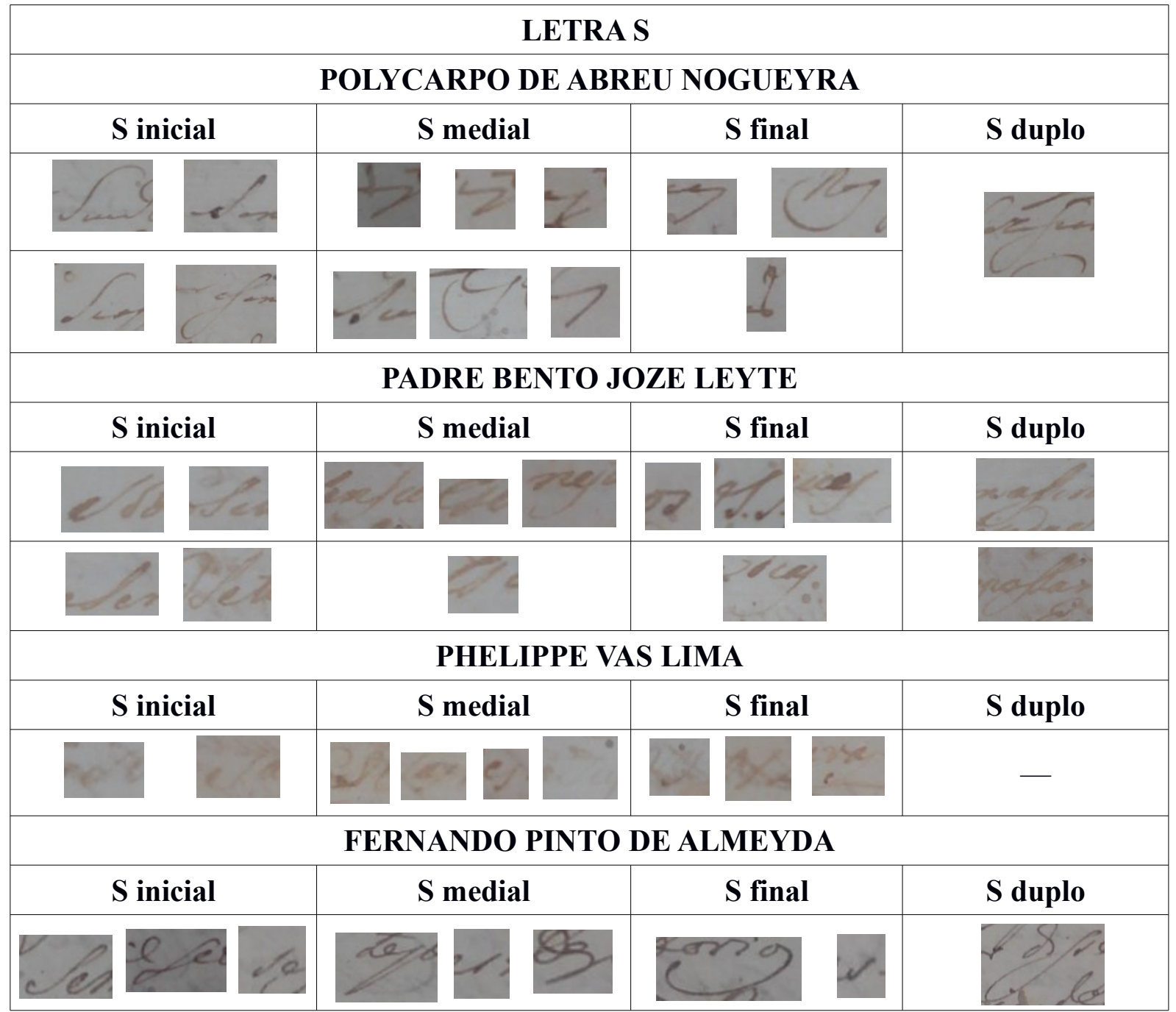




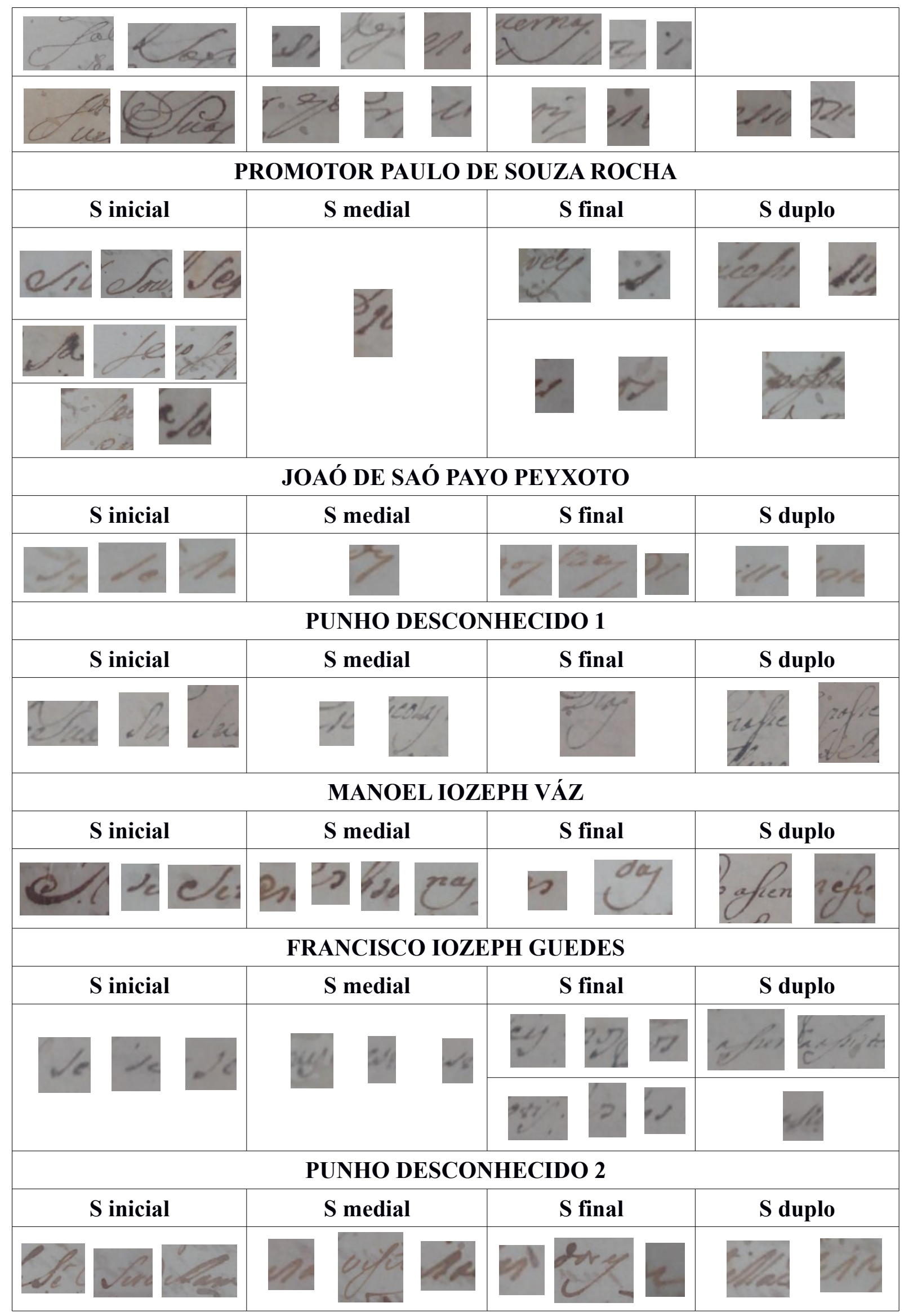




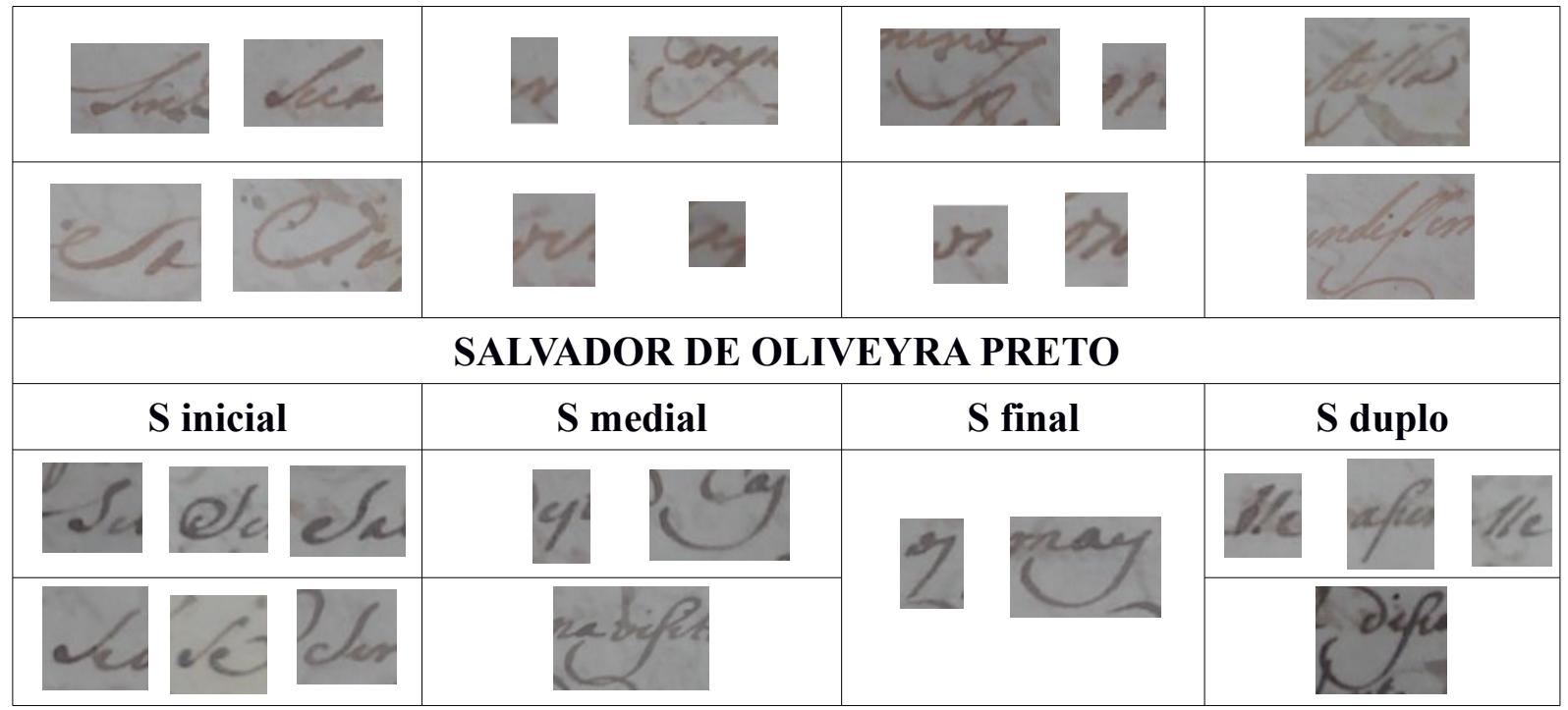

\begin{tabular}{|c|c|c|}
\hline \multicolumn{3}{|c|}{ DITONGO -ÃO } \\
\hline \multicolumn{3}{|c|}{ POLYCARPO DE ABREU NOGUEYRA } \\
\hline Localização & Fac-símile & Transcrição \\
\hline $4 \mathrm{r}$. & & Acçaõ \\
\hline $48 \mathrm{v}$ & & escrivaó \\
\hline \multicolumn{3}{|c|}{ PADRE BENTO JOZE LEYTE } \\
\hline Localização & Fac-símile & Transcrição \\
\hline $6 \mathrm{r}$. & & reaggravaçaõ \\
\hline $6 \mathrm{r}$. & & certidaó \\
\hline \multicolumn{3}{|c|}{ PHELIPPE VAS LIMA } \\
\hline Localização & Fac-símile & Transcrição \\
\hline- & - & - \\
\hline \multicolumn{3}{|c|}{ FERNANDO PINTO DE ALMEYDA } \\
\hline Localização & Fac-símile & Transcrição \\
\hline $37 \mathrm{v}$. & & chaõ \\
\hline
\end{tabular}




\begin{tabular}{|c|c|c|}
\hline \multicolumn{3}{|c|}{ PROMOTOR PAULO DE SOUZA ROCHA } \\
\hline Localização & Fac-símile & Transcrição \\
\hline $13 \mathrm{r}$. & & mostraraó \\
\hline \multicolumn{3}{|c|}{ JOAÓ DE SAÓ PAYO PEYXOTO } \\
\hline Localização & Fac-símile & Transcrição \\
\hline $15 \mathrm{r}$. & & condiçaó \\
\hline \multicolumn{3}{|c|}{ PUNHO DESCONHECIDO 1} \\
\hline Localização & Fac-símile & Transcrição \\
\hline $18 \mathrm{r}$. & & moçaõ \\
\hline \multicolumn{3}{|c|}{ MANOEL IOZEPH VÁZ } \\
\hline Localização & Fac-símile & Transcrição \\
\hline $18 \mathrm{r}$. & & maô \\
\hline $46 \mathrm{v}$ & & ficaraó \\
\hline \multicolumn{3}{|c|}{ FRANCISCO IOZEPH GUEDES } \\
\hline Localização & Fac-símile & Transcrição \\
\hline $18 \mathrm{v}$ & & naõ \\
\hline \multicolumn{3}{|c|}{ PUNHO DESCONHECIDO 2} \\
\hline Localização & Fac-símile & Transcrição \\
\hline $21 \mathrm{r}$. & & obrigaçaó \\
\hline $21 \mathrm{ve}$ & & chamaõ \\
\hline $23 \mathrm{r}$. & & naõ \\
\hline \multicolumn{3}{|c|}{ SALVADOR DE OLIVEYRA PRETO } \\
\hline Localização & Fac-símile & Transcrição \\
\hline $28 \mathrm{v}$ & & poderiaõ \\
\hline
\end{tabular}


Além dos alógrafos dos grafemas listados acima e das variantes gráficas do ditongo “ão", a letra "r" também possui uma variante que foi identificada nos manuscritos estudados. Este alógrafo da letra "r" é representado pelo número dois (2) e é denominado "r de dois", representando sempre um "r" minúsculo em início de palavra. Seguem-se alguns exemplos extraídos da documentação:

\begin{tabular}{|c|c|c|}
\hline \multicolumn{3}{|c|}{ R DE DOIS } \\
\hline \multicolumn{3}{|c|}{ POLYCARPO DE ABREU NOGUEYRA } \\
\hline Localização & Fac-símile & Transcrição \\
\hline $14 \mathrm{r}$. & 4 & recebido \\
\hline \multicolumn{3}{|c|}{ PADRE BENTO JOZE LEYTE } \\
\hline Localização & Fac-símile & Transcrição \\
\hline $6 \mathrm{r}$ & & recolhida \\
\hline \multicolumn{3}{|c|}{ PHELIPPE VAS LIMA } \\
\hline Localização & Fac-símile & Transcrição \\
\hline $6 \mathrm{v}$. & & retro \\
\hline \multicolumn{3}{|c|}{ FERNANDO PINTO DE ALMEYDA } \\
\hline Localização & Fac-símile & Transcrição \\
\hline $40 \mathrm{v}$ & & rezulta \\
\hline \multicolumn{3}{|c|}{ PROMOTOR PAULO DE SOUZA ROCHA } \\
\hline Localização & Fac-símile & Transcrição \\
\hline $13 \mathrm{r}$. & & referidos \\
\hline \multicolumn{3}{|c|}{ JOAÓ DE SAÓ PAYO PEYXOTO } \\
\hline Localização & Fac-símile & Transcrição \\
\hline $17 \mathrm{v}$. & & referidos \\
\hline \multicolumn{3}{|c|}{ PUNHO DESCONHECIDO 1} \\
\hline Localização & Fac-símile & Transcrição \\
\hline - & - & - \\
\hline
\end{tabular}




\begin{tabular}{|c|c|c|}
\hline \multicolumn{3}{|c|}{ MANOEL IOZEPH VÁZ } \\
\hline Localização & Fac-símile & Transcrição \\
\hline $46 \mathrm{v}$ & $\operatorname{lemide}_{i 0}$ & remedio \\
\hline \multicolumn{3}{|c|}{ FRANCISCO IOZEPH GUEDES } \\
\hline Localização & Fac-símile & Transcrição \\
\hline $18 \mathrm{v}$. & rearro: & reporto \\
\hline \multicolumn{3}{|c|}{ PUNHO DESCONHECIDO 2} \\
\hline Localização & Fac-símile & Transcrição \\
\hline $23 \mathrm{v}$ & & respeito \\
\hline \multicolumn{3}{|c|}{ SALVADOR DE OLIVEYRA PRETO } \\
\hline Localização & Fac-símile & Transcrição \\
\hline $26 \mathrm{v}$ & ongens & recommendada \\
\hline
\end{tabular}

Não menos importante do que as abreviaturas e os alógrafos, é relevante também observar o modo como os nomes das rés são escritos por cada um dos redatores do processocrime aqui analisado, o que ratifica a ausência de norma, isto é, de um padrão de escrita na língua portuguesa do século XVIII até mesmo para a redação de nomes próprios. O único nome, porém, que apresenta um padrão de escrita seguido por todos os redatores é o de Thereza Leyte, sempre grafado com "h", “z” e "y" (no sobrenome). Abaixo, segue-se uma tabela com as diversas grafias dos nomes de mãe e filha:

\begin{tabular}{|c|c|c|}
\hline Nome do redator & Nome da mãe & Nome da filha \\
\hline Polycarpo de Abreu Nogueyra & Thereza Leyte & $\begin{array}{c}\text { Escolastica Pinta da Sylva/ } \\
\text { Escolastica da Sylva }\end{array}$ \\
\hline Padre Bento Joze Leyte & Thereza Leyte & Escolastica Pinta da Silva \\
\hline Phelippe vas Lima & Thereza Leyte & Escolastica Pinta da Silva \\
\hline $\begin{array}{c}\text { Fernando Pinto de Almeyda } \\
\text { Promotor Paulo de Souza } \\
\text { Rocha }\end{array}$ & Thereza Leyte & $\begin{array}{c}\text { Escolastica Pinta da } \\
\text { Silva/Silua }\end{array}$ \\
\hline
\end{tabular}




\begin{tabular}{|c|c|c|}
\hline Joaó de Saó Payo Peyxoto & Thereza Leyte & $\begin{array}{c}\text { Escolastica Pinta da Sylva/ } \\
\text { Silua }\end{array}$ \\
\hline Punho desconhecido 1 & - & Escolastica Pinta da Sylua \\
\hline Manoel Iozeph váz & Thereza Leyte & Escholastica Leyte \\
\hline Francisco Iozeph Guedes & - & - \\
\hline Punho desconhecido 2 & Thereza Leyte & Escolastica Pinta da Silva \\
\hline Salvador de Oliveyra Preto & Thereza Leite & Escholastica Pinta da Sylva \\
\hline
\end{tabular}


8. O PROCESSO-CRIME DE MANOEL GARCIA CONTRA ESCHOLASTICA PINTA DA SYLVA E THEREZA LEYTE: FAC-SÍMILES E TRANSCRIÇÕES 


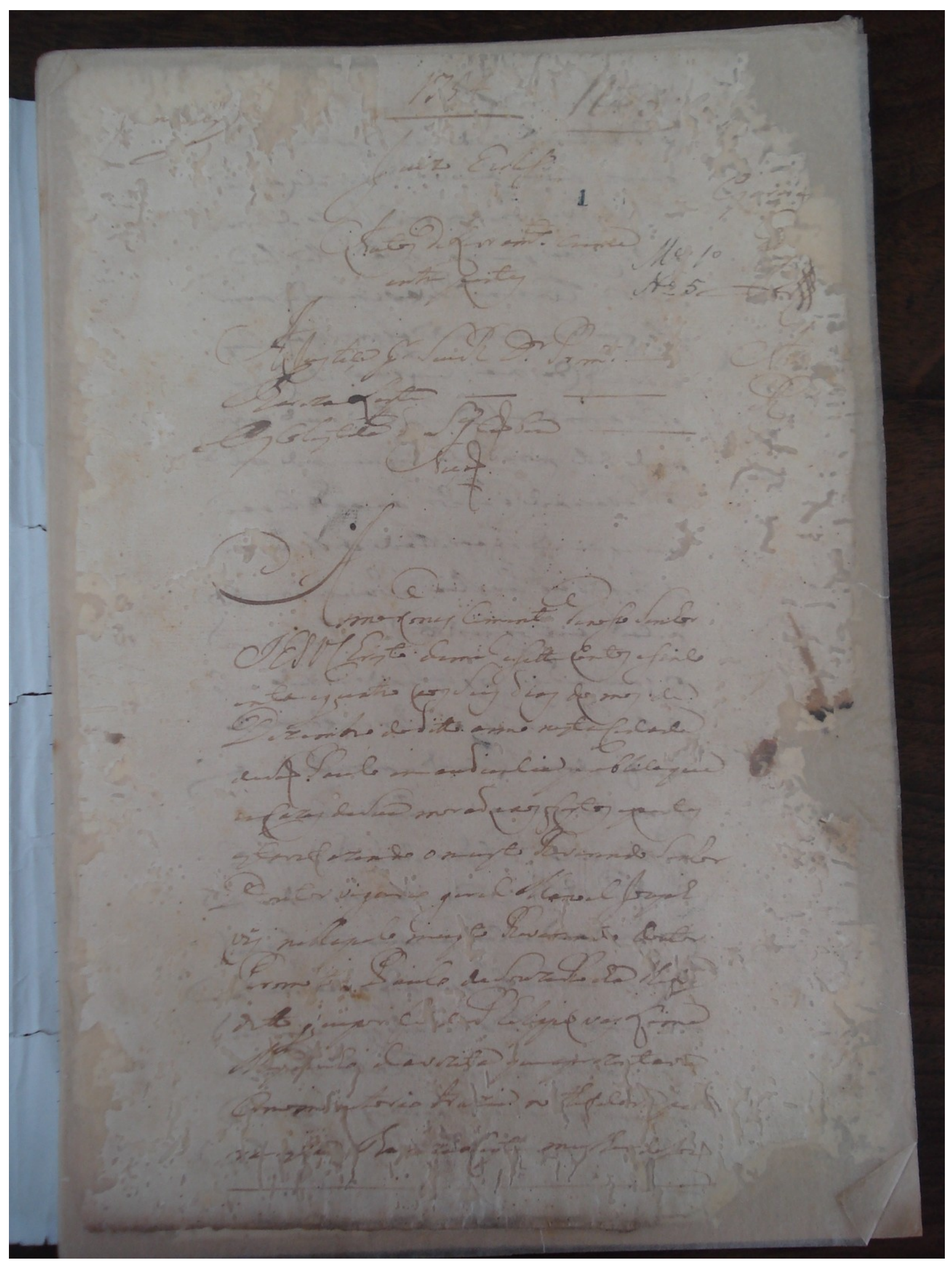




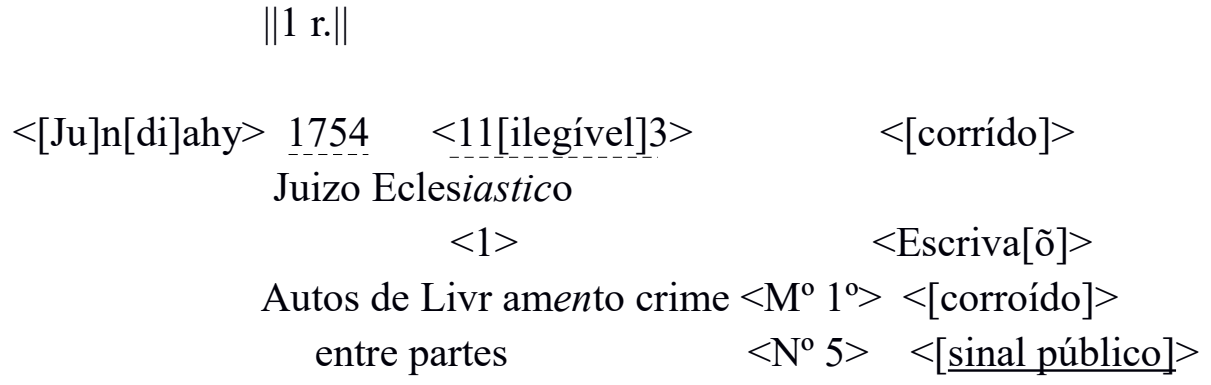

[espaço]

A Justiça por ${ }^{253}$ SeuReverendo Doutor Promotor

$<\mathrm{A}>$

TherezaLeyte

EsColastica d[a] Sylva $a^{254}$ taõ bem

$<\mathrm{R}>$

Acçaõ

[espaço]

10 Annodonas Ciment[o] denosso Senhor

IESUChristo demil esettecentos esinco

enta equatro aos Seis dias do mes de

Dezembro doditto anno nestaCidade

deSaõ Paulo emaudiencia publicaque

15 emCazas deSua morad[a]aos feytos epartes

estavafazendo o muyto R[e]verendo Senhor

Doutor vigario geral Manoel Jozeph

vás nellapelo muyto Rever[e]n[do] Doutor

Promo[tor] Paulo daS[o]uzaRocha lhef[oy]

20 ditto quepor fe d[e]Phelippe vas Lima

$\mathrm{M}[\mathrm{e}] \mathrm{y}[\mathrm{ri}] \mathrm{nho}$ davizita queapreze[n]tava

Comomonitorio $^{255}$ trazia no thifica[da] pa

ra [corroído]s[ilegível] The[re]zaLeyt[e] mulher de[I]oaõ

253 "p" p" por "por", segundo NUNES, Borges E.. Abreviaturas paleográficas portuguesas. Lisboa: Edições Cosmos, 1981, p. 63.

254 "S" por "Silva"/"Sylva", de acordo com FLEXOR, Maria Helena Ochi. Abreviaturas: manuscritos dos séculos XVI ao XIX. 2 ed. aum.. São Paulo: Arquivo do Estado/Editora UNESP, 1990, p. 379.

255 Segundo o dicionário Caldas Aulete Digital, uma "monitória" pode ser definida como: 1. Aviso, advertência, conselho. 2. Repreensão, reprimenda. 3. Dir. can. Citação jurídica eclesiástica, feita sob pena de excomunhão (monitória papal). [F.: Fem. substv. de monitório. Hom./Par.: monitória (sf.), monitoria (sf.).]. Disponível em: http://www.aulete.com.br/monit\%C3\%B3ria 


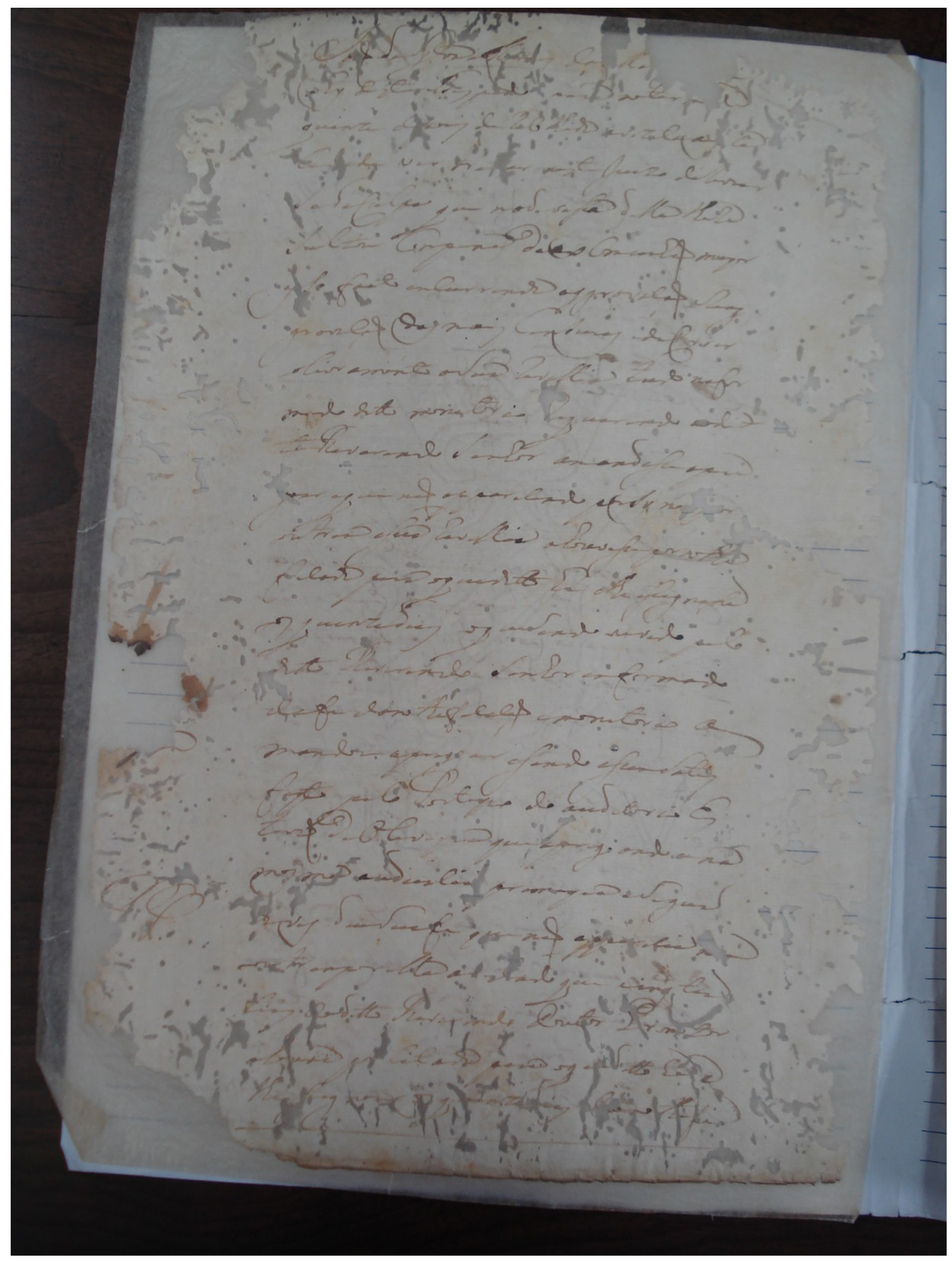


[[Io[a]õ]] daSylva Mor[a]es da[vi]lla [corroído]

$\|1 \mathrm{v}$.

ahy deste Bisp[a]do para notar [ilegível]

quinze $\mathrm{d}[\mathrm{e}]$ pois de $\mathrm{r}[\mathrm{e}]$ co lhida avizitaaes ta

$\mathrm{Ci}[\mathrm{d}]$ ade vir tra[t]ar neste Juizo delivrar

SedaCulpa que nadevassa della lhere

30

$<$ [corroído] $>$ Sultou Compena deex Comunhaõ mayor

e[pe]lo facto encurrendo aggravaçaõ ereag

gravaçaõ das mais Censuras edeCriar

olivramento aSua revellia tudo nafor

$\mathrm{m}$ [a]do ditto monitorio requerendo [ao]dit

$\mathrm{t}[\mathrm{o}]$ Reverendo Senhor omandasseapre

35

goar eque naõ apparecendo porsy n[empo]r

outrem esua revellia ohouvessepor nothi

ficada para oqueditto ha elhe assegurasse

os quinzedias oqueSendo ouvido pelo

ditto Reverendo Senhor informado

40

dafedano thificaçaõ emonitorio o

$<$ [corroído] $>$ mandou apregoar esendo assimSatis

feyto pelo Porteyro do auditorio Es

tevaõ deOliveyra que apreg[o] ando ana

mesma a[u]diencia primeyra eSegun

45

$<$ PP $>$ [d]aves Sua[[Sua]]fe que naõ appa[r]ecia n[em]

$\mathrm{o}[\mathrm{u}]$ trempor ella o[e]s[t]ado que eins tan

cias doditto Reverendo Doutor Promotor

ohouve po[r] citado para oq[ue]ditto ha e

lheassig nou os $\mathrm{q}[\mathrm{u}]$ inz $[\mathrm{e}]$ dias dano thifi 


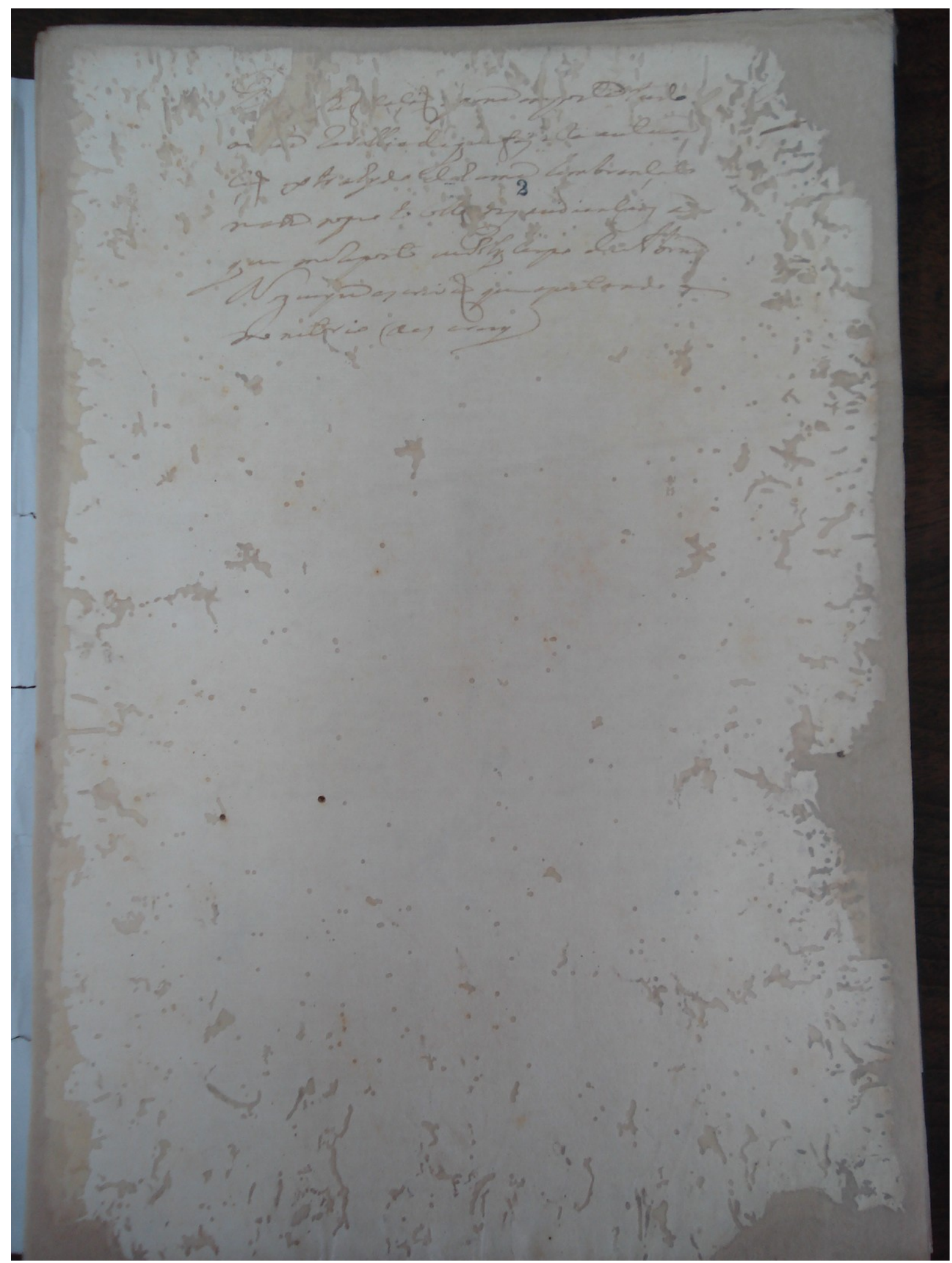


||2 r. $\|$

$50[[\mathrm{D}[$ ano $]$ thif[i] $]]$ caçaõ [corroído]pena importe tudo $<$ [corroído $]>$ $\mathrm{a}$ [S] ua revelliadequefis aditaautua $<$ [corroído] $>$ ç[a]õ ex trahydo dehuma lembrançato mada nopro to collo das $<\uparrow 2>$ audienci[a]s a que mereporto euPoly carpo d[e]Abreu

55 Nogueyra escrivaõ que aportando o mo ratorio oes crevy 


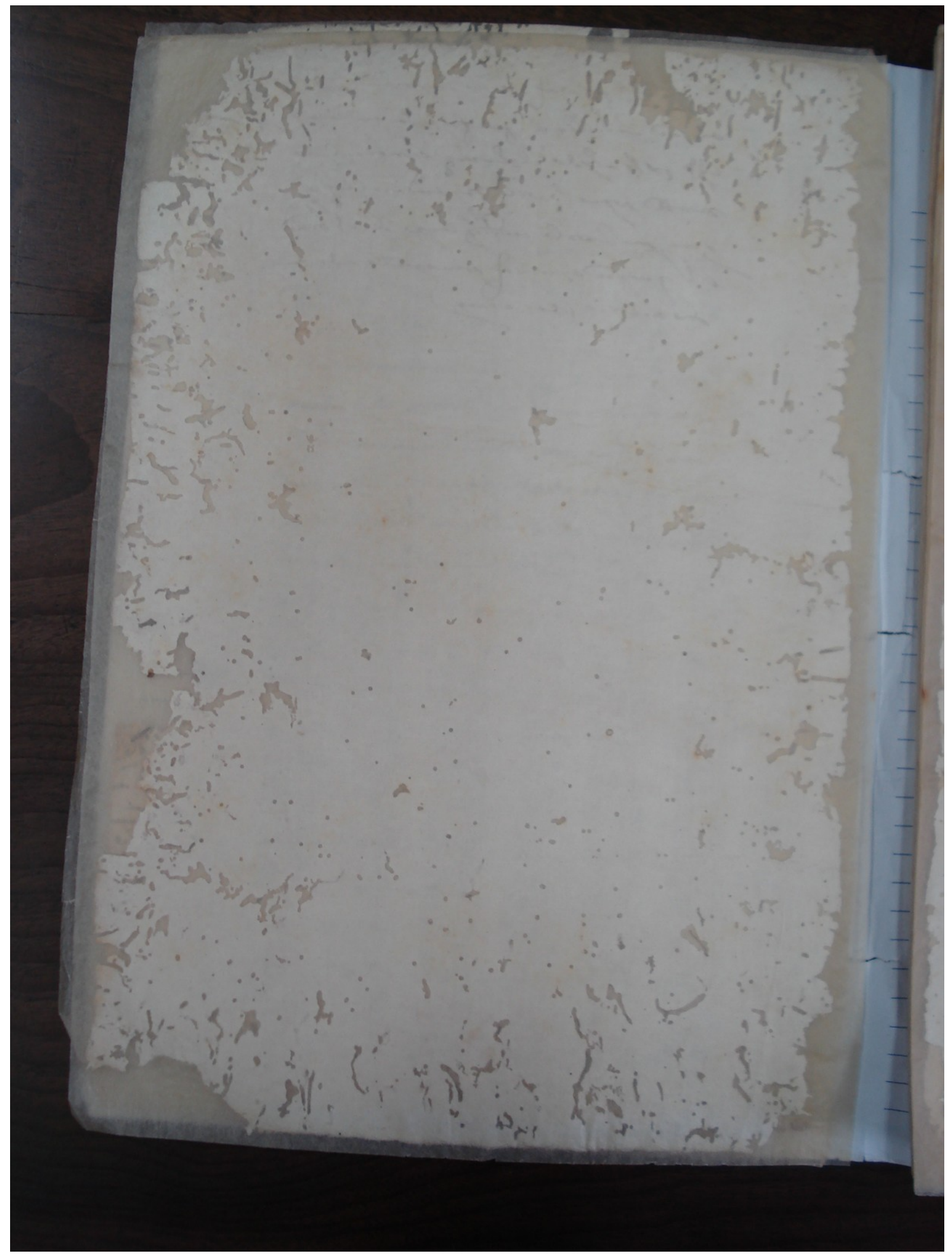


||2 v. $\|$

[página em branco] 


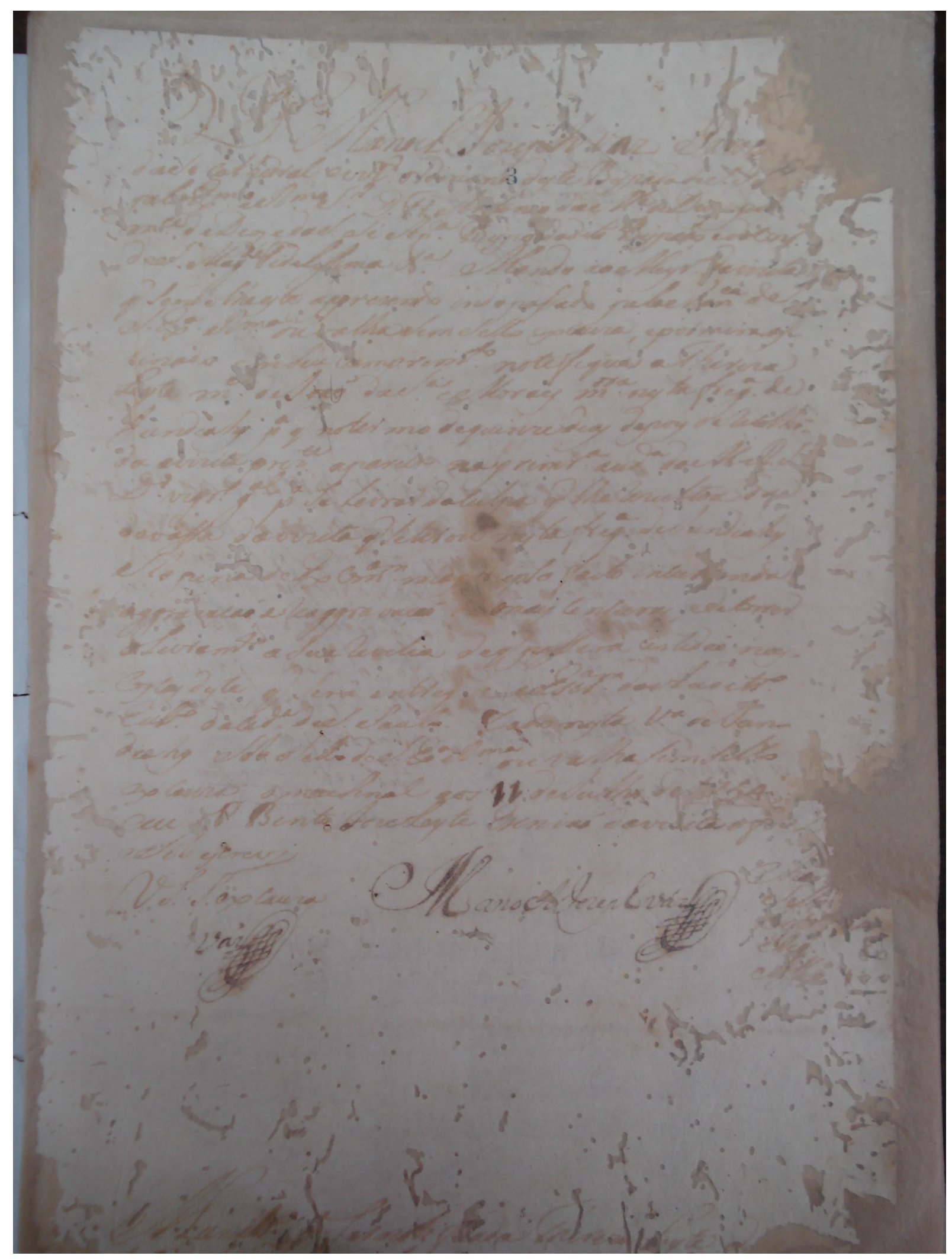


||3 r. $\|$

ODoutor Manoel Iozephvaz Paroc[o] $]^{256}$

daSe cathedral evizitador ordinario $<3>$ deste BispadodeSaó $\mathrm{Pa}[\mathrm{ulo}]$

peloExcelentissimo eReverendissimo Senhor Dom Frei Anton[i]o daMadre deDeos po[r]

60

merce deDeos, edaSanta Sé Apostolica Bispadodito Bispado edoconselho

deSua MajestadeFidelissima ${ }^{257}$ Senhoria Mando ao Meyrinho ${ }^{258}$ davisita

que sendo lheeste appresendo indopassado pelachancelari $\mathrm{a}^{259}$ de

Sua Excelencia Reverendissima ouvalha sem sello ex causa, epor mimos

[1]ivrado emSeucumprimento noteseque aTheresa

65 Leyte mulhe[r] deIoaõ daSilva eMoraes moradora nesta freguesia de Jundiahy para que notermo dequinzedias depois derecolhi -

da avisita presente aparec[e] naprimeira audiencia doMuitoReverendo Senhor

Doutor vigario geral paraSe livrar daculpa que lheresultou da

davassa $^{260}$ davisita que setirou nestafreguesia deIundiahy

70 Sob pena deEx comunham mas [mancha] [r] eplo facto encu[rre]nda

aggravaçaó, ereaggravaçaó [mancha] omais censuras, edecorrer

oLivramento aSua revelia deque passena certidaó nas -

Costas deste, que Serâ entreg[u]e aoEscrivam doAuditorio

Ecclesiastico dacidade deSaó Paulo [espaço] Dado nesta Villa deIun -

diahy Sob oSello deSua Excelencia Reverendissima ouvalha sem sello

ex causa omeuSinal aos 11 deIulho de1754

eeu [o]Padre Bento IoseLeyte Escrivaó davi[s]ita of[i]z

$<$ corroído $]>$

eSob escrevj

VoSsa Senhoria ex cauza Manoel Iosephváz[sinal público]

$<$ corroído $]>$

$<$ Sell[o] $>$

80

váz[sinal público]

$<$ [ilegível] $>$

$<$ [ilegível] 100>

[espaço]

Munitorio [p]araSer noti [fic]ada Theresa Leyte d[corroído]

256 A partir daqui, o punho é do Padre Bento Joze Leyte.

257 Segundo o dicionário Caldas Aulete Digital, "Sua Majestade Fidelíssima", ou "Fidelíssimo", é um título majestático utilizados pelos reis de Portugal desde D. João V, título este concedido a ele e a seus descendentes pela Cúria Romana - mais especificamente pelo Papa Bento XIV, em 1748 - como reconhecimento da fidelidade católica desses reis. Disponível em: http://www.aulete.com.br/fidel $\% \mathrm{C} 3 \% \mathrm{ADssimo}$

258 "Meyr" por "Meyrinho", segundo FLEXOR, Ibidem, p. 269.

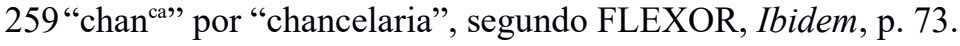

260 "davassa" por "devassa”. 


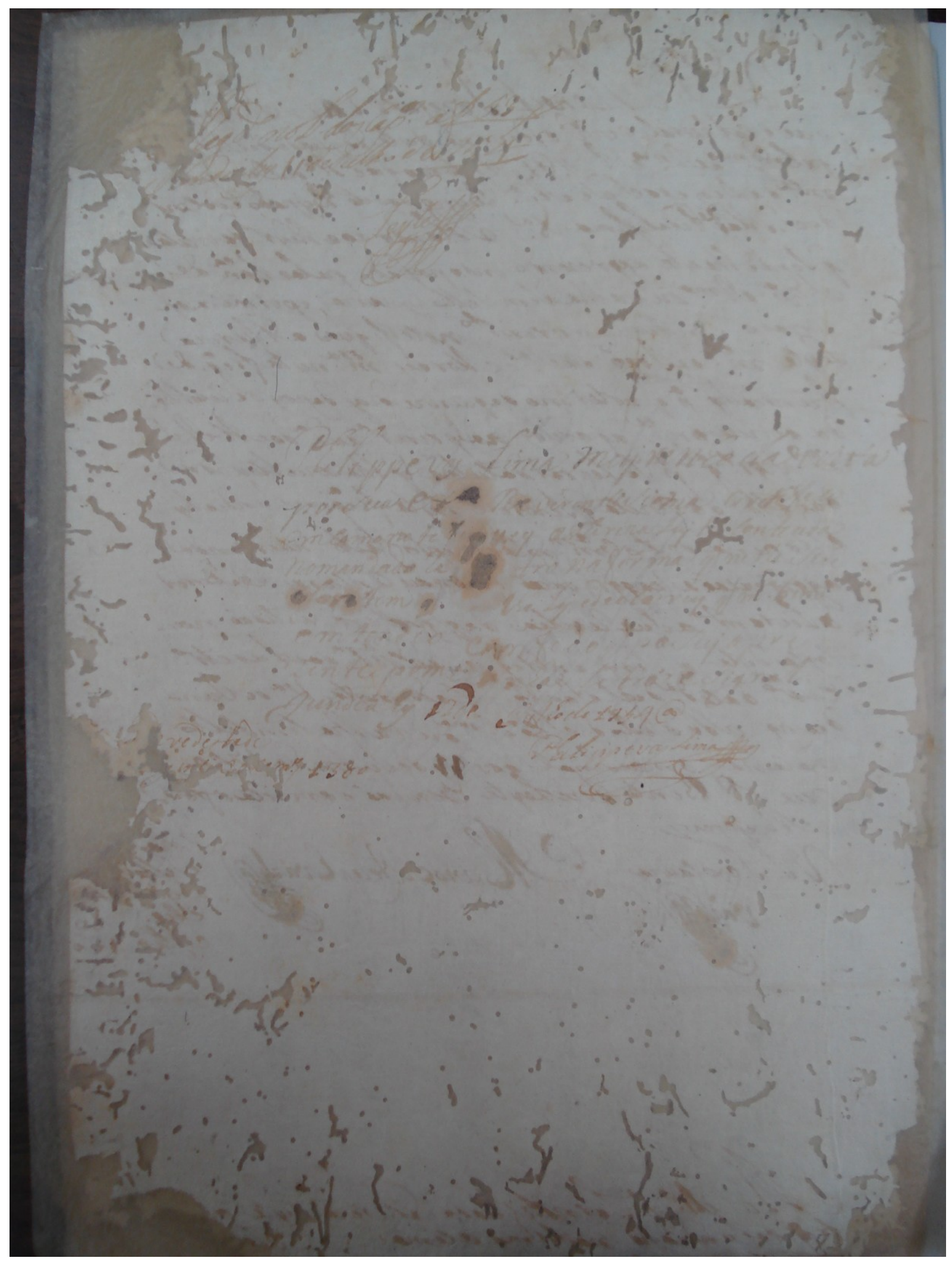




$$
\text { ||3 v. } \|
$$

[corroído] Regimento noLivr[o] ${ }^{261}$ dos Capitulos afolha53 Verso

Iundi[a]hy 11 deIulho de1754

85

[espaço]

$$
\underset{\text { [espaço] }}{\text { Leyte[sinal público] }}{ }^{262}
$$

Phelippe vas Lima meyrinho davizita ${ }^{263}$

por Suaexcelencia ReverendiSima certefeco

Emcomo notefiquey athereza Leyt[e] conteuda

nomandado re [corroído] tro naforma que nelle Seu

90

Seratem que [espaço] lhe Ly edaclarey que muy[to] bem

emtendeo comfedo que paSey apre

zente pormi[borrão]nha Letrá eSignal

Jundiahy 12 de Iulho de 1754 assinado $^{264}$

[De]ve destade

PheLippe vas Lima[sinal público]

95 [li]gen[ç]ia [ilegível] 1380

261 "L" por "Livro", segundo FLEXOR, Ibidem, p. 242.

262 Até aqui, o punho é do Padre Bento Iose Leyte.

263 De acordo com o dicionário Caldas Aulete Digital, um "meirinho" pode ser definido da seguinte forma:

"1. Ant. Jur. Antigo funcionário do poder judiciário que corresponde hoje ao oficial de justiça" ou " 2 .

Ant. Jur. Antigo magistrado que, nomeado pelo rei, governava um território ou comarca". Disponível em: http://www.aulete.com.br/meirinho

264 “@” por "assinado", de acordo com FLEXOR, Ibidem, p. 467. Contudo, a autora estabelece que tal abreviatura foi utilizada somente no século XIX. 


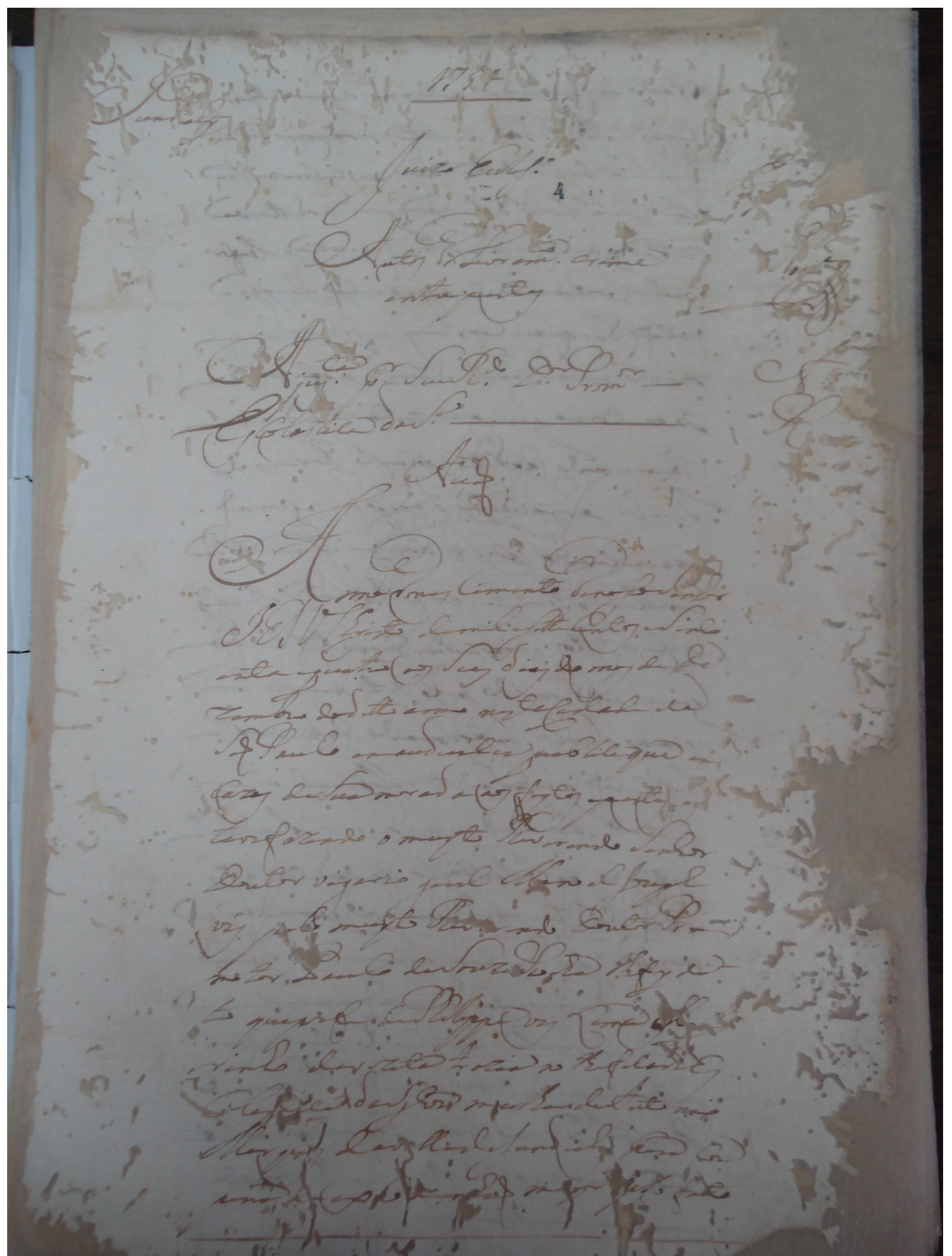


||4 r. $\|$

1754

$<[$ corroído $]>$

$<$ Iundiahy $>\quad$ espaço]C

Juizo Ecclesiastico

100

$<4>$

Autos doLivramento crime entre partes

[espaço]

A justiça ${ }^{265}$ por SeuReverendo Doutor Promotor

$<$ Es[cr]i[vaõ $]>$

$<$ [rubrica $]>$

$<$ [rubrica $]>$

EsColastica daSylva $<\mathrm{A}>$

\section{Acçaõ \\ [espaço]}

105 Annodonas Cimento denossoSenhor IESUChristo demil esetteCentos eSinco entaequatro aos Seis dias do mes de De zembro doditto anno nestaCidade de Saõ Paulo emaudiencia publicaque em

110 Cazas deSua morada aos feytos epartes es tavafazendo o muyto Reverendo Senhor Doutor vigario geral Manoel Jozeph vás pelo muyto Rev[er]endo Doutor Pro motor Paulo daSouza Rocha lhefoy dit

115 to queporfe dePhelippe vas Lima [Mey] ${ }^{266}$ rinho davizita trazia no thificadaEs Colastica daSylva mulher deAntonio Marqu[e]s dav[i]lladeJundiahy para com pena, de ex Comunhaõ mayor pelo facto

265 "jus ${ }^{\text {ta" }}$ por "justiça", segundo FLEXOR, Ibidem, p. 240.

266 Ao que parece, o escrivão cometeu um erro ao redigir a letra "M" ou a redigiu por cima de outra letra, pois, apesar de haver uma corrosão, é possível distinguir a cauda de uma letra na mesma posição ocupada pelo "M". 


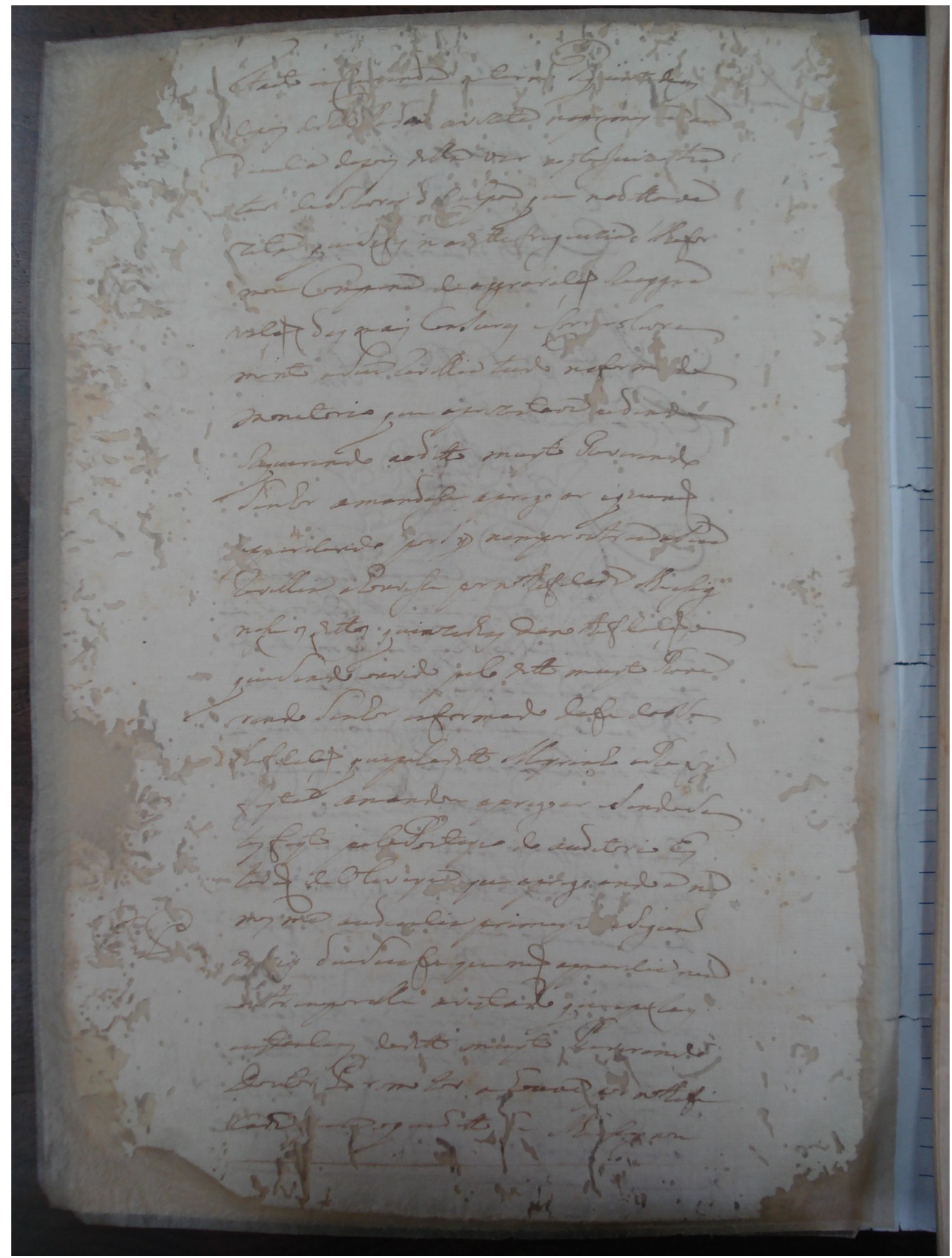


||4 v.

120

[[Facto $]$ inC[urr]endo noter[mo] deq[u]in[ze]dias

depois dereco[lh]ida avizita naprimey [r]a au

diencia depois della vir nesteJuizo tra

tar deSelivrar d[a]Culpa que nadittavi

zita queSefes nadittafreguezia selhefor

125

mou Compena deaggravaçaõ ereaggra

vaçaõ das mais CenSuras eCorr[e]r olivra

mento aSua revellia tudo naform[a] do

monitorio que aprezentava pedindo

erequerendo aoditto muyto Reverendo

130 Senhor omandasse aprego ar equenaõ

[a]pparecendo porsy nempor outra asua

revellia ohouvesse por nothificada elheassig

nasse os dittos quinzedias dano thificaçaõ, o

queSendo ouvido pelo ditto muyto Reve

135

rendo Senhor enformado dafe daNo

thificaçaõ quepeloditto Meyrinho aRe foy

$<$ [corroído $]>$ feyta amandou apregoar SendoSa

tisfeyto peloPorteyro do auditorio Es

tevaõ deOliveyra que aprego ando a na

140

mes ma audiencia primeyr[a] eSegun

$<$ PP $>$ d[a][v]es deuSuafequenaõ apparecia nem

outra ${ }^{267}$ emporelle avistado que epelas

enstancias doditto muyto Reverendo

Doutor Promotor ahouve por nothifi

145

cada [p]ara oqueditto he elhe[a]ssignou

267 “outr" no manuscrito original. 


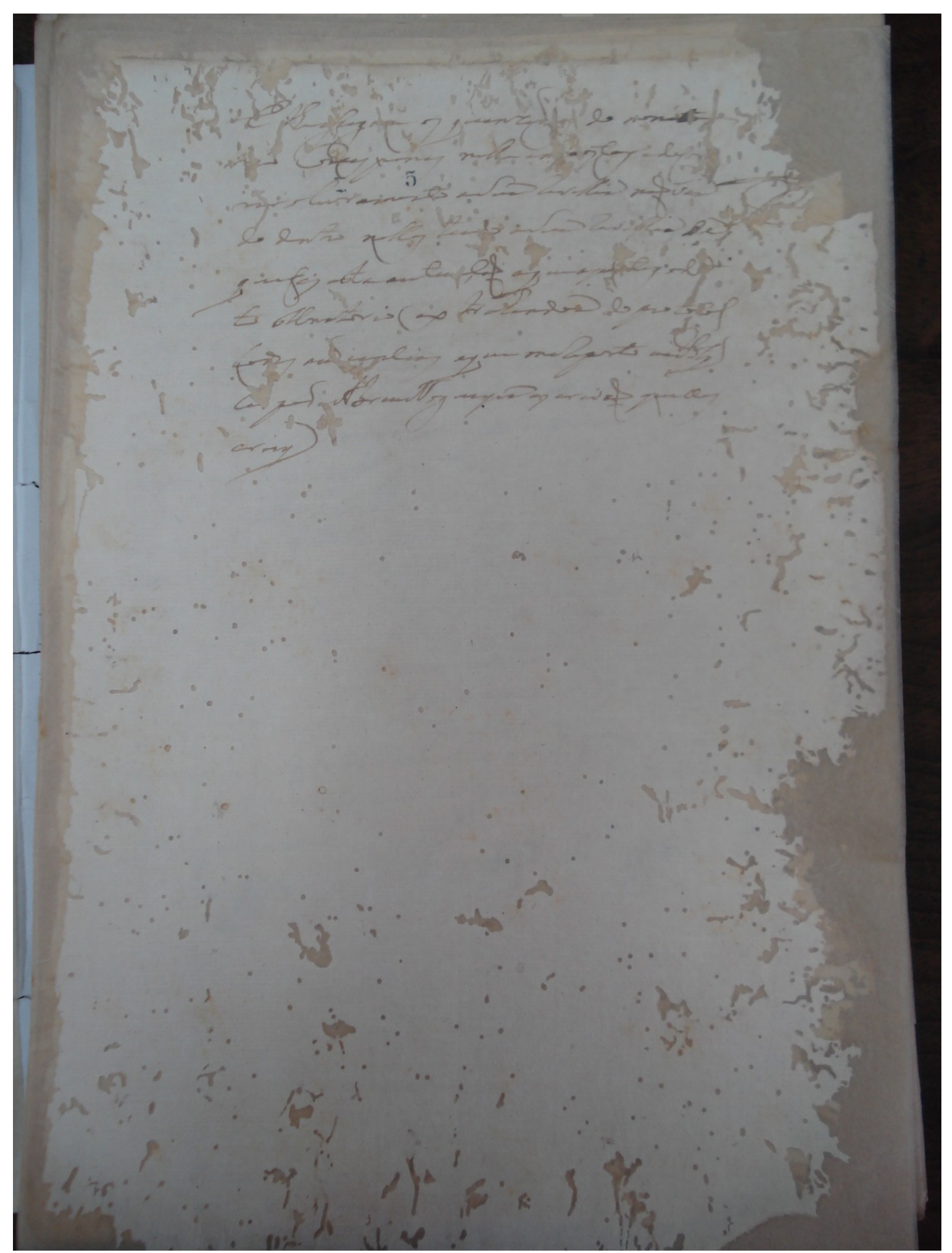


\|5 r. $\|$

[[Elheassignou $]$ os quinzed[i]as do monito

[ri]o Comas penas nelle e[m]postas edeCor

rer olivramento $<\uparrow 5>$ aSua revellia naõ ven $<$ [corroído] $>$

do dentro nelles tudo aSua revellia de $<[\mathrm{P}]>$

150 quefis estaautu[a]çaõ aqueaj[corroído]tas od[i]t

to Monitorio ex trahindo[a] do protocol

lodas audiencias aque mereporto euPoly

$\mathrm{Ca}[\mathrm{r}]$ podeAbreuNogueyra escrivaõ queoes

crevy 


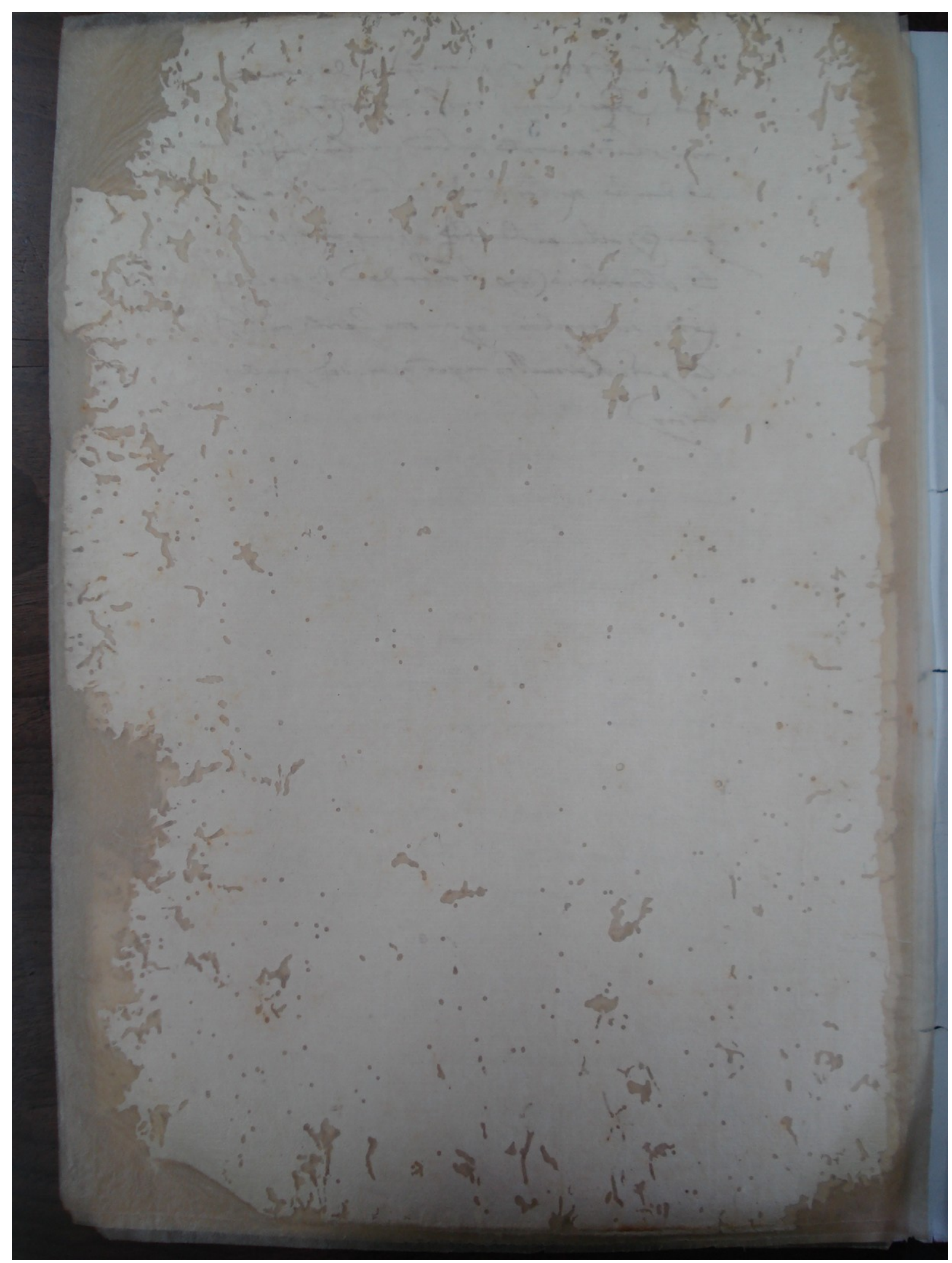


\|5 v. $\|$

[página em branco] 


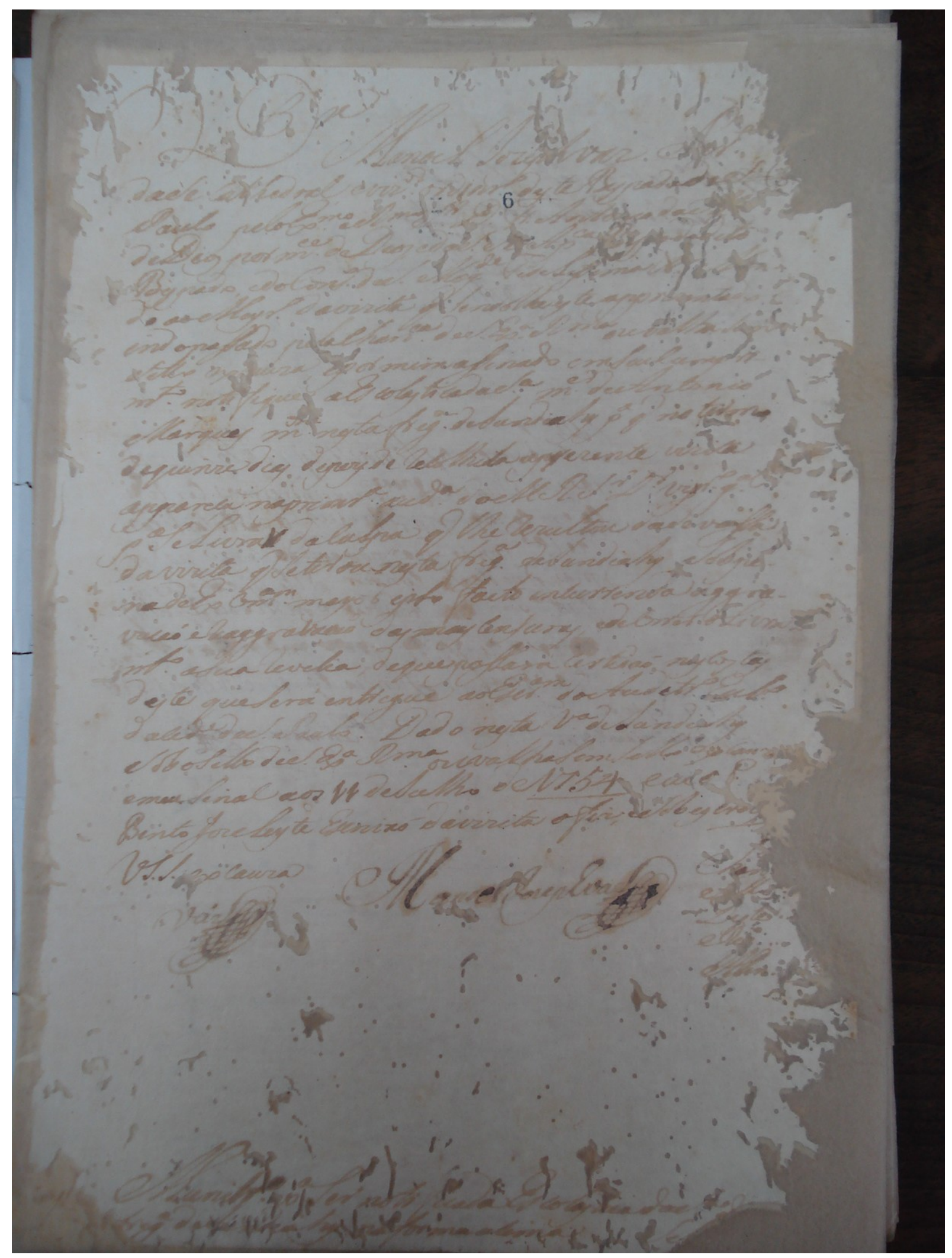


||6 r. $\|$

155 ODoutor Manoel Iozephvaz Paroco ${ }^{268}$

daSe Cathedral evizitador ordin $a$ rio ${ }^{269}<\uparrow 6>$ deste BispadodeSaó $\quad<$ [corroído] $>$ Paulo peloExcelentissimo eReverendissimo Senhor Dom Frei Anto[n]io da[Madre] deDeos por merce deDeos, edaSanta [Se] Apostolica B[i]s[p]ododito Bispado, edoConSelho deSua Magestade FideLissima [ilegível] M[a]n -

160 do aoMeyrinho davizita que Sendolheesteappr[es]entado indopassado pelaChancelaria deSua Excelencia Reverendissima ouvalha Sem Sello ex [ca]uza, epor mim assinado emSeuCumpri mento notifique aEscolasticadaSilva mulher deAntonio Marques morador[a $]^{270}$ nesta freguesia deIundiahy para que no termo

165 dequinze dias depois de recolhida aprezente vizita appareça naprimeyra audiencia doMuyto Reverendo Senhor Doutor vigario geral paraSeLivrar ${ }^{271}$ daCulpa que lhe rezultou dadevassa davizita que Setirou nesta freguesia deIundiahy Sob pe nadeEx comunham maisob ipto facto encurrenda aggra -

170 vaçaó ereaggravaçaõ das mais Censuras, edeCorrer oLivra mento aSua revelia, deque passara certidaó nas costas deste queSerá entregue aoEscrivam doAuditorio Ecclesiastico dacidade deSaó Paulo. Dado nesta Villa deIundi[a]hy Sob oSello deSua Excelencia Reverendissima ouvalhaSem Sello ex cau[za]

175 emeuSinal aos 11 deIulho de1754 eeu o Padre Bento JozeLeyte Escrivaó davizita ofiz, eSob escre[vj]

VoSsa Senhoria ex cauza $<$ Chan[corroído] $>$ váz[sinal público] Mano[el] Iozephva[z][sinal público]

$<[\mathrm{Se}] 11 \mathrm{lo}>$ $<$ Deste $>$ $<\operatorname{Re}\left[\right.$ g] imento $^{272}>$ $<$ [ilegível] $>$

[espaço]

Munitorio paraSer noti [f]icadaEscolas[ti]cadaSilv[a] [corroído] freguesia deI[un]diahy naforma acima [espaço] Se[corroído]

268 "Par"" por "Paroco", segundo FLEXOR, Ibidem, p. 313.

269 "ordinr" por "ordinario", de acordo com FLEXOR, Ibidem, p. 301.

270 "m ora" por "moradora", conforme consta em FLEXOR, Ibidem, p. 256.

2710 " $r$ " final em "livrar" foi redigido por cima de outra letra.

272 "Reg" por "Regimento", segundo FLEXOR, Ibidem, p. 362. 


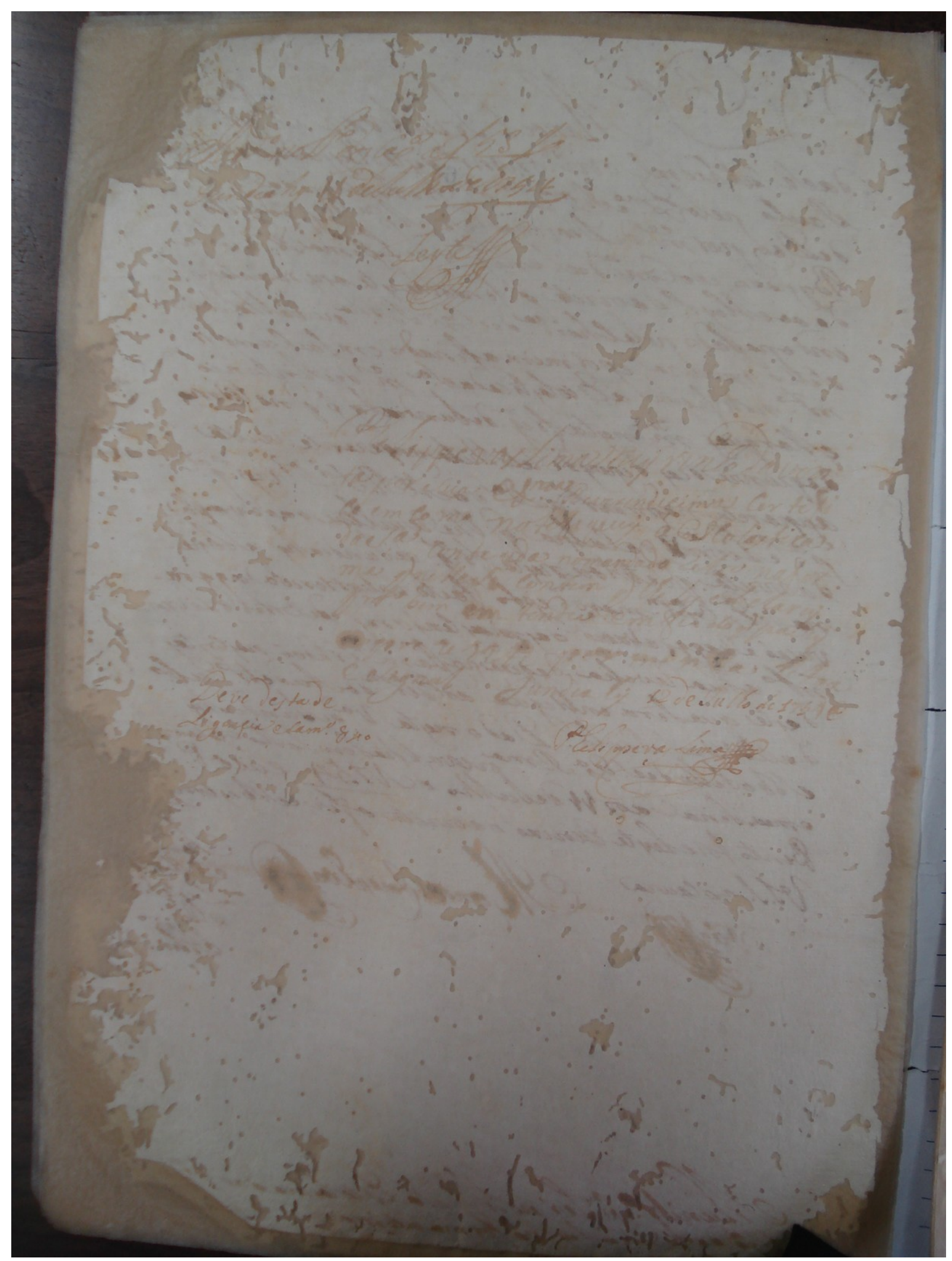


||6 v.

Regimento noLivro dos Capitulos afolha53 Verso

185 [I] undiahy 11 deIulhode1754

[espaço]

Leyte[sinal público] $]^{273}$

[espaço]

PheLippevas Lima Meyrinho davizi

ta por Sua Excelencia Reverendiçima Cer tefi

co emcomo notefiquey aESColastica

190

daSilva conteuda nomandado retro nafor

ma que nelleSe contem que lhely ed[e]clarey

que muyto bem em tendeo emfe do que paSey

[a] pre zeNte por $\min [\mathrm{h}] \mathrm{a}$ Letra

ESignal [espaço] Jundiahy 12 de Iulho de 1754 assinado $^{274}$

195 Deve desta de

PheLippe vas Lima[sinal público]

Ligençia [ilegível] 840 


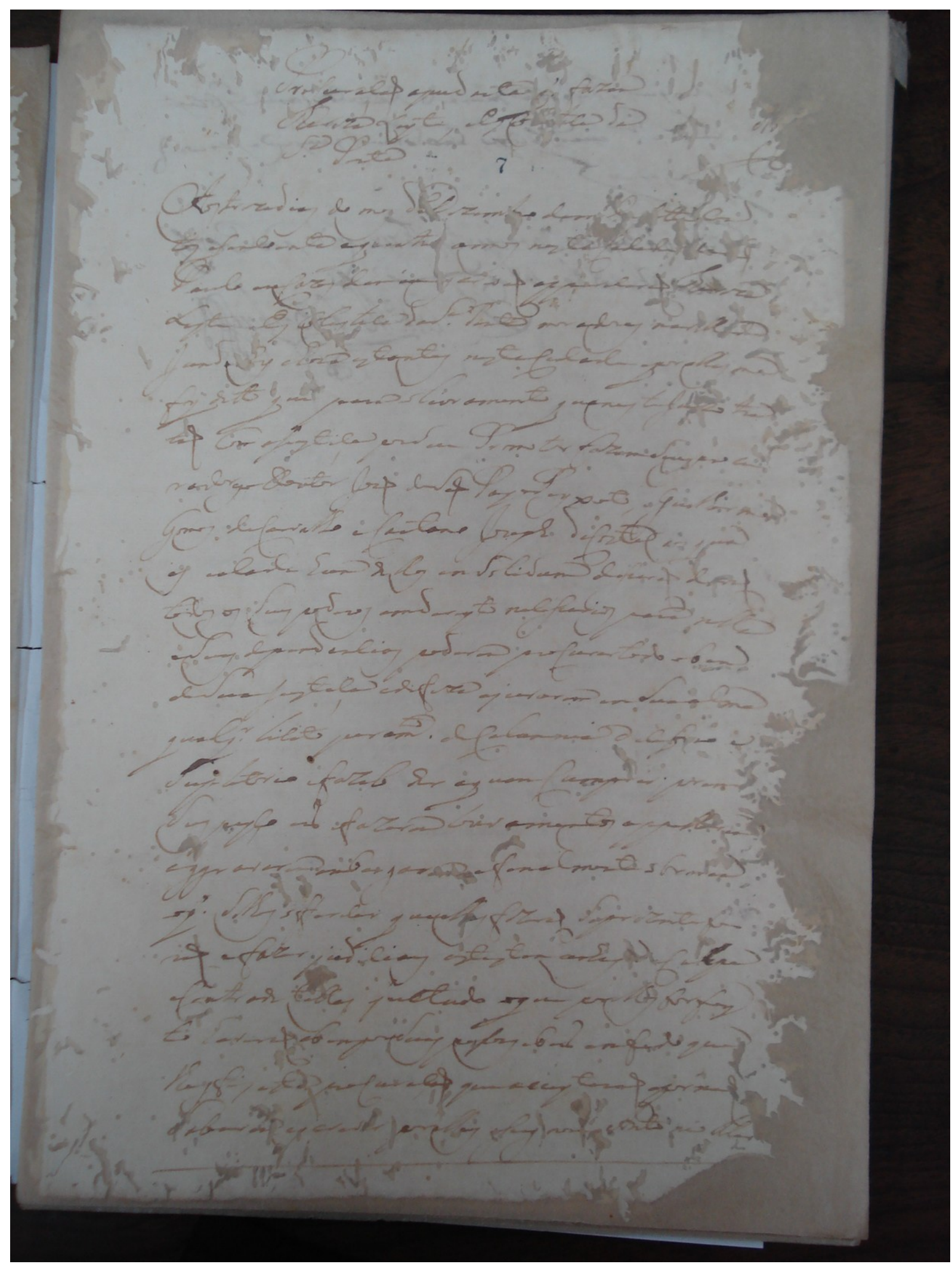




$$
\text { \|7 r. } \|
$$

ProCuraçaõ apud $\operatorname{acta}^{275}$ [ilegível]que fazem

Thereza Leyte, eEsCo[las]tica da

$$
<\text { corroído }]>
$$

Silva Pinta

200

$$
<7>
$$

\section{[espaço]}

Aos trezedias do mes deDezem[br]o dem[i]1[ese]tte cen

tos esincoenta equatr[o] annos nestaCidade [deSa]õ

Paulo emCazas demim[e]scrivaõ app[a]receraõ Thereza

Leyte eEs Colastica daSilva Pinta moradoras navill[a]de

205 Jundi[a]hy ehora estantes nestaCidade epor ellas me

foy ditto que para olivramento quenes teJu[i]zo tra

taõ Com ajustiça porSeu Promotor fazemSeus procu

radores oDoutor Joaõ deSaõ PayoPeyxoto, eGuilherme

Gomes deCarvalho eCaetano Jozeph daCosta aos qua

210 es emCada hum delles emSolidam disseraõ d[e]raõ

todos os Seus poderes emdireyto necessarios para nella

eSuas dependencias poderem proCurar todo obem

deSuajustiça edefeza ejurarem emSuaalma

qualquer licito juramento deCalunnia decef[o]ro e

215 Supletorio efazelo dar aquemCumprir por em

Sus peyÇo ens efaZerem livramentos appellarem

aggravarem embargar[em] efinalmente obrarem

oque Selhes offerecer queell[a]s fiZeraõ Seprezentefo

raõ efazer judiciaes astestemunhas [de]Culpa

220 eContraditallas quetudo ${ }^{276}$ oque porelles for fey

to haveraõ ebemporSuas pessoas ebens enfado que

lhes fis esta proCuraçaõ queacceytaraõ epor naõ

Saberem escrev[e]r porellas assig nou Anto nio Mar

275 Segundo o website Migalhas, procuração apud acta significa "procuração nos autos, junto aos autos", que vem a ser uma outorga de poderes. Disponível em: http://www.migalhas.com.br/Latinorio/34,MI162757,81042-Procuracao+apud+acta. Além disso, no website JurisWay consta a informação de que a procuração apud acta seria uma "[...] procuração dada nos próprios autos da causa pelo respectivo escrivão, perante o juiz oficiante, ou lavrada em cartório, perante duas testemunhas. Tem caráter judicial, não sendo válida extrajudicialmente. Equipara-se à procuração por instrumento público". Disponível em: https://www.jurisway.org.br/v2/pergunta.asp? idmodelo $=6626$

276 Aparentemente, o escrivão cometeu algum erro ao redigir a letra "e" em "que". 


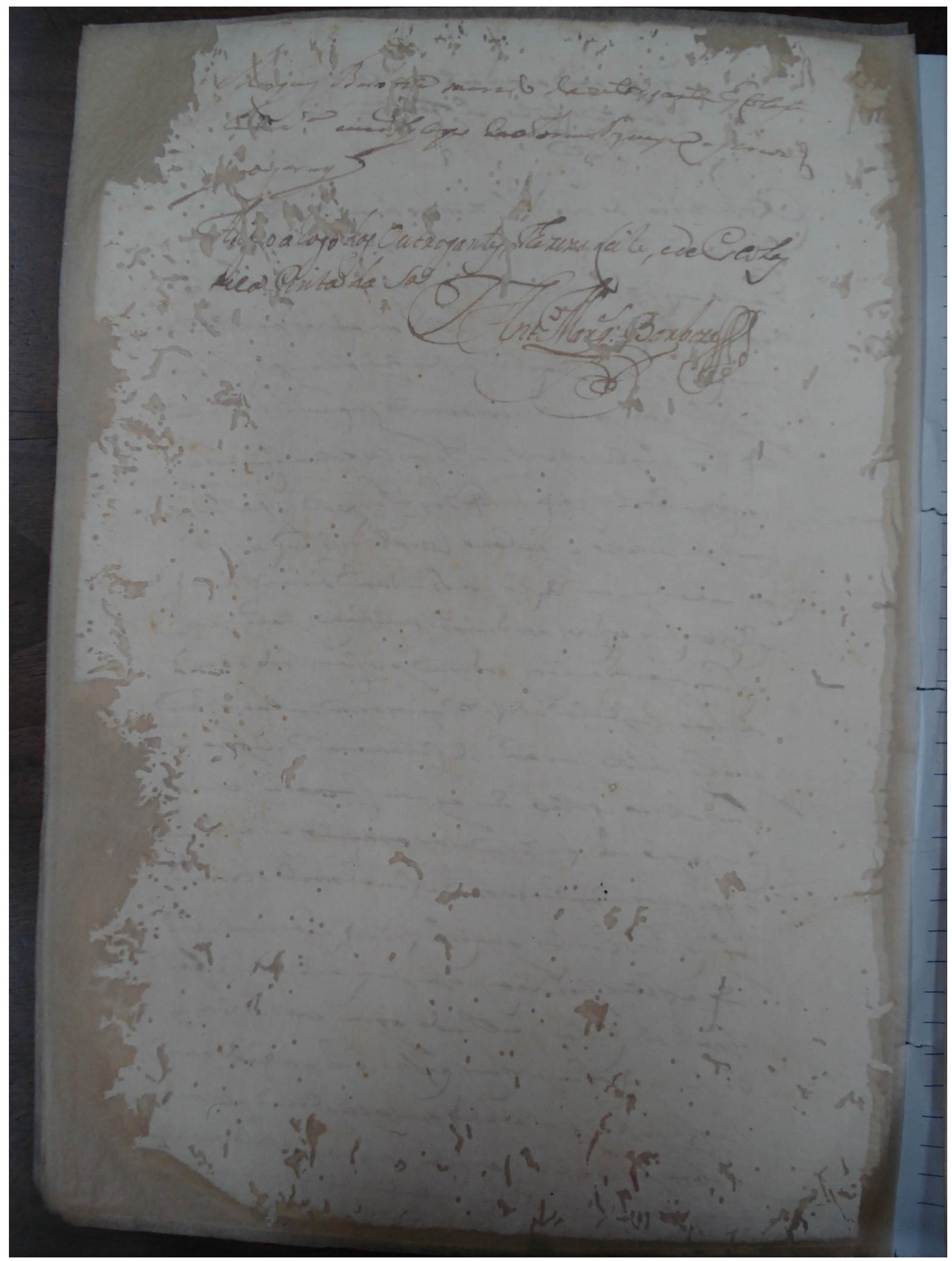




$$
\text { ||7 v. | }
$$

[[M[a]r]]ques Barb[o]za marido daoutorgante EsColasti

$225 \mathrm{Ca}[\mathrm{da}]$ Silva eeuPolycarpo deAbreuNogueyra escrivã̃

[que]oescrevy

$$
\text { [espaço] }
$$

A[sign]o a rogo das Outrogantes, Thereza Leite, edeEscoLas tica Pinta da Silva

$\underline{\text { AntonioMarques Barboza[sinal público] }}{ }^{277}$

277 A partir da linha 227 (“A[sign]o a rogo das Outrogantes [...]”) até o final desta página, a letra é de Antonio Marques Barboza. 


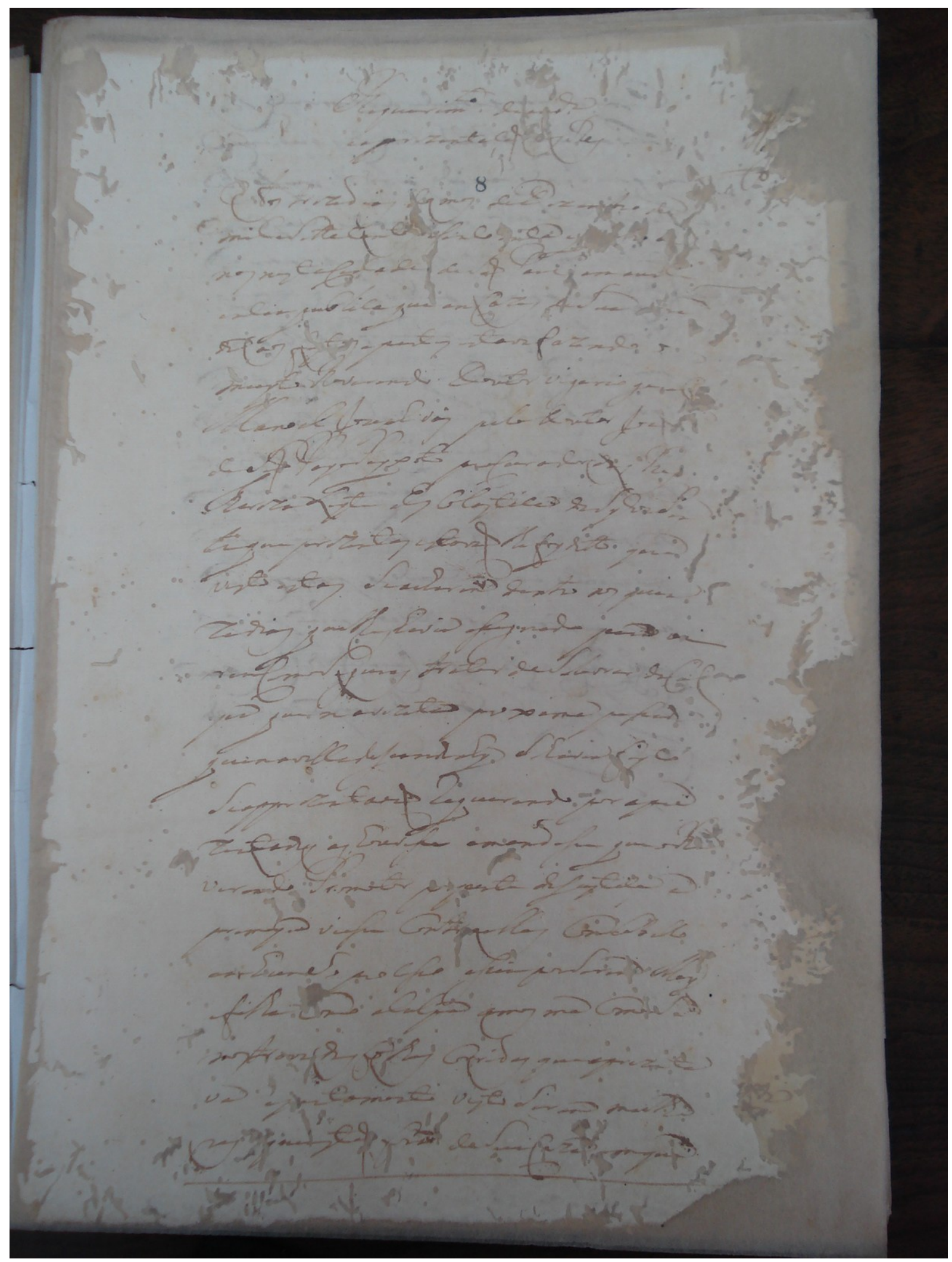


||8 r.

230

$$
\begin{array}{cc}
\text { Requerimento daa[u]diencia }{ }^{278} & \\
\text { eaprezentaçaõ das Res } & <\text { ilegível] }> \\
\text { [espaço] } & <\text { [corroído }]> \\
<8> &
\end{array}
$$

Aos treZedias do mes deDezembro de

235 mileSettecentos esinco [e]nta e[quatro] a[n]

nos nestaCidade deSaõ Paul[o] em audi <

encia publicaque emCazas deSua [mo]ra

da aos fe[y]tos epartes estavafaZendo o

muyto Reverendo Doutor vigario geral

240 Manoel Jozeph vás peloDoutor Joaõ

deSaõ PayoPeyxoto proCurador das Res

Thereza Leyte eEs Colastica daSylvaPin

taque preZentes estavaõ lhefoy ditto que

visto estas Seacharem dentro nos quin

245 Zedias quelhes havia assignado para $^{279}$ [vi]

remComoSeguras tratar deSelivrar daCul

pa que navizita proxima passada

quenavilladeJundiahy Sehavia fey to

SeappreZentavaõ requerendo por apre

250 Zentadas as houvesse emandasse que oR[e]

verendo Promotor $\mathrm{p}$ [or]parte dajustiça e

primeyra viesse Contr aellas Comlibello

em humSo processo assimporSere[m] May

efilha $\mathrm{C}[\mathrm{o}] \mathrm{mo}$ aCulpa ames ma ComoSe

255 mostravadas folhas Corridas queaprezenta

va ej[u]ntamente visto Serem mulhe

res que $[\mathrm{e}]$ staõ fora $\mathrm{d}[\mathrm{e}]$ SuaCaza [e]mque

278 "aud" a" por "audiencia", conforme consta em FLEXOR, Ibidem, p. 37.

279 Ao que parece, o escrivão cometeu algum engano ao redigir o "a" final em "para". 


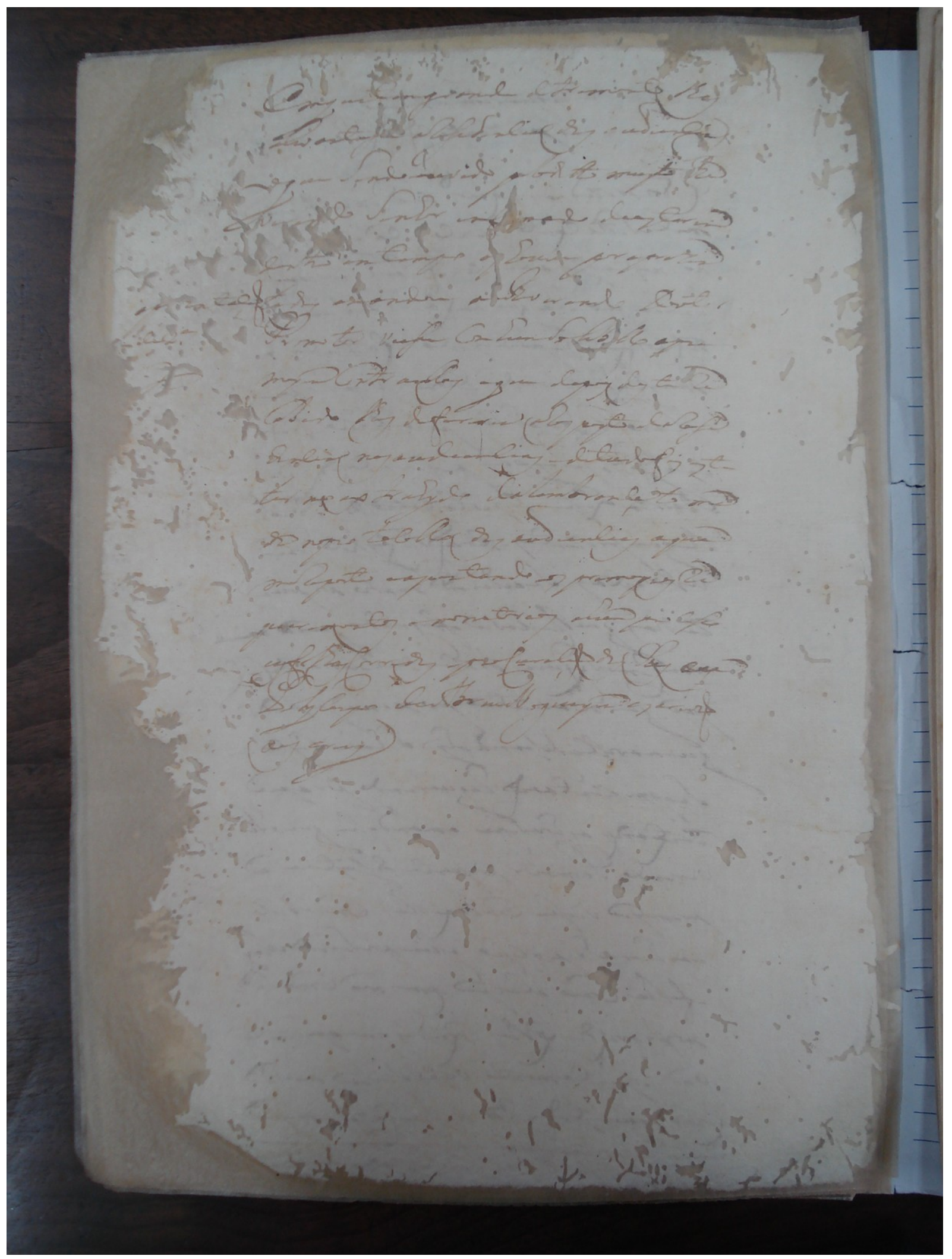


||8 v.

[[Emque]]tangrande detrimento lhes

alevant[asse] aresidencia das audiencias

260

oque Sendo ouvido peloditto muyto Re

ve[r]endo Senhor enf[or]mado deestarem

dentro emtempo o[q]ue houve por apreZen

$<$ ap[re]zentaçaõ $>$ tadas amandou a[o]Reverendo Doutor

$<\left[\mathrm{de}^{\mathrm{a}}\right]>\quad$ Promotor viesse Com humSolib[e]llo apri

$265<$ [ilegível] $>$ meyra Contr aellas eque depois des te re

Cebido lhes defereria arespeyto daresi

dencia nas audiencias edetudofis este

ter mo extrahydo dalembrança to ma

da nopro tocollo das audiencias aque

270

mereporto eajuntando os primeyros re

$\mathrm{q}[\mathrm{u}]$ erimentos emonitorios ahum processo

eas folhas Corridas eproCuraçaõ das Res eu ${ }^{280}$

PolyCarpo deAbreuNogueyra escrivaõ

oes crevy 


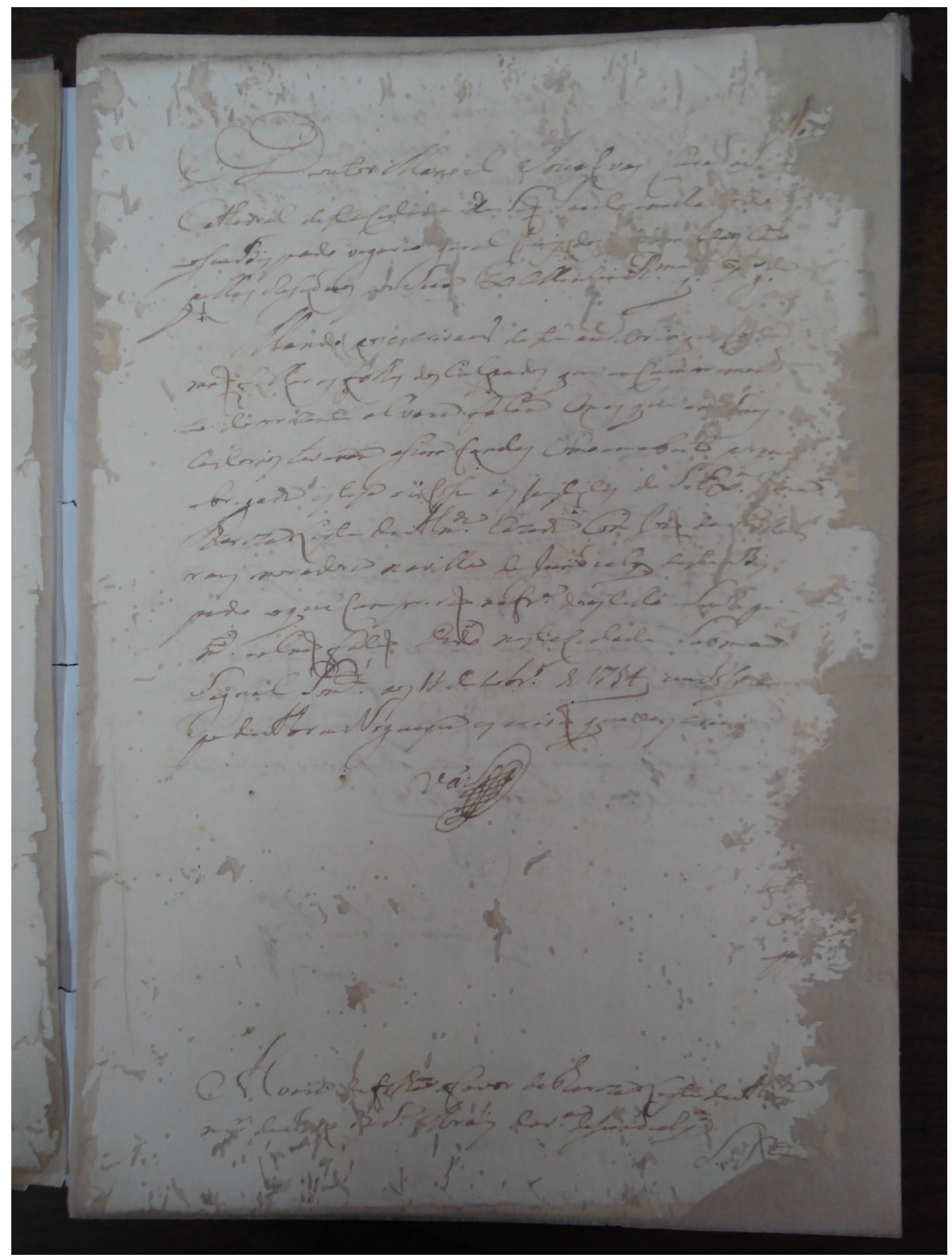


||9 r. $\|$

275

$<$ [corroído] $>$

ODoutor Manoel Iozeph vas CuradaSe

$<$ corroído $]>$

Cathedral destaCidad[e] $<\uparrow 9>$ de Saõ Paul[o] enella [eto]do

oseuBispado vigario geral Juis dos $[\mathrm{Ca}] \mathrm{z}[\mathrm{a}] \mathrm{m}[\mathrm{en}]$ tos $\mathrm{Ca}$

pellas eresiduos $\mathrm{p}[\mathrm{o}] \mathrm{rSua}$ ExCellenciaReverendissima ${ }^{281}$ que Deos guarde

[espaço]

280 Mando aos escrivaens deste auditorio qu[e] Cada

maõ fallar as folhas dos Culpados que emCumprimen

to dopreZente alvara falam Comos que e[m] Seus

Cartorios tiverem ${ }^{282}$ assim fendas Como emaberto porqu[e]

obrigada esteja o ufosse as Justicas de Sua Excellencia Reverendissima

285 ThereZa Leyte deAlmeyda Cazada Com Joaõ daSylva Mo

raes moradora navilla de Jundiahy deste Bis

pado oqueCumpriraõ naforma $\mathrm{a}^{283}$ do estillo eSeuregi

mento entraõ façaõ [espaço] Dado nestaCidade Sob meu

Signal Somente ${ }^{284}$ aos 11 de dezembro ${ }^{285}$ de1754 eeuPolyCar

290 podeAbreuNogueyra es crivaõ queoescrevy

$\underline{\text { váz[sinal público }]^{286}}$

Alvara defolha afavor deThereza Leyte deAl[m]eyda mulher ${ }^{287}$ deI[oa]õ daSylva Morais davilla dejundiahy

Signal S[om]mente

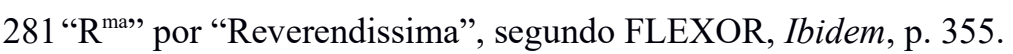

282 Aparentemente, o escrivão cometeu algum erro ao redigir o " $r$ " ou o "e" na sílaba "re", em "tiverem".

283 "fra" por "forma", segundo FLEXOR, Ibidem, p. 189.

284 "Som te" por "Somente", como consta em FLEXOR, Ibidem, p. 413.

285 "debr" por "dezembro", de acordo com FLEXOR, Ibidem, p. 116.

286 Punho de Manoel Iozeph Váz.

287 "'m" por "mulher", segundo FLEXOR, Ibidem, p. 256. 


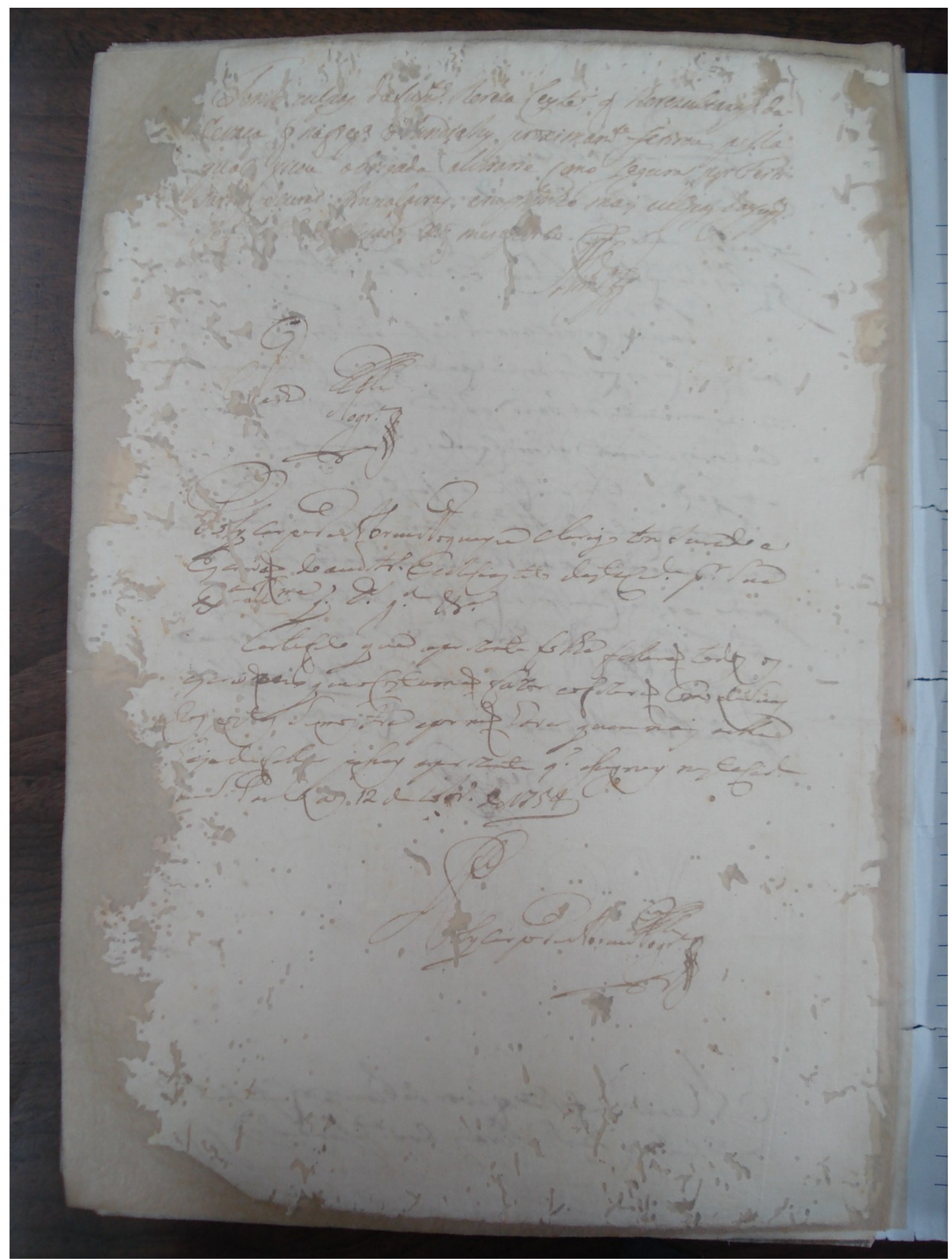


$\|9 \mathrm{v}$.

300 Tenho culpas daSupplicante ${ }^{288}$ Thereza Leyte que lherezultaraõ da devaca que nafreguesia $\mathrm{d}[\mathrm{eI}]$ undiahy proximamentesetirou pella qual ficou obrigada alivrarseComo segura por Fei[ti] sar[ias] ecurar empalavras enaõtenho mais culpas dasupplicante seguinte ${ }^{289}$ [trecho corroído] [p]ecados aque mereporto

$$
\text { [espaço] }
$$

Dada [sinal público $]^{291}$

$\underline{\text { Nogueyra }}^{292}$

[sinal público]

$$
\text { [espaço] }
$$

Poly carpodeAbreuNogueyra clerigo tonSurado e

310 Esc[ri]vaõ do auditorio Ecclesiastico destaCidade por Sua

Excelencia Reverendissima que Deos guarde Vossa Senhoria

$$
\text { [espaço] }
$$

Certifico que aprezente folha fallaraõ todos os escrivaens $^{293}$ que oCostumaõ faz[e]r eofizeraõ Como deSuas res postas Semostra epor naõ haver quemmais aelle

315 hajadefall[a]r passey aprezente que assigney nestaCidade deSaõ Paulo aos 12 dedezembro de1754

\section{$\underline{\mathrm{P}[\mathrm{o}] \mathrm{lycarpo} \text { deAbreuNogueyra }}$}

[sinal público]

288 "supp "te" por "supplicante", de acordo com FLEXOR, Ibidem, p. 420.

289 "seg ${ }^{\text {te" }}$ por "seguinte", conforme consta em FLEXOR, Ibidem, p. 394.

290 Até aqui, o punho é de Fernando Pinto de Almeyda, escrivão da Câmara Episcopal.

291 A partir daqui, o punho é do escrivão Polycarpo de Abreu Nogueyra.

292 "Nogra" por "Nogueyra", segundo FLEXOR, Ibidem, p. 286.

293 Inicialmente, Polycarpo de Abreu escreveu "escrivão", porém, percebendo o erro, redigiu a sílaba "aens" por cima do "õ". 


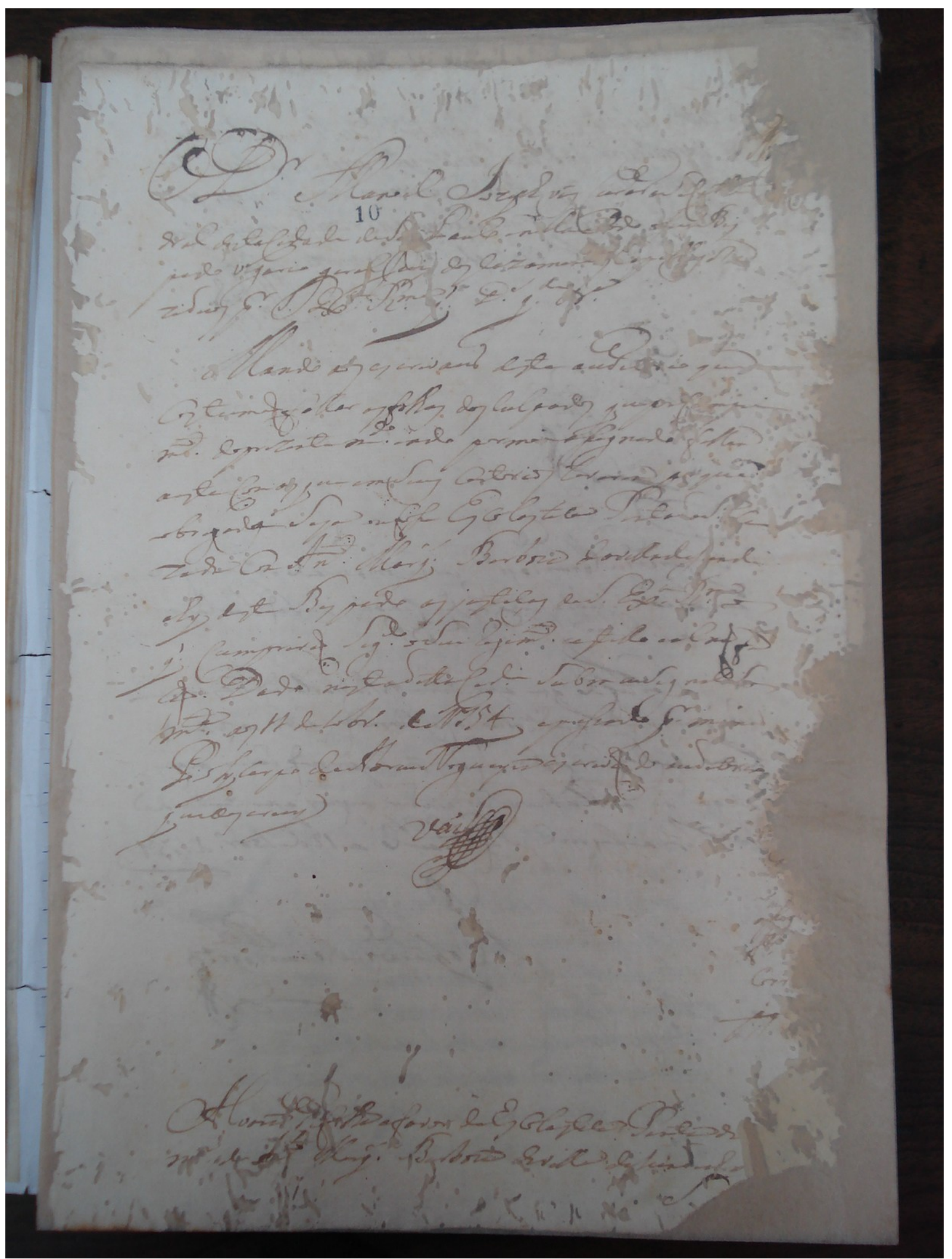


$<$ [corroído] $>$

320 ODoutor Manoel Iozeph vás CuradaSeCat[h]e

dral destaCidade $<\uparrow 10>$ deS[aõ] Paulo en[e]llae[to]do oseuBis

pado vigario geral Juis doscazamen[tos] Capell[a]s ere

ziduos por Sua Excelencia Reverendissima que Deos guarde [V]ossa Senhoria

[espaço]

Mando aos es crivaens deste audi[to]rio que

325 Costumaõ fallar as folhas dos Culpados qu[e] porC $[\mathrm{u}] \mathrm{mpri}$

mento doprezentemanda $\mathrm{do}^{294}$ indo por mi[m]assignado fallam

aestaCom os que emSeus Cartorios tiverem $\mathrm{p}$ [or] que

obrigados $^{295}$ Seja oufosse EsColastica Pinta[d]aSylva Ca

Zada Com Antonio Marques Barboza davilladej[u]ndi

330 ahy deste Bis pado as justiças daSua Excelencia Reverendissima o

que Cumpriraõ Segundo ${ }^{296}$ oSeu regimento eestillo entraõ fa

çaõ. Dado nestadittaCidade Sub meuSignal So

mente aos 11 de dezembro de1754 [espaço] epassado por $\mathrm{m}$ [im]

Polycarpo deAbreuNogueyra escrivaõ do auditorio

335 queoescrevy

$\underline{\text { Váz [sinal público] }}$

$$
\begin{aligned}
& <\text { af[a]z }> \\
& <\mathrm{f}[\text { ilegível] }> \\
& <\text { Corr[corroído] }>
\end{aligned}
$$

Alvara defolha afavor deEsColastica Pinta da[Sylva] mulher $\mathrm{d}[\mathrm{e}] \mathrm{A}[\mathrm{n}]$ tonio Marques Barboza davilla dejundiahy

Signal [Somente]

294 "mo" por "mandado", segundo FLEXOR, Ibidem, p. 254.

295 Ao que parece, o escrivão redigiu "obrigada", mas, posteriormente, corrigiu para "obrigados".

296 "Seg"do" por "Segundo", de acordo com FLEXOR, Ibidem, p. 393. 


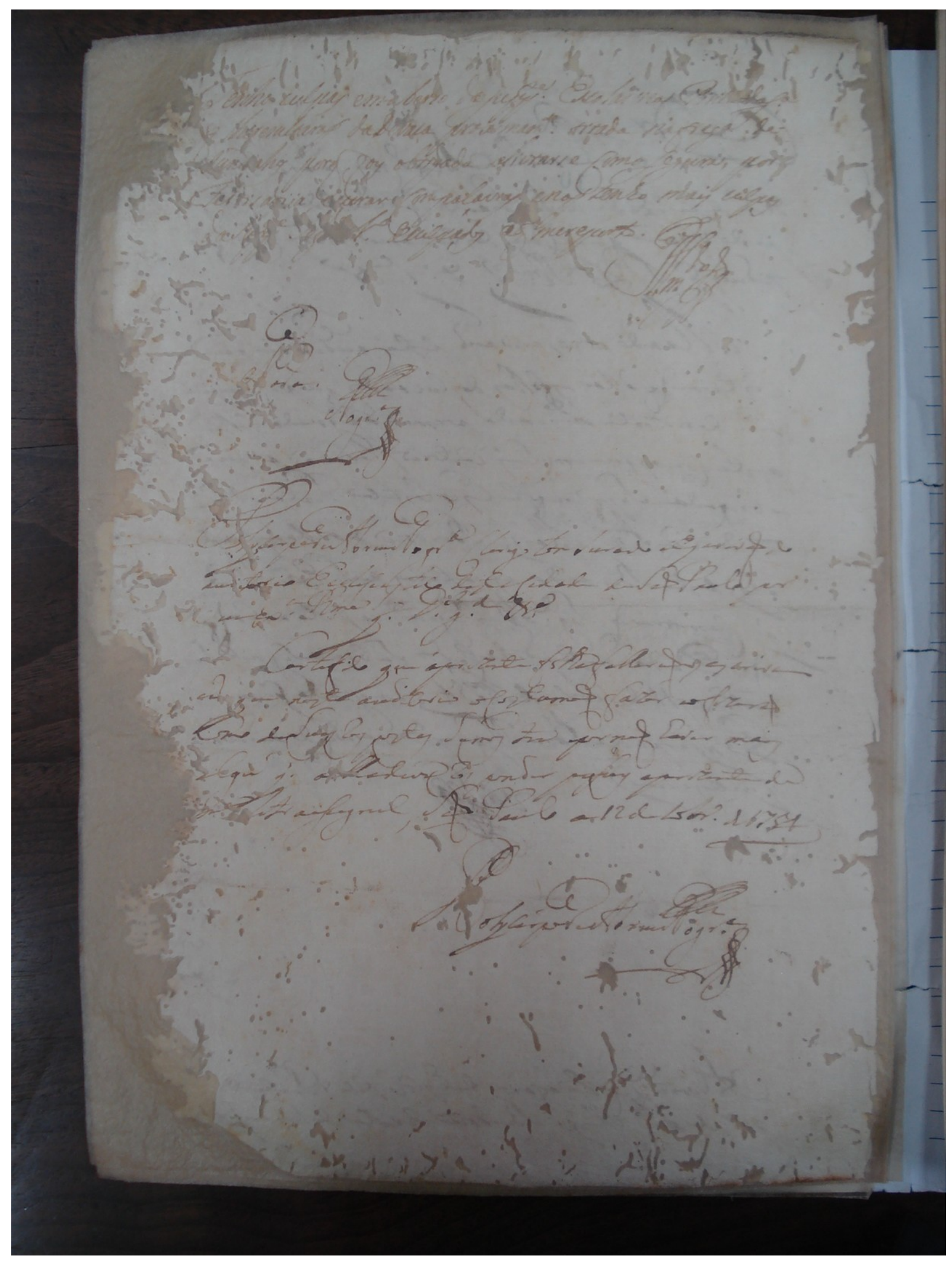


||10 v. $\|$

Tenho culpas em aberto dasupplicante Escolastica Pint[a] dasylva

345 que lheresultaraõ daDevaça proximamente tirada nafreguesia de Iund[i]ahy porque foy obrigada alivrarseComo segura, por Fei[t]isa[r]ia ecurar Compalavras enaõ tenho mais culpas das[upp]lican[t]e seguint[e] [corroído]o deculpados aque mereporto.

Almeyda [sinal público]

[espaço]

350 Dada [sinal público]

$\underline{\text { Nogueyra }}$

[sinal público]

[espaço]

PolycarpodeAbreuNogueyra Clerigo tonSurado eEscrivaõ do $\mathrm{au}[\mathrm{d}]$ itorio Ecclesiastico destaCidade deSaõ Paulo por

355 Sua Excelencia Reverendissima que Deos guarde VossaSenhoria

[espaço]

Certifico que aprezente folha fallaraõ os escriva ens que $\mathrm{n}[\mathrm{e}]$ ste auditorio oCostumaõ fazer eofizeraõ Como deSuas res postas Semos tra epor naõ haver mais algú que a[e]lledava res ponder passey aprezente de 360 minhaLetraessignal, Saõ Paulo a12dedezembro de1754 [espaço] [sinal público]

PolycarpodeAbreuNogueyra [sinal público] 


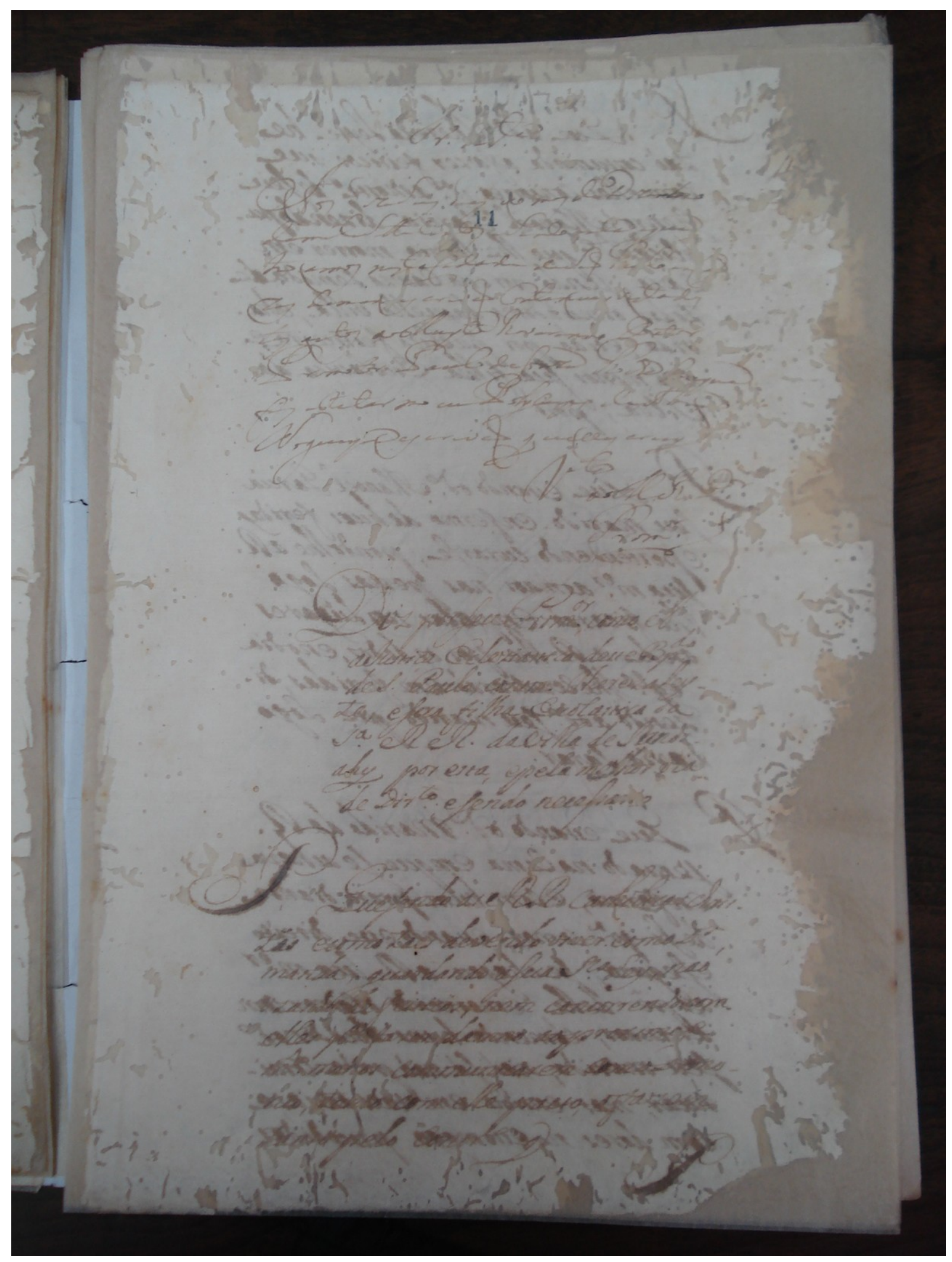


||11 r.

365

\author{
Termo [corroído]ta \\ [espaço]
}

Aos [d] ezeSeis dias do mes deDezembro

demileSettecentos $<\uparrow 11>$ eSinco [e]nta equa

tro annos nestaCidade deSaõ $\mathrm{P}[\mathrm{au}] \mathrm{lo}$ emCa

Zas demin escri[v]aõ Continuey vistades

370

375

tes autos aoMuyto Reveren[d]o Doutor

Promotor Paulo desouza Rocha [de]que

fis estetermo euPolycarpo de[A]bre[u]

Nogueyra escrivaõ queoes crevy

\section{Visto $^{297}$ aoMuytoReverendo Doutor}

$$
\text { [espaço] }
$$

Diz por seuPromotor, como eh ${ }^{299}$

aIustiça Ecleziastica deste Bispado

deSaó Paulo, contra TherezaLey -

te, esua filha $\mathrm{E}[\mathrm{z}]$ colastica da

380 Silva Rés ${ }^{45}$ davilla de Iundi -

ahy por esta, epela melhor via

de Direito esendo necessa[rio]

\section{[espaço]}

Provara Quesendo as Rés catholicas chris -

tãs ecomo taes devendo viver como Deus

manda; guardando asua Santa Ley, naó

vzando de feiticos, nem concorrendo com

elles po[r] fazer damno aoproximo, e

muyto menos communicarem com oD[e]mo -

nio, tendo com elle pacto, ofazem

390

tanto pelo contrario que
$<$ corroído $]>$

$<$ [corroído $]>$

$<$ corroído $]>$

$\mathrm{P}$

297 "V"to" por "Visto", de acordo com FLEXOR, Ibidem, p. 446.

298 Até aqui, o punho é do escrivão Polycarpo de Abreu Nogueyra.

299 A partir desta linha, o punho é do promotor Souza.

45 No manuscrito, a palavra está representada como "RR.”. Segundo E. Borges Nunes (1981: 73), a abreviatura "RR." era utilizada para as palavras "reos" ("réus"), "rees" ("rés") e "reverendos" (ou "reuerendos"), porém, foi utilizada entre os séculos XIV e XVII. Apesar de esta documentação pertencer ao século XVIII, o uso foi o mesmo, referindo-se às rés do processo em questão. 


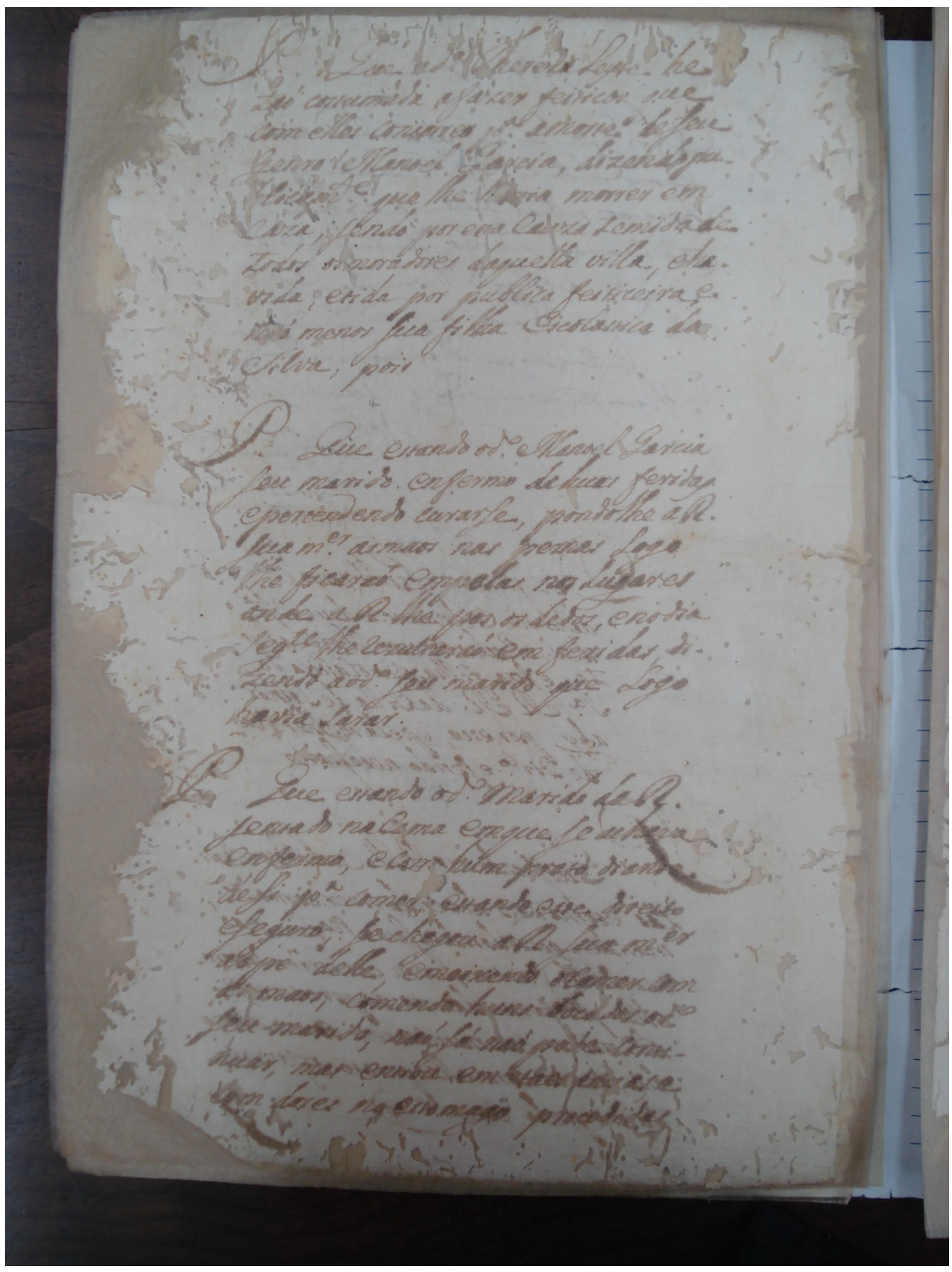


||11 v.

Provara [espaço] Que adita TherezaLeyte he taó costumada afazer feitiços que com elles concorreo para amorte deseu

395 genro Manoel Garcia, dizendo pu [b]licamente que lhe [ha]via morrer em caza, sendo por es [t]acauza temidade todos o[s] moradores daquella villa, eha vida, etida por publica feiticeira e

400 [na]ó menos sua filha Escolastica da Silva, pois

[espaço]

Provara [espaço] Que estando odito Manoel Garcia seu marido enfermo dehuas feridas epertendendo curarse, pondolhe a Ré

405 sua mulher as maos nas pernas Logo lhe ficaraó Empolas nos Lugares onde a Ré lhe pos os dedos, e nodia Seguinte lhe rezultaraó em feridas, di zendo aodito seu marido que Logo

410 havia Sarar.

[espaço]

Provara [espaço] Que estando odito marido daRé sentado nacama em que se achava enfermo, ecom hum prato diante desi para comer, estando este direito

415 eseguro, se chegou aRé sua mulher aopê delle, emeixendo ocomer com as maos, comendo $\mathrm{h}[\mathrm{u}] \mathrm{ns}$ bocados odito seu marido, naó só naó pode conti nuar, mas entrou em tae[s] an[c]ias e 420 com dores no estomago procedidas 


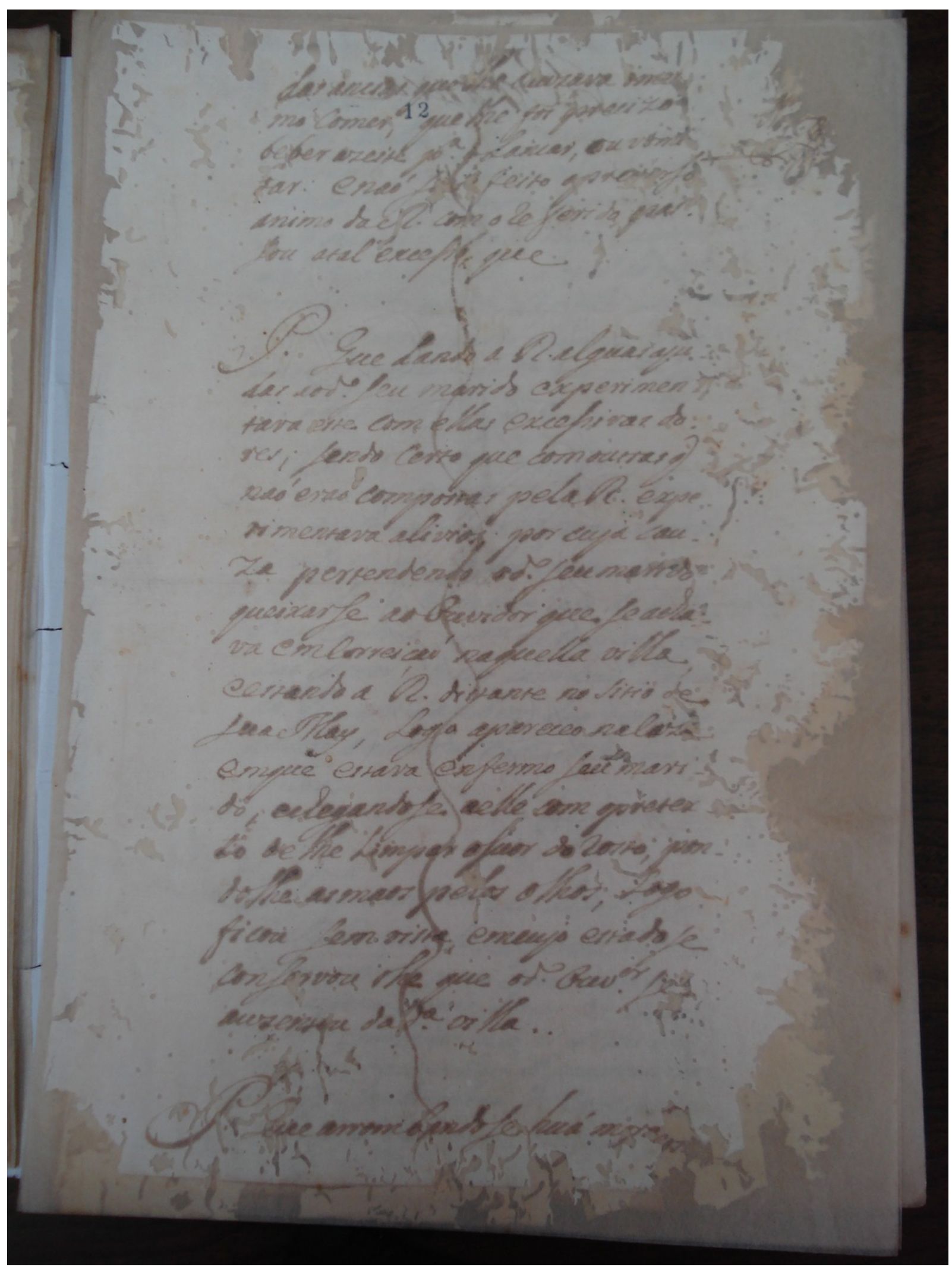


||12 r.

das ancias que lhe cauzava ome[s] -

mo comer, $<\uparrow 12>$ que lhe foi precizo $\quad<$ [corroído] $>$

beber azeite para [o]Lancar, ou vomi - <[ilegível] $>$

tar E naó s[corroído] feito opre[ve]rso

425 animo daRé com o referido pas -

sou atal excesso que

[espaço]

Provara Que dando a Ré alguas aju -

das aodito seu marido experimen -

tava este com ellas excessivas do

430 res; sendo certo que com outras que

naó erao compostas pelaRé expe

rimentava alivios, por cuja cau -

za pertendendo odito seu marido

queixarse aoOuvidor que se acha -

435 va emcorreiçaó naquella villa

eestando a Ré distante no Sitio de

suaMay, Logo apareceo nacaza

emque estava enfermo seu mari -

do, echegandose aelle com opretex -

440 to de lhe Limpar osuor do rosto, pon -

dolhe as maos pelos olhos, Logo

ficou sem vista, emcujo estado se

conservou the que odito Ouvidor se

auzent[o]u da dita villa.

[espaço]

445 Provara Que arrobandose huá mora[da] 


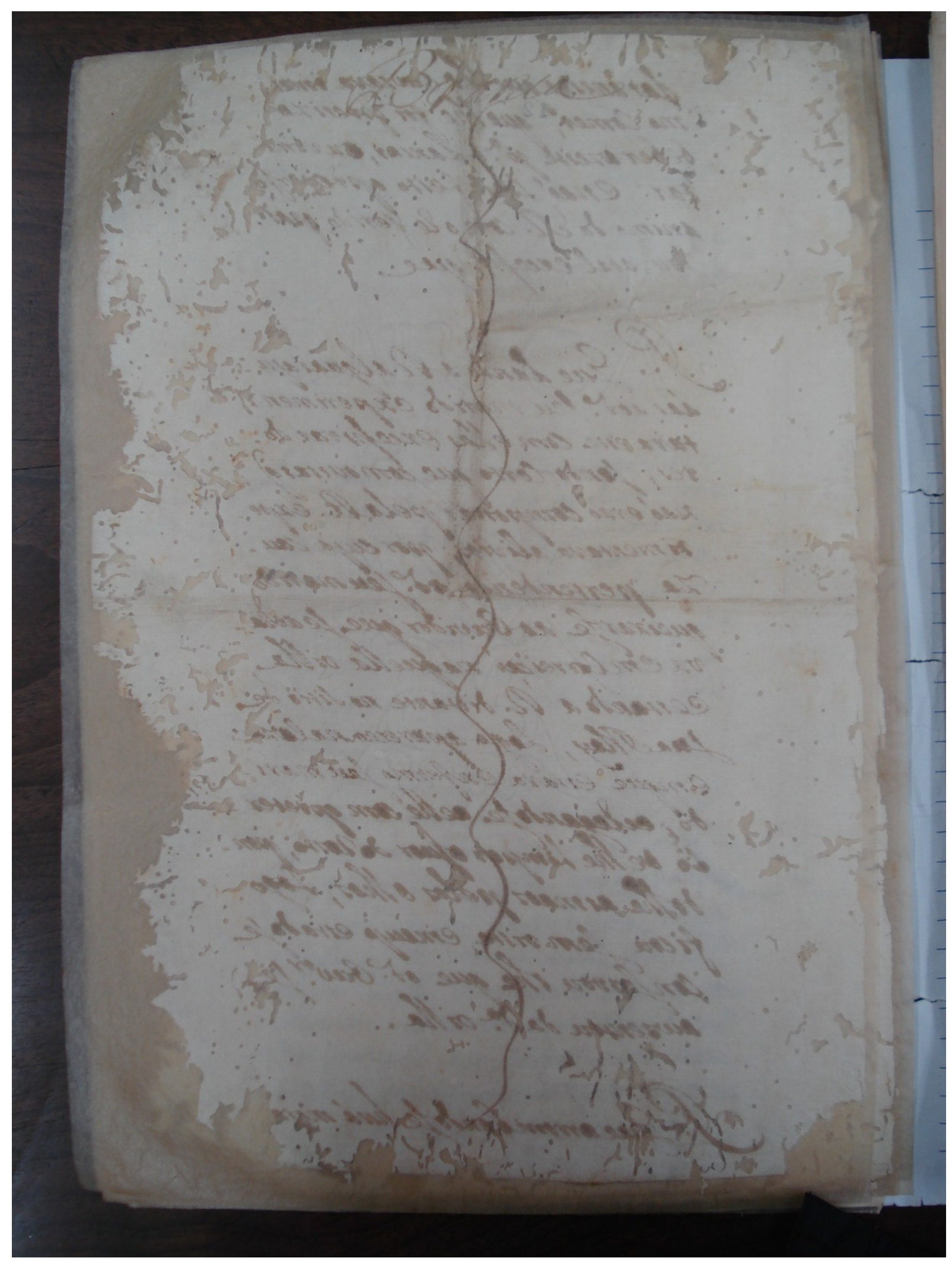


||12 v.

Branca

[linha espiralada na vertical] 


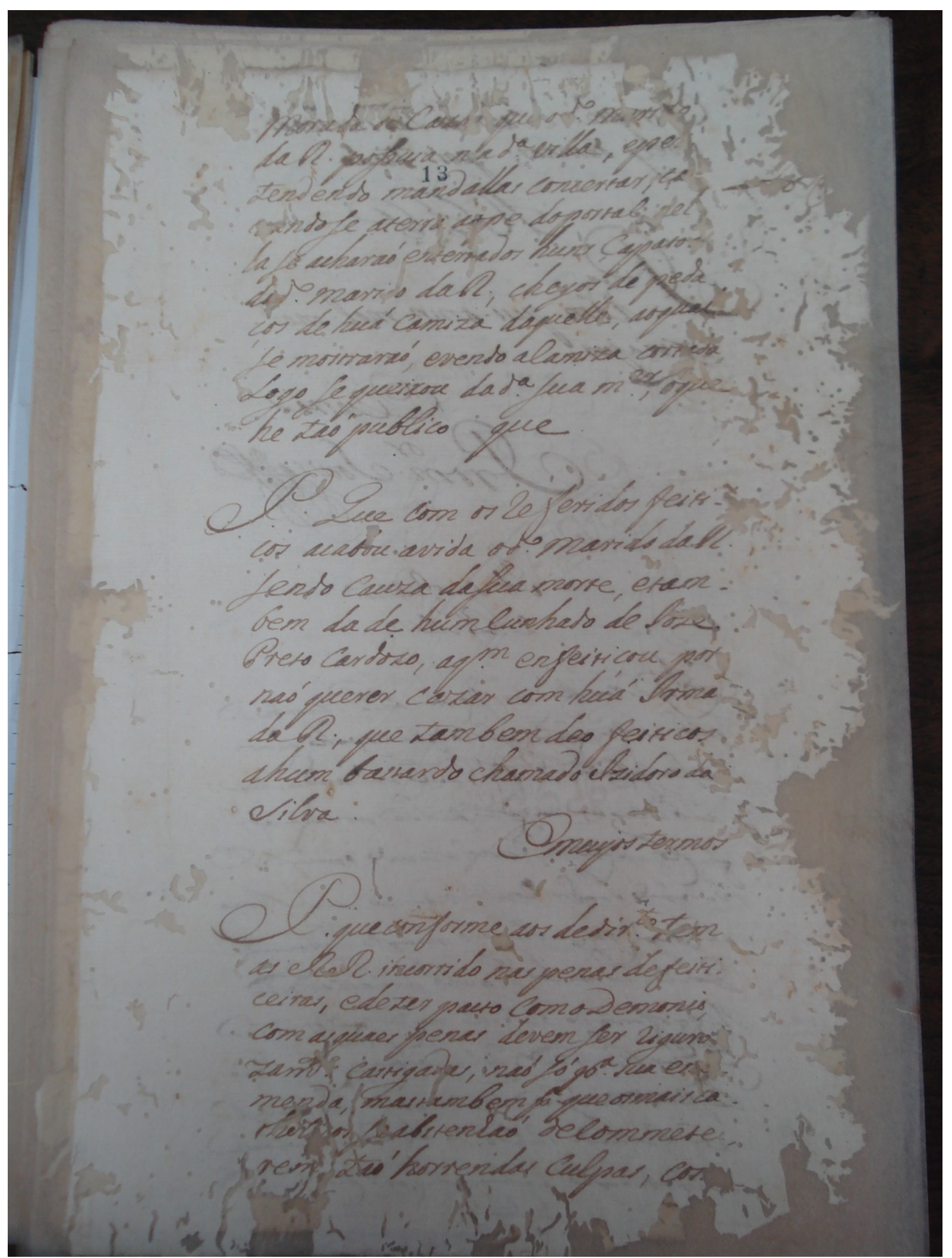


||13 r.

[[Morada]] d[e] caz[a] qu[e] odito m[a]ri[do]

daRé possuia $<\downarrow 13>$ na dita villa, epe[r]

tendendo mandallas concertar, ca

450 vandose aterra aope doportal nel

$<\uparrow[$ corroído $]>$

la se acharaó enterrados huns çapatos

do dito mari[d]o daRé, cheyos de peda -

ços de huá camiza daquelle, aoqual

se mostraraó, evendo acamiza cortada

455 Logo se queixou da dita sua mulher, oque he taó publico [espaço] que

[espaço]

Provara Que com os referidos feiti -

cos acabou avida odito marido daRé

sendo cauza dasua morte, etam -

460 bem da de humcunhado de Ioze

Preto cardozo, aquem enfeitiçou por

naó querer cazar com huá Irma

daRé, que tambem deo feiticos

ahum bastardo chamado Izidoro da

465 Silva.

\section{Emcujos termos \\ [espaço]}

Provara queconforme aos dedireito $\mathrm{t}[\mathrm{e}] \mathrm{m}$ as Rés ${ }^{48}$ incorrido nas penas defeiti ceiras, ede ter pacto com oDemonio,

470 com as quaes penas devem ser riguro zamente castigadas, naó só para sua e[m] menda, mas tambem para que os mais ca thol[i]cos s[e] abstenhaó decommete rem taó horrendas culpas, co[m]

48 No manuscrito, está grafado "RR.". 


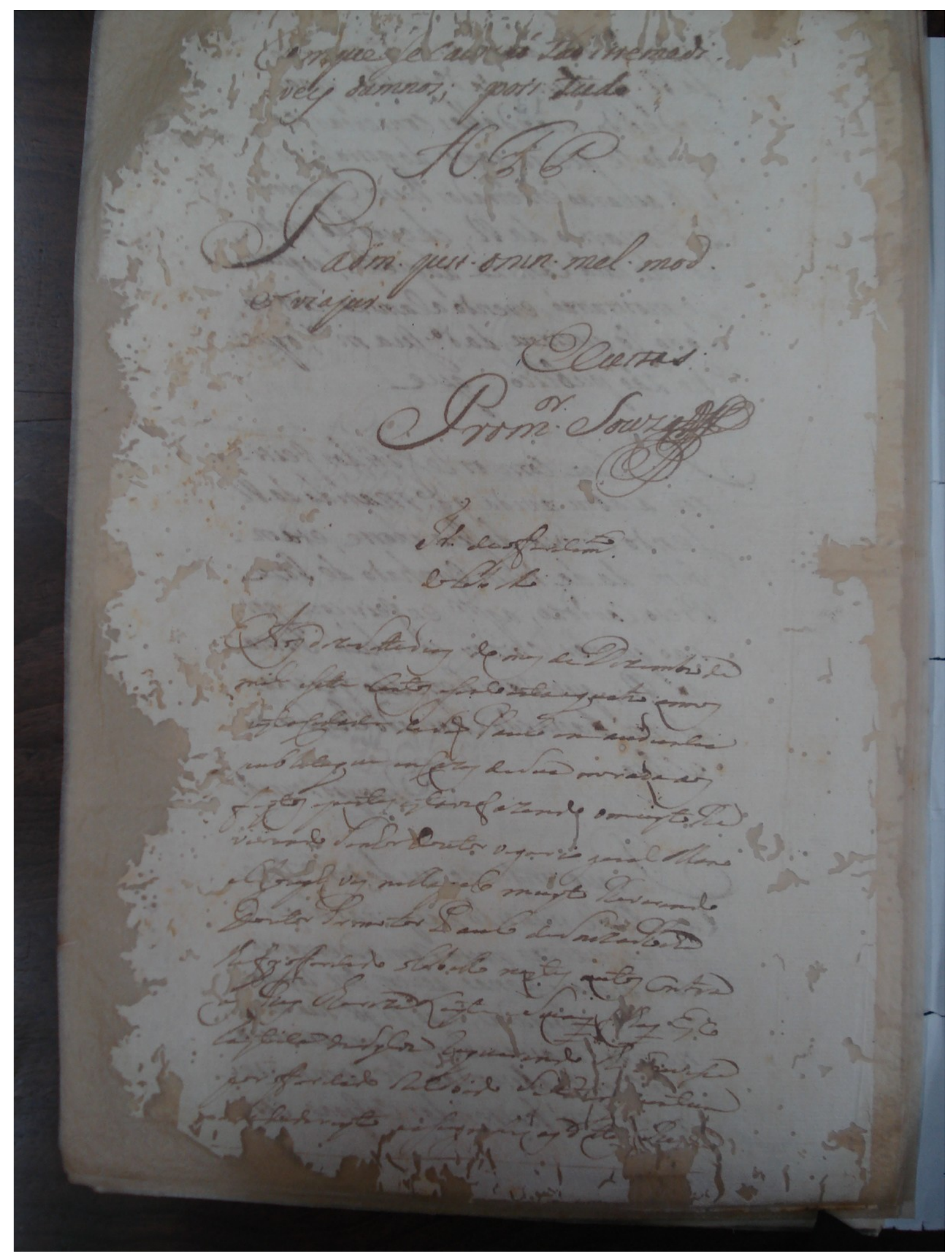


||13 v. $\|$

475 [[Com]]que seca[uzar]aó ta[ó] irremedi -

[a]veis damnos; [espaço] pois tudo

H. F. P.

[espaço]

Per administrare justitia onin melius $\bmod u s$

et viajuridica.

[espaço]

480

ECustas

Promotor Souza[sinal público]

[espaço]

Termo de offerecimento ${ }^{300}$

doLibelLo

[espaço]

Aos dezeSettedias do mes de Dezembro de

485 mil esette Centos esinco entaequatro annos

[n] estaCidade deSaõ Paulo em audiencia

publ[i]caque emCazas deSua moradaaos

feytos apostos estavafazendo o muyto Re

verendo SenhorDoutor vigario geral Mano

490 el Jo[z]eph vas nella[p]elo muyto Reverendo

Doutor Promotor Paulo desouzaRocha

lhefiz offerecido oLibello nestes autos Contra

as Res Thereza Leyte esuas [fil] has ${ }^{301}$ Esco

lastica daSylva requerendo ${ }^{302}[1] \mathrm{h}[\mathrm{e}]$ [ho]uvesse

495 por offerecido Recebido Siet in $\mathrm{q}[\mathrm{u}] \mathrm{antum}^{303}$

[e]radedireyto eassign[a]do as dittas $\operatorname{Re}[\mathrm{s}] \mathrm{d}[\mathrm{a}]$

300 A partir da expressão "Termo de offerecimento do Libello", o punho passa a ser do escrivão Polycarpo de Abreu Nogueyra.

301 O escrivão havia redigido ambas as palavras no plural: "suas filhas", mas inseriu alguns riscos nas duas letras "s", ao final das duas palavras.

$302 \mathrm{O}$ primeiro " $\mathrm{r}$ " na palavra "requerendo" foi redigido com uma nota tironiana, representada pelo número 2, no manuscrito original.

303 De acordo com o site "Jusbrasil", a expressão latina Si et in quantum significa "suficiente, ou tanto quanto bastante para ser admitido ou concedido, em caráter provisório." Disponível em: https://www.jusbrasil.com.br/topicos/295396/si-et-in-quantum/definicoes 


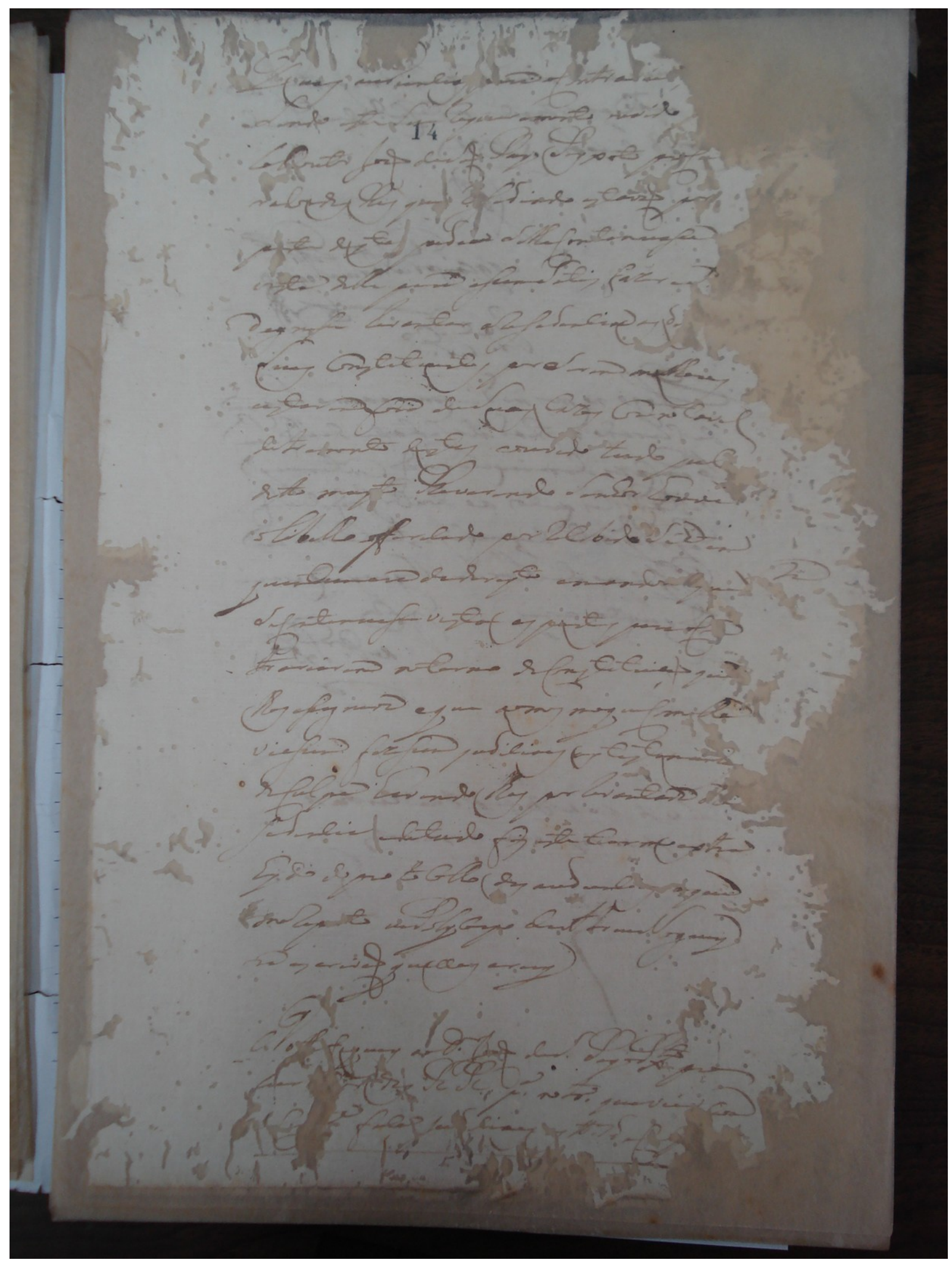


||14 r.

Duas audiencias $\mathrm{p}[\mathrm{a}] \mathrm{ra}$ oContra[r]io, Sendo este Seu requerimento ouvido

loDoutor joaõ $<\uparrow 14>$ deSaõ Payo Peyxoto $\operatorname{pr}[\mathrm{o}] \mathrm{Cu}$

500 radordas Res que r[e]sidindo estavaõ por

$\mathrm{p}[\mathrm{a}] \mathrm{rte}$ destas pediu dellaContinuasse

vista delle para assimSatis fazer e[corroído]

dignasse levantar aresidenciadas di[corroído]

Suas Constituintes por Serem mulheres

505 eestarem fora deSuas Cazas Com notavel

detrimento destas ouvido tudo pel[o]

ditto muyto Reverendo Senhor houve

olibello offerecido por recebido Síet in

quantumera dedireyto emando[u] [q]ue

$<\uparrow n>$

510 SeContinuasse vista as partes para $[\mathrm{o}] \mathrm{Co}[\mathrm{n}]$

trariarem notermo daConstituiçaõ qu[e]

lhes assignava eque aomes moqueComella

viessem fizessem judiciaes as testemunhas

daCulpa havendo lhes por levantada [Re]

515 sidencia edetudo fis estetermo extra

hydo do pro to Collo das audienci[a]s a que

merep[or] to euPolyCarpo deAbreuNoguey

ra escrivaõ queoes crevy

[espaço]

No[thi]fiquey aoDoutor j[oa]õ deSa ̃̃ PayoPeyxoto ${ }^{304}$ pro

520 Cur[ad]or das Res ${ }^{305}$ para no termo ${ }^{306}$ quevie[r] Com

$\mathrm{S}$ [corroído] faça ju[d]iciaes [a]s testemunhas ${ }^{307}$ daC[ulpa]

304 "Px" to" por "Peyxoto", de acordo com FLEXOR, Ibidem, p. 344.

305 "RR", no manuscrito original.

306 "tr" por "termo", segundo FLEXOR, Ibidem, p. 438.

307 "tt" 


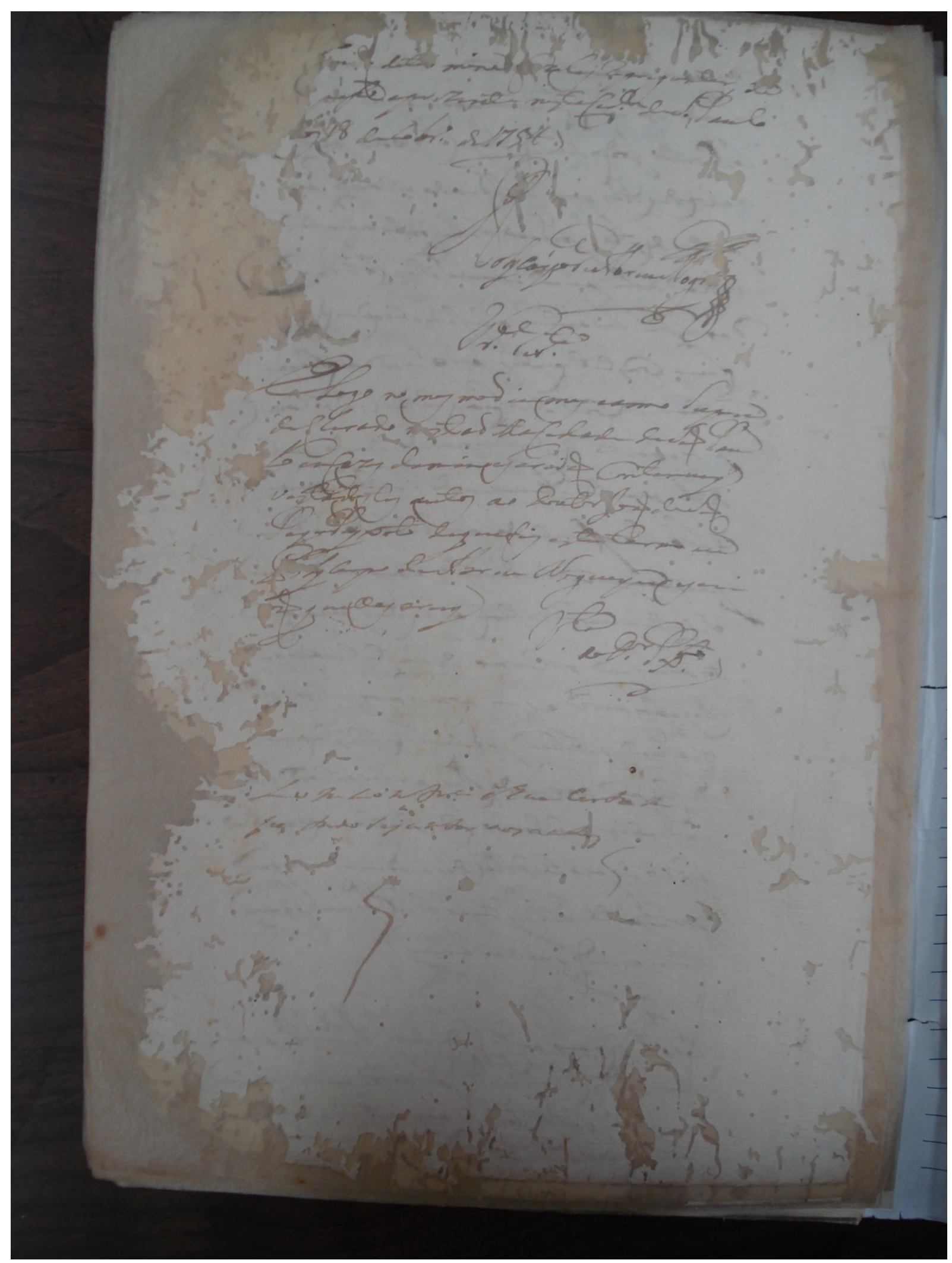




$$
\text { ||14 v. }
$$

[corroído]r[corroído]õ dete[r] mina f[a]zelas repreguntar [t]e passe aprezente nestaCidade deSaõ Paulo

[a]os 18 dedezembro de 1754

$$
\text { [espaço] }
$$

[sinal público]

\section{PolycárpodeAbreuNogueyr[a]}

[sinal público]

Termo devisita

$$
\text { [espaço] }
$$

ELogo no mes modiames eanno Supra

530 deClarado n[e]stadittaCidade deSaõ Pau

lo emCazas demin escrivaõ Continuey

vistadestes autos ao Doutor Joaõ deSaõ

PayoPeyxoto dequefis este termo eu

PolyCarpo deAbreu Nogueyra escri

535 [v]aõ queoescrevy

$$
\text { Vista aoDoutor Peyxoto }{ }^{308}
$$

\section{[espaço]}

Com contrariedade ehua certidam ${ }^{309}$

para tudo sejuntar aos aut[o]s

[risco]

540

[risco] 


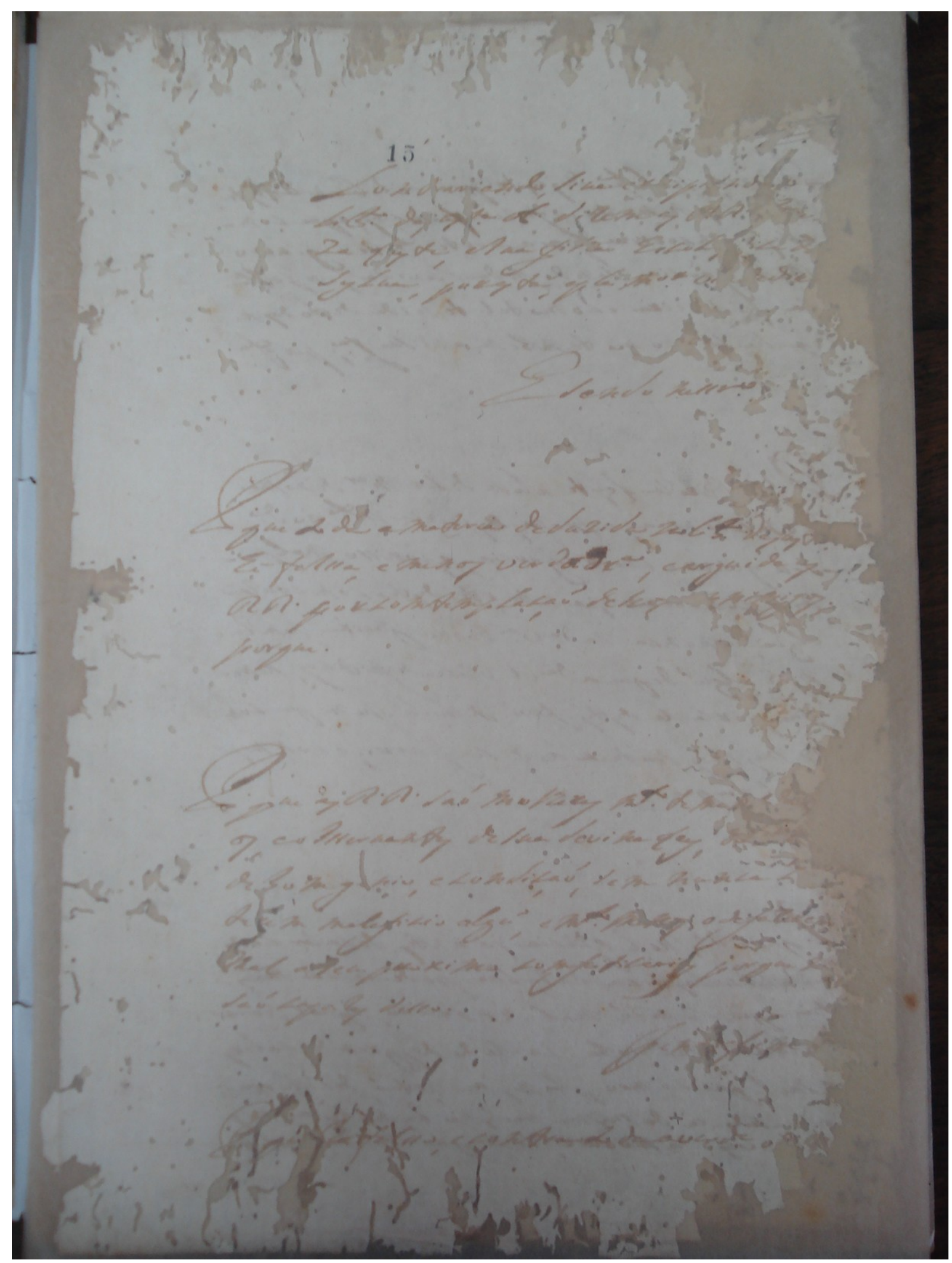


||15 r. $\|$

$$
<\text { [corroído }]>
$$

$<15>$

Contrariando, Siva[corroído]ip[corroído]nd[corroído] o

Libelo dajustiça Autora diZem as Rés ${ }^{310}$ [There]

$545 \mathrm{Za} \mathrm{L}[\mathrm{e}] \mathrm{yte}, \mathrm{eSua}$ fil[h]a EscoL[as]tica da

SyLua, poresta, epela melhor ${ }^{311} \mathrm{v}$ [corroído]dedir[corroído]

$$
\begin{aligned}
& \text { [espaço] } \\
& \text { E Sendo necessario }{ }^{312} \\
& \text { [espaço] }
\end{aligned}
$$

Provara que toda a materia deduzida no libelo dajust[iça] hé falssa, e menos verdadeira, earguida as

550 Rés por comtempLaçaó de seos [corroído] [i]ni[m]igos. porque.

$$
\text { [espaço] }
$$

Provara que as Rés saó molheres muito temi[corroído]

os, eobsservantes de sua devina Ley, [corroído]

de bom g[e]nio, e condiçaó, sem nunca [corroído]

555 te[r]em maleficio algú, e muito $\mathrm{m}[\mathrm{e}] \mathrm{n}[\mathrm{o}] \mathrm{s}$ o defaZere[m]

mal a[s]eu proximo comfeiticari[a]s porque [ilegível]

saó capaZes disso.

$$
\text { Fin [corroído] [ilegível] }
$$

[espaço]

Provara qu[e] he falsso, econtra todaaverdade

310 Nos manuscritos originais, o procurador das rés, Joaó de Saó Payo Peyxoto, sempre faz o uso da sigla "RR" ao escrever a palavra "rés" (plural).

311 A abreviatura " ${ }^{\text {or }}$ " pode ser desenvolvida em "maior" e "melhor". Aqui, optou-se pela segunda opção.

312 "ness ${ }^{\text {ro" }}$ por "necessario", segundo FLEXOR, Ibidem, p. 285. A autora, contudo, estabelece o uso dessa abreviatura entre os séculos XVI e XVII. 


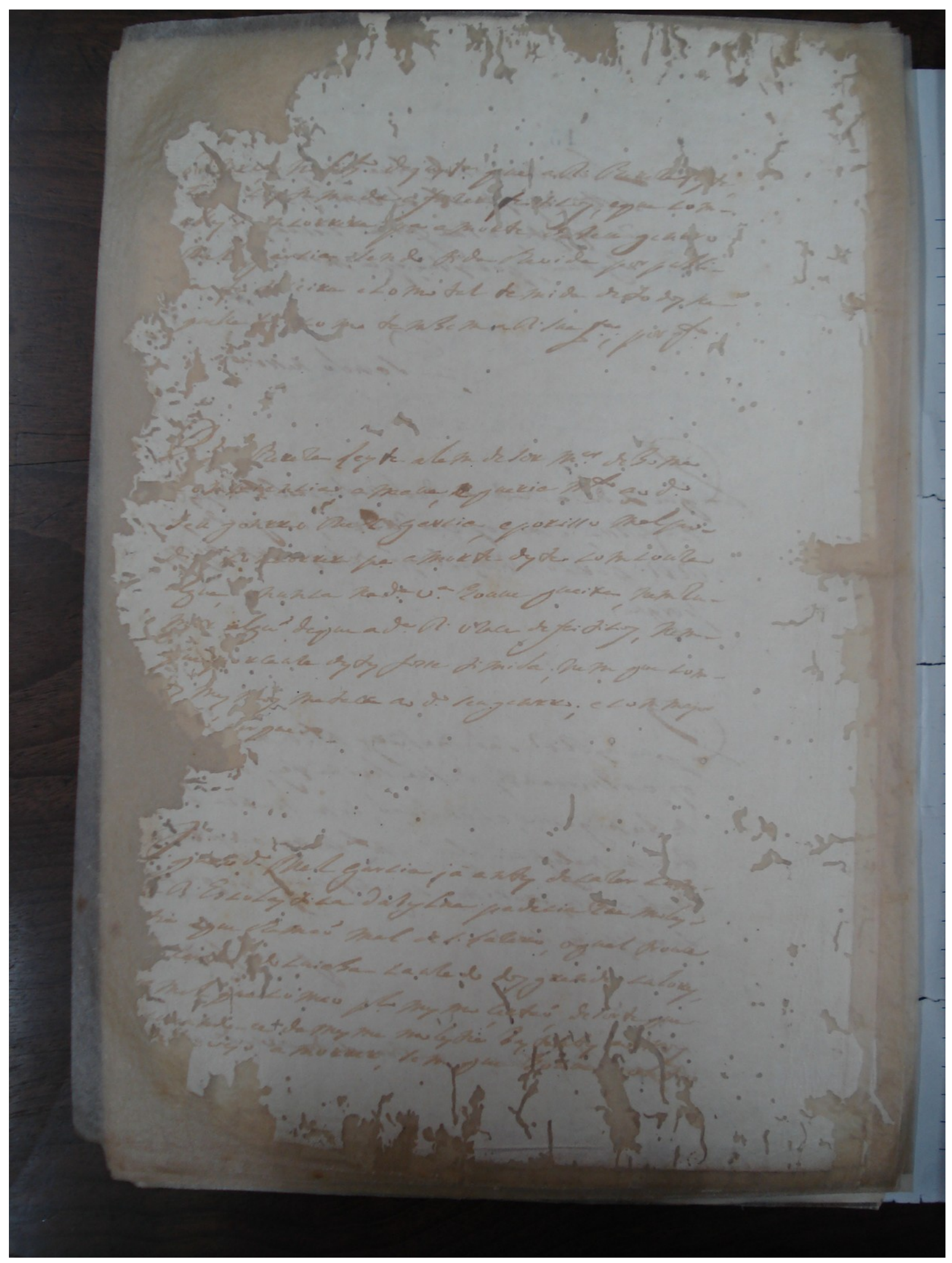


||15 v.

560 o d[i]Zerçe n[o]Libelo dajustiça que a Ré ThereZa[Ley]te, [he][corroído] c[o]stumada a f[a]Zer feitiços, eque com elles [co]ncorrera para amorte deSeu genrro Mano ${ }^{313}$ garcia sendo tida ehavida por publi ca feit[i]ceira e como tal temida detodos na-

565 quella v[ila] como tambema Ré sua filha ${ }^{314}$; por quanto

\section{[espaço]}

Provara q[ue] [corroído] ThereZa Leyte alem deser mulher de huma [corroído] [c]omciencia amaua, equeria muito ao dito seu genrro Manoel garcia, eporisso malpo di[corroído] co[mc]orrer para amorte deste com couZa

570 algúa, [e]nunca nadita vila houue queixa, nemru $\mathrm{m}[\mathrm{o}] \mathrm{r}$ algú deque a dita Re uZace defeiticos, nem [q]ue [p]or cauZa destes fosse timida; nem que com [corroído]os mesmos matasse ao dito seu genrro; e com major [corroído]ó [p]or qu[ilegível]

\section{[espaço]}

575 Provara qu[e] o ditto Manoel garcia já antes decaZar com

[a] Ré EscoLastica daSyLva padecia hua moles tia [a]que chamaó mal de saó LaZaro, oqual trouce [do] cer[taó] do cuiaba cauZa do dos grave de calores, [corroído] maL quecomeo pelo mesmo çertaó, desorteque

580 [corroído]ndo - ce da mesma molestia basta[n]tes a[nn]os [corroído] vejo a morrer, sem que ho[u]ue[corroído] [c]ontr[a] 


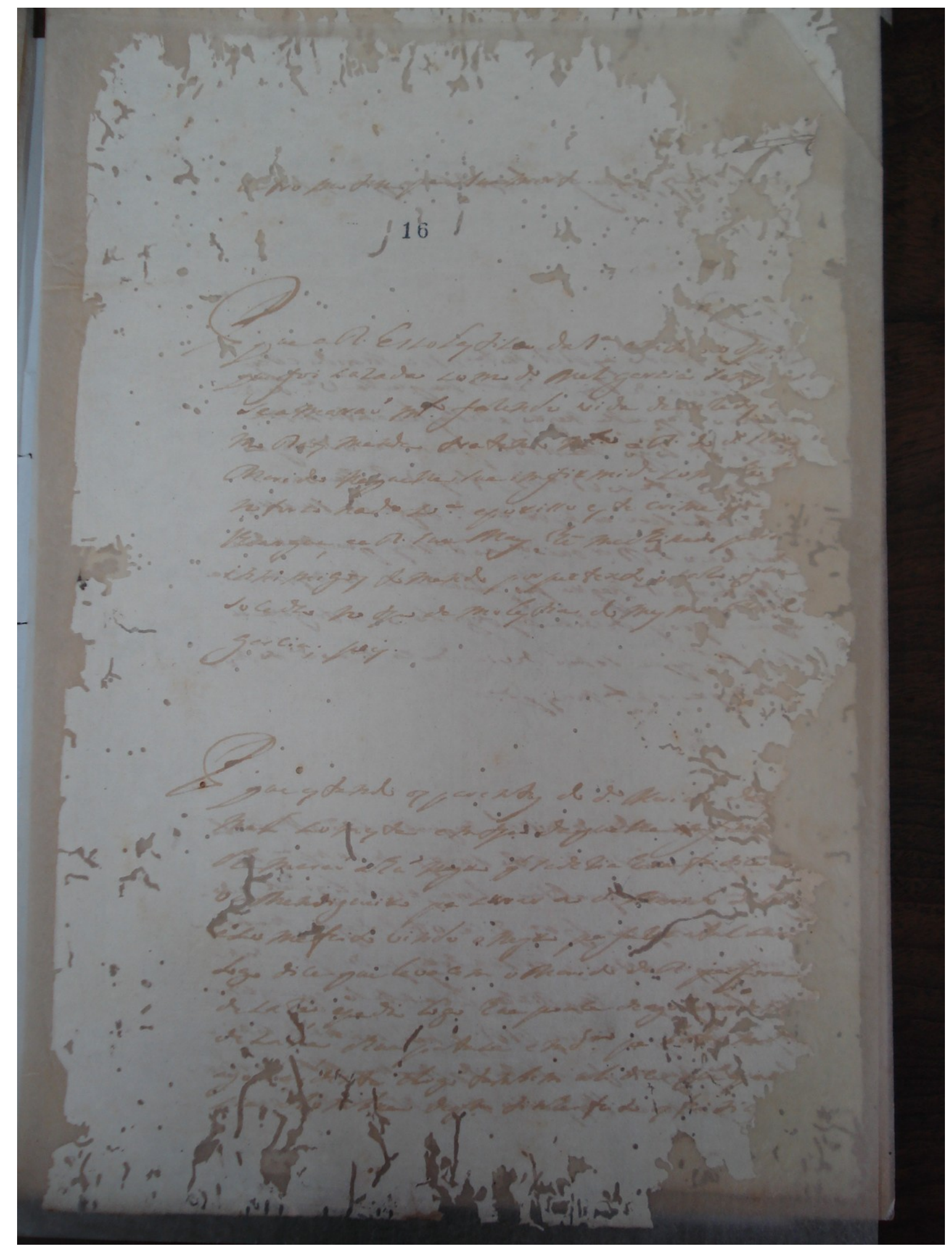


\|16 r. $\|$

$<[$ corroído $]>$

[ou]tro motivo paraaSuamorte.

$$
<16>
$$

[espaço]

585 Provara queaRé EscoLastica daSylva [ilegível]t[e] [corroído]o tempo ${ }^{315}$ que foi caZada como dito Manoel garcia semp[re] seamaraó muito faZendo vida decaZados [co] mo Deos manda tratan[d]o muito a Ré do dito s[eu] Marido naquella sua imfirmidade com[corroído]o [corroído]

590 notorio naditaVila eporisso este crime [para] $1 \mathrm{~h}[\mathrm{e}] \mathrm{argue}$, ea Ré suaMay hé machinado por [corroído] innimigos tomando por pertexto o caZo que socedeo no tempo damolestia do mesm[o] Manoel garcia; pois.

[espaço]

595 Provara que estando os parentes do dito Mari[do] da [corroído] maL com esta emtempo daquellaimfir[midade] ch[a]maraó ahú negro que sediZia hemfeitica vaMandigueiro para curar ao dit[o] Marido d[a] [Ré] ecomefeito vindo o negro para faZ[er] atal cura

600 Logo dice que levacem o Marido daRé para fora decaZa, epedio logo hua pouca de ago[a] arden[te] de cana ehua pataca em dinheiro para [ilegível]t[ilegível]m[corroído] ago[a] a[r]dente Logo tambem ali dice que [a]pa[corroído] c[i]a aSombra dequem tinha feito os feitic[os] 


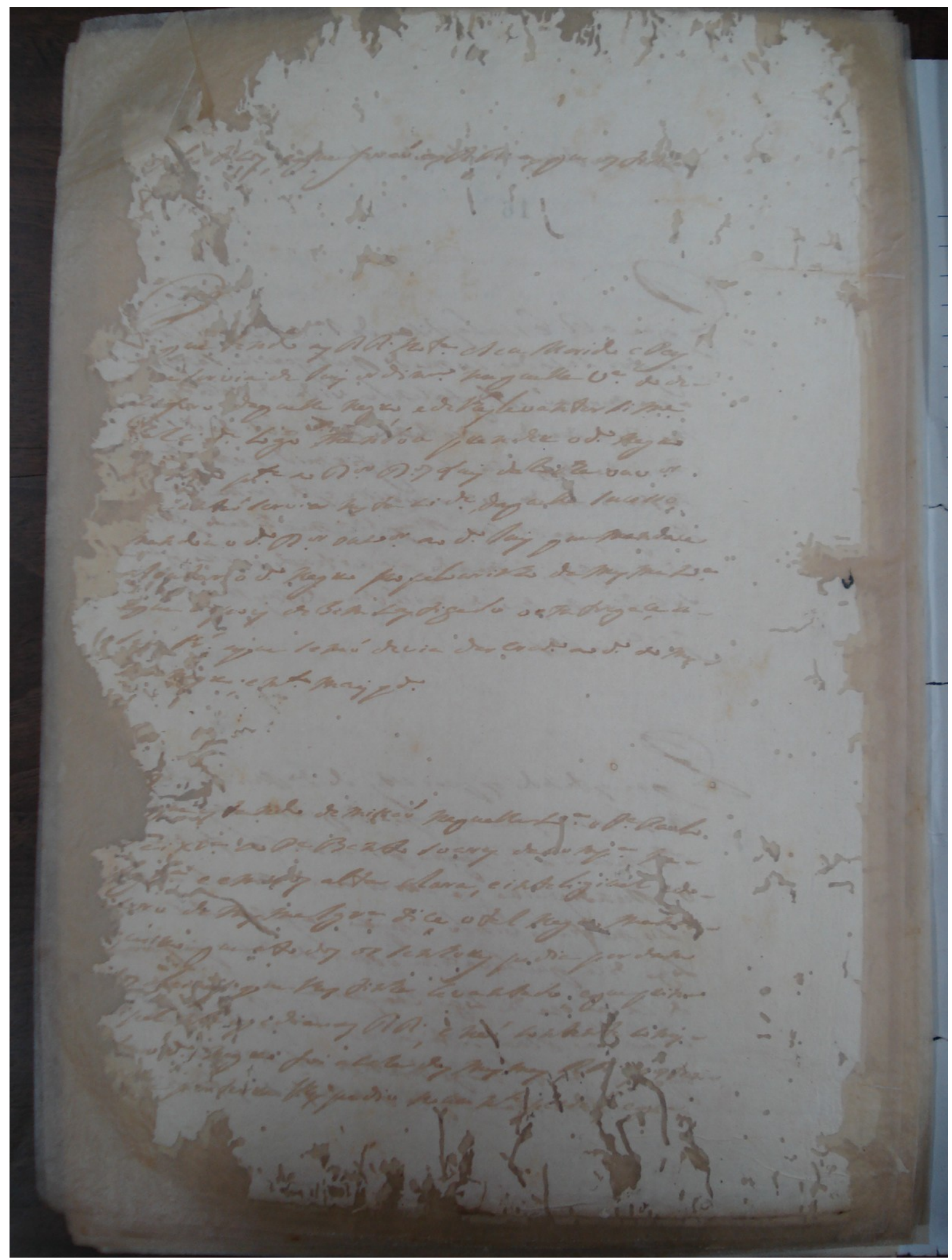


||16 v.

605 [[os feitiços]], equeforaó as Rés as que os t[corroído]

[corroído]o.

[espaço]

Provara que [t]endo as Rés noticia ${ }^{316}$ eSeu Marido e Pais

[corroído]e servia de Iuis ordinario ${ }^{317}$ naquella Vila do de -

$\mathrm{z}$ [a]foro daquelle negro, e de lhes levantar simelhant $\mathrm{e}^{318}$

610 [ilegível]Za dita Logo mandou prender o dito negro

[corroído]o parte ${ }^{319}$ ao Doutor Domingos ${ }^{320}$ Luis da Rocha ouvidor

[corroído] e[n]taó servia nesta cidade, daquelle sucesso,

mandou o dito Doutor ouvidor ao dito Iuis quemandace

aSoutar o dito negro no ${ }^{321}$ pelourinho damesma Vila

615 eque [de]pois de Bem castigalo o emtregaçe a -

a se[u] senhor eque se naó devia dar credito ${ }^{322}$ ao dito do mes -

[mo] negro; emuito mais quando

\section{[espaço]}

[Provara] que estando de missaó naquella Vila o Padre Paulo

Teixeira ${ }^{323}$ ao Padre Bento soares da[c]ompanhia ${ }^{324}[\mathrm{n}] \mathrm{a}-$

620 Igreja e em [v]os alta clara, e inteligiuel edo -

coro da $\mathrm{m}$ [e]smaIgreja dice o tal neg[ro] man[di] -

gueiro queatodos os senhores pedia perdam

[pel]os alei[ves] que lhes tinha levantado equeprin -

[c]ipalmente pedia as Rés, e naó contente comis -

625 [to] o dito negro foi a caZa das mesmas Rés [corroído]postran -

[corroído][e] por terra lhes pedio nouamente pe $[\mathrm{r}] \mathrm{da}[\mathrm{m}] \mathrm{eq}[\mathrm{u}] \mathrm{e}$

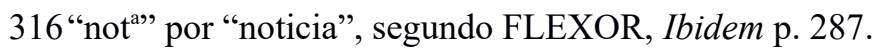

317 “ordin ${ }^{\text {ro" }}$ por "ordinario", segundo FLEXOR, Ibidem, p. 300. A autora, no entanto, estabelece o uso de tal abrevitura somente para os séculos XVI e XVII.

318 "sime" "por "similhante", segundo FLEXOR, Ibidem, p. 401.

319 "p p" por "parte", de acordo com FLEXOR, Ibidem, p. 311.

320 "D ${ }^{\text {os" }}$ por "Domingos", segundo FLEXOR, Ibidem p. 107.

321 Ao que parece, o escrivão cometeu um erro e redigiu um "p" ao invés de um "n" em "no", porém, corrigiu o equívoco.

322 "cred" por "credito", segundo FLEXOR, Ibidem, p. 103.

323 "Teixr r" por "Teixeira", segundo FLEXOR, Ibidem, 426.

324 “comp" por "companhia", de acordo com FLEXOR, Ibidem, p. 84. 


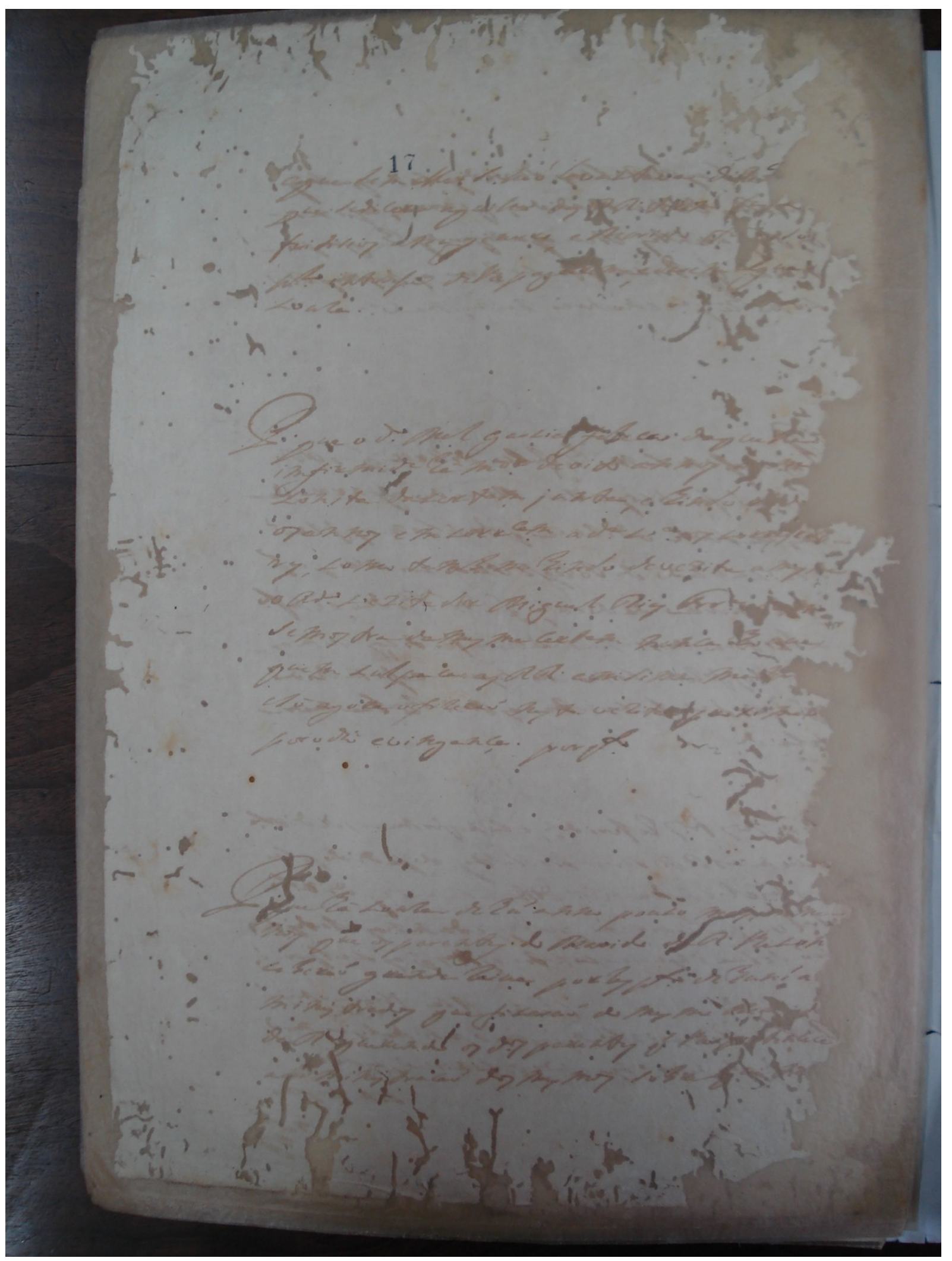


\|17 r.

$<17>$

[[eque]] sem elle senaó Levantava diZ[e][corroído]

que sedicera aquillo das Rés te[re]m fe[ito]

630 feitissos aSeu genrro, e Marido f[corroído] so

pelo interesse delhe pagarem, e darem algua

couZa

\section{[espaço]}

Provara que o dito Manoel garcia faLeceo daquella imfirmidade há maior de oito annos [co]m[o]

635 consta dacertidam ${ }^{325}$ junta, e hindo [corroído]do[corroído] os annos em correicam a dita Vila os corregedo res, como tambem hindo de veZita a mes[corroído] o Reverendo VeZitador Miguel Dias Ferreira ${ }^{326}$ [co]mo se mostra da mesma certidam nunca houue

640 quem culpa ce as Rés em Simelhante mate[ria] eSó agora o fiZeraó nesta veZita proxim[a] por odio e vingança por quanto

\section{[espaço]}

Provara quehá couZa de hú anno pouco m[ai]s [ou] me nos que os parentes do Marido d[a]Ré lhecon

645 ceberaó grande raiua por respeito de hunś a[d] ministrados que ficaraó do mesmo $\mathrm{Ma}[\mathrm{ri}] \mathrm{d}[\mathrm{o}]$ da Ré querendo os ditos parentes que lhe $\mathrm{p}$ [er]tencece aadministracaó dos mesmos sobreque t[iveraó] 


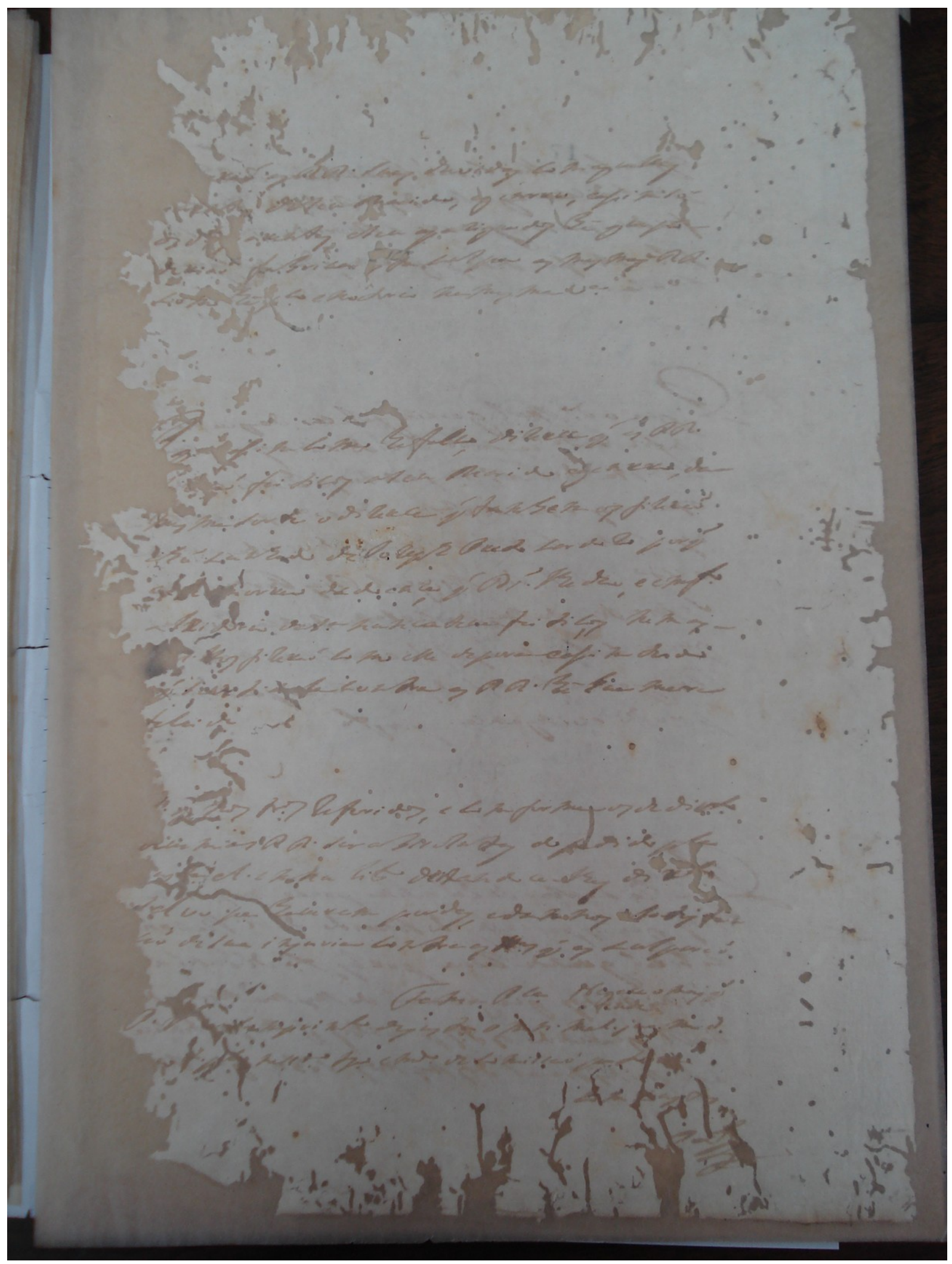


||17 v. $\|$

[[[tive]raó]] as Rés suas duvidas com aquelles

$650[\mathrm{p}] \operatorname{ar}[\mathrm{en}] \mathrm{t}[\mathrm{es}]$, deSeu Ma[r]ido, egenrro, eassim so -

[corroído] os d[itos] [p]arentes eSeu apaziguados hé que po -

deriaó fabrica[r] [e]sta culpa as mesmas Rés [corroído]

como hé publico ${ }^{327}$ e notorio na mesma Vila

[espaço]

Provara $\mathrm{q}[\mathrm{ue}]$ assim como hefalço diZerce que as Rés

655 [corroído]aó feiticos aSeu Marido egenrro, da mesmasorte o diZerce que tambem os fiZeraõ

ahú cunhado de IoZeph Preto cardoZo porque

[e][corroído] [m]orreo de doença que Deos ${ }^{\text {r28 }}$ lhe deo, e emuito

a Izidorio daSylva nunca teue feitiços nem as -

660 [corroído]i lhos fiZeraó como elle depora eassim tudo

que s[ilegível]ti[ilegível]la contra as Rés hé hua mera

falcidade

\section{[espaço]}

[ilegível] nos termos ${ }^{329}$ referidos, e comforme os de direito

[corroído]com as Rés ser abssolutas ${ }^{330}$ do pedido pela

665 [I] us[tiç]a Autora emSeulibelo ${ }^{331}$ deixando ce lhes direito

Salvo para hauerem perdas, edannos [e]Satisfa -

[ç]aó de sua injuria contra as testemunhas que as culparaó

[espaço]

Fam[a] Publica Negace o mais que
Pude

670 Para [corroído] cumprimento dejustiça o [ilegível] mal [ilegível]mo

[corroído]o [corroído] pelo necessario ${ }^{332}$ tempo emandado de comissaó para t[corroído]

com cust[a]s

[rubrica]

[sinal público]

327 "po" por "publico", segundo FLEXOR, Ibidem, p. 307.

328 "Dś" por "Deos", de acordo com FLEXOR, Ibidem, p. 147.

329 "t $\mathrm{t}$ "os" por "termos", segundo FLEXOR, Ibidem, p. 424.

330 No volume 1 de seu Diccionario da lingua portugueza, Antonio de Moraes Silva (1813: 15) oferece diversos significados para a palavra "absoluto", dentre eles "livre de pena" e "Absolvido de peccados". 331 "lib" por "libello", conforme consta em FLEXOR, Ibidem, p. 247.

332 "ness ${ }^{\text {ro" }}$ por "necessario", segundo FLEXOR, Ibidem, p. 285. Contudo, a autora estabelece o uso da presente abreviatura somente para os séculos XVI e XVII. 


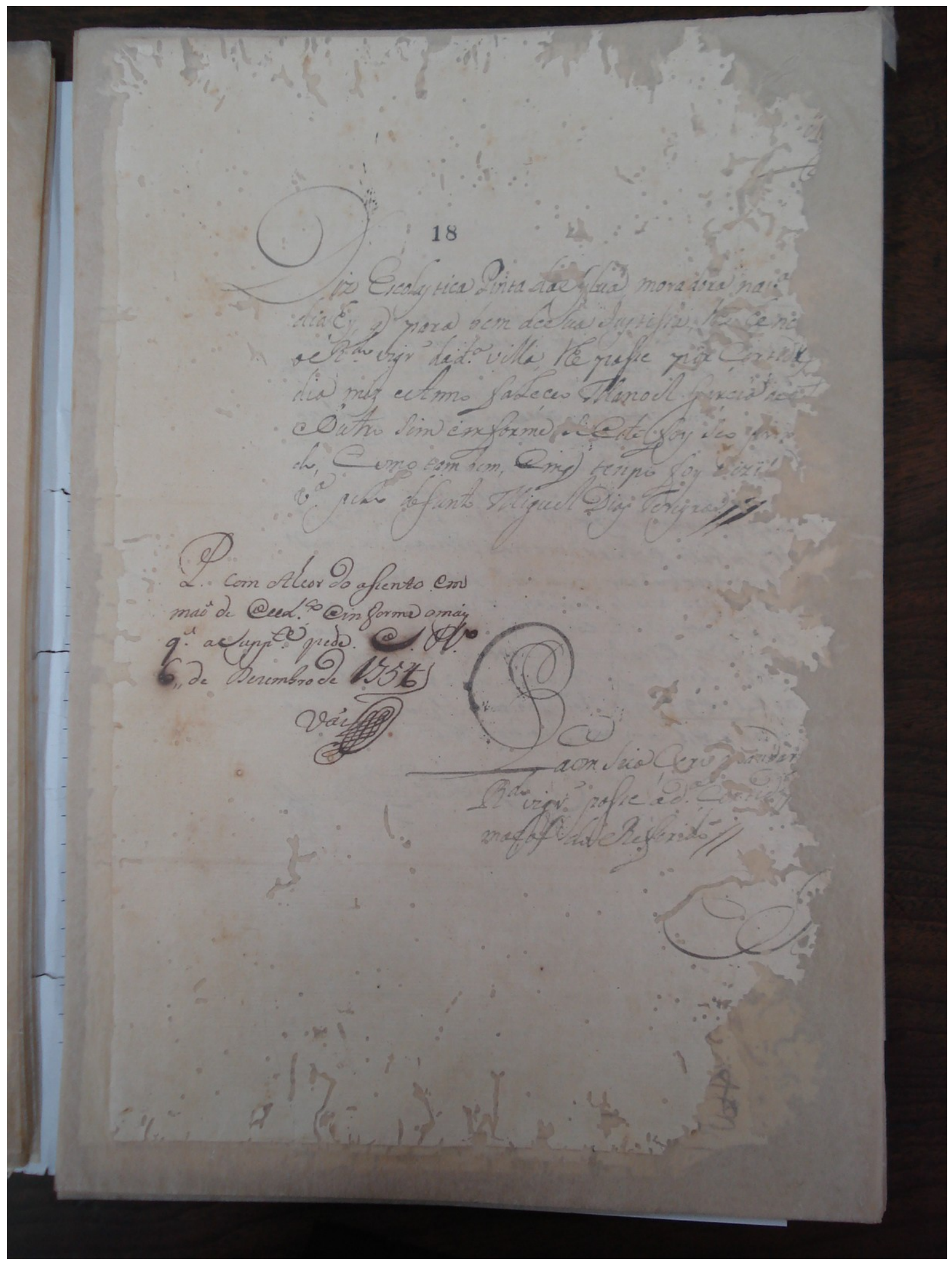


||18 r. $\|$

675

$<$ [corroído] $>$

$<$ corroído $]>$

[espaço]

$<18>$

[espaço]

Diz EscoLastica Pinta daSylua moradora na[v]illa [de Iun] ${ }^{333}$

diahy, que para bem deSua Iustissa, [1ha] he ne[corroído]

680 oReverendo vigario da dita ${ }^{334}$ villa, lhe passe por Çertidaõ dia mez eAnno faLeçeo Manoel Garçia de[corroído] eOutro Sim emforme [Se]Cité foy Seo pri[corroído] do, Como tam bem, Emque tenpo foy [v]izi[t][corroído] villa peLo defunto Miguel Dias Fereyra

\section{[espaço]}

685 Para com Accor do assento $\mathrm{em}^{335}$

maô de [ilegível] ein forme o mais

que aSupplicante pede. Saó Paulo ${ }^{336}$

6 , de Dezembro de $1756^{337}$

\section{Váz [sinal público]}

\author{
Paraaem Seio Çerio [m]andar ${ }^{338}$ \\ Reveren $\mathrm{d}[\mathrm{o}]$ vigario passe adita Çertida[õ] \\ moçaõ doReferido
}

[espaço]

333 Neste parágrafo, o punho passa a ser do escrivão desconhecido 1 .

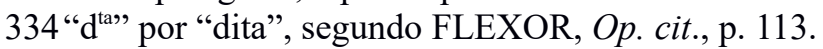

335 Este parágrafo foi redigido por Manoel Iozeph Váz.

336 "S P1" por "Saó Paulo", de acordo com FLEXOR, Ibidem, p. 414.

337 O número 6, em "1756", foi redigido por cima de um número 4.

338 A partir daqui até o final do manuscrito, o punho volta a ser do escrivão desconhecido 1 . 


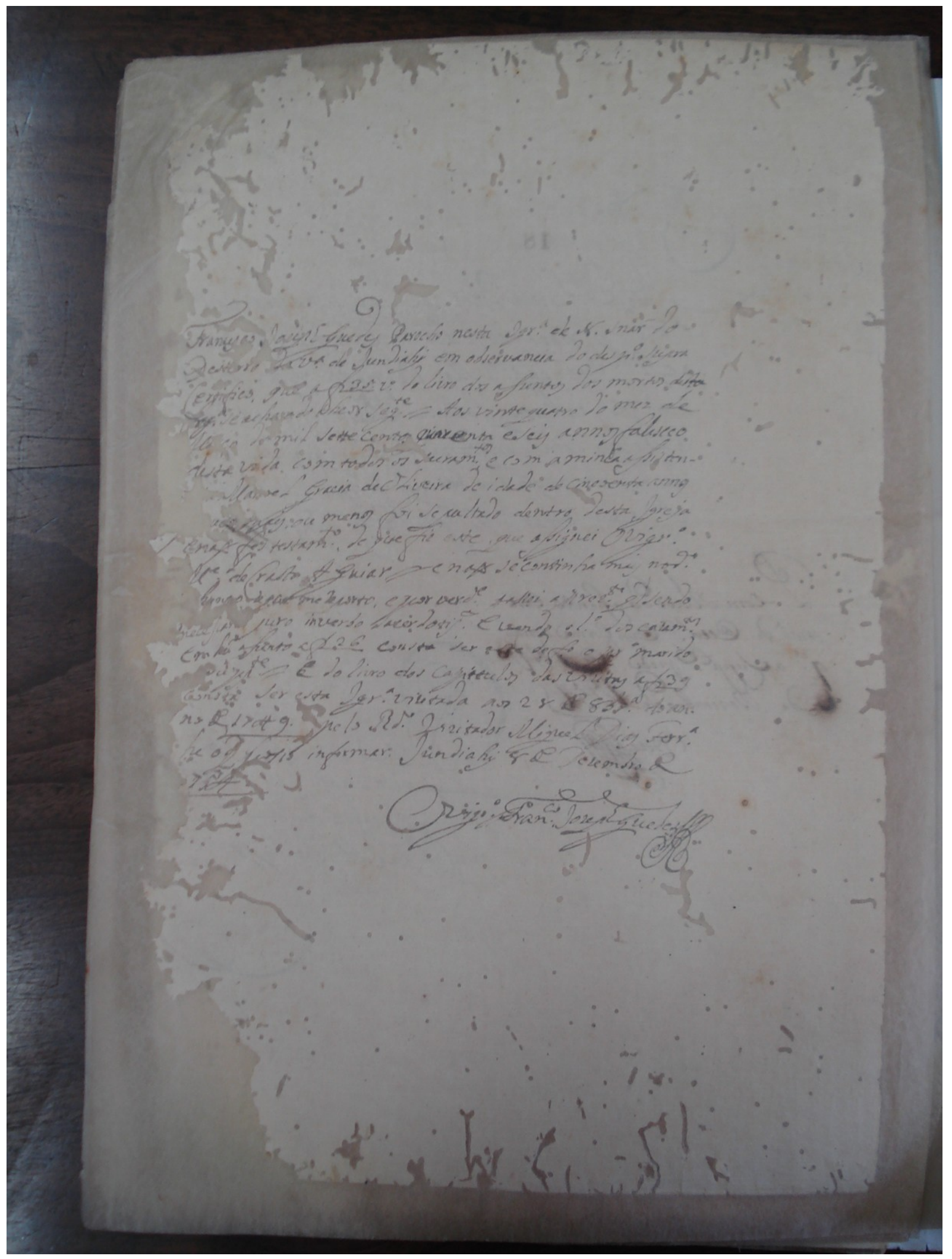


||18 v.

[espaço]

Francisco Ioseph Guedes Parocho nesta Igreja de Nossa ${ }^{339}$ Senhora $^{340}$ do

695 Desterro d[a] Villa de Iundiahy em observancia do despacho ${ }^{341}$ supra

Certifico que afolha $35^{342}$ verso ${ }^{343}$ do livro dos assentos dos mortos desta freguesi $\mathrm{a}^{344}$ se achava do theor seguinte Aos vinte quatro do mez de $\mathrm{Ma}[\mathrm{r}]$ ço do mil sette centos quarenta ${ }^{345}$ eseis annos falesceo desta vida com todos os $\mathrm{s}[\mathrm{a}] \mathrm{cramentos}$ e com a minha assisten -

$700 \quad$ cia] $\mathrm{Ma}[\mathrm{n}]$ oel Gracia de OLiveira de idade de cincoenta annos [corroído]ue[corroído] mais ou menos foi se pultado dentro desta Igreja Enaõ fes testamento de que fiz este que assignei $\mathrm{O}$ vigario Manoel de Crasto A Guiar $=$ naõ se continha mais noditto [corroído]h[corroído]o[ilegível] a que me reporto, e por verdade passei a prezente que sendo

705 [ilegível]necessar[corroído] juro inverbo Sacerdotis ${ }^{346}$. E vendo oSenhor dos cazamentos Em hú assento efolha26 consta ser a[buraco]e de fo o primeiro marido [s]upplicante $\rightleftharpoons \mathrm{E}^{347}$ do livro dos capitulos das vizitas afolha39 consta ser esta Igreja vizitada aos 28 de Outubro ${ }^{348}$ do an no de 1749 [espaço] pelo Reverendo Vizitador MigueL Dias Ferreira

710 he o que posso informar. Iundiahy 8 de Dezembro de [1]754

\section{OVigario Francisco IozephGuedes[sinal público]}

339 "N" por "Nossa", de acordo com FLEXOR, Ibidem, p. 279.

340 "Snar" por "Senhora".

341 “desp" por "despacho", conforme consta em FLEXOR, Ibidem, p. 129.

342 "f" por "folio", segundo FLEXOR, Ibidem, p. 179.

343 "v" por "verso", de acordo com FLEXOR, Ibidem, p. 444.

344 "frga" por "freguesia", como consta em FLEXOR, Ibidem, p. 191.

345 Aparentemente, o "e" em "quarenta" foi escrito por cima de outra letra.

346 "Com palavra de sacerdote”, em comunicação pessoal (Prof. Dr. Marcelo Módolo).

347 O "E" (maiúsculo) foi redigido por cima de um "e" (minúsculo).

348 No manuscrito original, foi utilizada a abreviatura "8br" (FLEXOR, Ibidem, p. 465). 


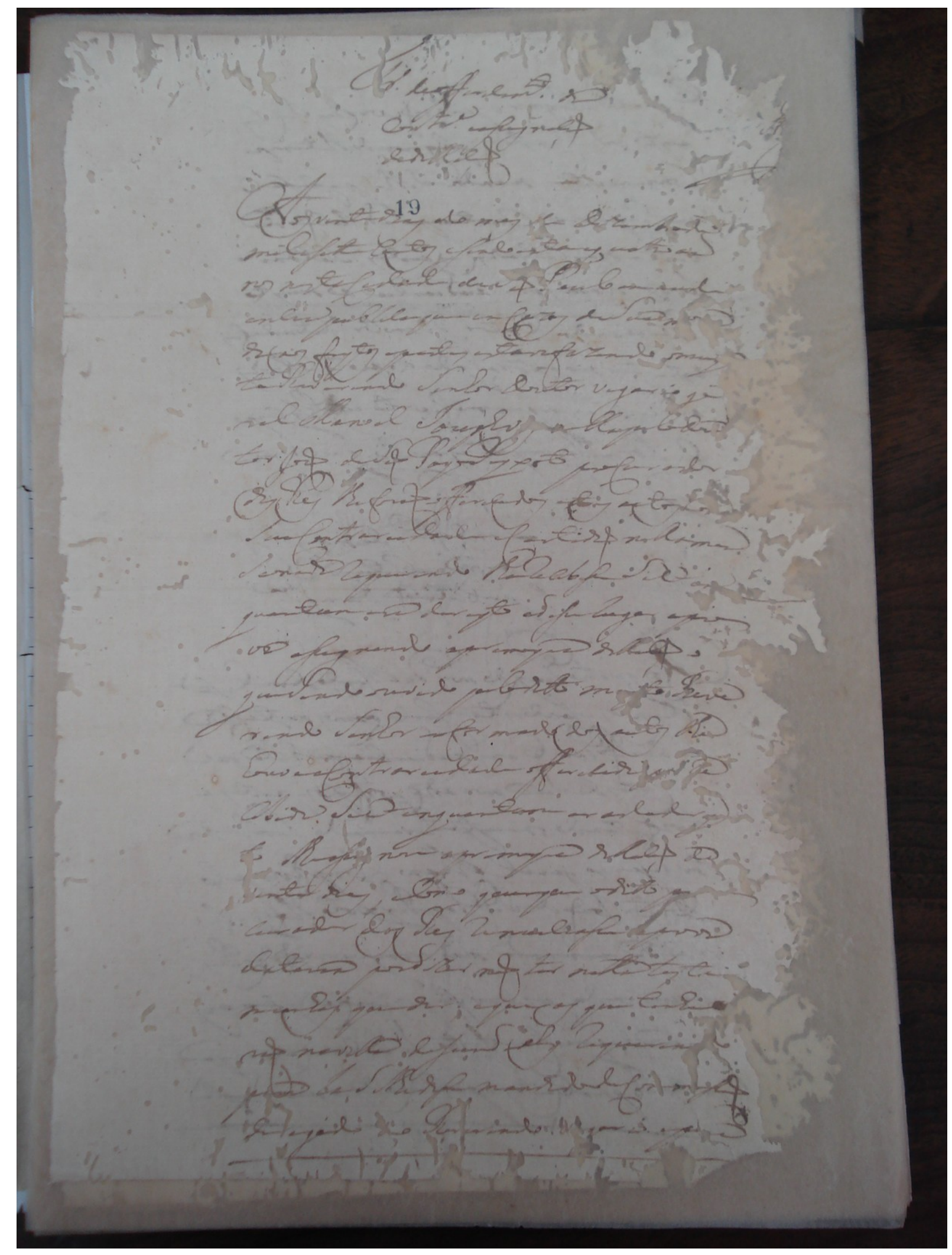


||19 r.

Termo deofferecimento da

Contrariedade eassignaçaõ

$<$ [corroído $]>$

$<\underline{\mathrm{N}[\text { ogueyra }]}>$

715

d[a]di[1]laçaõ

$<$ [sinal público $]>$

$<19>$

Aos vintedias do mes de $\mathrm{D}[\mathrm{e}] \mathrm{zemb}[\mathrm{r}]$ ode

milesetteCentos esinco entaequatro an

720 nos nestaCidade deSaõ Paulo em audi

encia publica que emCazas deSua $\mathrm{m}$ [ora]

daaos feytos epartes estavafazendo omuy [corroído]

toReverendo Senhor Doutor vigario ge

ral Manoel Iozephv[as] [e]ellepeloDou

725 tor joaõ deSaõ PayoPeyxoto proCurador

das Res lheforaõ offerecidos estes a[u]tos $\mathrm{Co}[\mathrm{m}]$

SuaContrariedade eCertidaõ $\mathrm{n}[\mathrm{e}]$ llamen

Sionada requerendo lherecebesse Sièt in

quantum era direyto edisserogar apro

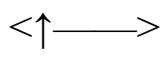

730 va assignando aprimeyra dillaçaõ o

queSendo ouvido peloditto $\mathrm{m}$ [uy]to Reve

rendo Senhor enfor mado dos autos the

houveaContrariedade offerecida $\mathrm{p}$ [or] re

Cebida Siet inquantum eradedir[e]y

735 to elheass[ig]nou aprimeyra dillaçaõ de

vinte dias, eComo querque oditto $\mathrm{p}$ [ro]

Curador das Res renunciasse aprova

dataram pordiz[e]r naõ ter nella tes te

munhas quedar eque as que tinha ${ }^{349}$

740 vaõ navilla dejundiahy requeren[d]o

$\mathrm{p}$ [ar]a baSelhedasse mandadodeComm[i]ssaõ

dirigido [a]o Reverendo v[i]gario ep[ar]a

349 Há um borrão de tinta após a letra "a" em "tinha", como se o escrivão quisesse apagar alguma letra. 


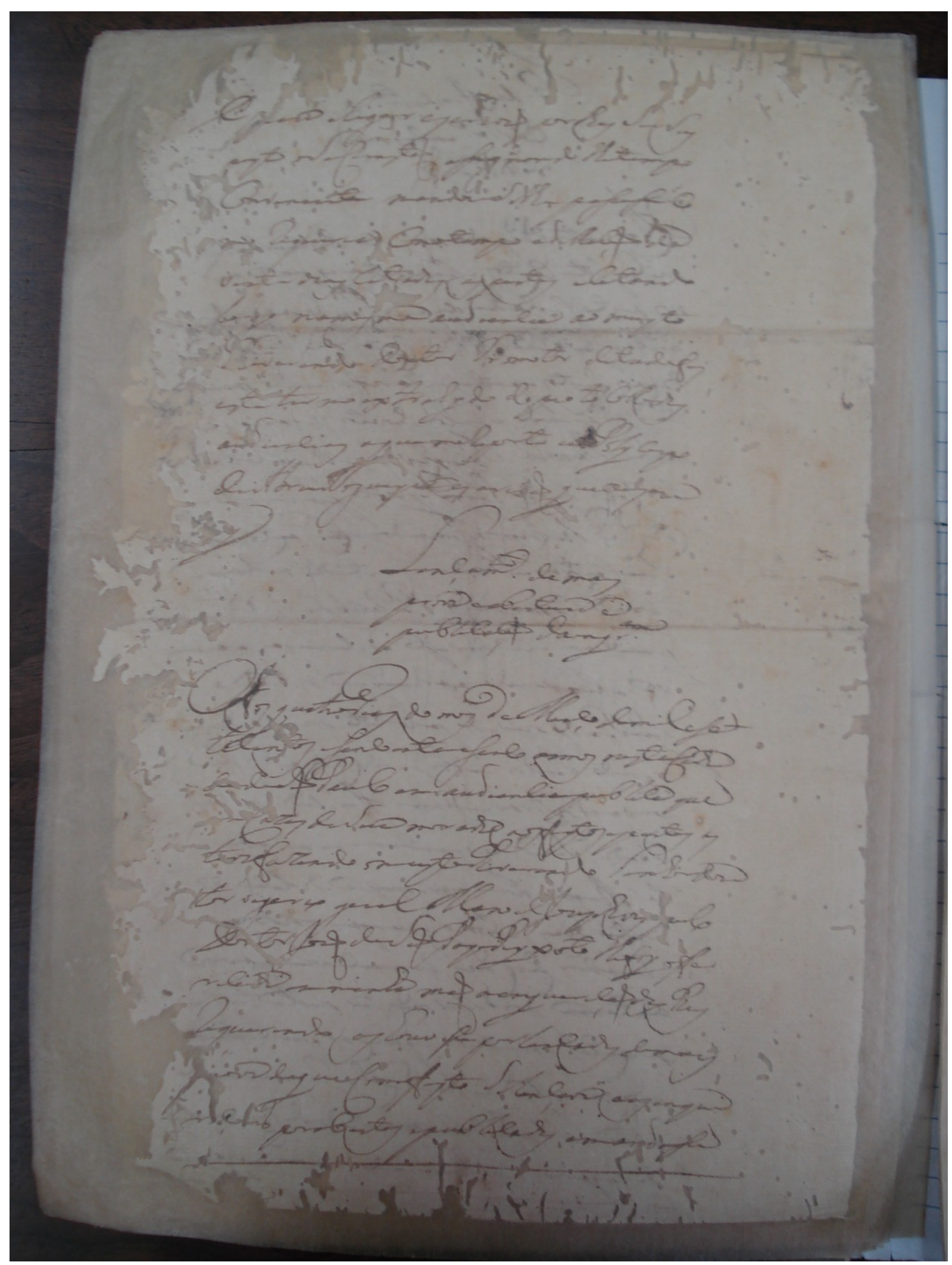


||19 v.

[[E para]] alegar escr[i]vaõ por lhes Ser Sus peyto oSaCristaõ ass[i]gnando lhetempo

745 Conveniente mandouSelhe passasseco mo requeria Comotempo ad[e]llaçaõ de vinte dias Citadas as partes eCitando [ilegível] namesma audiencia ao muyto Reverendo Doutor Promotor detudofis

750 este termo extrahydo do pro to Collodas audiencias aquemereporto euPolyCarpo deAbreuNogueyra escri[v]aõ queoescre [v]y

Lançamento de mais prova eabertura e publicaçaõ dainquiriçam ${ }^{350}$ [espaço]

Aos quatrodias do mes deMarço demileset teCentos esincoentaesinco annos nestaCida dedeSaõ Paulo em audienciapublica que

760 [e]mCazas deSua morada aos feytos epartes es $\mathrm{t}$ [a]vafazendo omuytoReverendo SenhorDou tor vigario geralManoel jozephvas pelo Do[u]tor Joaõ deSaõ PayoPeyxoto lhefoy offe recida aminha maõ aenquiriçaõ das Res

765 requerendo as houvesse porlancadas demais [pr]ova dequeComeffeyto Selançava aas enqui r[i]ço[e]ns porabertas epublicadas emandasse 


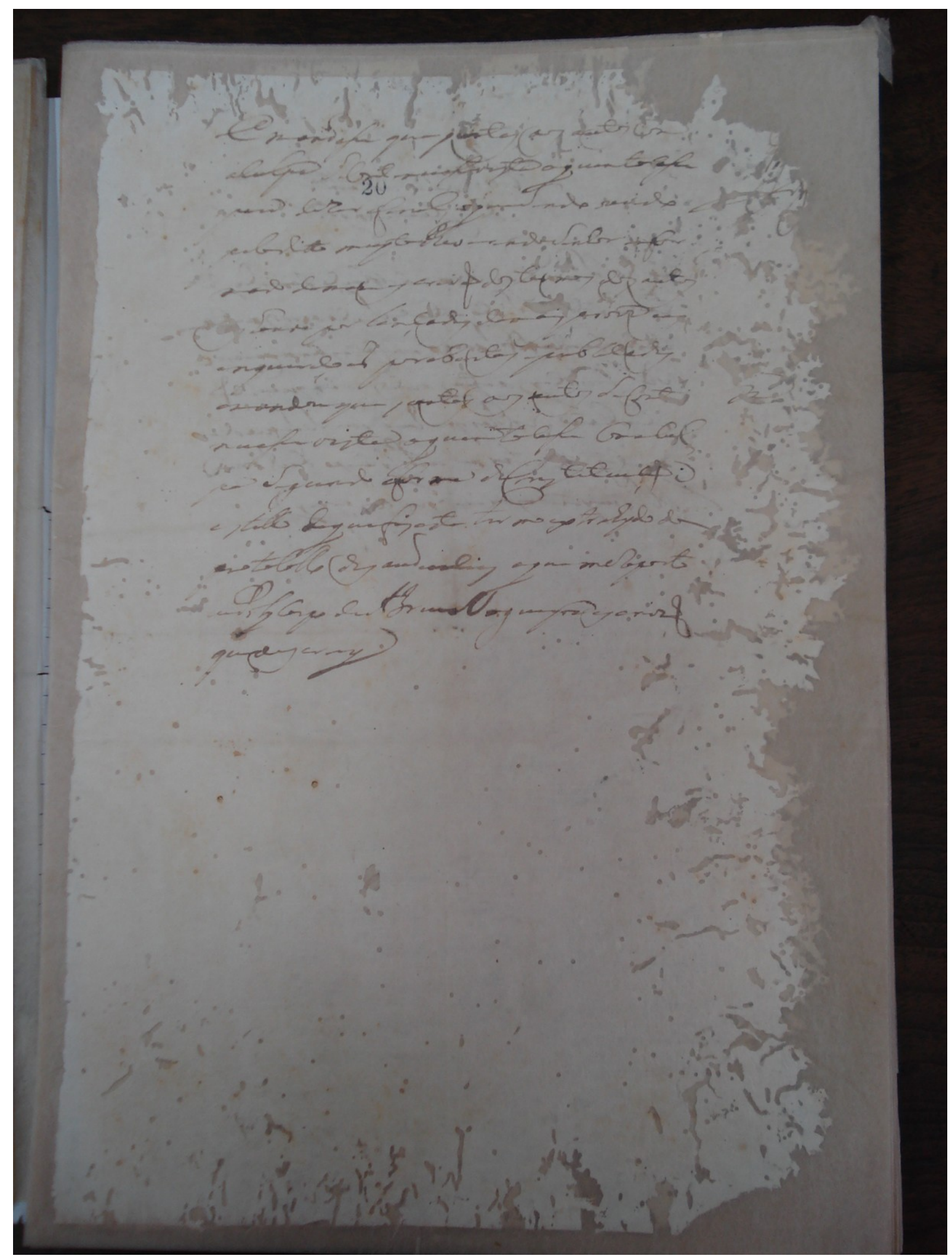


||20 r. $\|$

[[E mandasse $]$ que juntas aos autos Com $\quad<$ corroído $]>$

aCulpa SeContinuass[e]vista oquanto[c]asse $\quad<$ Nog[ueyra] $>$

770 para dizer $<\uparrow 20>$ afinal, oqueSendo ou[v]ido

$<$ [sinal público $]>$

peloditto muytoReverendoSenhor enfor

mado demeuescrivaõ dostermos dos autos

[a]s houve por lançadas demaisprova eas

enquiriçoens por abertas epublicadas

775 emandouque juntas aos autos SeCont[i]

nuasse vista oquantocasse ComoCul

pa Segundo aforma daConstituiçaõ e

estillo dequefis este ter mo extrahydo do

protoCollo das audiencias aquemereporto

780 euPolyCarpo deAbreuNogueyra escrivaõ

queoescrevy 


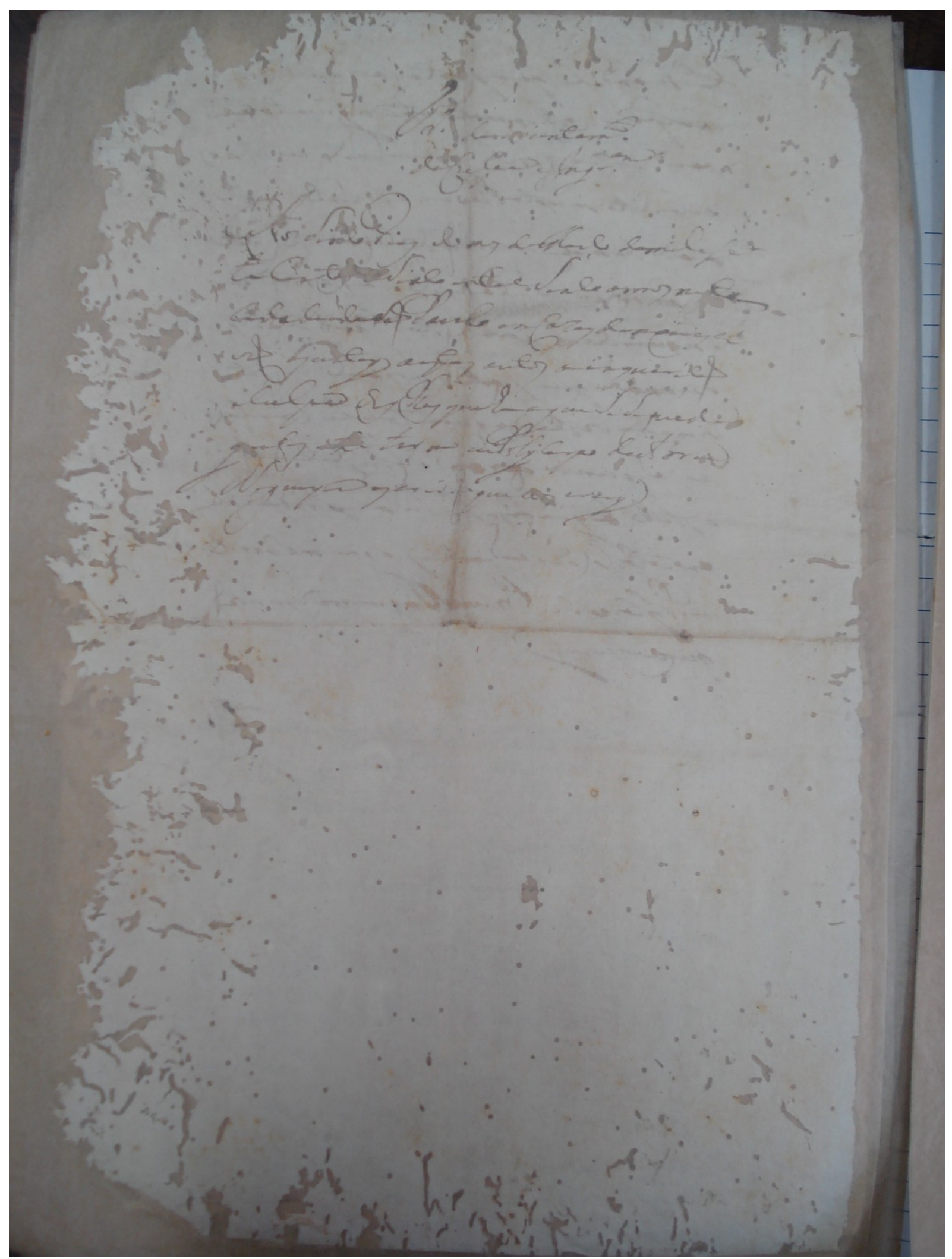


||20 v. $\|$

Termo de[corroído]untamento

daCulpa eInquiriçam

[espaço]

Aos Sinco dias do mes deMarço demileset

785 te Centos [e]Sinco entaeSinco annos ne[s]ta

CidadedeSaõ Paulo emCazas demim escri

vaõ ajuntey aestes autos ainquiriçaõ

eCulpa das Res queha aqui SeSeguede

$\mathrm{q}[\mathrm{u}]$ efis [est]e ter mo euPolyCarpo deAbre[u]

790 Nogueyra escrivaõ queo[es]crevy 


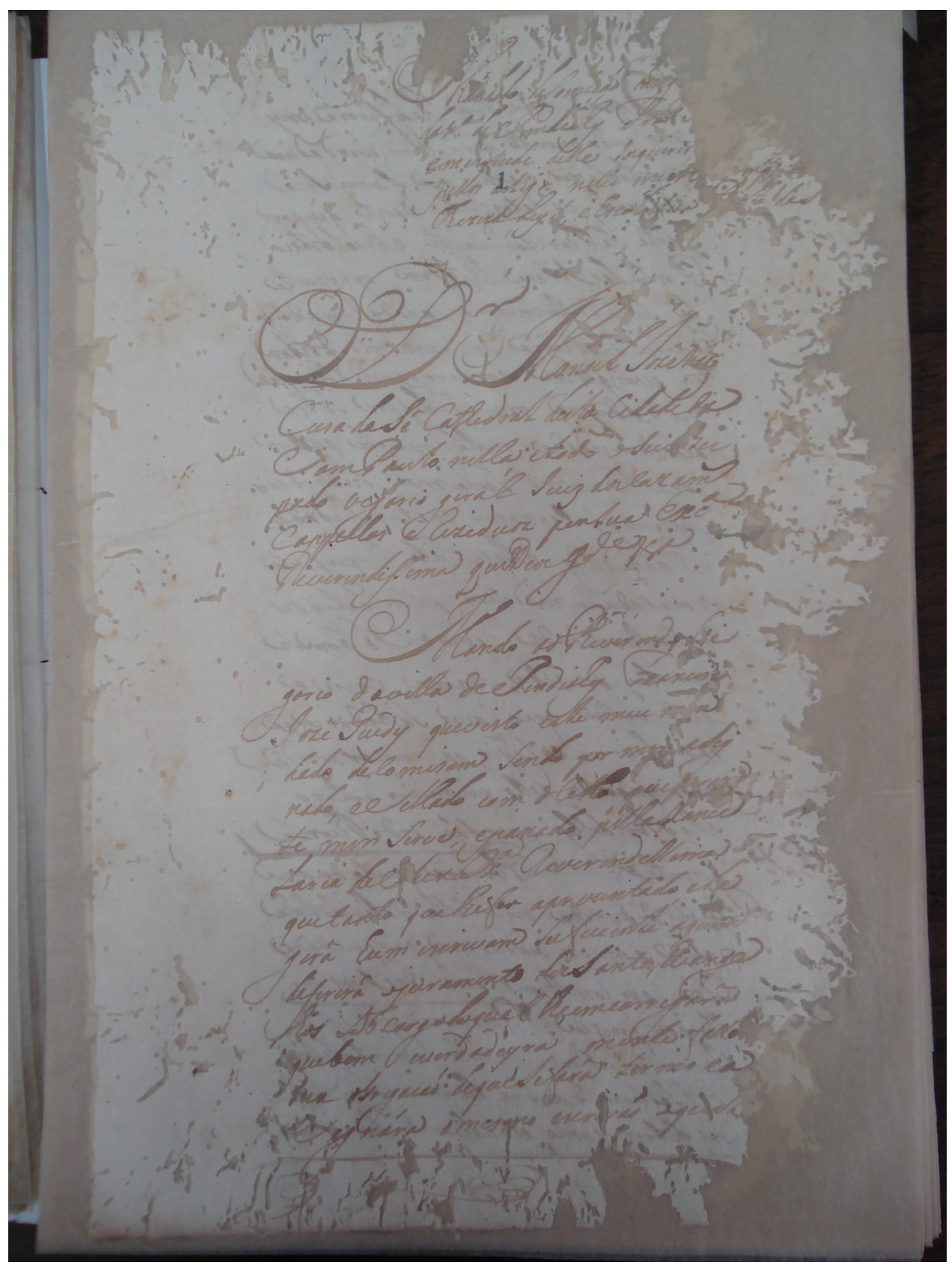


||21 r.

Mandado deCo[m]içaó d[ore]g[corroído]

davilla deIundiahy Fr[ilegível]

em virtude delhe Inquirir

pellos $<\uparrow 1>$ artigos nelle inco[nt][corroído] [m]parte

795 TherezaLey[te], e Escolastica [Pin]ta daS[ilva]

[espaço]

ODoutor Manoel IozêVa[z]

Cura daSê Cathedral desta Cidadede

SamPaulo nella, etodo oSeu bis

pado vigario geral Iuiz doscazamentos

800 Cappellas e reziduoz porSua Excelencia ${ }^{351}$

Reverendissima queDeosguarde VossaSenhoria

[espaço]

Mando aoReverendo [Vi]

gario davilla deIindiahy ${ }^{352}$ Francis[co]

Iozê Guedes quevisto este meu [ma]n

805 dado decomisam Sendo por m[in] aSig

nado, eSellado com ocello quep[o]r [ar]

te min Serve, epassado pellaXance

Laria deSuaExcelencia ${ }^{353}$ Reverendissima

quetanto quelhefor apresentado, eLe

810 gerâ hum escrivam Suficiente aquem

deferirá ojuramento dosSantos Euange

lhos Sob cargodoqual lheemcarregarâ

[corroído]quebem everdadeyra mente fasso

[s]ua obrigaçaó dequeSefarâ termo ea

815 Signara o mesmo escr[i]vaó [o]qual

351 "Exc" "por "Excelência", de acordo com FLEXOR, Ibidem, p. 174.

352 "Iindiahy" por "Iundiahy". Provavelmente a troca de "u" por " $\mathrm{i}$ " tenha sido resultado de um erro por parte do escrivão.

353 "Ex" por "Excelência", segundo FLEXOR, Ibidem, p. 172. 


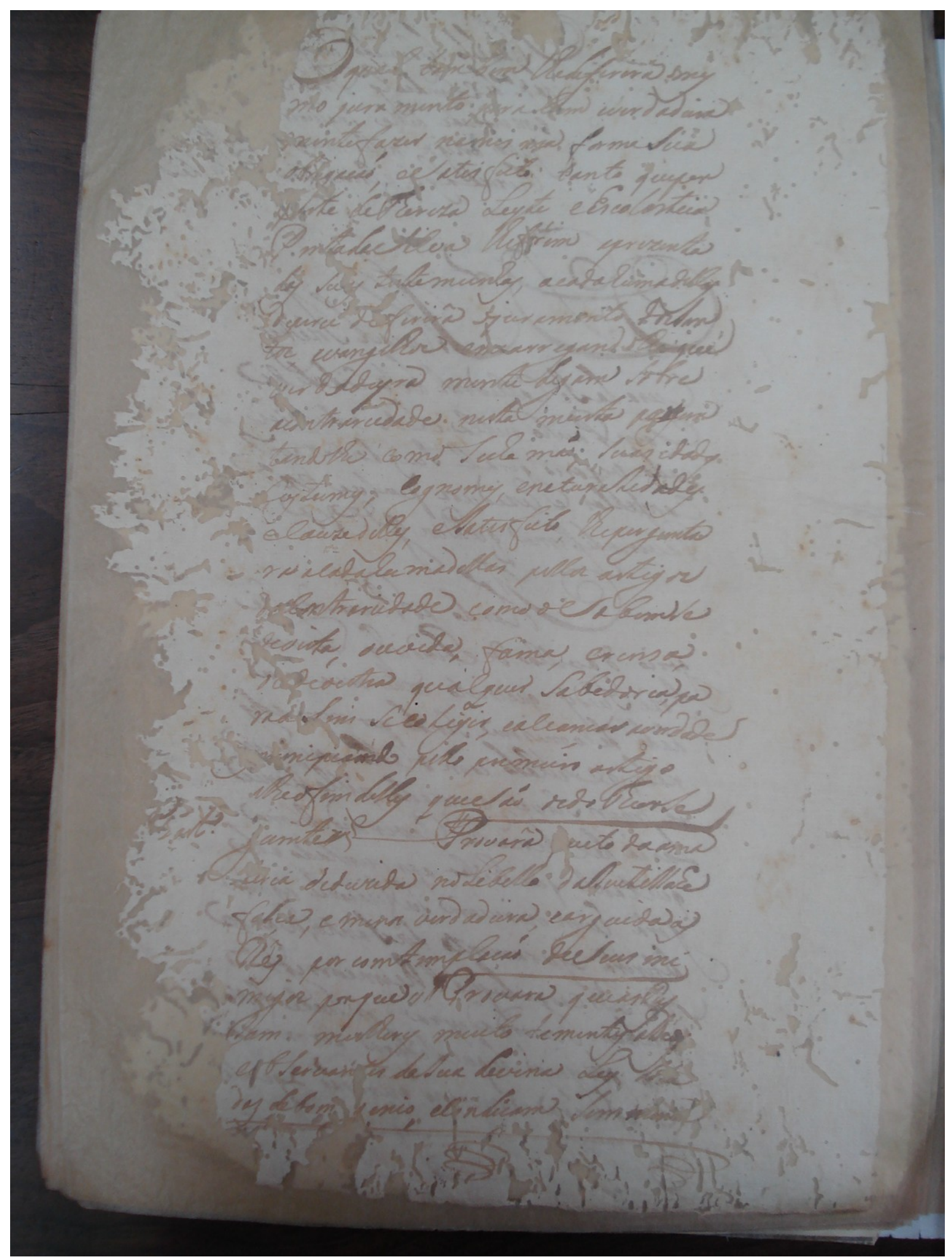


[[O qual]] tambem lhedeferira omes mo juramento parac[o]m everdadeira mente fazer names ma formaSua obrigaçaó, eSatisfeito tanto quepor $\mathrm{p}$ [a]rte deThereza Leyte eEscolastica PintadaSilva lhef[ó]rem aprezenta das $\mathrm{Su}[\mathrm{a}] \mathrm{s}$ testemunhas, acadahumadellas depor ce deferirâ ojuram[e]nto dosSan tos, evangelhos emcarregandolheque verdadeyra mente Leyam Sobre aco[n]trariedade nesta muita pergun ${ }^{354}$ tandolhe comoSecha maõ, suas idades Costumes, cognomes, enaturaLidades ecauzadelles, eSatisfeito, lhepergunta ra acadahumadellas pellos artigoz $\mathrm{d}[\mathrm{a}] \mathrm{C}[\mathrm{o}]$ ntrariedade como oSabem se devista, ouvida, fama, crensa, $\mathrm{o}[\mathrm{u}]$ deoutra qualquer Sabedoria, pa raaSim SecoLigir, ealcançar av[e]rdade [pr]inipiando ${ }^{355}$ pello primeiro artigo atheofim delles queSáó osdo TheorSe guinte, § [espaço] Provarâ [q]ueto da ama [t]eria dedusida noLibello daIustissahe falça, e menos verdadeira, earguida as migos porque, // Provara queas Res Sam mulheres muito tementes aDeos e[o]bServantes daSua divina Ley [ilegível] das debom genio, econdiçam Sem [nun]

3540 " $\mathrm{r}$ " em "perguntando" foi provavelmente inserido por cima de outra letra, como uma espécie de correção. ao redigir a segunda letra " $n$ " da mesma palavra. 


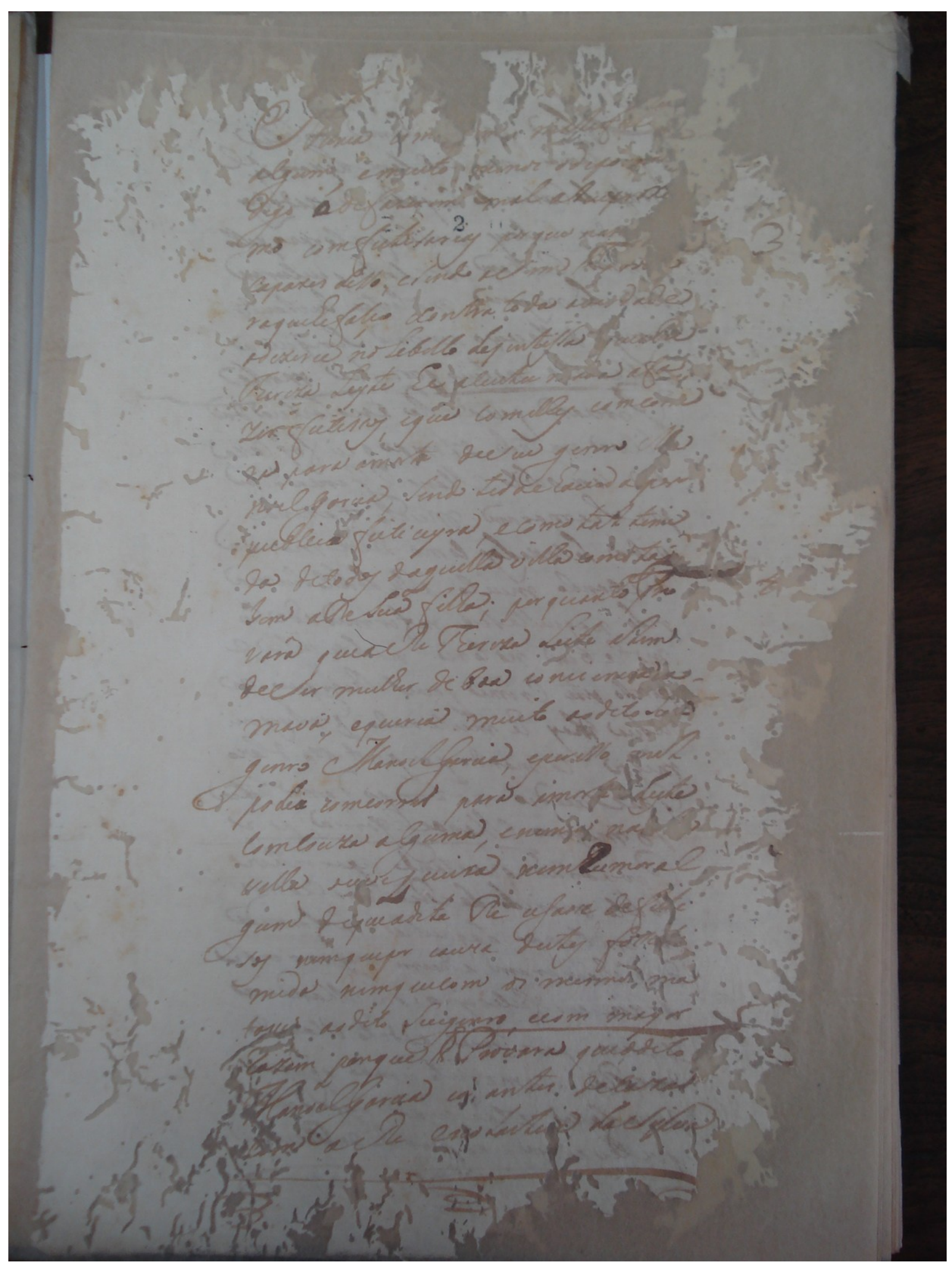


845 [[Nun]]ca com[corroído][m] malef[icio]

algum, e muito menos o depo[ilegível] [corroído]

digo odefazerem ${ }^{356}<\downarrow 2>$ mal aSeuprox[corroído]

mo comfeitisarias por que na[corroído] <3>

capazes disso, e sendo aSim [G][corroído]

850 raquehefalço econtra toda averdade

odizer ce noLibello dajustissa queaRe

Thereza Leyte he acustu mada afa

zer feitissos, eque comelles comco[rr]e

ra para amort[e] deSeu genro Ma

855 noelGarcia, Sendo tidaehauidapor

publica feiticeyra, ecomo taL temi

da detodos daquella villa comota[ó]

bem aReSua filha; por quanto Pro

varâ queaRe Thereza Leite aLem

860 deSer mulher de boa conciencia a -

mava, equeria muito ao dito $\mathrm{se}[\mathrm{u}]$

genro ManoelGarcia, epor isso maL

podia comcorrer para amorte deste

comcouza alguma, e nunca na[corroído]

865 villa ouvequeixa nemrumor ${ }^{357}$ al $\quad<$ [corroído] $>$

gum dequeadita Re usasse defeiti

sos nemquepor causa destes fosse $\mathrm{t}[\mathrm{e}]$

mida nemquecom os mesmos ma

tasse ao dito Seugenro, ecom mayor

870 razam porque $/ \S$ Provara queodito

ManoelGarcia ia antes decazar

com aRe escoLasti[c]a daSylva

356 Aparentemente, o "o" no início da frase foi redigido por cima de outra letra, pois a tinta apresenta maior realce.

$357 \mathrm{O}$ "r" inicial em "rumor" foi representado graficamente pelo número 2, que aparenta ter sido redigido por cima de uma letra "l". 


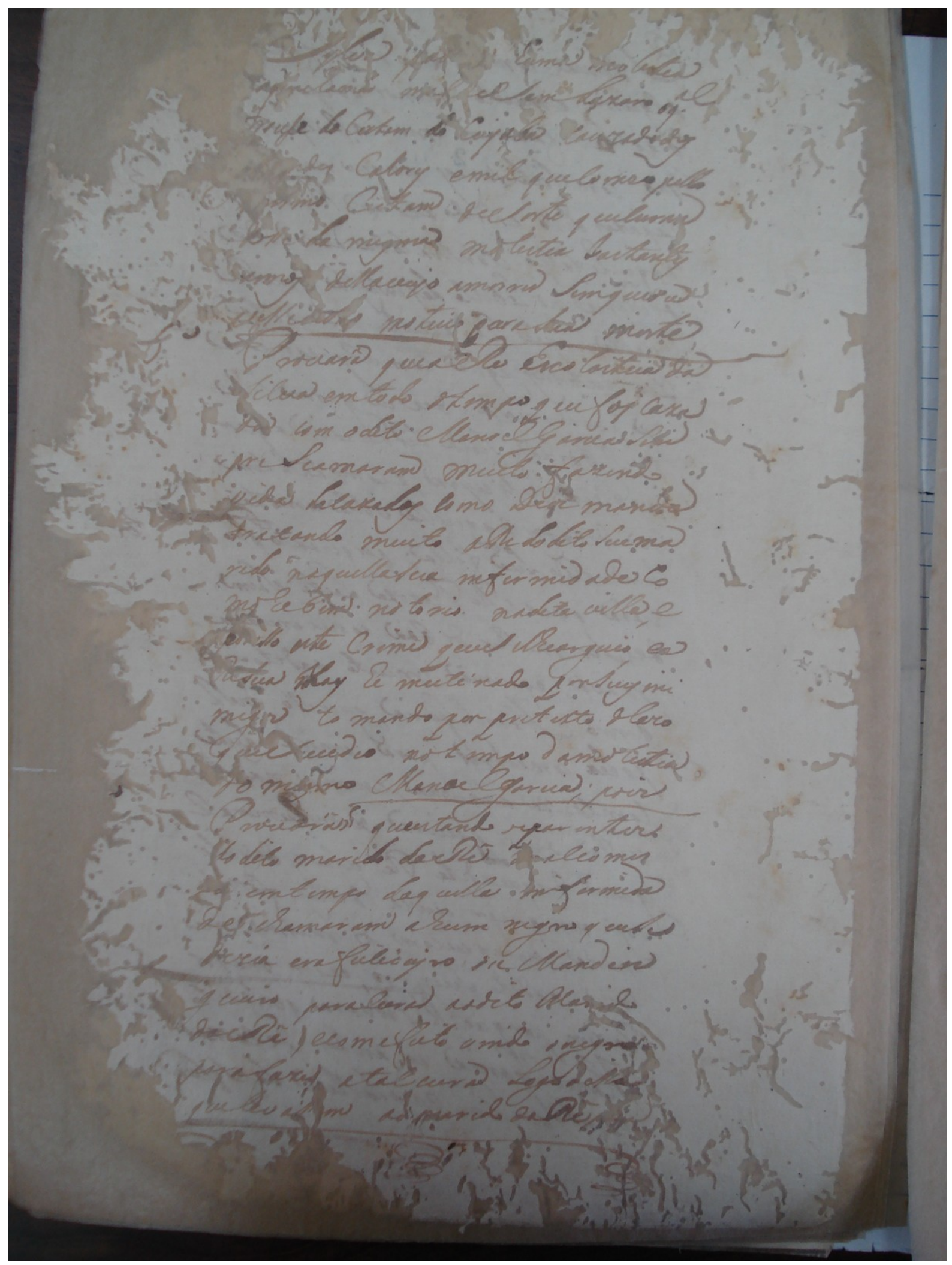


\|22 v. $\|$

[[Sylva]] pa[corroído] huma molestia

875

aq[corroído]chamaó maldeSamLazaro oqual

trouse do Certam do Cuyaba causad[o] dos

[corroído]dos Calores emel quecomeo pello

[m]esmo C $[\mathrm{e}] \mathrm{rtam}$ deSorte quecuran

dosse da mesma molestia bastantes

annos dellaueyo amorrer Semqueou

880

vesse[ilegível]o motiuo paraSua morte

$<6^{\circ}>\quad$ Prouarâ queaRe Escolastica da

Silua emtodo otempo quefoj caza

da com o dito ManoelGarcia Sem

preSeamaram muito fazendo

885

vida decazados como Deos manda

tratando muito aRe do dito Seu ma

rido naquellaSua infermidade co

mohebem no torio nadita villa, e

po[r] isso este Crime queSelhearguio, ea

890

ReSua May he mutivado porSeus ini

$\operatorname{mig}[\mathrm{o}] \mathrm{s}$ to mando por pretexto ocaso

queSucedeo notempo damolestia

$<$ [corroído]> do mesmo ManoelGarcia; pois

Prouarâ § queestando osparentes

895

do dito marido daRê [corroído]rceo mor

[corroído] emtempo daquella infermida

de chamaram ahum negro queSe

dizia erafeiticeyro / , e Mandin

gueiro paracurar aodito Mar[i]do

900

daRê, ecom efeito vindo o negro

parafazer atal cura Logo [d]iss[e][ilegível]

quelevas[se]m ao marido daRê $\mathrm{p}[\mathrm{ar}] \mathrm{a}$ 


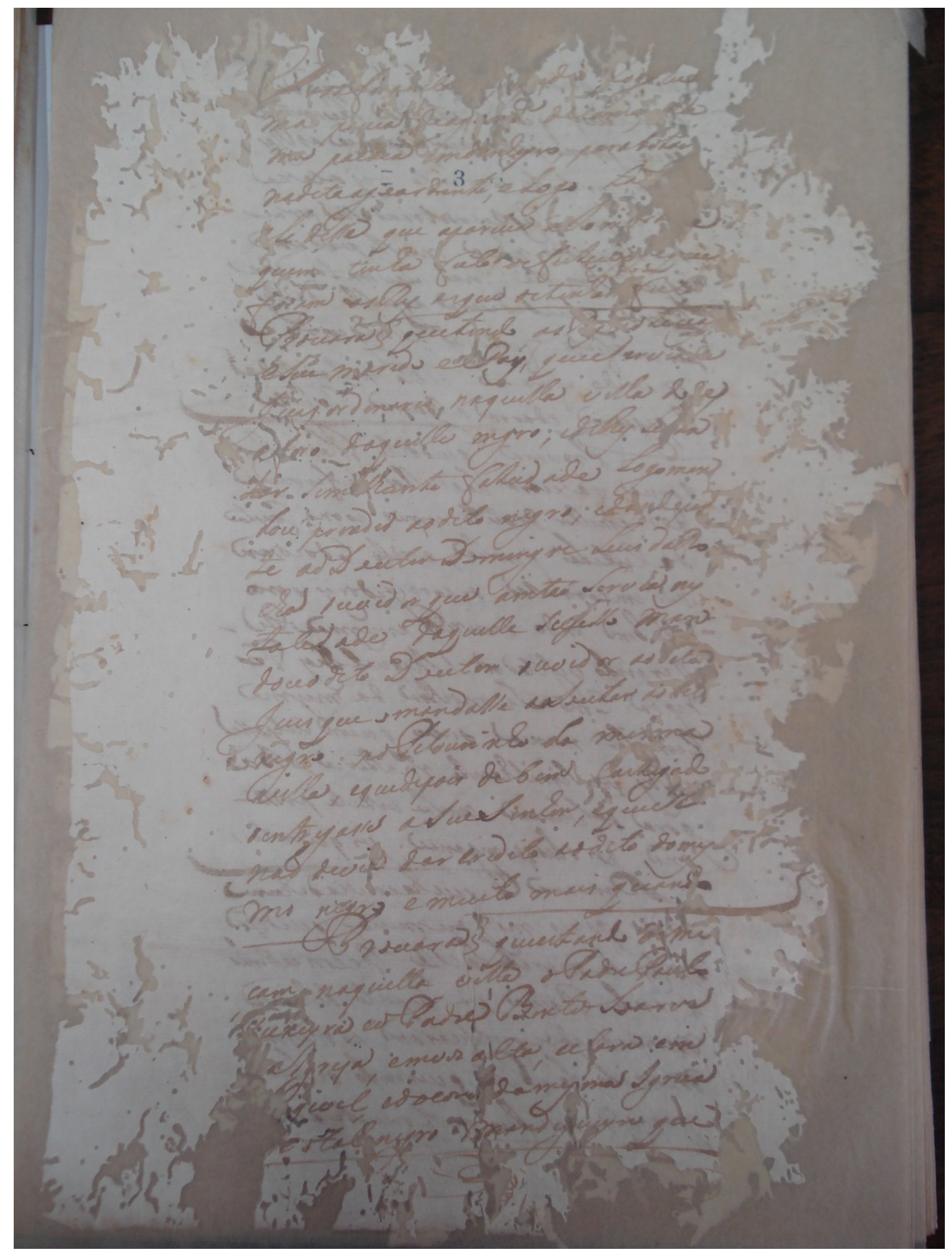


\|23 r. $\|$

[[Para]]foradeca[corroído]ed[eo] Logo [hu]

ma pouca [corroído] deag[ilegível] decomo, [ilegível]a

905 ma pataca $^{358}$ emd[i]nheyro, parabotar

naditaageardente ${ }^{359},<\uparrow 3>$ eLogo ta[corroído]

ali disse que aparecia aSom[b]ra [d]e

quem tinha feito osfeitiços, [d]eque

foram as Res asque ostinha[m] feito

910 Prouarâ $\S$ quetendo as $\mathrm{R}[\mathrm{e}] \mathrm{s}$ noticias $\quad<\uparrow 8^{\circ}>$

eSeu marido eePay, queServiade

Juis ordinario naquella villa do [d]es

aforo daquelle negro, edelhes Le[v]an

tar Sem[e]lhante faLcidade Logo man

915 dou prender ao dito negro, edandopar

te aoDoutorDomingos Luis daRo

cha ouuidor que amtaó Servia nes

tacidade daquelle susesso man

douo dito Doutor ouvidor ao [d]ito

920 Juis que o mandasse aSoutar ao [d]it[o]

negro noPelourinho da mesma

villa, equedepois debem castigado

o entregasse aSeuSenhor, equeSe

naõ devia dar credito aodito do mes

925 mo negro e muito mais quando

Prouara $\S$ queestando demi

çam naquella villa oPadrePaulo

Teixeyra, eoPadre BentoSoares

[corroído]aIgreja, emvos alta, eclara em

930 [corroído]givel, edocoro da mesma Igreia

[corroído][e] otal negro mandigueyro que

358 Segundo Antonio de Moraes Silva (1813: 410), no volume 2 de seu Diccionario da lingua portugueza, "pataca" seria uma "Moeda de prata do valor de 750 reis, e são as de Castella. [...] No Brasil, a Pataca vale 320 reis."

359 "ageardente" por "aguardente". 


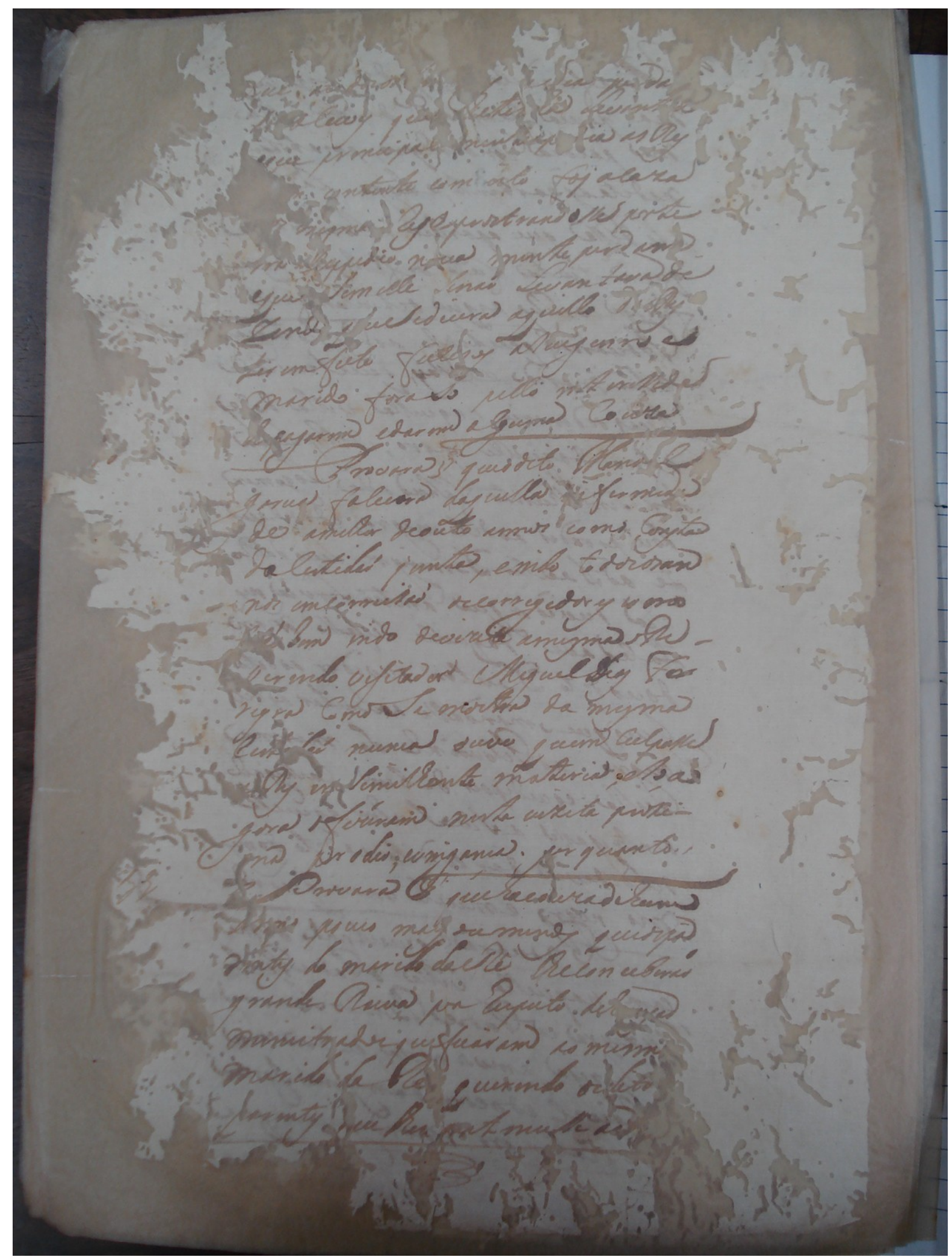


$<[$ corroído $]>$

935

[[Que]] a[ilegível]dos os [corroído]s [p]e[d]ia pe[r]da[corroído]

$\mathrm{p}$ [corroído] aleives que [1]heti[n]ha Levant[a]d[o]

eque principal mente [o]p[corroído]dia as Res

[corroído] contente com isto foj acaza

[corroído]s mesma[corroído] res e prostrandosse porte

rra [e]lhespedio $n[o]$ ua mente perdam

eque Sem elle Senaó Levantara di

Zend[o] queSedicera aquillo dasRes

940

teremfeito feitisos aSeugenro e

marido foraSo pello interessede

[1]h[e]pagarem edarem alguma Couza

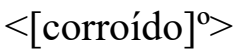

Provara $\S$ queo dito Mano[e]1

Garcia falecera daquella [in]fermida

945

de amelhor deouto annos como Consta

dacertidaó junta, e indo todosos an

nos emcorreisaó oscorregedores como

[corroído][á]o bem indo devisita amesma oRe -

verendo visitador MiguelDias Fer

950

reyra ComoSe mostra da mesma

Certidaó nunca ouve quem culpasse

$\mathrm{a}[\mathrm{s}]$ Res em Semelhante materia, eSo, a

gora ofiséram nesta vizita proxi -

ma por odio, evingança por quanto

$955<11>$

Provara § quehacousadehum

anno pouco mais ou menos queospa

rentes do marido daRê lhecon ceberáo

grande Raiva por respeito deh[un]s ad

ministrados queficaram ao mesm[o]

960

marido daRe querendo osdito[s]

parentes que lhes [pe]rtencesse a[o] [corroído] 


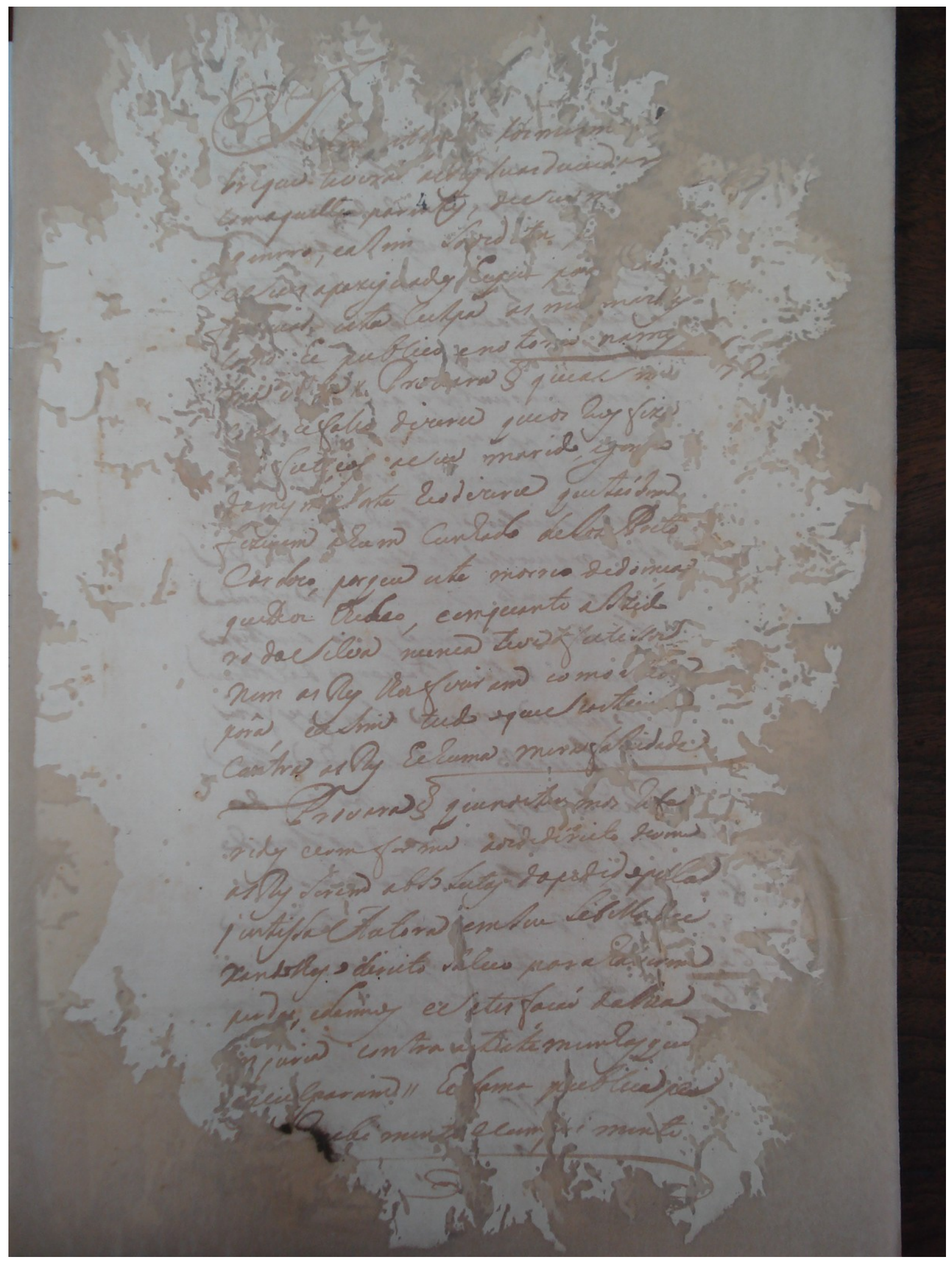


T[ilegível]it[ilegível] dos mesm[os] [corroído]

breque tivera[ó] asRes suas duuidas [corroído]

comaquelle[s] parentes, deseu $\mathrm{m}$ [arido] $\quad<\uparrow[$ corroído] $><\uparrow[$ corroído] $>$

965 [e]genrro, eaSim <个4> So[corroído]osd[i]tos [pa][corroído]

eSeus apaziguados heque po[r][corroído]a[ó]

$\mathrm{f}[\mathrm{abr}] \mathrm{icar}$ esta CuLpa as $\mathrm{m}[\mathrm{es}] \mathrm{masRes}$

como he publico eno tor[i]o names

ma v[i]la ${ }^{360}$ " Provara § queaSim $<[1] 2>$

970 como hefalço diserce queos rios fize

[corroído] feit[i] ços aseu marido, egen[rr]o

dames $\mathrm{m}[\mathrm{a}]$ Sorte heo diserce quetaó bem

fizeram ahum Cunhado deIoz[e]Preto

Car doso, porque este morreo dedoença

975 queDeos lhedeo, e emquanto aIzido

ro daSilva nunca teve feitissos

nem as Res lhesfiseram como Sed[e]

porâ, eaSim tudo oqueSeost[corroído]

contra as Res hehuma mera faL[c]idade

$980 \quad$ Provara $\S$ quenost[er]mos refe

ridos ecomforme aosdedíreito devem

as Res Serem abSoLutas dopedidopella

justisSaAutora emSeu Libello dei

xandolhes o direito Saluo parahaverem

985 perdas, edannos eSatisfaçaó daSua

[i]n juria contra a[s]testemunhas que

[a]s culparam// he fama publica per

[corroído]ebi ment[corroído] ecumpri mento

360 Ao que parece, o escrivão possuía a intenção de redigir a palavra "vila" utilizando uma abreviatura por sobreposição, mas desistiu e fez uma tentativa de grafar a letra "i" no lugar das letras sobrepostas, deixando a palavra escrita por extenso. 


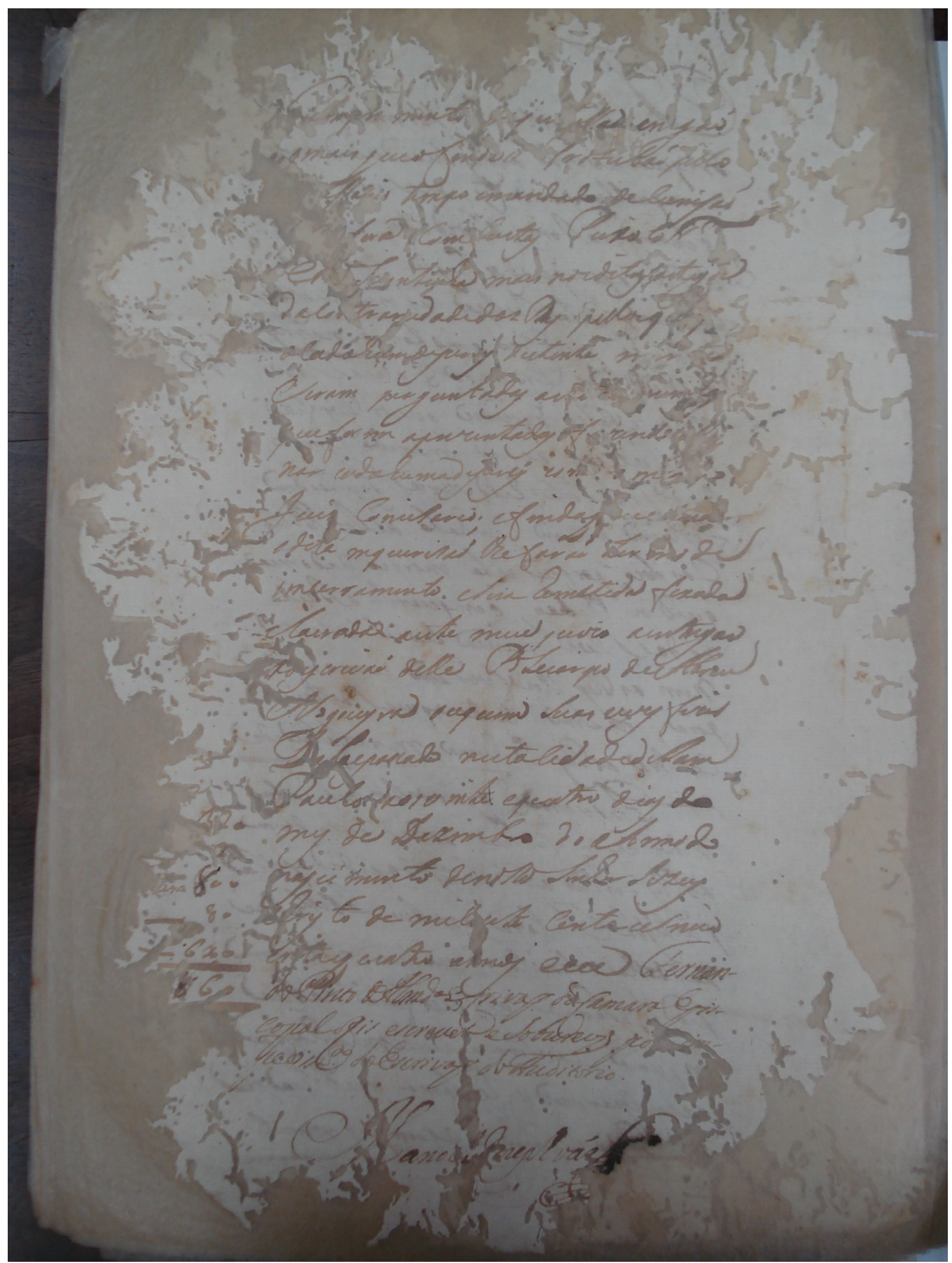


990

995

1000

1005

1010
[[C[u]mpri mento]] deju[sti]ssa en[corroído]gaó o mais queofor [d][ilegível] [p]rotubaó pello [corroído][ilegível] tempo emandado deconisaó ${ }^{361}$ [corroído][f]ora comcustas Peixo to [sinal com traço horizontal] e[corroído]S[ilegível]nt[en]ha mais nosditos artigos dacontrar[i]edadedas Res pellosq[corroído] acadahum[a]depor[corroído]s distinta [ilegível] Seram perguntadas aste[stem] unhas queforem apresentadas f[a]sendo [corroído] nar cadahumadepores com o $\mathrm{m}[\mathrm{esm}] \mathrm{o}$ Juis ComiSario; efindaq[u]ee [ilegível] adita inquirisaó lhefaraó ter mo de imcerramento eSera rematida fexada elacrada aeste meu juiso aentregar ao escrivaó delle PoLicarpo deAbreu Nogueyra ouquem Suas veses fiser Dadaepassado nestacidadedeSam $<\downarrow 320>$ Paulo aos vinte equatro dias do $<\downarrow \_$[corroído]2 $>$mes de Dezembro do Anno do $<$ [ilegível]800> nascimento denossoSenhor Iezus

$<-80>\quad$ chris to de mil[s] ete cent[os] eSinco $<-6700>$ entaequatro annos eeu Fernan ${ }^{362}$ $<\underline{860}>$ doPinto deAlmeydaesCrivaõ daCamaraEpis $<$ [corroído] $>$ copal ofis escreuer eSobscrevj po[r] im pedimento doEscrivaõ doAuditorio.

[espaço]

$\underline{\text { Manoel Iozephváz[sinal público] }]^{363}}$

361 "conisaó" por "comisaó" ("comissão").

362 A partir do nome "Fernando" até o final do parágrafo, o punho é do escrivão Fernando Pinto de Almeyda.

363 Assinatura e sinal público do punho de Manoel Iozeph váz. 


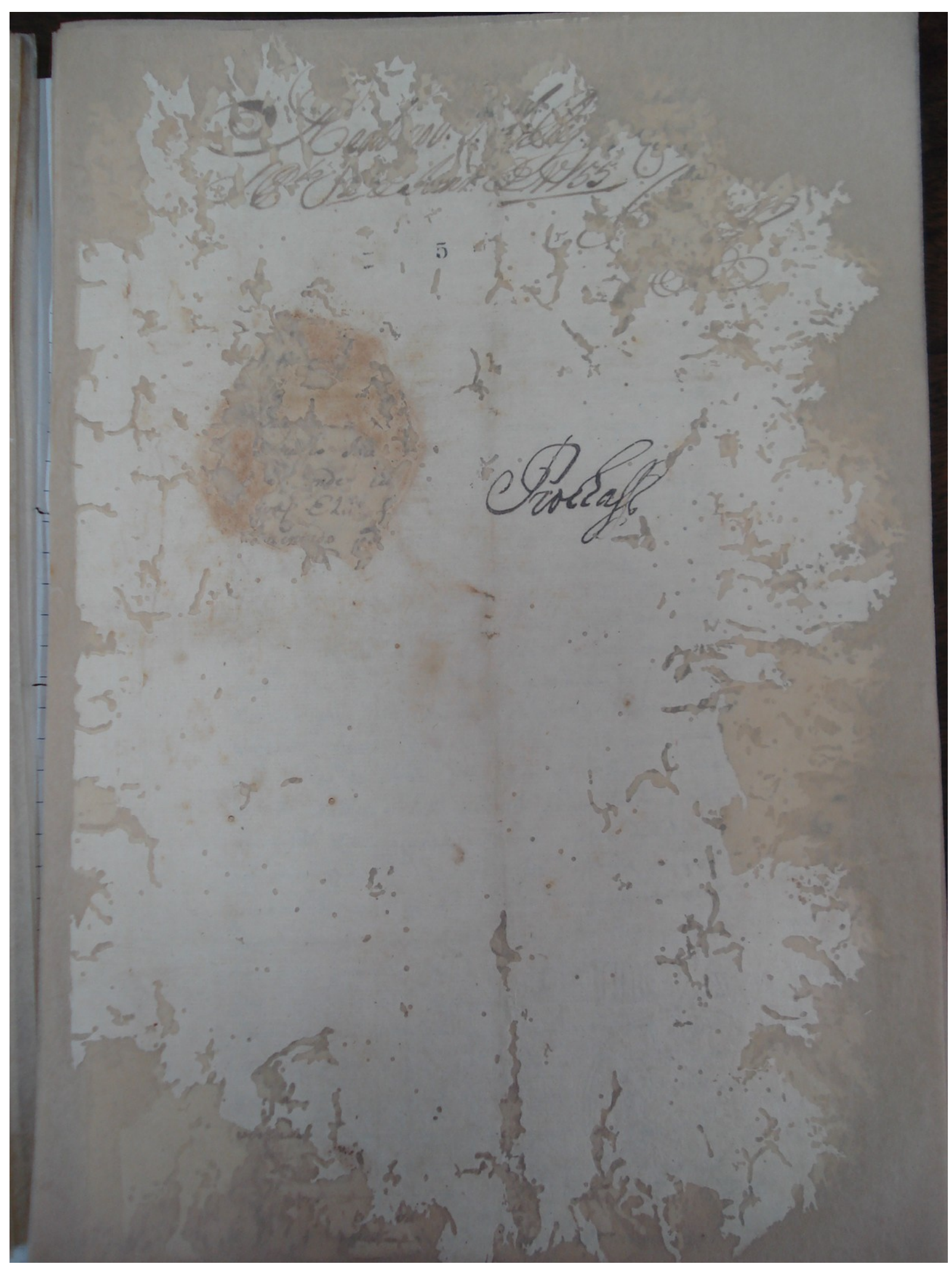


||25 r. $\|$

1015 Reg[corroído]o[corroído]Reg[corroído]

Saõ Paulo_2 deIaneyr[o] $]^{364}$ de $1755^{365}$

[Guedes]

$<5>\quad$ [sinal público]

[marca em formato circular] $\mathrm{P}$ [rochesso]

364 "Ianr"” por "Ianeyro" (Janeiro), segundo FLEXOR, Ibidem, p. 213.

365 Devido à corrosão do suporte material, não é possível afirmar de quem seria o punho nesta página, porém, assume-se que seja do Padre Bento Joze Leyte pela semelhança do traçado. 


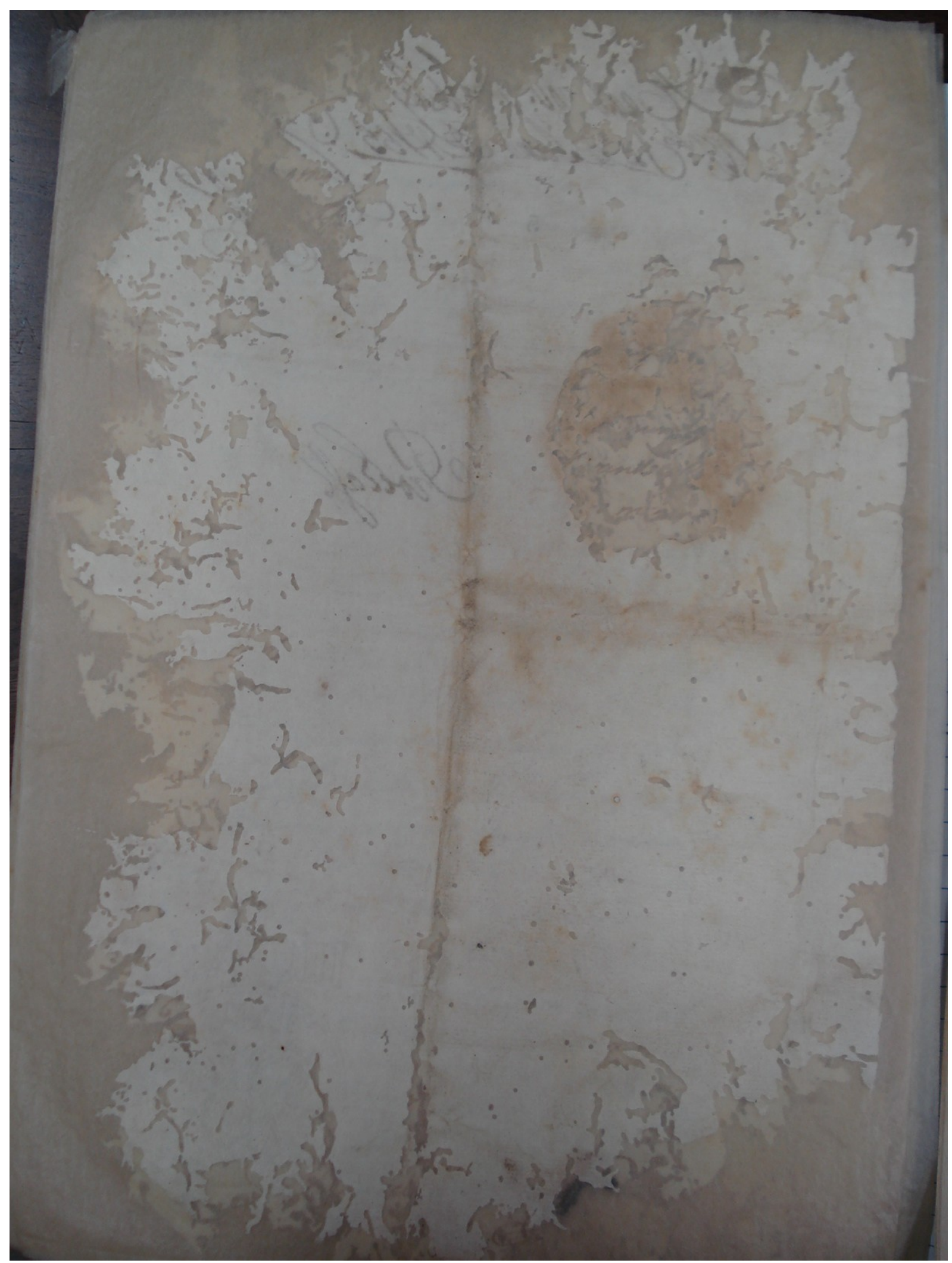


||25 v.

[página em branco] 


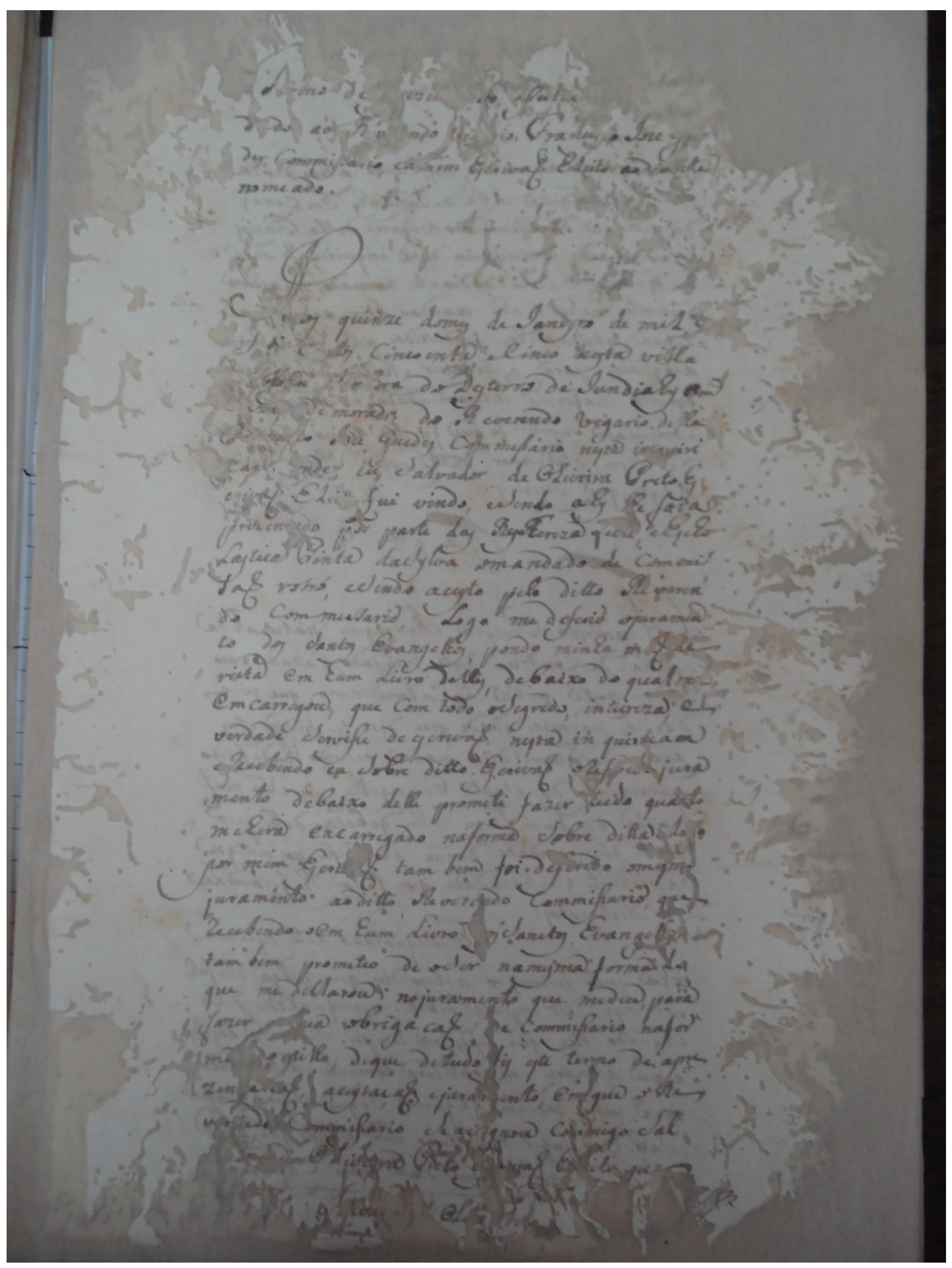


$\| 26$ r. $\|$

1020 Anno d[o] [corroído]v [corroído][do] [a]s[u] [corroído] $\mathrm{d}[\mathrm{a}]$ do aoR[e]v[ere]ndo vi[ga]rio, Francis[c]o Ioze G[ue] des Commis[s]a[r]io ea mim Escrivaõ Eleito ao d[i]ante nomeado.

$$
\text { [espaço] }
$$

Aos quinze domes de Ian[ey]ro de mil [e]

1025 S[ette] c[en]tos Cinco enta ecinco [n] esta villa [de Nossa Senho]ra doDesterro de Iundiahy em [cazas] de morada do Reverendo vigario della [Francisc]o I[o]ze Guedes commissario nesta i[nqu]iri ça[m] [o]nde eu Salvador de OLivrira ${ }^{366}$ Preto Es

1030 c[ri]vaõ El[eito] fui vindo, eSendo ahy [1] he foi a prezen[ta]do po[r] parte das ResThereza Lei[te] eEscho Lastica Pinta daSylva omandado de commis saõ rotró ${ }^{367}$, eSendo aceyto pelo ditto $\mathrm{R}[\mathrm{e}]$ veren do commissario, Logo me deferio ojuramen

1035 to dos Santos Evangelhos, pondo minha m[a]õ [d]i reita em hum Livro delles, debaixo do qual [me] emcarregou, que com todo oSegredo, inteireza, e verdade Servisse de escrivaõ nesta in quir[i]çam [e]recebendo eu Sobre ditto Escrivaõ oref[er]id[o] jura

1040 mento debaixo delle prometi fazer tudo qua[n]to mehera encarregado naforma Sobre ditta $[\mathrm{e}] \mathrm{Lo}[\mathrm{g}] \mathrm{o}$ por mim Escri[va]õ tam bem foi deferido omesm[o] juramento ao ditto Reverendo commissario, que recebendo oem hum Livro [d]os Sanctos Evangelh[os]

1045 tambem prometeo de oSer namesma forma do que me declarou no juramento que medeu, para fazer [s] ua obrigaçaõ de commissario nafor $\mathrm{m}[\mathrm{a}]$ do estillo, deque detudo fis este termo de apre zen[t]açaõ, aceytaçaõ ejuramento, em que o Re

$1050 \mathrm{v}[\mathrm{e}] \mathrm{r}[\mathrm{en}] \mathrm{do}$ Commissario Se a[si]gnou co[m]migo Sal [vador] d[e] OLiveyra Preto [Escri]vaõ E[le]ito que [corroído] [ilegível] [Guedes][sinal público] ${ }^{368}$ S[a]lva[dor de] OL[iveyra] [Preto] 


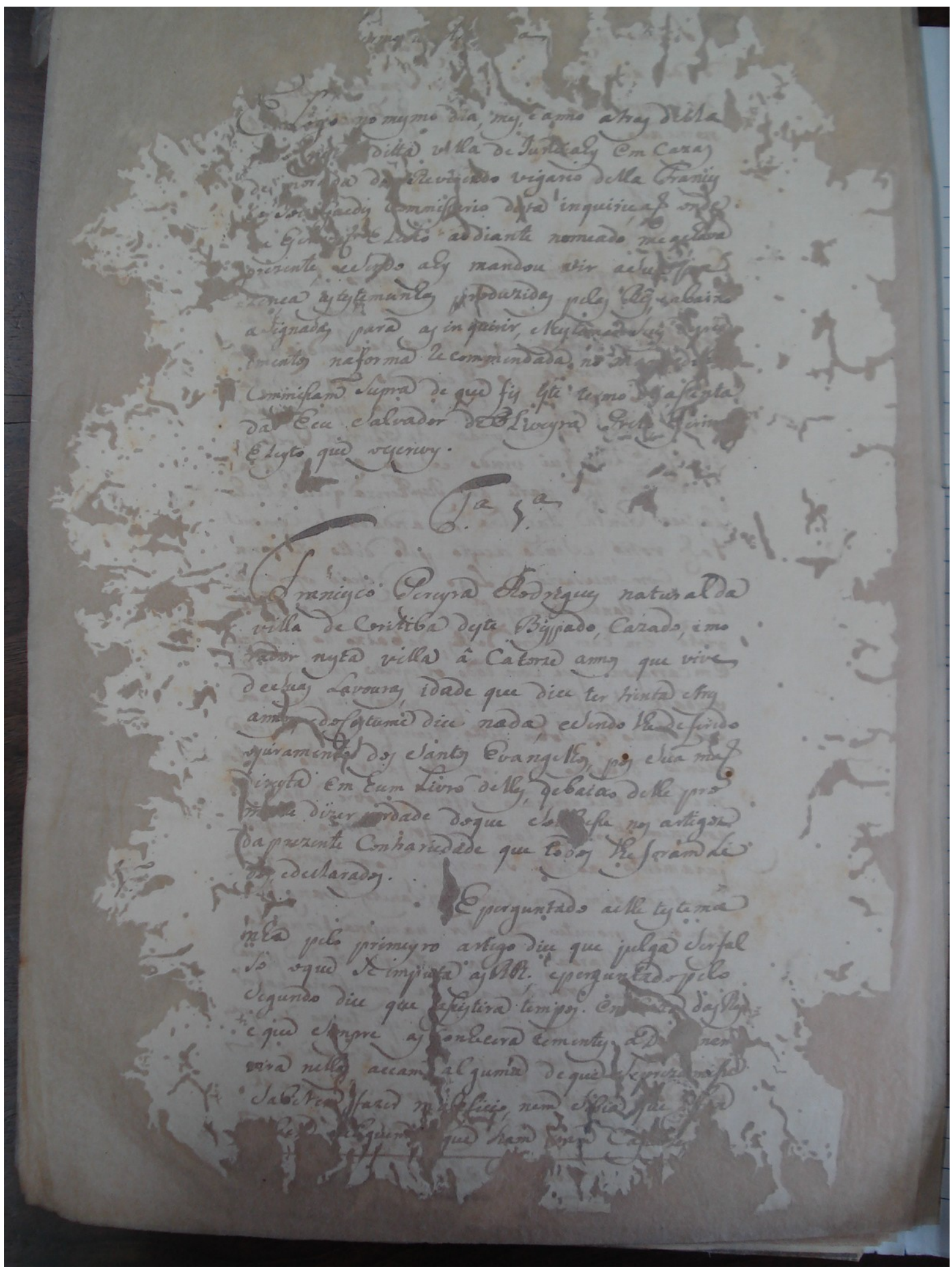


||26 v. $\|$

[trecho corroído]a

[espaço]

1055 E Logo no mesmo dia, mes, e anno atras della nest[a] ditta villa de Iundiahy em cazas

de morada do Reverendo vigario della Francis

co Ioz[e] Guedes commissario desta inquiriçaõ onde

[e]u Esc[ri]vaõ ELe[i]to ao diante nomeado me achava

1060 prezente, eSendo ahy mandou vir aSu[a] p[re]

zença as testemunhas produzidas pelas Rês, e abaixo

aSignadas para as in quirir, elhes tomad[o] seus depo

imentos naforma recommendada no ma[nd] $\mathrm{ad}[\mathrm{o}]$ [de]

commissam supra de que fis este termo de assenta

1065 da E eu Salvador deOLiveyra Preto Escriv[aõ]

ELeyto que oescrevy.

\section{Testemunha $1^{\mathrm{a}}$ \\ [espaço]}

Francisco Pereyra Rodrigues natural da

villa decoritiba deste Bispado, Cazado, e mo

1070 rador nesta villa â Catorze annos que vive

deSuas Lavouras, idade que dice ter trinta etres

annos, edoCostume dice nada, eSendo the deferido

ojuramento dos Santos Evangelhos, pos Sua maõ

direyta em hum Livro delles, debaixo ${ }^{369}$ delle pro

$1075 \mathrm{~m}$ [eteu] dizer [ve]rdade doque So[ub]esse nos artigoz

daprezente Contrariedade que todos lheforam $\mathrm{Li}$

dos, edeclarados.

E perguntado aelle testemu

nha pelo primeyro artigo dice que julga ser fal

1080

so oque se imputa as Rés ${ }^{49}$, eperguntadopelo

Segundo dice que assistira tempos em caza das Res

e que $\mathrm{S}[\mathrm{e}] \mathrm{mpre}$ as conhecera tementes $\mathrm{aD}$ [eus] nem

vira nellas accam alguma de que Seprezumisse

Saberem fazer maleficio, nem Sabia que [assim]

1085 [corroído]he[m] [ea]lguem [corroído] que nam [e]ram Cap[a]zes

369 Aparentemente, o "d" em "debaixo" foi redigido por cima de um "q" minúsculo.

49 Ao longo do punho do escrivão Salvador de Oliveyra Preto, a palavra "rés" (no plural) aparece, nos manuscritos, grafada como sigla ("RR"), havendo apenas três ocorrências da palavra escrita por extenso ("Res", "Rês" e "Res"). Assim, devido ao fato de haver variação ortográfica no mesmo punho, optou-se pela forma modernizada ("Rés") ao desenvolver-se tais abreviaturas. 


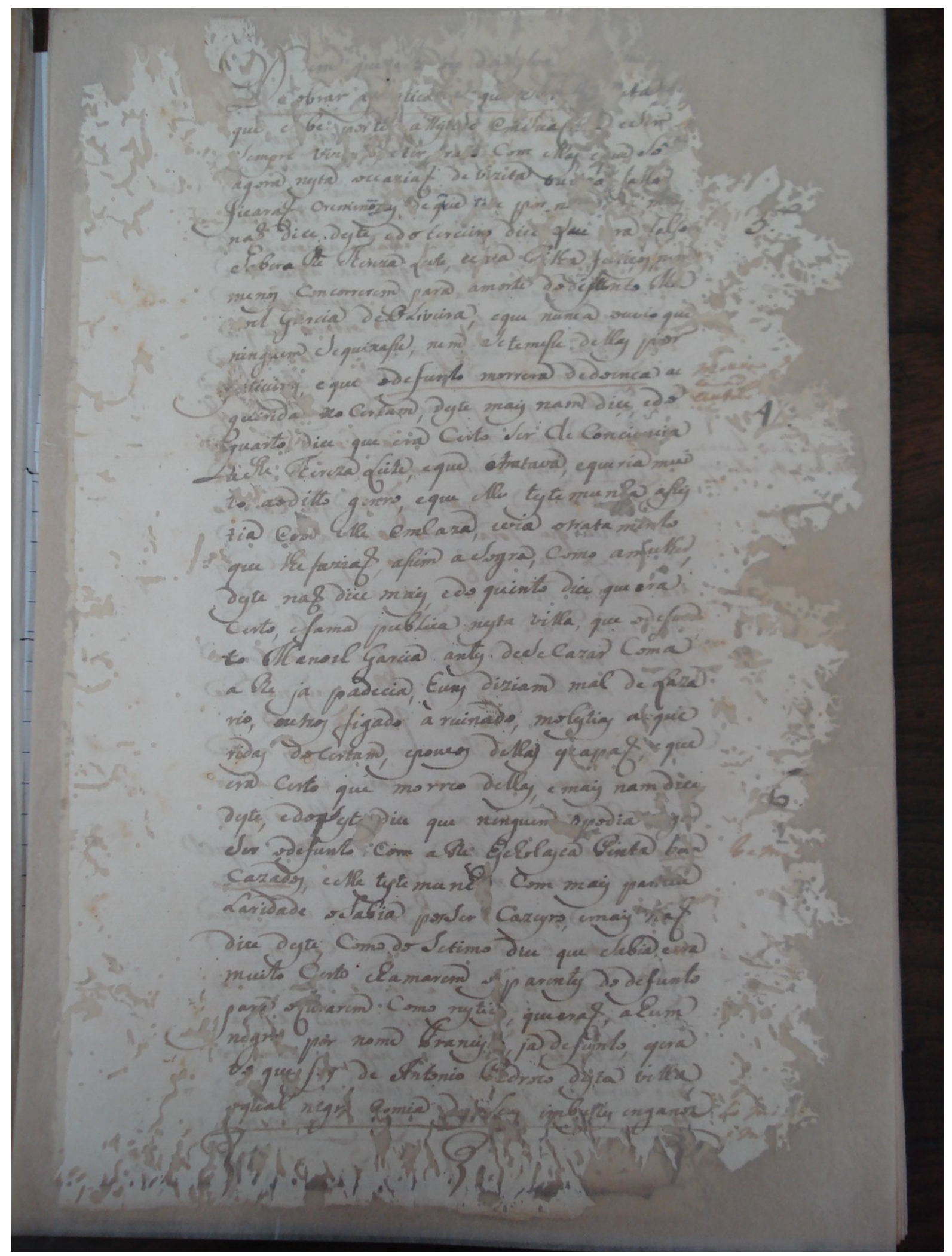


De obrar as[corroído]tica[corroído]qu[corroído]ta que $\mathrm{S}[\mathrm{a}]$ be por te[r] assistido emSuaC[aza] eSer $\quad<\uparrow[$ corroído] $>$ Sempre viz[corroído] eter [t]ra[to] com ellas, eque Sô $<\uparrow[$ corroído] $>$ agora nesta occaziaõ de v[i]zita ou[vi]o falla[r]

1090 ficaraõ criminō[z]as, de $\mathrm{q}<7>$ ue t[ev]e por $\mathrm{n}$ [corroído] [corroído] $\mathrm{m}$ [a]is naõ dice deste, edoterceiro dice que [e]ra falso $\quad<3^{\circ}>$ $\mathrm{S}[\mathrm{a}]$ bera Re Thereza Leite, eSua Filha feitiços, nem menos concorrerem para amorte do defunto Ma [no]el G[a]rcia deOLiveira, e que nunca ouvio que

1095 ning[u]em Se quixasse ${ }^{370}$, nem Se temesse dellas por

f[ei]ticeir[a]s, e que odefunto morrera dedoença ac <morreo d[corroído]> quirida no certam, deste mais nam diçe edo $\quad<\uparrow[$ [ilegível] $>$ Quarto diçe que era Certo ser de Conci[en]cia $\quad<\uparrow c e r t a o ́>\quad<4>$

1100 to aoditto genro, eque elle testemunha assis tia com elle emcaza, evia otrata mento que lhefaziaõ, assim aSogra, como amulher, deste naõ dice mais, edo quinto dice que era certo, efama publica nesta villa, que odefu[n]

1105 to Manoel Garcia antes deSecazar Com a

[[a]] Re ja padecia, huns diziam mal de Laza rio, outros figado a ruinado, molestias a[c] que ridas docertam, epoucos dellas escapaõ, e que era certo que morreo dellas, e mais nam dice

1110 deste, edo [risco] sest[o] dice que ninguem o podia [corroído] [ger] <个6> Ser odefunto com aRe Escholasca ${ }^{50}$ Pinta bem $<$ bem [corroído]> cazados, eelle testemunh[a] com mais par[ticu] Laridade oSabia porSer Cazeyro, emais naõ dice deste, Como doSetimo dice que Sabia era

1115 muito Certo chamarem os parentes do defunto para oCurarem Como rustic[o]s $\mathrm{s}^{371}$, queeraõ, ahum negro por nome Francis[co], ja defunto, escra vo que f[o]y de Antonio P[e]drozo desta villa, oqual negr[o] comia d[os] seus imbu[s]tes enganoz $<$ comi[corroído] $>$ $<\mathrm{im}[$ corroído] $>$

370 "Quixasse" por "Queixasse".

50 "Escholasca" por "Escholastica".

371 Raphael Bluteau, no volume 7 de seu Vocabulario Portuguez \& Latino (1728: 402), define a palavra "rústico" como "homem do campo", "grosseiro", "vilão", "descortês". Antonio de Moraes Silva, no volume 2 de seu Diccionario da lingua portugueza (1813: 650), oferece acepções parecidas para a mesma palavra, definindo-a como "camponês", "inurbano", "descortês". 


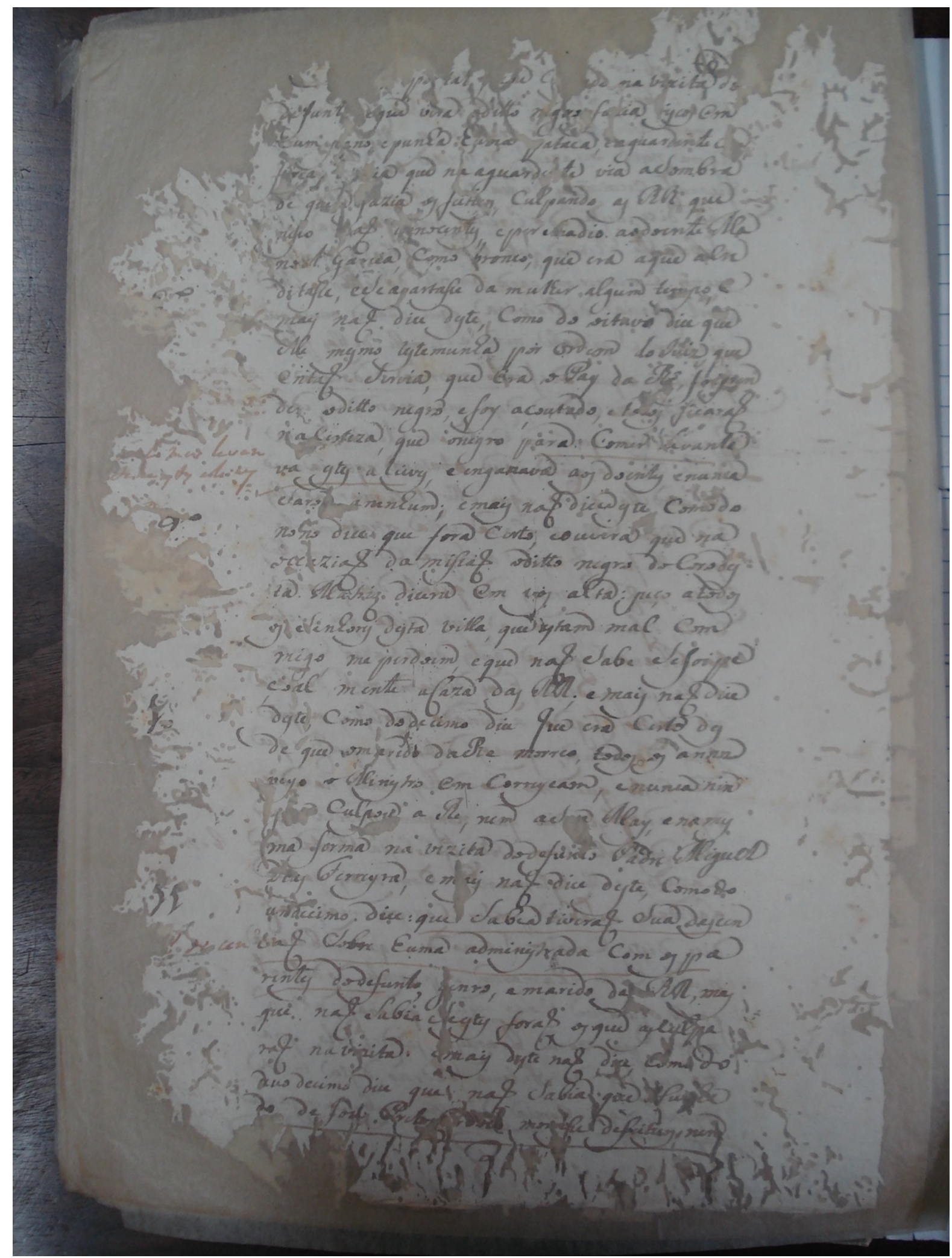


||27 v. $\|$

[corroído] po[r]tal [corroído]m G[corroído]do na vizitaçaõdo defunt[o] eque vira oditto $n[e]$ gro fazia $[r]$ iscos em hum pano epunha huma pataca, eaguardente [com] f[o]rça [corroído]ia que na aguarde[n]te via aSombra de quem fazia os feitiços, culpando as Rés que nisso [s]aõ i[n]nocentes, eper s[u]adio ao doente Ma no[e]l Garcia, como bronco, que era aque acre $<8^{\circ}>$ ditasse, eSe apartasse da mulher algum tempo, e mais naõ dice deste, Como do oitavo dice que elle mesmo testemunha por ordem do Iuiz que entaõ Servia, que era oPay da Rê, fo[i] pren der oditto negro, e foy açoutado, e to[d]os ficaraõ

$<\downarrow[$ para $]$ comer levan $>$ nacerteza, que onegro para Comer Levanta $<\mathrm{ta}[\mathrm{v}] \mathrm{a}[\mathrm{e}] \mathrm{stes}$ aleives $>$ $<9^{\circ}>$

1140 va estes aleives, eenganava aos doentes enunca Saro[u] a nenhum; emais naõ dicedeste como do nono dice que fora certo, eouvira que na occaziaõ da missaõ oditto negro docoro des ta Matriz dicera em vos alta: peço a todos os Senhores desta villa, que estam mal com migo, me perdoem, eque naõ Sabe Sefoi pe çoal mente aCaza das Rés; e mais naõ dice $<10>\quad$ deste, como do decimo dice que era Certo des de que omarido daRe morreo, todos os annoz veyo oMinistro emcorreycam, e nunca nin g[uem] culpou a Re, nem aS[u]a May, e na mes ma forma na vizita dodefun[t]o Padre Miguel Dias Ferreyra, e mais naõ dice deste, como do $<11>\quad$ undecimo dice: que Sabia tiveraõ Sua descen $<$ [corroído]ó de cen $>$ caõ Sobre huma administrada com os pa rentes dodefunto, genro, emarido da[s] Rés, mas que naõ Sabia Seestes foraõ os que as culpa raõ navizita e mais deste naõ dice, $\operatorname{com}[\mathrm{o}]$ do duo decimo dice que naõ Sabia que $[\mathrm{o}] \mathrm{Cu}[\mathrm{n}]$ ha do de Ioz[e] Preto C[a]rdozo mor[r]esse defeiticos, nem 


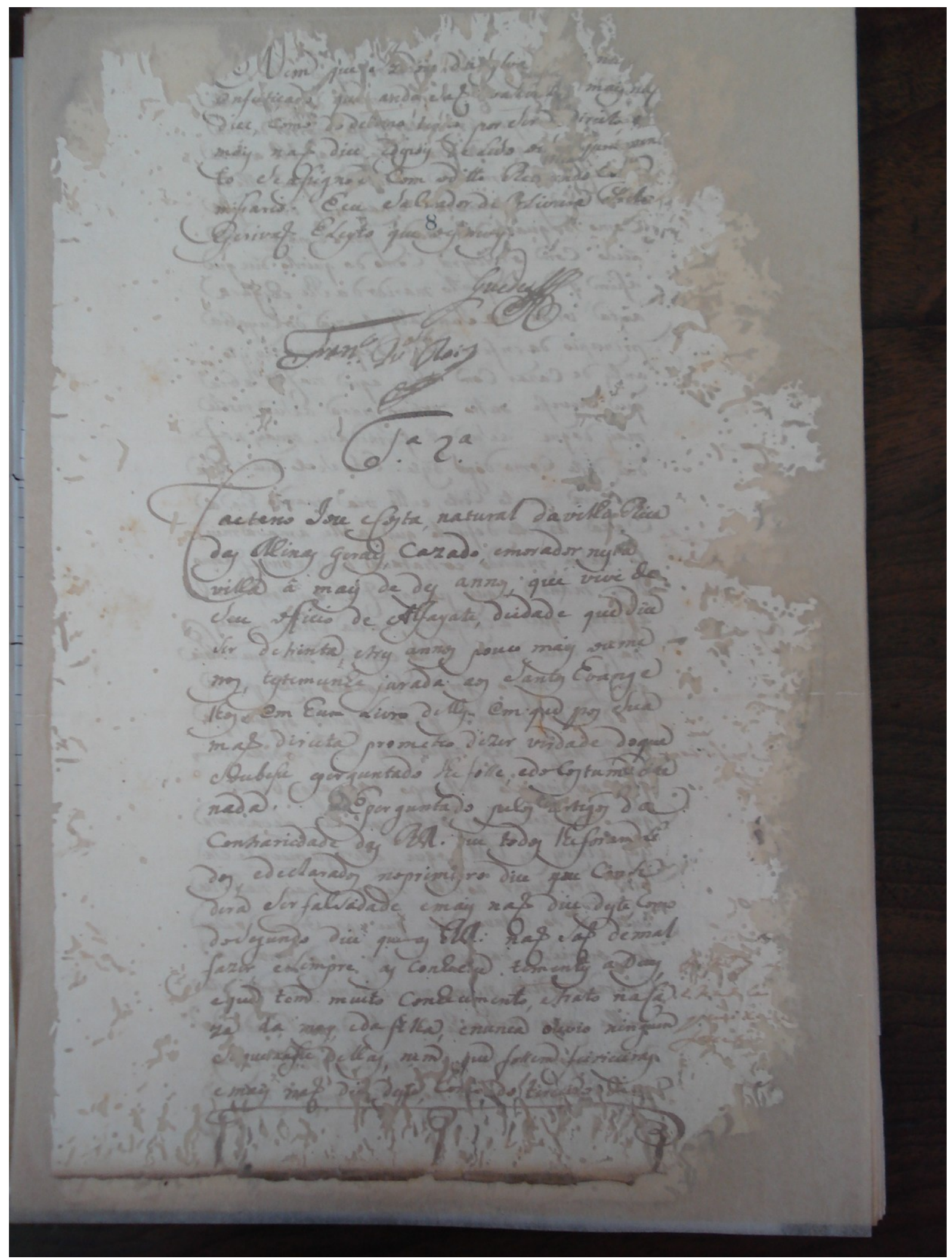


$\| 28$ r. $\|$

1155 [[Nem]] que Iz[i]doro daSylva [corroído] na[corroído] enfeitiçado, que anda Saõ [e] v]alent[e] [e] mais naõ dice, como do de[ci]mo ter[c]io por Ser d[e] direito, e mais naõ dice edepois de Lido oS[eu] jur[a]men to Se assignou com od[i]tto Re[ver]endo co[m]

1160 missario Eeu Salvador de OLiveira Preto Escrivaõ ELeyto que $<\uparrow 8>$ oes[c]revy.

\section{$\underline{\text { Francisco Pereira Rodriguez }}^{373}$}

\section{Guedes[sinal público] ${ }^{372}$}

\section{[sinal público]}

1165

Testemunha $2^{\mathrm{a}}$

[espaço]

Caetano Ioze Costa, natural da villa Rica

das Minas Gerais, cazado, emorador nes[t]a

villa â mais de des annos, que vive de

Seu officio de Alfayate, deidade que dice

1170 ser de trinta etres annos pouco mais ou me nos, testemunha jurada aos Santos Evange

lhos em hum Livro delles em que pos Sua maõ direita prometeo dizer verdade do que Soubesse eperguntado lhe fosse, edocostum[e] d[i]ce

1175 nada. [espaço] E perguntado pelos artigos da contrariedade das Rés [q]ue todos lheforam Li dos, edeclarados noprimeyro dice que consi dera Ser falsidade emais naõ dice deste, como doSegundo dice queas Rés naõ Saõ de mal

1180 fazer, esempre as conh[e]c[e]u tementes aDeus, <tementes [corroído]> eque tem muito conhecimento, etrato naCa < nunca $>$ za da may, edafilha, e nunca ouvio ninguen <queixa [corroído]> $\mathrm{S}[\mathrm{e}]$ que[i]xasse dellas, nem que fossem feiticeiras $<$ feiti[corroído] $>$ emais naõ di[ce] deste, como do terceiro di[ce] 


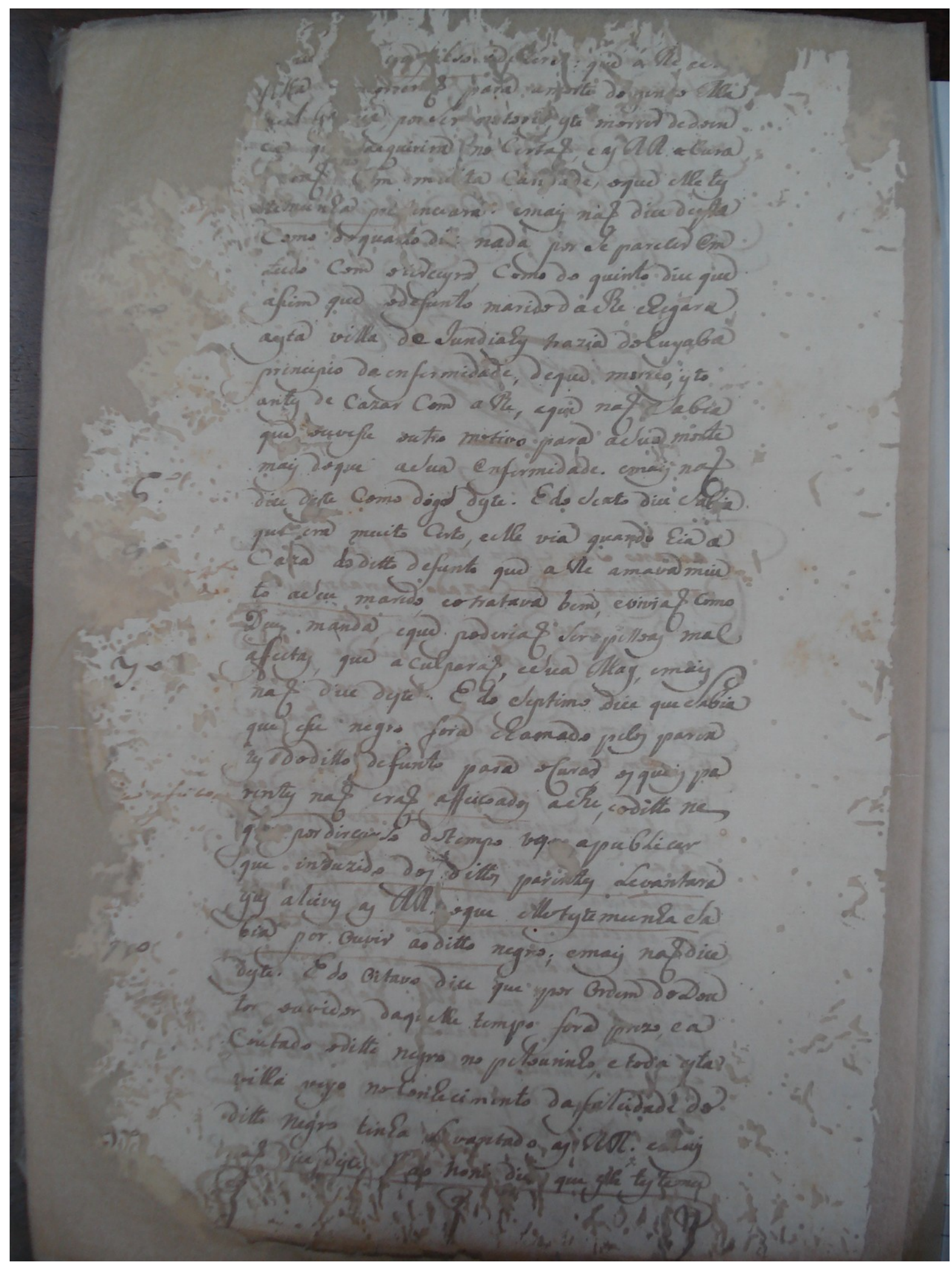


||28 v. $\|$

1185

$1190<$ <corroído $]>$

1195

$<6^{0}>$

1200

$<\downarrow$ corroído] muito $>$

$<$ [corroído]do $>$

$1205<7^{0}>$

$<[\mathrm{e}] \mathrm{raó}$ afeicoa $>$

$<[\mathrm{do}] \mathrm{s}>$

1210

$<[8]^{\circ}>$

1215 [[[d]ice]] [corroído] e[r]a f[a]lso e dizer [se]: que áRe eS[ua]

filha [conc]orrer[a]õ para amorte do gen[r]oMa

[n]oel Ga[rc]ia, por ser $\mathrm{n}[\mathrm{o}]$ torio, este morrer dedoen

ca q[ue] [corroído]acquirira nocertaõ, e as Rés ocura

[r]aõ c[o]m mu[i]ta caridade, oque elle tes

temunha pre[z]enciara emais naõ dice desta

como doqua[r]to di[ce]: nada por se parecer em

tudo com oterceyro, como do quinto dice que

assim que odefunto maridodaRe chegara

aesta villa de Iundiahy trazia docuyaba

principio da enfermidade, deque morreo, isto

antes de cazar Com aRe, eque naõ Sabia

que ouvesse outro motivo para aSua morte

mais doque aSua enfermidade emais naõ

dice deste como digos deste. E do sexto dice Sab[i]a

que era muito certo, eelle via quando hia a

$>$ Caza do ditto defunto que aRe amava mui

to aSeu marido, eotratava bem, eviviaõ como

Deus manda, e que poderiaõ Ser pessoas mal

affeitas, que a culparaõ, eSua May, emais

naõ dice deste. E do Septimo dice que Sabia

que esse negro fora chamado pelos paren

tes doditto defunto para oCurar os qu[ai]s pa

rentes naõ eraõ affeicoados aRe, e oditto ne

$\mathrm{g}[\mathrm{r}] \mathrm{o}$ por dire[ilegível] so dotempo vey[o] apubLicar

que induzido dos dittos parentes Levantara

es[t]es aleives as Rés oque elletestemunha $\underline{\mathrm{S}} \mathrm{a}$

bia por ouvir ao ditto negro; emais naõ dice

deste. E do oitavo dice que por ordem doDou

tor ouvidor daquelle tempo fora prezo, e a

Çoutado oditto negro no pelourinho, etoda esta

villa veyo noconhecimento da falcidade do

ditto negro tinha $\mathrm{L}[\mathrm{e}]$ vantado as Rés $\mathrm{e}[\mathrm{m}]$ ais

$<[9]^{\circ}>\quad[\mathrm{n}]$ aõ dice deste $\mathrm{E}[\mathrm{d}]$ o nono di[ce] que esta testemu 


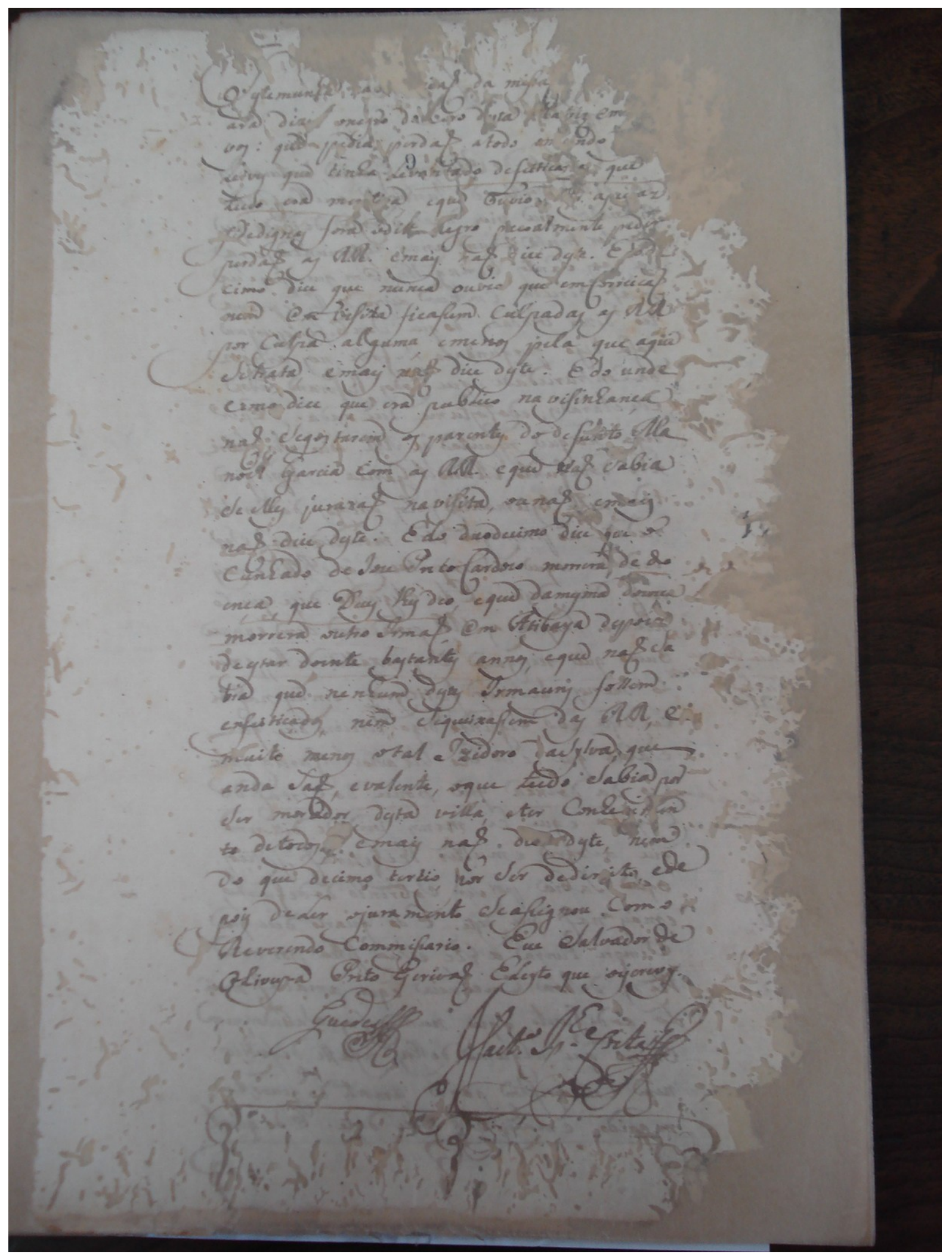


||29 r. $\|$

[[Testemu]]nha [n]a [occaz]iaõ da missaõ [corroído]

1220

ara dizi[a] onegro do coro desta Matriz em [corroído]

vos: que pedia perdaõ atodo omundo [corroído]

Leives que tinha Le $<\uparrow 9>$ vantado defeiticar[i]as que

tudo era me[n]ti[r]a eque ouvio [corroído] ape[corroído]az

fidedignas fora oditt[o] [n] egro peçoalmente pedir

1225 perdaõ as Rés emais naõ dice deste. E do de

cimo dice que nunca ouvio que emCorreicaõ

nem em visita ficassem culpadas as Rés

por culpa alguma, emenos pela que aqui

Setrata, emais naõ dice deste. E do unde

1230 cimo dice que era pubLico na visinhança

$<$ corroído $]>$

naõ Segostarem os parentes dodefunto Ma

noel Garcia com as Rés e que nao ${ }^{374}$ Sabia

Se elles juraraõ na visita, ou naõ emais

naõ dice deste. E do duodecimo dice que o

$<1[2]>$

1235 cunhado de Ioze PretoCardozo morrera, de do <de do[corroído]>

ença, que Deus lhes deo, eque damesma doença $<$ [corroído] $>$

morrera outro Irmaõ, em Atibaya depoi[z]

de estar doente bastantes annos, eque naõ $\mathrm{Sa}$

bia que nenhum destes Irmauns fossem

1240 enfeitiçados, nem Sequeixassem das Rés, e muito menos otal Izidoro daSylva, que $<$ corroído $]>$

anda Saõ, evalente, oque tudo Sabia por

Ser morador desta villa, eter Conhe[c]i[m]en

to detodos [corroído] emais naõ di[ce] deste, nem

1245 do que decimo tercio, por Ser dedir[e]ito ede $\quad<$ [corroído] $>$

pois de Ler ojuramento Se assignou com o

Reverendo commissario. E eu Salvador de

OLiveyra Preto Escrivaõ ELeyto que oescrevy.

Guedes[sinal público] ${ }^{375}$

Caetano Iozeph Cozta[sinal público] $]^{376}$

374 Ao que parece, o "n" em "não" foi grafado por cima de um "s".

375 Assinatura e sinal público de Francisco Iozeph Guedes.

376 Pela comparação do traçado, tudo indica que a assinatura da testemunha é do punho do escrivão

Salvador de Oliveyra Preto. 


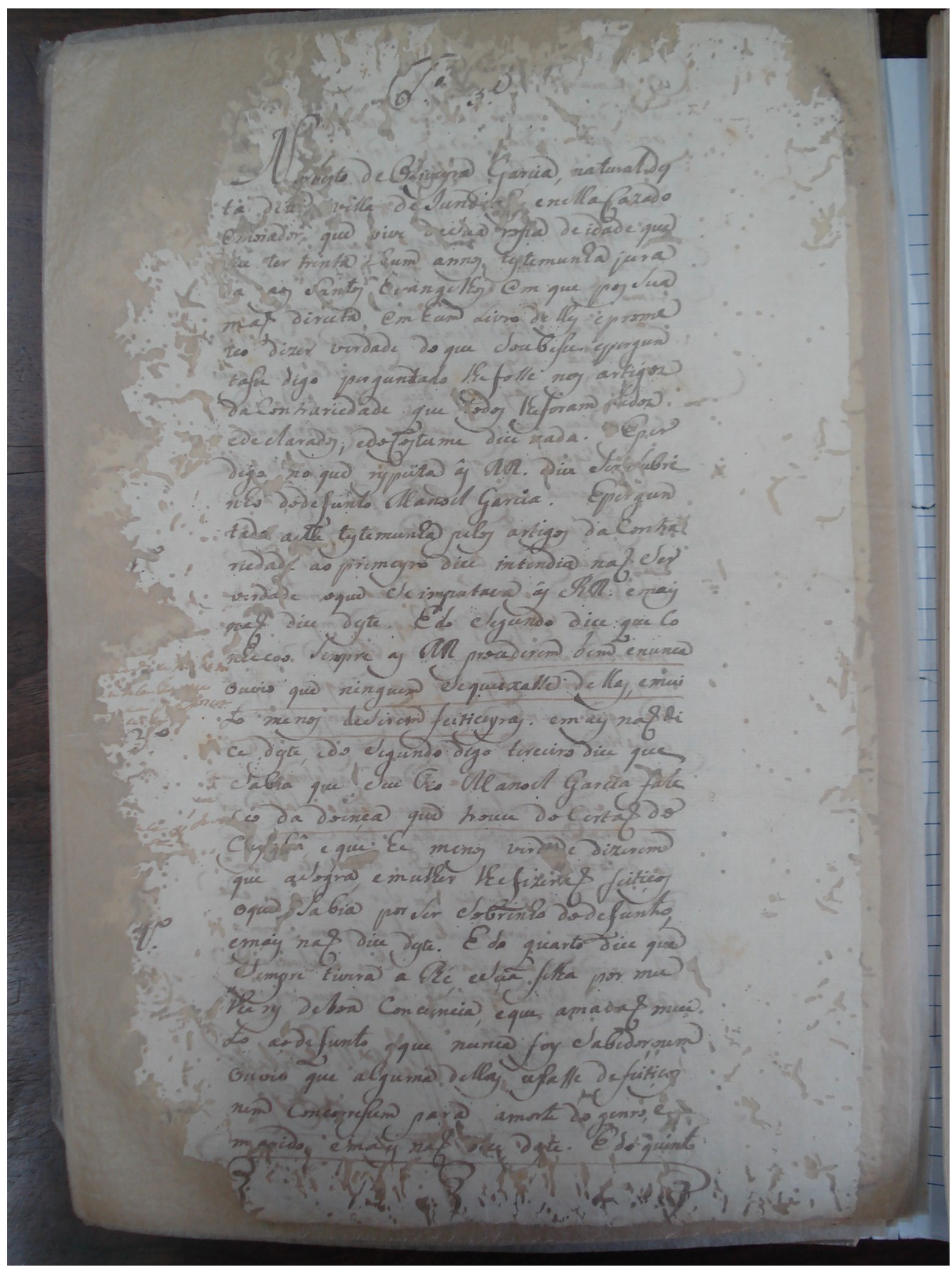


||29v..

Testemunha $3^{\mathrm{a}}$

[espaço]

Norberto deOLiveyra Garçia, natural des

ta dit[ta] villa deIund[i] ahy enellaCazado

emorador, que vive deSua rossa deidade que

1255

[d]ice ter trinta ehum annos testemunha jura

da aos Santos Evangelhos em que pos Sua

maõ direita emhum Livro delles eprome

teo dizer verdade do que Soubesse epergun

tasse digo perguntado lhefosse nos artigoz

1260

$1265<[1]^{0}>$

$<\downarrow[$ proc] ederem bem $>$

$<$ [n] unca h[ouvi]o $>$

$1270<\uparrow$ [quei]xa d[ellas] [p]or ser $>$

$<\uparrow[$ feiti]ceiras $>$

$<\uparrow 3^{\circ}>$

$<$ [doe]nca que tro[uce] $>$

$<$ [cer]taó $>$

1275

$<4^{0}>$

dacontrariedade que [t]odos lheforam [1]idoz

edeclarados, edoCostume dice nada. Eper

digo no que respeita âs Rés edice Ser Subri

nho dodefunto Manoel Garcia. [espaço] Epergun

tado aelle testemunha pelos artigos dacontra

riedade ao primeyro dice intendia naõ Ser

verdade oque Seimputava âs Rés emais

naõ dice deste. E do Segundo dice: que co

nheceo sempre as Rés procederem bem, enunca

ouvio que ninguem Sequeixasse dellas, emui

to menos deserem feiticeyras emais naõ di

ce deste, edo Segundo digo terceiro dice que

Sabia que Seu Tio Manoel Garcia fale

ceo da doença que trouce docertaõ do

c[u]y[ab]â, e que he menos verd[a]de dizerem

que aSogra, emulher lhefizeraõ feitiços

o que sabia por ser Sobrinho dodefunto, emais naõ dice deste. $E$ do quarto dice que

Sempre tivera a Ré, eSua filha por mu

lheres deboa conciencia, eque amavaõ mui

1280 to aodefunto, eque nunca foy Sabedor, nem ouvio que alguma dellas usasse de feitiços nem concorressem para amorte do genro, e marido emais naõ dice $\mathrm{d}[\mathrm{e}] \mathrm{ste}$. $\mathrm{E}$ do quinto 


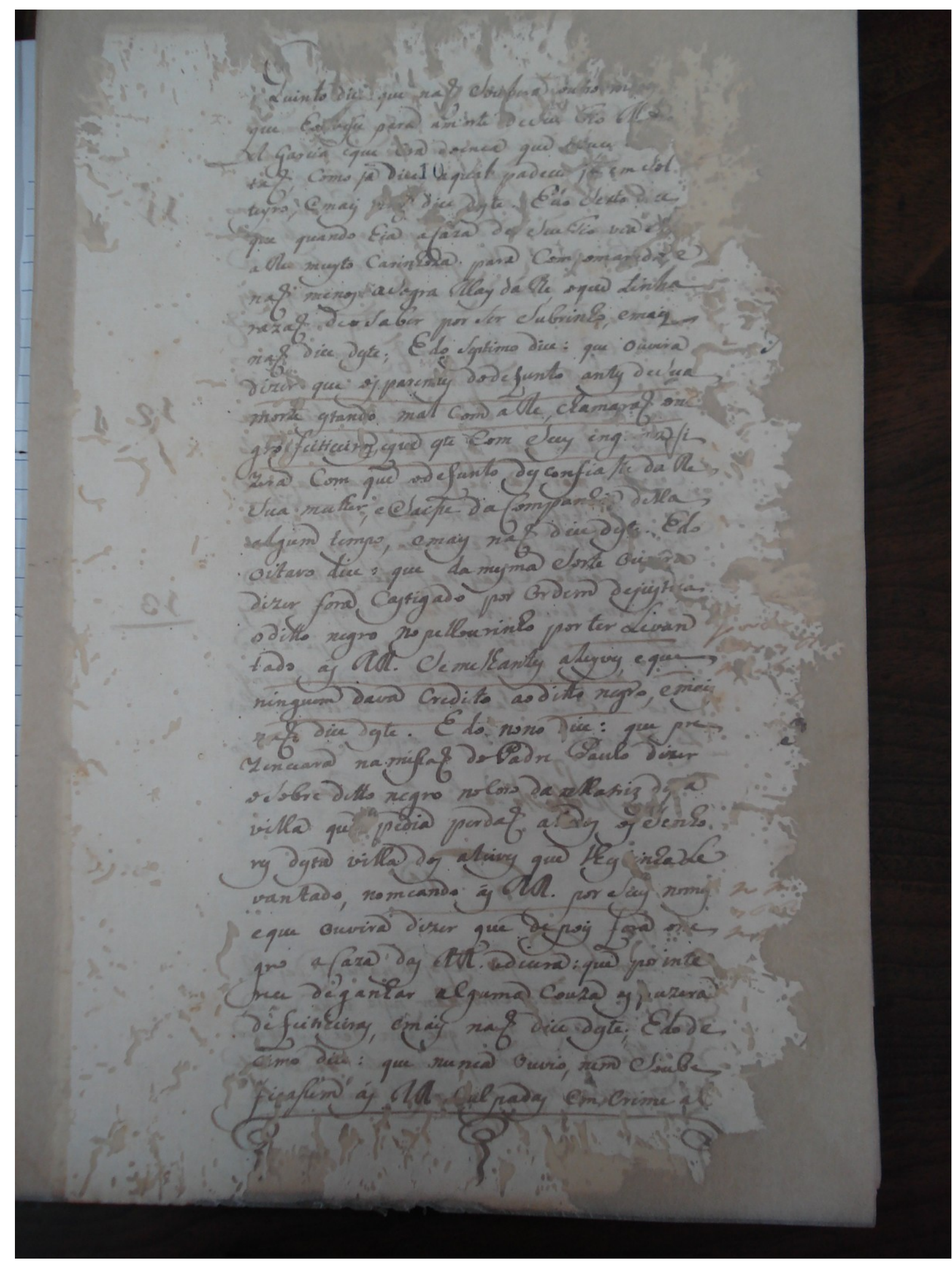


||30 r.

[[Quinto]] dic[e] que naõ Soubera outro m[corroído]

1285 que ho[u]vesse para amorte deSeu Tio M[ano]

el Garcia eque era doença que [tro]uçe [corroído]

taõ, como ja dice $<10>$ aqual padeci[a] j[a] emSol

teyro, emais $\mathrm{n}[\mathrm{a}]$ õ dice $\mathrm{d}[\mathrm{e}]$ ste. E do Sexto dice

que quando hia aCaza de Seu Tio via [corroído]

1290 aRe muyto carinhoza para Com omarido, e

naõ menos aSogra May daRe, oque tinha

razaõ deoSaber por Ser Subrinho, emaiz

naõ dice deste; E do Septimo dice: que ouvira $\quad<7>$

dizer que os parentes dodefunto antes deSua

1295 morte estando mal com aRe, chamaraõ one

gro feiticeiros ${ }^{377}$, eque este com Seus eng[ano]z fi

zera Com que odefunto desconfiasse da Re

Sua mulher, e Saisse daCompanh[i]a della

algum tempo, emais naõ dice deste. Edo

1300 oitavo dice que da mesma Sorte ou[vi]ra

dizer fora castigado por ordem dejustiça

o ditto negro no pellourinho por ter Levan <por t[e]r [corroído]>

tado as Rés Semelhantes aleyves, e que $\quad<$ corroído] as R[és]>

ninguem dava credito ao ditto negro, emais $<\uparrow n$ [corroído] al[e]i[ves] $>$

1305 naõ dice deste. E do nono dice: que pre $\quad<9>$

zenciara na missaõ doPadre Paulo dizer

osobre ditto negro nocoro da Matriz des[t]a

villa qu[e] pedia perdaõ at[o]dos os Senho

res desta villa dos aleives que lhes [t]inha Le

1310 vantado, nomeando ās Rés por Seus nomes <no mi[corroído]>

eque ouvira dizer que depois fora one $\quad<\uparrow a s$ Rés [corroído] $>$

gro aCaza das Rés edicera: que por inte $\quad<\uparrow n o[m e s]>$

reçe de ganhar alguma couza as puzera

defeiticeiras, emais naõ dice deste; E do de

$<$ corroído $]>$

1315 cimo dice: que nunca ouvio, nem Soube

fi[c]assem ás Rés culpadas em crime al

3770 "s" final, em "feiticeiros", foi riscado duas vezes, isto é, foi rasurado, indicando que o escrivão se equivocou ao escrever a palavra no plural. 


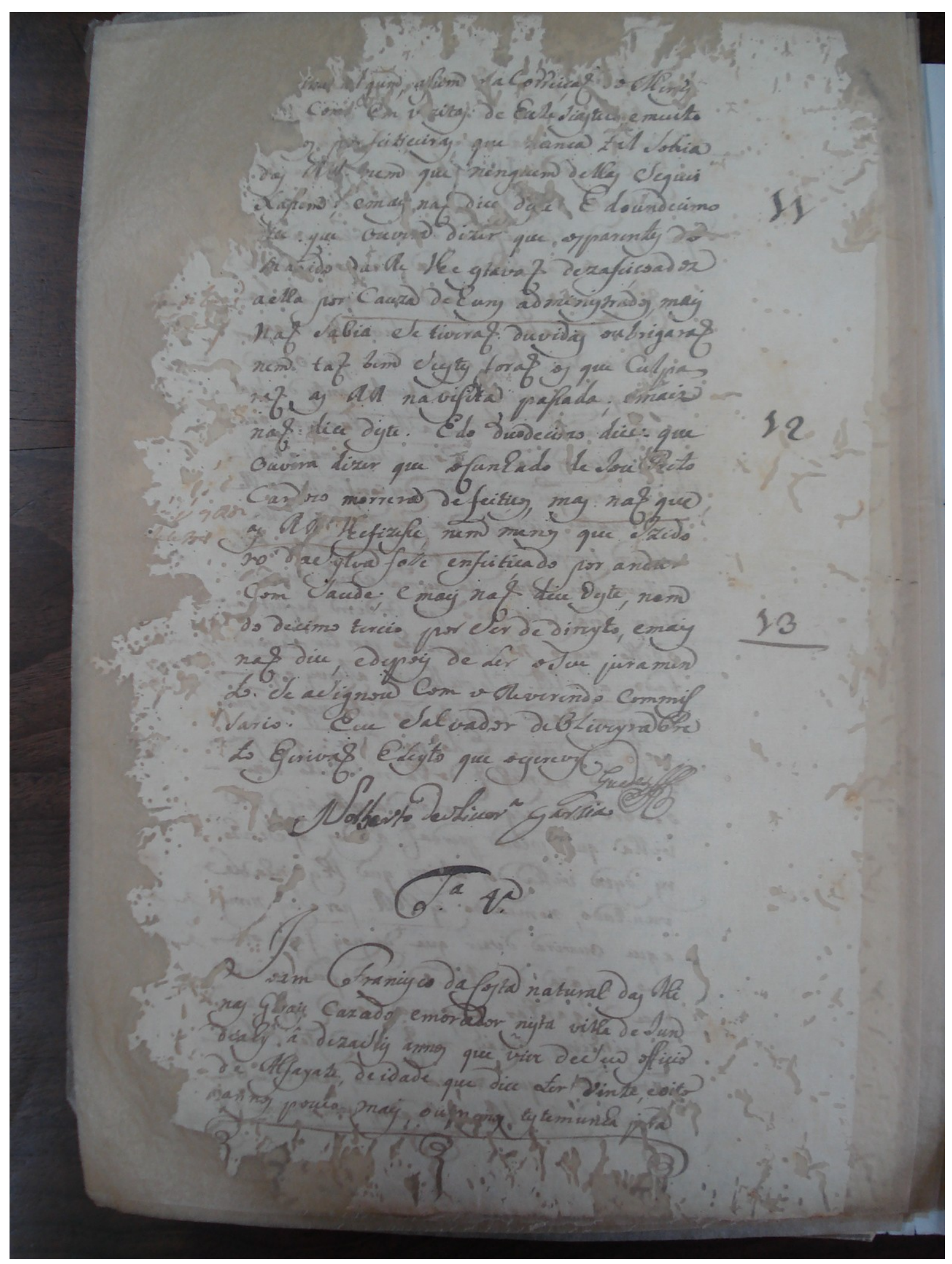


||30 v.

1320

$<$ cau $]$ Za de hunś $>$

$1325<[$ administr $] \mathrm{ad}[\mathrm{o}] \mathrm{s}>$

$1330<\downarrow[$ na]ó que as Rés>

$<[$ fi]Zece ne $>$

1335

$<[$ corroído $]>$

1340

1345

[[[cr]ime al]]gum, assim nacorreiçaõ doMinis

[corroído] co[m] em v[i]zitas de EccLesiasti[ca], emuito

[men]os p[or] feitiçeiras que nunca tal Sabia

das Rés nem que ninguem dellas Sequei

xassem; emais naõ dice des[t]e E do undecimo $\quad<11>$

[d]ice que ouvi[r]a dizer que os parentes do

ma[r]ido da Re lhe estavaõ dezafeiçoadoz

aella por cauza dehuns administrados, mais

naõ Sabia Se tiveraõ duvidas ou brigaraõ

nem taõ bem Seestes foraõ os que culpa

raõ as Rés navisita passada; [e]maiz

naõ dice deste. E do duodecimo dice: que

$<12>$

ouv[i]ra dizer que oCunhado de Ioze Preto

Cardozo morrera defeitiços, mas naõ que

as Rés lhefizesse, nem menos que Izido

ro daSylva fosse enfeitiçado por andar

com Saude; emais naõ dice deste, nem

do decimo tercio por Ser de direyto, emais

naõ dice, edepois de Ler oseu juramen

to Se asignou com oReverendo commis

sario. Eeu Salvador deOLiveyra Pre

to Escrivaõ ELeyto que oescrevy

Guedes[sinal público] ${ }^{378}$

$\underline{\text { Norberto deoLiueyra Garcia }}^{379}$

[espaço]

Testemunha $4^{\mathrm{a}}$

[espaço]

Ioam Francisco daCosta natural das Mi

nas G[e]rais cazado emorador nesta villa de Iun

diahy â dezaS[e]is annos que vive deSeu officio

de Alfayate, deidade que dice ter Vinte, eoito

annos pouco mais, ou menos testemunha $\mathrm{j}[\mathrm{u}] \mathrm{ra}$

378 Assinatura e sinal público de Francisco Iozeph Guedes.

379 Assinatura do próprio punho da testemunha. 


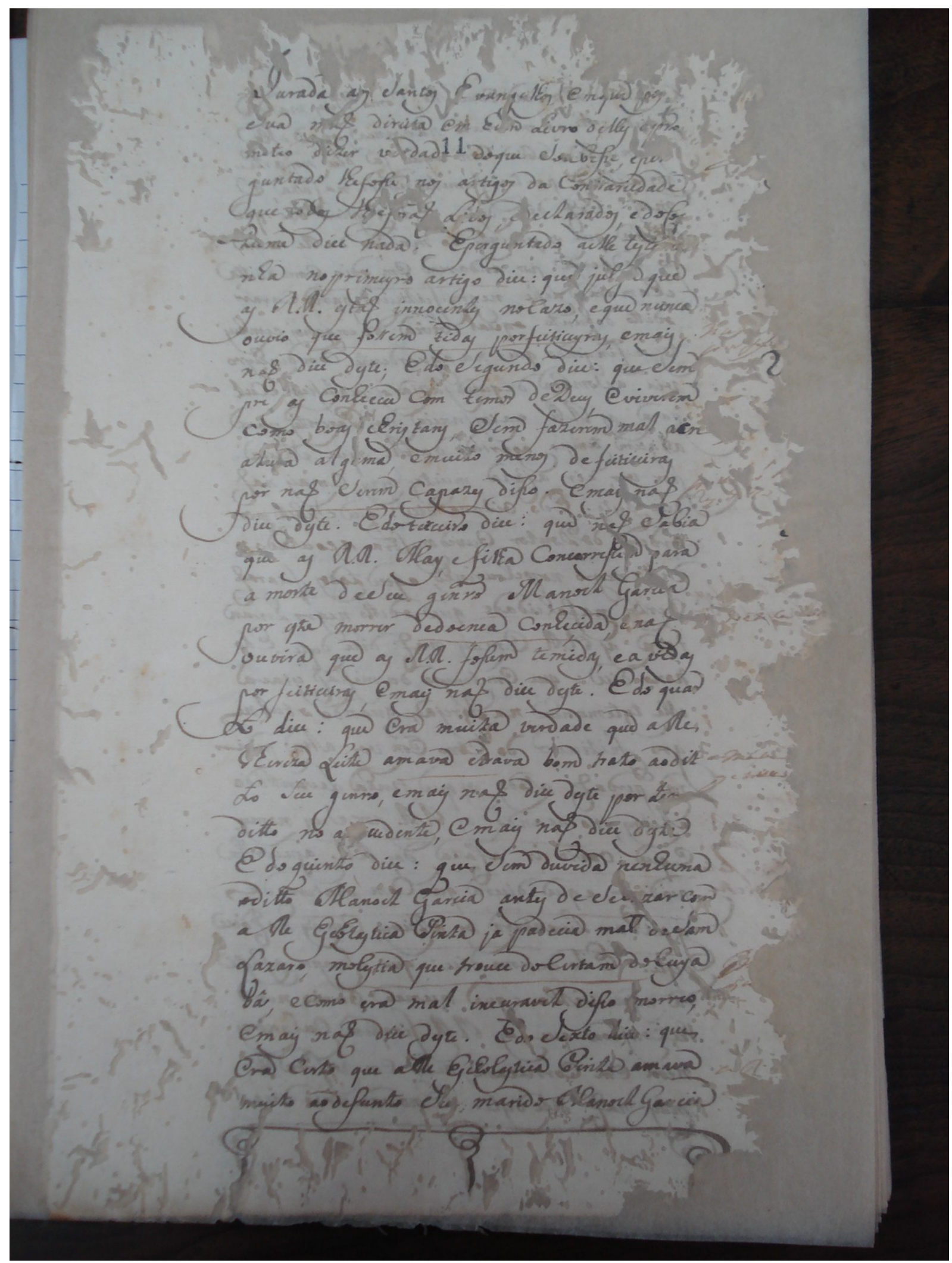


[[Iura]]da a[o]s Santos Evangelhos emque pos

Sua maõ direita em hum Livro delles epro

meteo dizer verdad $[\mathrm{e}]<11>$ doque Soubesse, epe[r]

$<$ [corroído $]>$

1350

guntado lhefosse nos a[r]tigos da con[t]rariedade

$<$ corroído $]>$

que todos lhef[o]raõ Lidos, edeclarados, e doCos

tume dice nada. Eperguntado aelle teste[mu]

nha no primeyro artigo dice: que julga que

$<\downarrow[$ corroído $]>$

as Rés estaõ innocentes nocazo, eque nunca

1355 ouvio que fossem tidas por feiticeyras, emais <nu[nca] [corroído]>

naõ dice deste; E do Segundo dice: que Sem $\quad<\uparrow$ por feiti[corroído] $\quad<2>$

pre as conheceu com temor deDeus, eviverem

como boas christans, Sem fazerem mal acri

$\mathrm{atu}[\mathrm{r}] \mathrm{a}$ alg[u]ma, emuito menos de feiticeiras

1360 por naõ Serem capazes disso e mais naõ <p[o]r [na]ó s[corroído]>

dice deste. E doterceiro dice: que naõ Sabia $<\uparrow$ Zes d[is]so $>$

que as Rés May, efilha Concorressem para

$<\uparrow[$ corroído] $>$

a morte deSeu genro Manoel Garcia

por este morrer dedoença conheçida, e naõ $\quad<$ de] doenca [corroído] $>$

1365 ouvira que as Rés fossem temidas, e a vidas

por feiticeiras, e mais naõ dice deste. E do quar

to dice: que era muita verdade que aRe,

Thereza Leite amava edava ${ }^{380}$ bom trato ao dit <amav[a]>

to Seu genro, emais naõ dice deste por ter $\quad<\uparrow$ genrro $>$

1370 ditto no a[nt]ecedente, emais naõ dice deste

E do quinto dice: que Sem duvida nenhuma

oditto Manoel Garcia antes de se[ca]zar com

aRe Escholastica ${ }^{381}$ Pinta ja padecia mal deSam

Lazaro, molestia que trouce docertam docuya $<$ [ilegível] $>$

1375 bâ, e como era mal incuravel disso morreo, <个[corroído] $>$

emais naõ dice deste. E do Sexto dice: que

era certo que aRe Escholastica Pinta amava $\quad<\mathrm{aRe}>$

muito ao defunto Seu maridoManoel $\mathrm{Ga}[\mathrm{r}]$ cia

3800 "d" em "dava" foi redigido por cima de um "tr".

381 É provável que o escrivão tenha redigido o nome de Escholastica sem o "h", acrescentando-o posteriormente. 


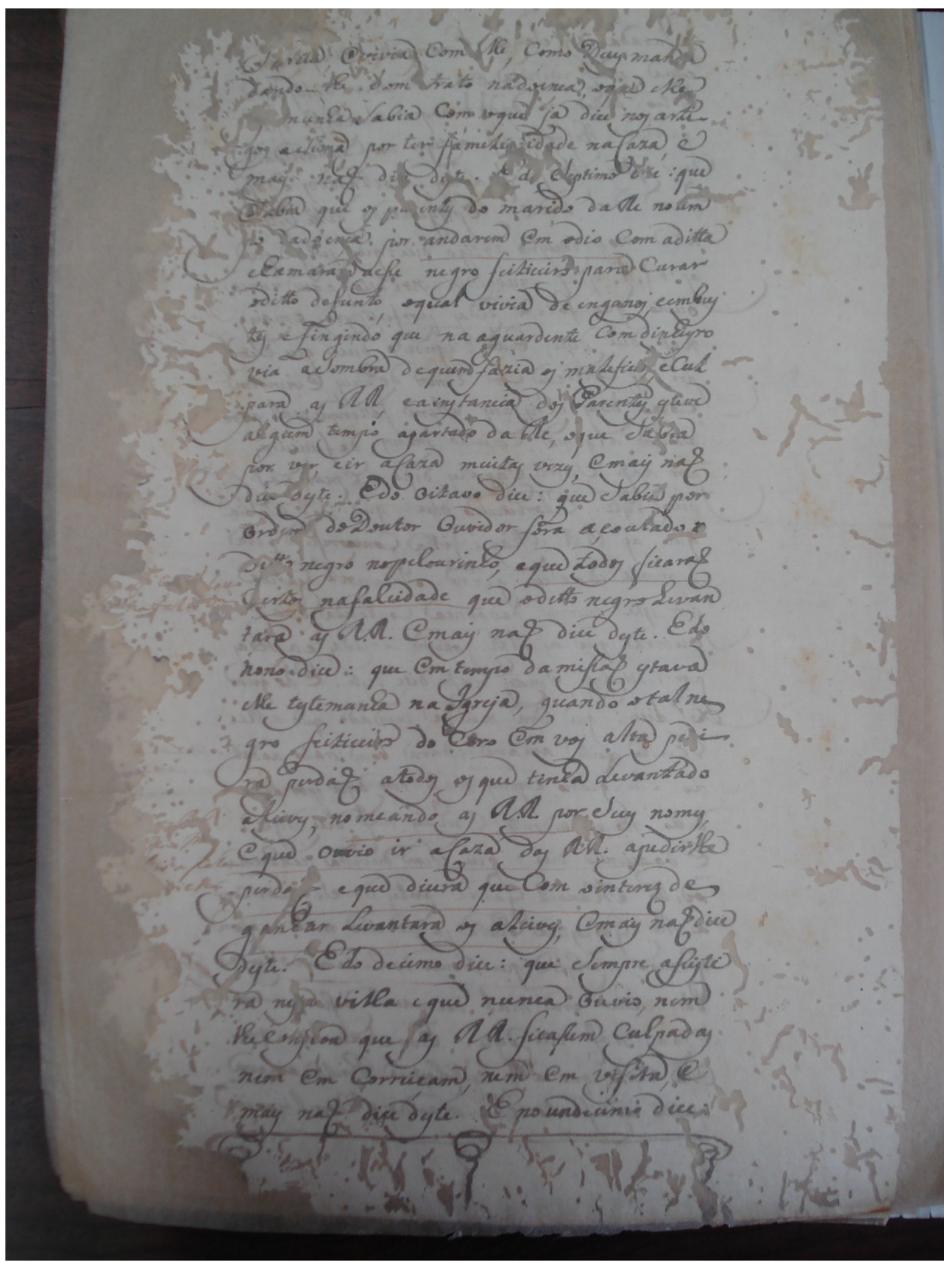


1380

1385

1390

$<[\text { corroído }]^{\circ}>$

1395 $<\downarrow$ [todo]s fi c[araó] [c]er> $<$ [corroído] na falcidade $>$

$<$ corroído $^{0}>$

1400

1405 $<$ as Rés $>$ $<\uparrow$ nom[e]s $>$ $<\uparrow[$ corroído]ir a caZa $>$ $<\uparrow[$ corroído]dirlhe $>$
\|31 v. $\|$

[[Garcia]] evivia com [e]lle, como Deus manda dando - lhe bom trato nadoença, oq[u]e elle [te]s[te]munha Sabia com oque ja dice nos arti gos aSima por ter famili[a]ridade naCaza, e mais naõ di[ce] deste. E d[o] Septimo d[ic]e: que Sabia que os $\mathrm{pa}[\mathrm{r}]$ entes do marido daRe no [t]em po dadoença por andarem em odio com aditta chamara[m] a esse negro feiticeiro para curar oditto defunto, oqual vivia de enganos, eembus tes, efingindo que na aguardente com dinheyro via aSombra dequem fazia os malefic[i]os, ecul para as Rés, e ainstancia dos Parentes esteve algum tempo apartado da Re, oque Sabia por v[e]r, eir aCaza muitas vezes, emais naõ dice deste. Edo oitavo dice: que Sabia por ordem doDoutor Ouvidor fora açoutado [o] ditto negro nopelourinho, eque todos ficaraõ certos nafalcidade que oditto negroLevan tara as Rés Emais naõ dice deste. E do nono dice: que em tempo da missaõ estava elle testemunha na Igreja, quando otal ne gro feiticeiro do coro em vos alta pedi ra perdaõ atodos os que tinha Levantado aleives, nomeando as Rés por Seus nomes, e que ouvio ir aCaza das Rés apedir lhe perdaõ eque dicera que Com o interez de ganhar Levantara os aLeives, emais naõ dice deste. $\mathrm{E}$ do decimo dice: que Sempre assisti ra nes[t]a villa e que nunca ouvio, nem lhecon[st]ou que as Rés ficassem culpadas nem em correiçam, nem em visita, e mais naõ dice deste. E no undecimo dice: 


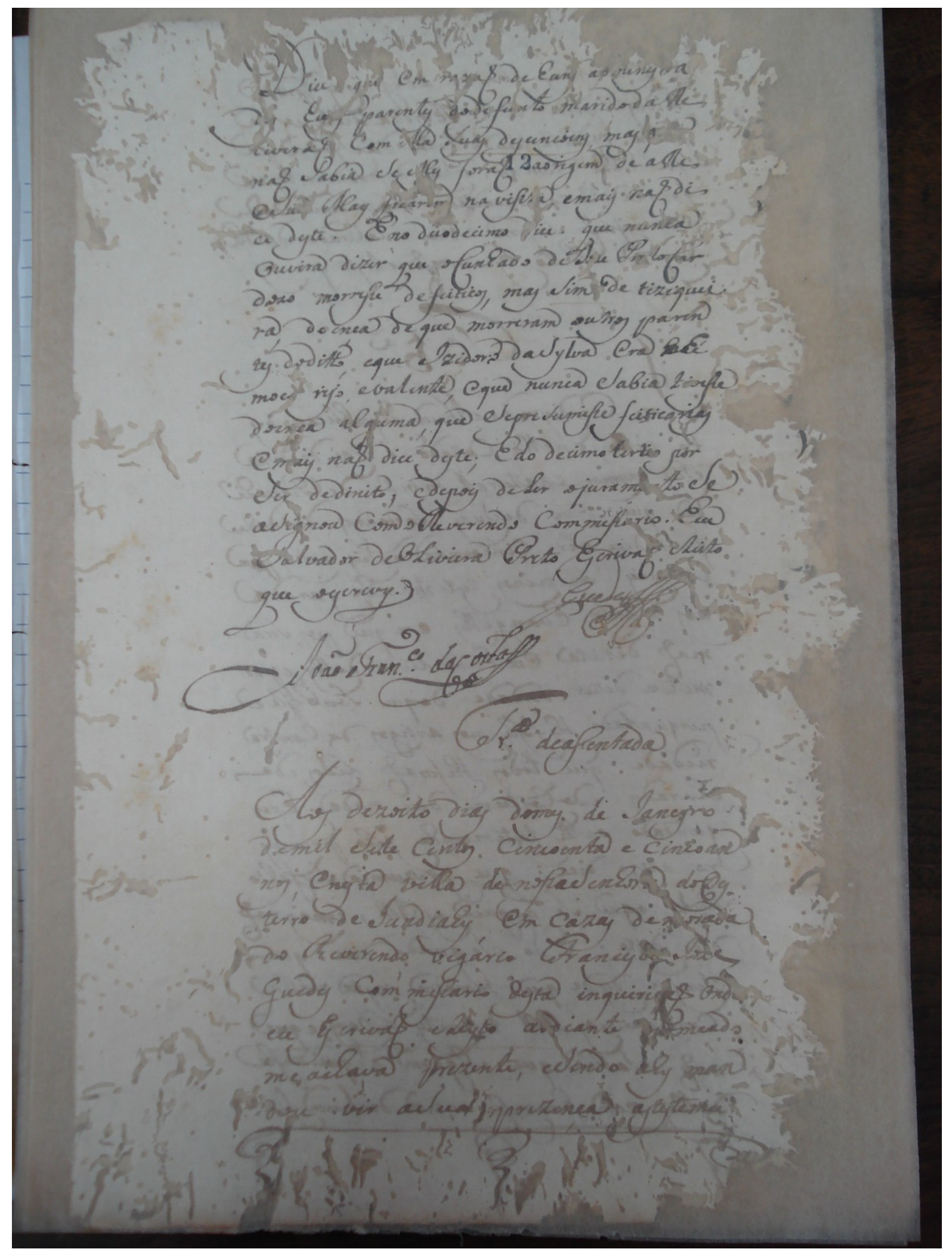


||32 r.

[[Dice]] que em razaõ de huns adminis[t]ra $\mathrm{d}[\mathrm{o}] \mathrm{s}$ hu[ns] parentes dodefunto maridodaRe tiveraõ com ella $\underline{\text { Suas descencoens, }}$ mas q[ue] $<[\mathrm{Su}]$ as [corroído] $>$ naõ Sabia Se elles foraõ $<12>$ aorigem de aRe

$1415 \mathrm{eSu}[\mathrm{a}]$ May ficar[e]m navisi[t]a emais naõ di ce deste. E no duodecimo dice que nunca $<\uparrow 1[2]>$ ouvira dizer que oCunhado deIoze Pr[e]toCar

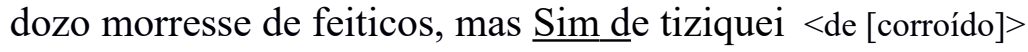
ra, doença de que morreram outros paren

1420 tes doditto, eque Izidoro daSylva era ahi ${ }^{382}$ moc[o] rijo evalente, eque nunca Sabia t[i]vesse doenca alguma, que Sepresumisse feiticarias e mais naõ dice deste; E do decimo tertio por Ser dedireito, edepois deLer ojuram[en]tto Se

1425 aSignou Com o Reverendo Commissario. Eeu Salvador deOLiveira Preto Escrivaõ eLeito que oescrevy. $\quad$ Guedes [sinal público] ${ }^{383}$

João Francisco daCozta[sinal público] ${ }^{384}$ Termo deassentada [espaço]

1430 Aos dezoito dias domes de Ianeyro demil Sete Centos cincoenta e cinco an nos, enesta villa de nossaSenhora doDes terro de Iundiahy em cazas de morada do Reverendo vigário Francisco Ioze

1435 Guedes com missario desta inquiriçaõ ond[e] eu Es crivaõ eLeyto aodiante [no]meado me achava prezente, eSendo ahy man dou vir aSua prezença as testemu 


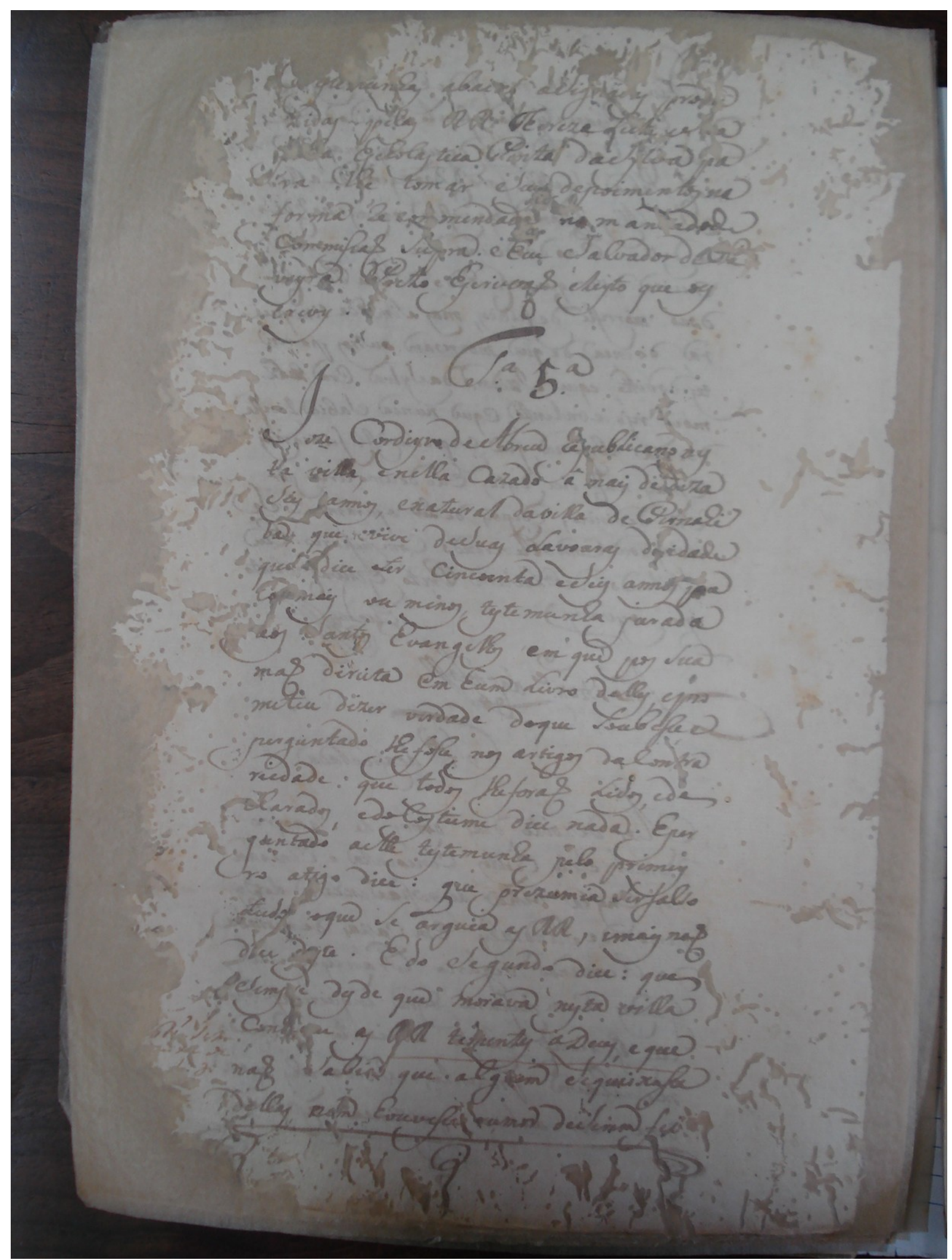


1440

1445

1450

1455

1460

$<$ corroído $^{0}>$

$<[2]^{0}>$

1465
\|32 v. $\|$

[[[T] estemu $]]$ nhas abaixo aSignadas produ zidas pelas Rés TherezaLeite eS[u]a f[ilh]a Escholastica Pinta daSylva pa ra lhe tomar Seus depoimentos na forma recommendada no mandadode commissaõ Supra eE[[e]]u Salvador deOli veyra Preto Escrivaõ eLeyto queoes crevy.

\section{Testemunha $5^{\mathrm{a}}$ [espaço]}

Ioze Cordeyro deAbreu repubLicano nes ta villa, enella cazado â mais de diza Seis annos, enatural davilla de Pernahi ba que vive deSuas Lavouras d[e]idade que dice ter cincoenta eSeis annos pa $\operatorname{co}^{385}$ mais ou menos, testemunha jurada aos Santos Evangelhos em que pos Sua maõ direita em hum Livro delles, epro meteu dizer verdade doque Soubessee perguntado lhe fosse nos artigos dacontra riedade: que todos lhe foraõ Lidos, ede clarados, edocostume dice nada. Eper guntado aelle testemunha pelo primey ro atigo ${ }^{386}$ dice: que prezumia Ser falso tudo oque Se arguia as Rés, emais naõ $\mathrm{d}[\mathrm{i}]$ ce $\mathrm{d}[\mathrm{e}]$ ste. E do Segundo dice: que Sempre desde que morava nesta villa conh[ece]u as Rés tementes aDeus, e que naõ Sabia que alg[u]em Sequeixasse dellas, nem houvesse rumor deSerem fei 


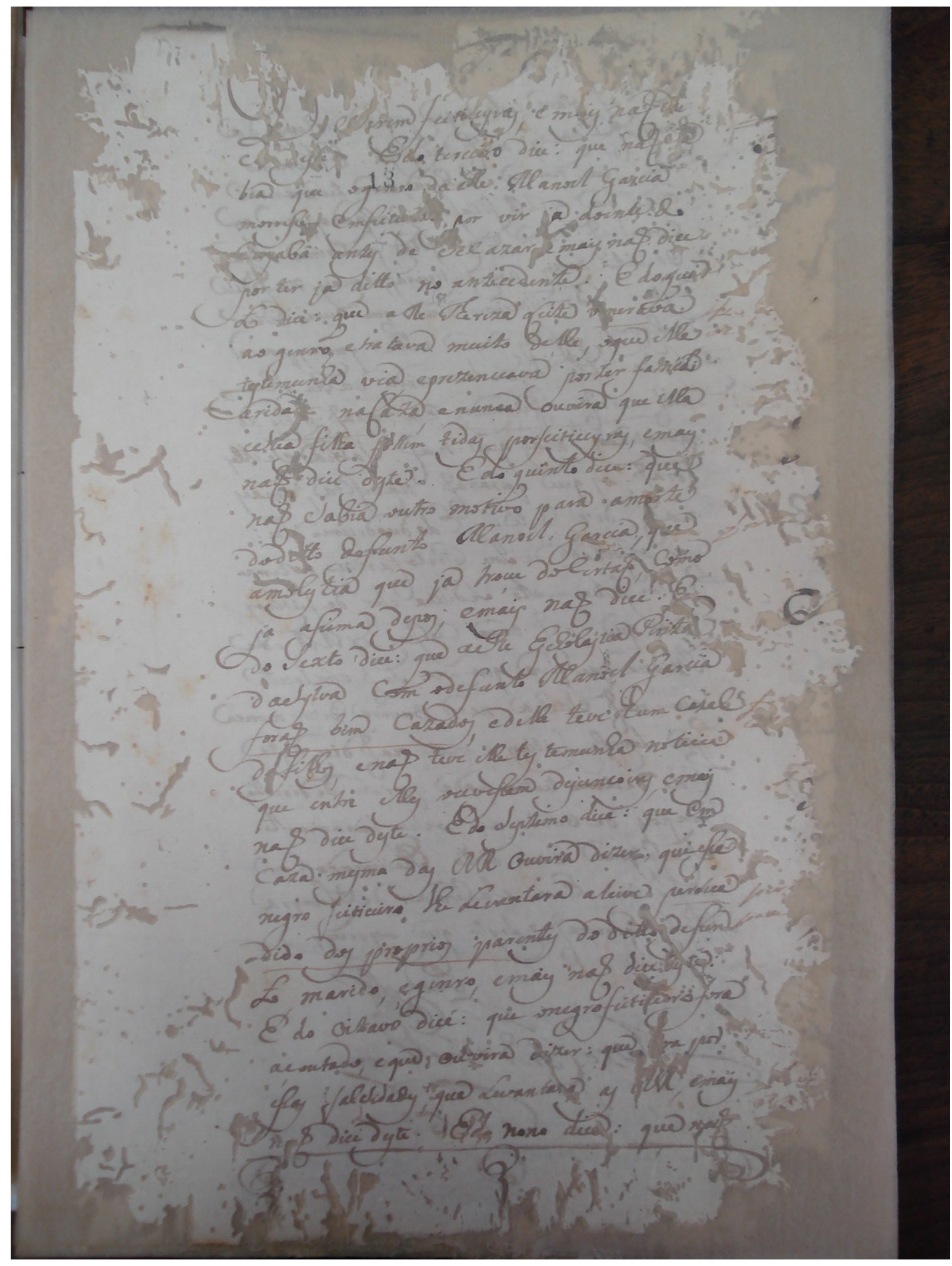


||33 r. $\|$

[[DeSerem fei]]ticeyras, emais naõ di

$\mathrm{c}[\mathrm{e}] \operatorname{des}[\mathrm{t}] \mathrm{e}<\downarrow 13>\mathrm{E}$ do terceiro dice: que naõ Sa

$<\downarrow[$ corroído $]>$

$<3>$

1470 bia que ogenro daRe Manoel Garcia

morresse emfeitiç $[\mathrm{a}] \mathrm{d}[\mathrm{o}]$ por vir ja doente do

cuyabâ antes de Secazar e mais naõ dice

por ter ja ditto no antecedente. E do qu[ar]

to dice: que aRe Thereza Leite v[e]nerava $<\downarrow[$ ilegível] $>$

1475 ao genro, etratava muito delle, oque elle <[ilegível] $>$

testemunha via eprezenciava por ter famiLi

aridad[e] naCaza, enunca ouvira que ella

eSua filha fossem tidas por feiticeyras, emais

naõ dice deste. E do quinto dice: que $\quad<5>$

1480 naõ Sabia outro motivo para amorte

doditto defunto Manoel Garcia, que $<$ que a[corroído] $>$

amolestia que ja troçee docertaõ, como

ja assima depos; emais naõ dice. $\mathrm{E}$

do Sexto dice: que aRe Escholastica Pinta $\quad<6>$

1485 daSylva com odefunto Manoel Garcia

foraõ bem cazados, e delle teve hum cazal <fo[raó]>

$\mathrm{d}[\mathrm{e}]$ filhos, enaõ teve elle testemunha noticia $<\uparrow c a Z[\operatorname{ados}]>$

que entre elles ouvessem descencoens, emais

naõ dice deste. E do Septimo dice: que em $\quad<7>$

1490 caza mesma das Rés ouvira dizer queesse

negro feiticeiro lhe Levantara aleive persua <per[corroído]>

dido dos proprios parentes do ditto defun $\quad<$ pare[ntes] $>$

to marido, egenro, emais naõ dice deste.

$<\uparrow[$ corroído] $>$

E do oitavo dice: que onegro feitice[i]ro fora

1495 açoutado, e que ouvira dizer: que [e]ra por

essas falsidades, que Levantara as Rés, emais <que L[e]v[corroído]>

$\mathrm{n}[\mathrm{a}]$ õ dice deste. $\mathrm{E}$ do nono dice: que naõ $\quad<\uparrow[R e ́ s]>$ 


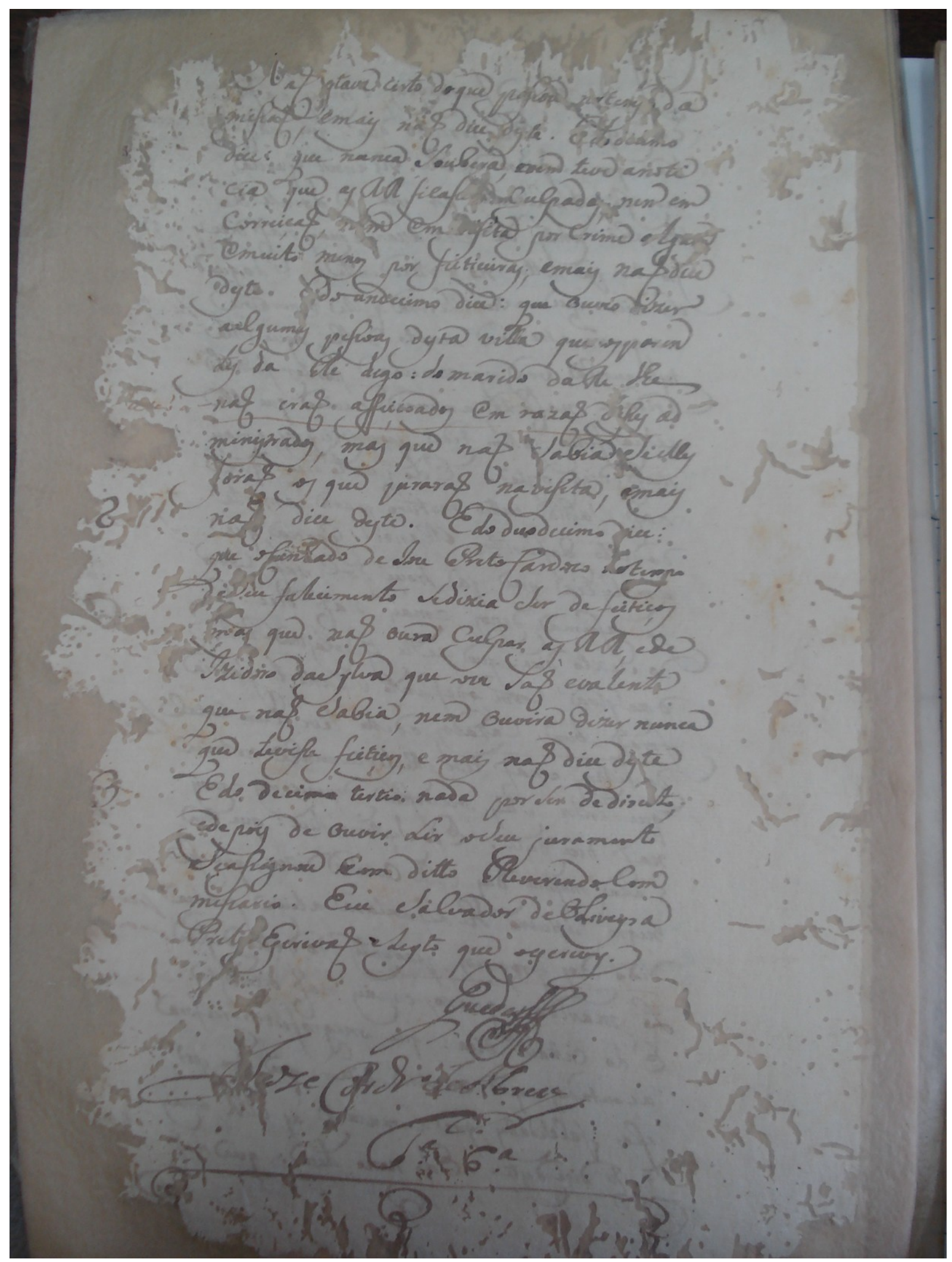


||33 v. .

[[Naõ]] estava certo do que passou notemp[o] da missaõ, emais naõ dice deste. E do decimo

1500

dice: que nunca Soubera, enem teve anoti cia que as Rés ficass[em] culpadas, nem em correiçaõ, $\mathrm{n}[\mathrm{e}] \mathrm{m}$ em [vi] sita por crime algum emuito menos por feiticeiras, emais naõ dice deste $\mathrm{E}$ doundecimo dice: que ouvio dizer

1505 algumas pessoas desta villa que os paren tes da Re digo: do marido daRe lhe $<$ [corroído] [e]raó a - > naõ eraõ affeiçoados em razaõ desses ad $<$ [corroído $]>$ ministrados, mas que naõ Sabia Seelles foraõ os que juraraõ na visita, emais

$1510<[1] 2>$

1515 $<[1] 3>$ 1520 naõ dice deste. $\mathrm{E}$ do duodecimo dice: que oCunhado de Ioze PretoCardozo [n]oterpo ${ }^{86}$ deSeu falecimento Sedizia Ser de feitiços mas que naõ oura ${ }^{87}$ culpar as Rés, ede Izidoro daSylva que vive Saõ evalente que naõ Sabia, nem ouvira dizer nunca que tivesse feitiços, e mais naõ dice deste E do decimo tertio nada por Ser de dire[i]to, edepois de ouvir Ler oSeu juramento Seassignou com ditto Reverendocom missario Eeu Salvador deOLiveyra Pret[o] Escrivaõ eLeyto que oescrevy. Guedes[sinal público] ${ }^{387}$ Joze Cordeyro deAbreu[sinal público] ${ }^{388}$ Testemunha $6^{\mathrm{a}}$ 


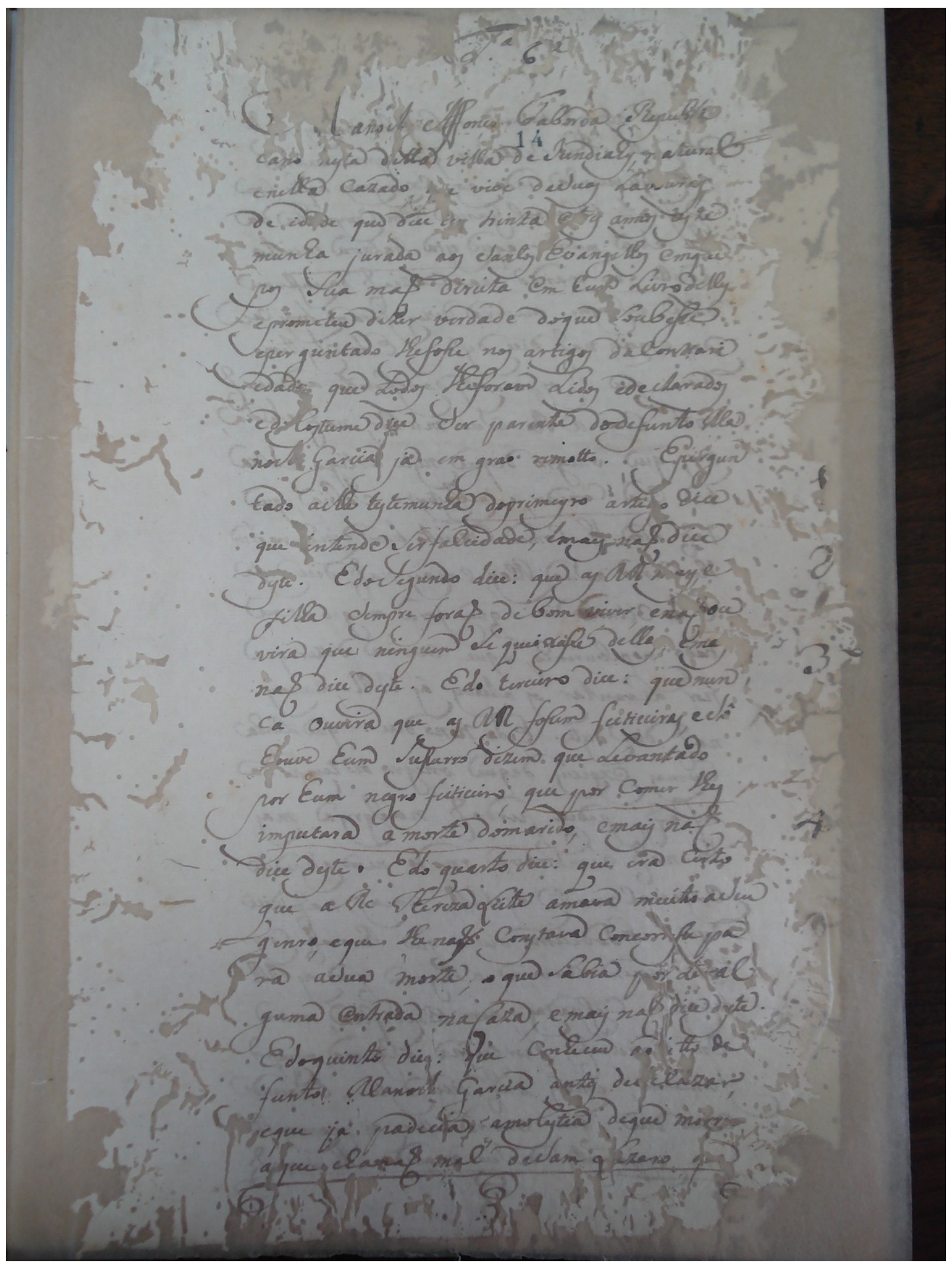


||34 r. $\|$

1525

[[Testemunha $\left.\left.6^{\mathrm{a}}\right]\right]$

[espaço]

Manoel Affonço $<\downarrow 14>$ Taborda Republi

cano nesta ditta villa deIundiahy, natural

$<[$ corroído $]>$

enella cazado, $\mathrm{q}[\mathrm{u}] \mathrm{e}$ vive deSuas Lav[o]uras, de id[a]de que dice te[r] trinta etres annos teste

1530 munha jurada aos Santos Evangelhos emque

pos Sua maõ direita em hum Livro delles

eprometeu dizer verdade doque Soubesse

eperguntado lhefosse nos artigos dacontrari

edade que todos lheforam Lidos edeclarados

1535 e doCostume dice Ser parente dodefunto Ma

noel Garcia ja em grao remotto. [espaço] Epergun

tado aelle testemunha doprimeyro artigo dice $\quad<1>$

que intende Ser falcidade, emais naõ dice

deste. E doSegundo dice: que as Rés may, e $\quad<2>$

1540 filha Sempre foraõ debom viver, enaõ ou vira que ninguem Se queixasse dellas, ema[i]s

naõ dice deste. $E$ do terceiro dice: que nun

ca ouvira que as Rés fossem feiticeiras, e Sô

houve hum Sussurro dizem que Levantado

1545 por hum negro feiticeiro, que por comer lhes $<$ por co[mer] $>$

imputara a morte domarido, emais naõ $<4>$

dice deste. E do quarto dice: que era certo

que aRe Thereza Leite amava muito aSeu

genro, eque the na $\tilde{0}^{389}$ constava concorr[e]sse pa

1550 ra asua morte, o que Sabia por te[r] al

guma entrada naCaza, e mais naõ dice deste.

E doquinto dice: que c[o]nheceu ao ditto de

funto Manoel Garcia antes deSecazar, $\quad<\downarrow j a>$

eque ja padecia amolestia deque morr[eo] $<\downarrow$ [corroído] $>$

1555 a que chamaõ mal deSam Lazaro qu[e] $\quad<\downarrow$ [corroído] $>$

389 Aparentemente, o escrivão cometeu um erro ao redigir a nasal "õ". 


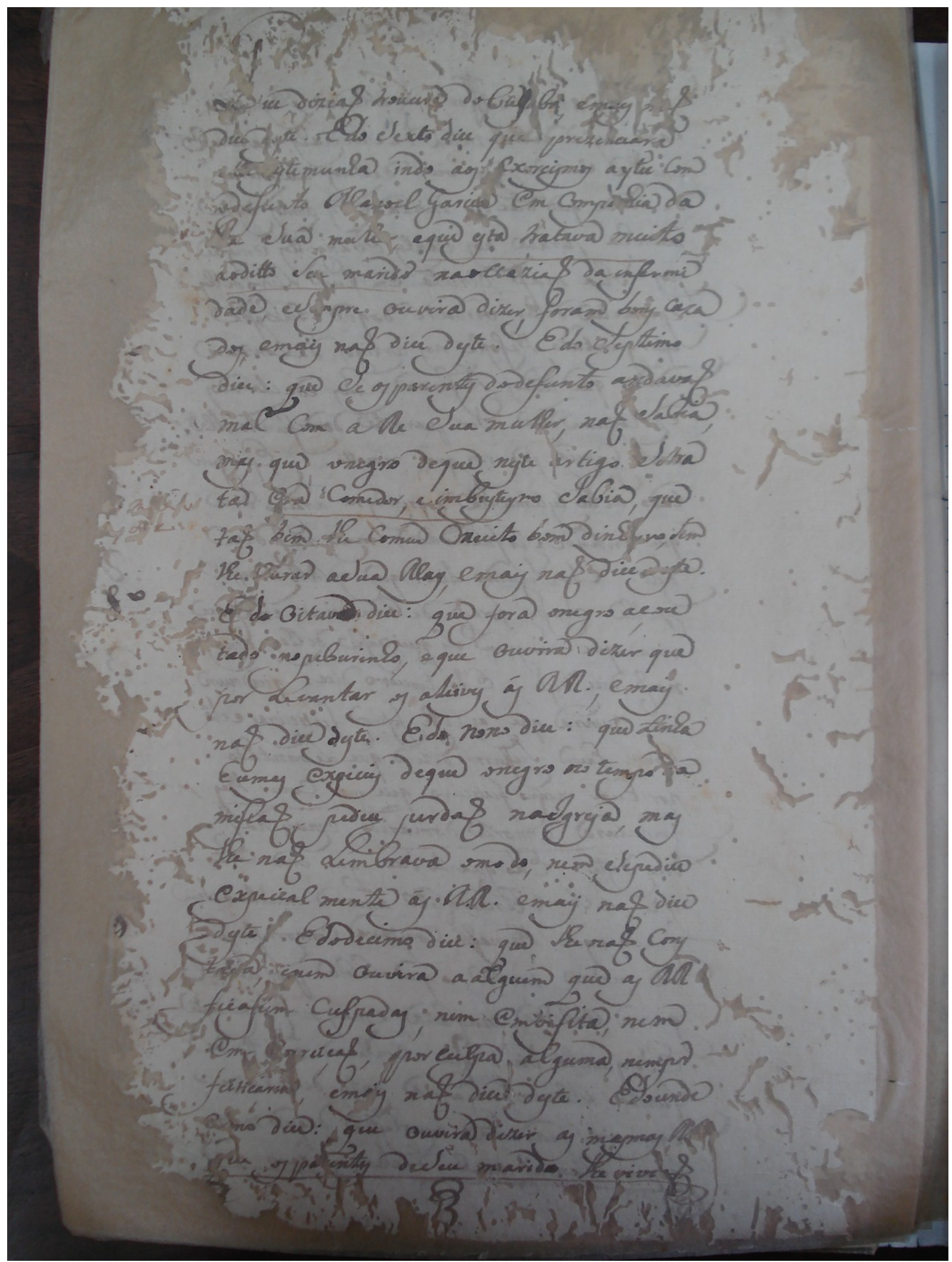


||34 v. |

1560

$<[7]^{0}>$

1565

$1570<8^{\circ}>$

$<[9]^{0}>$

1575

$<[10]^{0}>$

[[Que]] diziaõ troucera doCuyabâ, emais naõ dice deste. E do Sexto dice que prezenciara

elle [t]estemunha indo aos exorcismos a ytu com odefunto Manoel Garcia emcompa[n]hia da

$<q u e>\operatorname{Re}$ Sua mulh[e]r, eque esta tratava mu[i]to aoditto Seu marido naoccaziaõ da enfermi dade, eS[e]mpre ouvira dizer, foram bons caza dos, emais naõ dice deste. E do Septimo dice: que Se os parentes dodefunto andavaõ mal com aRe Sua mulher, naõ Sabia, mas que onegro deque neste artigo Setra $<[\mathrm{co}] \mathrm{m}[\mathrm{edo}] \mathrm{r}>$ ta era comedor ${ }^{390}$, e imbusteyro Sabia, que $<\uparrow[i m b u] s t[e]$ iro $>$ taõ bem lhe comeu Omuito bom dinh[e]yro, Sem lhe curar aSua May, emais naõ dice deste. $\mathrm{E}$ do oitavo ${ }^{391}$ dice: que fora onegro açou tado no pelourinho, e que ouvira dizer que por Levantar os aLeives ás Rés, emais naõ dice deste. E do nono dice: que tinha humas expecies deque onegro no tempo da missaõ pediu perdaõ naIgreja, mas lhe naõ Lembrava omo do, nem Sepediu expecial mente ās Rés emais naõ dice deste $\mathrm{E}$ dodecimo dice: que lhe naõ cons $\mathrm{ta}[\mathrm{v}] \mathrm{a}$, enem ouvira a alguem que as Rés ficassem culpadas ${ }^{392}$, nem emvisita, nem em correiçaõ, por culpa alguma, nempor feitiçaria, emais naõ dice deste. [espaço] E do unde c[i]mo dice: que ouvira dizer as mesmas Rés que os parentes deSeu marido lhe viviaõ

390 Antonio de Moraes Silva, no volume 1 de seu Diccionario da lingua portugueza (1813: 418), define a palavra "comedor" como "O que come múito, ou pouco; e vulgarmente dos que illudem outrem, para lhe comerem alguma coisa." O dicionário Caldas Aulete Digital (disponível em: http://www.aulete.com.br/comedor) apresenta diferentes significados para essa palavra, dentre eles "aproveitador" e "parasita". Portanto, "comedor" pode se referir a uma pessoa que se aproveita de outra ou de alguma situação, com o objetivo de obter dinheiro ou outro benefício qualquer.

391 Aparentemente, o escrivão colocou uma letra "d" no lugar do "o" e, ao perceber o erro, escreveu um "o" por cima daquela.

392 O escrivão colocou um "s" no lugar do "l”, mas corrigiu o erro. 


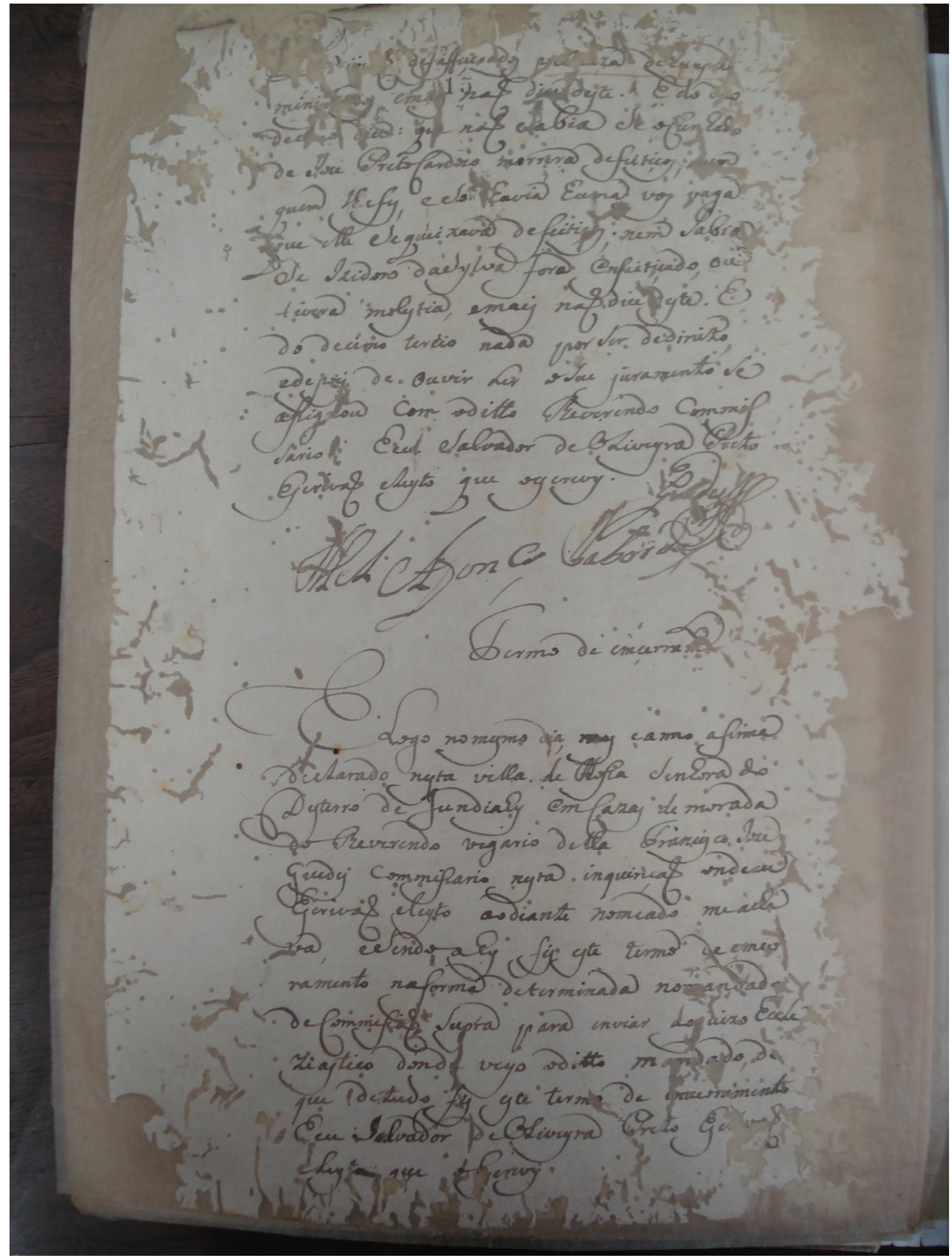


\|35 r. $\|$

1585 [[[V]i[via]õ]] desaffeiçoados $\mathrm{p}$ [orcau]za dehuns [ad] $\quad<$ [ilegível][corroído]> mini[stra]dos ema[i]s $<\uparrow 15>$ naõ dice deste. $\mathrm{E}$ do d[u]o $<\uparrow[$ [ilegível] $>$ dec[im]o dice: $\mathrm{q}[\mathrm{ue}]$ naõ [S]abia Se oCunhado de Ioze PretoCardozo morrera defeitiços, [n]em quem lhefes, e Sô havia huma vos vaga

1590 que elle Se queixava defeitiç[o]s; nem Sabia Se Izidoro daSylva fora enfeitiçado, ou tivera molestia, emais naõ dice deste. $\mathrm{E}$ do decimo tertio nada por Ser dedireito, edepois de ouvir Ler oSeu juramento Se

1595 assig[n]ou com oditto Reverendo commis sario E eu Salvador deOLiveyra Preto Escrivaõ eLeyto que oescrevy.

$$
\frac{\text { Manoel Afonço Taborda[sinal público }]^{394}}{\text { [espaço }]_{\text {Termo de emçerramento }}}
$$

E Logo no mesmo dia, mes e anno assima declarado nesta villa de Nossa Senhora do Desterro de Jundiahy emCazas de morada doReverendo vigario della Francisco Ioze

1605 Guedes commissario nesta inquiriçaõ ondeeu Escrivaõ eleyto ao diante nomeado meacha va, eSendoahy fis este termo de emcer ramento naforma determinada no[m]andad[o] deCommissaõ Supra para enviar ao [j]uizo Eccle

1610 ziastico dond[e] veyo oditto mandado, $\mathrm{d}[\mathrm{e}]$ que detudo fis este term[o] de [en]cerramento E eu Salvador deOLiveyra Preto Esc[ri]vaõ [e]Leyto que oescrevy 


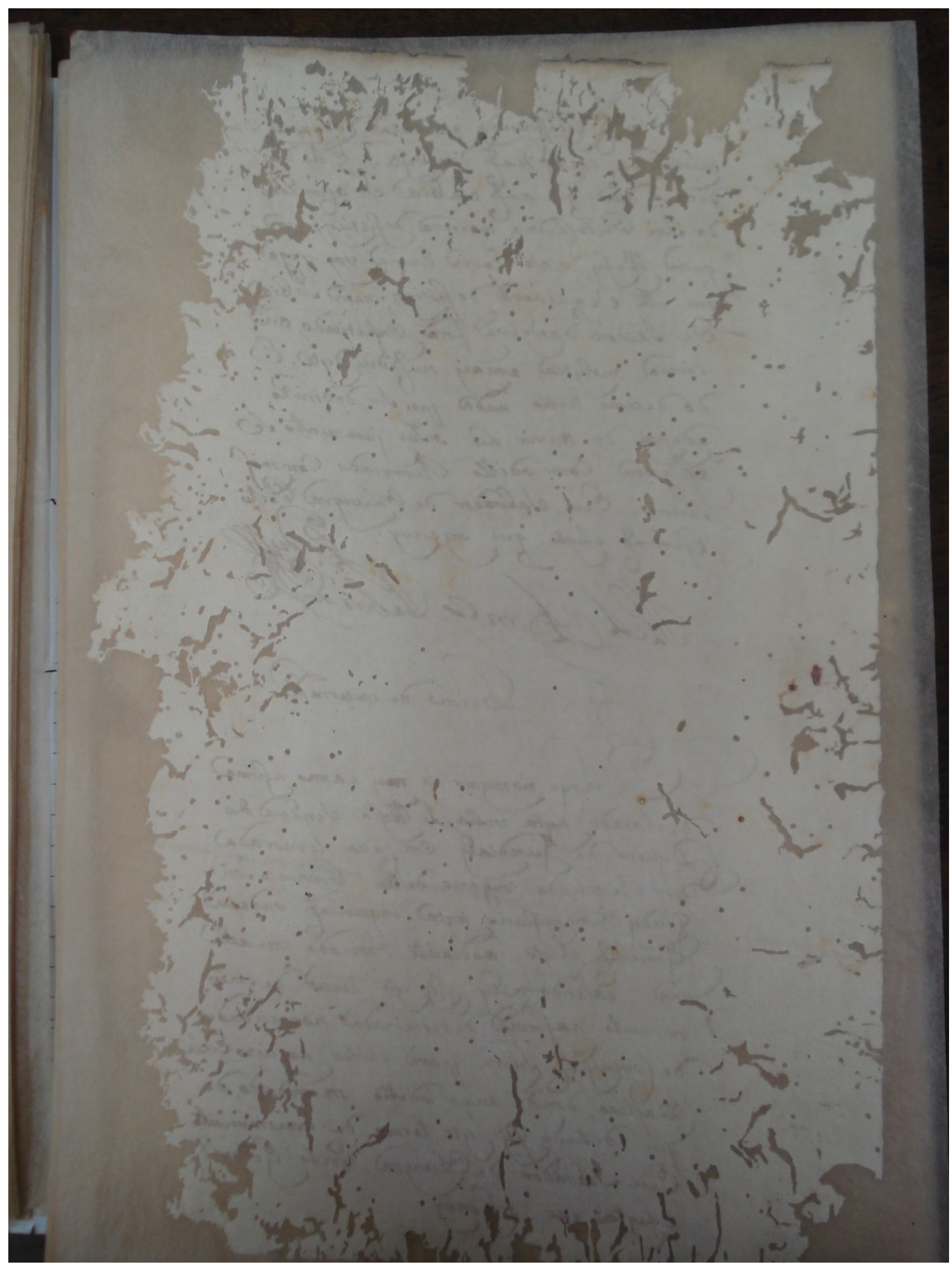


||35 v. $\|$

[página em branco] 


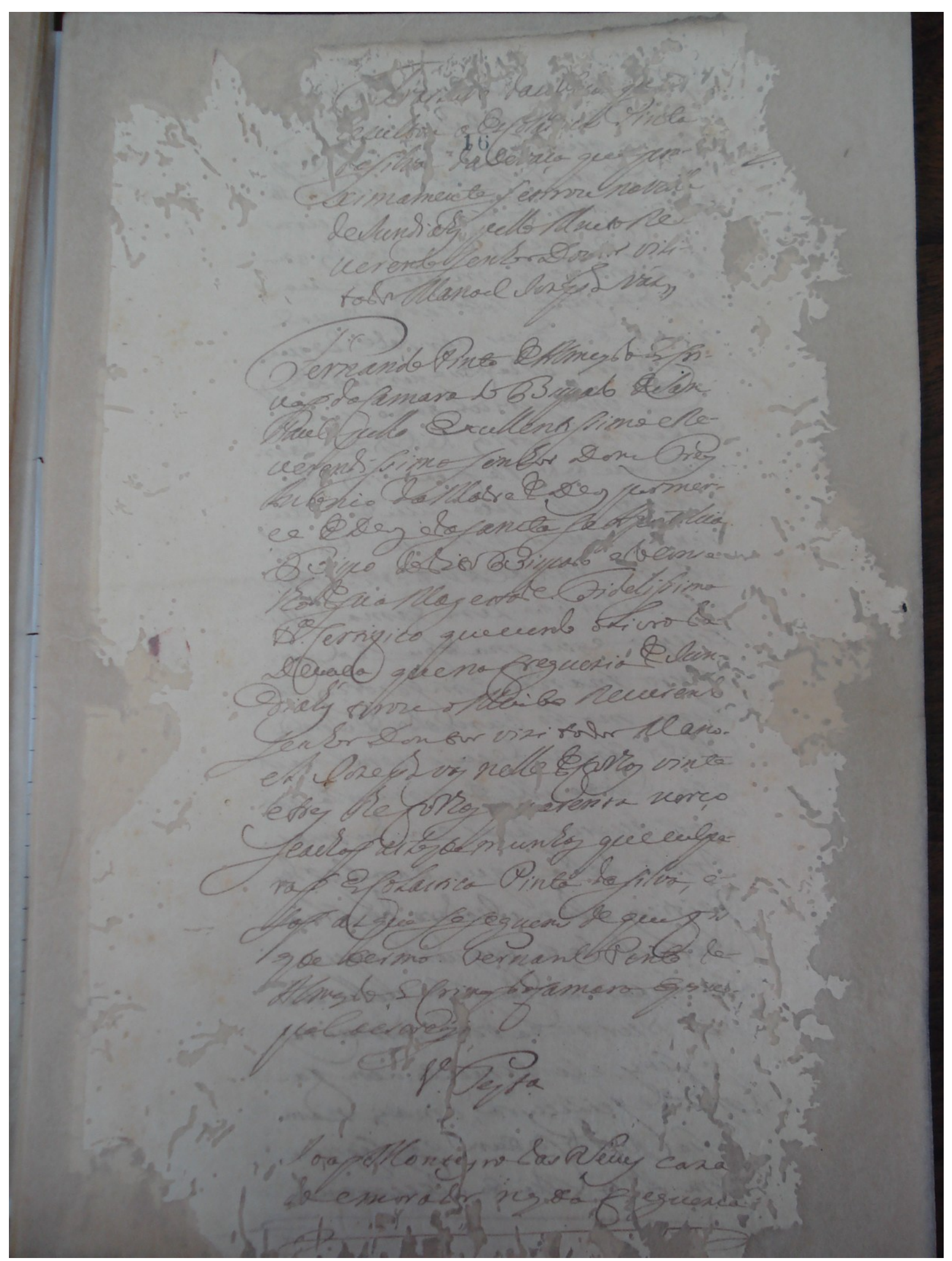


||36r.

Tras[corroído]e da c[u]lpaqu[e]

1615 rezulto[u] aEzCola[sti]ca Pinta

dasilva $<\uparrow 16>$ daDevaça quepro- $\quad<$ [corroído] $>$

ximamente setirounavilla

deIundiahy pelloMuitoRe

uerendosenhorDo[uto]r vi[z]i -

1620 tadorManoel Iozephváz

[espaço]

FernandoPinto deAlmeydaEsCri -

uaõ daCamaradoBis[p]ado deSam

Paul[o]pello ExcellentissimoRe -

uerendissimosenhor DomFrey

1625 Antonio daMadredeDeos pormer -

ce $d e$ Deosedasancta feAp[os]t[o]lica

doBispo doditoBispado edoconse

lhodesuaMagestadeFidelissima

menteCertifico queuendo oLivroda

1630 Deuaça quenafregueziade Iun -

diahy tirouoMuito Reuerendo

senhorDoutor vizitadorMano -

el Iozephvas nelledefolhos vinte

etres thefolhas $\mathrm{q}[\mathrm{u}]$ arenta verço

1635 seachaõ ai testemunhas queculpa -

raõ EsColastica Pinta dasilva, e -

saõ az queseseguem dequefis

estetermoFernandoPinto de -

AlmeydaEsCri[u]aõdaCamaraEpisco -

1640 paloescrevj

$1^{\mathrm{a}}$ Testemunha

[espaço]

IoaõMonteyrodas Neues caza

doemorad[o]r nestaf $[r]$ eguezia 


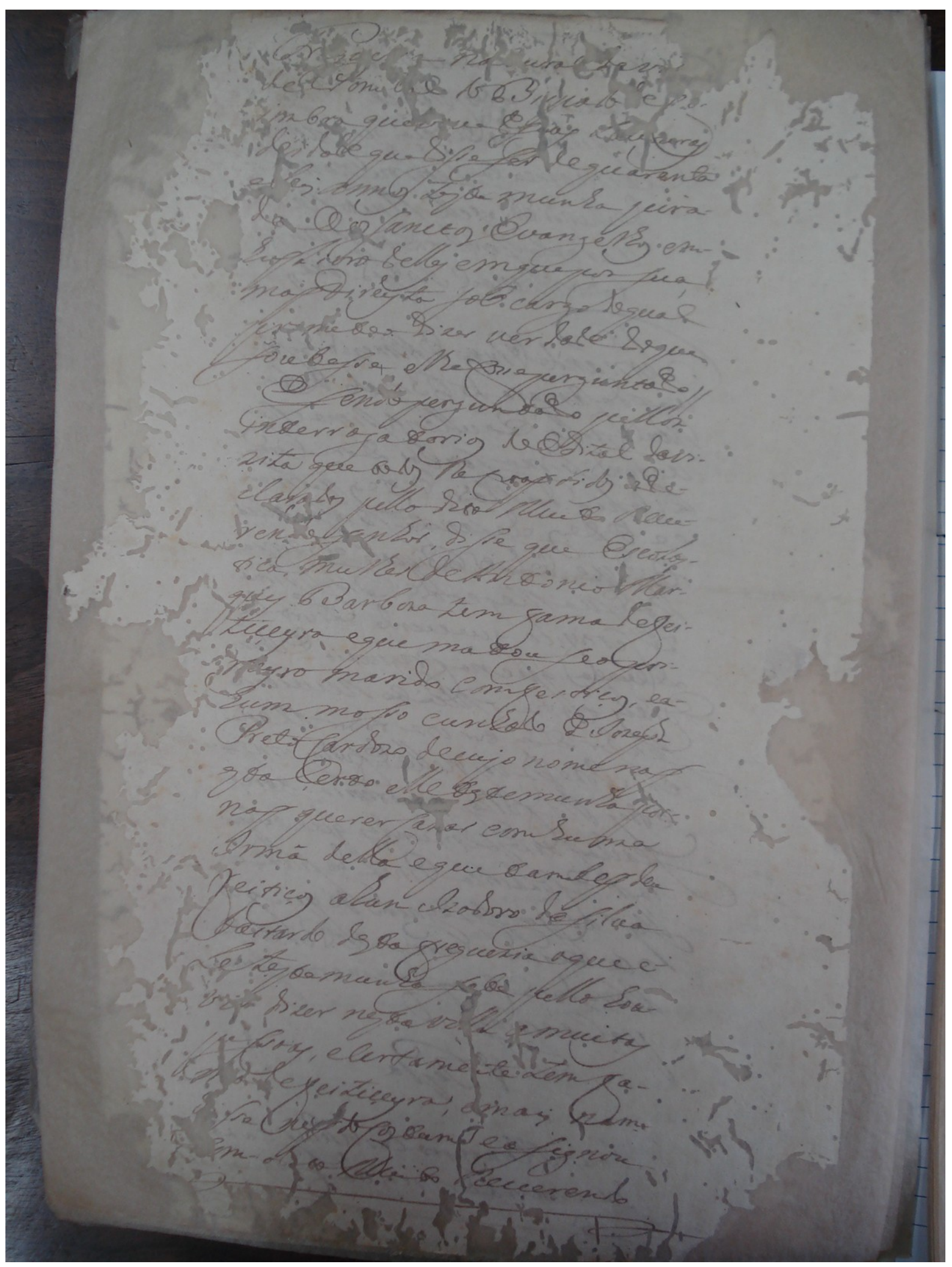


||36 v. $\|$

[[Fr[e]gue[zi]a]] naturaldavi[lla]

1645 dePonical doBispado deCo-

imbra quev[i]uedesuas Lauouras

deidadequedisseser dequarenta

eSeis annos testemunha jura-

daaos sanctosEvangelhos em -

1650 hũLivrodelles emquepozsua

maõdireyta sob cargo dequal

prometeodizer uerdadedoque

soubesse elhefosseperguntado

Esendoperguntado pelloz

1655 interrogatorios doEdital davi zita quetodos lheforaõ lidos ede clarados pellodito Muito Reue rendosenhor, disse queEscoLas tica mulher deAntonioMar -

1660 ques Barboza tem famadefei tiçeyra equematouseopri -

meyromarido comfeitiços, ea hummosso cunhado de Iozeph PretoCardozo decujo nomenaõ

1665 estaçerto elletestemunha por naõ quererCa[z]ar comhuma Irmâ della equetambẽ deu feitiços ahun Izodoro ${ }^{395}$ dasilua bastardo destafreguezia aquee -

1670 Letestemunhasabe pellohouvir dizer nestavilla amuitas pessoas, ecertame[n]te temfa ma defeitiçeyra, emais nam disse nẽ doCostume easignou

1675 com od[i]toMuito Reuerendo 

||37 r.

[[Reuerendo]]senhor [corroído] Eeu Padr[e] Ben -

toIoz[e]phLeyte EsCriuaõ davizita oes -

crevj[ilegível] IoaõMonteyrodas Neues/vá[z] $\quad<$ [corroído]>

$<17>$

1680

$2^{\mathrm{a}}$ Testemunha

[espaço]

Izidoro dasilua deMoraes cazado

morador destafreguezia naturaldes -

taVilla queviuedesuaRoça deidade

quedisseser devinteequatroan -

1685 nos pouco mais oumenos testemu -

nha jurada aos sanctosEuange -

lhos emhumLivrodelles emquepos

suamaõdireita sobcargo do qual

prometeodizer uerdad[e] doquesou -

1690 besse elhefosseperguntado $=\mathrm{E}$ sendoperguntado pellos interro gatorios doEdital quetodoslhefo raõ lidos edeclarados pellodito Muito

Reuerendosenhor dissequeestan

1695 doManoelgarçia deoLiueyraCu randosse dehum[a]sferidas emcaza doPay delle testemunha ofoy vizi tarEsCoLasticadasilua suamu lher ehojeCazadaComAntonio $\mathrm{Ma}[\mathrm{r}]$

1700 ques eapalpandolhe as pernas que tinha inchadas onde ellapos os dedos nomesmo diaficaraõ empollas eno outrodia feridas dizendolheque agoraestaua sam elogohavia de -

1705 sarar, eemoutro dia estando od[it]o enfermopar[a] Comer dehũ prato 


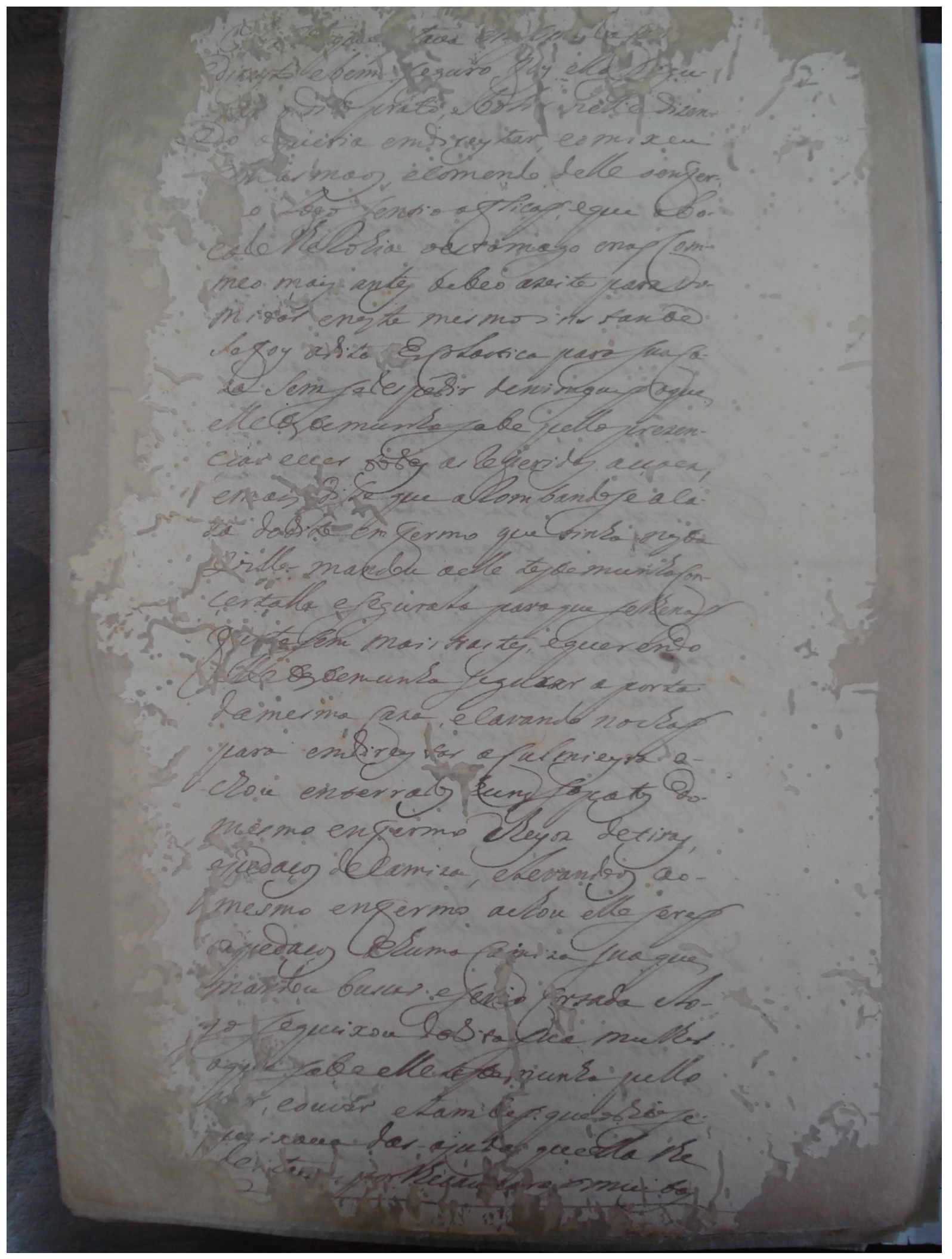


||37 v.

[[Pra[to]]] que [es]taua e[m]sim[a]daC[ama] [corroído]

direyto ebemseguro foy ella segu -

rar o di[t]oprato, ebolir nelledizen -

1710 do oqueria emdireytar, eo mixeu

comas maos, ecomendo delleo enfer -

[m]o Logosentioafliçaõ, eque obo -

cadolheRohia oestomago enaõCom -

meo mais antes bebeo azeite paravo -

1715 mitar eneste mesmoinstante

Sefoy aditaEsCoLastica parasuaCa -

za Semsedespedir denimguẽ oque

elletestemunhasabe pelloprezen -

çiar euer todas as referidas acçoez,

1720 emais disseque aRombandoseaca -

za do ditoenfermo ${ }^{396}$ que tinha nesta

Villa mandou aelle testemunhaCon çertalla eseguralaparaqueselhenaõ

furtasem mais trastes, equerendo

1725 [e]lletestemunha segurar ${ }^{397}$ aporta

damesmaCaza, ecavando nochaõ

para emdireytar aCulmieyra a -

chou enterrados hunssapatos do -

mesmo enfermo cheyoz ${ }^{398}$ detiras,

1730 epedaços decamiza, eLevandoos ao -

mesmo enfermo achou elleserẽ

$\mathrm{o}$ [z]pedaços dehumaCamiza suaque

mandoubuscar esev[i]o Cortada eLo -

gosequeixoudaditasuamulher

1735 oquesabeelletestemunha pello

$\mathrm{v}[\mathrm{e}] \mathrm{r}$, eouvir etambẽ queoditose -

queixauadas ajudas queellalhe

deit[aua] porlhecau[z]araõ muitos

396 Ao redigir o " $\mathrm{n}$ " em "enfermo", parece que o escrivão esteve prestes a cometer um erro e quase redigiu um "m", ao invés do " $n$ ".

397 O "r" medial em "segurar" parece ter sido redigido por cima de outra letra.

398 Aparentemente, no início da palavra, o escrivão colocou um "d" no lugar do "c", porém, corrigiu o erro em seguida. 


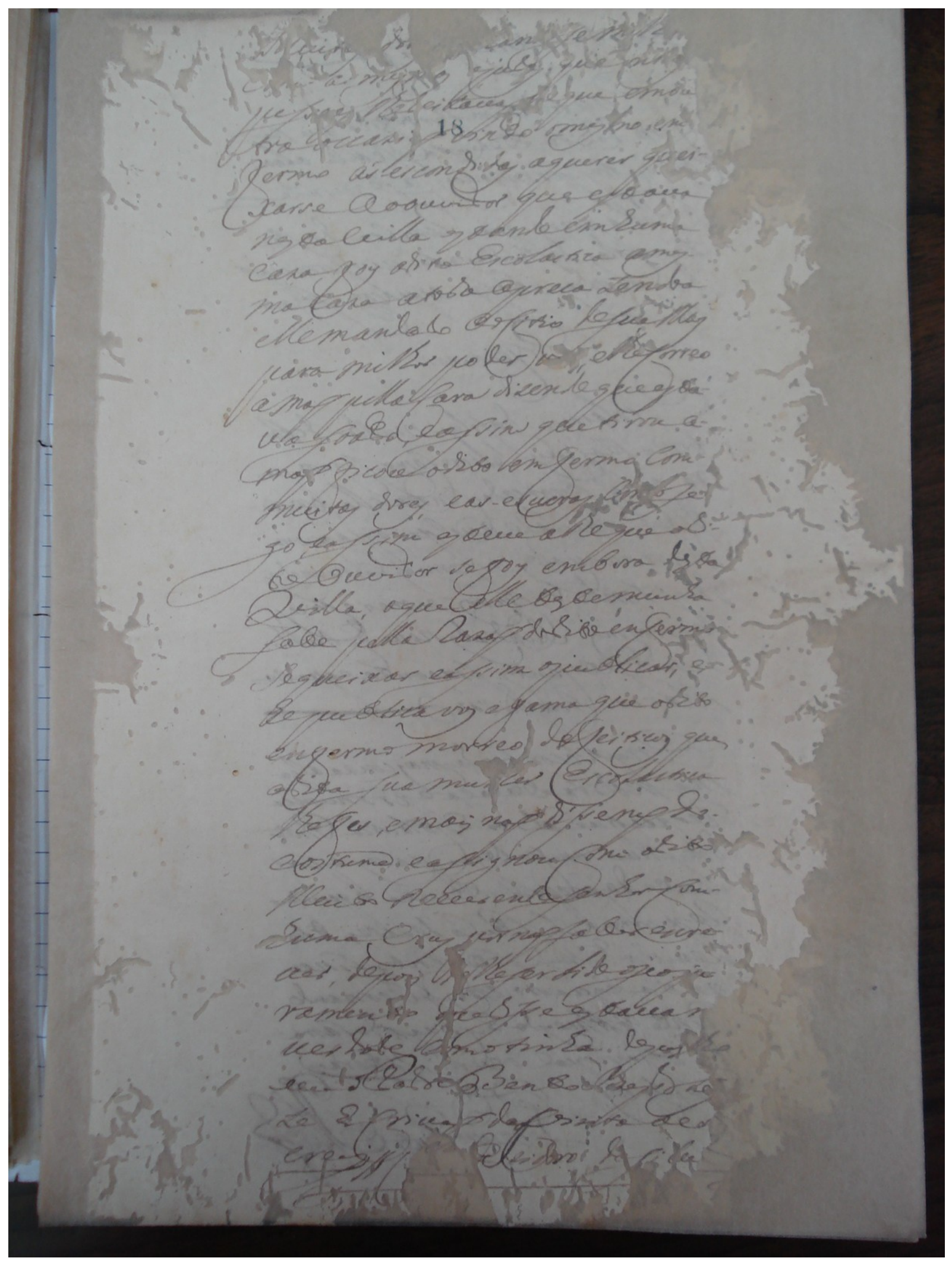


||38 r. $\|$

[[Muitos]] [corroído] do[corroído] an[corroído] semlh[e]

$1740 \mathrm{co}[\mathrm{m}]$ as mesmas ajudas queout $[\mathrm{r}] \mathrm{as}$

pessoaslhedeitauaõ equeemou

traoccazi[a]õ $<\uparrow 18>$ vindo omesmo em -

fermo as escondidas aquerer quei -

xarseaoouvidor queestaua

1745 nestauilla estandoemhuma

caza foy aditaEscolastica ames -

macaza atodoopre[ç]o tendoa

ellemandado aoCitio desuaMay

para milhor poder v[er], elheCorreo

1750 amaõ pellaCara dizendoqueesta -

uasoado, eassim quetiroua -

maõ ficouodito emfermo com -

muitas dores, eas - escuras c[om]ose -

go, eassim esteueaRequeodi -

1755 toOuvidor sefoy embora desta

Villa, oque elletestemunha

sabe pellaRazaõ doditoenfermo

sequeixar eassim opublicar, e

hepublicavos afamaqueodito

1760 enfermomorreo defeiticos que

adita suamu[lh]er EscoLastica

lhefes, emais naõ dissenẽdo -

costume easignouCom odito

Muito ReuerendosenhorCom -

1765 humacrus por naõsaber escre -

uer, depo[i]s [de]lheser Lidooseoju -

ramento quedisseestaua[m]

uerdade comotinha depos[corroído]

eeu oPadreBento IozephLey

1770 te EsCriuaõ daVisitaoes ${ }^{399}$

$\operatorname{crevj}_{/ /}$[corroído] Izidoro dasilu[a]

399 Ao que parece, o escrivão colocou um "C" no lugar do "V" de "vizita". Entretanto, o mesmo corrigiu o erro. 


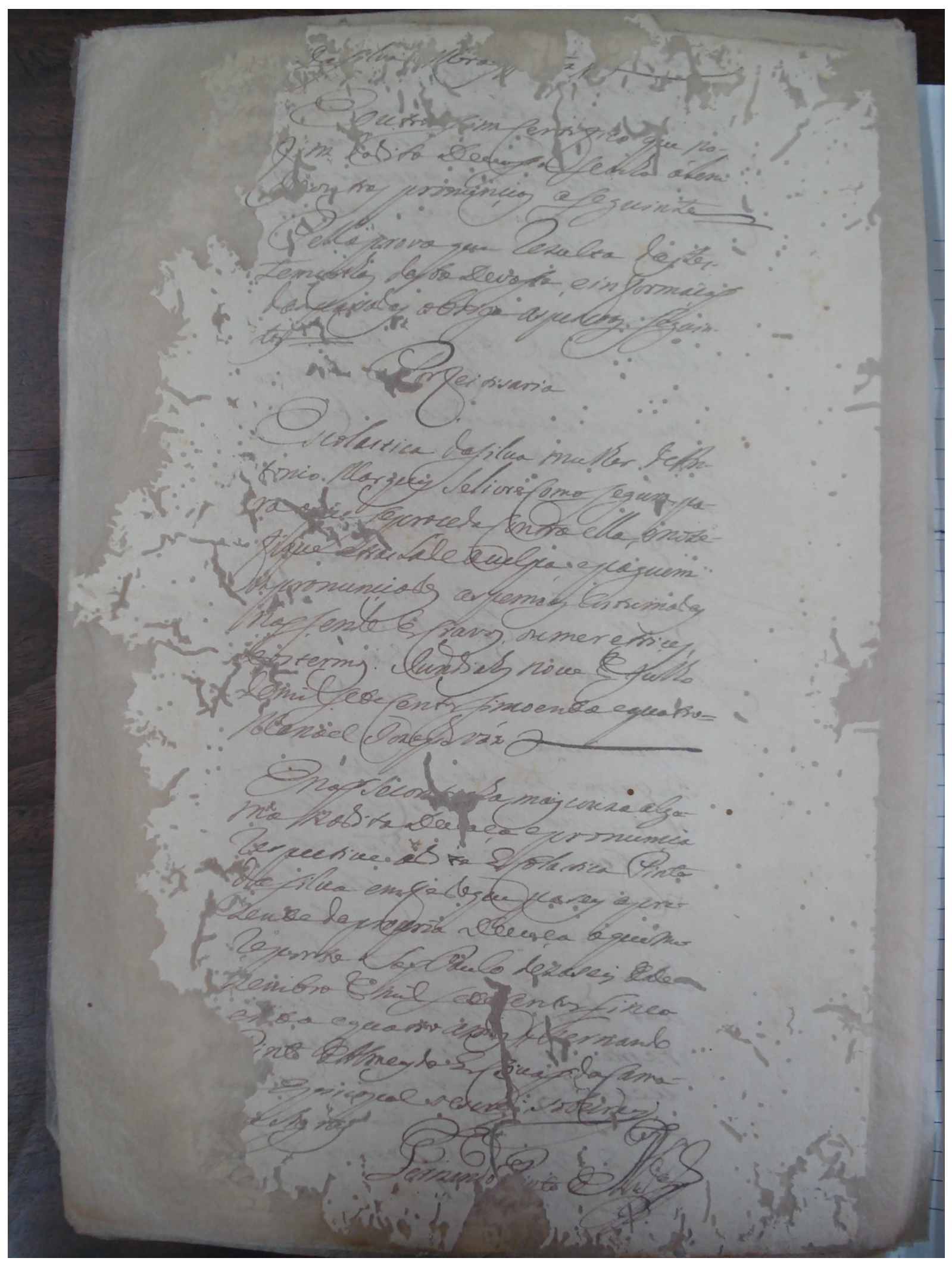


||38 v.

[[dasilva]] Mora[e]s [corroído]z [corroído]

[espaço]

Eoutro simCertifico que no -

fim daditaDeuassa seacha áLem

$1775 \mathrm{~d}[\mathrm{e}]$ outras pronunçias aseguinte

[espaço]

Pellaprovaque rezulta das tes temunhas destaDevassa, einformaçaõ

das passadas obriga as pessoasseguin tes

1780

$$
\begin{aligned}
& \text { Porfeitisaria } \\
& \text { [espaço] }
\end{aligned}
$$

Escolastica dasilua mulher deAn -

tonio Marques SelivreComosegura pa -

raoqueseprocedaContraella, enote -

fiqueetras ladeaculpa, epaguem

1785 azpronunçiadas as pennascostumadas

naõsendoEsCravas, oumeretriçes,

[e]os termos. Iundiahy nouede Julho

de milseteCentossincoentaequatro=

Manoel Iozephváz

$$
\text { [espaço] }
$$

1790 Enaõ Secont[in] ha mais couzaalgu -

manaditaDeuaça epronunçia

respectiua aditaEsColastica Pinta

dasilua emfedoque pasey apre -

zentedapropria Deuaça aqueme -

1795 reportoSaõPaulo dezaseis deDe

zembrodemilseteCentossinco -

entaequatro ann[o]s / Fernando

Pinto deAlmeydaEsCriuaõ daCama -

[ra]Episcopaloescre[vj], sobscrevj,

1800 [e]aSignej

FernandoPinto deAlmeyda[sinal público] 


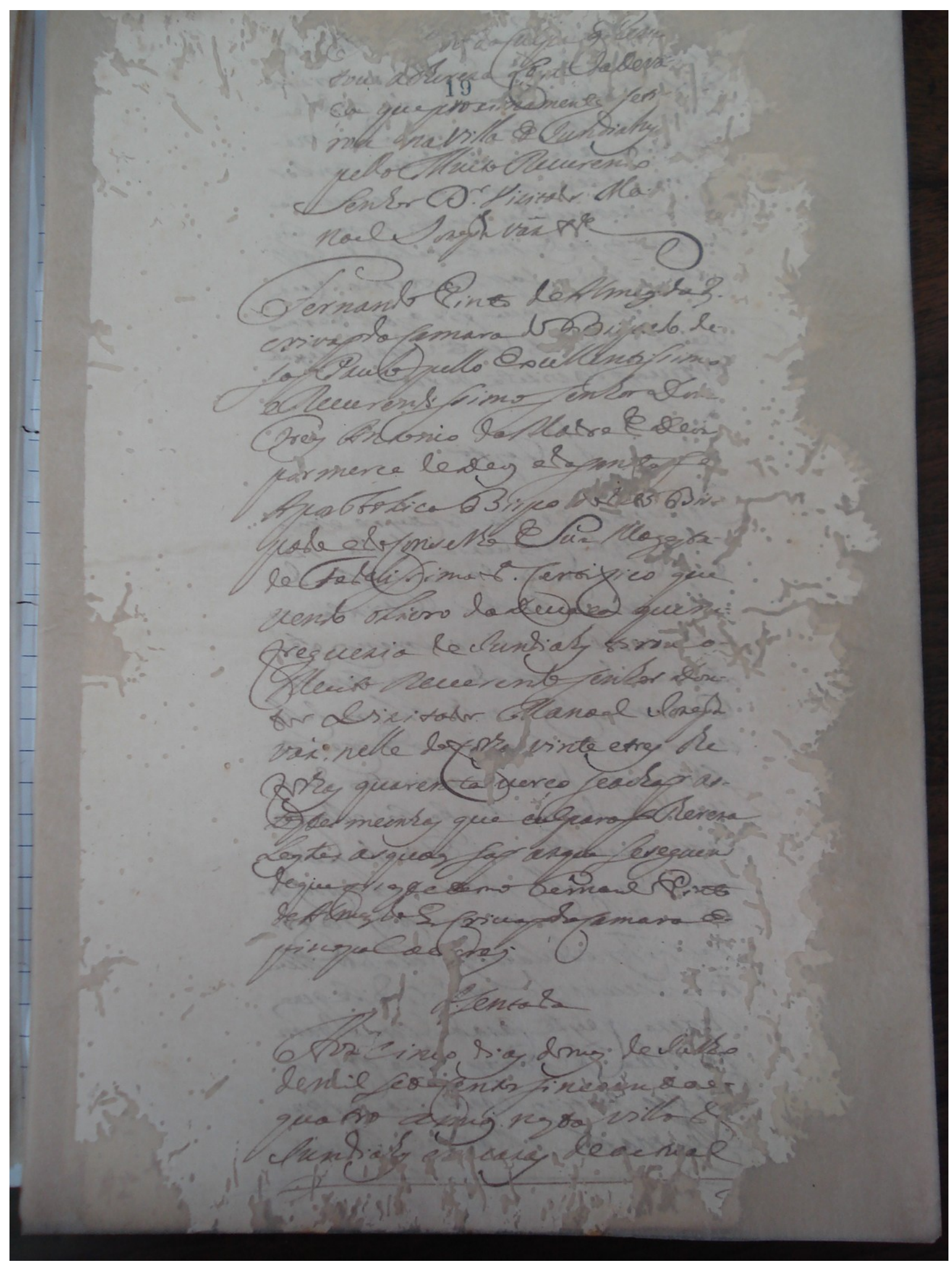


||39 r. $\|$

[corroído] daCulpa que rezu[1]

tou aThereza $<\downarrow 19>$ Le[y]t[e] daDeva -

ça queproximamenteseti -

1805 rou navilla de Iundiahy

pelloMuitoReuerendo

Senhor Doutor Vizitador Ma

noelIozephvâz[rubrica]

[espaço]

FernandoPinto deAlm[e]ydaEs -

1810 crivaõdaCamara doBi[s]pado de saõPaulopello Excellentissimo

eReuerendissimosenhor Dom

Frey Antonio daMadredeDeoz

por merçe deDeos edasan[c]ta se

1815 AposTholicadoBispo doditoBis padoedoConselhodeSua Magesta deFedelissimamenteCertifico que uendo oLivro daDeuaça quena freguezia de Iundiahy tirouo -

1820 MuitoReuerendosenhor Dou tor Vizitador Manoel Iozeph vaz nelle defolha[s] vinte etres the folhas quarenta verço seachaõ as testemunhas queculparaõ Thereza

1825 Leyte as quaessaõ azqueseseguem dequefis estetermoFernandoPinto deAlmeydaEsCriuaõdaCamaraE piscopaloe[s]crevj

\section{Asentada}

1830 Aoz cinco dias domes de Iulho demil seteCentossincoentae quatroannos nestavillad[e] Iundiahy emcazas deactual 


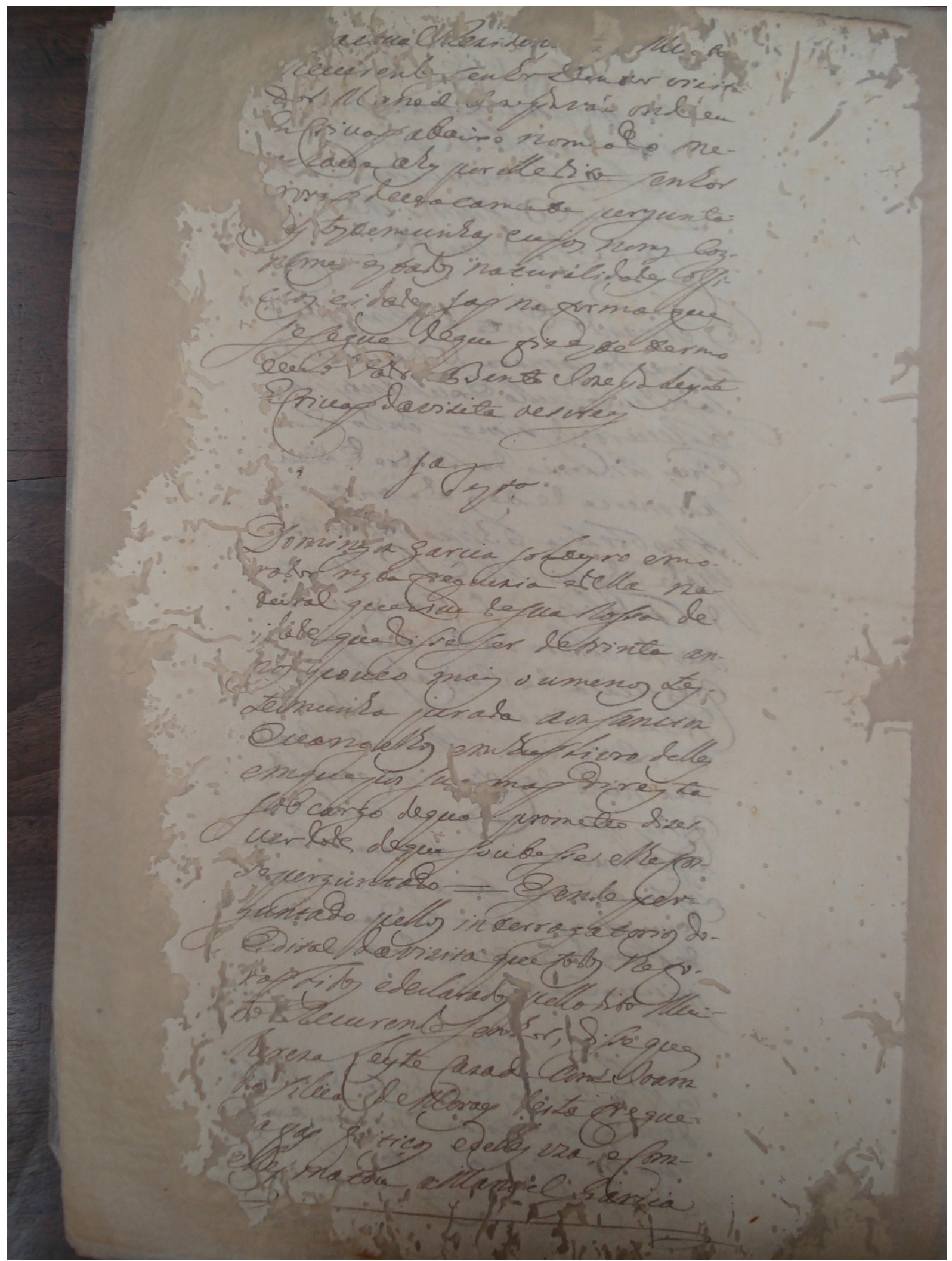


||39 v. $\|$

[corroído]actualRezidenç[ia] [corroído] Muito

1835 ReuerendosenhorDoutor vizita -

dor Manoel I[o]zephváz ond[e]eu

EsCriuaõ abaixo nomeado me -

achauaahy por elleditosenhor

[f]oraõ deuotamente pergunta -

1840 [d]as testemunhas cujos nomescoz -

tumes estados naturalidades offi -

çios eidades saõ naformaque

sesegue deque fis estetermo

eeuoPad[re]Bento IozephLeyte

1845 EsCriuaõ davizita oescrevj

$1^{\text {aTTestemunha }}$

[espaço]

Domingoz garçia soLtejro emo -

rador nestafreguezia edella na -

tural queviuedesuaRossa de -

1850 idadequedisseser detrinta an -

nos pouco mais o umenos tes -

temunha jurada aozsanctoz

Euangelhos emhũ Livro delles

emquepos suamaõdireyta

1855 sob cargo doqua[1] prometeo dizer

uerdade doquesoubesse elhefos -

seperguntado _ Esendoper -

guntado pellos interrogatorios do -

Edital davizita quetodos lhefo -

1860 raõLidos edeclarados pelloditoMui -

to Reuerendosenhor, disse que

TherezaLeyteCazadacom Ioam

dasilua deMoraes destafregue -

[zi]afas fe[i]tiços edelles vza, eCom -

1865 elles matou aManoelGar[ç]ia 


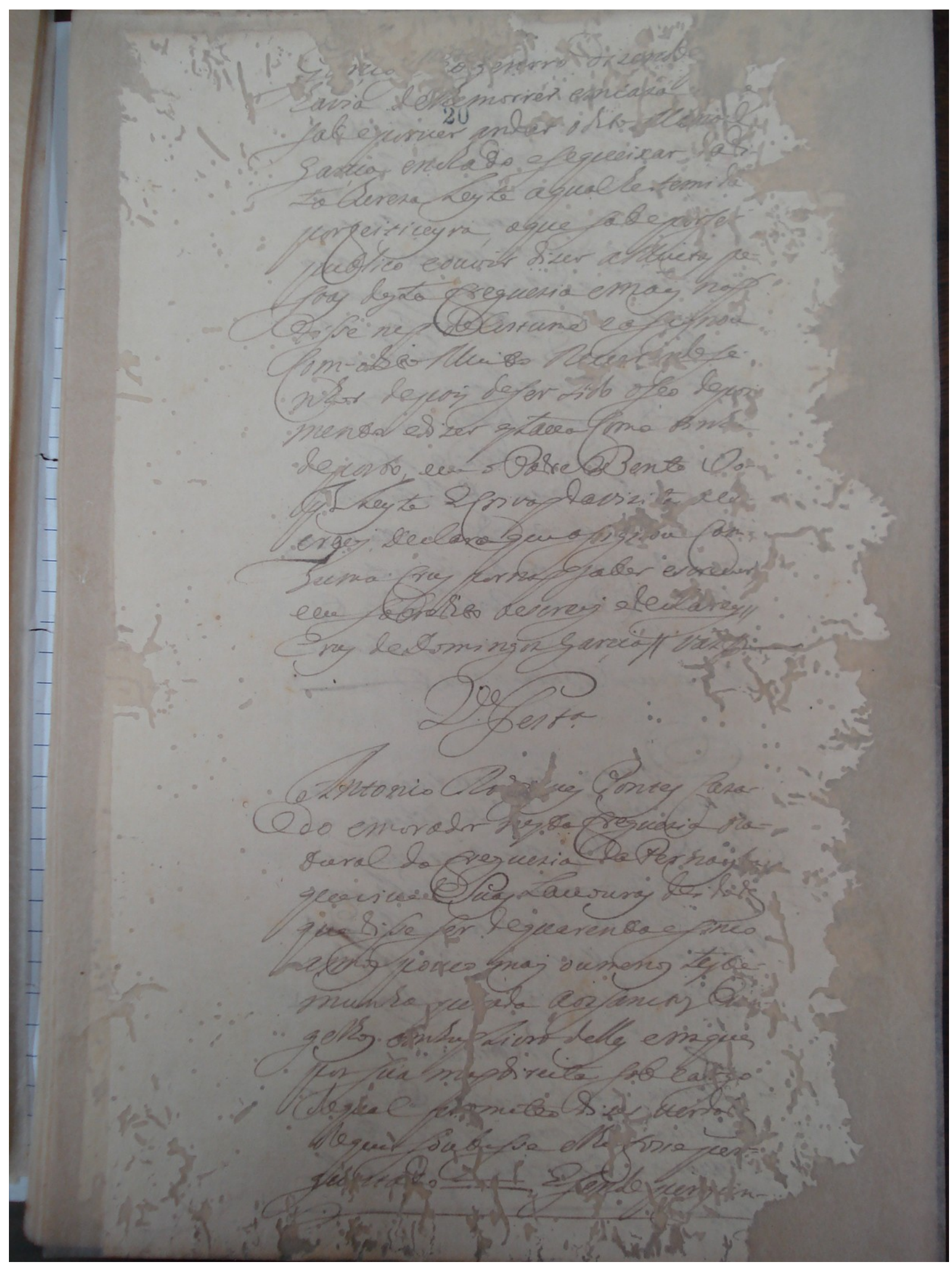


||40 r. $\|$

[[Garçia]] [corroído]o genrro dizendo [corroído]

havia delhemorrer emcaza [corroído][e]

sabeporuer $<\uparrow 20>$ andar o ditoManoel

Garçia enchado esequeixar dadi -

1870 taTherezaLeyte aqualhetemida

por feitiçeyra, oquesabeporser

publico eouvir dizer aMuitas pe-

soas destafreguezia emais naõ

disse nẽ docostume easignou

1875 Com - oditoMuito Reuer[e]ndose -

nhor depois deser Lido oseo depoi

mento edizer estaua Como tinh[a]

deposto, eu oPadreBento Io-

zephLeyte ${ }^{400}$ EsCrivaõ davizita oes -

1880 creuj declaroqueasignouCom

humaCrus por naõ saber escreuer,

eeusobredito oescreuj edeclarey,

Crus deDomingozGarçia/ váz/_

$2^{\mathrm{a} T e s t e m u n h \mathrm{a}}$

[espaço]

1885 Antonio Ro[drig]ues Pontes Caza -

do emorador nestafreguezia na -

turaldafreguezia daPernayba

queviuedeSuas Lauouras deidade

quedisseser dequarentaesinco

1890 annos pouco mais oumenos teste -

munhajurada aos sanctosEv[a]n -

gelhos emhũLivrodelles emque

possuamaõdireita sobcargo

doqualprometeo dizer uerdade

1895 doquesoubesseelhefosseper -

guntado_ Esendopergun -

400 O escrivão suprimiu a sílaba “ze”, escrevendo somente "IophLeyte”, ao invés de "IozephLeyte". 


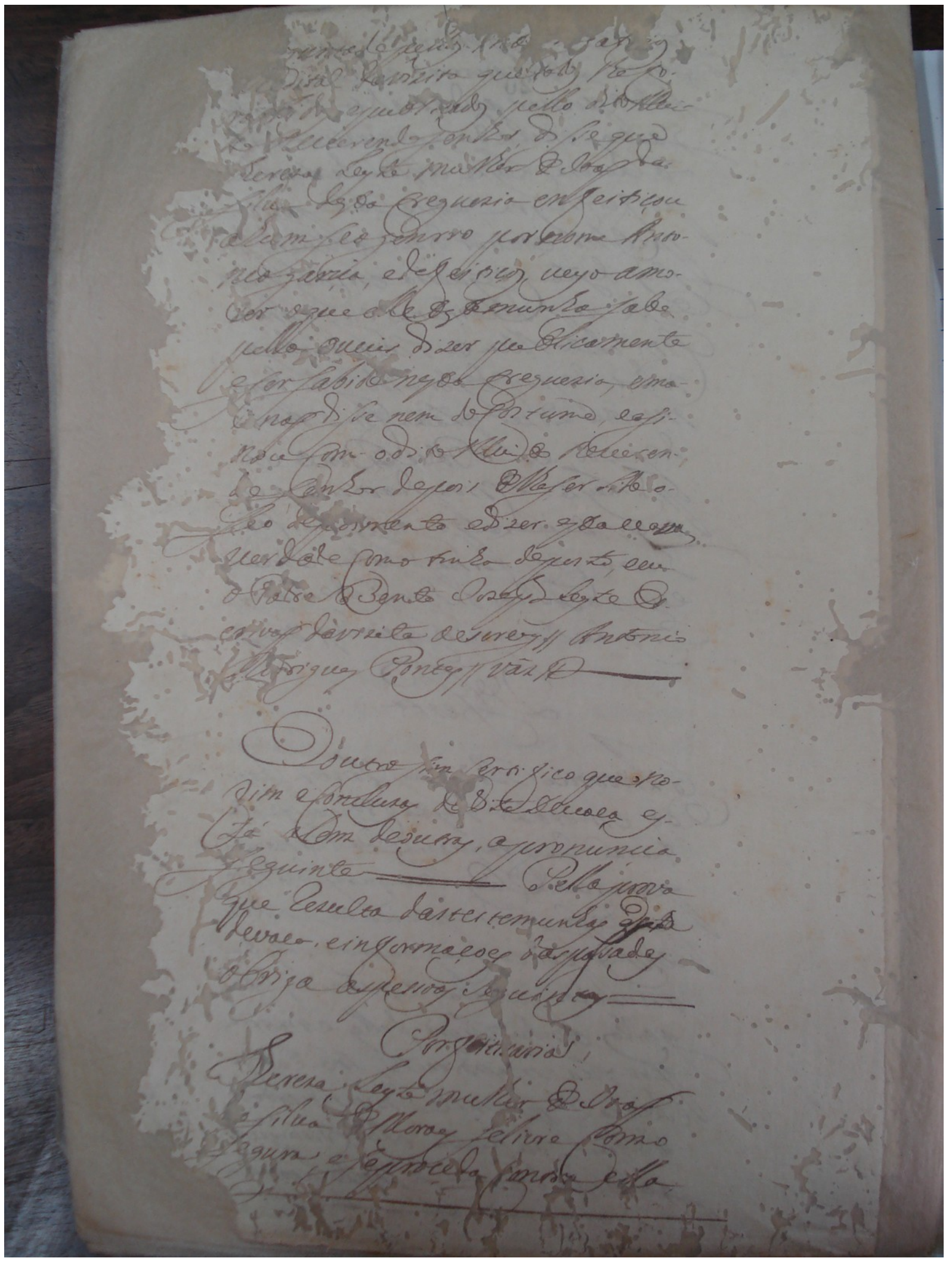




$$
\text { ||40 v. }
$$

[[[per]gun]]tadopellos int[erro]gat[or]ios

[corroído] [e]dital davizita quetodos lhefo -

raõLidos epublicados pello ditoMui -

1900 toReuerendosenhor, disseque

Thereza Leyte mulher de Ioaõda -

silu[a] destafreguezia enfeitiçou

ahumseogenrro por nomeAnto -

niogarçia, edefeitiços ueyoamo -

1905 rer oqueelletestemunhasabe

pelloouuir dizer publicamente

esersabidonestafreguezia,ema -

$\mathrm{i}[\mathrm{s}]$ naõ disse nem doCostume, easi -

nouCom - o ditoMuito Reueren -

1910 dosenhor depois delheser Lido o -

seo depoimento edizer estaua[[va]]

uerdadeComotinha deposto, eeu

oPadreBento IozephLeyteEs -

crivaõ davizita oescrevy / Antonio

1915 RodriguesPontes / vâz

[espaço]

Eoutrosim Certifico que no -

fim eConcluzas d[a]ditaDeuaça es -

tá alem deoutras, apronunçia

seguinte

Pellaprova

1920 que Rezulta das testemunhas que esta

devaça, einformaçoes das passadas

obrigaaspessoas Seguintes

$$
\text { Porf[e]itisaria }
$$

TherezaLeyte mulherde Ioaõ

1925 dasilua deMoraes selivreComo

segura, eseproçeda Contraella 


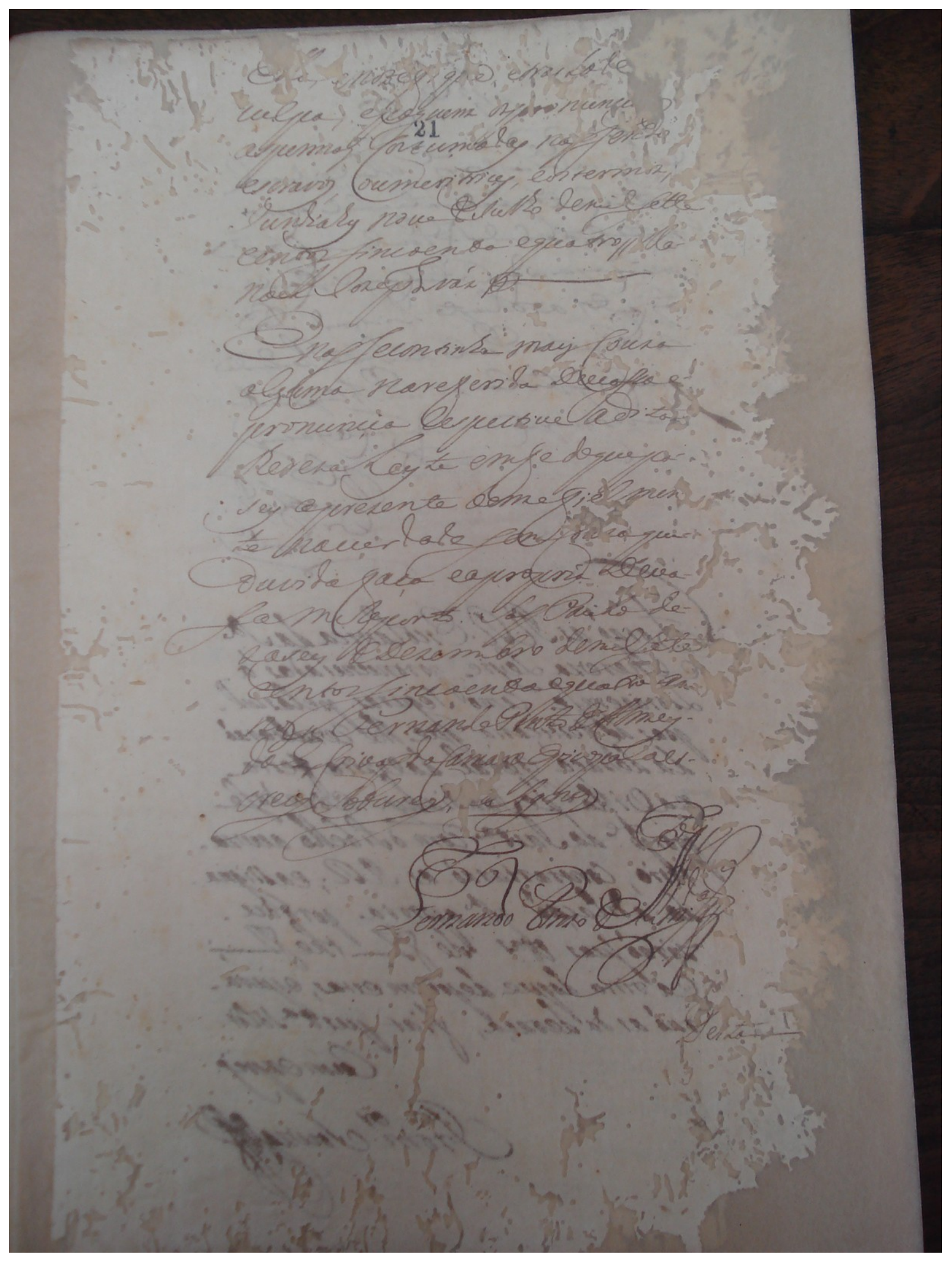


||41 r.

[[Ella]], enotefique etra[s] Lade [corroído]

culpa, epaguem $<\downarrow 21>$ azpronunci[ada]s

as pennasCostumadas naõsendo

1930 escravas, oumeritriçes, eos termoz;

Iundiahy noue $d e$ Iulho demilsette

centozsincoenta equatro $\mathrm{Ma}$ -

noel Iozephváz [rubrica]

$$
\text { [espaço] }
$$

E naõsecontinha maisCouza

1935 alguma nareferida Deuassae -

pronunçia Respectiue ${ }^{401}$ adita

TherezaLeyte emfedoquepa -

sey aprezente bemefielmen

te nauerdade semCouzaque -

1940 duvidafaça eapropria Deua -

sameReporto. SaõPaulode -

zaseis deDezembro demilsete

centossincoentaequatroan -

nos// FernandoPinto deAlmey -

1945 daEsCrivaõdaCamaraEpicopaloes ${ }^{402}$ -

crevj Sobscrevj, [e]aSignej

Fernando Pinto deAlmeyda[sinal público]

$<$ Desta $>$ 


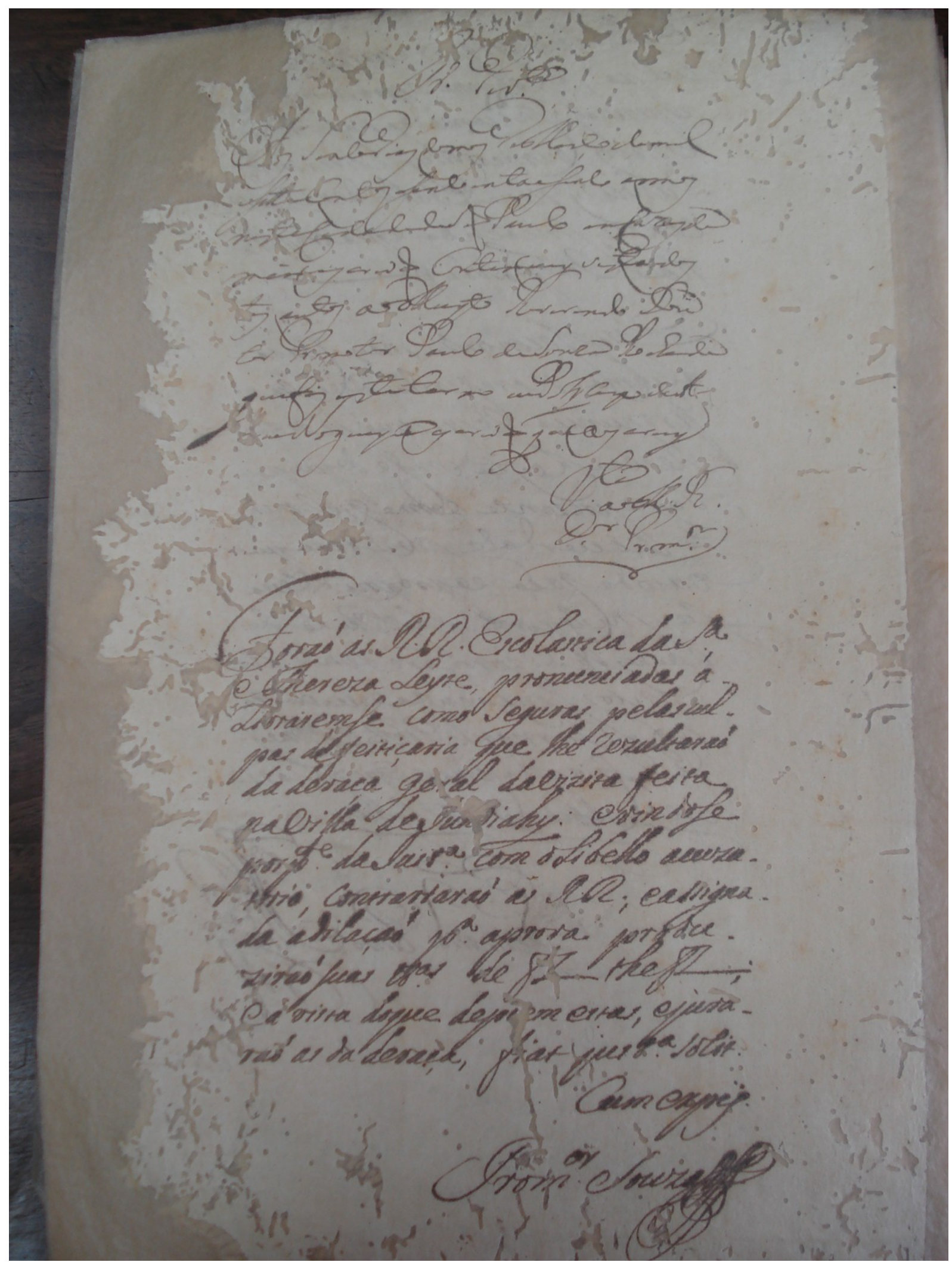


||41 v.

$\mathrm{Termo}^{403}$ deVista $^{404}$

1950 Aos Sincodias domes deMarço demil esetteCentos esinco entaesinco annos nestaCidadedeSaõ Paulo emCazas de min escrivaõ Continuey vistades tes autos aoMuyto Reverendo Dou

1955 tor Promotor Paulo deSouza Rochade quefis este termo euPolycarpo deA [br]euNogueyra escrivaõ q[u]eoescrevy

Vista aoMuyto Reverendo

Doutor Promotor

\section{[espaço]}

1960 Foraó as Rés Escolastica daSilva $\mathrm{a}^{405}$

eThereza Leyte, pronunciadas á

L[i]vraremse como Seguras pelas cul -

pas defeitiçaria que lhe rezultaraó

da devaça geral davizita feita

1965 navilla deIu[nd]iahy. evindose

por parte daIustiça com oLibello acuza -

torio, contrariaraó as Rés, eassigna -

da adilaçaó para aprova produ -

ziraó suas testemunhas ${ }^{406}$ de folha thefolha,

1970 ea vista doque dep[o]em estas, ejura -

raó as da devaça, fiat justitia solit.

Cum expis

Promotor Souza[sinal público]

403 "Tr" " por "Termo", segundo FLEXOR. Ibidem, p. 438.

404 A partir daqui, o punho volta a ser do escrivão Polycarpo de Abreu Nogueyra.

405 A partir daqui, o punho volta a ser do promotor Paulo de Souza Rocha.

406 " $t t^{\text {as" }}$ por "testemunhas", de acordo com FLEXOR. Ibidem, p. 440. 


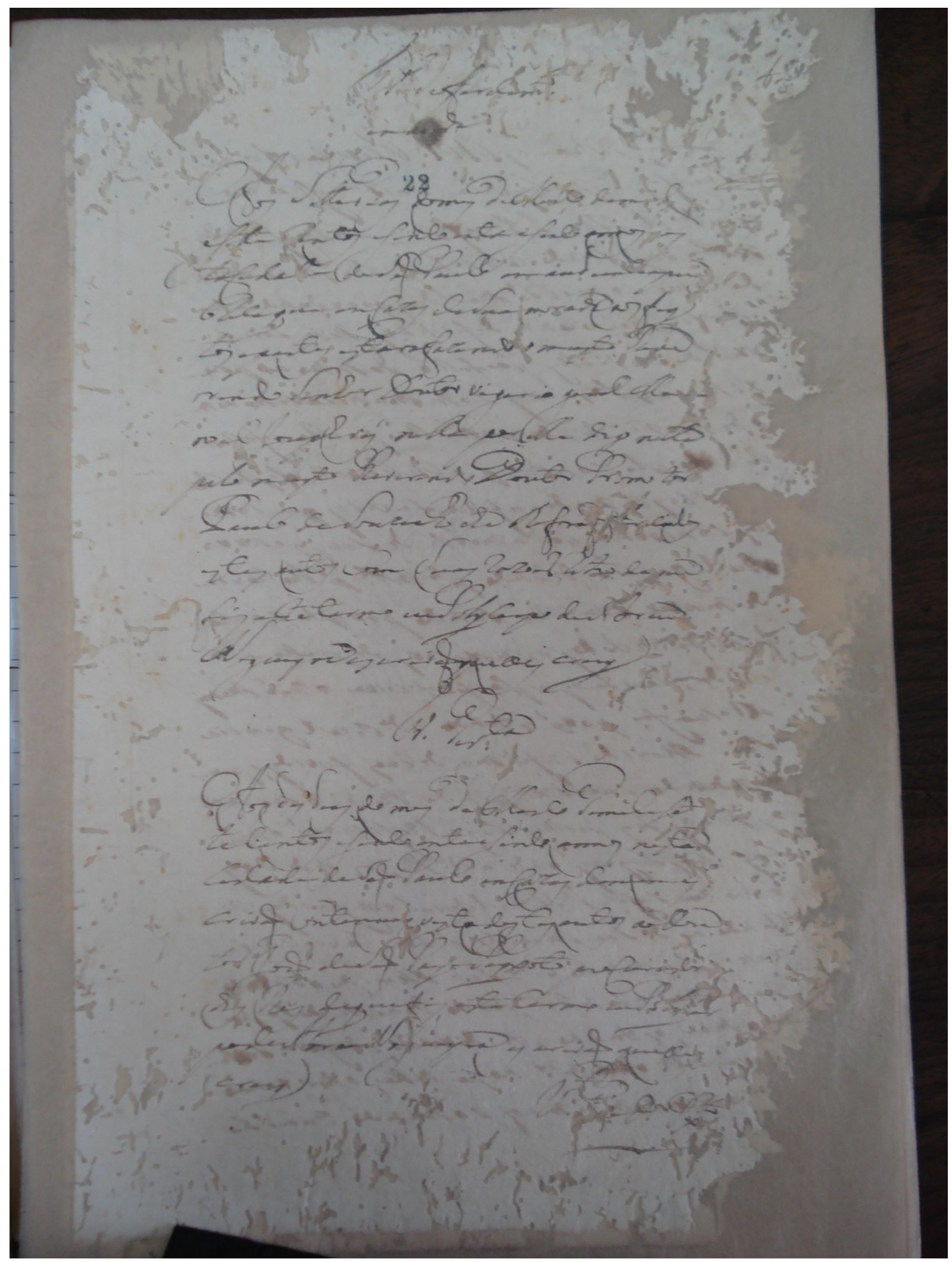


||42 r.

1975

Termo deofferecimento

$<42>$

em[ilegível]da

[espaço]

$<22>$

Aos Settedias domes deMarço demil

$<$ [ilegível] $>$

esette [C]entos esincoentaesinco annos [n]es

taCida[d]e deSaõ Paulo emaudienciapu

1980 blicaque emCazas deSuamorada aos fey tos epartes estavafazendo o muyto Reve rendo Senhor Doutor vigario geralMa noel Jozephvás nella por elle digo n[el]la pelo muyto Reverendo Doutor Promo tor

1985 Paulo deSouzaRo cha lheforaõ [offe]recidos estes autos Com Suas razoens retro de que fis estetermo euPolyCarpo deAbreu

Nogueyra escrivaõ queoescrevy

[espaço]

Termo devista

[espaço]

1990 Aos des dias do mes deMarço demileset teCentos esinco entaesinco annos nesta Cidade deSaõ Paulo emCazas demines crivaõ Continuey vistadestes autos aoDou to[r] Joaõ deSaõ PayoPeyxoto proCurador

1995 das Res dequefis estetermo euPoly[C]ar podeAbreuNogueyra es crivaõ queoes crevy 


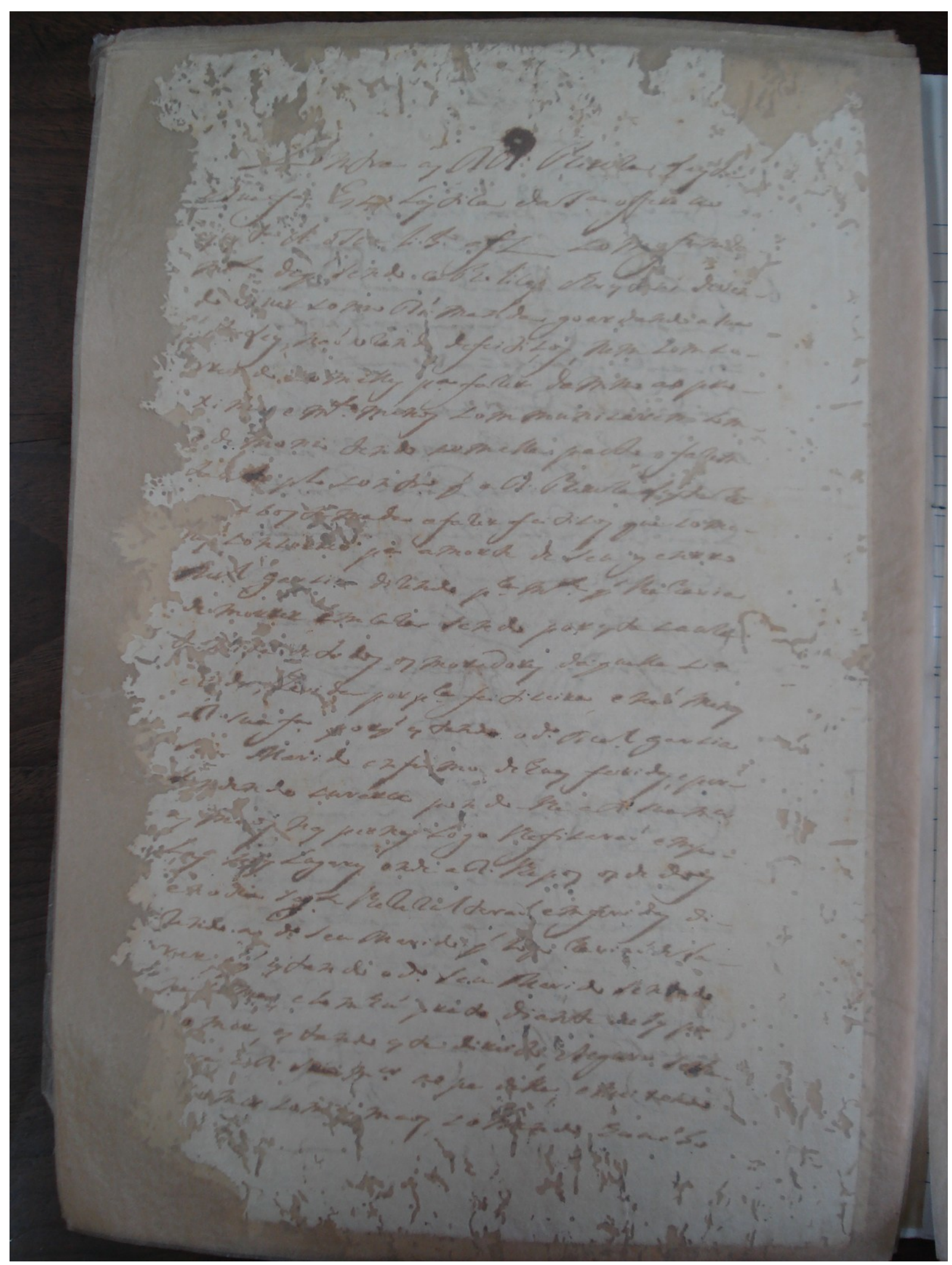


||42 v.

[borrão de tinta]

2000 Contra as Rés ThereZa Leyte ${ }^{407}$

eSua filha EscoLastica daSylva offereceo

[a]justiça Autora oSe[u] libelo ofiZ com o fumda -

mento deque sendo catholicas christ[a]nś deven -

do viver como Deoś manda guardando a sua

2005 Sant[a] Ley, naó uZand[o] defeitiços, nem comco -

rre[n]do [c]om elles para faZer damno ao pro -

xim[o] e muito menos communicare[m] com -

o demonio tendo com elle pacto o faZem

tan[to] pelo contrario que a Ré ThereZaLeytehé

2010 [ta]o cost[u]mada a faZer feiticos que come -

[lle]s concorreo para a morte de seu genrro

Manoel ga[r]ci[a] diZendo publica mente ${ }^{408}$ que lhe havia

de morrer em caZa sendo por estacauZa

t[e]mida de todos os moradores daquella Vila

2015 e [ti]d[a], ehavida por publica feiticeira, e naó menos

aRé sua filha porque estando o dito Manoel garcia

$\mathrm{s}[\mathrm{eu}]$ Marido enfe[r]mo de huas feridas, e per -

$\mathrm{t}[\mathrm{en}]$ dendo curarce pondo lhe aRé sua mulher

as maos nas pernas Logo lhe ficaraó empo -

2020 Las n[o]s Lugares onde aRé lhepos os dedos

e no dia seguinte lhe reZultaraó emferidas di -

Zendo ao dito seu Marido que Logo haviaó deSa -

rar, [e]que estando o dito seu Marido sentado

na c[a]ma, e com hú prato diante de sy para

2025 [c]omer, estando este direito, eSeguro se[c]he -

[ga]ra aRé sua mulher ao pe delle, e meixendo

[o]comer com [as] maos, comendo hunś bo

407 A partir daqui, o punho é do procurador Joaó de Saó Payo Peyxoto.

408 " $\mathrm{p}^{\text {ca }} \mathrm{m}^{\text {te" }}$ por "publicamente", de acordo com FLEXOR, Ibidem, p. 307. 


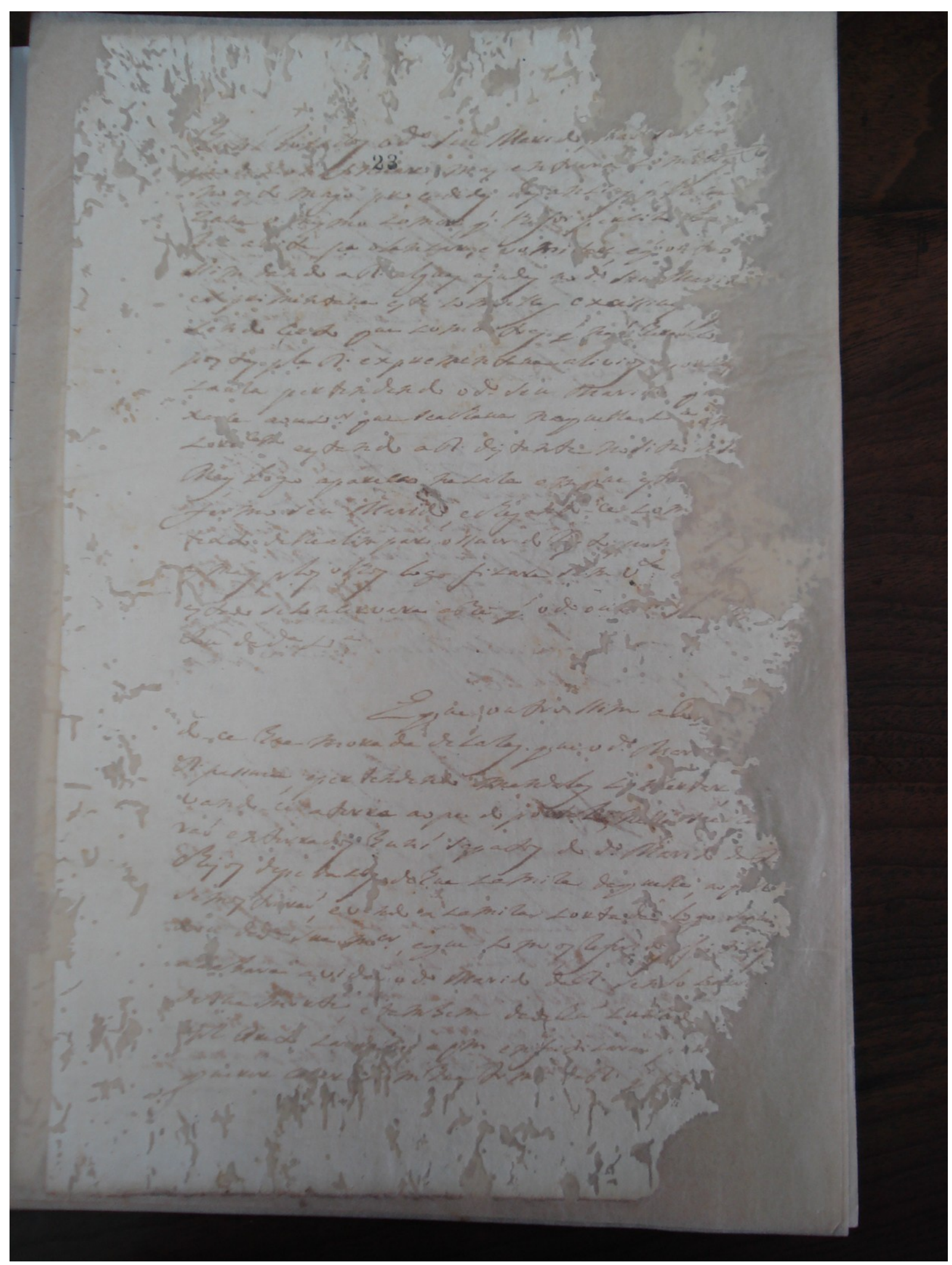


||43 r.

[[hunś bo]]cados $<\downarrow 23>$ o ditto seu Marido, [n]aó [só] naó pode continuar, mas entrara com dores

2030 no estomago procedidas das anci[a]s que lhecau -

Zaua o mesmo comer, que lhe foi perciz[o] be -

be[r] a[ze]ite para o lancar, e vomitar, eque outro

ssim dando aRé alguas ajudas ao dito seu Mari[do]

exprimentaua este com ellas excessiu[a]s [corroído]

2035 sendo çerto que com o[u]tras que naó heraó co[m]

postas pela Ré exprementaua alivios porc[corroído]

cauZa pertendendo o dito seu Marido q[uei]

$\mathrm{xa}[\mathrm{r}]$ ce ao Vidor $^{409}$ queseachaua naquella Vila e[m]

cor[r]eicam eestando aRé distante no sitio des[ua]

2040 May, Logo apareceo nacaZa emque est[corroído]

fermo seu Marido, echegando-ce com [corroído]

texto delhelimpar ossuor do r[o]sto pon [corroído]

as maos pelos olhos logo ficara sem vista [corroído]

estado seconcervara athé que o dito ou[vidor] [corroído]

2045 tou daditta Vila

[espaço]

E que outrossim a[corroído]

do-ce hua morada de caZas queo dito Mar[ido] [corroído]

Ré possuia, epertendendo mandalas c[o]ncertar, [corroído]

vando - ce aterra ao pe do po[r]taL, n[e]lle seac[ha]

2050 raó enterrados hunś sapatos do dito Marido daRé

chejos depedacos de hua camiZa daquelle, ao q[corroído]

semostr[a]raó, evendo a camiZa cortada logo sequei

xara dadita sua mulher, eque com os referidos $\mathrm{f}[\mathrm{e}]$ itiços

a[c]abara avida o dito Marido daRé sendo cau[Za]

2055 deSuamorte, e tambem dadehú cunhad[o] [corroído]

IoZ ${ }^{410}$ Preto ca[r]do[Zo] a quem enfeiticara $\mathrm{p}[\mathrm{o}] \mathrm{r}$ [corroído]

querer ca[z]ar [co]m hua Irm[a] daRé que t[corroído]

409 "uvidor" por "ouvidor".

410 O escrivão suprimiu, talvez por distração, o "e" final em "Ioze" (José). 


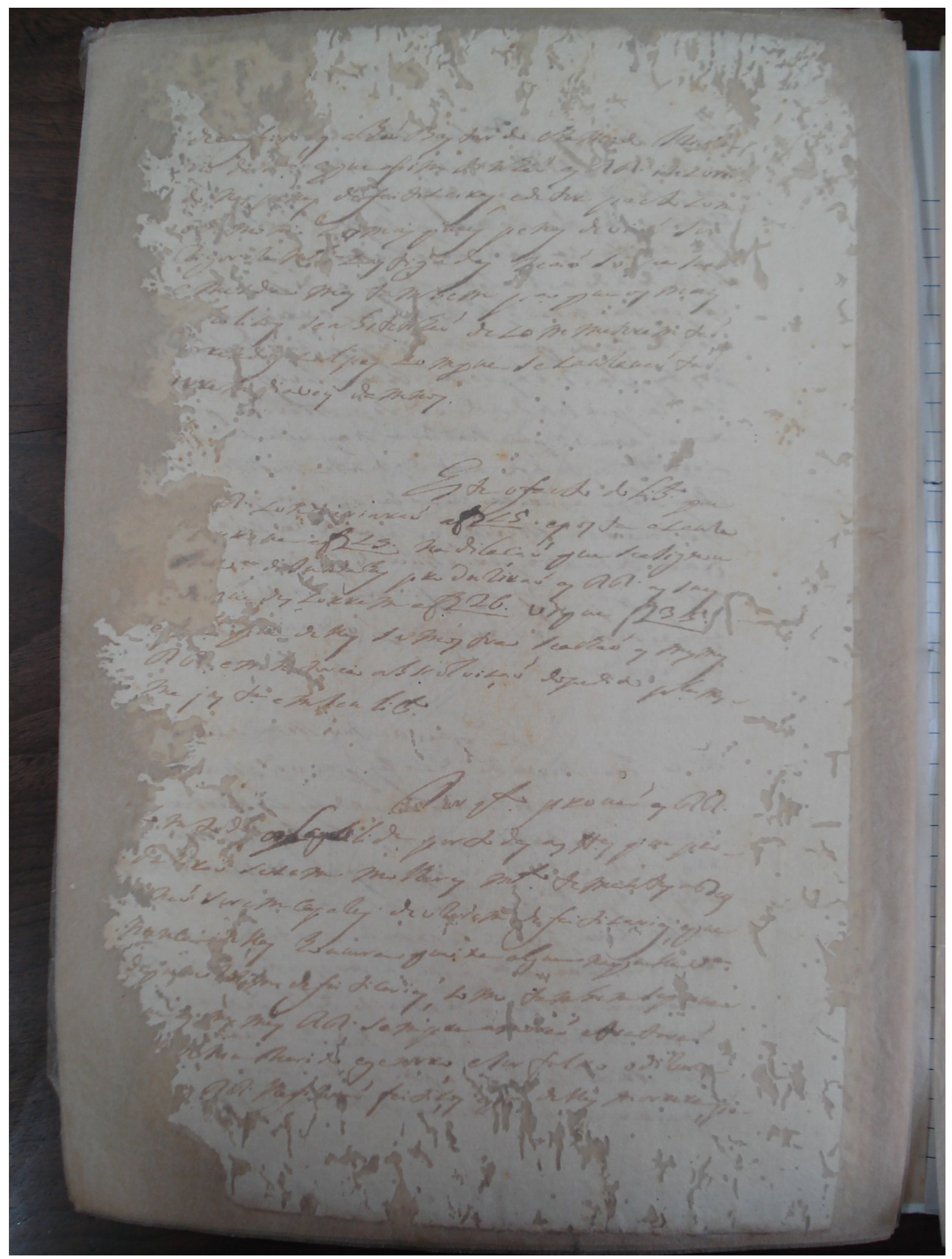


||43 v.

de[o]feit[iço]s ahú Bastardo chamado Izi[do] rio daS $[y l v a]$ equeassim tinhaó as Rés incorri -

2060 do nas penas defeiticeiras, edeter pacto com o d[e]mon[i]o com ${ }^{411}$ as quaes penas devi[aó] ser rigoroZamente castigadas naó só para sua eme[n]da mas tambem para que os mais [cat]holicos seabstenhaó de commeterem taó

$2065[\mathrm{~h}]$ orrendas c[u]lpas comque secauZauaó taó irrem[e]diaveis damnos.

[espaço]

Este oferecimento do libelo que

[corroído] Ré con[tr]ariaraó afolha 15 eposta acauza [corroído] [p]r[o]ua afolha 15 na dilaçaó que seaSignou

2070 [corroído] Vil[a] d[e]Iundahy ${ }^{412}$ produZiraó as Rés as suas [corroído]que descorrem afolha26 Vi que folha35 e[corroído] que dellas se mostra seachaó as mesmas Rés em n[o]toria abssolviçaó dopedido pela mes ma j[u]stiça emSeu libelo

\section{[espaço]}

$$
\text { Por quanto prouaó as Rés }
$$

comt[o]d[a] a Legalidade por todas as testemunhas que pro duziraó serem molheres muito tementes aDeos [corroído] naó serem capaZes de uZarem de feiticarias, eque nunca [d]ellas houuera queixa algua naquellaVila

2080 dequ[e] vZ[ace]m defeiticarias, como tambemsep[ro]ua [q]ue as mesmas Rés sempreamaraó etrataraó [corroído]SeuMarido, egenrro, eSer falsso o diZerc[e] [corroído] Rés lhefiZeraó feitiços eq[ue] delles morrera,po - 


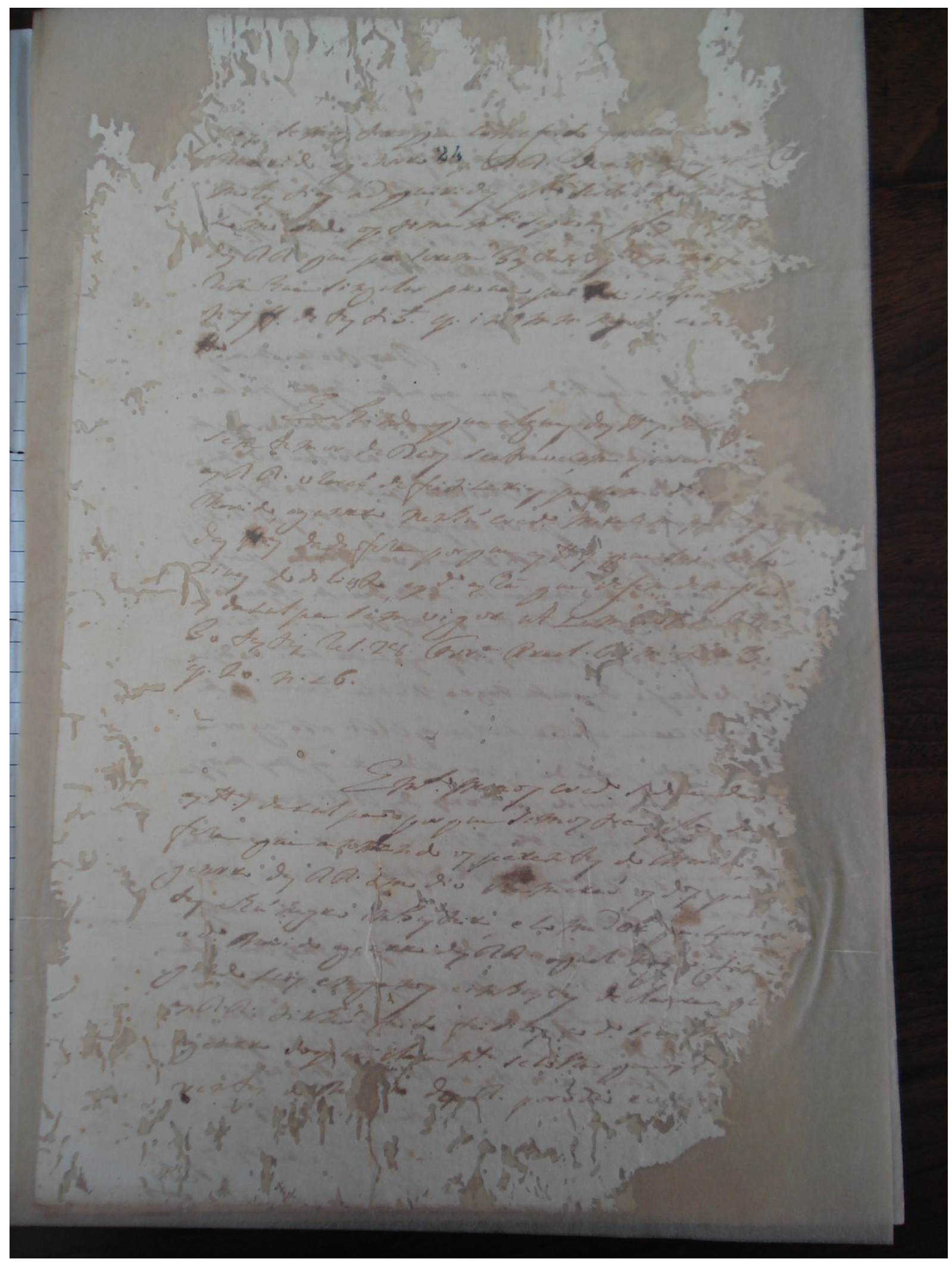


||44 r.

[[po]]is se mostra quecom efeito e[corroído] [ilegível]

2085 [corroído]Marido egenrro $<24>$ [da]s Rés dea[corroído]guas, $\quad<$ [corroído] $>$ molestias adquiridas pelo sertaó do cuiaba como $\mathrm{t}[\mathrm{u}$ ]do optimamente seproua pelas [corroído] das Rés que po[r] serem bastan[te]s em nota rem hua singular proua por [ilegível]Liu[corroído]

2090 nas folhas ${ }^{413}$ de tas libelo ep. in[corroído]mn[ilegível] cada [corroído] testemunha

\section{[espaço]}

Eahindaquealguas das testemunhas [ilegível] [corroído]

semtemor de Deos seatreveçem ajurar [corroído] as Rés vZaraó de feiticarias para com o dito [corroído]

2095 Marido, egenrro nenhú credito merecem, [ilegível] [corroído] das testemunhas dadefeZa por que as testemunh[a]s que s[a]ó [e]xclu Zivas do delito, equando as há que defemdem ficaó as daculpa sem vigor ut com[trecho corroído] bo tas tis re 128 Ferreira Pret. [trecho ilegível]

2100 ep. 20. n. 16.

[espaço]

E muito $\mathrm{m}[\mathrm{en}]$ os credito $\mathrm{s}[\mathrm{e}] \mathrm{de}[\mathrm{u}] \mathrm{edar}$

as testemunhas daculpa por que se mostra pela[s] da [de]

feza que an[d]ando os parentes do Mari[d]o, e genrro das Rés emodio chamaraó os ditos pa[ren]

2105 tes ahú negro imbusteiro, e comedor para cura[r] o dito Marido egenrro das Rés oqual $\mathrm{n}[\mathrm{e}] \mathrm{g}[\mathrm{r}] \mathrm{o}$ fim $\mathrm{g}[\mathrm{in}]$ do seos enganos e imbustes declarara qu[e] as Rés tinhaó feito feiticos ao dito se[o] $\mathrm{Ma}$ [rido] egenrro doque cla[r]amente se colhe que os $\mathrm{d} i t[\mathrm{os}][\mathrm{pa}]$

2110 rentes do M[ari]do d[a] Ré por odio e vin[gança] 


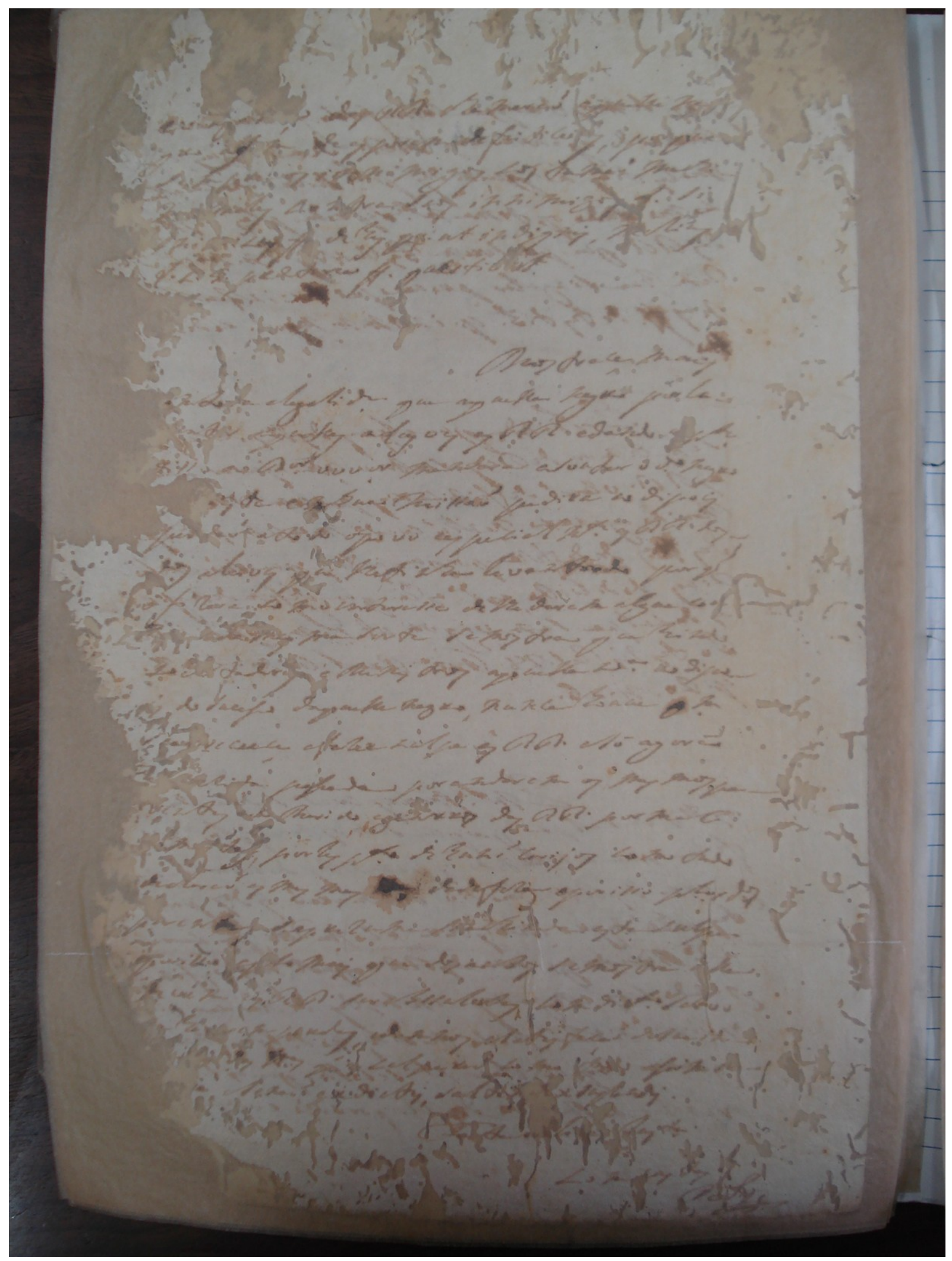


||44 v.

[[e vi[ng]a[nça]]] das Rés chamaraó equezei ne gro aq[ue]m de esporem de feiticei[ra]s, o por que sem [ilegível] os innimigos costumaó machi [corroído] males contra seos innimigos L. si

2115 Ini[corroído]cos folhas de bispo ut indignis, melius

L. c. [ilegível] preterce folhas questio[corroído]t

[espaço]

Mostraçe mais

[corroído]nto[corroído]aelegalidade que aquelle negro por la -

[corroído]ent[corroído]r aquellas aLusoes as Rés edando [corroído]parte

2120 disso ao Doutor ovvidor mandara asoutar o dito negro

[corroído]ste emhua missaó pedira ao dipois

perdaó atodo opovo eespecialmente as Rés dos -

ditos aleives que lhetinha Levantado por que

o fiZera com o interesse de lhe darem algua cou -

$2125 \mathrm{z}$ [a] [corroído] da mesma sorte se mostra que hindo

V[ezi]tadores e Ministros aquella Vila ao dipo -

is do sucesso daquelle negro, nunca houue quem

sea[t]reueçe afaZer culpa as Rés eSó agorā

[corroído] [v]ezita passada por andarem os mesmos pa -

2130 rentes d[o] Marido egenrros das Rés por mal

[corroído]m[corroído]tas, por respeito de hunś carijos como tudo

declaraó as mesmas [testemunhas] dadefeza epor isso pelos ditos

paren[te]s sepreZumiss[e]ahi[n]da estaculp[a] -

epor isso epelo mais que dos a[u]tos se mostra [e]lla

2135 devem as Rés ser abssolutas, com direito salvo

[corroído] ha[ver]em perdas, edannos eSatisfaçaó deSua in -

[corroído] as testemunhas q[ue] [as] culparaó como t[ud]o assim n[corroído] -

[corroído]a eSenaó exidietis, salt[corroído]x suplendj

$\mathrm{Fa}[$ corroído]ta[corroído]la[corroído][J]ustiça

Com custas

$\underline{\text { Peyxoto }}$ 


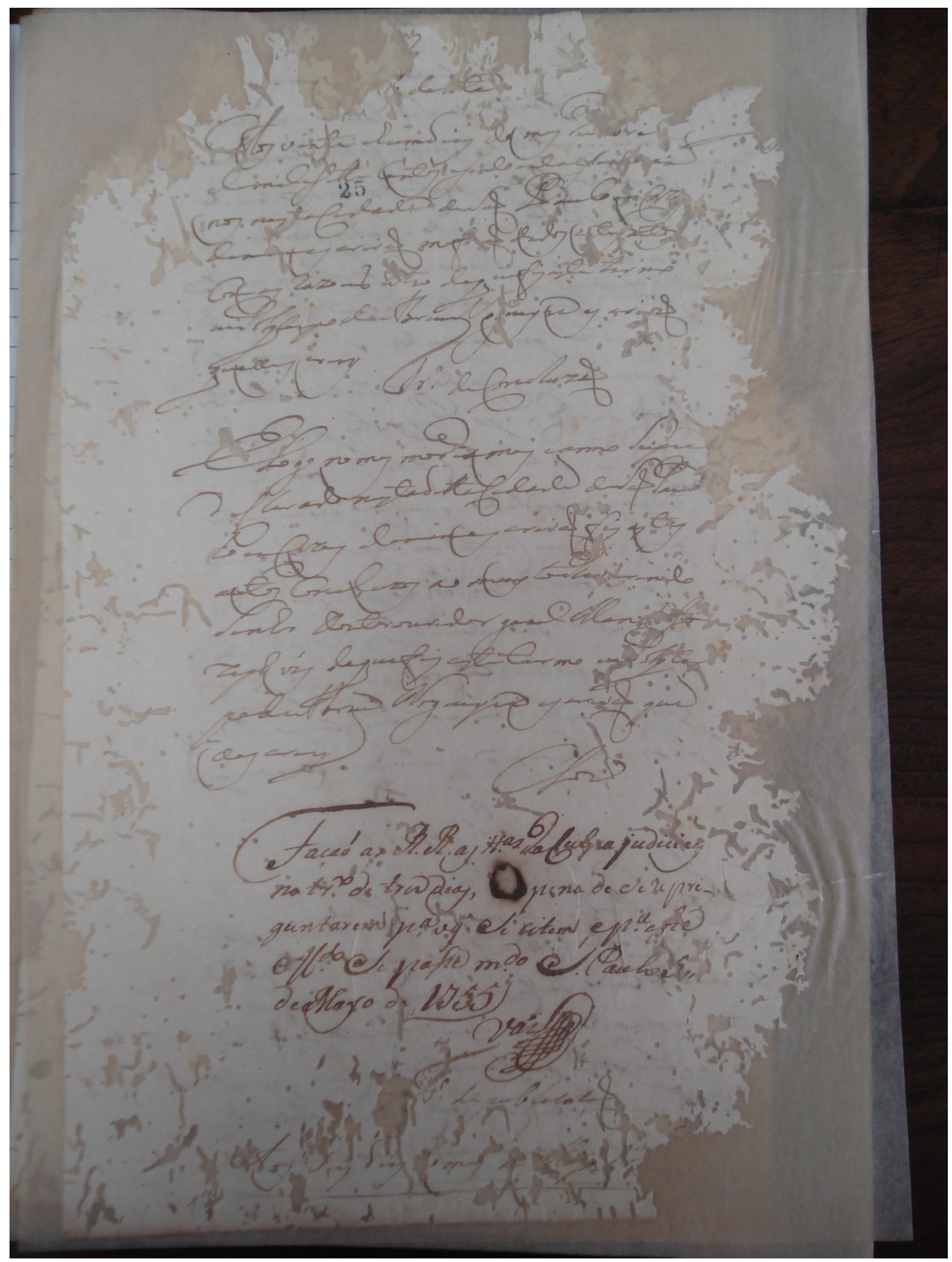


[T]ermo da[corroído]ta ${ }^{414}$

[espaço]

Aos vinte ehumdias do mes de[ab]ril

$<[$ corroído $]>$

demil esette $<25 \downarrow>$ Centos esinco entaesin[c]o an

2145 nos nestaCidade deSaõ Paulo em Caz[a]s

dem[i]nescrivaõ mefo[r]aõ dados e[s]tes autos

Com as razoens dequefis este termo

euPolycarpo deAbreu Nogueyra escrivaõ

queoescrevy

2150

Termo deConcluzaõ

[espaço]

ELogo no mes modiames eanno Supra

deClarado nestadittaCidade deSaõ Pau

lo emCazas deminescrivaõ fis est [e]s

autos ConCluzos ao muy toRev[e]rendo

2155 Senhor Doutor ouvidor geral Man[oel] Jo

zeph vás dequefis este termo eu PolyCar

podeAbreu Nogueyra escrivaõ que

oescrevy

$$
\text { ConcLuzoz }{ }^{415}
$$

[espaço]

2160 Façaó as Rés as testemunhas daCulpa judiciaes ${ }^{416}$ no termo de trez dias, [corroído] pena de se repre guntarem para oque se citem, epara esse eMuito se passe mandado ${ }^{417}$ Saó Paulo 5" deMayo de 1755

2165

$$
\text { Váz[sinal público] }
$$

Termo de publicaçaõ ${ }^{418}$

[espaço]

Aos Seis dias [d]o mes [de] M[ayo] [de] [corroído]

414 A partir daqui, o punho volta a ser do escrivão Polycarpo de Abreu Nogueyra.

415 "CL ${ }^{\text {oz" }}$ por "ConcLuzoz", segundo FLEXOR, 1990, p. 76. A autora apresenta diversas abreviaturas para a referida palavra, dentre elas " $\mathrm{CL}^{\text {os" }} \mathrm{e}$ " $\mathrm{Cl}^{\circ 2 \text { ", }}$, que mais se aproximam da abreviatura encontrada no manuscrito original.

416 A partir daqui, o punho é de Manoel Iozeph Váz.

417 " $\mathrm{m}$ do" por "mandado", podendo também ser desenvolvido por "mando", de acordo com FLEXOR, Idem, p. 254.

418 A partir daqui, o punho volta a ser de Polycarpo de Abreu Nogueyra. 


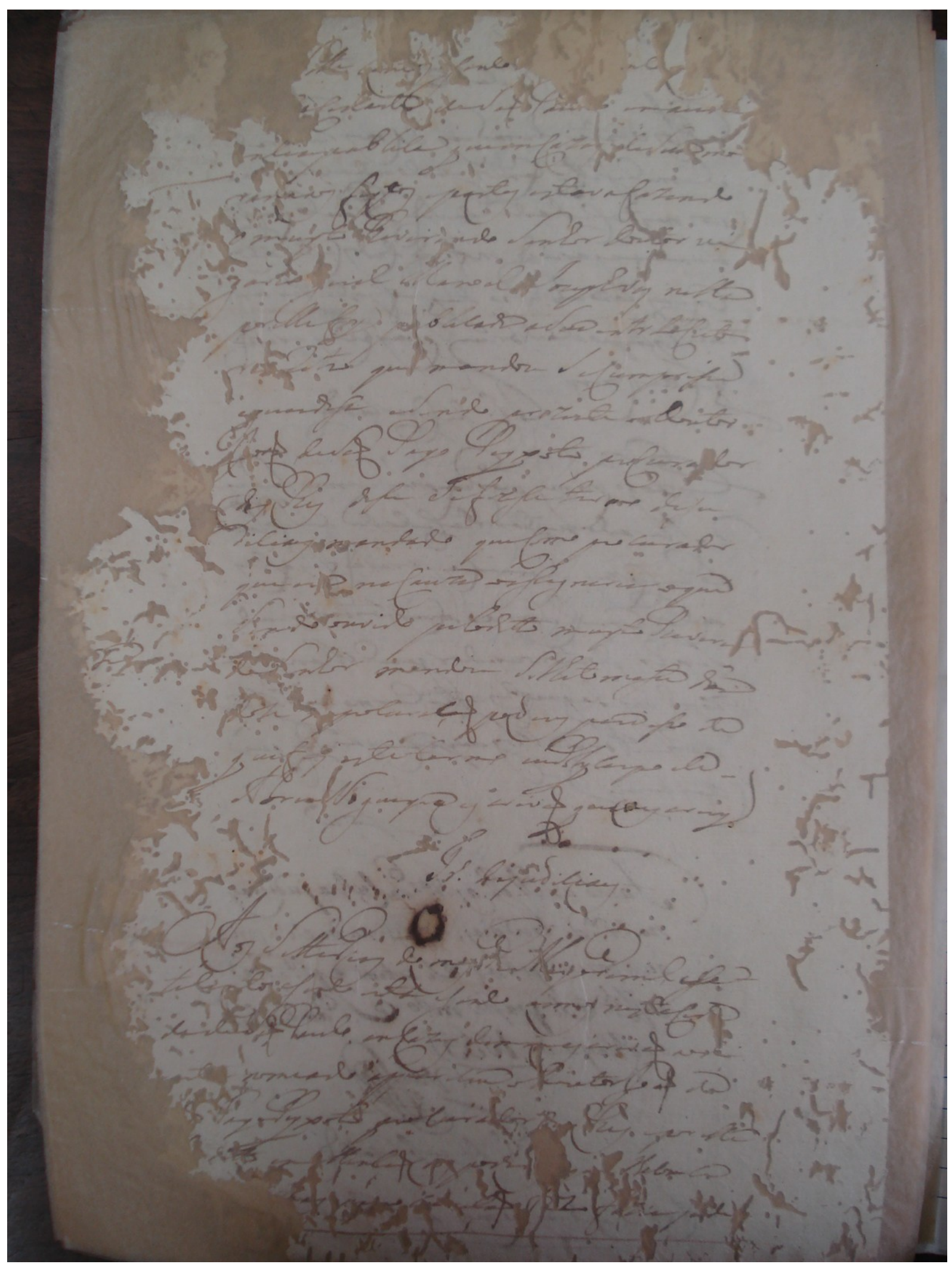


||45 v. $\|$

[corroído] Sette Centos [e]sinco [corroído]nc[corroído]

[corroído]aCidade deSaõ Pau[1]o emau[di]

2170 [e]nciapublica queemCazas deSua mo

$<{ }^{419}>$ radaaos feytos epartes estavafazendo

o muyto Reverendo Senhor Doutor vi

gario geral Manoel Iozephvas nella

por ellefoy $\mathrm{p}[\mathrm{u}]$ blicada aSua entr LoCiato

2175 re[corroído] retro qu[e] mandou SeCumprisse

eguardasse eSendo prezente oDoutor

Joaõ deSaõ Payo Peyxoto proCurador

das Res dasse Sefizesse ter[m]o deju

diciaes mandado queComo procurador

2180 que er[a] naCauza oassignaria oque

Sendo ouvido peloditto muyto Reveren

$<\mathrm{n}>$ doSenhor mandou Selhetomasse dan

dose [na]procuraçaõ poderes para isso de

quefis este termo euPolycarpo de

2185

AbreuNogueyra es crivaõ queoescrevy

[espaço]

Termo dejudiciaes

[espaço]

[buraco]

Aos Settedias do mes deMayodemil eset

tecentos esinco enta esinco annos nestaCid[a]

dedeSaõ Paulo emCazas deminescrivaõ aodi

$2190 \quad$ [a]nt[e] nomeado appareceu oDoutor Joaõ d[e]

[Sa]õ PayoPeyxoto proCurador da[s] Res epor elle

[corroído] d[ilegível] emMenÇaõ aos poder[es] [corroído] [corroído] lhecom c[a]

[corroído]as [ilegível]proc[ur]açaõ folha7 faziajudi

419 Este traço na horizontal está localizado entre as linhas 2170 e 2171. 


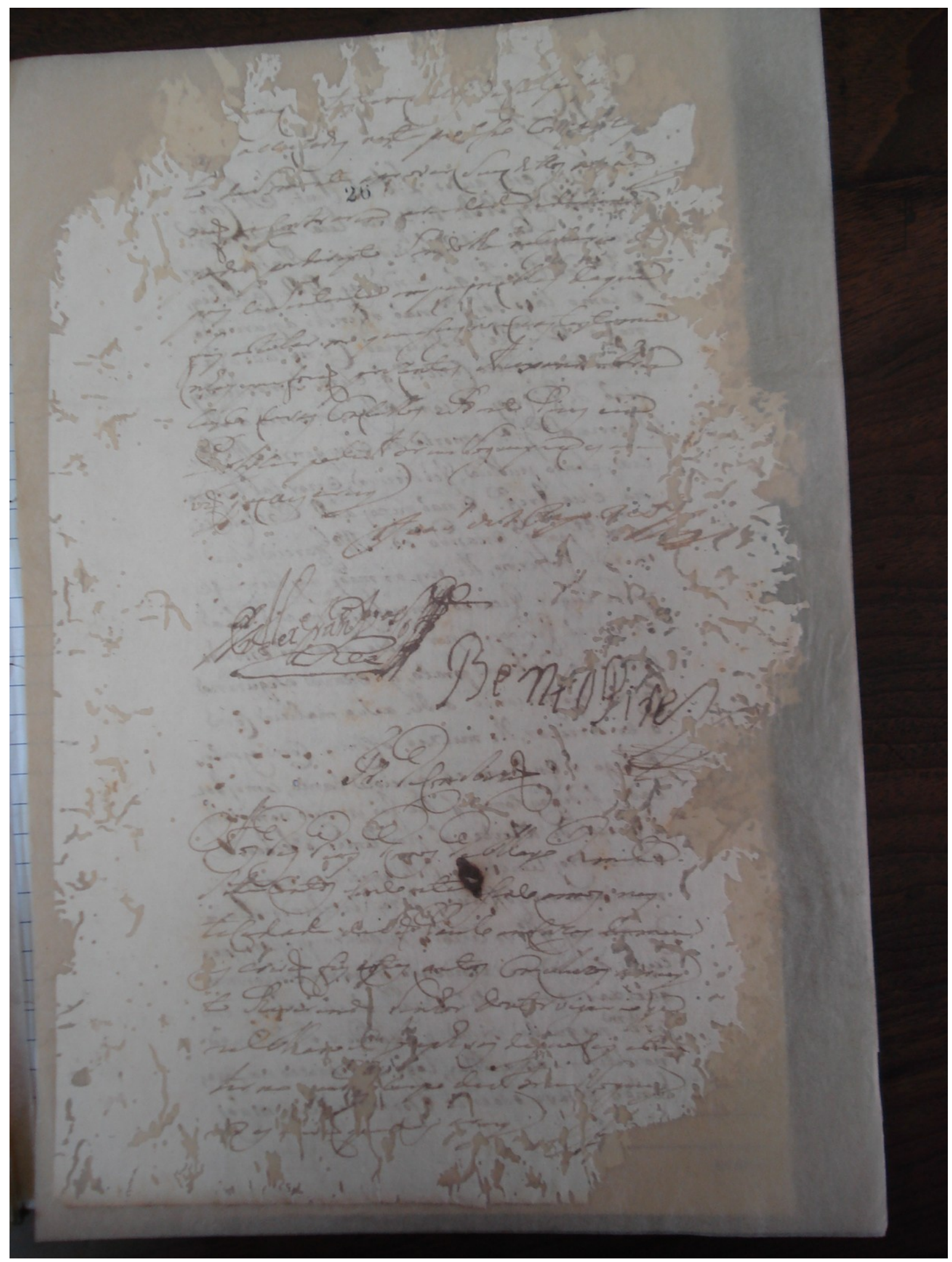


||46 r. $\|$

[[[jud]iciaes]] [corroído] t[e]stem[u]nhas daCulpa p[corroído]

2195 [corroído] accuzadas neste pr[oce]sso Co[corroído] [corroído]

to deSom[e]nte $<\downarrow 26>$ aprovar Seus dittos no que $\quad<$ [corroído] $>$

naõ [e]mContraram arendada edi[ilegível]da

poder pordireyto Sendolheneces[s]ario, d[e]

pois deuSentença em pugnillas deque

2200 fis esteter mo queassignou eas testemu

nhas equeforaõ prezentes Alexand[re] Fran

CisCo devas ConCellos eBento Pires eeu

PolycarpodeAbreuNogueyra es c[r]i

vaõ queoescrevy

Joaó deSaó Payo Peyxot[o]

[sinal público] ${ }^{420}$

[espaço]

[sinal público]AlexandrefranciscoVasCo[sinal público]

[assinatura $^{421}$

$\underline{\text { Bento Pires }}$

2210

Termo deConcluzaõ

[sinal público] $]^{422}$

[espaço]

Aos des dias domes deMayo demile

Sette C[e]ntos esinco enta [buraco] [e]sinco annos nes

taCidade deSaõ Paulo emCazas demin

escrivaõ fis estes autos Concluzos a[om]uy

2215 to Reverend[o] Senhor Dout[o]r vigario ge

ralManoel Jo[z]ephvas dequefis este

termo euP $[\mathrm{oly}]$ Carpo deAbreuNoguey

[ra] es[cr]ivaõ que oes crevy

[ilegível] 


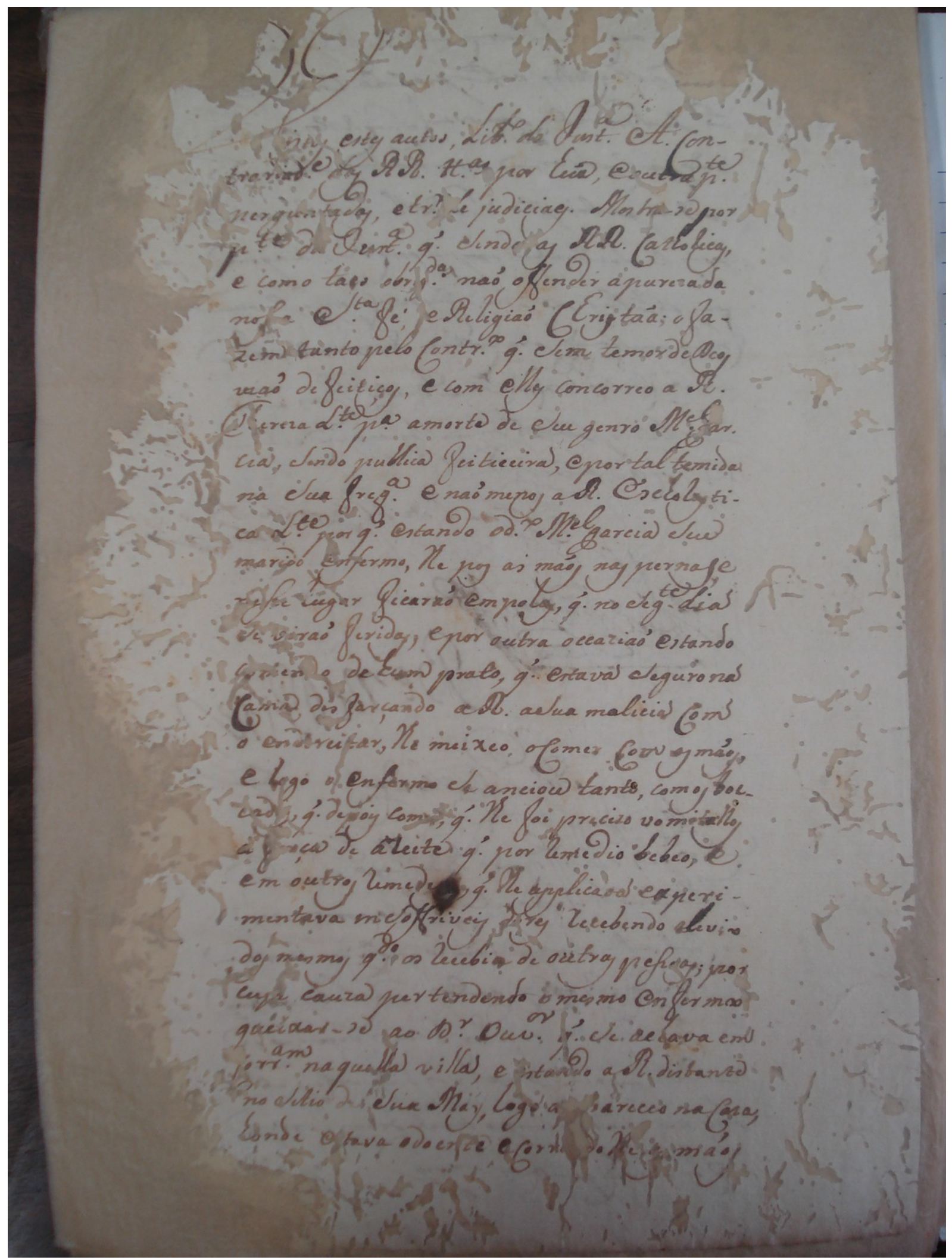


||46 v.

2220 Vistos estes autos, Libelo ${ }^{423}$ da Iustiça Autora Con $^{424}$ -

trariadade $\mathrm{e}^{425}$ das Rés testemunhas por huã, eoutra parte

perguntadas, e tr?[corroído]Le judiciaes. Mostra-se por

parte da Iustiça que sendo as Rés Catholicas,

e como taes obr[i]gadas naó offender a pureza da

$2225 \operatorname{nos}[\mathrm{s}] \mathrm{a}$ Santa fé, e Religiaó Christaã; o fa -

zem tanto pelo Contrario que sem temor de Deos

uzaó de feitiços, e com elles concorreo a Ré

Threza Leyte para amorte de seu genro Manoel gar

cia, sendo publica feiticeira, e por tal temida

2230 na sua freguesia e naó menos aRé Escholasti -

ca Leyte por que estando o dito Manoel garcia seu

marido enfermo, lhe pos as máos nas pernas e

[n]esse lugar ficaraó em polas, que no seguinte dia

se viraó feridas, epor outra occaziaó estando

2235 comendo de hum prato, que estava seguro na

Cama, desfarçando aRé asua malicia Com

o end[i]reitar, lhe meixeo oComer Com as máos,

e logo o enfermo se anciou tanto, com os boc -

cad[o]s, que depois com[eo], que lhe foi precizo vom[i]tallos

2240 a f[o]rça de azeite que por remedio bebeo, e

em outros remedi[os], que lhe applicava experi -

mentava insoffriveis dores recebendo alivio ${ }^{426}$

dos mesmos quando os recebia de outras pessoas; por

cuja cauza pertendendo o mesmo enfermo[[o]]

2245 queixar-se ao Doutor Ouvidor que se achava em

Correiçam ${ }^{427}$ naquella villa, e [e]stando aRé distante

no sitio de sua May, logo a[corroído][p]areceo naCaza,

honde e[s]tava o doente eCorr[en]do lhe as máos

423 Conforme consta em FLEXOR, 1990, p. 247.

424 A partir deste fólio, o punho é de Manoel Iozeph váz.

425 "Contrariadade" por "Contrariedade".

426 Ao que parece, o "l" em "alívio" foi redigido por cima de outra letra ou simplesmente o redator tentou algum tipo de correção.

427 “Corr am” por "Correiçam", segundo FLEXOR. Ibidem, p. 100. 


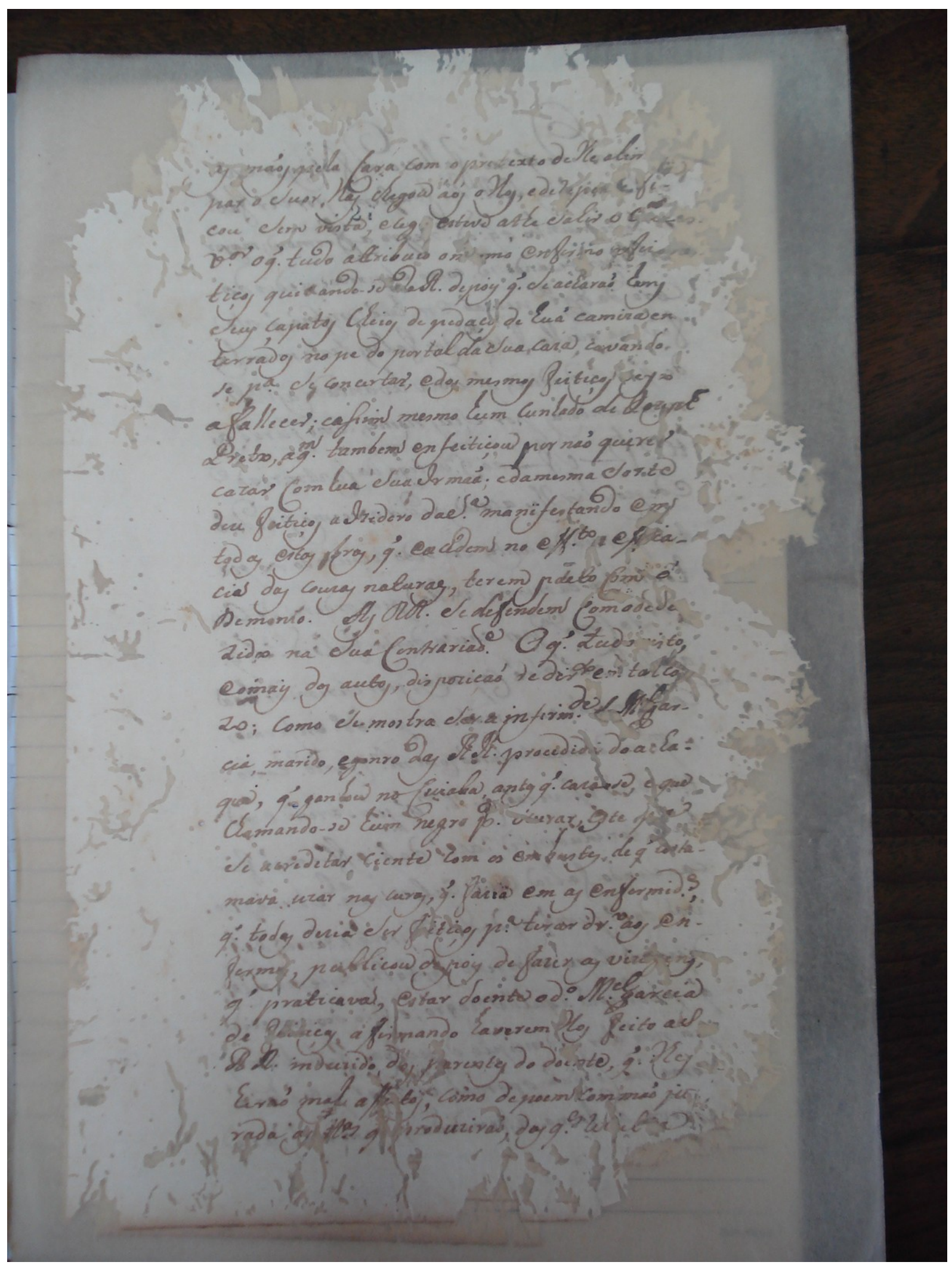


||47 r.

[[as máos]] pela Cara com o pretexto de lhe alim

2250 par o suor, lhas $<\downarrow 27>$ chegou aos olhos, e de repe[nt]e fi cou sem vista, e ceg[o] estava athe sahir o [ilegível] visitador ${ }^{428}$ o que tudo áttribuio o [mes]mo enfermo afei tiços quixando-se daRé depois que se acharaó huns seus çapatos cheios de pedaços de huá camiza en

2255 terrados no pe do portal da suacaza cavando se para se concertar, e dos mesmos feitiços [v]eyo afallecer; eassim mesmo hum cunhado de Iozeph Preto, aquem tambem enfeitiçou por naó querer cazar Com hua sua Irmaã; edamesma sorte

2260 deu feitiços a Izidoro daSilva manifestando em todas estas obras, que ex cedem no effeito [corroído] e[ffi]ca cia das couzas naturaes, terem pacto Com o Demonío. [espaço] As Rés se defendem Como de $\mathrm{d}[\mathrm{u}]$ zido na suaContrariadade $\mathrm{O}$ que tudo [v]isto,

2265 eomais dos autos, dispoziçaó de direito em tal ca zo; como se mostra ser a infirmidade [de] Manoel gar cia, marido, eg[e]nro das Rés procedida do a[c]ha que, que ganhou noCuiaba, antes que caza[r]se, e que chamando-se hum negro para ocurar, este para

2270 se acreditar ciente com os embustes, de que costu mava uzar nas curas, que fazia em as enfermidades, que todos deziá ser f[e]itiços para tirar dinheiro ${ }^{429}$ aos en ferm[o]s, publicou depois de fazer as viz[ag]ens, que praticava, estar doente o dito Manoel garcia

2275 de f[e]i[t]iços affirmando haverem lhos feito aS Rés induzido, dos parentes do doente, que lhes heraó mal affe[i]tos, como depoèm commaó ju rada as testemunhas que produziraó, das quaes re[zu]1[t]a 


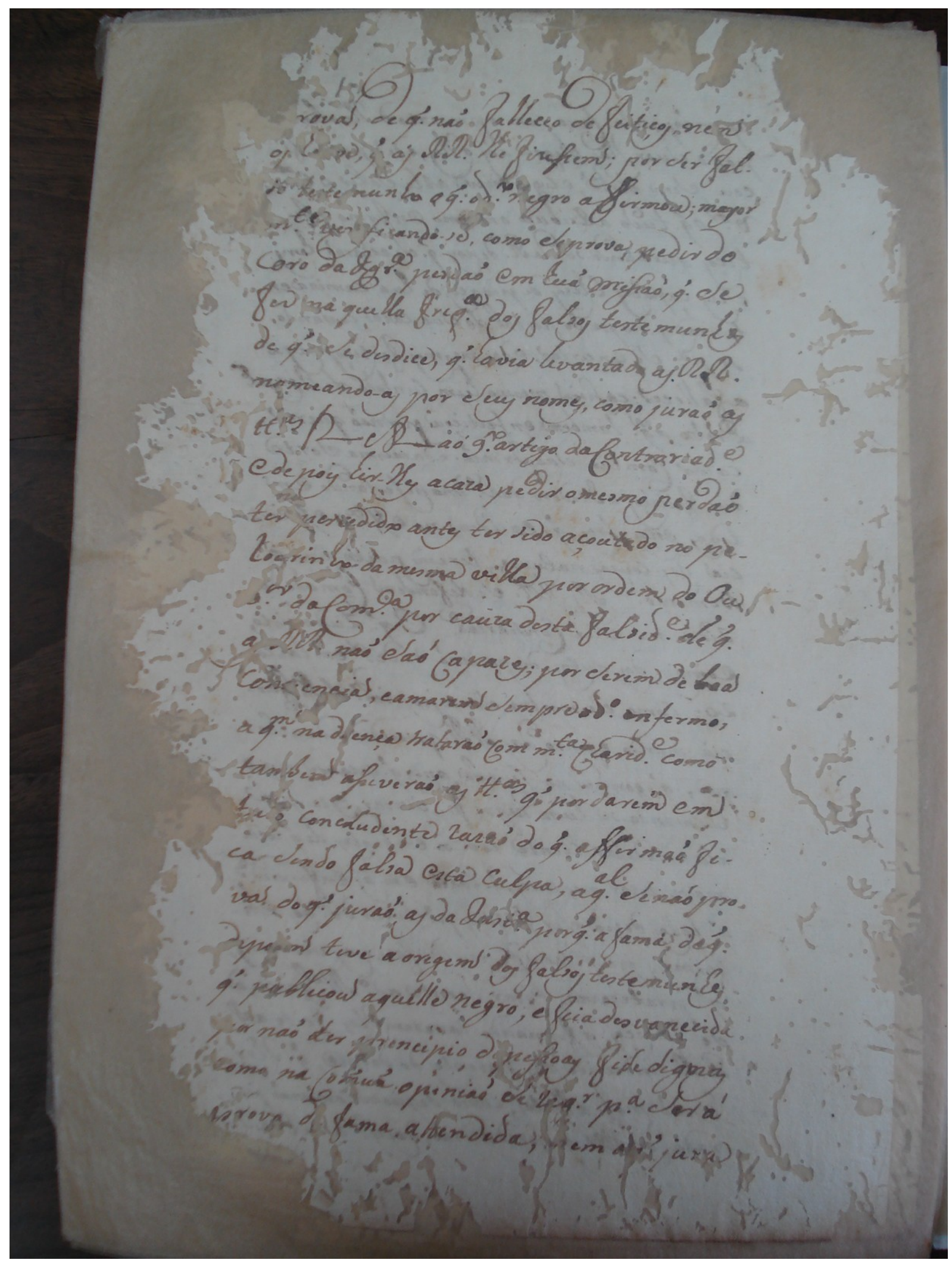


||47 v.

[corroído]rava, de que naó falleceo de feitiços, nem

2280 os h[ou]ve, que as Rés lhe fizessem; por ser fal -

so te[s]temunho o que o dito negro affirmou; mayor

mente ${ }^{430}$ ver[i]ficando-se, como se prova, pedir do

Coro da Igreja $\mathrm{a}^{431}$ perdaó em huá missaó, que se

fez na quella freguesia dos falsos testemunhos

2285 de que se desdice, que havia levantad[o] as Rés

nomeando-as por seus nomes, como juraó as

testemunhas folha efolha aó $9^{\circ}$ artigo daContrariadade

e depois hir-lhes a caza pedir o mesmo perdaó

ter percedido antes ter sido açoutado no pe -

2290 lourinho da mesma villa por ordem do $\mathrm{Ou}$

vidor daComarca por cauza desta falsidade de que

as Rés naó saó Capazes; por serem de boa

con[c]iencia, eamarem sempre o dito enfermo,

a quem na d[o]ença trataraó Com muita Charidade como

2295 tambem asseveraó as testemunhas que por darem em

$\mathrm{tu}[\mathrm{d}] \mathrm{o}$ concludente razaó do que affirmaó fi -

ca sendo falsa esta culpa, aqual senaó pro

va do que juraó as da Iustiça porque a fama doque

depo[e]m teve a origem dos falsos testemunhos

2300 que publicou aquelle negro, e fica desvanecida

por naó ter prencipio d[e] pessoas fide dignas,

como na Coḿum opiniaó se requer ${ }^{432}$ para ser a

prova $\mathrm{d}[\mathrm{e}]$ fama attendida, [corroído] em oque jura

430 “ $m$ te" por "mente", segundo FLEXOR. Ibidem, p. 257. De acordo com o mesmo dicionário, outra opção para esta abreviatura seria "morte", que também é apropriada para o referido contexto.

431 "Igra" por "Igreja", segundo FLEXOR. Ibidem, p. 214.

432 "2eq" ("req") por "requer", de acordo com FLEXOR. Ibidem, p. 369. 


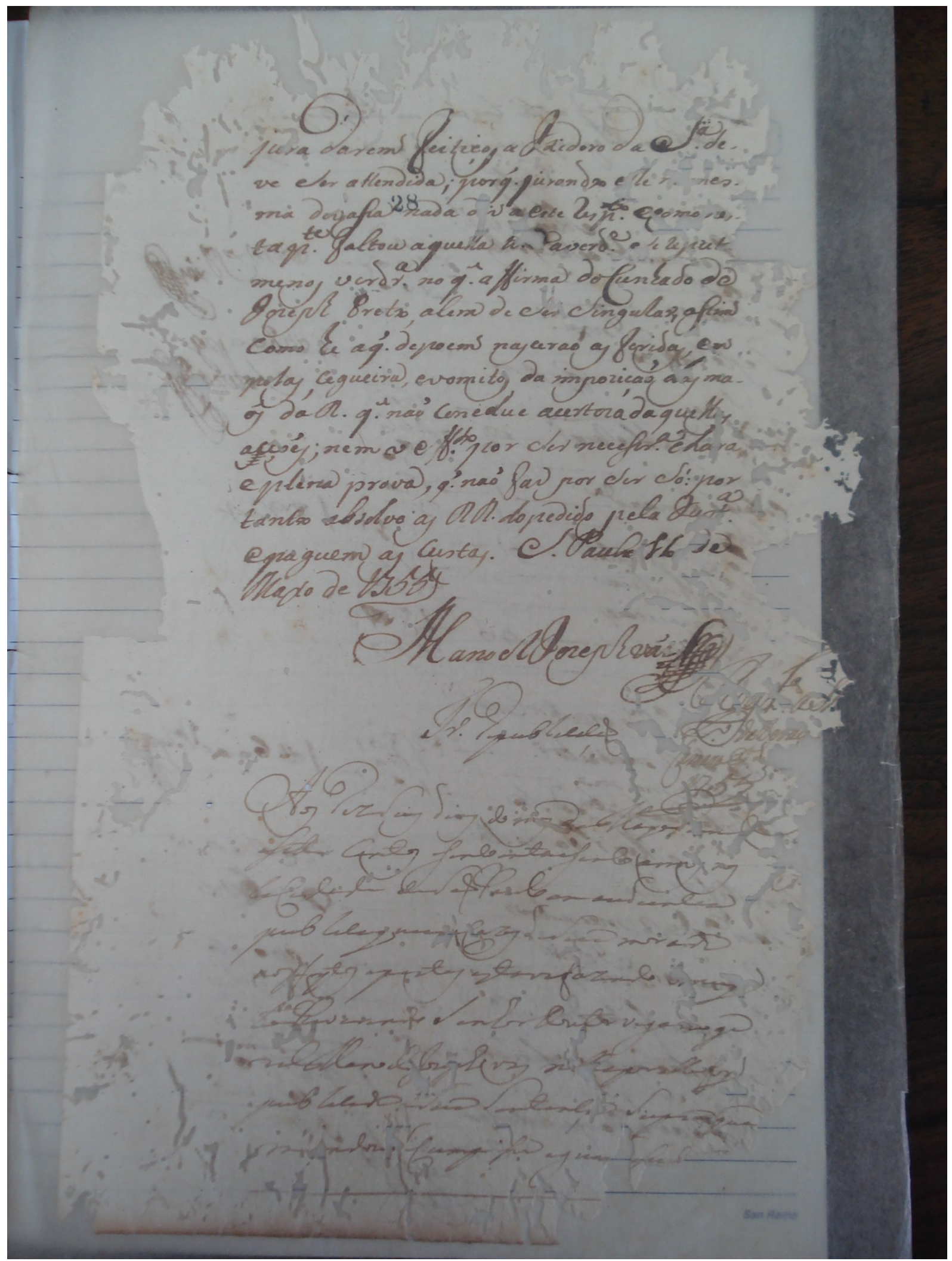


||48 r.|

[[jura]] darem feitiços a Izidoro da Silva de -

2305 ve ser attendida; porque jurando elle n[a] mes -

ma devassa $<28>$ nada $\mathrm{d}[\mathrm{i}] \mathrm{z}$ aeste respeito eComo nes -

ta parte faltou aquella t[corroído]averdade se reput[a]

menos verdadeira no que affirma doCunhado de

Iozeph Preto, alem de ser singular, assim

2310 como he oque depoem nasceraó as feridas, em

polas, cegueira, evomitos, da impoziçaó [d]as ma -

ós daRé que naó concLue acerteza daquell[a]s

acçoés ${ }^{433}$; nem o effeito por ser necess $a$ ri $\mathrm{a}^{434}$ clara

e plena prova, que naó faz por ser só: por

2315 tanto absolvo as Rés do pedido pela Iustiça

epaguem as custas. Saó Paulo 16 de

Mayo de 1755

\section{Manoel Iozeph váz[sinal público]}

$$
\begin{array}{cc}
\text { Termo depublicaçaõ }{ }^{437} & \text { Regimento }^{435} \text { as[corroído] } \\
& \text { [ilegível] daDe[v]aç[a] } \\
\text { CamaraEpiscopal [corroído] }
\end{array}
$$

[espaço]

Aos dezaSeis dias do mes deMayod[e]mil

esette Centos esinco entaesinco annos nes

2325 taCidade deSaõ Paulo em audiencia

publicaqueemCazas deSua morada

aos[f]feytos apostos estavafazendo o muy

toReverendo SenhorDoutor viga[ri]o ge

ralManoelJoz[e]ph vas n[e]llaporellefoy

2330 publicada aSua Sentença Supra que

$\mathrm{m}[\mathrm{a}]$ ndou SeCumprisse egua[rd][a]sse [corroído]

433 No manuscrito original, logo abaixo da letra "c" há uma cauda que foi riscada posteriormente pelo escrivão, o que indica que, inicialmente, ele pode ter grafado um "s" no lugar do "c".

434 "necessr" " por "necessaria", segundo FLEXOR. Ibidem, p. 283.

435 "Reg ${ }^{\text {to" }}$ por "Regimento", de acordo com FLEXOR. Ibidem, p. 362.

436 Este trecho inserido na margem, à direita da mancha, foi redigido por um punho diferente, e supõe-se que tenha sido pelo padre Bento Joze Leyte.

437 A partir da frase "Termo de publicação" até o final do manuscrito, o punho é do escrivão Polycarpo de Abreu Nogueyra. 


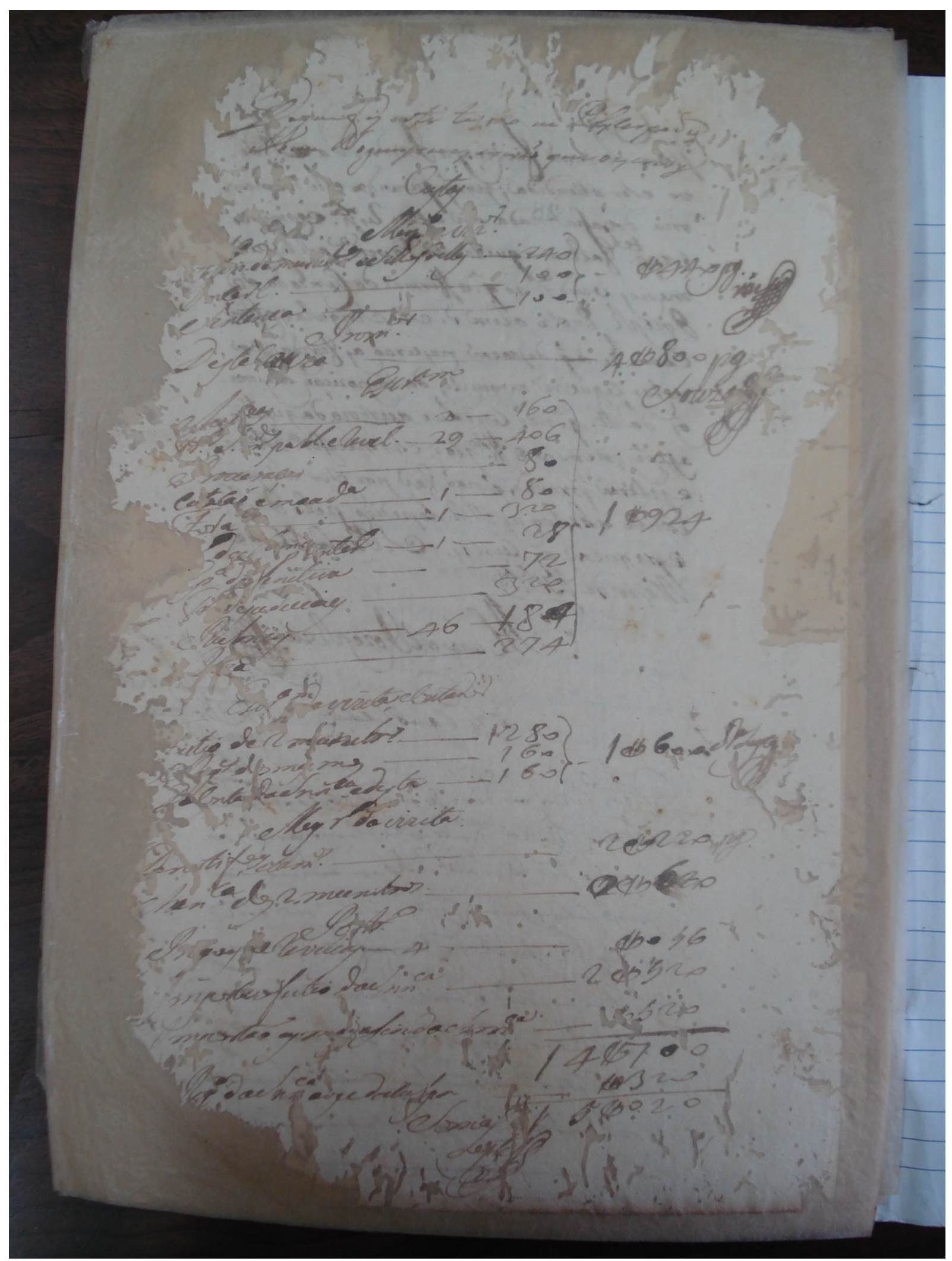


||48 v.

Deque fis este te[r]mo eu PoLycarpo de

Abreu Nogueyra escrivaó que o escrevy

Custas

2335

Ministro [e]v[i]zitador

[ilegível]de[ilegível]os eSellos delles

[ilegível]cerl. 240

Sentença $100>$ - réis $440 \mathrm{pg}$. 100 váz [sinal público]

Promotor

2340 Destacauza 4 réis 800 pg Escrivam

Souza [sinal público]

I[ilegível]as___ 2 _ 160

[ilegível] s[corroído]ds paraM. e revelias __29_406

eProcuraçao _ 80

2345 cotacaó emaudiencia___

Fora__ $1 \ldots 320$

[corroído]de[ilegível]nted___

[corroído]para deSenetica___

Term[o] dejudiciaes $\quad 320$

eRubr[i]cas

$46 \quad 184$

$\mathrm{D}$ [corroído]a 274

Escrivam davisita econtador

Feitio de R 1280

[ilegível] dos mesmos $160 \succ-1$ réis 600 IozeLeyte

2355 DaConta[corroído]daSentenca edesta 160

[sinal público]

\section{Meyrinho da vizita}

Den[o]tificaçoes ecamos

chancelaria dos r. munitorios 2 réis $220 \mathrm{pg}$

$\mathrm{Po}[\mathrm{r}]$ termo

2360 eP[corroído]goas [d]e revelias 4 réis 056

Importaofeitio daSentenca 2 réis 520

Importao os mais asin daSentenca 14 réis 520

Regimento daSente[n]ca ao pedaculpa réis 320

S[ilegível] 5 réis 020

Leyte[sinal público] [rubrica] 


\section{NOTA}

Em razão da quantidade de informações contidas na última página da documentação (fólio 48 v.) e do modo como tais informações estão organizadas (como se fossem uma lista de itens), não foi possível inserir notas de rodapé na transcrição do verso deste fólio, caso contrário, não seria possível acomodar a transcrição completa em uma única página. Portanto, as notas de rodapé foram retiradas da transcrição, para melhor acomodar o texto na página e colaborar para que o leitor possa comparar o manuscrito original com a transcrição, de maneira mais fácil.

Todavia, as informações que seriam inseridas em notas de rodapé serão listadas, abaixo, na presente nota:

- As duas primeiras linhas da transcrição, até a palavra "escrevy", são do punho do escrivão Polycarpo de Abreu Nogueyra.

- Já na linha seguinte, a partir da palavra "Custas", até o final do manuscrito, o punho passa a ser do Padre Bento Joze Leyte.

- As assinaturas e sinais públicos inseridos ao lado direto do manuscrito, são, respectivamente, de Manoel Iozeph váz (linha 2338), Promotor Paulo de Souza Rocha (linha 2341) e Padre Bento Joze Leyte (linhas 2354 e 2355).

- A abreviatura por sinal especial localizada ao lado de números, indicando valores, foi substituída pela palavra "réis", de acordo com FLEXOR (1990: 467).

Além das quatro observações elencadas acima, é relevante dar atenção a uma abreviatura mista que aparece unicamente no verso deste último fólio. Trata-se da abreviatura "Snn"a", desenvolvida por "Sentenca" (linhas 2355, 2361 e 2362), segundo FLEXOR (1990: 406). 


\section{CONSIDERAÇÕES FINAIS}

O processo-crime contra as rés Thereza Leyte e Escholastica Pinta da Sylva é, como já mencionado no início deste trabalho, uma documentação inédita, nunca antes editada ou publicada e sua transcrição e posterior publicação oferecem informações fundamentais não somente acerca da atuação do Tribunal do Santo Ofício na América portuguesa, mas também revela aspectos da língua portuguesa escrita no século XVIII.

A partir da leitura dos fac-símiles e da transcrição semidiplomática do processo-crime em questão foi possível verificar uma quebra de paradigma, pois, junto a presente documentação, foram encontrados outros processos de feitiçaria, cujos réus constituem-se de escravos e escravas, o que nos levou a inferir que as rés do processo aqui estudado também seriam escravas. Entretanto, a leitura e transcrição dos manuscritos revelaram que a acusação de feitiçaria foi fruto de uma contenda entre a família de Manoel Garcia de Oliveira e as rés, causada pela exigência do direito de posse sobre uns "administrados", isto é, escravos indígenas. Segundo testemunhas do processo, os parentes do falecido não tinham um relacionamento muito amistoso com Thereza e Escholastica e, por desejarem a posse dos índios Carijós, contrataram um escravo negro chamado Francisco, que era conhecido por fazer feitiços, com a finalidade de que o mesmo curasse a doença de Manoel Garcia, que fora acometido por lepra, e espalhasse boatos contra mãe e filha, alegando que ambas praticavam feitiçaria e que a morte de Manoel fora causada por elas. Portanto, o desejo pela posse dos escravos indígenas, por parte dos parentes de Manoel, teria motivado a denúncia contra Thereza Leyte e Escholastica Pinta da Sylva. Caso mãe e filha fossem condenadas pelo crime de feitiçaria, deixariam de ser um obstáculo aos parentes do falecido, os quais obteriam a posse dos referidos escravos.

Além disso, é necessário lembrar que o pai de Escholastica exercia a função de juiz ordinário na Vila de Jundiaí e que o mesmo havia ordenado a prisão do feiticeiro Francisco (já falecido à época do processo) e que ele também fosse açoitado no pelourinho e depois devolvido a seu dono, o que evidencia a influência de uma estrutura de poder local.

Assim, se o objeto do conflito entre ambas as partes era escravos, isso leva a crer que as rés eram brancas, revelando totalmente o contrário do que se assumia no início da pesquisa, isto é, que as acusadas eram negras e escravas. Além disso, há outro fator que indica que Thereza e Escholastica fossem brancas: Thereza Leyte era proprietária de um sítio. Apesar de 
terem a pele branca e estarem em meio a uma disputa por escravos, consta nos manuscritos que as rés eram analfabetas. Além do motivo da denúncia, da cor da pele das rés e do fato de as mesmas não saberem escrever, a documentação trouxe outras informações importantes: Manoel Garcia falecera no ano de 1746, isto é, oito anos antes da abertura do processo, não havia deixado testamento escrito e Escholastica já estava novamente casada.

Assim, as acusadas, sujeitas à pena de excomunhão, não foram condenadas pelo crime de feitiçaria, sendo, finalmente, absolvidas, em maio de 1755. Portanto, Thereza e Escholastica, mãe e filha, não foram condenadas e nem encaminhadas para Portugal, onde geralmente eram executadas as penas contra pessoas condenadas pela Inquisição.

A segunda visitação do Santo Ofício ocorreu no século XVII, século anterior ao processo de Thereza e Escholastica, e compreendeu apenas o território da Bahia. Já a terceira visitação viria a ocorrer somente nove anos após a abertura do presente processo-crime, em 1763, e abarcaria apenas as regiões do Grão-Pará e Maranhão. Ainda assim, mesmo não havendo visitação oficial do Santo Ofício na região sudeste e principalmente no interior, ainda havia uma preocupação por parte da Igreja em manter mesmo as vilas do interior livres da heresia, e nesses locais mais afastados e precários, eram estabelecidas as visitas diocesanas, cujas mesas possuíam um caráter mais simplificado, e foi o que ocorreu na "Villa da Nossa Senhora do Desterro de Iundiahy", resultando no processo que acusa Thereza Leyte e Escholastica Pinta da Sylva de serem feiticeiras.

A partir de todas as informações elencadas acima, conclui-se que o processo está inteiro, não havendo nenhuma continuação que possa estar armazenada no Arquivo Nacional da Torre do Tombo, em Lisboa, onde também são mantidos documentos relacionados à Inquisição e à colônia.

Em relação às estruturas gramaticais presentes no texto, observa-se a predominância do uso do "y" para indicar as semivogais na formação de ditongos, por exemplo: "Leyte", "Nogueyra", “Oliveyra", "Cordeyro", “Almeyda”, "Pereyra”, “Jundiahy”, "Ley”, "Pay”, "May" ("mãe"), "feytos", "muyto". Além da utilização do "y” como semivogal, nota-se também que há variação entre "i” e "j” (“Ianeyro", "Iozeph”, "Iulho”, "Iundiahy”, "Iustiça”, “escrevj”) e entre "u" e "v" ("Neues", "Silua", "uendo", “uerdade", "Reuerendo"). O emprego de pontuação e acentuação também diverge do atual, variando também de um punho para outro.

Portanto, em linhas gerais, a edição desta documentação proporcionou não apenas uma 
reflexão acerca da atuação da Inquisição em terras brasileiras, mais especificamente no interior de São Paulo, mas proporcionou também um olhar para as relações sociais, para o tipo de comércio, meios de subsistência, práticas religiosas e para o modo de vida dos habitantes da Jundiaí colonial, além de revelar aspectos da língua portuguesa escrita no século XVIII, evidenciando uma ausência de padrões gramaticais. 


\section{REFERÊNCIAS}

A história de Jundiaí. Site da prefeitura de Jundiaí. Disponível em: https://www.jundiai.sp.gov.br/a-cidade/historia/

Portal tudo.com.vc: "Abaixo-assinado foi responsável pela elevação de Jundiaí à vila". Disponível em: https://tudo.com.vc/abaixo-assinado-foi-responsavel-pela-elevacao-dejundiai-vila/

ALMEIDA, Candido Mendes de. Ordenações Filipinas - Código Phillipino ou Ordenações e Leis do Reino de Portugal. Volume I. Livro I. Rio de Janeiro, 1870. Edição por reprodução em fac-símile da Fundação Calouste Gulbenkian, com nota de apresentação por Mario Júlio de Almeida Costa. Coimbra. 1985, pp. 6-10.

Ordenações Filipinas - Código Phillipino ou Ordenações e

Leis do Reino de Portugal. Volume III. Livros IV e V. Rio de Janeiro, 1870. Edição por reprodução em fac-símile da Fundação Calouste Gulbenkian. Coimbra. 1985, pp. 1147-1148 e 1150-1151.

BERWANGER, Ana Regina \& LEAL, João Eurípedes Franklin. Noções de paleografia e de diplomática. Santa Maria: Editora da UFSM, 1991.

BETHENCOURT, Francisco. História das Inquisições: Portugal, Espanha e Itália - Séculos $X V$-XIX. São Paulo: Companhia das Letras, 2000.

BLUTEAU, Raphael. Vocabulario portuguez \& latino: aulico, anatomico, architectonico ... Coimbra: Collegio das Artes da Companhia de Jesu, 1712-1728. 8 v. Disponível em: http://dicionarios.bbm.usp.br/pt-br/dicionario/edicao/1

BOCCIA, Sandra. “As bruxas paulistas”. In: Revista Veja, ed. 1619, 13/10/1999. Disponível em:

https://acervo.veja.abril.com.br/index.html\#/edition/1619?page=62\&section=1\&word=1999

BUENO, Francisco da Silveira. Grande dicionário etimológico-prosódico da língua portuguesa - vocábulos, expressões da língua geral e científica - sinônimos, contribuições do tupi-guarani. Volumes 2 e 3. São Paulo: Edição Saraiva, 1964-1965.

CAMBRAIA, César Nardelli. Introdução à crítica textual. São Paulo: Martins Fontes (Col. Leitura e Crítica), 2005.

Codigo Phillippino, ou Ordenações e Leis do Reino de Portugal: recopiladas por mandado D'El-Rey Phillippe I. Edição comentada por Cândido Mendes de Almeida. Rio de Janeiro: Typographia do Instituto Philomatico, 1870. Livros I e II. 
CONTRERAS, L. N. "Método en paleografía". In. Manual de paleografía. Madrid: Cátedra, 1994.

CRUZ, António. “Teoria da braquigrafia”. In. Paleografia portuguesa. Porto: Cadernos Portucale, 1987.

Dicionário Caldas Aulete Digital. Disponível em: http://www.aulete.com.br/

FERNANDES, Nathalia Reis. Sujeito nulo na história do português de São Paulo: 18781947. Dissertação (Mestrado em Filologia e Língua Portuguesa) - Faculdade de Filosofia, Letras e Ciências Humanas, Universidade de São Paulo. São Paulo, 2012, pp. 54-55. Disponível em: http://www.teses.usp.br/teses/disponiveis/8/8142/tde-12122012-100624/ptbr.php

FERNANDES, Neusa. A Inquisição em Minas Gerais no século XVIII. $3^{\mathrm{a}}$ edição. Rio de Janeiro: Mauad, 2014.

FERREIRA, Fernando Luis Vieira. Juizes e tribunaes do Primeiro Imperio e da Regenciapelo dezembargador Vieira Ferreira. Boletim do Instituto Historico e Geographico Brasileiro. Rio de Janeiro: Imprensa Nacional, 1937.

FLEXOR, Maria Helena Ochi. Abreviaturas: manuscritos dos séculos XVI ao XIX. 2 ed. aumentada. São Paulo: Arquivo do Estado/Editora UNESP, 1990.

HERCULANO, Alexandre. História da origem e estabelecimento da Inquisição em Portugal. $13^{\mathrm{a}}$ ed. Tomo I. Lisboa: Livraria Bertrand, 1960.

MACEDO, Camilla de Freitas (Universidad del País Vasco). "Sesmarias indígenas na São Paulo colonial: uma interseção entre estatutos pessoais e situações reais”. In.: Dimensões Revista de História da Ufes, n. 39, 2017, pp. 127 e 129. Disponível em: http://periodicos.ufes.br/dimensoes/article/view/18629/0.

MAIA, Patrícia Albano, MIRANDA, Lílian Lisboa. São Paulo colonial: sua gente e seus costumes. São Paulo: Atual, 2006.

MARQUES, Juliano Ricardo. Jundiaí, um impasse regional: o papel do município de Jundiaí entre duas regiões metropolitanas: Campinas e São Paulo. Dissertação (Mestrado em Geografia Humana) - Faculdade de Filosofia, Letras e Ciências Humanas, Universidade de São Paulo. São Paulo, 2008. Disponível em: http://www.teses.usp.br/teses/disponiveis/8/8136/tde-02102009-173006/es.php 
MEA, Elvira Cunha de Azevedo. "O Santo Ofício português - da legislação à prática", Estudos em Homenagem a João Francisco Marques, coordenação de Luís A. de Oliveira Ramos, Jorge Martins Ribeiro, Amélia Polónia; Vol. II, Porto, 2001.

MEGALE, Heitor, TOLEDO NETO, Sílvio de Almeida, FACHIN, Phablo Roberto Marchis, (org.). "A Escrita no século XVIII". In.: Por Rumos da Agulha: Documentos do Ouro do Século XVIII. São Paulo: Editora Cubo, 2015, p. 19.

MENDES, Ubirajara Dolácio. Noções de paleografia. São Paulo: Departamento do Arquivo do Estado de São Paulo - Secretaria da Educação, 1953.

MICHAELIS - Dicionário Brasileiro da Língua Portuguesa. Disponível em: https://michaelis.uol.com.br/moderno-portugues/

MONGELli JÚNIOR, Jair. “O Arquivo da Cúria Metropolitana de São Paulo: acervo, atividades e projetos". In: Mundo Archivistico. Disponível em: http://www.mundoarchivistico.com/?menu=articulos\&id=200.

MONTEIRO, John Manuel. Negros da terra: índios e bandeirantes nas origens de São Paulo. São Paulo: Companhia das Letras, 1994.

MOTA, Ana Claudia de Ataide Almeida. Confessar em segredo: edição e estudo de um Livro de Confissões quinhentista (Inquisição de Lisboa, Liv. 777, Salvador, Bahia, 1591-1592). Volume 1. Tese (Doutorado em Filologia e Língua Portuguesa) - Faculdade de Filosofia, Letras e Ciências Humanas, Universidade de São Paulo. São Paulo, 2016.

SILVA, Antonio de Moraes. Diccionario da lingua portugueza - recompilado dos vocabularios impressos ate agora, e nesta segunda edição novamente emendado e muito acrescentado, por ANTONIO DE MORAES SILVA. Lisboa: Typographia Lacerdina, 1813. Disponível em: http://dicionarios.bbm.usp.br/pt-br/dicionario/edicao/2 SILVA, Maria Beatriz Nizza da., org. BACELLAR, Carlos de Almeida Prado, GOLDSCHMIDT, Eliana Réa, e NEVES, Lúcia M. Bastos P. História de São Paulo colonial [online]. São Paulo: Editora UNESP, 2009.

SIQUEIRA, Sonia Aparecida de. A Inquisição portuguesa e a sociedade colonial. São Paulo: Ática, 1978.

SOUZA, Laura de Mello e. O diabo e a Terra de Santa Cruz: feitiçaria e religiosidade popular no Brasil colonial. São Paulo: Companhia das Letras, 2009.

SPINA, Segismundo. Introdução à edótica: crítica textual. São Paulo: Cultrix, Ed. da Universidade de São Paulo, 1977. 